\title{
Het burgerlijk kleed van de staat : beschouwingen over de tweewegenleer
}

Citation for published version (APA):

Teunissen, J. M. H. F. (1996). Het burgerlijk kleed van de staat : beschouwingen over de tweewegenleer. [Doctoral Thesis, Maastricht University]. W.E.J. Tjeenk Willink. https://doi.org/10.26481/dis.19960329jt

Document status and date:

Published: 01/01/1996

DOI:

10.26481/dis.19960329jt

Document Version:

Publisher's PDF, also known as Version of record

\section{Please check the document version of this publication:}

- A submitted manuscript is the version of the article upon submission and before peer-review. There can be important differences between the submitted version and the official published version of record.

People interested in the research are advised to contact the author for the final version of the publication, or visit the DOI to the publisher's website.

- The final author version and the galley proof are versions of the publication after peer review.

- The final published version features the final layout of the paper including the volume, issue and page numbers.

Link to publication

\footnotetext{
General rights rights.

- You may freely distribute the URL identifying the publication in the public portal. please follow below link for the End User Agreement:

www.umlib.nl/taverne-license

Take down policy

If you believe that this document breaches copyright please contact us at:

repository@maastrichtuniversity.nl

providing details and we will investigate your claim.
}

Copyright and moral rights for the publications made accessible in the public portal are retained by the authors and/or other copyright owners and it is a condition of accessing publications that users recognise and abide by the legal requirements associated with these

- Users may download and print one copy of any publication from the public portal for the purpose of private study or research.

- You may not further distribute the material or use it for any profit-making activity or commercial gain

If the publication is distributed under the terms of Article $25 \mathrm{fa}$ of the Dutch Copyright Act, indicated by the "Taverne" license above, 
Het burgerlijk kleed van de staat 



\title{
Het burgerlijk kleed van de staat
}

Beschouwingen over de tweewegenleer

\author{
Proefschrift
}

ter verkrijging van de graad van doctor aan de

Rijksuniversiteit Limburg te Maastricht, op gezag van de Rector Magnificus,

Prof. mr. M.J. Cohen, volgens het besluit van het College van Dekanen, in het openbaar te verdedigen op vrijdag 29 maart 1996 om 16.00 uur

door

Joost Maria Hermanus Franciscus Teunissen

W.E.J. TJEenK WILLINK ZWOLLE 1996 
Beoordelingscommissie: prof. mr. F.A.M. Stroink (voorzitter)

Prof. mr. G.R. de Groot

Prof. mr. drs. G.E. van Maanen

Prof. dr. G.W. Mincke

Prof. mr. H.J. de Ru (VU Amsterdam)

Van dit proefschrift is tevens een handelseditie verschenen bij W.E.J. Tjeenk Willink Zwolle onder ISBN 9027143919 


\section{Inhoud}

Lijst van afkortingen

Ter inleiding

Noten bij Ter inleiding

Deel I Historische context

Hoofdstuk 1 Het feodale bestel

Hoofdstuk 2 De absolutistische politiestaat

1. Inleiding

2. Het humanistische mens- en wereldbeeld: spanning tussen vrijheidsideaal en machtsideaal

3. Het nieuwe soevereiniteitsbegrip als fundering van de Staat

4. Het ius politiae; politie- en justitiezaken; criminele en civiele zaken

5. Rechterlijke voorziening tegen overheidsoptreden; de fiscusleer

6. De politiestaat als wetgevingsstaat; inperking van het politiebegrip

7. Het juridisch individualiseringsproces en de opkomst van de moderne vrijheidsgedachte

8. Het Pruisische Allgemeine Landrecht (1794) 80

Noten bij hoofdstuk 2

Hoofdstuk 3 De rechtsstaat

1. Inleiding: van politiestaat naar rechtsstaat

2. Loskoppeling van dominium en imperium

3. Het rechtsstatelijke vrijheidsbegrip; publiekrechtelijke vrijheid en burgerrechtelijke vrijheid

4. Het ontstaan van het moderne burgerlijk recht; de inperking van het begrip 'civiel': 'droit civil' = 'droit privé'

5. De heerschappij van de wet en de verdere inperking van de 'politie'

6. 'Politie' en publiek domein; publiekrechtelijke eigendom en burgerrechtelijke eigendom

Noten bij hoofdstuk 3 
Deel II Het dualisme staat-'maatschappij' en het onderscheid tussen publiekrecht en privaatrecht

Hoofdstuk 4 Nogmaals: het cultuurhistorisch differentiatie-, individualiserings- en integratieproces; het ontstaan van het dualisme Staat-'maatschappij'

Noten bij hoofdstuk 4

Hoofdstuk 5 De overheidsactie uit onrechtmatige daad, ook voor publieke belangen. Ontwikkelingen in de jurisprudentie van de Hoge Raad

1. Inleiding

2. De rechtsontwikkeling in Frankrijk op het punt van de onrechtmatige overheidsdaad

3. Nederland: art. 1401 BW als 'uitwijkmethode' in het belang van de rechtsbescherming

4. Toepassing van de maatschappelijke zorgvuldigheidsnorm op overheidshandelen?

5. 'Omdraaiing': onrechtmatige daad ex art. 1401 resp. art. 6:162 BW jegens 'de overheid'

5.1. Het loslaten van de Limmen/Houtkoop-formule

5.2. Oprekking van de zorgvuldigheidsnorm

5.3. Het regressieve karakter van de recente jurisprudentie

6. Algemene zorgplichten van de burger voor 'collectieve belangen' van 'de maatschappij'; de Staat als zaakwaarnemer van deze belangen

Noten bij hoofdstuk 5

Hoofdstuk 6 Het juridisch pluralisme. De constitutieve betekenis van het dualisme Staat-'maatschappij'. De rol van de Staat in de rechtsvorming

1. Het bloot rechtspositivistische karakter van de 'twee-wegenjurisprudentie' van de Hoge Raad

2. Materiële rechtsbeginselen en positief recht; algemene en typische rechtsbeginselen; materiële competentiesfeer en formele bevoegdheden

3. Het burgerlijk recht als integerend privaat ius commune

4. Het juridisch pluralisme; 'samenleving' en 'maatschappij' zijn

5. Publiekrechtelijke rechtsvorming

6. Nogmaals: 'politie' en publiek domein 
7. Verwerping van de ambtentheorie

Noten bij hoofdstuk 6

Hoofdstuk 7 Een algemene overheidsactiebevoegdheid in het Burgerlijk Wetboek: artikel 3:305b BW

Noten bij hoofdstuk 7

Hoofdstuk 8 Behartiging van 'publieke belangen' door maatschappelijke organisaties: artikel 3:305a BW

Noten bij hoofdstuk 8

Slot

Noten bij Slot

Zusammenfassung

Noten bij Zusammenfassung

Literatuurlijst

Jurisprudentieregister

Curriculum vitae 



\section{Lijst van afkortingen}

a.w. aangehaald werk

AAe Ars Aequi

$\mathrm{AB} \quad$ Nederlandse Jurisprudentie, Administratiefrechtelijke beslissingen

adv.-gen. advocaat-generaal

AGvB Afdeling geschillen van bestuur Raad van State

ALR Allgemeines Landrecht für die Preussischen Staaten

a.m.v.b. algemene maatregel van bestuur

ARAS

Art.

Afdeling rechtspraak Raad van State

Awb

Artikel

B. en W. Burgemeester en wethouders

BR

BUPO

BVerfG

Bouwrecht

BVerfGE

Internationaal Verdrag inzake burgerrechten en politieke rechten

BW

$\mathrm{CBb}$

$\mathrm{Ch}$.

Bundesverfassungsgericht

CRvB

curs.

E

EHRM

Entscheidungen des Bundesverfassungsgerichtes

EVRM

Burgerlijk Wetboek

College van Beroep voor het bedrijfsleven

Chapitre

Centrale Raad van Beroep

cursivering

Entscheidungen

Europees Hof voor de Rechten van de mens

Europees Verdrag tot bescherming van de rechten van de mens en de fundamentele vrijheden

Gst. De Gemeentestem

Gw. Grondwet

Hfdst. Hoofdstuk

HNJV Handelingen Nederlandse Juristen-Vereniging

HR Hoge Raad

KG Kort Geding

m.nt. met noot

m.n. met name

MvA Memorie van Antwoord

MvT Memorie van Toelichting

NBW Nieuw Burgerlijk Wetboek

NJ Nederlandse Jurisprudentie 
NJB

NTB

p.

pp.

Pres.

$\mathrm{Rb}$

red.

RM

RMTh

RO

$R \& K$

R\&R

Rv

RvdW

RvS

SEW

Sr.

Stb.

Stcrt.

sv:

t.a.p.

$\mathrm{tB} / \mathrm{S}$

TK

TvO

TvS

TwK

UCBB

VU

$\mathrm{Vz}$.

W.

Wet arob

Wet RO

Wmb.

WPNR

WRO

WvSr.
Nederlands Juristenblad

Nederlands Tijdschrift voor Bestuursrecht

pagina

pagina's

President

Rechtbank

redactie

Rechtsgeleerd Magazijn

Rechtsgeleerd Magazijn Themis

Wet op de Rechtelijke Organisatie

Recht en Kritiek

Rechtsfilosofie en Rechtstheorie

Wetboek van Burgerlijke Rechtsvordering

Rechtspraak van de Week

Raad van State

Sociaal-Economische Wetgeving

Wetboek van strafrecht

Staatsblad

Staatscourant

Wettouek' van stratvoraèring

ter aangehaalde plaatse

Ten Berge/Stroink, Administratieve rechtspraak

overheidsbeslissingen

Tweede Kamer

Tijdschrift voor Overheidsadministratie

Tijdschrift voor Openbaar Bestuur

Tijdschrift voor Strafrecht

Tijdelijke wet Kroongeschillen

Uitspraken College van Beroep voor het bedrijfsleven

Vrije Universiteit

Voorzitter

Weekblad van het Regt

Wet administratieve overheidsbeslissingen

Wet op de Rechterlijke Organisatie

Wet milieubeheer

Weekblad voor privaatrecht, notariaat en registratie

Wet op de Ruimtelijke Ordening

Wetboek van strafrecht 
Voor Els,

Janneke en Marjolein 



\section{Ter inleiding}

In een kritische beschouwing die ik samen met prof. Tak schreef voor het Nederlands Juristenblad van 6 mei $1994^{\prime}$ naar aanleiding van de opneming in de Wet milieubeheer van een algemene zorgplichtbepaling (artikel 1.1a Wmb) trokken wij ten strijde tegen het naar ons oordeel te ruimhartige gebruik van het burgerlijk recht door 'de overheid'. Artikel 1.1 a Wmb, eerste lid, Wmb bepaalt: 'Een ieder neemt voldoende zorg voor het milieu in acht', en is mede bedoeld als een algemene grondslag om met bestuursrechtelijke dwangmiddelen (bestuursdwang of dwangsom) op te treden wegens schending van deze zorgplicht, waar specifieke milieuvoorschriften zijn overtreden. Het derde lid van bedoeld bepaling luidt:

'Het bepaalde in het eerste en tweede lid laat onverlet de uit het burgerlijk recht voortvloeien de aansprakelijkheiden de mogelijkheid van rechtspersonenals bedoeld in artikel 1, boek 2, van het Burgerlijk Wetboek, om uit dien hoofde in rechte op te treden'.

Dit artikellid zal moeten worden gelezen in het licht van de jurisprudentie van de Hoge Raad, volgens welke 'de overheid' publieke belangen, behalve via de publiekrechtelijke weg, 'ook mag behartigen door gebruik te maken van haar in beginsel krachtens het privaatrecht toekomende bevoegdheden, de bevoegdheid een overeenkomst naar burgerlijk recht te sluiten of de bevoegdheid een vordering op grond van een jegens haar gepleegde onrechtmatige daad bij de burgerlijke rechter in te stellen'. Dit uitgangspunt is, als bekend, door de Hoge Raad geformuleerd in het Windmill-arrest van 26 januari $1990^{2}$. Daarmee wordt de zogenaamde tweewegenleer - die is gebaseerd op de leer die het 'privaatrecht' ziet als het (al)gemene recht - met zoveel woorden erkend door dit rechtscollege. De vraag is 'slechts' of door het bewandelen van de privaatrechtelijke weg een doorkruising plaatsvindt van een publiekrechtelijke regeling, welke vraag dient te worden beantwoord aan de hand van enkele door de Hoge Raad geformuleerde criteria. De bedoeling van het derde lid van artikel 1.1a Wmb kan slechts zijn de doorkruisingsformule buiten spel te zetten. Immers, zodra men een - door bestuursrechtelijke sancties te handhaven algemene zorgplichtbepaling creēert, zou er altijd een publiekrechtelijke regeling zijn. Het derde lid is dan ook te zien als een uitdrukkelijke verklaring van de 
wetgever, dat gebruikmaking door 'de overheid' van 'privaatrechtelijke bevoegdheden' ter behartiging van het milieubelang niet moet worden gezien als een doorkruising van het publiekrecht (Alleen waar specifieke milieuvoorschriften worden overtreden, kán het doorkruisingscriterium zich tegen een civiele acties verzetten).

Het door de Hoge Raad niet gemotiveerde uitgangspunt dat 'de overheid' in beginsel zou beschikken over 'privaatrechtelijke bevoegdheden' ter behartiging van publieke belangen, wordt dus ook door de wetgever kennelijk aanvaard en zonder meer overgenomen. Door deze a priori-benadering van zowel de Hoge Raad als de wetgever wordt het genoemde uitgangspunt in het geheel niet geproblematiseerd. In ons NJBartikel veroordeelden we dit uitgangspunt als een contradictio in terminis, als een miskenning van de wezenlijke verschillen qua aard tussen publiekrecht en privaatrecht en als een voorbijgaan aan de rechtsstatelijke eisen die aan het overheidsoptreden moeten worden gesteld. In datzelfde artikel kritiseerden we ook het nieuwe artikel 3:305b van het Burgerlijk Wetboek, dat gebaseerd is op hetzelfde uitgangspunt en dat aan publiekrechtelijke rechtspersonen een algemene bevoegdheid geeft civiele gebods- en verbodsacties in te stellen tot bescherming van de belangen van andere personen, voor zover aan deze rechtspersonen de behartiging van deze belangen is toevertrouwd.

Dit - 'geruchtmakend' genoemde ${ }^{3}$ - NJB-artikel lokte scherpe kritiek uit ${ }^{4}$, waarop wij weer reageerden met een beschouwing in Recht en Kritiek ? In die beschouwing kon ook worden gereageerd op het inmiddels gepubliceerde Kabayel-arrest ${ }^{6}$, waarin het onderscheid tussen publiek- en privaatrecht volstrekt uit het oog lijkt te zijn verloren en waarin voor de ontvankelijkheid van een op artikel 6:162 BW gebaseerde vordering slechts nog als eis wordt gesteld dat er sprake is van een voldoend (proces)belang als bedoeld in artikel 3:303 BW.

Met dit boek beoog ik deze fundamentele kritiek op de gemene rechts- en tweewegenleer nader te onderbouwen. Wat mij is opgevallen in de reacties op het NJBartikel, is dat voorbij wordt gegaan aan de kern van de daarin geuite kritiek, namelijk dat er een principieel onderscheid qua aard bestaat tussen publiek- en privaatrecht en dat de opvatting dat 'het privaatrecht' aan de overheid 'privaatrechtelijke bevoegdheden' zou verlenen ter zelfstandige behartiging van publieke belangen reeds daarom niet juist kan zijn. Symptomatisch is dat deze kritiek wordt bestempeld als een 'dogmatische benadering' 7 . Met deze reactie wordt eigenlijk bevestigd, wat in het artikel in Recht en Kritiek wordt geconstateerd: 'een te geringe belangstelling voor de grondslagenproblematiek van de doorsnee Nederlandse rechtswetenschapper, die vooral pragmatisch wil zijn'. Deze houding is door Couwenberg als 'pragmatisch positivisme' getypeerd ${ }^{8}$. Dogmatisch is naar mijn mening toch vooral de benadering van de tweewegenleer, die zonder meer - als dogma! - tot 
positief recht verklaart dat 'de overheid' in beginsel beschikt over 'privaatrechtelijke bevoegdheden' ter behartiging van publieke belangen.

Reeds Kant wees er op dat de beantwoording van de vraag, of men bij positief recht überhaupt te maken heeft met wezenlijk recht, niet louter door dat positieve recht zelf gegeven kan worden. Een louter empirische rechtsleer vergeleek Kant dan ook met de houten kop (het toneelmasker) uit de fabel van Phaedrus: ein Kopf der schön sein mag, nur schade! dass er kein Gehirn hat' 9 .

Het antwoord op de vraag, of men te maken heeft men 'richtiges Recht', zal alleen gegeven kunnen worden wanneer men zich bewust is van de verwevenheid tussen het positieve, empirische recht en de grondslagen en beginselen die de normatieve basis van het positief recht zijn. Die beginselen kunnen pas in de loop van de historische ontwikkeling gekend worden. Die ontwikkeling heeft aan het eind van de achttiende eeuw en het begin van de negentiende eeuw geleid tot de doorbraak van de moderne rechtsstaatsidee, met welke idee bepaalde rechtsbeginselen intrinsiek zijn verbonden. Daartoe behoren o.a. de publiekrechtelijke beginselen van het algemeen belang en van de representatieve democratie en het legaliteitsbeginsel; daartoe behoort ook het beginsel van de burgerlijke vrijheid en gelijkheid, dat ten grondslag ligt aan het moderne burgerlijk recht. De doorbraak van de rechtsstaatsidee ging gepaard met een erkenning van de (onder)scheiding tussen Staat en burgerlijke 'maatschappij'. Deze scheiding vond haar juridische doorwerking in een principieel onderscheid tussen publiek- en privaatrecht, terwijl ook het beginsel van wetmatigheid van bestuur tegen de achtergrond van die scheiding moet worden geplaatst ${ }^{10}$. In recente literatuur is dit onderscheid echter, uit een oogpunt van de materiële inhoud van het recht, als 'verregaand obsoleet' aangeduid; er zou enkel nog een formeel onderscheid bestaan, namelijk als criterium ter afbakening van de rechterlijke competentie ${ }^{11}$. Het burgerlijk recht is, aldus Hirsch Ballin, multifunctioneel: het is niet alleen van toepassing op burgers, maar ook op de overheid als deze zich in het burgerlijk recht beweegt. Dit pleegt te worden geplaatst tegen de achtergrond van een ontwikkeling die beschreven wordt als een 'vermaatschappelijking van de staat' en een daarmee gepaard gaande 'horizontalisering van de bestuursbetrekkingen' ${ }^{12}$. De scheiding Staat-'maatschappij' en die tussen publiek- en privaatrecht worden daarbij als negentiende-eeuws gekarakteriseerd.

Als de Hoge Raad spreekt van 'privaatrechtelijke bevoegdheden' van 'de overheid' ter behartiging van openbare belangen, kan men inderdaad de vraag stellen wat nog het privaatrechtelijke is van dergelijke bevoegdheden. De aanduiding 'privaatrechtelijk' lijkt dan niet meer dan een etiket, waarbij wordt afgezien van de materiële inhoud van het desbetreffende recht. Uiteindelijk heeft de gemene rechtsleer dus geleid tot enerzijds een 'publicisering' van privaatrecht (bijvoorbeeld civiele onrechtmatige daadsacties ter behartiging van publieke belangen) en anderzijds tot een 'privatisering' van publiekrecht (zo wordt het publiek domein beschouwd als 'ge- 
wone' privaatrechtelijke eigendom, ten aanzien waarvan de overheid privaatrechtelijke bevoegdheden kan uitoefenen).

De vraag is of we hier moeten spreken van een 'progressieve' of van een 'reactionaire beweging in de historische ontwikkeling' ${ }^{13}$. Het ontstaan van het dualisme Staat-'maatschappij' en van het onderscheid tussen publiek- en privaatrecht was het resultaat van een lang cultuurhistorisch proces dat wordt gekenmerkt door een steeds verder gaande 'Ausdifferenzierung' van de menselijke samenlevingsverhoudingen en, gepaard daaraan, van het recht. De zin en functie van het onderscheid publiekrecht-privaatrecht kunnen slechts goed begrepen worden, wanneer men een goed inzicht heeft in die rechtsontwikkeling.

In Deel I van dit boek wordt onderzocht, welke de historisch context is van de differentiatie publiekrecht-privaatrecht. Daarbij wordt de historische ontwikkeling in drie hoofdfasen verdeeld: het middeleeuwse feodale bestel (en de overgangsvorm van de standen'staat'), de politiestaat die opkomt vanaf het einde van de vijftiende eeuw, en de rechtsstaat die doorbreekt vanaf het einde van de achttiende eeuw. Zo'n historisch onderzoek is te meer van belang, omdat door auteurs als Hamaker, Krabbe en Vegting een historische onderbouwing is gegeven aan de door hen verdedigde gemene rechtsleer. Volgens deze auteurs zou het privaatrecht reeds tijdens de Middeleeuwen het gemene recht zijn geweest, doch onder de politiestaat van zijn plaats zijn verdrongen door het nieuwe recht ('publiekrecht') van de absolutistische vorsten, waarna het onder de rechtsstaat weer zou zijn hersteld als gemeen recht waarop het nieuwe recht aanvullingen of uitzonderingen bevat.

In Deel II wordt nagegaan of de uitbreiding van de overheidswerkzaamheden in deze eeuw - de opkomst van de sociale rechtsstaat - inderdaad noodzakelijkerwijs leidt tot een loslaten van het dualisme Staat-'maatschappij', met als gevolg dat er geen principieel onderscheid meer kan worden gemaakt tussen publiek- en privaatrecht. In dit verband wordt ook de recente jurisprudentie van de Hoge Raad onderzocht, waarin immers de maatschappelijke zorgvuldigheidsnorm óók wordt aangelegd op de verhouding tussen burger en overheid die optreedt ter behartiging van publieke belangen, en die dus kan worden gezien als een bevestiging van het loslaten van dit dualisme.

Daarbij moet de vraag worden beantwoord, wat de aard is van het burgerlijk recht en, meer in het bijzonder, wat de omvang is van de (functies van) de door artikel 2:1 Burgerlijke Wetboek aan openbare lichamen verleende rechtspersoonlijkheid.

Met de opvatting dat tussen publiek- en privaatrecht, wat de materiële inhoud ervan betreft, géén wezensverschillen meer zouden bestaan, hangt namelijk het wetspositivisme samen dat - op basis van de ambtentheorie van Logemann - heeft geleid tot het maken van een streng onderscheid tussen enerzijds overheidsorganen ('ambten') 
en anderzijds openbare lichamen-rechtspersonen ('publiekrechtelijke rechtspersonen'). Dit onderscheid wordt gemaakt, omdat alleen gekeken wordt naar de formele regeling van de bevoegdheden van overheidsorganen: het positieve publiekrecht kent (publiekrechtelijke) bevoegdheden toe aan deze ambten en niet aan openbare lichamen, reden waarom tussen beide een 'wezenlijk' onderscheid zou bestaan. Anderzijds zouden de openbare lichamen-rechtspersonen aan hun rechtspersoonlijkheid 'privaatrechtelijke bevoegdheden' ontlenen. Op de op het Windmill-arrest geuite kritiek, dat de opvatting van de Hoge Raad dat 'de overheid' in beginsel beschikt over 'krachtens het privaatrecht toekomende bevoegdheden', een ongemotiveerd 'a priori' is ${ }^{14}$, reageert Bloembergen met het betoog 'dat het wettelijk stelsel meebrengt dat aan de overheid deze bevoegdheden toekomen' is. Artikel 2:1 Burgerlijk Wetboek kent - aldus Bloembergen - aan een groot aantal overheidslichamen rechtspersoonlijkheid toe. Uit lid 3 van artikel 2:1 in relatie met artikel 2:5 zou dan voortvloeien 'dat in beginsel ieder vermogensrecht aan een overheidslichaam kan toekomen en - via art. 3:32 - dat zo'n lichaam elke privaatrechtelijke rechtshandeling kan verrichten. Bovendien kan zo'n lichaam in bepalingen als art. 6:162 en 6:203 zowel 'hij die' 'degene die') als 'een ander' zijn, enz., enz. Kortom, op deze manier is de overheid als rechtssubject het privaatrecht binnengesluisd en is het overheidsprivaatrecht gegeven'. Daarbij zou de doorkruisingsformule ervoor zorgen, dat het publiekrecht niet op onaanvaardbare wijze wordt doorkruist.

Wat in dit betoog in de eerste plaats opvalt, is dat kennelijk wordt aangenomen dat het Burgerlijk Wetboek 'privaatrechtelijke bevoegdheden' zou verlenen. Maar dat zou toch ook betekenen dat óók private (rechts)personen hún privaatrechtelijke bevoegdheden ontlenen aan de wetgever? Dat zou een staatsabsolutistisch standpunt zijn! In de tweede plaats wordt kennelijk aangenomen, dat dit Wetboek aan 'de overheid' die 'privaatrechtelijke bevoegdheden' óók toekent ter behartiging van publieke belangen. Dan rijst nogmaals de vraag: wat is eigenlijk het 'privaatrechtelijke' aan die bevoegdheden? Ten derde: als er tussen ambten - dragers van publiekrechtelijke bevoegdheden - en openbare lichamen-rechtspersonen - dragers van 'privaatrechtelijke bevoegdheden' een wezenlijk onderscheid zou moeten worden gemaakt, hoe kan er dan sprake zijn van doorkruising? En maakt men géén wezenlijk onderscheid tussen beide soorten 'personen', hoe is dan te verklaren dat de wetgever aan 'de overheid' (de ambten) welbewust slechts specifieke publiekrechtelijke bevoegdheden heeft toegekend ter behartiging van bepaalde belangen, terwijl diezelfde overheid daarnáást nog zou beschikken over algemene, niet gespecificeerde - zogenaamd 'privaatrechtelijke' - bevoegdheden ter behartiging van allerlei, ook 'ongeschreven' publieke belangen?

Tevens worden in dit boek de nieuwe artikelen 3:305a en 3:305b van het Burgerlijk Wetboek ('collectief actierecht'), die tot stand zijn gekomen op basis van opvattingen 
die óók ten grondslag liggen aan de recente twee-wegenjurisprudentie, aan een kritisch onderzoek onderworpen.

Bij het schrijven van dit boek ben ik gaandeweg steeds meer onder invloed gekomen van het denken in de rechts- en staatsleer die, op de basis van zijn wijsbegeerte, op een indrukwekkende manier is uitgewerkt door Herman Dooyeweerd. De humanistische rechtsfilosoof Cliteur heeft van Dooyeweerd gezegd, dat hij een leer van de rechtsstaat heeft ontwikkeld waarvan staatsrechtelijk Nederland nauwelijks kennis heeft genomen, maar die superieur is aan wat men daarover leert in de handboeken van het Nederlandse staatsrecht, en dat hij op beide vooronderstellingen van het model van de pluriforme samenleving - consensus én verschil - grensverleggende inzichten naar voren heeft gebracht ${ }^{16}$. Dit kan ik alleen maar beamen. Dooyeweerd heeft een overtuigende kritiek gegeven op het formalistische rechtspositivisme, dat voor een op materiële rechtsbeginselen gefundeerde rechtsstaat een grote bedreiging vormt. En ik maakte al duidelijk, dat naar mijn oordeel een dergelijk formalisme ook tot uitdrukking komt in de gemene rechtsleer en tweewegenleer.

Dit boek is in hoofdzaak geschreven tussen september 1993 en maart 1994 en tussen oktober 1994 en februari 1995. Een arrest als 'Kabayel'(HR 18 febr. 1994, AB 1994, 415) - waardoor bij mij de woorden opkwamen: 'something's rotten, and it's not in the state of Denmark' - zorgde voor de psychische energie om het boek in een vrij rap tempo te voltooien. In de maanden november en december 1995 heb ik, sporadisch, nog nieuw materiaal in het manuscript verwerkt en - wat belangrijker is - de omvang ervan aanmerkelijk gereduceerd van meer dan 600 tot ca. 350 pagina's. Indachtig Kants uitspraak in het voorwoord tot de 'Kritik der reinen Vernunft': 'Manches Buch wäre viel deutlicher gewesen, wenn es nicht so gar deutlich hätte werden sollen', heb ik gemeend er wijs aan te doen enkele hoofdstukken weg te laten en de desbetreffende verhandelingen later, in aangepaste vorm, te publiceren.

Op deze plaats wil ik uiting geven aan mijn blijvende erkentelijkheid jegens mijn promotor prof.mr. A.Q.C. Tak voor het vertrouwen dat hij steeds in mij heeft gesteld en wiens kritische commentaar het manuscript zeer ten goede is gekomen. Eveneens moge ik mijn dank uitspreken voor de nuttige aanbevelingen die de leden van de beoordelingscommissie mij na lezing van het manuscript nog toe deden komen. In het bijzonder wil ik prof.mr. G.E. van Maanen danken voor zijn gedegen en constructieve commentaar op het manuscript. 
Nettie Litjens maakte het manuscript op voortreffelijke - en snelle! - wijze cameraready.

Tenslotte gaat natuurlijk dank uit naar Els en mijn beide dochters Janneke en Marjolein, die mij er steeds weer van wisten te doordringen dat er in het leven nog belangrijkere dingen bestaan dan het schrijven van een proefschrift. 


\section{Noten bij Ter inleiding}

1. J.M.H.F. Teunissen, A.Q.C. Tak, 'Recht ist, was der Umwelt nütze? (Over zorgplichtbepalingen, civiele acties en tweewegenleer. Een overdenking n.a.v. de opneming van een zorgplichtbepaling in de Wet milieubeheer)', NJB 1994, pp. 605-616.

2. HR 26 jan. 1990, AB 1990, 408, Gst. 6914.10 (Windmill-arrest).

3. D.A. Lubach, Kroniek 'Bestuur en privaatrecht', NTB 1994, pp. 242-247 (p. 242).

4. Reacties van C. Lambers, J. Verschuuren en G. van der Veen, afgedrukt in NJB 1994, pp. 1006-1010.

5. A.Q.C. Tak, J.M.H.F. Teunissen, 'Wie zorgt er voor de rechtsstaan? Een voortgezet debat', Recht en Kritiek 1994, pp. 340-354.

6. HR 18 febr. 1994, AB 1994, 415 (Kabayel-arrest).

7. Lubach, t.a.p., p. $242 / 243$.

8. S.W. Couwenberg, 'De omstreden Staat', Alphen a/d Rijn 1974, pp. 114-116; dez., 'Een nieuwe kijk op staatsrechtenstaatsrechtbeoefening', uittreerede Erasmusuniversiteit Rotterdam 1992, Kampen 1992. p. 4/5, waar gewezen wordt op het 'pragmatisch positivisme' in de Nederlandse staatsrechtsbeoefening. waarbij als voomaamste criterium geldt of het positieve recht voldoende aansluit bij de conventionele wijsheid van de spraakmakende gemeente en of men er in de praktijk mee uit de voeten kan. Deze betrekkelijk geringe theoretische belangstelling staat niet op zichzelf, zo merkt Couwenberg in zijn uittreerede nog op: 'Zij is bijvoorbeeld ook kenmerkend voor de Nederlandse geschiedwetenschap en heeft waarschijnlijk iets te maken met onze volksaard'.

9. I. Kant, 'Metaphysische Anfangsgründe der Rechtslehre', 1797, uitg. Wiesbaden 1956, p. 336. We zouden ook kunnen verwijzen naar de aan Leibniz toegeschreven uitspraak: 'Nichts ist praktischer als eine gute Theorie', De uitspraak wordt ook geciteerd bij H.J. van Eikema Hommes, 'De transcendentaal-juridische methode. Haar betekenis voor de juridische vakwetenschappen', AAe 1979, pp. 719-730 (p. 719). De titel van Kants werkje 'Über den Gemeinspruch: das mag in der Theorie richtig sein, taugt aber nicht für die Praxis', 1793, is ironisch bedoeld. $\mathrm{Vgl}$. ook de aan Leibniz toegeschreven uitspraak: 'Nichts ist praktischer als eine gute Theorie".

10. Aldus terecht: J.L.M. Gribnau, 'De wederkerige rechtsbetrekking als nieuw paradigma', R \& R 1993 , pp. 87-95 (p. 90), en R. Foqué, 'De ruimte van het recht', oratie Rotterdam 1992, p. 24.

11. E.M.H. Hirsch Ballin, 'Voorbij het onderscheid van publiekrecht en privaatrecht', in: E.M.H. Hirsch Ballin, J.B.M. Vranken e.a., 'Bestuursrecht en nieuw BW'. Zwolle 1988, p. 16, ook opgenomen in: dez., 'Rechtsstaat en beleid (Een keuze uit het werk van mr. E.M.H. Hirsch Ballin)', pp. 251-260.

12. Vgl. Gribnau, t.a.p.

13. H. Dooyeweerd, 'Maatstaven ter onderkenning van progressieve en reactionaire bewegingen in de historische ontwikkeling ', in: Verslag van de plechtige viering van het 150 -jarig bestaan der Koninklijke Nederlandse Akademie van Wetenschappen, 6-9 mei 1959, Amsterdam 1958, pp. $61-77$ (ned.), pp. 139154 (Frans), pp. 213-228 (Engels); ook afgedrukt in: M.E. Verburg. 'Herman Dooyeweerd. Grenzen van het theoretisch denken', Baarn 1986, pp. 85-109.

14. A.Q.C. Tak, 'Publiek domein, Overheidscontract en rechterlijke wetshandhaving', NTB 1990, pp. 265 270 (p. 269).

15. A.R. Bloembergen, 'Overheidsprivaatrecht: schets van een algemeen deel', WPNR 1992, nr. 6074 (themanummer 'De overheid in het privaatrecht twintig jaar later'), pp. 950-957 (p. 953).

16. P.B. Cliteur, 'Maar dan komt het verschil', Trouw 8 okt. 1994. 


\section{Deel I}

\section{Historische context}





\section{Hoofdstuk 1}

\section{Het feodale bestel}

De feodale tijd, welke aanvangt met het uiteenvallen van het Frankische rijk in de vroege Middeleeuwen, kent niet de romeinsrechtelijke onderscheiding tussen 'ius publicum' en 'ius privatum' '. Het feodale bestel wordt gekenmerkt door (meer of minder) ongedifferentieerde samenlevingsverbanden die hun leden totaal, naar alle levenssferen, omvatten ${ }^{2}$. Deze totalitaire verbanden vervullen al die taken tegelijk waarvoor zich in de loop van het cultuurhistorisch differentiëringsproces allerlei afzonderlijke eigen-geaarde, scherp van elkaar te onderscheiden - gedifferentieerde - gemeenschappen zullen vormen, die ieder een specifieke bestemming hebben (zoals Staat, onderneming, kerk, vrije vereniging, gezin etc.). Deze ongedifferentieerde verbanden absorberen de mens als enkeling. Een private vrijheidssfeer van de mens als zodanig, die een vrij maatschappelijk verkeer mogelijk maakt, wordt nog niet erkend. De rechtspositie van de mensen is nog slechts een sequeel van de ongedifferentieerde levenskringen waartoe zij behoren.

\section{Vermenging van 'imperium' en 'dominium'}

Deze ongediffentieerde verbanden bezitten ook brokken 'overheidsgezag' ('imperium') over hun onderhorigen op de wijze van een privaat dominium: 'overheidsrechten' worden beschouwd als private vermogensbelangen, die overdraagbaar en beleenbaar zijn (de zgn, heerlijke rechten, de regalia majora). Deze vermenging van 'imperium' en 'dominium' is kenmerkend voor het feodale bestel. Dit dominium is dus niet te vergelijken met ons moderne burgerlijk eigendomsrecht, dat immers een zuiver privaat vermogensrecht is en als zodanig geen gezag geeft over andere personen.

Men ontmoet in het feodale bestel geen burgerlijk recht, geen publiekrecht, geen intern bedrijfsrecht etc., maar slechts een ongedifferentieerd recht. Want zolang de samenleving een nog grotendeels ongedifferentieerd karakter draagt, bevindt ook de rechtsorde zich in een nog ongedifferentieerde toestand en kan er dus geen sprake 
zijn van een publiekrecht en een privaatrecht, die naar innerlijke geaardheid verschillen. Men kent nòch de idee van de Staat ${ }^{3}$ als een publiekrechtelijke rechtsgemeenschap (res publica), de idee dus dat overheidsgezag geen privaat bezit maar een publiek ambt is dat uitsluitend in het algemeen belang (res publica) mag worden uitgeoefend, nòch de idee van het burgerlijk recht, waarin de mens als zodanig, onafhankelijk van zijn toebehoren tot bijzondere gemeenschappen, als rechtsgenoot wordt erkend.

Terwijl een eigenlijk staatsinstituut ontbreekt, fungeert de Rooms-katholieke kerk als het totaal-verband van heel de christenheid. Er is een kerkelijke eenheidscultuur en in haar canoniek recht - dat sterk door het Romeinse recht is beinnvloed -, brengt de kerk een kerkelijk 'wereldrecht' voort. In de middeleeuwse cultuur fungeert het kerk-instituut als de 'boven-natuurlijke boven-bouw' boven een ongedifferentieerde 'wereldlijke' of 'natuurlijke onder-bouw' '; juist de ongedifferentieerdheid van de onderbouw stelt de kerk in staat heel die onderbouw te beheersen. Bekend is de tweezwaardenleer, die inhoudt dat er twee vormen van macht zijn, een geestelijke macht, uitgeoefend door de kerk, en een tijdelijke, uitgeoefend door de wereldlijke heren. En die tijdelijke macht zou per definitie ondergeschikt zijn aan de geestelijke, omdat geestelijke waarden verheven zijn boven materiële. De opvatting ontstaat dat God de twee zwaarden aan de paus heeft verleend, die zelf het tijdelijke zwaard aan de wereldlijke heren toevertrouwt, om het in dienst van God en zijn Kerk te hanteren ${ }^{5}$.

\section{Mund-principe en sibbe-principe}

In die wereldlijke onderbouw zijn in hoofdzaak twee typen van ongedifferentieerde verbanden te onderscheiden ${ }^{6}$ : het heerschappelijk verband (met name het leenverband ${ }^{7}$ ) - gekenmerkt door het mund- of maagschapsprincipe - en het gildeverband - gekenmerkt door het sibbe-principe -, welke beide vormen zich overigens ook onderling kunnen verbinden.

Met de Duitse term 'Mund' (etymologisch verwant met het latijnse 'manus', in de zin van de gewapende hand als symbool van de huismacht) wordt gedoeld op de ongedifferentieerde ('totalitaire') heerschappij die werd uitgeoefend door het hoofd van de Romeinse familia - de pater familias - en van de Germaanse huisgemeenschap (maagschap) over zijn familieleden en personeel, en het daarbij behorende 'dominium'. 'Mondig' (mundig) werd de Germaan als hij uit de Mund van zijn huischef ontslagen werd en zelf een huisgemeenschap kon stichten. Het mund-principe werd later (vanaf de 5e eeuw) ook toegepast op de verhouding tussen de merovingische koning en zijn strijdmakkers, die in zijn huis kwamen wonen en deel gingen uitmaken van 's konings mundkring (quasi-maagschapsband). De merovingische koningen breidden hun huismacht nog verder buiten haar oorspronkelijke grenzen uit, 
door al hun onderdanen onder hun algemene mund te brengen en de eigenlijke bestuursambtenaren en militaire leiders in een bijzondere, engere mundkring op te nemen.

Het mund-principe vindt dus zijn uitdrukking in een 'autoritatieve', persoonlijke heerschappij van een machthebber over aan hem onderhorigen (heerschappij- en onderworpenheidsverhouding) ${ }^{8}$. Het beeld van de koning en - in de latere Middeleeuwen - van de landsheren is dat van de goede huisvader voor wie zijn 'dominium' en de daaraan verbonden 'hoogheidsrechten' zijn eigen private belangen - als huisvader - zijn en die ze dienovereenkomstig ('patrimoniaal') behartigt ' .

In tegenstelling tot het mund-principe vindt het sibbe- ofwel broederschapsprincipe zijn uitdrukking vindt in een 'van onder op' gevormd, 'genootschappelijk' (dus door een aantal personen gezamenlijk uitgeoefend) hoogste gezag. In de oud-Germaanse sibben oefenden de sibbe-hoofden (de hoofden van de afzonderlijke huisgemeenschappen) gezamenlijk het hoogste gezag uit. De oud-Germaanse sibbe (het op vaderlijke afstamming gegronde grote familieverband, te vergelijken met het Romeinse gens) kende geen heerschappij- en onderworpenheidsverhouding (die bestond wèl binnen de huisgemeenschappen die deel uitmakten van de sibbe), maar was op genootschappelijke leest geschoeid en kende aan alle tot haar behorende leden gelijke rechten toe.

In de Merovingische tijd werd dit sibbe-principe nagenoeg geheel verdrongen door het mund-principe, omdat - als opgemerkt - de Merovingische vorsten hun huismacht uitbreidden tot al hun onderdanen, die daarmee onder een algemene mund worden gebracht. Het sibbe-principe vormde immers een bedreiging voor het mundprincipe.

Pas mét het ineenstorten van het Frankische rijk - vanaf de 10e eeuw - en de daarmee gepaard gaande versplintering van het koninklijk gezag in allerlei 'heerlijke' en feodale heerschappij- en onderworpenheidsverhoudingen, zal het sibbe-principe echter weer gestalte kunnen krijgen in de vorm van de gildeverbanden, markgemeenschappen e.d., die in feite kunstmatige - want niet op natuurlijke afstamming gebaseerde - sibbe-verbanden zijn en die een tegenwicht zullen gaan vormen tegen het mund-principe ${ }^{10}$.

\section{De feodalisering}

Het in de Karolingische tijd tot essentieel element van het Frankische rijk uitgebouwde leenverband wordt gekenmerkt door de vazallistische, persoonlijke verhouding tussen koning-leenheer en zijn vazallen-leenmannen, die de fideles, de getrouwen van de koning zijn ". De koning - die het regnum beschouwt als zijn privépatrimonium - pleegt zijn vazal als contraprestatie voor zijn belofte van 'consilium et auxilium' (raad en bijstand) een beneficium (lett.: weldaad) te verlenen, dat door- 
gaans bestaat uit het in leen geven van een landsdeel. Deze belening van land impliceert overdracht van overheidsgezag, zoals de militaire leiding over de plaatselijke weerbare bevolking en het rechterschap in oude zin over de plaatselijke bevolking. Dit gezag blijft steeds aan het koninklijke onderworpen; het mag zonder toestemming van de koning niet worden vervreemd en is steeds gebonden aan de voorwaarden van trouwe dienst in een (leen)verbandsverhouding. Het kan dus eenzijdig door de koning worden teruggenomen: het leen is een ambtsleen.

Wanneer echter vanaf de tiende eeuw het koninklijk gezag begint te verzwakken, kunnen de plaatselijke leenmannen zich allengs onafhankelijker van de koning maken en verkrijgt hun dominium feitelijk een exclusief ('soeverein') karakter, waarover zij vrij beschikken en dat erfelijk wordt. Formeel bezit de leenman zijn 'dominium' nog steeds niet op eigen titel maar krachtens zijn leenverhouding met de leenheer ${ }^{12}$, maar feitelijk is de situatie een andere geworden en worden de in leen gegeven gezagsrechten behandeld als private vermogensbelangen van de leenman. Deze vermenging van 'imperium' (overheids 'bevoegdheden') en privaat 'dominium' (privaat subjectief vermogensbelang) is, als gezegd, kenmerkend voor het feodale bestel. In het feodale 'dominium'-begrip wordt geen onderscheid gemaakt tussen overheids 'bevaegdheden' en private subjectieve rechten. 'Daminium' betekent 'heerschappij', zónder onderscheid tussen 'heerschappij van (private) eigendom' en heerschappij in de zin van overheidsmacht ${ }^{13}$.

De leenmannen, die in de Karolingische tijd nog afzetbare 'ambtenaren' waren geweest, worden mede ten gevolge van het feit dat de lenen erfelijk zijn geworden, tot landsheren ${ }^{14}$. Daarmee begint de periode die men als de landsheerlijke periode of het (eigenlijke) feodale bestel pleegt aan te duiden. De verhouding tussen vazalliteit en beneficium is daarmee omgekeerd: terwijl oorspronkelijk de vazalliteit de causa was van het beneficium - en men dus een leen kreeg omdat men vazal was -, wordt men nu vazal omdat men een leen heeft verworven. Lenen en de daaraan verbonden gezagsrechten zijn vererfbaar en verhandelbaar, hetgeen er toe leidt dat enerzijds onderbelening plaats vindt van (gedeelten van) lenen en anderzijds leenmannen hun bezit weten te vergroten door andere lenen te verwerven. Deze algehele feodalisatie heeft tot gevolg dat de verhouding tussen de opper-leenheer en zijn leenmannen resp. die tussen de leenman en zijn achter-leenmannen feitelijk steeds meer het karakter krijgt van een 'contract' dat wederzijdse rechten en plichten meebrengt ${ }^{15}$.

Het gezag van een landsheer bestaat in de kern uit de rechten die de Karolingische leenmannen als ambtenaren hadden uitgeoefend: de bestuurlijke leiding en het rechterschap in oude zin over de aan zijn rechtsmacht onderworpen bevolking, de militaire leiding over de weerbare bevolking e.d. Om die kern groeperen zich in de 
loop van de latere Middeleeuwen allerlei rechten die oorspronkelijk slechts aan de koning zelf toekwamen. Tal van deze 'hoogheidsrechten' (iura regalia) - die immers worden beschouwd als behorende tot het 'private' vermogen - worden verworven van de koning als tegenprestatie voor financiële bijdragen of militaire hulpverlening aan de koning, of ook wel aangematigd. Tot de iura regalia die een landsheer kan hebben, behoren bijv. het recht op diensten van de 'ondersaten', het recht op boeten en verbeurd verklaarde goederen, het bede- c.q. belastingrecht, het muntrecht, het recht van tolheffing, het recht van veer etc. ${ }^{16}$ Men kan zeggen dat het gezag van een landsheer bestaat uit een bundel van verschillende 'hoogheidsrechten', die persoonsgebonden en niet alleen levenslang maar ook erfelijk zijn ${ }^{17}$.

Die hoogheidsrechten zijn weliswaar verbonden aan een domein - dat de landsheer als leenman in (erfelijk) leen heeft van zijn leenheer -, maar dit domein (landsheerlijkheid) is zijn persoonlijke domein. Dit domein en de daaraan verbonden rechten kan hij dan ook doen vererven, verpanden, verpachten, in leen geven of vervreemden. In hedendaagse terminologie zouden we zeggen: het gaat niet om bevoegdheden van een publiekrechtelijk ambt (officium) waarvan hij de 'toevallige' drager is en die moeten worden uitgeoefend in het algemeen belang (res publica), maar om persoonlijke rechten die een economisch karakter hebben. De iura regalia berusten dus op een ongedifferentieerde vermenging van publieke overheidsbevoegdheid en privaat subjectief vermogensrecht (vermenging van 'imperium' en privaat 'dominium'). Zijn hoogheidsrechten kan de landsheer zelf of door middel van ambtenaren uitoefenen. Waar het gaat om ambten die inkomsten opleveren, geschiedt de aanstelling van ambtenaren veelal door het desbetreffende ambt aan een gegadigde te verpachten of te verpanden.

Maar de landsheren gaan ook op grote schaal over tot het uitgeven in leen of vervreemden van hun rechten tegen contraprestaties van meestal financiële aard, waardoor de begunstigden op hun beurt patrimonieel overheidsgezag verwerven. Daardoor ontstaan binnen de graafschappen en hertogdommen talrijke heerlijkheden ${ }^{18}$.

\section{Het middeleeuwse gildewezen; de opkomst van de steden}

Het tweede verbandstype dat - naast het heerschappelijk verband - overal is terug te vinden, is het door het sibbe- of broederschapsprincipe gekenmerkte gildeverband. Met het ineenstorten van het Frankische rijk en de versplintering van het koninklijk gezag in allerlei feodale en 'heerlijke' verhoudingen heeft het sibbe-principe weer de kans gekregen tot gelding te komen, en wel in de vorm van de buur- of markgemeenschappen ${ }^{19}$ en gildeverbanden. Het op het sibbe-principe gegronde gildewezen gaat dan een tegenwicht vormen tegen de op het mund-principe gebaseerde feodale heerschappij- en onderworpenheidsverhoudingen. 
De buur- of markgemeenschappen worden in de overgeleverde bronnen soms uitdrukkelijk 'gilden' genoemd; men kan zeggen dat de oudste gilden identiek zijn met die buurgemeenschappen ${ }^{20}$. Met de opkomst van de middeleeuwse stad, sluiten de poorters zich aaneen in een zgn. burg-gilde. En wanneer zich binnen de ommuring van het burg-deel kooplieden gaan vestigen in zgn. koopmanswijken, sluiten zij zich aaneen tot koopmansgilden ('hanzen'). Ook de beoefenaars van hetzelfde ambacht, die eveneens in wijken en straten bijeenwonen ${ }^{21}$, sluiten zich aaneen, en wel in ambachtsgilden. Ook deze gilden - die in oorsprong broederschappen ('fraternitates'), niet berustend op natuurlijke afstamming, zijn en berusten op vrijwillige aaneensluiting in een eedgenootschap - hebben een totalitair ongedifferentieerd karakter: zij omvatten alle leden (de gildebroeders) mét hun gezinnen naar alle levenssferen. Een van de wezenlijke kenmerken van het gildewezen is de gildedwang: alleen die poorters die het door het gilde voorgestane bedrijf of ambacht uitoefenen, kunnen tot het verband worden toegelaten, terwijl alle niet tot het gilde behorende koop- of ambachtslieden zijn uitgesloten van de mogelijkheid tot uitoefening van het desbetreffende bedrijf of ambacht (gildeban). Deze monopoliepositie weten zij te bewerkstelligen op basis van een van het stadsbestuur afgeleide competentiesfeer - die we als 'publiekrechtelijke' autonomie zouden kunnen aanduiden - met daaraan verbonden verordeningsbevoegdheden (zgn. gilde-keuren) en een eigen jurisdictie (met daaraan verbonden straf-bevoegdheden).

De macht van de gilden in de steden is immers groot, hetgeen er in veel gevallen ook toe leidt dat ze een overwegende politieke invloed in de stadsbesturen zelf weten te verwerven. Daarnaast heeft een gilde militaire taken - en is het in zoverre militair verbandsonderdeel van de stedelijke organisatie - en is het in de regel ook een kerkelijke groepsorganisatie met eigen altaar, beschermheilige en kerkelijke diensten. Het middeleeuwse gildewezen vertoont dus als ongedifferentieerd samenlevingsverband de trekken in zich van de zeer verschillende samenlevingskringen, die in de loop van het cultuurhistorische differentiëringsproces uiteen zullen gaan. Het gilde vertoont niet alleen het karakter van een private, economisch gekwalificeerde, beroeps- of bedrijfsvereniging, maar tevens dat van een broederschap die ook banden heeft met de gezinnen der gildebroeders (banden van wederkerige hulp en bijstand in alle levensomstandigheden). Bovendien maakt het als dwangverband deel uit van de stedelijke rechtskring en heeft het een eigen, van de stad afgeleide 'publiekrechtelijke' competentiesfeer, terwijl het veelal via zijn politieke leden ook deel uitmaakt van het stadsbestuur. Verder is het militair onderdeel van de stedelijke organisatie en vertoont het de structuur van een kerkelijke groepsorganisatie ${ }^{22}$.

De 'publiekrechtelijke competentiesfeer' ${ }^{23}$ van de gilden is - als gezegd - afgeleid van die van de stad, die haar op haar beurt ontleent aan een of meer privileges, dat wil zeggen: door de landsheer of grondheer (en soms de keizer ${ }^{24}$ ) verleende voor- 
rechten tot het voeren van zelfbestuur en een eigen jurisdictie. In de steden vinden we dus een vervlechting van heerschappelijke en gildestructuur (mund-principe en gilde-principe).

Deze voorrechten worden vooral in de late Middeleeuwen verkregen als contraprestatie voor financiēle steun die de lands- of grondheer van de stad ontvangt ${ }^{25}$. De formeel eenzijdig verleende privileges dragen doorgaans materieel het karakter van een 'overeenkomst' tussen de landsheer en de stad die ze ontvangt en die de inhoud ervan in hoofdzaak ook zelf heeft aangegeven. Binnen het kader van zo'n privilege kan het stadsbestuur zelf regels - stedelijke keuren ${ }^{26}$ - uitvaardigen. Voorzover ze niet door verlening van voorrechten daarvan zijn bevrijd, blijven de steden vallen onder de lands- of grondheerlijke heerschappij, die echter steeds meer zal verzwakken (totdat zich - vanaf de dertiende eeuw - een centralisatieproces gaat voordoen; daarover hierna).

Voorzover een stad wordt geprivilegieerd - stadsrecht verkrijgt -, komt zij als autonome rechtskring los te staan van de rechterlijke organisatie van het platteland, waarin het met stadsrecht begiftigde gebied gelegen is: 'stadsrecht breekt landrecht'. 'Landrecht' is de aanduiding voor het in de vorm van een privilege door de landsheer voor gehele landstreken - veelal samenvallende met de landsheerlijke gewesten - gecodificeerde gewoonterecht ${ }^{27}$.

Vooral de opkomst van de steden als autonome rechtskringen - vanaf de twaalfde eeuw - is van grote betekenis voor het cultuurhistorische en juridische differentiëringsproces, dat allengs zal leiden tot een scheiding van publieke overheidsmacht en privaat vermogensbelang en een daarmee gepaard gaande erkenning van de rechtssubjectiviteit van de 'burger' als zodanig - zowel in staatkundige als in burgerrechtelijke zin -, los van en naast zijn lidmaatschap van sociale verbanden ${ }^{28}$.

Hoezeer echter de opkomst van de steden ook van betekenis zal zijn voor de ontwikkeling van de moderne vrijheidsgedachte ${ }^{29}$, mag niet uit het oog worden verloren dat nòch de markgenootschappen, nòch de steden, nòch de gilden zich tijdens de Middeleeuwen reeds weten te verheffen boven het peil der ongedifferentieerde samenlevingsverhoudingen, hetgeen voor de erkenning van een wezenlijke individuele vrijheid een onoverkomelijke hinderpaal vormt. De rechtssubjectiviteit van de mens wordt nog steeds geheel beheerst door zijn lidmaatschap van ongedifferentieerde verbanden. Pas in het verdere verloop van het cultuurhistorische differentieringsproces zal er ruimte komen voor een private vrijheid-in-gelijkheid van de mens als zodanig, nást en onafhankelijk van zijn lidmaatschap van allerlei - dan gedifferentieerde - verbanden. Dit juridisch persoonlijkheidsbeginsel zal eerst tot uitdrukking kunnen komen tegelijkertijd met de scheiding van publieke overheidsmacht en privaat vermogensrecht ${ }^{30}$. In de middeleeuwse verhoudingen is er echter nog 
de ongedifferentieerde vermenging van imperium en (privaat) dominium; evenmin als voor het moderne burgerrechtelijke vrijheidsbegrip vinden we in deze verhoudingen dus een aanknopingspunt voor het moderne begrip van de burgerrechtelijke, private eigendom ${ }^{31}$.

Hetzelfde geldt voor het staatkundige vrijheidsbegrip: zo komen binnen de steden de staatkundige rechten niet toe aan ieder individu als zodanig, maar zijn het aan een groep personen in hun kwaliteit van leden van de poorterij toekomende voor-rechten. Het poorterschap is ook erfelijk. Zowel het staatkundige als het burgerrechtelijke vrijheidsbegrip zal pas vanaf de zeventiende eeuw tot doorbraak komen en eerst na 1789 (Franse revolutie) definitief kunnen worden gerealiseerd.

Waar voor de Middeleeuwen de term 'vrijheid' wordt gebruikt, gaat het dus niet om oorspronkelijke persoonlijke vrijheid, maar om bepaalde afhankelijkheidsverhoudingen waarvan de desbetreffende groepen van personen bevrijd zijn ${ }^{32}$. 'Rechten en vrijheden van de enkeling waren derivaten van de vrijheid van zijn stad, stand of land, waarop zijn burgerschap, zijn behoren tot een bepaalde stand, aanspraak gaven', schrijft Donner ${ }^{33}$. En deze vrijheid is niet een oorspronkelijke: 'de vrijheid' van een stad betekent slechts, dat de stedelingen - via een of meer privileges (verknegen rechten, 'iuna quaesita') - bevrijd zijn van hun verplichtingen ten opzichte van de lands- of grondheer. De 'vrijheid' kan dus de meest verschillende inhouden aannemen: zij is afhankelijk van het 'land', het markgenootschap, de stad, de beroepsstand (gilden!) etc., waartoe de desbetreffende personen behoren, terwijl binnen één verband ook nog onderscheid bestaat tussen 'volle leden' en andere leden ${ }^{34}$. 'Vrijheid' van het onmiddellijk onderdaanschap aan de landsheer betekent tegelijkertijd een alzijdige afhankelijkheid van de mens van het ongedifferentieerde samenlevingsverband waarvan hij lid is en dat, op basis van verkregen privileges, binnen een autonome rechtskring zonder inmenging van hoger gezag zijn zaken mag regelen. Hier is zeker geen sprake van het moderne staatkundige resp. burgerrechtelijke begrip van vrijheid-in-gelijkheid van iedere mens als zodanig.

Ook de middeleeuwse landrechten worden, wat het personen-, familie-, erf- en procesrecht betreft, in belangrijke mate beheerst door het principe van de zgn. 'Ebenbürtigkeit', hetgeen wil zeggen dat men in een gehele reeks van rechtsverhoudingen slechts kan treden met personen gerangschikt in dezelfde of een lagere 'stand', Vreemdelingen - dat wil zeggen: allen die niet in het territoir thuishoren en andere 'rechtlozen' - personen die geen 'stand' hebben - zijn buitengesloten en daarmee in allerlei opzicht aan de willekeur van de landsheer prijsgegeven.

En waar men bij de gerechten bescherming zoekt tegen buitensporige gezagsuitoefening, doet men dit niet met het oogmerk van de erkenning van een individueel - ook 
aan ieder ander - toekomend recht, maar ter bescherming van een bijzonder voorrecht van de groep, stand of stad, waartoe men behoort. Individuele rechtsbescherming staat dus zeker niet op de voorgrond.

Niettemin: mét de opkomst van de steden als autonome rechtskringen komt een 'derde stand' (naast adel en geestelijkheid) tot ontwikkeling, die van de stedelijke burgerij (binnen de steden verenigd in koopmans-en ambachtsgilden). Deze autonomie kan worden verstevigd en vergroot, wanneer in de late Middeleeuwen de oude beden en de opbrengsten uit de landsheerlijke domeinen niet meer voldoende zijn om te voorzien in de toenemende financiële behoeften van de landsheren. $\mathrm{Zij}$ moeten dan in stijgende mate een beroep doen op de bezittende standen van stad en land, en wel met een nieuw soort beden. Deze nieuwe beden moeten goed worden onderscheiden van de oude beden, die de landsheer op grond van een tot zijn iura regalia behorende bederecht kan heffen van zijn ondersaten, ook zonder hun toestemming. De nieuwe beden kunnen echter pas worden geheven nadat instemming is verkregen, welke instemming doorgaans aan condities wordt gebonden (bijv, nieuwe privileges) ${ }^{35}$.

\section{De opkomst van de standen 'staat'}

Aanvankelijk komen onderhandelingen tot stand tussen de landsheer en individuele steden alsook plattelandskringen ${ }^{36}$. later gebeurt dit tussen de landsheer en vertegenwoordigers van de standen (de 'staten') in het parlement, de statenvergadering (kort: de 'staten') ${ }^{37}$. Wil de landsheer geld hebben, dan verricht hij bij de staten een bede ${ }^{38}$. De staten vragen dan als tegenprestatie de erkenning van een (nieuw) privilege, dat de landsheer dan in het vervolg tegenover hen bindt.

De toegenomen betekenis van de steden - en daarmee van de stedelijke poorterij leidt dus, mede doordat de landsheer financieel op ze is aangewezen, tot de instelling van standenvergaderingen waarin de drie standen of 'staten' vertegenwoordigd zijn, en waarmee de landsheer dient samen te werken opdat regeren voor hem mogelijk blijft. De historische oorsprong van deze parlementen is te zoeken in de feodale curia regis, waarin de koning-leenheer over belangrijke zaken overleg pleegde met zijn vazallen, die hem consiulium verschuldigd waren ${ }^{39}$. De landsheerlijke raden zijn hiervan de feitelijke voortzetting. Met de toenemende - vooral financiële afhankelijkheid van de grote landsheren van de stedelijke poorterij alsook van de lagere landadel wordt de landsheerlijke raad uitgebreid met vertegenwoordigers van de stedelijke poorterij en lagere landadel ${ }^{40}$.

Als tegen het einde van de Middeleeuwen de Nederlandse gewesten geleidelijk worden verenigd onder één en dezelfde landsheer, vinden - voor het eerst in 1464 te Brugge - op verzoek van de landsheer bijeenkomsten plaats van afgevaardigden van de staten van de verschillende gewesten: de Staten-Generaal. Ofschoon in de lands- 
heerlijke parlementen de oorsprong is gelegen van de westerse representatieve democratie, zijn deze parlementen geen volksvertegenwoordiging in de latere betekenis van het woord: het gaat hier niet om representatie van de gehele bevolking maar om de behartiging van de belangen van de onderscheidene standen ('staten'!) tegenover de landsheer ${ }^{41}$.

Door de geschetste ontwikkelingen zijn aan het einde van de Middeleeuwen niet alleen de verhoudingen tussen landsheer en zijn leenmannen, maar ook die tussen landsheer en de - in de 'staten' verenigde - verschillende stedelijke en landelijke rechtskringen verhoudingen geworden die wederzijdse rechten en plichten meebrengen. Tegenover het gezag dat een landsheer op grond van zijn iura regalia kan doen gelden jegens zijn lagere heren resp. jegens de steden en plattelandskringen staan de aanspraken die laatstgenoemden, vertegenwoordigd in de staten, op grond van hun wel-verworven rechten (iura quaesita) hebben jegens de landsheer ${ }^{42}$. De idee dat deze verhoudingen wederzijdse rechten én plichten inhouden, impliceert ook een recht van ongehoorzaamheid en weerstand (het ius resistendi) bij niet-naleving door de landsheer van zijn plichten, dat wil zeggen: bij niet-respectering door de landsheer van de (voor-)rechten die de 'wederpartij' in het verleden heeft verkregen ${ }^{43}$.

De door zijn voorganger verleende privileges moeten door een nieuwe landsheer worden bezworen alvorens de staten de eed van trouw en gehoorzaamheid afleggen. De notie van een weerstandsrecht - dat uiteindelijk ook mee kan brengen dat de landsheer vervallen wordt verklaard van zijn rechten - zal een belangrijke rol zal spelen in de opstand van de Nederlanden tegen Filips II.

Men kan zeggen dat de verhouding van wederkerigheid, zoals die eertijds bestond tussen leenheer en leenmannen, waarbij beide 'partijen' hun rechten bezaten die zij wederkerig dienden te eerbiedigen, wilden samenwerking en daardoor beider rechten gehandhaafd blijven, aan het eind van de Middeleeuwen is vervangen door een wederkerigheidsverhouding tussen landsheer en staten, zijnde de vertegenwoordiging van de in standen opgesplitste bevolking. Van Apeldoorn schrijft:

'Het leenstelsel had een knak gekregen, maar het feodalisme leefde in andere vorm voort. Het dualisme van de 'leenstaat': verdeling van de macht tussen vorst en leenadel, maakte plaats voor het dualisme van de 'standenstaat': vorstenmachten standenmacht. En op de tegenwerkingvan die standen of hun vertegenwoordigers, de Staten, taai vasthoudend aan 'spetiale ende particuliere privilegien, vryheyden, exemptien, rechten', is het streven der landsheren naar centralisatie telkens gestuit' "

Reeds in het standenstaatwezen van de veertiende en vijftiende eeuw komt de publieke rechtsidee - de idee van een zelfstandig staatswezen als res publica - als reactie tegen de feodale praktijken op, waarbij de statenvergaderingen een politiek tegenwicht vormen tegenover de macht van de landsheren. Zo wordt in 1356 bij de 
bekende Blijde Incomste ('Joyeuse Entrée') van hertogin Johanna van Brabant in het zgn. Brabants Privilege aan de landsheer de medewerking der standen voorgeschreven in gewichtige zaken van publiek belang (zoals het verklaren van oorlog, het sluiten van verdragen, het slaan van de munt) en wordt de landsheer het verbod afgedwongen om grondgebied te verpanden of te vervreemden en tot het verhuren door de landsheerlijke rechterlijke ambtenaren van hun ambten ${ }^{45}$. Daaruit komt het streven naar voren van de standen om te voorkomen dat overheidsbevoegdheden door de landsheer aan zijn private vermogensbelangen dienstbaar worden gemaakt ${ }^{46}$.

Niettemin verdraagt dit standenstaatswezen met zijn dualistische machtsopbouw zich niet de publieke rechtsidee dat de Staat het karakter heeft van zelfstandige, 'einheitliche', publiekrechtelijke rechtsgemeenschap op basis van het 'Zwangsmonopol'. Dat de standen'staat' dit karakter niet heeft, komt ook hierin naar voren dat de staten geen volksvertegenwoordiging zijn doch de eigen belangen van de onderscheidene standen tegenover de landsheer behartigen. Een staatkundige vrijheid-in-gelijkheid van het individu als zodanig wordt, evenmin als een burgerrechtelijke vrijheid-ingelijkheid, ook in het standenstaatswezen nog niet erkend. Slechts binnen een echte, integrerende publieke rechtsorde zal een staatkundige rechtssubjectiviteit van ieder mens als zodanig - met rechten en plichten op gelijke voet met ieder ander, onafhankelijk van zijn lidmaatschap van sociale groepen - mogelijk worden, terwijl pas op basis van zo'n publieke rechtsorde óók de positivering van burgerlijk recht en de burgerrechtelijke vrijheid-in-gelijkheid van iedere mens als zodanig zal kunnen worden gerealiseerd.

Ook in de standen'staat' zijn de rechten van de mensen nog slechts een sequeel van de (voor-)rechten van de ongedifferentieerde verbanden waarvan zij deel uitmaken. Juridische verhoudingen in het maatschappelijk verkeer zijn hier - anders dan in het moderne burgerlijke rechtsverkeer - niet aanwezig tussen individuen als zodanig, maar slechts in de vorm van maatschapsbetrekkingen tussen de leden der verschillende (ongedifferentieerde) verbanden als zodanig. Anders gezegd: de mensen fungeren in die relaties niet als private personen, doch als leden van de sociale groep waartoe zij behoren.

De standen'staat' is een overgangsvorm in de ontwikkeling van het Westerse staatswezen, tussen het feodale bestel en de gecentraliseerde 'politiestaat' ${ }^{47}$, die vanaf het einde van de achttiende eeuw weer zal worden opgevolgd door de liberale rechtsstaat.

\section{Het centralisatieproces in de late Middeleeuwen}

De overgang naar de 'politiestaat' zal mede mogelijk worden door het centralisatieproces dat in de late Middeleeuwen plaats vindt: de macht wordt allengs weer meer geconcentreerd bij de landsheren. Zo weet de Franse koning reeds in de der- 
tiende en veertiende eeuw een centraal gezag te bewerkstelligen en de stedelijke vrijheden uit te hollen.

Dit centralisatieproces gaat gepaard met wat men een zekere 'ontpersoonlijking' van de rechtsverhoudingen zou kunnen noemen. In de eerste plaats worden - waar mogelijk - de lagere adellijke heren, wier rechten persoonsgebonden en niet alleen levenslang maar ook erfelijk zijn, vervangen door niet-adellijke ambtenaren, die worden benoemd en bezoldigd door de vorst en die hun gezag volledig aan hem ontlenen (en niet aan persoonlijke rijkdom). Ten tweede is van belang de hiermee gepaard gaande verschuiving in de opvatting betreffende de basis van de vorstenmacht. De 'Personenverbandstaat' wordt méér een 'Oberflächenstaat', aldus Van Caenegem ${ }^{48}$. Men geeft o.i. de ontwikkeling preciezer weer, door te zeggen dat het feodale dominium steeds meer wordt beschouwd als een 'staats'territoir, waarbinnen het koninklijk gezagsrecht wordt uitgeoefend. De voor het feodale bestel zo kenmerkende vermenging van dominium en imperium betekende dat het koninklijke gezagsrecht een ongedifferentieerd 'gezagsrecht op dominium' was, waarvan het gezag ten aanzien van de op dat dominium levende personen als het ware een sequeel was ${ }^{49}$. Het koninklijke gezagsrecht wordt nu meer en meer tot gezag ten aanzien van personen, levend op een bepaald afgebakend territoir. De iura regalia worden als het ware losgekoppeld van het dominium, dat nu 'staats'territoir wordt. Georg Jellinek omschrijft deze ontwikkeling als volgt:

'(D)ie Gebietsherrschaft des Königs (bildet) sich allmählich um ... zur Herrschaft über die Menschen, so dass das Gebiet zum Herrschaftsbereich wird' (curs. dzz.; JT) ${ }^{\text {*o }}$.

Deze verschuiving in opvatting wordt ongetwijfeld mede bevorderd door de receptie van het Romeinse recht ${ }^{51}$.

Een centralisatieproces doet zich ook voor in de Nederlanden, als aan het einde van de Middeleeuwen - in de vijftiende eeuw - de Bourgondische en Habsburgse vorsten het gezag in de verschillende Nederlandse gewesten hebben weten te verwerven. Deze vereniging van gewesten onder één landsheer impliceert nog niet de vestiging van een eenheidsstaat; zij betekent alleen een personele unie.

Om hun machtspositie in de gewesten te verstevigen, moeten deze vorsten in eerste instantie de lagere leenadel van zijn plaats verdringen. Daarbij vinden de vorsten veelal ondersteuning van de zijde van de steden. Maar alras streven zij er naar de gewesten samen te smelten tot een centrale eenheidsstaat, veelal met terzijdestelling van de bestaande privilegiën, ó́k die van de stedelijke standen.

De eerste fase in dit centralisatieproces is het creëren van een uniforme rechterlijke en bestuursorganisatie binnen de verschillende gewesten, door het instellen van centrale gerechtshoven ${ }^{52}$ en regeringsraden in die gewesten. Vooral de instelling van gewestelijke Hoven wordt als een ernstige inbreuk op de bestaande rechten en 
privileges beschouwd, waartoe ook het 'ius de non evocando' behoort: het recht om niet dan voor het 'eigen' gerecht terecht te staan "33.

De tweede fase in het centralisatieproces is de instelling van centrale colleges voor de gezamenlijke gewesten. Men denke aan de oprichting van de Grote Raad of Parlement van Mechelen (1473) ${ }^{54}$, bedoeld als centraal appèl-college, de Raad van State, de Geheime Raad en de Raad van Financiēn, alsmede aan het bijeenroepen van de Staten-Generaal. Zowel voor het toestaan van de gevraagde beden als om te adviseren bij het vaststellen van plakkaten die in alle gewesten zullen gelden, worden de Staten-Generaal onder Karel V vele malen bijeengeroepen, hetgeen in eerste instantie een sterke factor is in het tot stand brengen van een staatkundige eenheid.

Ook op het gebied van de wetgeving streven de Bourgondische en Habsburgse vorsten naar unificatie, door in de afzonderlijke gewesten dezelfde plakkaten en ordonnanties vast te stellen ${ }^{55}$. Men denke aan de door Karel V en Philips II tussen 1531 en 1569 uitgevaardigde ordonnanties tot optekening door steden en landschappen van hun costumen ('gewoonterecht') met bevel deze ter homologatie (goedkeuring) toe te zenden, en aan de bekende Ordonnanties van Philips II uit 1570 op de Criminele Justitie resp. op de Stijl van procederen in criminele zaken ${ }^{56}$.

Verder wil de landsheer zich ook op het terrein van de financiën onafhankelijk maken ten opzichte van de staten, en wel door de invoering van vaste belastingen. Bekend is de beoogde invoering in 1569 onder Philips II van de tiende en twintigste penning, d.w.z. heffingen van tien resp. twintig procent op de verkoop van roerend resp. onroerend goed. Van Apeldoorn schrijft:

'Was de landsheer erin geslaagd vaste, blijvende belastingen in te voeren ter vervanging van de buitengewone beden, dan zou hij onafhankelijk geworden zijn van de Staten en zouden deze de vestiging van een eenheidsstaat onder het absolute gezag van de vorst niet hebben kunnen verhinderen' ${ }^{27}$.

Terwijl de staten van oordeel zijn dat de landsheer slechts aanspraak kan maken op - naast de opbrengsten van zijn domeinen - de hem door de staten toegestane beden, stelt de landsheer zich op het standpunt dat hij als soeverein bevoegd is zonder toestemming van zijn onderdanen belastingen op te leggen.

Deze en andere maatregelen stuiten op groot verzet van de staten, omdat zij menen dat daardoor hun privileges en oude costumen geschonden worden. Terwijl de staten zich op het standpunt stellen dat de landsheer alleen beschikt over de rechten die van oudsher tot zijn landsheerlijkheid behoren (de iura regalia) en waar tegenover staan de verworven rechten der ondersaten - beter: die van de bijzondere rechtskringen (steden, standen, corporaties) -, uitgeoefend en bewaakt door met name de statenvergadering, wordt door de landsheer en zijn ambtenaren de stelling ingenomen dat hij een soevereiniteit ter bevordering van het algemeen belang heeft, waarvan niet 
geheel of gedeeltelijk afstand kan worden gedaan door het verlenen van privileges ('plenitudo potestatis'), en dat hij uit dien hoofde bevoegd is om eenzijdig algemeen geldende ordonnanties en belastingen in te voeren ${ }^{58}$.

Deze nieuwe opvatting was in ons land reeds verdedigd door Philips van Leiden in zijn omstreeks 1355 geschreven 'Tractatus de cura reipublicae et sorte principantis'. Daarin betoogt hij dat de vorst de overheidsmacht als een onvervreemdbaar, één en ondeelbaar goed rechtstreeks over de onderdanen dient uit te oefenen, en dat het algemeen belang de vorstelijke macht rechtvaardigt. Alle heerlijke rechten waarbij derden stukken overheidsgezag als privaat vermogensgoed bezitten, zouden daarom ongedaan dienen te worden gemaakt ${ }^{59}$.

Ondanks de pogingen van de Bourgondische en Habsburgse vorsten, zal deze - later door Jean Bodin binnen het kader van zijn staatsabsolutistisch souvereiniteitsbegrip uitgewerkte (waarover hiernà) - opvatting hier te lande uiteindelijk (nog) niet tot gelding blijken te kunnen komen.

De opstand tegen Spanje, die uiteindelijk leidt tot de afzwering van de landsheer bij het door de Staten-Generaal op 29 juli 1581 vastgestelde Plakkaat van Verlatinge ${ }^{60}$, is niet een strijd voor 'de vrijheid' - het gaat niet om de 'natuurlijke' vrijheid in staatkundige resp. burgerrechtelijke zin - maar voor het behoud van de onaantastbaar geachte privileges, de voor-rechten van de bijzondere rechtskringen van ongedifferentieerd karakter. Het betreft dus nog steeds rechtsposities die berusten op een vermenging van publieke overheidsbevoegdheden en private vermogensbelangen, welke posities als verkregen rechten door de 'wederpartij' zouden moeten worden gerespecteerd. Het verlatingsrecht wordt gebaseerd op schending door de landsheer van de 'privilegien, costumen en oude hercomen' van zijn onderdanen (nl. de Nederlanden), die immers hun eed van trouw hebben gezworen 'op conditien, contracten ende accoorden, die welcke brekende oock nae recht de Prince van de heerschappij van den lande is vervallen'. Fruin merkt op:

'(B)ij de Nederlanders heerschte toen nog, meer dan de moderne, de middeleeuwsche opvatting. Grondslag der verhouding tusschen vorst en volk was de huldigingseed. Breekt de natie haar eed, dan verliest zij haar privilegie; breekt de vorst den zijnen, dan verliest hij de regeering' ${ }^{61}$.

De rechtsontwikkeling onder de Republiek der Zeven Verenigde Nederlanden wordt door De Monté Verloren/Spruit als volgt beschreven:

'Vanuit rechtshistorisch oogpunt bezien, is de periode van de Republiek van minder groot belang dan de voorafgaande. De rechterlijke organisatie bleef in grondtrekken gelijk aan die uit de late middeleeuwen. Hoewel de rechtsontwikkeling niet stilstond, hebben zich in het bestel van de rechtskringen, in de grondbezitsverhoudingen en de daarmede samenhangenderechten, en de standenstructuur, geen fundamentele wijzigingen voorgedaan. (....) (De) locale codificaties daargelaten, is er op het gebied van de rechtsvernieuwingen de unificatie van het recht ... niet veel gebeurd. Een 
boven-gewestelijk recht is niet ontstaan. De opstand tegen de landsheer heeft in de noordelijke Nederlandenhet centraliserend en unificerend streven van de Bourgondischeen Habsburgse vorsten afgebroken. (....) In het algemeen kan gesteld worden, dat de continuitteit, zowel in formele als in materiele zin, tussen de laat-middeleeuwseperiode en de Republiek zeer sterk was, ja dat er op het gebied van de rechterlijke organisatie, het recht en de rechtsvormingmeestal identiteit is blijven bestaan' *.

Pas een nieuwe 'revolutie' - die van 1795 - zal in de Republiek de eenheidsstaat als res publica en de definitieve erkenning van zowel de staatkundige als de burgerrechtelijke vrijheid-in-gelijkheid van ieder individu als zodanig, met - als keerzijde daarvan - erkenning van het principiële onderscheid tussen publiek- en privaatrecht, onder gelijktijdige afbraak van de ongedifferentieerde rechtskringen met hun vermenging van imperium en dominium (o.a. definitieve afschaffing heerlijke rechten, gilde- en standenbestel), brengen. De idee van een publieke rechtsorde eist immers de erkenning van de overheidsmacht als publiek ambt en haar scherpe onderscheiding van private vermogensrechten. Met de Bataafse 'revolutie' van 1795 worden de opvattingen die tot gelding zijn gekomen in de Franse revolutie (1789), naar de Republiek geëxporteerd. En de Franse revolutie is 'slechts' het resultaat van een historisch differentiërings-, individualiserings- en integreringsproces, dat met de afbraak van het feodale bestel gestalte krijgt in de opbouw van de gecentraliseerde 'politiestaten' (o.a. in Frankrijk ${ }^{63}$ ).

\section{De receptie van het Romeinse recht}

Van nauwelijks te onderschatten belang voor dit proces is de receptie van het Romeinse recht in de latere Middeleeuwen, welk recht als aanvulling van het inheemse recht zal worden overgenomen: het wordt het gemene recht bij uitstek ${ }^{\text {64 }}$ en zal daardoor een blijvende invloed op de westerse rechtsontwikkeling verkrijgen. Juist de verbrokkeling en het gebrek aan uniformiteit van het in talloze ongedifferentieerde rechtskringen geldende inheemse recht, bevordert de receptie van het Romeinse recht zeer ${ }^{65}$. Mede onder invloed van het Romeinse recht raken op het Europese continent de idee van de Staat als res publica en de idee van een burgerlijk recht dat als zelfstandig rechtsgebied is gebouwd op de grondslag van de burgerlijke vrijheid en gelijkheid van de mens als zodanig ingeburgerd, welke ideeën door de Franse revolutie over de gehele linie definitief zullen worden verwezenlijkt. Voor de opkomst van een modern staatsinstituut is de receptie van het Romeinse recht reeds hierom van grote betekenis, omdat de juristen in allerlei - overigens vaak uit hun verband gerukte - citaten uit het gerespecteerde Corpus Juris Civilis een juridisch fundament weten te vinden voor een sterk centraal monarchaal gezag ${ }^{66}$. 


\section{Het middeleeuwse recht als ongedifferentieerd recht; de 'naieve school' der} gemene rechtsleer

In de negentiende en twintigste eeuw zal het middeleeuwse recht veelal als 'privaatrechtelijke rechtsorde' worden gekwalificeerd. Dit is onjuist. Dooyeweerd merkt terecht op:

'Het middeleeuwse rechtsleven, zoals het zich vóór de receptie van het Romeinse recht en vóor de doorbraakvan de moderne staatsidee vertoonde, droeg geheel de karaktertrekkenvan de samenleving waartoe het behoorde. Voor de onderscheiding van de intrinsiek aan de staatsstructuur gebonden gedifferentieerderechtssferen van het publiek recht en het burgerlijk privaatrecht was hier nergens een aanknopingspuntte vinden' 6 .

De door de Duitse rechtshistoricus $\mathrm{G}$. von Below ${ }^{68}$ ondernomen poging om deze onderscheiding hier wèl terug te vinden, moet als onvruchtbaar worden beschouwd, omdat zij geen rekening houdt met de ongedifferentieerde structuur der middeleeuwse samenleving. Ook een zuiver privaatrechtelijke opvatting van de middeleeuwse gezagsverhoudingen is onjuist, omdat zij het ongedifferentieerde karakter van die verhoudingen negeert. Waar Dooyeweerd betoogt dat de onderscheiding van de gedifferentieerde rechtssferen van het publiekrecht en van het burgerlijk privaatrecht 'intrinsiek aan de staatsstructuur gebonden' is, brengt hij tot uitdrukking dat slechts op basis van een integrerende publiekrechtelijke rechtsorde van de Staat, waarin alle mensen als zodanig binnen het staatsterritoir gelijkelijk als rechtssubject worden erkend (staatkundige vrijheid-in-gelijkheid), een op de beginselen van de burgerlijke vrijheid en gelijkheid rustend burgerlijk recht - als integrerende burgerrechtelijke rechtsorde - kan worden gepositiveerd ${ }^{69}$. Een burgerlijke rechtsorde is niet mogelijk zonder een wezenlijke Staat. En die ontstaat eerst vanaf de vijftiende eeuw.

Door auteurs als Hamaker, Krabbe en Vegting is mede een historische onderbouwing gegeven aan de door hen verdedigde gemene rechtsleer. De rechtsontwikkeling wordt door Hamaker aldus aangeduid, dat het privaatrecht 'het oude traditionele' - reeds in de Middeleeuwen ook voor de overheid geldende - recht is, 'dat een ieder bindt jegens een ieder, het cement van de maatschappij, de grondslag van het maatschappelijk leven' ${ }^{70}$, hetgeen eerst zou zijn veranderd onder het vorstenabsolutisme met het ontstaan van de regel 'princeps legibus solutus est', waarna met het wegvallen van het vorstenabsolutisme weer de oude verhouding zou zijn herleefd. Terwijl het privaatrecht daarmee wederom het (al)gemene recht zou zijn geworden, zou het publiekrecht het nieuwe - na de Middeleeuwen en met de absolute Staat opgekomen - recht zijn, dat slechts aanvullingen of uitzonderingen op het privaatrecht als het (al)gemene recht bevat.

Met een beroep op de middeleeuwse rechtstoestanden betogen Krabbe en Vegting, dat er géén materieel onderscheid bestaat tussen privaat- en publiekrecht, terwijl Hamaker met een beroep op diezelfde rechtstoestanden betoogt dat er sprake is van 
een principiēle tegenstelling tussen beide, maar de opvattingen corresponderen in die zin dat het privaatrecht het algemene recht zou zijn terwijl het publiekrecht daarop aanvullingen c.q. uitzonderingen bevat. De reden dat Hamaker een principiēle tegenstelling meent te zien, is dat hij aan het publiekrecht het eigenlijke rechtskarakter ontzegt:

'Ja, ik geloof te kunnen aantoonen, dat dit verschil zo wezenlijk is, dat men zich gedrongen kan voelen tot de vraag, of wel privaat- en publiekrecht beide gelijkelijk aanspraak hebben op den naam van recht. (...) Ik denk daaraan, dat het publiekrecht, juist als het aan de overheid de middelen en bevoegdheden ter uitvoering van haar taak verschaft, een inbreuk is op het privaatrecht, de strekking heeft aan de overheidspersonen bij de volvoering van hun taak vrijdom te geven van het privaatrecht, hun de bevoegdheidte verieenen tot aanslagenop het leven, de vrijheid, den eigendom en de beurs der ingezetenen. Voorwaar eene opvallendeverhoudingtusschen privaat-en publiekrecht en die wel recht geeft hier van een tegenstelling te spreken: eene verhouding als die tusschen den regel en de uitzondering, tusschen water en vuur. (...) Wat we noemen privaatrecht, maar eigenlijk eenvoudig recht moest heeten, is in werkelijkheid niets anders dan de inhoud van het rechtsbewustzijn. (...) Wat we noemen publiek-recht, daarentegen, is het Overheidsbevel in den vorm der wet'.

Over de 'maatschappelijke toestand' tot aan het eind der Middeleeuwen merkt Hamaker dan ook op, dat men deze:

'pleegt ... aan te duiden met het woord privaatrecht; alles was privaatrecht, zegt men, of werd privaatrechtelijk opgevat. Beter schijnt mij te zeggen: alles was recht. De overheid ... stond niet boven maar in het recht, dat hem bond gelijk den minste zijner onderzaten, zooals thans de rijke er aan onderworpen is zoo goed als de arme'.

Hoe foutief deze opvattingen zijn, is hierboven reeds in het licht gesteld: men kijkt met een moderne, privaatrechtelijke bril naar het oude recht en trekt dan uit het feit dat in het feodale bestel stukken 'overheidsgezag' werden beschouwd als private vermogensbelangen - 'zaken in den handel' - de conclusie dat het ging om een privaatrechtelijke rechtsordening. Exemplarisch is het volgende betoog van Krabbe:

'Het leenstelsel is een privaatrechtelijke gezagsordening en overheidsrecht wordt verkregen uit krachte van het contract, de rechtsvorm van het privaatrecht. De Staat is niet alleen onder het gemeene recht gesteld, maar ook geen ander recht dan dit is voor zijn samenstelling en bevoegdheid denkbaar' 7 .

\section{Vergelijkbare opmerkingen maakt Krabbes leerling Huart:}

'(De opvatting) dat in principe de, in de middeleeuwen wortelende fundamentele eenheid van alle recht gehandhaafd blijft en dat men slechts dan zijn toevlucht neemt tot een van het gemeene afwijkend recht, wanneer het keurslijf van het privaatrecht den Staat te zeer zou bemoeilijken bij de volvoering van zijn taak, is eenvoudig de weerspiegeling van de grondslagen van ons rechtssysteem' $n$.

Vegting merkt op dat, indien in Nederland 'de regel dat privaatrecht is het gemeene recht' geldt, zal moeten worden aangetoond

'dat uit de rechtsontwikkeling, zooals die zich hier te lande heeft afgeteekend, volgt dat het private recht ook gelding had voor de overheid, dat eerst de in de $19 \mathrm{e}$ eeuw ontstane denkbeeldenover het 
bestaan van een scherpe scheiding tusschen privaat- en publiekrecht twijfel hierover hebben doen ontstaan. (...) Hamaker's globale aanduiding van de rechtsontwikkeling wijst in die richting'.

Bij Hamakers beschrijving plaatst Vegting enige notities, 'notities intusschen, die zijn conclusie voor het geldende recht niet verzwakken maar versterken'. Zo stelt Vegting de vraag of de regel 'princeps legibus solutus' in ons land ooit heeft gegolden:

'Heeft hier de vorst absoluut geregeerd, en zoo ooit, had dan ook na 1581 de overheid absoluut gezag?' $n$

Volgens Vegting had in ons land het privaatrecht ook ná de Middeleeuwen de functie van gemeen recht.

Vegting brengt hier de grote betekenis van de Franse revolutie 6́ók voor ons land niet eens ter sprake! De rechtshistorische beschouwingen van Hamaker, Krabbe, Huart en Vegting zijn schoolvoorbeelden van 'het toepassen van moderne denkvormen en begrippen op het oude recht' ${ }^{74}$. Miskend wordt dat het moderne burgerlijk recht zowel de wezenlijke staatsidee als de verwezenlijking van de juridische vrijheid en gelijkheid van iedere mens als zodanig vóoronderstelt; beide ontbreken in de Middeleeuwen. Evenmin als het middeleeuwse recht publiekrecht is, is dit recht te beschouwen als burgerlijk recht - de 'burger' bestaat nog niet eens! -; het is ongedifferentieerd recht waarin 'overheidsgezag' wordt beschouwd als privaat vermogen. En het in het burgerlijk recht erkende beginsel van de contractsvrijheid in materiële zin - dat door Krabbe en anderen wordt teruggeprojecteerd in de Middeleeuwen is vooral uitgewerkt door natuurrechtelijke schrijvers uit de zeventiende en de achttiende eeuw ${ }^{75}$.

Wat door de 'naïeve school' óók steeds over het hoofd wordt gezien, is dat het begrip 'burgerlijk' c.q. 'civiel' vóór het revolutietijdperk een veel ruimere betekenis had dan het nadien zou krijgen; oudtijds overlapten het begrip 'burgerlijk' ('civiel') en het begrip 'politie' elkaar grotendeels ${ }^{76}$.

Exemplarisch is ook dat Hamaker voortdurend spreekt van 'de maatschappij', en hij het privaatrecht ziet als 'het oude traditionele recht ..., het cement van de maatschappij, de grondslag van het maatschappelijk leven'. Het begrip 'maatschappij' ('civil society') is eerst opgekomen na de zeventiende eeuw, als tegenstelling tot de 'Staat'. 'Maatschappij' vóóronderstelt geïndividualiseerde betrekkingen tussen burgers en/of sociale groepen, op voet van juridische vrijheid-in-gelijkheid, waarbinnen men zijn eigen private belangen kan nastreven, en als tegenhanger een afzonderlijk staatsinstituut als res publica.

Reeds omdat het beeld dat auteurs als Hamaker, Krabbe, Huart en Vegting hebben geschetst van de historische rechtsontwikkeling vertekend is $"$, had - bij nadere beschouwing - bij aanhangers van de door deze auteurs verdedigde gemene rechts- 
leer toch op zijn minst twijfel moeten rijzen over de juistheid van door hen uit deze ontwikkeling getrokken conclusie, namelijk dat het privaatrecht het algemene, ook voor 'de overheid' geldende recht is.

Een juister beeld van de rechtsontwikkeling vanaf de Middeleeuwen geeft Radbruch, die deze ontwikkeling beknopt als volgt samenvat:

'Die Û̉berwindungdes Feudalismus fiel mit der Bewusstwerdung des Unterschiedsvon privatem und ôffentlichem Recht zusammen. Die Entwicklung zum Polizeistaat offenbarte sich in der Befreiung des offentlichen Rechts von privatrechtlichen Verunreinigungen, die parallele Entwicklung der Anfânge des Rechtsstaats umgekehrt in der Befreiung des Privatrechts aus offentlich-rechtlichen Bindungen' $n$.

De periode van de absolutistische politiestaat breekt aan in de zestiende eeuw. De feodale verhoudingen en instellingen zullen in die periode geleidelijk worden afgebroken, om pas met de Franse revolutie geheel te worden afgeschaft. 


\section{Noten bij hoofdstuk 1}

1. Beroemd is de definitie van Ulpianus in zowel de Digesten als de Instituten (Dig. $1,1,1,2 ;$ Inst. 1,1,4): '...publicum ius est, quod ad statum rei Romane spectat; privatum quod ad singulorum utilitatem pertinet... $\therefore$ Hiermee is overigens niet gezegd dat de romeinsrechtelijke onderscheiding (geheel) correspondeert met ons onderscheid tussen publiek-en privaatrecht. $\mathrm{Vgl}$. over het verschil tussen ius publicum en ius privatum: B. Hermesdorf, 'Schets der uitwendige geschiedenis van het Romeinse recht', 7e druk, Utrecht 1971, pp. 17 e.v.: G.C.J.J. van den Bergh, 'lets over publiek- en privaatrecht', in: 'Ter recognitie' (Van der Linden-bundel), Hilversum 1987, pp. 9-17.

2. $\quad \mathrm{Vgl}$. H. Dooyeweerd, 'Vernieuwing en bezinning' (bewerking door J.A. Oosterhoff), Zutphen 1959. i.h.b. pp. 51 e.v.; dez.. 'Verkenningen in de wijsbegeerte, de sociologie en de rechtsgeschiedenis', Amsterdam 1962, i.h.b. pp. 116 e.v. Aan Dooyeweerds beschrijving en analyse van het cultuurhistorisch differentiërings-, individualiserings- en integreringsproces hebben we veel kunnen ontlenen.

3. Het begrip 'staat' heeft in de Middeleeuwen dan ook niet de betekenis die het later zal krijgen. 'Status' betekent niets anders dan 'toestand'. In middeleeuwse oorkonden wordt wel gesproken van 'status rei': de toestand van het koninkrijk. Later zal het tweede substantief weggevallen en krijgt 'staat' zijn huidige betekenis. 'De Staat' zal allengs belangrijker worden dan het koningschap: het publiek gezag wordt ontpersoon-lijkt, ver-ambtelijkt.

4. $\mathrm{VgI}$. $\mathrm{H}$. Dooyeweerd, 'De strijd om het souvereiniteitsbegrip in de modeme rechts- en staatsleer', rede t.g.v. 70e herdenking van de stichting der VU op 20 oktober 1950, Amsterdam 1950, p. 5/6, alwaar ook wordt opgemerkt dat deze onderlinge verhouding beantwoordt aan het rooms-katholieke grondmotief: het motief van natuur en genade. En: 'Het sacrum imperium romanum en de kerk omvatten de gehele christenheid, waarvan de keizer als het wereldlijk en de paus als het geestelijk hoofd werd beschouwd. Maar het gezag van de keizer steunde tot de $14 \mathrm{e}$ eeuw goeddeels op de kerk'.

5. Vgl. R.C. van Caenegem, 'Over koningen en bureaucraten', 2e druk, Amsterdam/Brussel 1980, p. 168 , die verwijst naar de krachtige kerkelijke sancties van excommunicatie en interdict. Bij excommunicatie wordt de betrokkene door de kerkelijke overheid uit de gemeenschap van gelovigen gestoten, hetgeen in een monolithisch-christelijke samenleving neerkomt op uitstoting uit alle beschaafde samenleving. Het interdict is een drukkings- en strafmiddel waarbij de kerkelijke diensten worden geschorst tot bepaalde maatregelen van de wereldlijke overheid zijn ingetrokken.

6. Vgl. Dooyeweerd, 'De strijd om het souvereiniteitsbegrip', a.w., pp. 5-7.

7. 'Feodaal' is ontleend aan 'feudum': leen

8. Op dit primitieve 'Führer-' en 'Gefolgschaftsprincipe' is overigens teruggegrepen in het Derde Rijk.

9. Vgl. P. Gerbenzon, N.E. Algra, 'Voortgangh des rechtes', 4e druk, Groningen 1975, p. 35/36, 47, en Dooyeweerd, 'Vemieuwing en bezinning', a.w., p. 73-75.

10. Vgl. H.J. van Eikema Hommes, 'Hoofdlijnen der rechtssociologie en de materiēle indelingen van publiek- en privaatrecht', Zwolle 1975, pp. 30-33.

11. De hoogste, direct met de koning verbonden laag is die der grote heren: strijdmakkers, metgezellen (comites), raadgevers, deels ook huisgenoten van de koning.

12. Door de glossatoren zal een onderscheid worden gemaakt tussen het dominium directum van de leenheer en het dominium utile van de leenman. Ulrik Huber (1636-1694) spreekt later van 'oppereigendom' en 'nuttelijk eigendom'. Op de onderscheiding tussen dominium directum en dominium utile is de latere theorie van het zgn. 'dominium eminens' (oppereigendom = opperheerschappij van de landsheer) terug te voeren, die nog besproken zal worden.

13. Zie over de term 'dominium' de uiteenzettingen bij G.C.J.J. van den Bergh, 'Eigendom. Grepen uit de geschiedenis van cen omstreden begrip', 2e druk, Deventer 1988, m.n. pp. 7-9, pp. 36-38, p. $45 / 46$ en p. 59, alwaar wordt gewezen op de verschuivingen in de betekenis die dit begrip in de loop van de tijd heeft gekregen. Pas in de nieuwe tijd zal men gaan onderscheiden tussen politieke heerschappij ('imperium', 'dominium civile') en privaateigendom ('dominium privatum'). Een scheiding tussen beide 
wordt - zoals Van den Bergh terecht opmerkt - eerst mogelijk wanneer men sedert de $18 \mathrm{e}$ eeuw, en in het bijzonder vanaf de Franse revolutie, het onderscheid van publiek-en privaatrecht als constitutioneel beginsel definieert. De scheiding van 'imperium' (publiekrechtelijke bevoegdheden) en 'dominium' (in de zin van privaat domein) c.q. tussen publiekrecht en privaatrecht gaat - aldus Van den Bergh weliswaar terminologisch terug op Romeinse teksten, maar krijgt dan pas een nieuwe, politiek-constitutionele betekenis.

Wanneer wij hierna zeggen dat het feodale bestel wordt gekenmerkt door een ongedifferentieerde vermenging van 'imperium' en 'dominium', gaan we dus uit van een wezenlijke onderscheid dat pas na de Franse revolutie is voltrokken. Zoals ook Van den Bergh, a.w., p. 9, terecht opmerkt, zal men teneinde de geschiedenis te kunnen begrijpen en verklaren, veelal gebruik moeten maken van pas later ontwikkelde onderscheidingen en begrippen, van 'anachronistische begrippen'.

14. Het woord 'landsheer' komt overigens eerst in zwang vanaf de 13 eeuw, tezelfdertijd als zich de hiema nog te bespreken verschuiving van 'Personenverbandsstaat' naar 'Oberflachenstaat' voordoet.

15. R.C. van Caenegem, 'Geschiedkundige Inleiding tot het Recht, II. Publiekrecht', Brussel 1988, p. 52: '(D)it was tweerichtingverkeer tussen de top en de basis en deze laatste kon de leenheer-koning ter verantwoording roepen in geval van onrechtmatig optreden en hem zelfs de leentrouw opzeggen indien hij zijn gedrag niet verbeterde'. De verhouding tussen (achter-)leenmannen en hun 'ondersaten' blijf echter een (eenzijdige) heerschappij- en onderworpenheidsverhouding (mund-principe).

16. Vgl. J.Ph. de Monté Verloren, J.E. Spruit, 'Hoofdlijnen uit de ontwikkeling der rechterlijke organisatie in de Noordelijke Nederlanden tot de Bataafse omwenteling', 5e druk, Deventer 1972, pp. 101-119, die inzake het bederecht opmerken dat 'bede' of 'precarium' de aanduiding is van de belasting, bezien vanuit het oogpunt van de landsheer, die echter, hoezeer aan de bede in oorsprong ook cen weigerbaar verzoek ten grondslag gelegen moge hebben, rechtens een vordering heeft tot betaling van de bede door zijn onderzaten. Deze bedegerechtigheid moet goed worden onderscheiden van het nieuwe soort beden, die in de late Middeleeuwen - in de $14 \mathrm{e}$ en vooral in de $15 \mathrm{e}$ eeuw - ontstaan, welke de landsheer pas kan heffen na toestemming te hebben verkregen van de standen.

17. Men kan nog een onderscheid maken tussen de hoogheidsrechten als de heerlijke rechten in eigenlijke zin (de regalia majora), en de regalia minora, d.w.z. de heerlijke rechten om bij uitsluiting binnen de omgrenzing van een heerlijkheid te jagen, te vogelen, te vissen etc, welke rechten in latere tijden veelal afzonderlijk - dus los van het domein - worden verhandeld. Ze verliezen dan hun heerlijk karakter; worden ze later toevallig met de heerlijkheid wederom in één hand verenigd, dan worden ze weer heerlijk als voorheen.

18. Vgl. De Monté Verloren/Spruit, a.w., p. 35 en pp. 125-134; A.S. de Blécourt, 'Heerlijkheden en heerlijke rechten', Tijdschrift voor rechtsgeschiedenis 1918-1919, pp. 45-107; 175-190; 489-519; 19201921. pp. 42-134; 163-219. De Blécourt omschrijft 'heerlijkheid' als 'een stuk overheidsgezag, dat men niet als ambtenaar, derhalve niet als ondergeschikte uitoefent, maar dat men als eigen erfelijk recht - zij het ook gemeenlijk in leen - heeft'. De kern van het gezag van de heren is - aldus dMV/S - gelegen in het recht op het rechterschap in oude zin met de daaraan verbonden opbrengsten van de jurisdictic, zoals boeten en bedragen, die de heer ontvangt van ambtsdragers die hij daartoe mag aanstellen. De meeste heerlijkheden worden in leen gehouden van de landsheer (zgn. feodale heerlijkheden), maar daarnaast komen in de late middeleeuwen sporadisch ook zgn. allodiale heerlijkheden voor, die ontstaan als de landsheer de desbetreffende heerlijke rechten in vrije eigendom verkoopt of schenkt. 'Allodiaal' of 'edeleigen goed' is al hetgeen met iure suo bezit, zonder dat men het 'houdt' van een 'heer', 'Feodaal' daarentegen is datgene, wat men 'houdt' in leen in de ruime zin van het woord, d.w.z. voor welks bezit men de 'man' van een 'heer' is.

19. Ongedifferentieerde genootschappen voor de exploitatie van collectieve gronden en wateren, gekarakteriseerd door wederzijdse hulp-en bijstandsverlening in alle levensomstandigheden. Zie De Monté Verloren/Spnit, a.w., pp. 60-67 en pp. 132/133; Gerbenzon/Algra, a.w., p. 120/121.

20. Vgl. Dooyeweerd, 'Vernieuwing en bezinning', a.w., p. 74.

21. Ook uit dit bijeen wonen op hetzelfde territoir, komt naar voren dat het gildeverband behoort tot dezelfde verbands-hoofdvorm als de buur- of markgemeenschap. 
22. Dooyeweerd, 'Vernieuwing en bezinning', a.w., pp. 223 e.v.

23. 'Publiekrechtelijk' is hier, wederom, tussen aanhalingstekens geplaatst, omdat de hier bedoelde autonomie niet kan worden verstaan wat we in onze huidige samenleving daaronder verstaan. Haar grenzen zijn niet bepaald door het algemeen belang (res publica) van een staatsgeheel, maar louter formeel door privileges. Er is sprake van een vermenging van 'imperium' en 'dominium': het 'publiek' belang valt samen met het eigen, private belang.

24. De desbetreffende steden - die dus geen andere wereldlijke heer boven zich hebben dan alleen de keizer - worden ook wel 'rijksonmiddellijke steden' genoemd.

25. Veelal is het 'stadrecht' dat de landsheer aan de steden sehenkt, slechts een sanctionering van de rechten die de stedelingen zich reeds in feite hebben toegeezigend; de bestaande toestand wordt erkend in de vorm van een officicel privilege. Verder is - aldus De Monté Verloren/Spruit, a.w., p. 147 - bij enige van de oudste steden in de noordelijke Nederlanden, zoals Utrecht, Groningen, Deventer en Tiel, van uitdrukkelijke verlening van stadsrecht waarschijnlijk geen sprake geweest, maar heeft zich onder de in deze nederzettingen gevestigde koop-en ambachtslieden langs gewoonterechtelijke weg een recht van stedelijk karakter en een stedelijke rechterlijke organisatie ontwikkeld, welke blijkbaar door de landsheer stilzwijgend is erkend.

26. Het karakter van zelfgekozen recht ligt trouwens in het woord keur ( $=$ keuze $)$ besloten. Binnen het kader van het stadsrecht (het recht van de 'polis') ontstaat het begrip 'politie'. In eerste instantie wordt met 'politie' gedoeld op de opbouw van de binnen het stedelijk territoir (binnen de stadsmuur) aanwezige samenleving (de stedelijke huishouding), die mede wordt geregeld op basis van stedelijke keuren, die later ook politieverordeningen worden genoemd. Vanaf de $16 \mathrm{e}$ eeuw wordt de aanduiding 'politie' ook gebruikt voor maatregelen van dezelfde soort voor het gehele 'land', getroffen door de soevereine vorst of - namens hem - door zijn ambtenaren. De absolute staten die ontstaan na de Middeleeuwen worden daarom ook wel aangeduid als 'politiestaten', en de algemene bevoegdheid van de vorst wordt wel zijn 'ius politiae' genoemd. Op deze ontwikkeling zullen we hierna nog uitgebreid ingaan.

27. Een voorbeeld is het Drentse Landrecht van 1412, gegeven door bisschop Frederik van Blankenheim. en het Overijsselse Landrecht. Vgl. Gerbenzon/Algra, a.w., p. 70/71 en De Monté Verloren/Spruit, a.w., p. 171/172, die ook opmerken dat door deze afbrokkeling van het centrale gezag ook de hegemonie van het personaliteitsbeginsel verbleekt om steeds meer plaats te maken voor het territorialiteitsbeginsel.

28. Vgl. Otto von Gierke, 'Das Deutsche Genossenschaftsrecht', Bd. II, Berlin 1877, Par. 24 e.v., m.n. Par. 25: 'Die Stadtpersōnlichkeit und das Stadtrecht'.

29. Het woord 'burger' komt trouwens van het laat-Latijnse 'burgus', het Franse 'bourg' en het Nederlandse 'burg': in de Middeleeuwen een versterkte woonplaats (waanit de stad zou ontstaan). Vgl. ook de bekende uitspraak: 'Stadtluft macht frei'.

30. Zie H.J. van Eikema Hommes, 'De elementaire begrippen der rechtswetenschap', Deventer 1972, pp. 484-488.

31. Zo is bijv, ook in de zgn. vrije markgenootschapen het dominium van de eigengeërfden niet een burgerrechtelijk vermogensrecht (in de huidige betekenis), maar een ongedifferentieerd recht waarvan tevens de 'publiekrechtelijke bevoegdheden' tot het medebestuur van het markgenootschap, aandeel in het keurrecht en in de eigen rechtspraak essentièle en onafsplitsbare bestanddelen vormen. De overdracht van de 'eigendom' van een hoeve, impliceert dus tevens de overdracht van 'publiekrechtelijke bevoegdheden' (cum politia et justitia). Daarom is deze overdracht niet volkomen vrij, maar aan allerlei beperkende bepalingen in de buurschaps- of markekeuren onderworpen.

32. 'Privi-lege' betekent trouwens naar de letter ook: bevrijding van 'wet(ten)'.

33. C.W. van der Pot, A.M. Donner, 'Handboek van het Nederlandse Staatsrecht', 9e druk, Zwolle 1972. p. 456.

34. Bijv. binnen de markgenootschappen tussen volle geěrfden en andere leden; binnen de gilden tussen enerzijds de volle bedrijfs- of beroepsgenoten (de gildebroeders) en anderzijds de blote schutsgenoten (de vrouwen en kinderen, behorende tot de gezinnen der gildebroeders), terwijl - ingeval een gilde een 
'publiekrechtelijke competentiesfeer' heeft verkregen - ook een onderscheid bestaat tussen de politieke en andere bedrijfs- of beroepsleden.

35. Vgl. De Monté Verloren/Spruit, a.w., pp. 106-108, die opmerken dat de beden daarmee ook meer het karakter krijgen, dat het woord 'bede' aangeeft: dat van een verzoek dat - al komt dit niet veelvuldig voor - geweigerd kan worden. Vgl. ook F.H.M. Grapperhaus, 'Belasting, vrijheid en eigendom. Hoe belastingheffing leidde tot meer zeggenschap voor burgers en meer eenheid tussen staten', Zutphen 1989. Grapperhaus beschrijft het verband tussen de belastingheffing (de beden) en de opkomst van de moderne vrijheidsidee. Daarbij bedenke men echter dat het in de late Middeleeuwen nog niet gaat om de idee van de individuele vrijheid in modeme zin, maar om de 'vrijheden' in de betekenis van voorrechten van bepaalde groepen (verkregen als tegenprestatie voor de inwilliging van beden).

De gedachte 'No taxation without representation' gat terug op de praktijk in het standenstaatswezen (waarover hiema), dat belastingheffing slechts mogelijk is met instemming van degenen van wie die belastingen worden geheven. Maar ook hier geldt dat het in het standenstaatswezen nog niet gaat om de staatkundige vrijheid van ieder individu als zodanig, welke gestalte krijgt in de moderne representatieve democratie, maar om de representatie (in de standenvergaderingen) van groepen (standen, steden, gilden).

36. Bijv. de markgenootschappen: in Drente is tot ca. 1600 de Landdag een vertegenwoordiging van de gelijkberechtigde volle buren en kan van andere standen nog niet gesproken worden.

37. Van Caenegem, 'Van koningen en bureaucraten', a.w., p. 57, merkt op dat er voor de landsheren ook een praktische hinderpaal is om beden te doen aan individuele steden: de landsheren beschikken niet, zoals de latere absolute vorsten, over het ambtenarenkorps om een nationale inning van de belastingen te verzekeren; hiervoor zijn ze aangewezen op locale instanties, zoals stadsbesturen.

38. Als de beden een min of meer permanent karakter krijgen, ontstaan daaruit uiteindelijk de belastingen.

39. Van Caenegem, 'Geschiedkundige Inleiding', a.w., p. 71.

40. Het gaat hier om de grote lijn: de samenstelling van de 'staten' is in de verschillende gewesten niet dezelfde, afhankelijk als zij is van de krachtsverhoudingen binnen een gewest. $\mathrm{Vgl}$. De Monté Verloren/Spruit, a.w., pp. 135-140.

41. Ook na de Franse tijd zijn trouwens in Nederland de Staten-Generaal nog een standenvertegenwoordiging. Pas bij de grondwetsherziening van 1848 zal voor de Tweede Kamer een stelsel van rechtstreekse verkiezing door de staatsburgers worden ingevoerd, zij het nog niet voor alle staatsburgers: een algemeen kiesrecht wordt eerst in 1917 grondwettelijk gerealiseerd.

42. Vermeld zij overigens dat reeds in de late Middeleeuwen door juristen de opvatting wordt verdedigd, dat aan de landsheer een algemeen dominium eminens t.a.v. zijn grondgebied zou toekomen, dat hem het recht zou geven om buiten zijn iura regalia dwang uit te oefenen op zijn onderdanen, zij het alléen in uitzonderingsgevallen voorzover zulks uit een oogpunt van algemeen belang (salutis publicae causa) nodig is en slechts tot aan de grenzen van de iura quaesita.

43. 'Plichten' betekent dus voor de landsheer: respectering van de aan de 'wederpartij' toekomende voorrechten (de iura quaesita).

44. L.J. van Apeldoom/J.C.M. Leyten, 'Inleiding tot de studie van het Nederlandse recht'. 17de druk, Zwolle 1972, p. 237. De laatste opmerking geldt echter specifiek voor de Nederlanden, want elders - met name in Spanje, Frankrijk en Pruisen - vormt de standen'staat' de overgangsfase naar de absolutistische politiestaat.

45. Van alle gewesten heeft Brabant na het Groot Privilege van 1356 de meest vergaande voor-rechten.

46. Dat dit streven was ingegeven door de eigen - private - belangen van de standen, doet daaraan niet af.

47. Althans in Frankrijk, Spanje, Pruisen, Oostenrijk.

48. Van Caenegem, 'Geschiedkundige Inleiding', a.w., p. 66/67. We merkten al op, dat het woord 'landsheer' in dezelfde periode ingang vindt. Vgl. ook Dietmar Willoweit, 'Deutsche Verfassungsgeschichte. Vom Frankenreich bis zur Teilung Deutschlands', München 1990, die deze geschiedenis verdeelt in vier fasen, waarvan de eerste (tot 1254) wordt samengevat als 'Vom Personenverband zur Reichsorganisation' en de tweede (1254-1410) als 'Reichsordnung und Staatsbildung'. Zeker in de eerste fase kan van een 'staat' in de huidige betekenis van het woord nog niet worden gesproken; de term 
'Personenverbandstaat' maar ook de term 'Oberflächenstaat' zijn daarom nogal ongelukkig. Men krijgt in deze periode weliswaar oog voor het bestaan van een 'staat', maar kan dit abstracte begrip slechts verwoorden door de vorst als persoon te onderscheiden van de vorst als belichaming van de 'staat' ('The king's two bodies', waarvan de étn sterfelijk, de ander onsterfelijk is). Vgl. Gerbenzon/Algra, a.w., p. 110.

49. Men kan dus wel spreken van 'Personenverbandstaat'; de iura regalia zijn persoonlijke rechten van de koning t.a.v, een 'Personenverband', omdat dit 'Personenverband' verbonden is met zijn dominium. Men houde dus in het oog dat het 'gezagsrecht' over die personen een sequeel is van het 'gezagsrecht' m.b.t. het dominium.

50. Georg Jellinek, 'System der subjektiven offentlichen Rechte', 2e druk, Tubingen 1919, p. 78 (noot). Vgl. ook R. Kranenburg. 'Het Nederlandsch Staatsrecht', 7e druk, Haarlem 1951, pp. 491 e.v.; A.A.H. Struycken, 'Het Staatsrecht van het Koninkrijk der Nederlanden, 2 e druk, Amhem 1928, pp. 206 e.v.

51. Zo wordt door juristen op romeinsrechtelijke basis de idee van het dominium eminens geconstrueerd, een opper-eigendom van de vorst over zijn grondgebied dat een algemene gezagsbevoegdheid over zijn 'ondersaten' zou impliceren (Overigens geeft reeds de term 'dominium eminens' c.q. 'opper-eigendom' aan, dat men zich nog niet heeft ontworsteld aan de feodale opvatting die imperium en dominium vermengt). Deze idee zal een grondslag vormen voor de latere idee van het 'ius politiae', dat aan de absolute vorsten - als hoogste Overheid - 'van nature' zou toekomen.

52. Een voorbeeld is de inrichting van het Hof van Holland, Zeeland en West-Friesland, dat in 1462 met de hoogste rechtspraak in deze gewesten wordt belast, en sinds 1531 uitsluitend Hof van Justitie wordt.

53. De rechtspraak is weliswaar een ius regalium bij uitstek van de landsheer, doch dit recht is - zoals we zagen - in de loop van de tijd beperkt door allerlei privileges, 0 .a. inhoudende het voor-recht tot eigen jurisdictie, mede implicerende het ius de non evocando. Zo behoeft een poorter alleen voor zijn stadsgerecht terecht te staan. $\mathrm{Vgl}$. De Monté Verloren/Spruit, a.w., pp. 121-125.

De gewestelijke Hoven ontstaan doorgaans als een juridische afsplitsing van de landsheerlijke regeringsraden. Als verzelfstandigde juridische afdelingen worden ze met de rechtspraak in hoogste instantie namens de landsheer belast. In deze afsplitsing van de judicielle taken manifesteert zich reeds het latere onderscheid tussen 'politie' en 'justitie', waarover méer hierna.

54. De Grote Raad is aanvankelijk de centrale regeringsraad van de Bourgondische vorsten, waarvan in 1473 een juridische afdeling wordt afgesplitst - ook wel Parlement genoemd - en naar Mechelen overgeplaatst. Na de dood van Karel de Stoute wordt - bij het Groot-Privilege, dat Maria van Bourgondiē in 1477 wordt afgedwongen - dit afzonderlijke Parlement weer opgeheven. In 1504 wordt door Philips de Schone het Parlement van Mechelen weer ingesteld, waarna het - althans in de zuidelijke Nederlanden - tot 1795 als hoogste beroepsinstantie blijft bestaan. De noordelijke gewesten verzetten zich tegen de instelling van een Hof voor alle gewesten en bestaande uit landsheerlijke ambtenaren, omdat zij hierin een aantasting zien van het ius de non evocando (hetzelfde bezwaar dus dat eerst tegen de instelling van gewestelijke Hoven was geuit). Holland en Zeeland - die zich aanvankelijk als enige van de noordelijke gewesten aan de rechtsmacht van het college onderwerpen -, onderwerpen zich na de opstand aan de jurisdictie van een eigen hoogste appèlcollege, de in 1581 ingestelde Hoge Raad.

Voor het gehele gebied van het 'Heilige Rōmische Reich Deutscher Nation' is in 1495 door de Habsburgse keizer Maximilian I het Reichskammergericht te Spiers (later te Wetzlar) als centrale rechterlijke instantie ingesteld. Bij het Verdrag van Augsburg van 1548 worden de Bourgondische gewesten, waaronder de Zeventien Nederlanden, samengebracht in de Bourgondische Kreits - $66 \mathrm{k}$ al een centraliserende maatregel-, maar worden ze tegelijkertijd vrijgesteld van de jurisdictie van het Reichskammergericht. Door de talrijke privilegia de non evocando of de non appellando wordt het Reichkammergericht overigens ook in de gebieden die onder zijn jurisdictie vallen, in veel gevallen buiten spel gezet. Zie P.L. Nève, 'Het Rijkskamergerecht en de Nederlanden. Competentie-territoirarchieven', diss. Nijmegen 1972, Assen 1972, die er 0.a. (p. 127) op wijst dat hoewel formeel de band van de noordelijke Nederlanden met het Rijk nooit is opgeheven, het Verdrag van Augsburg in rechterlijk-organisatorische zin kan worden beschouwd als de definitieve losmaking der Bourgondische 
Nederlanden van het Rijk. Zie over de merkwaardige geschiedenis van het 'Heilige Römische Reich Deutscher Nation' (dat pas in 1806 onder druk van Napoleon nu ook formeel verdwijnt door de uittreding van de Rijnbondstaten die geacht kunnen worden tot het Rijk te behoren, en de daarop volgende neerlegging van keizer Frans II van zijn Roomse troon; hij blijft overigens keizer van Oostenrijk): Van Caenegem, 'Geschiedkundige Inleiding', a.w., pp. 108-111; J.H.A. Lokin/W.J. Zwalve. 'Hoofdstukken uit de Europese Codificatiegeschiedenis', Groningen 1990, pp. 182 e.v. Het Duitse keizerrijk dat in 1871 ontstaat (en in 1918 aan zijn einde komt), wordt dan ook wel het 'Zweite Deutsche Reich' genoemd. Wanneer het 'Dritte Reich' ontstaat en wordt vernietigd, is overbekend.

55. Omdat er nog geen echte eenheidsstaat is, waarvan de gewesten onderdelen zijn, kan de gemeenschappelijke landsheer rechtens geen plakkaten en ordonnanties tot stand brengen, die voor alle gewesten gezamenlijk gelden. De door de landsheer gewenste unificatie wordt bereikt door in ieder gewest afzonderlijk dezelfde regeling in te voeren. Met plakkaten worden doorgaans de kortere regelingen aangeduid. 'Plakkaat' betekent oorspronkelijk 'oorkonde met opgeplakt zegel' c.q. 'aanplakbiljet' betreffende een bevel van overheidswege, dat wordt opgehangen op voor het publiek toegankelijke plaatsen. De meer uitvoerige regelingen plegen te worden aangeduid als 'reglement' of 'ordonnantie'. 'Edict' heten vooral stukken waarin reeds bestaande regelingen in herinnering worden geroepen. Zie De Monté Verioren/Spruit, a.w., p. 186-195: Gerbenzon/Algra, a.w., p. 112.

56. Voor zijn Duitse gebieden (behorende tot het 'Heilige Rōmische Reich Deutscher Nation') heeft Karel $V$ reeds in 1530 en 1532 nieuwe criminele wetboeken gegeven, in 1533 tezamen afgedrukt als 'Kaiser Karls V. und des Heiligen Römischen Reiches peinliche Gerichtsordnung', ook genaamd de 'Constitutio Criminalis Carolina' (kort: de Carolina). Evenals de Carolina zijn de bepalingen van de criminele ordonnantiên van 1570 in velerlei opzicht een verbetering, vergeleken met het oude recht. Zo wordt o.a. bepaald dat de misdadiger in gewone gevallen niet zonder bevel van de rechter in hechtenis mag worden gesteld, tenzij hij op heterdaad wordt betrapt. Een andere waarborg is, dat men in beginsel binnen 24 uur ondervraagd moet worden. Verder wordt het gebruik van de pijnbank, om de beklaagde tot belijdenis te nopen, zeer beperkt vergeleken met de oude situatie. Tevens wordt beoogd het misbruik van de compositie ('schikking' tegen afkoopsom uit te keren aan de gelaedeerde of zijn erfgenamen), nl. over criminele zaken (de echte misdrijven, d.w.z. de 'lijfstraffelijke' zaken) te keren. In die zaken zou niet meer 'civiel' - via het oude of ordinaire proces - kunnen worden geprocedeerd, maar 'crimineel' - via een nieuwe extraordinaire procedure, die begint met een onderzoek gevolgd door een eis van de overheid. Nást het onderscheid tussen 'politie' en justitie' zal het onderscheid tussen 'civiel' en 'crimineel' in de loop van de verdere rechtsontwikkeling van groot belang zijn (Zie hierna).

De criminele ordonnanties worden in 1576, bij de Pacificatie van Gent, door de Staten geschorst, maar zullen in de rechtspraktijk onder de Republiek toch nog veel invloed behouden.

57. Van Apeldoorn, a.w., p. 237. Wel geven de staten uiteindelijk toe aan de eis van het opbrengen van de 100 e Penning, die voor éenmaal betaald zou worden voor alle bezittingen. Zie ook: F.H.M. Grapperhaus, 'Alva en de Tiende Penning', Zutphen 1982.

58. Hetgeen impliceert dat, als in het verleden dergelijke privileges zijn verieend, de geprivilegieerden daarvan vervallen behoren te worden verklaard. Vgl. De Monté Verloren/Spruit, a.w., p. 184-186, alwaar ook gewezen wordt op een rapport van maart 1581 (houdende verslag van de onderhandelingen met de hertog van Anjou inzake de aan hem op te dragen landsheerlijkheid), waarin de twee standpunten inzake de betekenis van het woord 'souvereiniteit' naar voren komen. Daarin maken de vertegenwoordigers der gewestelijke staten bezwaar tegen opneming in het met Anjou te sluiten tractaat van het woord 'souverein', omdat dit zou kunnen worden verstaan als absolute souvereiniteit. Men kan zeggen dat, terwijl de landsheer uitgaat van de volle souvereiniteit, de staten uitgaan van een beperkte souvereiniteit. bestaande uit het complex van traditionele iura regalia.

59. Philippus de Leyden, 'De cura reipublicac et sorte principantis', ed. R. Fruin en P.C. Molhuysen, Den Haag 1900. Een bekend citaat is: '(P)rincipes habent aliqua jura, quae a se abdicare non possunt, et hoc ut salvetur Respublica, cuius salus consistit in potentia principis' ('Vorsten hebben enkele rechten, die zij niet kunnen afstaan, en wel opdat de Staat behouden blijve, waarvan het heil gelegen is in de macht van de vorst'). Vgl. R. Feenstra, 'Philip of Leyden and his treatise De cura reipublicae et sorte 
principantis', Glasgow 1970 , p. 65 , die dit de 'key sentence' noemt. Het tractaat is waarschijnlij geschreven op verzoek van graaf Willem V van Holland. Philips heeft gestudeerd in Orléans - en is i 1369 te Parijs gepromoveerd tot doctor decretorum -, waandoor hij vertrouwd is geraakt met d opvattingen van de Franse juristen die het absolute Franse koningschap theoretisch onderbouwden. W wezen er reeds op dat in Frankrijk (alsook in Engeland) de koningen reeds in de $13 \mathrm{e}$ en $14 \mathrm{e}$ eeuw he centraal gezag in handen weten te krijgen. De eerste jurist die hier te lande uitdrukkelijk ee onderscheid tussen publiek- en privaatrecht maakt, is - aldus Van Caenegem, 'Geschiedkundig Inleiding', a.w., p. 2 - Philips Wielant in zijn 'Praktijk Civile' (ca. 1518). Daarin verbindt hij ht publiekrecht met het 'gemeen nut', zoals het heffen van belastingen en de aanleg van havens en vestiny werken.

60. Bij de Pacificatie van Gent van 1576 hebben de gewesten zich verenigd tot een verbond, gericht op d verdrijving van de Spaanse troepen en op het treffen van een regeling met de landsheer. Bij dez Pacificatie zijn ook de criminele ordonnanties en de ketterplakkaten voorlopig geschorst verklaard. Zie over het Plakkaat van Verlatinge van 1581: De Monté Verloren/Spruit, a.w., pp. 184-18c J.H.P.M. van der Grinten, 'Het Plakkaat van Verlatinge', opgenomen in: dez., 'Verspreide opstellen. Nijmegen-Utrecht 1934, pp. 3-18; R. Fruin-H.T. Colenbrander, 'Geschiedenis der Staatsinstellinge in Nederland tot den val der Republiek', Den Haag 1901, p. 168/169, alwaar wordt gewezen op ht beroep dat in het plakkaat wordt gedaan op de Blijde Incomste van Brabant van 1356.

61. Fruin-Colenbrander, a.w., p. 169. J.K. Oudendijk, 'Het 'contract' in de wordingsgeschiedenis van e Republiek der Verenigde Nederlanden', Leiden 1961, wijst er op dat de opvatting die ten grondslag lit aan het Plakkaat in zoverre nieuw is, dat het dienstweigeringsrecht is omgezet in een verlatingsrech Voleens de oude ppvattine mocht eedbreuk door de landsheer slechts worden beantwoord met ea tijdelijke ongehoorzaamheid onder handhaving van de natuurlijke subjectie, volgens de nieuwe opvatting met opzegging voorgoed van het ganse onderdaadschap. Door Fruin-Colenbrander wordt nog opgemerkt dat een aantal streng gereformeerden - gezien zowel het Romeinse recht als de Bijbel (Rom. XIII, vs. 1,2) - toch nog sterk twijfelden of zij wel mochten afzweren. Eerst met de opvolging van Philips II door Philips III lagen de zaken anders: aan laatstgenoemde was immers geen eed gedaan (Het gebruik van de term 'natie' door Fruin is o.i. overigens ongelukkig: de natiegedachte is pas later tot ontwikkeling gekomen, en wel in nauwe samenhang met de doorbraak van het moderne staatswezen als res publica).

62. De Monté Verloren/Spruit, a.w., p. 200/201. E.e.a. neemt overigens niet weg dat zich in de Republiek rechtsontwikkelingen voordoen, die vergelijkbaar zijn met die in de absolutistische politiestaten. Men denke aan het ontstaan van het onderscheid tussen 'politie' en 'justitie' en tussen 'civiel' en crimineel'. waarop hierna nader wordt ingegaan. Vgl. J.V. Rijpperda Wierdsma, 'Politie en Justitie. Een studie over Hollandschen staatsopbouw tijdens de Republiek', diss. Leiden 1937, Zwolle 1937; J. van der Poel, Rondom compositie en compromis (Fiscale studie in bestuurs- en strafrecht)', diss. Utrecht 1942, Utrecht 1942; F.H. van der Burg, 'Preventieve Justitie en Plaatselijke Politie', diss. Utrecht 1961.

63. Dit is reeds goed gezien door Alexis de Toqueville, wiens scherpe analyse van de Franse revolutie we in de volgende paragraaf zullen behandelen.

64. De 'regel' wordt in de late Middeleeuwen: stadsrecht breekt landrecht, landrecht breekt gemeen recht. 65. Vgl. De Monté Verloren/Spruit, a.w., p. 208-217, waar náást deze factor nog de volgende factoren worden genoemd, die de receptie van het Romeinse recht sterk hebben bevorderd: het streven van de Duitse keizers tot versteviging van hun positie t.o.v. de paus (Door het keizerrijk te beschouwen als de onmiddellijke voortzetting van het Imperium Romanum en de Duitse keizers als de directe opvolgers van de Romeinse keizers); de algemene culturele opbloei vanaf het einde van de 11 e eeuw in Italiè en later Frankrijk en elders (de vroege renaissance); de toepassing door de juristen van het Romeinse recht in de hoogste rechterlijke colleges; de latere rationalistische natuurrechtsopvattingen waarin wordt uitgegaan van een naar tijd en plaats onveranderlijk recht (Dit recht zou zijn beschreven vorm gevonden hebben in het Romeinse recht). 
66. Vgl. veel geciteerde - van Ulpianus afkomstige - passage uit de Digesten van Justitianus (Dig. 1, 3 , 31 ) is: 'Princeps legibus solutus est: Augusta autem licet legibus soluta non est, principes tamen eadem illi privilegia tribuunt, quae ipsi habent' (De keizer is niet gebonden door de wetten; hoewel de keizerin niet boven de wet staat, kennen de keizers haar toch dezelfde voorrechten toe die zij zelf genieten). Van Caenegem, 'Over koningen en bureaucraten', a.w., p. 262, wijst er inzake de uitspraak van Dig. I, 3 , 31 op dat deze geen principiele onderbouwing voor het vorstenabsolutisme kan leveren, omdat deze uitspraak alleen een gevolg was van de afwezigheid van de nodige instellingen die de keizer zouden kunnen bedwingen, welke afwezigheid echter niet impliceerde dat de keizer niet ook de wetten zou moeten naleven. Aldus reeds Thomas van Aquino, 'Summa Theologiae', 1,2,96,5.

67. Dooyeweerd, 'De strijd om het souvereiniteitsbegrip', a.w., p. $6 / 7$.

68. G. von Below, 'Der deutsche Staat des Mittelalters', 2e druk, Leipzig 1925.

69. Ter voorkoming van misverstand merken we op deze plaats reeds op, dat dit in het geheel niet betekent dat bijv. de bevoegdheid van burgers tot rechtsvorming door het sluiten van contracten, aan de statelijke wetgever (het BW) is ontleend. De contractsbevoegdheid van burgers is een oorspronkelijke, inteme materiēle rechtsmacht. In de juridische ontstaansvormen van burgerlijke wetgeving (BW) en rechtspraak vindt een externe vervlechting en integratie plaats van dit niet-statelijk - 'niet-burgerlijk' ofwel 'bijzonder' - privaatrecht met het statelijke - 'burgerlijke' ofwel 'algemene' - privaatrecht, waardoor bijv. een contract burgerlijke rechtskracht verkrijgt en gebonden wordt aan de beginselen van de burgerlijke vrijheid en gelijkheid, terwijl in geval van geschil zonodig de burgerlijke rechter kan worden geadieerd en eventueel executie met inschakeling van statelijke organen mogelijk is (statelijk 'Zwangsmonopol'). We komen hier later uitgebreid op terug.

70. H.J. Hamaker, 'De tegenstelling van publiek- en privaatrecht', Verslag en Mededeelingen Kon. Akademie van Wetenschappen, Afd. Letterkunde, 3e reeks, deel XI, 1895, ook opgenomen in: dez.. 'Verspreide Geschriften', dl. VII, Haarlem 1913, pp. 134-163.

71. H. Krabbe, 'Administratieve rechtspraak', Groningen 1901, p. 88.

72. F.J.A. Huart, 'Misbruik van burgerlijk recht door de administratie', in: 'Staatrechtelijke opstellen aangeboden aan Krabbe', dl. II, Den Haag 1927, p. 182, ook opgenomen in: dez., 'Verspreide Geschriften', Alphen a/d Rijn 1949, pp. 13-29 (p. 17).

73. W.G. Vegting. 'Plaats en aard van het administratiefrecht', or. Amsterdam 1946. Alphen a/d Rijn 1946 , m.n. pp. 16-22.

74. H.R. Hoetink, 'Over het verstaan van vreemd recht', oratie Batavia 1929, ook opgenomen in: dez., 'Rechtsgeleerde opstellen', Alphen a/d Rijn 1982, pp. 21-61 (p. 38). En: 'Steeds wanneer vorschers uit lateren tijd pogen door te dringen tot de bedoeling en den geest van vervlogen tijden ...., loopt men het gevaar, dat men in het voorwerp zijner beschouwing meent te ontdekken hetgeen men zelf in het oog heeft'. Zoals Van den Berg. 'Eigendom', a.w., p. 9, terecht opmerkt, zal men teneinde de geschiedenis te kunnen begrijpen en verklaren, veelal noodzakelijkerwijs gebruik moeten maken van pas later ontwikkelde - dus 'anachronistische " - onderscheidingen en begrippen. Maar daarbij moet men uiteraard niet de fout maken, die begrippen op te vatten in de moderme betekenis ervan.

75. G. Dilcher, 'Die Auseinandersetzung von Staat und Gesellschaft im deutschen Vormairz (1815-1848)', in: 'Sozialwissenschaften im Studium des Rechts', dl. 4: Rechtsgeschichte, Munchen 1978, p. 73. beschrijft de ontwikkeling als volgt: 'Innerhalb der Rechtsordnung entspricht der von ständischen Schranken befreiten, liberalisierten Gesellschaft das aus den ubrigen Rechtsmaterien herausgelöste Privatrecht. Privatrecht existierte in der europäischen Rechtstradition zwar seit langem, vor allem in der Form des rồmisch-rechtlichen ius civile. Als herausgehobene Privatrechtsordnung ... bekommt Privatrecht eine neue Funktion ... Diese neue Funktion, die das Privatrecht anstelle von stăndischen Ordnungen und Polizeigesetzgebungen ûbernimmt, ist am kürzesten und zugleich präzisesten umrissen in der Formulierung 'from status to contract' (Sumner-Maine); Die gesellschaftsstrukturierende Funktion, die bisher stăndischer Status übte, wird nach Aufhebung der Standeordnung der auf Vertragsfreiheit beruhenden Privatrechtsondnung úbertragen. Erfolgreiche vertragliche Disposition úber Eigentum und Arbeitskraft bestimmt jetzt die soziale Stellung des einzelnen, nicht mehr Geburt in einem stăndisch bestimmten Rechtskreis'. 
D. Grimm, 'Soziale, wirtschaftliche und politische Voraussetzungen der Vertragsfreiheir', in: 'La formazione storica del diritto modemo in Europa', dl. III, Firenze 1977, pp. 1221-1248 (p. 1223), zegt: 'Befragt man die Forderung nach Vertragsfreiheit, wie sie gegen Ende des 18. Jahrhundert aus der Theorie in die politische Praxis vordrang, auf Thre konkrete Ziele, so zeigt sich, dass es um die Beseitigung dieser Beschrânkung der wirtschaftlichen Betâtigung ging. Vertragsfreiheit hiess Grundstucke ungehindert kaufen, teilen, belasten; Löhne frei vereinbaren, Preise frei aushandeln; Waren beliebiger Beschaffenheit herstellen und beliebigenorts anbieten dorfen. (...) Herrschaftsbefügnisse, offentliche Ämter, steuerliche Einnahmen sollten gar nicht mehr Gegenstand von Verträgen sein đürfen. Beides hängt freilich miteinander zusammen. Wenn Vertragsfreiheit die Befreiung des Wirtschaftssystems von staattichen und also die Herrschaft natürlicher Gesetze bedeutet, dann dienen die staatlichen Hoheitsrechte nur noch der Sicherung dieser natürlichen Ablăufe und können nicht ihrerseits wider Objekt wirtschaftlichen Interesses, Waren, sein."

76. Op deze begrippen - en de betekenisverschuivingen ervan - gaan we hierna nog uitgebreid in. Een triest voorbeeld van deze naieve school is - aldus Hardenberg, a.w., p. 354, nt. 100 - Vegting. In diens 'Publiek domein en zaken buiten den handel', Alphen a/d Rijn 1946, meent Vegting op basis van een historisch onderzoek de conclusie te kunnen trekken, dat het publiek domein moest worden opgevat als gewone 'burgerlijke' eigendom, omdat het publiek domein reeds vóór de Franse revolutie werd beschouwd als 'burgerlijke' eigendom en niets erop zou wijzen dat men in deze rechtspositie verandering had willen brengen. Vegting maakt hier in de eerste plaats de grote fout het oude begrip 'burgerlijk' op te vatten in de hedendaagse betekenis van het woord en miskent in de tweede plaats dat de Franse revolutie juist was gericht op een (definitieve) scheiding van 'imperium' en (privaat) 'dominium', die voordien nog met elkaar vermengd waren.

Ook Van den Bergh, 'lets over publiek- en privaatrecht', a.w., p. 17, merkt op 'dat men maar al te vaak het moderne, privaatrechtelijke eigendomsbegrip terugprojecteert in de geschiedenis en daardoor tot een vals beeld komt'.

77. Zoals we zagen, kan volgens deze auteurs de gelding van de gemene rechtsleer worden aangetoond op basis van de rechtsontwikkeling.

78. G. Radbruch, 'Rechtsphilosophie', 8e druk, Stuttgart 1973, p. 224. Het is overigens, strikt genomen, minder gelukkig te spreken van 'privatrechtlichen Verunreinigungen' en 'ôffentlich-rechtlichen Bindungen', want dit woordgebruik doet veronderstellen dat er voordien reeds een burgerlijk recht resp. publiekrecht, als naar hun aard eigen rechtsgebieden, was. Bedoeld wordt uiteraard dat brokken overheidsgezag werden beschouwd als waren zij private vermogensbelangen (in de modeme betekenis), terwijl - omgekeerd - echte private vermogensrechten niet bestonden voorzover deze 'van nature' gekoppeld werden geacht aan overheidsgezag (in de moderne betekenis). Gedoeld wordt m.a.w. op de ongedifferentieerde vermenging van 'imperium' en (privaat) 'dominium'. 


\section{Hoofdstuk 2}

\section{De absolutistische politiestaat}

\section{Inleiding}

De ontwikkelingen die hebben geleid tot de neergang van het feodale bestel en de opkomst van de politiestaat, zijn hierboven reeds genoemd. Zo wezen we op de opkomst van de steden - en daarmee van een derde stand -, die een nieuwe machtsfactor gingen vormen tegen de oud-feodale instellingen, en die door het afdwingen van de landsheer van privileges óók het landsheerlijke gezag wisten te verzwakken, althans in eerste instantie. Want juist ook door de afbraak van de machtsposities van de lagere adellijke heren - waaraan overigens de stedelijke standen maar al te graag bereid waren medewerking te verlenen - ontstond een situatie die de landsheren in de gelegenheid stelde de gedurende het feodale bestel in de handen van lagere adellijke heren geraakte 'overheidsrechten' weer aan zich te trekken om een centraal gezag te vestigen, waardoor ze uiteindelijk ook beter in staat zouden zijn de stedelijke privileges uit te hollen. Vanaf het einde van de Middeleeuwen moet de stedelijke autonomie het afleggen tegen de centrale landsheerlijke macht.

Dat de landsheren erin slagen een centraal gezag te vestigen, is mede mogelijk geworden doordat ze een meer permanent ambtelijke apparaat hebben kunnen opbouwen met vaak juridische geschoolde ambtenaren ${ }^{1}$.

De overgangsfiguur (tussen het feodale bestel en de politiestaat) van het standen'staat'wezen uit de veertiende en vijftiende eeuw heeft voor de opkomst van de publieke rechtsidee in die zin heilzaam gewerkt, dat de in standenvergaderingen georganiseerde standen een halt konden toeroepen aan die landsheerlijke praktijken waarbij de landsheren hun gezagsrechten als privaat bezit beschouwden ${ }^{2}$.

Ook merkten we reeds op dat dit differentiatieproces leidt tot de aanvaarding van de rechtsidee van de gemonopoliseerde overheidsmacht die enkel wordt beschouwd als publiek ambt (res publica) en niet als privaat vermogensbelang, onder afbraak van de feodale ongedifferentieerde rechtsverhoudingen waarbij zich stukken overheids- 
macht als privaat bezit in handen van steden, standen etc. bevonden. We zagen voorts dat dit proces mede is bevorderd door de receptie van het Romeinse recht.

Dat zich een sterk centraal staatsgezag kon vestigen, is ook mogelijk geworden door de teloorgang van de kerkelijke 'eenheidscultuur', die in de Middeleeuwen alle levenssferen onder de kerkelijke macht had gesteld. Door de opgang van de steden was de greep van de kerk op heel het leven toch al verslapt. En in de renaissanceperiode wordt het rooms-katholicisme als leidende cultuurfactor teruggedrongen door het opkomende humanisme. In overeenstemming met deze nieuwe levens- en wereldbeschouwing (waarover hierna méér) gaan de wereldlijke machten zich aan de geestelijke leiding door de kerkelijke machten onttrekken ${ }^{3}$. Met name in de landen van de Contra-reformatie zal de kerk juist in dienst worden gesteld van de wereldlijke macht, om het centrale gezag te verstevigen.

Dat de centralistische politiestaten in grote delen van Europa uiteindelijk kunnen zegevieren, wordt in de hand gewerkt door de crisissituatie in het zestiende-eeuwse Europa met zijn godsdiensttwisten en burgeroorlogen, waarbij men veelal in een krachtig optreden van een absolute vorst nog de enige redding ziet.

Tegenover de idee van de standen'staat', dat de verhouding tussen landsheer en standen een wederkerig karakter heeft met wederzijdse rechten en plichten, wordt nu de idee van de absolute vorstensoevereiniteit op het staatsterritoir gesteld.

Het vorstenabsolutisme gaat uit van de theorie dat de wil van de soevereine vorst wet is en dat de vorst dus ook niet door de 'wetten' gebonden kan zijn - dus ook niet door eerder verleende privileges -, aangezien hij zelf de wetten maakt en hij anders zichzelf zou binden: 'princeps legibus solutus est', een opvatting waarvoor een theoretische onderbouwing wordt gegeven door Jean Bodin ${ }^{4}$.

De absolutistische denkbeelden dienen ertoe om een sterk centraal gezag te vestigen en uit de versplinterde gemeenschappen van de Middeleeuwen min of meer samenhangende staten te maken. Daarmee wordt de moderne politiestaat verdedigd tegen enerzijds de middeleeuwse feodale instellingen en voorrechten en anderzijds tegen de leer die de voogdij van de kerk over iedere aardse macht verkondigt.

De aanduiding 'politiestaat' houdt verband met het 'ius politiae', zijnde de algemene bevoegdheid van de hoogste overheid om alle maatregelen, inclusief ge- en verbodsvoorschriften, te treffen die in het algemeen belang nodig werden geacht. De term 'politiestaat' is, evenals de term 'absolutisme', geïntroduceerd door negentiendeeeuwse auteurs, die deze termen polemisch gebruiken, als tegenhanger van de hen verdedigde 'rechtsstaat'. Daardoor zal de term 'politiestaat' een negatieve bijklank krijgen s. Men bedenke echter dat de 'politiestaat' een fase is in het cultuurhistorische differentiëringsproces dat leidt tot de afbraak van de structuren van het feodale en standenbestel. Nadat de opkomende Staten het 'Zwangsmonopol' over hun terri- 
toir hebben kunnen vestigen en consolideren, zullen zij zich geleidelijk tot wezenlijke publieke rechtsgemeenschappen (rechtsstaten) gaan ontwikkelen.

Dit proces verloopt uiteraard niet zonder slag of stoot. De ontwikkeling tot aan het einde van de achttiende eeuw is te zien als een geleidelijke afbraak van de feodale instellingen en het standenbestel, die eerst door de Franse revolutie definitief worden opgeruimd. In de praktijk is ook in het Frankrijk van Lodewijk XIV - dat toch steeds als hét model van het 'hoogabsolutisme' wordt gezien - de vorstenmacht nooit een volledige, een écht absolute macht ${ }^{6}$.

Zo vormen in Frankrijk de hoogste gerechtshoven, de 'cours souverins' een krachtig tegenwicht tegen de macht van de koning. Ruim een derde daarvan draagt de naam van 'parlement', waarvan het 'Parlement de Paris' de invloedrijkste is. Zo kunnen de parlementen invloed uitoefenen op de koninklijke wetgeving door hun remonstratierecht ('droit de remonstrance') en registratierecht ('droit d'enregistrement'). In de late Middeleeuwen was namelijk het gebruik ontstaan dat nieuwe koninklijke ordonnanties naar de parlementen werden gestuurd, alwaar ze werden voorgelezen en vervolgens ingeschreven in de parlementaire registers, waardoor ze ook geacht werden te zijn gepubliceerd en te moeten worden nageleefd. Uit dit 'droit d'enregistrement' ontwikkelt zich de gewoonte - en daarmee het recht - dat de parlementen kritische op- en aanmerkingen naar voren kunnen brengen ('remonstreren', vandaar: 'droit de remonstrance'). De koninklijke ordonnantie wordt dan niet geregistreerd, maar teruggezonden naar de koning om hem in de gelegenheid te stellen de tekst te amenderen of eventueel in te trekken. Aldus zijn de parlementen in staat de koninklijke wetgeving te frustreren. En hun onafhankelijkheid tegenover de koning wordt nog hierdoor versterkt, dat de rechterlijke magistraten onafzetbaar zijn: de rechterlijke posten zijn namelijk privé-bezit (en koopbaar ${ }^{7}$ ). Juist ook de gerechten zijn daardoor tijdens het ancien régime bolwerken van de feodaliteit en het standenbestel. Het zijn de gegoede standen die hun voorrechten met hand en tand verdedigen en telkens weer verzet bieden tegen het streven van de koningen naar een absoluut gezag. Zo verzet het Parlement van Parijs zich in 1648 tegen enkele nieuwe belastingwetten die de kroon wil afkondigen - door welke wetten bepaalde fiscale voorrechten van de hoge adel zouden worden aangetast -; dit leidt tot een conflict tussen de kroon en hoge adel, dat uitmondt in de Fronde (1648-1653). Lodewijk XIV ontneemt in 1667 aan de parlementen het 'droit de remonstrance'.

Bij een edict van 1683 worden de steden onder regeringstoezicht geplaatst. Ook worden de eertijds locale gildenorganisaties op nationale leest geschoeid: koninklijke ordonnanties houden de oude gilden weliswaar formeel in stand, maar nemen hun statuten tot voorbeeld voor nieuwe nationale bedrijfsorganisaties.

$\mathrm{Na}$ de dood van Lodewijk XIV in 1715 hernemen de parlementen hun 'droit de remonstrance' ${ }^{8}$. In 1771 ontneemt Lodewijk XV alle macht aan de parlementen, 
die dan bij zijn dood in 1774 weer herleven. In mei 1788 schaft Lodewijk XVI wederom het 'droit de remonstrance' af, welke maatregel in september van dat jaar weer moet worden opgeschort tot de historische samenkomst op 5 mei 1789 van de Staten-Generaal (de eerste sinds 175 jaar). Deze besluiten op 3 november 1789 tot de 'mise en vacances' van de parlementen, die een jaar later definitief worden afgeschaft.

Ook de parlementen hebben het succes van de absolutistische politiestaat - en daarmee de aanvaarding van de publieke rechtsidee, de definitieve afbraak van het standenbestel en de feodale samenlevingsstructuren, en daardoor ook de vrijmaking van de mens uit die structuren - uiteindelijk niet kunnen verhinderen. Door de revolutie wordt weliswaar getracht een nieuwe samenleving op te bouwen, gebaseerd op de menselijke rede; dit doende voltooit men slechts een ontwikkelingsproces, waarvan de politiestaat de motor is geweest. Omdat Lodewijk XV (1715-1774) en Lodewijk XVI (1774-1792) echter het talent missen om een snelle, verdere modernisering van de staatsstructuur zelf krachtig ter hand te nemen, is het met name de derde stand die de laatste resten van het feodale bestel - en tévens de monarchie - opruimt, om zelf een actieve rol te kunnen gaan spelen in de politiek van de door die monarchie gefundeerde natiestaat.

Tot een krachtige modernisatie komt het in de achttiende eeuw wél in enkele verlicht absolutistische Staten, waarvan het Pruisen van Frederik II en het Oostenrijk van Jozef II de klassieke voorbeelden zijn. In de rationalistische geest van de achttiendeeeuwse Verlichting (de 'Aufklärung') breken zij met het religieuze karakter van de monarchie om een neutrale Staat ${ }^{9}$ met een krachtig ambtenarendom (zonder koopbare posten) in te richten, wiens taak de 'Beförderung der gemeinen Wohlfahrt und Sicherheit' is ${ }^{10}$. De rationalistische natuurrechtsleer van de Verlichting - volgens welke het recht rationeel ('vernunftrechtlich') en kenbaar ('gemeinverständlich') moet zijn - inspireert tot een omvangrijke wetgevende en codificerende arbeid. De verlichte vorst is ervan overtuigd dat hij zelf ook binnen de perken van zijn wetten moet opereren. Het verlicht absolutisme blijft echter een absolutistisch regime: de soevereine vorst beschouwt zich wel als representant van zijn volk, maar acht zich bij zijn optreden niet gebonden aan de medewerking van het volk. Een krachtige derde stand, die in de nationale politiek een actieve rol wil spelen, ontbreekt trouwens in Pruisen nog.

Maar het is zeker een belangrijke stap vooruit in de richting van een constitutionele Staat en de heerschappij van de wet, een proces dat zal worden versterkt na de 'export' van de ideeên van de Franse revolutie. Aan het eind van de negentiende eeuw zal ook in Duitsland de derde stand (de burgerij) zijn staatkundige rechten voor zich opeisen en zal daar een parlementair bestel ontstaan ". 
In de noordelijke Nederlanden verloopt de ontwikkeling anders dan elders op het Europese continent. Het streven van de landsheer naar centralisatie stuit hier op de tegenwerking van de Staten, die krachtig vasthouden aan bestaande voorrechten en zich uiteindelijk losmaken van hun landsheer (Philips II). De Staten der afzonderlijke gewesten volgen op in de macht van de landsheer en beschouwen voortaan zichzelf als de soeverein binnen het gewest. De Republiek der Zeven Verenigde Nederlanden is een statenbond, waarin de gewesten samenwerken ter behartiging van bepaalde gemeenschappelijke belangen maar waarbij ze vasthouden aan hun eigen soevereiniteit. Hierboven wezen we er op dat er onder de Republiek op het gebied van de rechtsvernieuwing en unificatie van het recht weinig fundamenteels gebeurt tot aan de 'revolutie' van $1795^{12}$.

De rechtsstaat zal ontstaan uit - en als reactie op - de politiestaat, die op zijn beurt een reactie is op het feodale bestel en de standen'staat'.

In de periode van de politiestaat wordt het overheidsgezag ont-persoon-lijkt, verambt-elijkt: 'overheidsrechten' worden ambtsgebonden, publieke bevoegdheden en worden niet langer beschouwd als persoonlijke rechten met een vermogensrechtelijk karakter, die als 'zaken in den handel' vervreemdbaar zijn.

Dit proces gaat gepaard met een concentratie bij de Staat van de voorheen ook bij andere, niet-statelijke verbanden aanwezige 'overheidsrechten' (heerlijke rechten) en met een vrijmaking van individuen uit die ongedifferentieerde verbanden. In de politiestaat worden de mensen gelijkelijk als onderdanen beschouwd, hetgeen leidt tot de aanvaarding van de (juridische) gelijkheid van iedere mens, éérst in de relatie tot de Staat en uiteindelijk ook in de relaties tussen burgers onderling.

Dit proces is dus een differentieproces (scheiding van imperium en dominium, van het publieke en het private, van Staat en 'maatschappij'), een individualiseringsproces én tegelijkertijd een proces van integratie (in en door de Staat).

De erkenning van een eigen rechtssubjectiviteit van ieder individu als zodanig, zowel in staatkundige als in burgerrechtelijke zin, zal leiden tot doorvoering van het representatiebeginsel (waarop het democratisch karakter van de rechtsstaat zal berusten), tot de erkenning en positivering - in de vorm van grondrechten - van eigen, niet-statelijke rechtssferen alsmede tot positivering door de Staat van een op het beginsel van de burgerlijke vrijheid-in-gelijkheid gefundeerde, integrerende burgerrechtelijke rechtsorde, waardoor een vrij burgerlijk-maatschappelijk verkeer wordt gewaarborgd en waardoor ook het ontstaan van vrije, gedifferentieerde maatschappelijke verbanden mogelijk wordt.

Voor een goed inzicht in de betekenis van juist de absolutistische politiestaat in Frankrijk voor het individualiseringsproces en de opkomst van de moderne vrijheidsgedachte, is niets zo verhelderend als het lezen van 'L'Áncien Régime et la 
Révolution', waarin Alexis de Tocqueville een scherpe analyse geeft van de oorzaken van het verdwijnen van de structuren van het feodale en standenbestel, en van de daardoor ontketende democratiseringsprocessen ${ }^{13}$. Tocqueville toont aan dat de Franse revolutie niet een plotseling breukpunt in de geschiedenis is, maar veeleer het culminatiepunt van een ontwikkeling die in gang is gezet door de absolutistische politiestaat.

Het zijn de Franse koningen, die in hun centralisatiestreven de structuren van het feodale en standenbestel afbreken en alles wat zich onder hen bevind egaliseren en daarmee de burgerij op gelijk niveau brengen met de adel (o.a. door afschaffing van standsprivileges, plaatsing van de steden onder regeringsvoogdij, opneming van burgers in het ambtelijk apparaat en in de regering, en een voor alle onderdanen gelijkelijk geldende koninklijke wetgeving). Enerzijds leidt dit tot het verlaten van de 'feodale en aristocratische vrijheidsopvatting' - die 'vrijheid' vereenzelvigt met het genot van aan rang, stand, gilde etc. verbonden voorrechten - en de doorbraak van een nieuw vrijheidsbegrip, waarbij men 'vrijheid' gaat zien als vrijheid van willekeur, d.w.z. als gelijkheid van alle onderdanen.

Op basis van de theorieën van de achttiende-eeuwse natuurrechtsfilosofen - o.a. Rousseau - wordt dit vrijheidsbegrip verruimd tot de idee die uitgaat van de 'natuurlijke vrijheid' van ieder individu. Tocqueville noemt dit de 'democratische vrijheidsopvatting'.

Anderzijds wordt de revolutie juist vergemakkelijkt door de centralisatie en de almacht van het staatsgezag - dat immers alle structuren van het ancien régime heeft afgeschaft die een tegenwicht konden vormen - en de door die centralisatie bevorderde nationale eenheid. Ook de scheiding der machten is feitelijk reeds ingevoerd, als ze met de revolutie een constitutionele basis verkrijgt.

Kortom: wat men veelal als gevolgen van de Franse revolutie beschouwt: de sterke centralisatie van het bestuur, de toegenomen macht van het ambtelijk apparaat, de afbraak van de structuren van het feodale en standenbestel, de idee van de individuele vrijheid-in-gelijkheid, de natie-idee, de machtenscheiding etc., dit alles voltrekt zich reeds lang vóór 1789 onder de politiestaat; het zijn niet zozeer de gevolgen als veeleer de oorzaken van de revolutic.

Juist de door de monarchie in gang gezette ontwikkelingen doen bij het Franse volk een mentaliteit ontstaan, die het naar een versnelling van dit proces heeft doen verlangen. Omdat - als gezegd - Lodewijk XV en Lodewijk XVI daartoe niet in staat blijken, groeit onder de bevolking de ontevredenheid over het moderniseringstempo, en daarmee ook de revolutiebereidheid ${ }^{14}$.

De staatsinstellingen die door de revolutie worden gebracht, zijn dus minder het resultaat van het abstracte denken der intellectuelen ('les philosophes'), dan van de reeds door de monarchie begonnen ontwikkelingen. Niettemin moet - aldus Tocque- 
ville - de rol die de 'filosofen' spelen in de voorbereiding van de revolutie bepaald niet worden onderschat. Het functieverlies van de traditionele samenlevingsstructuren, ook in ideologisch opzicht, leidt ertoe dat de kritische denkbeelden en 'verlichte' theorieën van de 'filosofen' een brede en rechtstreekse invloed op de volksopinie kunnen uitoefenen. In de vorm van 'een theorie in de ontwikkelde volksklassen' - Tocqueville doelt ongetwijfeld op Rousseaus theorie - wordt het aanvankelijk nog vage denkbeeld, dat ieder individu (en daarvan afgeleid: ieder volk) een 'natuurlijke vrijheid' heeft en het recht zijn eigen zaken te regelen, uitgewerkt en ontstaat een nog krachtiger streven naar vrijheid ${ }^{15}$.

De Franse revolutie van 1789 is belast met een dubbele ideologische erfenis, zoals naar voren komt uit de 'Déclaration des Droits de l'Homme et du Citoyen'. Deze is enerzijds geïnspireerd door Rousseaus leer van de volkssoevereiniteit en anderzijds - vooral via de Amerikaanse constituties, met name de 'Bill of Rights' die voorafgaat aan de Grondwet van Virginia van 1776 - door de politieke ideeën zoals die zijn geformuleerd door John Locke.

De staatsidee is dus de motor van het historisch ontwikkelingsproces dat uiteindelijk zal leiden tot de vestiging van de democratische rechtsstaat.

Hieronder geven we een korte beschrijving van de staatstheorieën die zijn ontwikkeld door Bodin, Hobbes, Locke en Rousseau, omdat daarin de ontwikkeling van (de opvattingen omtrent) de staatsidee vanaf de zestiende eeuw tot aan de Franse revolutie goed tot uitdrukking komt. $\mathrm{Zij}$ hebben hun theorieën niet geschapen uit het niets, maar daarmee een scherpe vorm gegeven aan in hun tijd opgang makende ideeën en ze daardoor doeltreffend gemaakt. Aldus trekken ze de historische ontwikkelingslijnen door tot een nieuw eindpunt in de theorie ${ }^{16}$.

Bodin definieert voor het eerst de nieuwe soevereiniteitsidee en omschrijft deze als de essentie van de Staat. Hobbes relateert de soevereiniteitsidee aan de representatiegedachte en legt hiervoor een fundering in het nieuwe contractsdenken, waarin de laat-middeleeuwse opvatting van een overeenkomst tussen vorst en standen (collectiviteiten dus) - implicerende wederzijdse rechten en plichten - is omgevormd tot een theorie die de (absolute) overheidssoevereiniteit rechtvaardigt als produkt van een overeenkomst van de (in de 'natuurtoestand') volstrekt vrije individuen en waarbij de soevereine overheid als representante van de daardoor ontstane volkseenheid is ingesteld.

In de theorieën van Locke en Rousseau wordt de ontwikkelingslijn in het denken over (de soevereiniteit van) de Staat verder doorgetrokken en worden de basisprincipes geformuleerd van de democratische rechtsstaat. 


\section{Het humanistische mens- en wereldbeeld: spanning tussen vrijheidsideaal en machtsideaal}

De staatsidee kan - aldus Couwenberg ${ }^{17}$ - worden beschouwd als de belangrijkste basisidee van het moderne politieke denken, zoals dit zich via Renaissance, Verlichting en de grote politieke revoluties van de tweede helft der achttiende eeuw ontwikkeld heeft. De moderne staat vormt het algemene kader waarbinnen de grote basisideeěn van dit denken (de beginselen van de rechtsstaat, het emancipatiestreven van de mens etc.) tot ontplooiing zijn gekomen.

In de theorieën van grote denkers als Bodin, Hobbes, Locke en Rousseau openbaart zich ook de intrinsieke spanning en dialectiek tussen de twee humanistische idealen die zich, onder invloed van de renaissancebeweging, vanaf het einde van de vijftiende ceuw in de Westerse cultuur zijn gaan openbaren, te weten enerzijds het humanistische vrijheids- en persoonlijkheidsideaal, dat is gericht op volledige emancipatie van de mens, en anderzijds het humanistische wetenschaps- en natuurbeheersingsideaal, dat is gericht op natuurwetenschappelijke beheersing van de werkelijkheid ter wille van de maximalisering van de menselijke macht en welvaart ${ }^{18}$. In het persoonlijkheidsideaal wordt de mens gezien als doel in zichzelf ('Selbstzweck'), als vrij denkende en scheppende persoonlijkheid die het lot in eigen hand neemt en zich vrij waant van bovennatuurlijke machten en traditionele opvattingen. Mede onder invloed van de renaissancebeweging begint de machtspositie van het rooms-katholieke kerkinstituut, dat als boven-bouw boven een ongedifferentieerde onder-bouw heel de middeleeuwse samenleving beheerste, aan het einde van de Middeleeuwen dan ook te vervallen ${ }^{19}$.

Door het vrijheidsideaal wordt het natuurwetenschappelijke beheersingsideaal voortgebracht. Want wil de mens zijn toekomst in eigen hand kunnen nemen, dan moet hij ook de natuur beheersen. Door ontdekking van de natuurwetten zullen alle natuurverschijnselen doorzichtig gemaakt worden en, door middel van toepassing van de mathematische natuurwetenschappelijke methode, ook berekenbaar en beheersbaar. Wanneer Galilei en later Newton de grondslagen leggen voor de mathematische natuurkunde - die inderdaad de weg naar beheersing van de natuur wijst door ontdekking van vaste natuurwetten -, dan wordt deze methode verheven tot een wetenschapsideaal dat op alle terreinen der wetenschap tot richtsnoer zou moeten dienen om de samenhang van de gehele werkelijkheid te ontsluieren en deze vervolgens te beheersen ('more geometrico'). Dit mathematische wetenschapsideaal wil heel de werkelijkheid vatten als een gesloten keten van oorzaak en gevolg, van fysisch-causale relaties beheerst door algemeen geldige en onveranderlijke natuurwetten. Dit door het humanistische vrijheidsideaal verwekte wetenschapsideaal is dus een beheersingsideaal. Dijksterhuis spreekt in dit verband van 'de mechanisering van het wereldbeeld' ${ }^{20}$. 
De twee humanistische idealen verkrijgen ook in de rechtswetenschap een overheersende invloed en leiden tot de rationalistische natuurrechtsleer, die uitgaat van een eeuwig en onveranderlijk ideaal recht, dat noodzakelijk voortkomt uit de rationele menselijke natuur en dat volgens de mathematische methode, louter deductief, uit enkele fundamentele rechtsaxioma's is op te bouwen ${ }^{21}$. Zo is volgens Hugo de Groot het gehele natuurrecht te ontwikkelen op de objectieve, aan menselijke willekeur onttrokken, natuurlijke grondslag, dat de mens, in onderscheid tot andere levende wezens een aandrift bezit tot vreedzame samenleving.

Maar ofschoon het natuurwetenschappelijke beheersingsideaal is verwekt door het humanistische vrijheidsideaal, bedreigt het dit laatste. Want als de gehele werkelijkheid, met inbegrip van de menselijke natuur, causaal-mechanisch is gedetermineerd, is er geen plaats meer voor menselijke vrijheid. Anders gezegd: wanneer alle gebeuren binnen onze ervaringswereld is gedetermineerd als een naturwetenschappelijk te verklaren keten van oorzaken en gevolgen, blijft er geen ruimte meer voor een vrij menselijk willen, denken en handelen. Waar blijft dan de vrijheid van de mens? Volgens Dooyeweerd zit er in het humanistisch grondmotief van natuur(beheersing) en vrijheid (der persoonlijkheid) dan ook een antinomie (innerlijke tegenstrijdigheid), die de grote humanistische filosofen dwingt tot geestesacrobatick om zowel het persoonlijkheids- als het wetenschapsideaal veilig te kunnen stel$\operatorname{len}^{22}$.

Het is de polaire spanning tussen het persoonlijkheidsideaal enerzijds en het naturwetenschappelijke beheersingsideaal anderzijds die vanaf het einde van de vijftiende eeuw het denken over recht en Staat zal bepalen. Couwenberg ziet hierin een polair-dialectische spanningsrelatie, waarin de polen - hoewel elkaars tegendelen - onverbrekelijk met elkaar zijn verbonden, met andere woorden: een tweeeenheid vormen. Het uit het nieuwe mensbeeld - de mens als een vrije en zelfstandige persoonlijkheid, die zelf zijn leven op het kompas van de menselijke rede vorm en inhoud geeft binnen een politieke samenleving waarin de staatsmacht het produkt is van en dienstbaar gemaakt wordt aan de zelfbepaling van iedere burger voortvloeiende emancipatiemotief krijgt na de Middeleeuwen steeds meer invloed op het politieke denken en komt - aldus Couwenberg - tot gelding in:

'een emancipatorischerechtsidee die als inspiratiebron en drijfkracht een centrale rol gaat spelen in de ontwikkeling van het moderne constitutionele recht naast en tegenover het ordescheppende machts/ beheersingsmotief. Beide motieven wortelen in hetzelfde rationalistische mens- en wereldbeeld dat sinds de Renaissance via het humanistische natuurrecht en wetenschapsideaal tot ontwikkeling komt. Zij vertegenwoordigenieder een specifieke strekking van dit mens- en wereldbeeld en creêren in hun onderlinge spanning en verwevenheid een bron van weergaloze dynamiek, die leidt tot een tomeloze expansiedrift op alle terreinen des levens en een toenemende versnelling van het historische proces. De constitutionele ontwikkeling voltrekt zich sindsdien in een spanningsveld 
dat bepaald wordt door het machts- en het emancipatiemotief als concurrerende ontwikkelingsprincipes. Zij draagt geen lineair, maar een polair-dialectischkarakter' 2 ,

Ofschoon deze polaire spanning tussen het nieuwe persoonlijkheidsideaal der vrije zelfbepaling en het door dit laatste zelf opgeroepen nieuwe wetenschapsideaal der soevereine beheersing van de werkelijkheid door het moderne natuurwetenschappelijke denken, op zichzelf onophefbaar is en het beheersingsideaal 'bij consequente doorvoering in heel die werkelijkheid geen plaats voor persoonlijke vrijheid overlaat' ${ }^{24}$, onderkent ook een auteur als Dooyeweerd de heilzame gevolgen die de humanistische idealen hebben gekregen voor de ontplooiing van de Westerse beschaving, in het bijzonder voor de ontwikkeling van de moderne rechtsstaat (erkenning van individuele mensenrechten die ten grondslag liggen aan de burgerlijke rechtsorde, liquidering van de ongedifferentieerde rechtsverhoudingen waarbij stukken overheidsgezag als 'zaak in de handel' worden beschouwd, humanisering van het strafrecht etc.) ${ }^{2 s}$.

\section{Het nieuwe soevereiniteitsbegrip als fundering van de Staat}

Bodins begrip van de absolute soevereiniteit; 'princeps legibus solutus' Bij de Franse jurist Jean Bodin (1530-1596) overweegt het beheersingsmotief, zulks in functie van een politiek die de Staat als een rationeel beheersingsinstrument wil opbouwen onder afbraak van de feodale instellingen. Bodins werk 'Les six livres de la République' (1576), verschenen in de laatste periode van de hugenotenoorlog, is dienstbaar aan het streven van de Franse vorsten naar monopolisering van de overheidsmacht ten behoeve van een allen gelijkelijk omvattende publieke, territoriale rechtsorde ${ }^{26}$. Het is het eerste werk waarin de moderne staatsidee - de idee van de Staat als 'einheitliche' res publica - theoretisch wordt verdedigd. Dit vele malen herdrukte boek heeft een enorme invloed uitgeoefend op de politieke en culturele geschiedenis van Europa. Donner noemt dit boek, dat door zijn behandeling van het begrip der soevereiniteit een duidelijk streep zet in de ontwikkeling van de Middeleeuwen naar de nieuwe tijd, 'een mijlpaal in de geschiedenis van het politieke en juridische denken' 27 . Om een stevige fundering te geven aan het overheidsgezag construeert Bodin het (absolute) soevereiniteitsbegrip. Met deze constructie wordt het hoofd geboden aan de omwentelingen in de samenleving en wordt de uiteenvallende unitaire kerkelijke 'wereldorde' omgevormd in een bestel van een aantal onderling onafhankelijke, soevereine staten.:

'De soevereiniteit is de hoogste macht over burgers en onderdanen, die niet aan de wetten gebonden is ${ }^{*} \times$.

Deze definitie is terug te voeren op de bekende, van Uplianus afkomstige en in de Digesten opgenomen omschrijving: 'Princeps legibus solutus est' ${ }^{29}$. 
De soevereiniteit wordt hier nog niet met de Staat als zodanig verbonden maar met de hoogste machthebber (de vorst, de soeverein) ${ }^{30}$, die wordt vereenzelvigd met de Staat. Anders gezegd: Bodin beschouwt de soeverein (de vorst) als méér dan als het hoofd van de Staat, namelijk als de grondslag waarop de existentie van de Staat in het algemeen berust. De leer van Bodin is - evenals die van Hobbes (zie hierna) een leer van de (absolute) vorsten- c.q. overheidssoevereiniteit, zoals de leer van Rousseau een leer van de (eveneens absolute) volkssoevereiniteit zal zijn. Terwijl dus in Bodins leer de vorst c.q. overheid wordt geïdentificeerd met de Staat ${ }^{31}$, wordt in Rousseaus leer het volk daarmee vereenzelvigd. Pas vanaf de achttiende eeuw zal in de staatsleer niet meer de vorst maar de Staat, als publieke rechtsgemeenschap van overheid en burgers, zelf soeverein worden verklaard (En binnen dit staatsverband zal de vorst als orgaan van dat verband worden beschouwd) ${ }^{32}$.

De (absolute) soevereiniteit is wezenlijk kenmerk van de Staat (dat wil dus zeggen: de vorst) en betekent volgens Bodin de hoogste, ondeelbare en onvervreemdbare macht van de Staat over alle mensen en corporaties binnen zijn grondgebied:

'La souverainetéest la puissance absolue et perpétuelle d'une République'.

De vorst heeft dus niet bepaalde soevereine rechten ('iura regalia'), maar hij heeft dé soevereiniteit ('puissance absolue'), welke soevereiniteit voortdurend ('puissance perpétuelle') ${ }^{33}$ en dus onvervreemdbaar is. 'République' staat hier niet voor de republikeinse regeringsvorm als tegenstelling tot de monarchistische, maar voor de Staat als res publica, als instituut van het algemeen belang ${ }^{34}$. De soevereiniteit is onbeperkt, in macht, in taak en in tijd:

'La souverainetén'est pas limitée, ni en puissance, ni en charge, ni à certain temps'.

De soevereiniteit impliceert volgens Bodin de bevoegdheid van de Staat (dus van de hoogste machthebber, de vorst) met uitsluiting van ieder ander op oorspronkelijke wijze positief recht te vormen binnen de grenzen van het statelijk territoir. De Staat vertoont dus niet de dualistische opbouw van de standen 'staat'. De eigendomsrechten op overheidsgezag, uitgeoefend door talloze groepen (standen, landschappen, gilden etc.) en lagere heren, worden aan deze onttrokken - of beter: ze worden als nietbestaanbaar gedacht, 'weg-gedacht' - en opgenomen in de ceén-en-ondeelbare soevereiniteit van de vorst.

Terwijl men eerder de aard van het koningschap c.q. de landsheerlijkheid bepaald zag door zijn verschillende iura regalia - de 'bundel' hoogheidsrechten - en de kern ervan gelegen achtte in het opperste rechterschap, en men bovendien de traditionele privileges der verschillende standen onaantastbaar achtte voor het vorstelijk gezag ('iura quaesita'), gaat Bodin uit van de absolute soevereiniteit die nu niet meer primair bepaald wordt door het opperste rechterschap maar door de soevereine 
- absolute en oorspronkelijke - bevoegdheid van de vorst tot algemene en bijzondere rechtsvorming ('wetgeving') binnen het staatsterritoir:

'La premier marque du Prince souverain, c'est la puissance de donner loy à tous en general, et à chacun en particulier' 13 .

Dit impliceert dat bij niet-statelijke samenlevingskringen geen oorspronkelijke bevoegdheid tot rechtsvorming aanwezig kan worden geacht, en dat alle bestaande positieve recht, ook het gewoonterecht, slechts juridische gelding heeft, indien of voorzover de soevereine machthebber het uitdrukkelijk of stilzwijgend erkent.

Deze leer is in de tijd van Bodin zeer functioneel, namelijk voorzover zij dient tot afbraak van de feodale rechten van standen, gilden, landschappen, lagere heren, etc., rechten die met een beroep op privileges en op gewoonterecht werden verdedigd. Door de rechtsgelding van alle positieve recht - privileges, landrecht, gewoonterecht etc. - afhankelijk te stellen van de soevereine wetgevende wil van de vorst, kunnen deze aanspraken op stukken overheidsmacht worden gebroken ${ }^{36}$.

Volgens deze leer kan men in iedere Staat een onderscheid maken tussen soeverein ('overheid') en onderdanen, welke laatsten allen gelijkelijk worden bestreken door het soevereine overheidsgezag. De basis voor het moderne concept van de staatsburger is hier reeds aanwezig. Tegelijkertijd wordt afscheid genomen van de opvatting volgens welke de verhouding tussen vorst en 'ondersaten' wordt beheerst door wederzijdse rechten en plichten, waarbij tegenover de iura regalia van de vorst de verkregen voor-rechten van standen, steden etc. staan.

Ook Kossmann wijst op de dynamische kracht die is uitgegaan van de nieuwe soevereiniteitsopvatting ${ }^{37}$ : doordat men het koningschap nu niet meer bepaald ziet door het opperste rechterschap doch door de wetgevende macht, is de functie van het koningschap niet meer - zoals voorheen - uitsluitend behoudend maar, integendeel, in hoge mate creatief geworden.

De vorst is dus niet aan het 'gemene recht' gebonden, en evenmin aan het door hemzelf gemaakte positieve recht, althans niet juridisch (wèl zedelijk). Immers, hij is 'legibus solutus' en de belichaming van de wet ('lex animata'), want hij stelt zelf de wetten vast. Wèl is de vorst rechtens gebonden aan het goddelijke recht en het natuurrecht, en daarnaast ook aan de door hem met zijn onderdanen en met vreemde vorsten gesloten overeenkomsten, zulks omdat de binding aan het contract wordt gefundeerd in het natuurrechtelijke principe 'pacta servanda sunt'.

Een andere grens aan de 'puissance publique' is hierin gelegen, dat het publiek domein onvervreemdbaar is. De soeverein moet in beginsel met de inkomsten uit dat domein uitkomen. En nieuwe belastingen dienen naar de opvatting van Bodin dan ook slechts met toestemming van de standen te worden ingesteld en geheven, behoudens het geval van dringende noodzaak ${ }^{38}$. 
Reeds in zijn in 1532 verschenen 'Il principe' (De vorst) ${ }^{39}$ had Macchiavelli verdedigd dat voor de vorst niet het recht of de moraal, maar slechts het staatsbelang maatstaf dient te zijn voor zijn optreden ${ }^{40}$. Deze opvatting, volgens welke de vorst iedere hem als doelmatig voorkomende maatregel mag treffen en niet is aangewezen op de uitoefening van specifieke 'hoogheidsrechten' (iura regalia), breekt met de middeleeuwse rechtsopvatting. Anders dan bij Bodin is er bij Macchiavelli echter geen binding van de staatsraison aan natuurrecht en gesloten verdragen.

Bodin is niet zo zeer belangrijk als vernieuwer, maar hij heeft de nieuwe soevereiniteitsopvatting voor het eerst in een heldere conceptie opgeklaard ${ }^{4 !}$.

Waar Donner stelt dat het werk van Bodin op zichzelf geen politieke theorie biedt, drukt hij zich dan ook ongelukkig uit ${ }^{42}$. Donner bedoelt vermoedelijk te zeggen dat Bodin weliswaar de soevereiniteit maakt tot de essentie van de Staat, maar er geen verklaring voor geeft in die zin dat hij haar niet afleidt van God danwel uit een 'maatschappelijk contract' noch haar anderszins fundeert. Deze fundering laat Bodin waarschijnlijk welbewust achterwege ${ }^{43}$. Want zowel indien hij het soevereine gezag zou hebben afgeleid van God alsook wanneer hij het had afgeleid uit de aanvaarding of een maatschappelijk verdrag, had hij - in een tijd waarin godsdiensttwisten woeden en waarin het standenstaatswezen nog niet geheel is verlaten - zijn soevereiniteitsconceptie té kwetsbaar gemaakt.

Hobbes' Staats-Leviathan: absolute overheidssoevereiniteit als volksrepresentatie Zo'n fundering wordt wèl geboden door Thomas Hobbes (1588-1679), voor wie - anders dan voor Bodin - soevereiniteit niet meer een nieuw begrip is maar het sleutelbegrip in zijn theorie. Om Bodins absolutistische soevereiniteitsbegrip, dat - consequent doorgevoerd - voor de vrije menselijke persoonlijkheid geen ruimte laat, tóch aannemelijk te maken vanuit het humanistisch vrijheidsideaal, maakt Hobbes gebruik van het denkmodel van het 'oorspronkelijk verdrag'.

Mét de onttheologisering en mechanisering van het wereldbeeld en de opkomst van het individualisme is de vraag naar de 'natuur' van de verschijnselen opnieuw actueel geworden. Het geseculariseerde politieke denken van de zeventiende en achttiende eeuw gebruikt het 'natuurlijke' als sleutelbegrip en het denkmodel van de 'oorspronkelijke overeenkomst' als fundering van de staat.

Het hoofdwerk van Hobbes, de 'Leviathan' (1651), biedt één van de eerste grote voorbeelden van de moderne verdragsfilosofieën ${ }^{44}$.

Evenals later bij Locke en Rousseau is het oorspronkelijke verdrag bij Hobbes louter een overeenkomst tussen de geïsoleerde individuen in een (veronderstelde) natuurtoestand ('state of nature'). Conform het humanistische persoonlijkheidsideaal gaan zij, in tegenstelling tot de middeleeuwse denkers, uit van individuen en niet van collectiviteiten. Volgens Hobbes leven in de natuurtoestand de individuen in een 
permanente toestand van oorlog van allen tegen allen ('bellum omnium contra omnes'; 'homo homini lupus'). Het instinct van zelfbehoud drijft de mensen tot het zoeken en zich garanderen van een veiligheid die een ordelijk en vreedzaam leven mogelijk maakt. De menselijke rede leert 'van nature' ${ }^{45}$ dat vrede alleen bereikt kan worden, indien een burgerlijke staat in het leven wordt geroepen bij een overeenkomst waarbij de individuele mensen al hun oorspronkelijke macht overdragen - en daarmee hun natuurlijke vrijheid prijsgeven - aan een soevereine machthebber, aan wie allen gelijkelijk zijn onderworpen en die in zijn persoon de veelheid van mensen als eenheid - als volk - representeert ${ }^{46}$. Reeds omdat het 'volk' in de natuurtoestand niet bestaat - die toestand kent slechts een verzameling individuen; de volkseenheid ontstaat eerst door het verdrag -, kan in de gedachtengang van Hobbes van een oorspronkelijke volkssoevereiniteit geen sprake zijn.

De soeverein is de bron van alle positieve recht, zowel het wettenrecht als - krachtens uitdrukkelijke of stilzwijgende autorisatie door de soeverein - van al het andere recht, zoals het gewoonterecht. Waar geen wet is, is ook geen rechtvaardigheid. Anders dan Bodin acht Hobbes de soeverein juridisch niet gebonden aan een natuurof goddelijk recht ${ }^{47}$.

Tegen de soeverein mag het 'volk' niet in opstand komen, omdat men bij het oorspronkelijk verdrag zelf zijn toestemming tot instelling van een absolutistische overheid heeft gegeven en al de daden van de laatste - die immers het volk als cenheid representeert - zijn eigen daden zijn: 'wie tegen het hoogste gezag opkomt, staat tegen zichzelf op'.

Toen hij begon met het schrijven van de 'Leviathan' zal Hobbes waarschijnlijk een rechtvaardiging van het absolutistische streven van het Engelse koningshuis Stuart voor ogen hebben gestaan. Wanneer na de puriteinse revolutie (1649) de Stuarts - zij het tijdelijk - ten val worden gebracht en de opperheerschappij van het Engelse parlement wordt gevestigd, valt het Hobbes niet moeilijk zijn theorie los te maken van de monarchale regeringsvorm. Want de (hoogste) overheid kan evengoed het parlement zijn!

\section{Lockes klassiek-liberale rechtsstaatsidee: beperkte soevereiniteit als 'fiduciary} power'; de overheid als beschermer van de private vrijheid ('property')

John Locke (1632-1704) ${ }^{48}$ gebruikt de fundamenten van Hobbes' theorie om daarop zijn eigen staats- en rechtsfilosofie te bouwen. Deze is neergelegd in zijn 'Two Treatises of Government' (1690), waarmee een ideologische basis wordt geboden voor het verzet tegen het vorstenabsolutisme van het Huis Stuart ${ }^{49}$. Met name de in de tweede 'Treatise' ${ }^{50}$ omschreven beginselen zullen van grote invloed zijn op de Amerikaanse constitutie en, via die constitutie, op de Franse 'Déclaration' des Droits de l'Homme en du Citoyen' (1789). Bij Locke wordt het primaat toegekend 
aan het humanistische ideaal van de autonome vrijheid van de individuele mens, dat bij Hobbes volledig overwoekerd was door het beheersingsideaal. Evenals Hobbes gaat Locke uit van een (veronderstelde) natuurtoestand, waarin iedere mens cen 'natuurlijke vrijheid' ('natural liberty') heeft, maar anders dan Hobbes neemt hij aan dat die 'natuurlijke vrijheid' onvervreemdbare mensenrechten op leven, vrijheid en eigendom ('life, liberty and property') - ook aangeduid met de overkoepelende term 'eigendom' (property') ${ }^{51}$ - impliceert, die ó́k bij verdrag niet kunnen worden prijsgegeven. Daarmee beperkt hij van meet af aan de inhoud van het oorspronkelijk verdrag door het geen ander doel te geven dan het rustig genot der natuurlijke mensenrechten in een burgerlijke Staat: de burgers hebben daarin hun 'natuurlijke vrijheid' hebben behouden, voorzover zij bij het verdrag niet een beperking daarvan hebben geaccepteerd ${ }^{52}$. Dit impliceert dat de idee van een absolute soevereiniteit van de (hoogste overheid) wordt verworpen en dat er náást het statelijk terrein - waarbinnen de overheidsmacht in het algemeen belang, onder een algemene wetgeving moet worden uitgeoefend - een geheel niet-statelijk ('maatschappelijk') terrein bestaat van natuurlijke, vrije relaties tussen de individuen, waarin zij naar eigen inzicht hun private belangen kunnen behartigen. En de overheidsmacht kan nimmer verder reiken dat het algemeen belang ('the common good', 'the public good of the society') vereist: een overheid die bij de uitoefening van haar bevoegdheden eigen, private belangen najaagt of die de absolute macht tracht te grijpen over de 'property', is voor Locke geen overheid meer en verbeurt het vertrouwen ('trust') van het volk 53 .

In de theorie van Locke manifesteert zich voor het eerst de idee van een onderscheiding tussen Staat ('government') en 'maatschappij' ('civil society'), tussen een publieke rechtsorde en een burgerrechtelijke rechtsorde, waarbinnen de individuen vrij zijn - binnen de perken die de wet overeenkomstig het algemeen belang stelt eigendom te verwerven en daarover autonoom te beschikken, onder garantie van het 'Zwangsmonopol' van de Staat ${ }^{54}$.

Bij Locke herkennen we ook reeds de trias politica: behalve een wetgevende (en hoogste) macht - gevormd door een volksvertegenwoordiging - en een uitvoerende macht ${ }^{55}$, dient er 'een erkende en onafhankelijke rechter' te zijn 'met bevoegdheid in alle geschillen uitspraak te doen volgens de wet', zulks ter waarborging van de private vrijheidsrechten der burgers ${ }^{56}$.

Slechts op basis van een algemene wetgeving kan worden ingegrepen in de 'property'; de wet begrenst en vestigt dus de overheidsbevoegdheden. Daar voorbij is dwang niet mogelijk; aldus is de wet tevens een waarborg voor de vrijheid en biedt zij rechtszekerheid. Er kan in de burgerlijke maatschappij geen vrijheid zijn zonder wet:

'The end of the law is not to abolish or restrain, but to preserve and enlarge freedom. For in all the states of created beings capable of laws, where there is no law there is no freedom' " 
Ook de idee van de volksvertegenwoordiging wordt door Locke betrokken op de publieke rechtsidee. Dit is eveneens een belangrijk verschil met de middeleeuwse rechtsopvattingen, waarin de statenvergaderingen niet optraden als representanten van de gehele bevolking in de Staat, maar slechts als behartigers van de eigen groepsbelangen van de standen of 'staten' tegenover de landsheer.

Locke erkent overigens dat de wetgever niet alles van te voren kan voorzien: er zijn situaties waarin de uitvoerende macht iets moet doen zonder dat daarvoor een specifieke wettelijke grondslag voor bestaat, ja zelfs soms moet handelen in strijd met de wet, met name in die - niet voorzienbare - gevallen waarin uit een oogpunt van algemeen belang snel optreden geboden is en de kwestie niet meer ter regeling aan de wetgever kan worden voorgelegd. Locke spreekt in dit verband van het aan de hoogste uitvoerende macht toekomende 'prerogative:

'(P)rerogative (is) nothing but a power in the hands of a prince to provide for the public good in such cases which, dependingupon unforseen and uncertainoccurrences, certain and unalterable laws could not safely direct. Whatever shall be done manifestly for the good of the people, and establishing the government upon its true foundations is, and always will be, prerogative $\$$. (....) This power to act according to discretion for the public good, without the prescription of the law and sometimes even against it, is that which is called prerogative; for since in some governments the law-making power is not always in being and is usually too numerous, and so too slow for the dispatch requisite to execution, and because, aiso, it is impossibie 00 foresee and so by laws 00 provide for all accidents and necessities that may concern the public, or make such laws as will do no harm, if they are executed with an inflexible rigour on all occasions and upon all persons that may come in their way, therefore there is a latitude left to the executive power to do may things of choice which the laws do not prescribe' ${ }^{99}$ (...) (P)rerogative can be nothing but the people's permitting their rulers to do several things of their own free choice where the law was silent, and sometimes too against the direct letter of the law, for the public good and their acquiescing in it when so done' 60 .

Omdat de wetgevende macht nagenoeg altijd te traag is voor de snelle afdoening die bij bestuurszaken vereist is, zal de administratie voor met name 'unforseen and uncertain occurrences' een eigen beleidsruimte moet worden gelaten, maar wel steeds binnen de grenzen van het algemeen belang ${ }^{61}$.

Locke verwerpt dus de staatsabsolutistische concepties van eerdere natuurrechtstheoretici en kan worden beschouwd als de eerste verdediger van de vroeg-liberale rechtsstaatsidee, omdat hij niet alleen de publieke rechtsidee en het statelijk 'Zwangsmonopol', maar tevens het bestaan van onvervreemdbare aangeboren mensenrechten, de machtenscheiding, de heerschappij van de wet, het representatiebeginsel, onafhankelijkheid van de rechterlijke macht en de onderscheiding Staat'maatschappij' erkent. Sinds Locke is men de private eigendom gaan verbinden met de burgerlijke vrijheid: private eigendom als vrij en volstrekt beschikkings- en genotsrecht, als eigendomsvrijheid. Het feodale denken kende hooguit een gebruiks- 
recht, dat overschaduwd werd door een hoogheidseigendom (dominium directum c.q. dominium eminens) ${ }^{62}$.

Lockes staatsidee is echter eenzijdig privaatrechtelijk gekleurd: het doel én tegelijkertijd de grens van de wetgevende macht is het waarborgen van de private eigendom: 'common good' c.q. 'public good of the society' valt dus samen met 'preservation of property' ${ }^{63}$. In Lockes natuurrechtelijke gedachtengang gaat het immers primair om het behoud van zoveel mogelijk 'natuurlijke vrijheid', zoals de mens die reeds vóór de vestiging van de Staat zou hebben genoten. Individuele vrijheid bestaat wezenlijk in de private eigendom, terwijl de publieke gemeenschap (de Staat) een constructie is met als doel de bescherming van die private eigendom, waarin alle menselijke basisrechten vervat zijn ${ }^{64}$. Men kan zeggen dat in deze visie de opdracht van de Staat enkel gelegen is in de handhaving van een private rechtsorde ter bescherming van de burgerrechtelijke vrijheid, waarvan de private eigendom de kern vormt (een 'nachtwakerstaat' dus). Voor Locke lijkt de democratie dan ook geen doel in zich zelf, maar alleen een middel ter bescherming van de private eigendom. Het verwondert ook niet, dat nergens expliciet de principiële eis van een algemeen kiesrecht voor de burgers wordt gesteld ${ }^{65}$.

Rousseaus idee der radicale democratie: absolute volkssoevereiniteit als staatkundige vrijheid

Evenals Locke vindt Jean-Jacques Rousseau (1712-1778) zijn uitgangspunt in de aangeboren vrijheidsrechten van de mens (de 'natuurlijke vrijheid'), maar anders dan bij Locke ligt bij hem niet de nadruk op de private vrijheid van de mens tegenover de Staat (en de functie van de Staat ter waarborging van die 'property'), maar op de vrijheid in de Staat, de staatkundige vrijheid van de mens als citoyen.

De natuurtoestand der mensheid was volgens Rousseau een louter door het natuurlijk vrijheidsgevoel van de mens beheerste toestand van onschuld en geluk. De rationalistische cultuur heeft de natuurlijke vrijheid en gelijkheid van de mens echter vernietigd en hem in slavernij en ellende gestort. Zij heeft ongelijkheid geschapen en de mensen aan de heerschappij van vorsten onderworpen, waarbij van de vrijheid en autonomie der menselijke persoonlijkheid weinig of niets is overgebleven. De beroemde eerste regel van zijn in 1762 verschenen 'Du contrat social, ou principes du droit politique' luidt:

'De mens wordt vrij geboren, maar overal is hij geketend' $\%$.

Omdat Rousseau echter ook wel inziet dat een terugkeer van een louter door het natuurlijke gevoel van de mens beheerste natuurtoestand niet wel mogelijk is, wil hij een antwoord geven op de vraag: op welke wijze kan een Staat en samenleving 
worden ingericht, waarin iedere mens, zich verbindende jegens allen, niettemin slechts aan zichzelf gehoorzaamt en even vrij blijft als te voren? ${ }^{67}$

Dit is - aldus Rousseau - het grondprobleem waarop het maatschappelijk verdrag de oplossing geeft. Ter waarborging van hun gelijke vrijheid hebben de mensen een verdrag gesloten, waarbij zij zich geheel hebben gegeven aan alle anderen, zodat niemand heerschappij over de ander verkrijgt, maar slechts allen gezamenlijk over allen heerschappij voeren, zodat ieder gelijk blijft aan de ander. Tegelijkertijd blijft hij vrij als tevoren, omdat wat hij afstaat hem als een deel van het geheel in een nieuwe vorm wordt teruggeschonken:

'Ieder van ons brengt in de gemeenschapzijn persoon en zijn gehele macht onder het opperbestuur van de algemene wil en wij ontvangendan, ieder lid als onderdeel van het geheel gezamenlijk' ${ }^{\circ}$.

Bij het verdrag is de natuurlijke vrijheid van de mensen dus geheel opgegaan in een hogere vorm van vrijheid: de ware - namelijk staatkundige - vrijheid als leden van de publieke gemeenschap, van actieve burgerrechten die aan alle burgers gelijkelijk toekomen, en niet slechts aan enkele uitverkorenen (zoals in een representatief stelsel).

Mét het sluiten van het maatschappelijk verdrag is de 'volonté de tous' geworden tot 'volonté générale' van het soevereine volk en zijn de mensen geworden tot staatsburgers. Deze 'volonté générale' openbaart zich in een op het algemeen belang ('intérêt commun') betrokken wetgeving, die per definitie geen nadeel kan toebrengen aan de vrijheid der burgers maar die hun vrijheid juist realiseert. Als staatsburgers ('citoyens') - dat wil zeggen: als leden van het soevereine volkslichaam - stellen zij wetten voor zichzelf als onderdanen ('sujets'). De wet is als uitdrukking van de 'volonté générale' het produkt van ieders vrijheid: de wet wordt geacht door ieder te zijn gewild en geldt voor ieder gelijkelijk. Wanneer iemand de wetgeving overtreedt, schendt hij dus zijn eigen vrijheid. Wordt hij tot naleving gedwongen, dan wordt hij tot eigen vrijheid gedwongen: 'on le forcera à être libre' ${ }^{69}$.

De soevereiniteit wordt niet tot uiting gebracht door de wil van allen ('volonté de tous') maar door de 'volonté générale' van het soevereine volk, hetgeen neerkomt op de wil van de meerderheid: de minderheid moet zich hebben vergist.

Rousseau komt dus terecht bij een totalitaire staatsleer, die grote gelijkenis vertoont met die van Hobbes, met dit verschil dat bij Rousseau de absolute soevereiniteit van de vorst is overgebracht naar het in de wetgevende vergadering verzamelde volk. Het (soevereine) volk en de Staat worden dus vereenzelvigd. Tegenover Hobbes' leer van de overheidssoevereiniteit plaatst Rousseau zijn leer van de volkssoevereiniteit. Deze soevereiniteit is absoluut, onvervreemdbaar en ondeelbaar, omdat ook het volk dit is.

De democratie van Rousseau is een radicale democratie. Van een representatieve democratie wil hij niet weten, omdat zo'n stelsel zou impliceren dat het volk het 
recht tot vrije zelfbepaling overdraagt aan een 'elite', die het dan weer zijn wil kan opleggen. Het soevereine volk kan niet vertegenwoordigd worden:

'ledere wet, die niet door het volk persoonlijk is bevestigd, is van onwaarde; het is geen wet. Het Engelse volk meent dat het vrij is. Het vergist zich deerlijk. Het is dat slechts gedurendede verkiezing der leden van het parlement. Zodra die zijn gekozen, is het slaaf, is het niets. In de korte ogenblikken van zijn vrijheid maakt het daarvan een gebruik, dat het verlies ervan rechtvaardigt' $\%$.

De bestuurders en de rechters zijn in deze visie slechts dienaren van het soevereine volk ('simples officiers du Souverin'), hetgeen ook betekent dat hun doen en laten volledig wordt gedetermineerd door de soevereine wetgeving. Van machtenscheiding kan geen sprake zijn.

Rousseaus vrijheidsbegrip heeft dus een étatisch karakter: (gelijke) vrijheid in en dór de Staat. Terwijl er bij Locke sprake is van een overspanning van de burgerrechtelijke vrijheid, wordt door Rousseau de staatkundige (publiekrechtelijke) vrijheid overtrokken. Bij het oorspronkelijk verdrag hebben de mensen hun individuele rechten ingeruild tegen medezeggenschap in de soevereiniteit, die toekomt aan de collectiviteit. Van onvervreemdbare mensenrechten - een vrijheid tegenover de Staat - en van een van de publieke sfeer te onderscheiden burgerrechtelijke rechtsorde kan geen sprake zijn, omdat ó́k de contractsbevoegdheid en de aan eigendom verbonden bevoegdheden zijn gebaseerd op verlening door de wet (emanatie van de volkswil) en in functie staan van het algemeen belang ${ }^{71}$. Eigendom heeft hier een zuiver positiefrechtelijk karakter.

Omdat de idee van de volksdemocratie in kleine Staten al een onmogelijkheid is, laat staan in grote Staten, leiden pogingen tot realisering van deze idee in de praktijk echter steeds tot een schijn-democratie onder leiding van een kleine elite (de partij), waardoor de Staat weer feodale karaktertrekken aanneemt ${ }^{72}$.

We wezen er al op dat in de 'Déclaration des Droits de l'Homme en du Citoyen' van 1789 enerzijds de door Locke geformuleerde staatkundige beginselen en anderzijds Rousseaus leer van de volkssoevereiniteit tot uitdrukking komen.

$\mathrm{Na}$ te hebben vastgelegd: 'De mensen zijn vrij geboren en blijven vrij en gelijk in rechten', geeft de Declaratie een catalogus van mensenrechten. Doel van het maatschappelijk verdrag is volgens art. 2 'het behoud van de natuurlijke en onvervreemdbare rechten van de mens: het recht op vrijheid, eigendom, veiligheid en op verzet tegen onderdrukking'.

In de vastlegging van de volkssoevereiniteit (art. 6: 'La loi est l'expression de la volonté générale' en art. 3: 'Le principe de toute souveraineté réside essentiellement dans la Nation') ligt het essentiële verschil met de Amerikaanse constituties. De conceptie van de volkssoevereiniteit sluit aan bij de vrijheidsopvatting van Rousseau - rechten worden de burger verleend door de wet als emanatie van de algemene 
wil - en is in wezen tegenstrijdig met de idee van de praeconstitutionele, onvervreemdbare vrijheidsrechten.

Men kan - zoals Mekkes terecht opmerkt ${ }^{73}$ - de grote betekenis van Rousseaus leer voor de doorbraak van de rechtsstaatsidee echter niet ontkennen met de stelling dat de staatsabsolutistische constructie van de 'volonté général' zich niet verdraagt met de leer van de onvervreemdbare mensenrechten. De door Locke verwoorde ideeën leiden tot de erkenning van onvervreemdbare mensenrechten (vrijheid tegenover de Staat), de doorvoering van een onderscheid tussen Staat en 'civil society' en daarmee tot de invoering van het moderne burgerlijk recht, dat berust op het beginsel van de burgerlijke vrijheid en gelijkheid. Wat echter o.i. vooral door Rousseau in het licht wordt gesteld, is het gemeenschapskarakter van het staatsverband en het belang van een publieke moraal: de (rechtsvormende) wil van de Staat is niet de optelsom van de private 'willen' van een toevallige verzameling individuen ('la volonté de tous'), maar de gemeenschapswil ('la volonté générale': de wil van de publieke rechtsgemeenschap ${ }^{74}$, die tot uitdrukking wordt gebracht door haar organen (met name de wetgever) en die nimmer op een privaat belang maar enkel op het algemeen belang ('salut public') gericht kan zijn. Rousseaus leer draagt aldus wezenlijk bij tot de monopolisering van de overheidsmacht ten dienste van uitsluitend publieke rechtsbedeling in een eenheidsstaat, en tot doorvoering van staatkundige rechten voor een ieder (vrijheid in en door de Staat).

\section{Het ius politiae; politie- en justitiezaken; criminele en civiele zaken}

\section{Het ius politiae}

De absolutistische Staten die vanaf de zestiende eeuw opkomen, worden - zo merkten we op - ook wel aangeduid als 'politiestaten'. Onder 'politie' (Frans: la police; Duits: gute Polizei) worden de op een goed geordende toestand van de gemeenschap (het staatsbestel: de politeia) gerichte overheidsactiviteiten verstaan, de maatregelen die bevorderlijk worden geacht voor 's lands oirbaer', het 'bonum commune'. In de veertiende eeuw doet door heel West-Europa opeens het woord 'politie' zijn intrede, aldus Donner ${ }^{75}$. Het begrip 'politie' ontstaat binnen het kader van het stadsrecht (het recht van de 'polis'). In eerste instantie wordt met 'politie' gedoeld op de opbouw van de binnen het stedelijk territoir (binnen de stadsmuur) aanwezige samenleving; vervolgens ontstaat de betekenis van: zorg voor de instandhouding van die samenleving (de huishouding) ${ }^{76}$. Met het oog daarop worden aan het eind van de Middeleeuwen in vele steden wetgevende maatregelen - 'keuren' op de 'policie' uitgevaardigd. 
Vanaf de zestiende eeuw wordt eenzelfde betekenis toegekend aan maatregelen van dezelfde soort voor het gehele 'land', getroffen door de soeverein of - namens de soeverein - door zijn ambtenaren. Het begrip 'politie' wordt dan gekoppeld aan het pas opgekomen soevereiniteitsbegrip. Hetzelfde geldt voor het begrip 'bonum commune' (gemeen nut), dat vanaf de zestiende eeuw steeds meer wordt gezien als de taak van de hoogste overheid.

Het 'ius politiae' wordt dan gefundeerd in de overheidssoevereiniteit en beschouwd als de 'van nature' aan de hoogste overheid toekomende algemene bevoegdheid om al die maatregelen te treffen die in het 'bonum commune' nodig worden geacht. Deze 'leer' van het 'ius politiae' is volgens Fleiner ontwikkeld in Frankrijk en elders overgenomen ${ }^{n}$. Waarschijnlijk vindt deze leer mede haar basis in de door middeleeuwse juristen met romeinsrechtelijke begrippen geconstrueerde idee van het dominium eminens, dat een opper-eigendom van de landsheer over zijn grondgebied en daarmee een algemene gezagsbevoegdheid over zijn 'ondersaten' zou impliceren. Een opvatting die past in de ongedifferentieerde middeleeuwse rechtsopvatting, waarin (privaat) 'dominium' en 'imperium' zijn vermengd. In het 'ius politiae' wordt die koppeling met (privaat) 'dominium' losgelaten ${ }^{78}$.

Ofschoon het begrip 'politie' overal in West-Europa ingang vindt ${ }^{79}$, zal de leer van het 'ius politiae' toch vooral een hechte basis leggen voor de absolutistische Staten (de politiestaten). 'Politie' en 'Staat' ( = hoogste overheid) als enige soevereine macht zijn onlosmakelijk aan elkaar geklonken. Fleiner, die een aanduiding geeft van de rechtsontwikkeling in Duitsland, schrijft:

'Der aus Frankreich übernommenen Theorie vom ius politiae (la police) gelang es, die erweiterte

Zuständigkeitder Staatsgewalt zu rechtfertigen. Das ius politiae sprach dem LandesherrnRecht und Pflicht zu, mit obrigkeitlicher Gewalt die Gefahren abzuwenden, die der irdischen Glückseligkeit, d.h. der Sicherheit und der Wohlfahrt der Bürger drohten. Das Ziel des ius politiae wurde die Herstellung des guten Zustandes des Staatswesens (= politia). Was das Interesse der "Policey" erforderte, durfte der Landesherr anordnen. Über die Notwendigkeit einer Anordnung und über die hierbei zur Anwendung zu bringenden Mittel, entschied seine freie 'Konvenienz'. Damit war aber der Grund gelegt für die absolute Fürstengewalt; der Polizeistaat war fertig' wo.

De praktische uitwerking van de politiek van de absolute vorsten geschiedt in toenemende mate door ambtenaren - vooral juristen - die in Duitsland, met name Pruisen, een academische vorming krijgen in de vanaf de zeventiende eeuw opkomende 'Polizei-' en 'Kameralwissenschaften'. Otto Mayer beschrijft de ontwikkeling als volgt:

'Im Öbergang zur neueren Zeit ... nimmt sie (die Polizei; JT) einen măchtigen Aufschwung: sie ist es geradezu, die den Staat in seinem ganzen Verhāltnis zum Unterthanen kennzeichnet: Heer und Justiz bleiben selbstāndig: alles, was danebenzur inneren Festigung und Stärkung des Gemeinwesens geschehenkann, ist Polizei, die rastlos neue Mittel und Wege findet und von der sich entwickelnden Kameralwissenschaft Anleitung dazu findet' (curs. dzz.; JT) ". 
Politie- en justitiezaken; civiele en criminele zaken; de fiscus

Mét de opkomst van het politiebegrip ontstaat vanaf de zestiende eeuw ook het onderscheid tussen 'justitie' (rechtspraak) en 'politie' (de rest van de overheidstaak) ${ }^{82}$, zij het dat soms de gehele overheidstaak wel met 'politie' wordt aangeduid ${ }^{83}$. Over de Nederlandse opvattingen ten tijde van de Republiek, die overeenkomst vertonen met die in Frankrijk en in Pruisen, schrijft Van der Poel:

"Justitie"' was, wat tot het volksrecht behoorde of er mee samenhing. politie, wat de vorst, als soeverein, ter behartiging van het algemeen welzijn, aan orde en regel, aan welvaartspolitiek en overheidszorg, voorschreef, inclusief de sancties, die hij er op stelde, of wat hij krachtens keurbevoegdheidaan de steden overliet' ${ }^{\mu}$.

Tussen wetgeving en bestuur bestaat aanvankelijk nog geen strikte scheiding: 'politie' is wetgeving + bestuur en bevat ook het complement ervan, de sanctie, aldus Van der Poel ${ }^{\mathrm{s}}$. Met deze omschrijving kan o.i. worden ingestemd, mits in aanmerking wordt genomen dat het aanvankelijk juist het terrein der 'justitie' is waarop de soevereine vorsten op basis van hun ius politiae omvangrijke wetgeving produceren ${ }^{86}$. Als later ook op het terrein der 'politie' wetgeving tot stand komt, die de uitoefening van de bestuursfunctie aan regels bindt, zal zich binnen de 'politie' allengs een onderscheid tussen wetgeving en bestuur gaan manifesteren. Men zal dan tevens kunnen onderscheiden tussen justitiewetgeving (wetgeving betrekking hebbend op justitiezaken) en politiewetgeving (wetgeving betrekking hebbend op politiezaken) ${ }^{87}$.

Om een indruk te krijgen wat onder 'politie' respectievelijk onder 'justitie' wordt begrepen, is het verhelderend deze onderscheiding af te zetten tegen een andere onderscheiding die eveneens tot de negentiende eeuw de juridische theorie en praktijk zal beheersen, namelijk die tussen 'civiel' en 'crimineel' ${ }^{88}$. De onderscheiding justitie tegenover politie enerzijds en de onderscheiding crimineel tegenover civiel anderzijds lopen tot de negentiende eeuw voor een belangrijk deel parallel.

Het criminele of lijfstraffelijke recht behelst minder dan wat men later - na de Franse revolutie - strafrecht zal noemen: het criminele recht heeft alleen betrekking op de crimina, de echte (hals- of andere ernstige) misdaden die ook zonder wettelijke norm als boos worden aangemerkt en waarop via lijf- of andere onterende straf behoort te worden gereageerd tegenover aangedaan lichamelijk leed e.d.: de 'eeuwige' of 'volksrechtelijke' misdaden. De wet houdt alleen een begrenzing in van de gevolgen van het begaan en soms nog een precieze omschrijving van het crimen in. Van der Poel wijst in dit verband op de driedeling die sinds de landsheerlijke tijd ontstaat tussen crimen, delict en contraventie. Wanneer vanaf het einde van de middeleeuwen steeds vaker politievoorschriften worden gegeven over allerlei zaken die nuttig of nodig worden geacht in het welvaartsbelang - waaronder het belang van 
de openbare orde en rust -, worden aan de desbetreffende ge- en verboden ook boetes verbonden. Als onterend worden overtredingen - 'contraventies' 89 - van dergelijke politionele voorschriften niet ervaren; de op niet-naleving ervan gestelde boetes worden dan ook niet als echte straf gezien. Die sancties hebben als doel de naleving van die voorschriften te verzekeren; anders dan bij het crimen speelt de aan- of afwezigheid van schuld geen rol. Deze sancties worden niet gerekend tot het criminele recht en tot de 'justitie', maar tot de 'politie'.

Een tussencategorie ontstaat als men een aantal overtredingen uit de zich steeds meer uitbreidende politievoorschriften gaat aanvoelen als zó ernstig, dat het opleggen van een sanctie als voor contraventie niet voldoende is. Een zwaardere en andersoortige sanctie wordt nodig, de straf. Die past men alleen toe, evenals bij crimen, indien er opzet, arglist e.d. ('fraude') bij aanwezig is; dit noemt men delicten ${ }^{\infty}$. Deze tussencategorie heeft dus ten dele eigenschappen met crimen, ten delen met contraventie gemeen. Volgens Van der Poel overweegt echter het 'civiele' en tevens 'politiële' karakter ${ }^{\text {'? }}$.

'Civiel' betekent - zo constateen Van der Poel - iets dat op geld waardeerbaar is en betreft dus niet alleen verhoudingen tussen burgers onderling, maar kan ook betekenen die tussen overheid en burgers ${ }^{92}$. Als 'civiel' worden dus ók de vorderingen van de overheid uit hoofde van bestuursboetes en belastingen beschouwd, terwijl de overtreding van een politionele verordening eveneens een civiele wordt genoemd. We kunnen dus zeggen dat de aanduiding 'civiel' wordt gebruikt voor vermogensrechtelijke zaken, in de ruime betekenis ${ }^{93}$. Schomaker schrijft in 1754:

'Alle zaken worden heden ten dage civiel geoordeeld, wanneer geen dood- of andere lijfstraffe

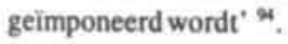

Tot de justitie behoren het criminele recht alsmede het 'civiele' recht, voorzover dit de verhoudingen tussen burgers onderling betreft.

Tot de politie behoren wetgeving en bestuur en het noodzakelijke complement daarvan: de bestuurssancties - waaronder de bestuursboeten (op contraventies en ook delicten) - , alsmede de belastingen ${ }^{\text {95 }}$. Het begrip 'civiel' overlapt dus gedeeltelijk het begrip 'politie', in ieder geval voorzover het gaat om de vermogensrechtelijke aspecten van de 'politie' $\%$.

Dit vermogensrechtelijke deel van de 'politie' wordt aangeduid met 'fiscus', welk begrip dus een ruimere inhoud heeft dan het huidige begrip 'fiscus' (slechts nog: belastingfiscus).

De term 'fiscus' is van romeinsrechtelijke oorsprong. Onder 'fiscus' (letterlijk: geldmandje) verstond men oorspronkelijk slechts de particuliere schatkist van de 
princeps, bedoeld ter bestrijding van de aan de uitoefening van het ambt verbonden persoonlijke onkosten, maar waaruit door de princeps ó́k voor publieke doeleinden (staatsdoeleinden) kon worden geput. De algemene schatkist, waarin de statelijke inkomsten stroomden en waaruit de statelijke uitgaven werden bekostigd, werd 'aerarium' genoemd. In de loop van de keizertijd vervloeide dit onderscheid en kende men slechts nog de fiscus als algemene aanduiding voor de staatskas ${ }^{97}$. Van de fiscus werd nog slechts onderscheiden het 'privatum patrimonium' als het echte privé-vermogen van de princeps.

In het feodale bestel met zijn ongedifferentieerde vermenging van 'imperium' en 'dominium', waarbij 'publieke bevoegdheden' worden beschouwd als persoonlijke 'private vermogensbelangen', betekent ook 'fiscus' niet meer de financiën van de Staat als publieke instelling, maar het persoonlijke vermogen van de koning resp. landsheer (en ook wel het koninklijk resp. landsheerlijk domein, als belangrijkste bron van inkomsten) ${ }^{98}$. Aan die fiscus zijn bijzondere ('fiscale') privileges ('privilegia fisci') verbonden ${ }^{9}$.

Vanaf de late de Middeleeuwen leidt het cultuurhistorisch differentiatieproces weer tot een scheiding van 'imperium' en (privaat) 'dominium' - en tot een daarmee gepaarde gaande ont-persoonlijking c.q. ver-ambt-elijking van het overheidsgezag -, wat ook niet zonder gevolgen kan blijven voor het fiscus-begrip. 'Fiscus' zal steeds meer worden begrepen als de publieke kas ${ }^{100}$, waaraan - omdat het de publieke kas is - bepaalde bijzondere bevoegdheden zijn verbonden ${ }^{101}$.

Tot het fiscale - en dus civiele (want vermogensrechtelijke) - deel van de 'politie' behoren met name de belastingen en de bestuurlijke boeten ${ }^{102}$. De aanduiding 'fiscus' wordt, elliptisch, ook gebruikt voor de overheid zelf, die waakt voor de belangen van de schatkist. Die fiscus heeft zijn eigen 'fiscaal recht' ('ius financiae'), dat wil zeggen een samenstel van bevoegdheden om het binnenkomen van de verschuldigde bedragen - boetes, belastingen etc. - beter te verzekeren ${ }^{103}$.

Nog weer later zal van ook wel van 'fiscus' worden gesproken als aanduiding van de overheid in al die gevallen waarin zij vermogensrechtelijk optreedt, dus óók in gevallen waarin de Staat wordt aangesproken wegens vermogensschade veroorzaakt door (beweerde) onrechtmatige overheidsdaad.

Deze uiteenzetting maakt duidelijk dat men zich er voor moet hoeden om burgerlijk recht, in de moderne zin van het recht dat regels geeft voor maatschappelijke betrekkingen tussen burgers en sociale groepen onderling, gelijk te stellen met het oude civiele recht ${ }^{104}$. Nog in de eerste decennia van de negentiende eeuw staan in Nederland de woorden 'civiel' en 'burgerlijk' niet tegenover 'politie' c.q. 'publiek(recht)', maar tegenover 'crimineel' en 'lijfstraffelijk'. 
Vorenstaande uiteenzetting was ook nodig om de rechtsontwikkeling te kunnen verstaan, die leidt tot de opkomst van de rechtsstaat. Twee kwesties zijn nu voor deze ontwikkeling van bijzonder belang.

De eerste kwestie betreft de verhouding tussen wetgeving en bestuur en tussen 'politie' (wetgeving en bestuur) en 'justitie'. Zolang wordt uitgegaan van een absolute soevereiniteit van de vorst, die ingevolge zijn ius politiae bevoegd wordt geacht tot alles wat in het algemeen belang nodig wordt geacht, worden wetgeving en bestuur resp. politie ('bestuur') en justitie ('rechtspraak') nog niet als afzonderlijke functies onderscheiden.

Zoals we nog zullen zien, zal wetgeving steeds meer worden beschouwd als een afzonderlijke functie, te onderscheiden van het politierecht (bestuursrecht). Bovendien gaat men de bestuursfunctie allengs beschouwen als uitvoering van wetgeving, hetgeen er vervolgens weer toe leidt dat 'politie' verder wordt verengd tot een onderdeel van de bestuursfunctie, alléén betrekking hebbend op de handhaving van openbare orde en rust en de bescherming tegen gevaren, of zelfs als een van rechtspraak, wetgeving en bestuur te onderscheiden overheidsfunctie. Deze ontwikkeling zal hierna worden geillustreerd aan de hand van het Pruisische Allgemeine Landrecht (1794). Als dan mét de doorbraak van de rechtsstaatsidee de beginselen van de machtenscheiding, de representatieve democratie, de scheiding Staat en maatschappij en een zelfstandige burgerrechtelijke rechtsorde definitieve erkenning en positivering krijgen in de Westeuropese rechtscultuur, rijst de vraag of en in hoeverre er nog bevoegdheden van het overheidsbestuur kunnen bestaan die niet hun grondslag vinden in de wet.

De tweede kwestie betreft de rechtsbescherming tegen de overheid: is voorziening bij de rechter mogelijk tegen optreden van de overheid in aangelegenheden van 'politie'? Deze vraag dringt zich met name op in die gevallen waarin door of namens de overheid vermogensschade is veroorzaakt bij de uitoefening van de 'politie'. Waar 'civiel' de ruime betekenis heeft van 'vermogensrechtelijk' en dus 6́6́k ziet op de geldelijke vorderingen van de overheid op haar onderdanen, zouden - omgekeerd - toch ook de vorderingen van onderdanen op de overheid terzake van de in het kader van de uitoefening van de 'politie' veroorzaakte (beweerd) onrechtmatige aantastingen van de vermogensbelangen van onderdanen als 'civiel' moeten worden aangemerkt, zo is het gevoelen bij velen.

Maar zijn de gewone gerechten wel bevoegd om zich, evenals in de gewone justitiezaken, te bemoeien met dergelijke geschillen tussen onderdaan en overheid? Is een rechterlijke bemoeienis met politiezaken niet als een aantasting van de overheidssoevereiniteit aan te merken?

Het is de fiscusleer die hier uitkomst zal bieden. Zoëven merkten we reeds op dat de term 'fiscus' allengs wordt gebruikt als algemene aanduiding voor de overheid 
die vermogensrechtelijk optreedt, dus óók in gevallen waarin de overheid wordt aangesproken terzake van vermogensschade veroorzaakt door (beweerde) onrechtmatige overheidsdaad. Zolang bij geschillen op het terrein der 'politie' geen voorziening open staat bij de gerechten, wordt de zgn. fiscus-leer gehanteerd als doelconstructie om tóch rechterlijke voorziening te kunnen verkrijgen. Die leer komt erop neer dat, voorzover het optreden van de overheid vermogensrechtelijke gevolgen heeft voor burgers, zij als fiscus opereert en hij in die hoedanigheid - op gelijke voet als andere vermogensrechtelijke subjecten - voor de gewone gerechten zou kunnen worden aangesproken.

Hier ligt de oorsprong van de in latere tijden gemaakte tweedeling tussen de overheid 'als overheid' ('als zodanig') en de overheid 'als fiscus', d.w.z. als vermogensrechtelijk subject. En omdat men in de negentiende eeuw vaak de fout zal maken 'vermogensrechtelijk' ( = 'civielrechtelijk' in de oude betekenis van het woord) gelijk te stellen aan 'civielrechtelijk' in de moderne betekenis van het woord, en men uit het oog verliest dat de fiscusleer een doelconstructie in het belang van de rechtsbescherming is, zal de misvatting ontstaan dat de overheid-fiscus de overheid 'in privaatrechtelijke hoedanigheid' is.

Op beide kwesties - de fiscusleer en de inperking van het politiebegrip - zullen we thans nader ingaan.

\section{Rechterlijke voorziening tegen overheidsoptreden; de fiscusleer}

Onder de politiestaat pleegt bemoeienis van de gewone gerechten met politiezaken door de Hoge Overheid als een aantasting van haar soevereiniteit te worden beschouwd. Dit wordt te méér als onaanvaardbaar aangemerkt, omdat óók de rechterlijke functie (de justitie) wordt geacht deel uit te maken van de soevereiniteit. Onder het Ancièn Regime wordt dit tot uitdrukking gebracht in de woorden 'Toute justice émane du roi' ${ }^{105}$. Dit impliceert óók dat de koning zich de bevoegdheid voorbehoudt arresten die in hoogste ressort door de Hoven - zijn Hoven - zijn gewezen en die daarom in beginsel niet meer aantastbaar zijn, toch te vernietigen. Daartoe wordt de juridische sectie van de Conseil du Roi belast met cassatie mede wegens rechtsschending, en mede ter verzekering van de eenheid van rechtspraak ${ }^{106}$.

In deze opvatting kan in politiezaken voor de onderdanen slechts voorziening mogelijk zijn bij de Hoge Overheid zèlf. In Frankrijk kan in vele geschillen in eerste instantie voorziening worden gevraagd bij de intendanten - koninklijke ambtenaren in de provincie -; tegen hùn beslissingen kan dan weer beroep worden ingesteld bij de Koning, die daartoe wordt geadviseerd door de Conseil du Roi. 
Ook in de Republiek der Zeven Verenigde Nederlanden worden de gewone gerechten regelmatig door de Hoge Overheid vermaand, zich buiten zaken van politie te houden en zich tot de justitie te beperken.

Zo wordt in Holland bij de zgn. Scherpe Resolutie van 1617 door de Staten - de soeverein in het gewest - bepaald, dat van alle stedelijke ordemaatregelen allén beroep op hun vergadering openstaat, terwijl aan de 'collegièn van justitie' iedere bemoeienis ter zake wordt ontzegd. En wanneer in 1674 de stad Haarlem zich ter statenvergadering beklaagt over de hinder die het van het Hof ondervindt, betoogt zij dat het beleid der politie enerzijds en de administratie der justitie anderzijds naar aard en eigenschappen zeer verschillen en niet aan dezelfde organen moeten worden opgedragen, omdat de justitie geen 'politieke' behandeling verdraagt: de taak van het Hof is strikt beperkt tot de justitie; de politie is 't eenemael ghesepareert' van de taak van het Hof 'en andere aenvertrouwt' ${ }^{107}$.

De Staten verklaren dan eenstemmig nogmaals, 'dat de Hoven van justitie gantsch niet en zijn bevoeght aen haer te trecken, of kennisse te nemen van eenige saecken van politie' ${ }^{108}$. En om te voorkomen dat de Hoven zich toch met dergelijke zaken zouden inlaten, onder voorwendsel dat zij tot de justitie behoren, of - omgekeerd dat justitiële zaken ten onrechte aan hun kennisneming zouden worden onttrokken, krijgen de Gecommitteerde Raden opdracht een lijst op te stellen van zaken die behoren tot de politie respectievelijk tot de justitie (Deze lijst is overigens, voorzover bekend, nimmer opgesteld).

Interessant is ook de resolutie die de Staten van Friesland in 1663 aannemen, naar aanleiding van een conflict tussen de Gedeputeerde Staten en het Friese Hof. Bepaald wordt dat het Hof ongehinderd de civiele en criminele jurisdictie mag uitoefenen, doch 'sonder sig in eenige manieren aan te matigen saecken, de politicque regieringe angaande, als daar syn: (volgt opsomming van aangelegenheden behorende tot de politie)' ${ }^{109}$. In al deze zaken zou slechts voorziening kunnen worden gevraagd bij de Gedeputeerde Staten, of de Staten zelf. We zien hier een vroege vorm van wat later administratief beroep zal worden genoemd.

Maar hoe nu in die gevallen waarin de rechter wordt geadieerd terzake van vermogensschade veroorzaakt door (beweerd) onrechtmatig overheidshandelen in aangelegenheden van politie? Dergelijke geschillen zijn weliswaar 'civiel' (vermogensrechtelijk), maar behoren strikt genomen tot het terrein der politie. Niettemin schijnt - zo concludeert Rijpperda Wierdsma - 'de rechtspraak ter zake van onrechtmatige overheidsdaden ... onder den Republiek niet als iets bijzonder te zijn beschouwd' ${ }^{110}$. Een zelfde conclusie wordt getrokken door J. Drion ${ }^{111}$ en Hartog, die er echter aan toevoegt: 'althans voor zoveel betrof de mogelijkheid van burgers om op te komen tegen gedragingen van lokale overheden' ${ }^{112}$. 
Dat een rechterlijke voorziening tegen een schadeveroorzakende handeling van de lagere overheid minder problematisch is dan waar het gaat om handelingen van de Hoge Overheid, zal hiermee te maken dat die Hoge Overheid de soeverein wordt geacht, zodat rechterlijke inmenging in de zaken van die Overheid als een aantasting van de soevereiniteit is te beschouwen. In 1669 merkt Groenewegen van der Made over de positie van de steden in de Republiek op:

'Civitates privatorum loco habentur quoad Principem' "1'.

In deze opvatting zijn de steden slechts 'civitates privatorum': zij hebben geen eigen, oorspronkelijke soevereiniteit, doch ontlenen hun hoogheidsrechten aan de vorst, dat wil zeggen (in de Republiek): de soevereine Staten. Het zijn 'subalterne corporaties', die tegenover de soeverein op één lijn staan met private personen. Rijpperda Wierdsma merkt op:

'Blijkbaar heeft men het althans niet in twijfel getrokken, dat een burger in een vordering tegen een stadsbestuur, strekkende om vergoeding te verkrijgen van door handelingen of nalatigheid van dat bestuur veroorzaakte schade, ontvankelijk was, en dat het tot de bevoegdheid van den gewonen rechter (stadsschepenen, in beroep de Hoven) behoorde om van dien eisch kennis te nemen' 14 .

Bovendien wordt, wáár door de gewone gerechten aansprakelijkheid terzake van schadeveroorzakend overheidshandelen aanwezig wordt geacht, doorgaans niet de overheid zelf doch de persoon van de overheidsdienaar aansprakelijk geacht ${ }^{115}$. De gedachte daarbij zal zijn, dat aldus de overheidssoevereiniteit onaangetast blijft.

Hartog vermeldt dat de 'centrale overheden' - waarmee hij doelt op de Staten - niet altijd 'buiten schot' zijn gebleven ${ }^{116}$. Rijpperda Wierdsma maakt melding van een in 1669 tussen Holland en Zeeland gesloten tractaat, waarbij met zoveel woorden is bepaald dat de Staten der beide gewesten niet voor een van de gerechtshoven kunnen worden gedaagd dan in zaken, waarin de Staten 'als privatorum loco' handelend zijn te beschouwen ${ }^{117}$. De uitdrukking 'privatorum loco' wordt door de door Rijpperda Wierdsma genoemde schrijvers ook wel wordt vertaald met 'in alle particuliere zaken' en met 'in zaaken van verschil over bezittingen of pretentien, die een ander ten haren lasten heeft'. Genoemde uitdrukking is te verklaren vanuit de in de Republiek nog levende ongedifferentieerde rechtsbeschouwing, waarin ook 'overheidsbezittingen' nog als private vermogensbelangen worden beschouwd. De opvatting dat de Staten, waar zij optreden 'privatorum loco', onder de rechtsmacht van de gewone gerechten vallen, is vergelijkbaar met de fiscusleer in de negentiendeeeuwse versie ${ }^{118}$.

Kijken we naar het koninkrijk Pruisen - de absolutistische politiestaat, die in de tweede helft van de zeventiende en de eerste helft van de achttiende eeuw ontstaat door het samensmeden van een aantal staatjes -, dan constateren we ook daar: 'in Polizeisachen gibt es keine Appellation' (namelijk bij de gewone gerechten), want 
'Regierungssachen (dus: 'Polizeisachen'; JT) sind keine Justizsachen'. En evenals de Franse koning, houdt ook de Pruisische koning zich uit krachte van zijn absolute soevereiniteit bevoegd om zaken die aan de gewone gerechten zijn voorgelegd, aan zich te trekken (alsook om aan rechters concrete aanwijzingen te geven). Daarmee is een college van adviseurs van de koning, het 'Kabinett', belast ${ }^{119}$. Men spreekt dan ook van 'Kabinettsjustiz', terwijl de aldus gedane uitspraken 'Machtssprüche' worden genoemd, omdat ze worden gedaan uit de volheid van de macht van de soeverein. Met de opkomst van de 'Aufklärung' (Verlichting) wordt Pruisen, onder het bewind van Frederik II (Frederik de Grote ${ }^{120} ; 1712-1786$ ), het model van het verlicht absolutisme. De 'Kabinettsjustiz' raakt in onbruik. In het Ressort-Reglement van 1749 bepaalt Frederik:

'dass regulariter alle Prozesssachen, welche das interesse privatum vel jura partium quarum interest betreffen, bei denen jeden Orts bestellten ordentlichenJustiz-Collegiis erörtert und decidiret werden müssen' '21,

En in zijn eerste politieke testament van 1752 schrijft hij:

'Ich habe mich entschlossen niemals in den Lauf eines gerichtlichen Verfahrens einzugreifen, denn in den Gerichten sollen die Gesetze reden und der Souverän schweigen' in.

Dit past geheel in zijn verlichte opvatting, dat ook de vorst zelf de wetten zou moeten respecteren. Aan zijn toezegging, niet in te grijpen in gerechtelijke processen, houdt hij zich niet altijd. Beroemd geworden is de kwestie rond de molenaar Arnold, waarin Frederik uiteindelijk de rechters ontslaat die weigerden hun tegen Arnold gewezen vonnis te herzien. Een rechter die in naam van de koning chicaneert, moet harder bestraft worden dan een straatrover! Dit optreden ten gunste van de kleine man vergroot de populariteit van Frederik bij het eigen volk maar ook in verlichte kringen in het buitenland ${ }^{123}$.

In het algemeen wordt een algemene competentie van de gewone gerechten om bescherming te bieden tegen aantasting van verworven rechten aanvaard. In politiezaken blijven de gerechten echter onbevoegd: ook in Pruisen geldt dat, indien de gerechten daarover zouden kunnen beslissen, ze de soevereiniteit van de vorst zouden aantasten, van wie de gerechten toch hun eigen competentie juist hebben gekregen. De beslechting van geschillen die voortvloeien uit de uitoefening van de 'politie' behoort niet tot de 'justitie', maar is een zaak van de politiēle overheid zèlf ${ }^{124}$.

Om nu in de politiestaat tóch rechterlijke voorziening mogelijk te maken, wordt de zgn. fiscusleer ontwikkeld, waarover wij hierboven reeds spraken. De achterliggende gedachte bij deze leer is dat steeds waar het 'mijn en dijn' in het geding is, voorziening bij de gewone rechter mogelijk zou moeten zijn, dus óók in politiezaken met een 'civiel' karakter. De constructie is dan deze dat, waar in het kader van de uitoefening van de 'politie' vermogensschade is veroorzaakt en daardoor verworven 
rechten van onderdanen zijn aangetast, voorziening bij de gerechten mogelijk is, niet tegen de Hoge Overheid - de soeverein - zelf, maar tegen de fiscus, als van de Staat afsplitsbare 'persona ficta et mystica'. Het gaat dan om een 'justizmässige Polizeisache' ${ }^{125}$. In de literatuur wordt deze fiscus wel aangeduid als 'der Prügelknabe für den Staat' ${ }^{126}$ en als 'mythischer Doppelgänger des Staates' ${ }^{127}$; we zouden ook kunnen zeggen: de bliksemafvanger van de Staat. Volgens Otto Mayer wordt de fiscus in deze leer beschouwd als 'Unterthan' van de Staat, als een met de Staat weliswaar 'in Zusammenhang bleibende, aber minderwertige juristische Person', die dus - anders dan de soevereine Staat zelf - als 'gewöhnlicher Privatmann' ${ }^{128}$ bij de gewone gerechten kan worden aangesproken. En in geval van veroordeling van de fiscus, sommeert de Staat de fiscus om het desbetreffende bedrag uit te betalen. Weliswaar zijn de gerechten dus niet bevoegd rechtstreeks een overheidsmaatregel aan te tasten, maar op grond van de fiscusleer achten zij zich wél bevoegd de fiscus - als de 'minderwertige juristische Person' - jegens een (andere) onderdaan te verplichten tot compensatie van de door aantasting van verkregen rechten geleden vermogensschade. Fleiner schrijft:

'(D)en landesherrlichen Territorialgerichten blieb die Kompetenz versagt, eine von der Regierung in "Policeysachen" erlassene Verfügung aufzuheben, Aber die Zivilgerichte erlangten auf Grund der Fiskustheorie die Zustăndigkeit, den "Fiskus" zur Bezahlung einer Schadensersatzsumme an den Untertan zu verurteilen, dessen 'wohlerworbenes Privatrecht' durch eine obrigkeitliche Verfügung verletzt worden war. Der Schadensersatzanspruch wegen Verletzung wohlerworbener Rechte übernahm damit die Funktion einer Rechtsschutzeinrichtungauf dem Gebiete des ôffentlichen Rechts. Es begründete keinen Unterschied, ob der staatliche Eingriff rechtgemāss oder rechtswidrig erfolgt war' $^{139}$.

Otto Mayer beklemtoont het praktische doel van fiscusleer in de politiestaat:

'Die alte Fiskuslehre allein hat es möglich gemacht, ohne Nachteil des vernūnftigen Denkens civilrechtliche Wirkungen unmittelbar mit obrigkeitlichen Akten zu verknũpfen. Es ist eben nicht der Staat selbst, den sie treffen, sondern den daneben stehender Fiskus' ${ }^{*} 10$.

De fiscus wordt in de politiestaat beschouwd als rechtspersoon, nog vóórdat de Staat zelf als rechtspersoon in civilibus wordt aangemerkt. Met de opkomst van de rechtsstaat heeft de fiscusleer echter haar functie verloren; daarmee:

'ist eine andere Auffassung unseres Staatswesens zum Durchbruch gekommen, der Staat ist anders geworden und der Begriff des Fiskus mit ihm. Ehemals war es richtig zu sagen: der Fiskus ist eine besondere Person neben dem Staat. Jetzt ist die der Wirklichkeit entsprechendeAuffassung ...: der Fiskus ist einfach der Staat selbst, von einer bestimmten Seite betrachtet. (...) Fiskus ist der Staat, als Subjekt des Staatsvermögens, der auf Vermōgensbesitzund Vermōgenserwerbgerichtete Staat' (curs. dzz.; JT) ${ }^{\text {B! }}$.

Deze opvatting van Otto Mayer heeft zich echter onvoldoende kunnen doorzetten: de fiscusleer - die toch slechts een doelconstructie was - is bijzonder hardnekkig gebleken. In de negentiende eeuw krijgt de fiscusleer een aangepaste gedaante, zoals we zo dadelijk zullen zien. 
Wanneer in de negentiende eeuw de rechtsstaat wordt gevestigd en de scheiding van de machten, waaronder een onafhankelijke rechterlijke macht, wordt gerealiseerd, blijft de oude tegenstelling politie-justitie bestaan, en wel als tegenstelling bestuurrechtspraak. Werd onder de politiestaat voorziening tegen overheidshandelen slechts mogelijk geacht door de politiële overheid zelf en werd voorziening door de gewone gerechten beschouwd als een aantasting van de soevereiniteit van de Hoge Overheid (van welke soevereiniteit ook de justitie deel uitmaak), ná de revolutie wordt juist met een beroep op de scheiding der machten geargumenteerd dat het de gewone rechter verboden zou zijn het bestuur op enigerlei wijze in zijn handelingen te belemmeren ${ }^{132}$. Wanneer men met Montesquieu het werk van de gewone rechter omschrijft als 'punir les crimes, juger les différends des particuliers', dan is er geen plaats voor een beoordeling door de rechter van het politiële overheidsoptreden. De Franse 'loi rélative à l'organisation de l'ordre judiciaire' van 24 augustus 1790 (artikel 13 van titel II) bepaalt:

'Les fonctions judiciaires sont distinctes et demeurenttoujours séparéesdes fonctionsadministratives.

Les juges ne pourront, peine de forfaiture, troubler de quelque manière que se soit, les opérations

des corps administratifs, ni citer devant eux les administrateurs pour raison de leur fonction'.

Geschillen voortvloeiende uit daden van de overheidsadministratie zouden moeten worden beoordeeld binnen de bestuurskolom zelf, want: 'Juger l'administration, c'est encore administrer'. In Frankrijk wordt in 1799 de Conseil d'État ingesteld - in feite een weder-instelling van de vroegere Conseil du Roi -, die (mede) als taak krijgt het staatshoofd te adviseren omtrent de in bestuursgeschillen te nemen beslissing. Door verzelfstandiging van de Conseil d'État (1872) zal dit administratief beroep uitgroeien tot een stelsel van onafhankelijke administratieve rechtspraak. Een vergelijkbare ontwikkeling zal in Pruisen voordoen.

En zowel in Frankrijk als in Duitsland is de bevoegdheid van de burgerlijke rechter in beginsel afhankelijk van het al dan niet toepasselijk zijn van materieel burgerlijk recht ${ }^{133}$. Zolang adequate, onafhankelijke administratieve rechtspraak (nog) ontbreekt, zullen theorieën worden bedacht teneinde niettemin de toegang tot de gewone gerechten te openen terzake van schadeveroorzakend overheidsoptreden. Om toch de oude civiele gedachte te kunnen handhaven, gaat men er toe over de fiscus in dit opzicht met de burger gelijk te stellen: wederom een doelconstructie dus. Maar dit leidt er al snel toe, dat men de fiscus gaat zien als de Staat 'in privaatrechtelijke hoedanigheid'. Zo beschrijft in 1840 Von Savigny de fiscus als 'Staat, als Subjekt von privatrechtlichen Verhältnissen gedacht' ${ }^{134}$.

Zo zien we zowel in de Duitse als in de Franse literatuur en jurisprudentie, dat onderscheidingen worden gemaakt tussen Staat en 'Fiskus', tussen Staat-'Puissance publique' en de Staat-'Personne morale', tussen 'actes de la puissance publique' en 
'actes de gestion'. De redenering is dat de Staat als 'Fiskus' resp. als 'Personne morale' fungeert als privaatrechtelijk rechtspersoon ${ }^{135}$.

Ook thans kan overigens veelvuldig aansprakelijkstelling van de Staat worden vermeden door de ambtenaar persoonlijk aansprakelijk te achten. Dit gebeurt met de redenering dat, waar de ambtenaar onrechtmatig handelt, dit handelen niet geschiedt op naam van de Staat en de ambtenaar dus als privaat persoon - 'privaatrechtelijk' handelt ${ }^{136}$. En als bij het arrest-Blanco van 1873 door het Tribunal des Conflits is vastgesteld, dat niet de burgerlijke rechter maar de Conseil d'État bevoegd is terzake van schadeacties tegen de Staat ${ }^{137}$, zal de burgerlijke rechter zich nog geruime tijd bevoegd blijven verklaren in schadeacties, waar de aansprakelijkheid van 'lagere corporaties' als departementen en gemeenten in het geding is ${ }^{138}$. De verklaring hiervoor zou wel eens dezelfde kunnen zijn als die, welke gegeven kan worden voor de bevoegdverklaring door de gewone gerechten terzake van schadeveroorzakende handelingen van steden in de Republiek der Verenigde Nederlanden: de steden zouden slechts zijn 'civitates privatorum' tegenover de Staat! ${ }^{139}$

Ook in de jurisprudentie van de Nederlandse Hoge Raad vinden we in de late negentiende eeuw het onderscheid tussen de overheid 'als overheid' en de overheid 'op gelijke voet als een privaat persoon', als 'privaatpersoon' ${ }^{140}$. De reden voor deze onderscheiding is - anders dan in Frankrijk en Duitsland - niet gelegen in een beperking van de competentie van de gewone rechter tot burgerrechtelijke twistgedingen. Immers, op grond van art. 165 van de Grondwet van 1815 en, vanaf de grondwetsherziening van 1848, het dan ongewijzigd gebleven art. 2 Wet op de Rechterlijke Organisatie $^{141}$ is zijn bevoegdheid een algemene ${ }^{142}$. Uit de totstandkomingsgeschiedenis van deze bepalingen kan men afleiden, dat daarin de oude betekenis van 'civiel' c.q. 'burgerlijk' tot uitdrukking komt, waarbij ook de vermogensrechtelijke kant van de 'politie' tot het 'civiele terrein' wordt gerekend ${ }^{143}$.

Het maken van de genoemde onderscheiding heeft wél te maken met een interpretatie van art. $1401 \mathrm{BW}$, volgens welke deze bepaling alleen ziet op de rechten en plichten van personen in het maatschappelijk verkeer. Baseert men zich bij de interpretatie van de artt. 1401 en 1402 BW op de totstandkomingsgeschiedenis van de Code Civil - en van de artt. 1382 e.v. van de Code -, dan moet men o.i. inderdaad concluderen dat bij art. 1401 is uitgegaan van de nieuwe, engere betekenis van 'civiel' (verhoudingen in het burgerlijk maatschappelijk verkeer) ${ }^{144}$. Hierin ligt de verklaring voor het onderscheid dat in een arrest als dat 21 april 1898 (Rhedense koe) wordt gemaakt tussen handelen van de overheid 'als zodanig' - waarop art. 1401 BW niet toepasselijk zou zijn - en 'als bijzonder persoon' ${ }^{145}$.

Waarschijnlijk mede door de grote invloed van Duitse opvattingen in de eind-negentiende eeuwse Nederlandse literatuur gaat men ook hier wel spreken van de onder- 
scheiding tussen Staat-overheid en Staat-fiscus, te verstaan 'als privaat persoon' ${ }^{146}$. In de oude fiscusleer ligt, als gezegd, de oorsprong van de veel gemaakte tweedeling tussen de Staat 'als zodanig' ('als overheid') en de Staat 'als privaatrechtelijk subject': Aan een voor procesrechtelijke doeleinden geconstrueerde leer worden dan materieelrechtelijke consequenties verbonden: zo wordt in Duitsland nog steeds gesproken van de 'Fiskus', waarmee gedoeld op de Staat die 'in privaatrechtelijke hoedanigheid' gebruik zou kunnen maken van privaatrechtelijke bevoegdheden. We kunnen dit aanmerken als een regressie, een terugkeer naar de oude ongedifferentieerde rechtsopvatting waarin 'overheidsrechten' werden beschouwd als private vermogensbelangen ${ }^{147}$.

\section{De politiestaat als wetgevingsstaat; inperking van het politiebegrip}

We merkten al op dat mét de opkomst van het politiebegrip - vanaf de zestiende eeuw - ook het onderscheid tussen 'justitie' (gewone rechtspraak) en 'politie' (de rest van de overheidstaak) ingang vindt. Oorspronkelijk geschiedde de rechtsvorming in het algemeen door middel van de rechtspraak en was het opperste rechterschap het ius regalium bij uitstek van de landsheer. Wat in hedendaagse terminologie 'wetgeving' en 'bestuur' wordt genoemd, maakte aanvankelijk deel uit van de rechtspraak: de machten werden niet alleen nog niet gescheiden, maar ook nog niet of nauwelijks onderscheiden ${ }^{148}$. En vooral tijdens de late Middeleeuwen zou rechtsvorming door de landsheer in meerdere of mindere mate een 'contractueel' karakter dragen ${ }^{149}$. Binnen die rechtscultuur ontbraken de voorwaarden voor eenzijdige normstelling met een abstract-generaal karakter, waarbij geen onderscheid wordt gemaakt tussen personen en tussen groepen (standen, steden, gilden etc.) onderling . Met de opkomst van de politiestaat is dit anders geworden. We wezen er reeds op dat in de politiestaat de kern van de (absolute) soevereiniteit van de Hoge Overheid primair bepaald wordt door de soevereine, dus absolute en oorspronkelijke, bevoegdheid van die overheid tot rechtsvorming ('wetgeving'), waarbij zij de bron wordt geacht van alle positieve recht, dus ook - krachtens uitdrukkelijke of stilzwijgende autorisatie - van het gewoonterecht. Het in deze soevereiniteit gefundeerde ius politiae geeft de soeverein de algemene bevoegdheid om eenzijdig alle maatregelen te treffen die met het oog op het 'bonum commune' nodig worden geacht, waartoe ook het stellen van regels met een algemeen-abstract karakter behoort. Daarmee wordt de basis gelegd voor het moderne (materiële) wetsbegrip, waarvan het abstract-generale karakter en de eenzijdigheid kenmerken zijn. Juist omdat het gemeenschapsbelang het uitsluitende richtsnoer wordt voor statelijke gezagsuitoefening in het algemeen, en wetgeving in het bijzonder, en het gemeenschapsbelang niet mag worden opgeofferd en uitgeruild tegen private belangen, is eenzijdigheid een 
kenmerk. Hier kan geen sprake zijn van een 'zaak in de handel', waarover onderhandeld kan worden en die tegen contraprestatie kan worden afgestaan aan anderen. Deze eenzijdigheid van de statelijke gezagsuitoefening conflicteert overigens op zichzelf niet met het natuurrechtelijke model van het sociaal contract. Denk aan het contractsmodel van Hobbes: bij dit contract is de soevereine overheid ingesteld, die vervolgens uit de volheid van zijn soevereiniteit eenzijdig opereert.

De politiestaat richt zich niet in de laatste plaats tegen de grote rechtsverscheidenheid; juist de optekening, codificatie en unificatie van het van streek tot streek en van stad tot stad verschillende, vaak ongeschreven recht is een instrument voor de politiestaat om zijn gezag te verstevigen. Door via omvangrijke wetgeving, juist op het terrein van de 'justitie', rechtseenheid en rechtszekerheid te brengen, kunnen feodaliteit en standenbestel verder worden afgebroken. Dat zulks op veel verzet stuit van de standen, steden etc. - die dit beschouwen als een aantasting van hun privileges - hebben we reeds gezien: de criminele ordonnanties uit 1570 waren mede aanleiding tot de opstand van de Nederlandse gewesten tegen Philips II.

Een voorbeeld van een geslaagde codificatie en unificatie op het terrein van het criminele recht noemden we al: de onder Karel V voor zijn tot het 'Heilige Römische Reich deutscher Nation' behorende gebieden in 1532 tot stand gekomen 'Constitutio Criminalis Carolina'. Bekend zijn ook de verschillende ordonnanties, waarmee de Franse koningen tamelijk omvangrijke codificaties tot stand brengen, zoals de 'Ordonnance civile pour la réformation de la justice' (1667), die de bron is van grote delen van de latere napoleontische 'Code de procédure civile'; de 'Ordonnance sur la procédure criminelle' (1670), waarvan later veel is overgenomen in de 'Code d'instruction criminelle'; en de 'Code du commerce' (1673), waarin het handelsrecht wordt gecodificeerd.

Maar pas in de verlicht absolutistische staten wordt, in de geest van de rationalistische natuurrechtsleer, overgegaan tot een echt omvangrijke codificatie, die de kenbaarheid en zekerheid van het recht en de rechtseenheid moet waarborgen. De rationalistische natuurrechtsleer gaat er van uit dat de onfeilbare menselijke rede de kenbron is van een ideaal, verstandelijk, niet door traditie en historie bepaald natuurrecht. Daarbij verzet de achttiende-eeuwse Verlichting zich echter tegen een slaafs navolgen van het Romeinse recht, dat men nu niet langer als de 'ratio scripta' ziet. Een universele gelding van dit recht wordt in strijd geacht met het 'natuurlijke' beginsel dat elk volk zijn eigen, in de landstaal geschreven recht moet hebben ${ }^{150}$.

De eerste natuurrechtelijke codificaties vinden plaats in Beieren: onder de keurvorst Maximilian III worden het criminele recht, het civiele recht en het procesrecht gecodificeerd in resp. de 'Codex juris Bavarici criminalis (1751), de 'Codex Maximilianeus Bavaricus Civilis' (1756) en de 'Codex juris Bavarici judiciarii' (1753) ${ }^{151}$. 
En de Habsburgse vorstin Maria-Theresia ${ }^{152}$ doet in 1753 een decreet uitgaan waarbij tot een exclusieve codificatie voor haar Duitse erflanden binnen het Roomse Rijk wordt besloten, een codificatie die pas in 1811 gereed komt in de vorm van het 'Allgemeine bürgerliche Gesetzbuch für die gesammten deutschen Erbländer der Österreichischen Monarchie' (ABGB) ${ }^{153}$.

In Pruisen komt onder Frederik de Grote in 1781 een codificatie tot stand van het procesrecht, het 'Corpus Juris Fridericianum', dat in 1793 wordt opgevolgd door de 'Allgemeine Gerichtsordnung für die Preussischen Staaten' (AGO), Maar het bekendst is toch het meer dan 19.000 artikelen tellende wetboek, dat op 1 juni 1794 onder de opvolger van Frederik de Grote in werking treedt onder de naam 'Allgemeines Landrecht für die Preussischen Staaten' (ALR) en dat een encyclopedische codificatie beoogt te bieden van het gehele materiële recht: civiel recht, crimineel recht, maar ook recht dat behoort tot de 'Polizei' ${ }^{154}$.

Deze op natuurrechtelijke grondslag gebouwde codificaties kenmerken zich door wijdlopigheid en drang naar materiēle volledigheid, omdat men meent dat de rationale wetgever alles kan voorzien en dat na de codificatie de werkzaamheden van de rechter slechts bestaan uit een mechanische toepassing van de geschreven wetten: de 'Vernunftstaat' is een wetgevingsstaat ${ }^{155}$. Maar deze wetgeving heeft primair betrekking op het terrein der 'justitie' (het criminele recht en het civiele recht voorzover geen betrekking hebbend op de 'politie', alsmede het bijbehorende procesrecht): het is vooral 'justitiewetgeving' ${ }^{156}$. De achterliggende gedachte - zéker ook bij de Pruisische codificaties - is geheel in de geest van de rationalistische natuurrechtsleer, dat de gerechten toepassing geven aan heldere wetten 'qui ne donnent pas lieu à des interprétations et à la chicane' en dus, in de woorden van Montesquieu, slechts nog 'les bouches de la loi' zijn. De justitiewetten moeten de kenbaarheid, toegankelijkheid en zekerheid van het recht waarborgen. En nadat de soevereine vorsten deze justitiewetgeving tot stand hebben gebracht, achten zij zich er (in beginsel) ook zelf aan gebonden ('In den Gerichten sollen die Gesetze reden und der Souverän schweigen'). Ofschoon de gerechten nog steeds beschouwd worden als de dienaren van de soevereine vorst - die recht spreken in naam van de vorst -, betekent dit een verdere verzelfstandiging van de 'justitiële overheid' ten opzichte van de 'politiële overheid' ${ }^{157}$ en een belangrijke stap vooruit in de richting van een constitutionele Staat.

Maar het is, als gezegd, in eerste instantie het terrein der 'justitie', waarvoor de soevereine vorsten - op grond van hun 'ius politiae'! ${ }^{158}$ - omvangrijke wetgeving tot stand brengen. Voor de 'politiële overheid' zèlf - waarvan de 'justitiële overheid' zich, als gezegd, steeds meer verzelfstandigt - kan aanvankelijk nog geen strak onderscheid worden gemaakt tussen (politiële) wetgeving en bestuur. Politiële wetge- 
ving treffen we vooral aan bij de lagere overheden, de steden, in de vorm van allerlei stedelijke keuren.

De wijze waarop in de politiestaten het ius politiae door de ambtenaren namens de vorst feitelijk moet worden uitgeoefend, is slechts neergelegd in interne instructies. Otto Mayer spreekt in dit verband van 'Polizeigesetze', maar voegt daar onmiddellijk aan toe dat van 'Gesetze' (in de latere betekenis) eigenlijk niet gesproken mag worden, nu daarmee niet is beoogd 'Rechtssätze zu schaffen', dus nieuw recht te positiveren. Hij beschrijft de ontwikkeling als volgt:

'(Das Polizeigesetz) bestimmt, was der Fürst rechtlich auch in Einzelfalle anordnen könnte; es ist lediglich Zweckmässigkeitssache,dass man die vielen gleichartigenFälle in dieser Weise zusammenfasst. Es bindet die Beamten bloss dem Fürsten gegenüber, insofern sie ihm zur Handhabung seiner Befehle verpflichtet sind; es kann ihnen in ihrem allgemeinen Amtsauftrag Spielraum gelassen sein, es auch mit der Handhabung eines solchen Gesetzes nach bestem Ermessen zu handeln, sie kōnnen im Einzelfall andere Anweisung bekommen, der Fürst selbst kann unmittelbar anders verfügen. (...) Die Vorschriften ...., welche den Verwaltungsbehördenin den ausführlichen Instruktionen fast zum Obermass gegeben werden, gehen den Unterthanen rechtlich nichts an. Er hat der Obrigkeit gegenuber keinen Anspruch darauf, dass es dabei bleibe, noch darauf, dass die vorgeschriebenenThătigkeiten geleistet, die angegeben Schranken der Amtsthătigkeit eingehalten werden. Wenn man sie veröffentlicht, oft geradezu wie die Gesetze, so hat das lediglich ăussere Zweckmässigkeitsgründe, sofern es vorteilhaft erscheint, dass die Unterthanen erfahren, was sie von den Beamten zu gewärtigen haben und sich danach richten. (...) (Die Instruktion) wirkt rechtlich nur für die Beamten, auf den Unterthanen wirkt nicht sie selbst, sondern erst ihre thatsächliche Ausführung durch jene. Es entsteht durch sie kein Recht, so wenig wie durch den allgemeinen Polizei- und Finanzbefehl' ${ }^{15}$.

Allengs veranderen die ambtelijke instructienormen echter van karakter doordat er in de praktijk ook een (zekere) externe werking aan wordt toegekend en ze dus steeds meer worden beschouwd als waarborgnormen. De statelijke gezagsuitoefening - de uitoefening van de 'politie' - wordt steeds meer een door wetten gereguleerde bevoegdheidsuitoefening. Dergelijke 'Polizeigesetze' funderen echter nog steeds niet de bevoegdheid, maar geven de grenzen aan tot hoeverre ambtenaren namens de soevereine vorst gebruik kunnen maken van het 'van nature' reeds bestaande 'ius politiae'. 'Polizeigesetze' hebben in die visie de functie van beperking van een reeds bestaande bevoegdheid der overheid om naar eigen inzicht te beslissen. Het rechtsgehalte van de wet is dus gelegen in de waarborg die zij biedt tegen willekeurig politieel overheidsoptreden (het rechtszekerheidsprincipe). Nog in de negentiende eeuw zal het legaliteitsbeginsel vereenzelvigd worden met een verbod van willekeur $^{160}$.

Doordat ook op het terrein der 'politie' steeds meer wetgeving (door de soevereine Hoge Overheid) tot stand komt, die de uitoefening der 'politie' namens de soeverein door ambtenaren c.q. subalterne overheden aan regels bindt, zal zich binnen de 'politie' het onderscheid gaan manifesteren tussen wetgeving en bestuur. Allengs 
ontstaat daardoor een enger begrip 'politie', dat alleen de bestuursfunctie betreft, te onderscheiden van de wetgevingsfunctie, als het wezenlijke element van de soevereiniteit van de Hoge Overheid. Wetgeving kan dan worden onderscheiden in wetgeving vóór de justitie en wetgeving vóór de politie (in de nieuwe - engere - betekenis van bestuur), in 'justitiewetgeving' en 'politiewetgeving'.

Een dergelijke ontwikkeling is overigens ook duidelijk waar te nemen binnen de Nederlandse Republiek. Als kern van de soevereiniteit van de Staten wordt ook hier de wetgeving beschouwd; de bestuurstaak wordt namens de Staten vrijwel geheel uitgeoefend door de Gecommitteerde Raden resp. Gedeputeerde Staten.

Het ontstaan van een scheiding tussen de wetgevingsfunctie en de bestuursfunctie heeft tot gevolg, dat men bestuur vooral zal gaan beschouwen als uitvoering van wetgeving (zij het nog steeds als uitvoering namens de soevereine Hoge Overheid). Dit leidt er weer toe dat 'politie' verder wordt verengd tot een onderdeel van de bestuursfunctie of zelfs wordt beschouwd als een van het bestuur te onderscheiden overheidsfunctie: 'politie' ziet dan op dat onderdeel van de totale overheidstaak, dat naar zijn aard niet kan worden gereguleerd door specifieke wettelijke regels, te weten de handhaving van de openbare orde en rust en de bescherming tegen gevaren, waarbij 'politie' dus wordt onderscheiden van het bestuur dat uitvoering van wetten behelst.

Kortom: door de toenemende scheiding onder de politiestaat tussen 'justitie' en 'politie', tussen 'justitiewetgeving' en 'politiewetgeving' en - binnen het terrein der 'politie' - tussen (politie)wetgeving en bestuur, heeft de scheiding tussen de drie machten: wetgeving ( $=$ emanatie van de wil van de soevereine vorst, later van het soevereine volk), bestuur (= uitvoering van politiewetgeving, inclusief de beslechting van bestuursgeschillen) en rechtspraak (= uitvoering van justitiewetgeving, door de gewone gerechten als 'les bouches de la loi') zich feitelijk reeds voltrokken, als ze in Frankrijk met de revolutie een constitutionele basis verkrijgt ${ }^{161}$. En mét de doorvoering van het beginsel van de machtenscheiding (trias politica) en van het beginsel van de representatieve democratie (waarvan men de eis van wetmatigheid van bestuur als uitdrukking zal gaan zien), zal de wet niet meer alleen worden gezien als beperking van de bestuursbevoegdheid maar óók en zelfs primair als de specifieke bevoegdheidsgrondslag. 


\section{Het juridisch individualiseringsproces en de opkomst van de moderne vrijheidsgedachte}

We zeiden dat de middeleeuwse ongedifferentieerde samenlevingsverbanden een hinderpaal vormden voor de erkenning van een individuele vrijheidssfeer van iedere mens als zodanig, onafhankelijk van diens toebehoren tot zo'n samenlevingsverband. Het juridisch differentiëringsproces leidt tot de opbouw van een ontwikkeld staatswezen (als res publica) onder geleidelijke afbraak van de ongedifferentieerde structuren van het feodale en standenbestel, die de mens naar alle levensaspecten ('totalitair') omvatten en waarin 'overheidsrechten' nog beschouwd werden als 'private vermogensbelangen' (vermenging van 'imperium' en 'dominium'). Kenmerkend voor dit differentiëringsproces is dus ook de scheiding van publieke overheidsmacht en private vermogensbelangen, alsmede de losmaking uit de oude totalitaire samenlevingsstructuren van de afzonderlijke mens, die uiteindelijk over zoveel persoonlijke handelingsvrijheid zal beschikken dat hij op eigen initiatief kan komen tot het vormen van gedifferentieerde, maatschappelijke verbanden.

Het juridisch differentiëringsproces is dus tegelijk een juridisch individualiseringsproces. Dit betekent dat ieder die zich binnen het staatsterritoir bevindt, als zodanig als rechtssubject wordt erkend op gelijke voet met ieder ander, onafhankelijk van zijn rol binnen samenlevingsstructuren, en dus onafhankelijk van zijn geloof, ras, stand etc. Van Eikema Hommes spreekt in dit verband van het juridisch persoonlijkheidsbeginsel en merkt op dat het fundamentele beginsel van de scheiding van publiek overheidsgezag en privaat vermogensrecht zijn keerzijde vindt in het fundamentele beginsel van de publiek- en burgerrechtelijke erkenning van de rechtssubjectiviteit van iedere mens als zodanig ${ }^{162}$.

Dit differentiëringsproces is tevens een juridisch integreringsproces. Het gaat dus om een juridisch differentiërings-, integrerings- én individualiseringsproces. In het publiekrecht worden alle mensen en niet-statelijke levenskringen binnen het staatsterritoir geïntegreerd in een publieke rechtsgemeenschap. En op basis van die - een ieder op het staatsterritoir omvattende - publieke rechtsorde is ook positivering mogelijk door de Staat van het burgerlijk recht, als integrerende burgerrechtelijke rechtsorde die is gebaseerd op het beginsel van de burgerrechtelijke vrijheid-ingelijkheid. Anders gezegd: eerst ná de (definitieve) vestiging van een wezenlijke publieke rechtsgemeenschap - de rechtsstaat - is de vestiging een wezenlijke burgerrechtelijke rechtsorde mogelijk ${ }^{163}$.

We hebben gezien dat dit proces vanaf het einde van de Middeleeuwen in gang is gezet door de centraliserende politiestaat en uitmondt in de Franse revolutie. Thorbecke legt de nadruk op de daarmee gepaarde gaande scheiding van 'imperium' en 'dominium', als hij schrijft: 
'De fransche omwenteling was inzonderheideen strijd tegen het stelsel, publieke regten in bijzondere eigendom te houden (bezitten)' ${ }^{164}$.

En Tocqueville wijst op de erkenning van het juridisch persoonlijkheidsbeginsel, als hij in zijn 'L'Áncien Régime et la Révolution' de ontwikkelingen analyseert (de sterke centralisatie van het overheidsbestuur, de afbraak van de structuren van het feodale en standenbestel, de individualisering en de natie-idee), die leiden tot het verlaten van de 'feodale en aristocratische vrijheidsopvatting' - die vrijheid ziet als het genot van bijzondere voor-rechten - en de doorbraak van de 'democratische vrijheidsopvatting' - die uitgaat van een gelijke 'natuurlijke vrijheid' van ieder individu - en tot de vervanging van de overheidssoevereiniteit door de volkssoevereiniteit.

Ofschoon Tocqueville de grote voordelen erkent van het door de omwenteling gevestigde bestel, waarschuwt hij ook tegen de gevaren van een 'democratisch absolutisme' die ontstaan door de combinatie van een gecentraliseerd absoluut gezag en volkssoevereiniteit. In Rousseaus leer van de volkssoevereiniteit wordt het vrijheidsbegrip van de 'natuurlijke vrijheid' gekoppeld aan de heerschappij van de wet als (gefingeerde) emanatie van de soevereine volkswil, waarmee men de 'echte' vrijheid wil bereiken door een algemene gelijkheid, die echter de individuele vrijheid vernietigt en waardoor een nieuwe vorm van despotisme ontstaat. Deze gevaren zijn door Tocqueville uitvoeriger beschreven in zijn andere hoofdwerk, 'De la démocratie en Amérique' (1835/1840):

'Ik vraag mij af, welke de trekken zijn waaronder de tirannie weer een nieuwe gestalte zou kunnen aannemen. Ik zie dan voor mij een ontelbare massa van in alle opzichten gelijke mensen, die egocentrisch bezig zijn met het rusteloos najagen van de onbeduidende, burgerlijke genoegens waarop zij hun zinnen hebben gezet. Ieder op zichzelf genomen vormt een eigen wereldje waarbuiten het lot der anderen zich voltrekt; ... zijn bestaan wordt begrensd door eigen persoon en belangen' 165 . Deze individuen willen vooral niet van elkaar afhankelijk zijn; want anderen zijn hun gelijke, dus niets méér dan zij! Wèl hebben ze behoefte aan één sterke macht om hun welvaren en gelijkheid te garanderen: de centrale overheid. En:

'Op grond van hun onderlinge gelijkheid schenkt niemand er geloof aan wat zijn buurman beweert.

Diezelfde gelijkheid geeft hun evenwel een bijna oeverloos vertrouwen in het oordeel van 'alleman'. Het komt hun immers onwaarschijnlijkvoor, dat de waarheid niet bij de meerderheid zou te vinden zijn, aangezien allen dezelfde graad van verstandelijke ontwikkeling bezitten. Dezelfde gelijkheid die een ieder onafhankelijkmaakt van ieder van zijn medeburgers, levert het individu geisoleerd en zonder verweer uit aan het machtwoord van de helft plus een' 106 .

De stelregel dat de meerderheid van een volk het recht heeft van àlle beslissingen, beschouwt Tocqueville als hoogst onjuist en verwerpelijk. Hij erkent het democratiebeginsel, maar verwerpt elke absolute macht, ó́k als deze de vorm aanneemt van volkssoevereiniteit, die neerkomt op de soevereiniteit van de meerderheid:

Wanneer ik weiger aan een onrechtvaardige wet te gehoorzamen, ontzeg ik geenszins aan de meerderheid het recht wetten uit te vaardigen.... Nooit zal ik echter aan de meerderheid toekennen wat ik aan de enkeling zal weigeren - absolute macht' ${ }^{16}$. 
Waarborgen voor het behoud van de vrijheid in een égalitaire samenleving, tegenwichten op een centraal staatsgezag en de macht van de meerderheid zijn volgens Tocqueville te zoeken in vrije maatschappelijke verenigingen, constitutionele regulering van het staatsgezag en vastlegging van grondrechten, plaatselijke en regionale autonomie, inspraak van de burger bij de bestuurlijke zaken van alle dag, een tweekamerstelsel en constitutionele toetsing ${ }^{168}$.

Tocqueville onderkent dat óók de rechtsmacht van de Staat is onderworpen aan een inherente begrenzing (die hij 'een algemene wet die gerechtigheid heet' noemt) en dat er naast het staatsverband ook andere - niet-statelijke - samenlevingsverhoudingen bestaan met een eigen - niet van de Staat afgeleide - rechtskring, die een tegenwicht bieden tegen de Staat en daardoor ook een waarborg voor de individuele vrijheid. Tocqueville komt dan ook op tegen staatsconcepties waarin alléén de individuele burgers worden gezien, die slechts in de Staat tot gemeenschap zijn gekomen, en in welke concepties dus geen eigen rechtssferen van niet-statelijke gemeenschappen worden onderkend:

'Dictatuur en democratie komen op een fatale wijze hierin overeen, dat zij dezelfde slechte eigenschappen in de mensen aankweken en bevorderen. Ook de democratie ziet de burger als een zelfstandig element zonder onderlinge verbindingen. En de dictatuur trekt scheidsmuren tussen de burgers op om onderlinge verbindingentegen te gaan. $\mathrm{Zij}$ denkentenslotte alleen maar aan zichzelf; de onverschilligheid voor anderen wordt een openlijk gehuldigde deugd. De dictatuur, die in ieder soort staatsbestel al iets gevaarlijks is, moet dus vooral in combinatie met democratie als levensgevaarlijk gelden. (..).

De gedachte dat bepaalde individuen een eigen rechtsbedeling zouden kunnen hebben, verliest snel zijn invloed op de geest van de mensen. De idee van een almachtig en voor ieder geldend recht binnen de menselijke samenleving is bezig de plaats van de vroegere opvatting in te nemen. Deze beginselen schieten wortel en groeien naargelang de levensomstandighedenen de individuen meer aan elkaar gelijk worden. De sociale gelijkheid werkt die opvattingen in de hand, die hunnerzijds weer de maatschappelijkegelijkheid zullen bevorderen' 10 .

Tocqueville hecht grote betekenis aan de eigen competenties en verantwoordelijkheden van niet-statelijke, maatschappelijke organisaties. Enerzijds worden daardoor eigen initiatieven, creativiteit en verantwoordelijkheden van individuele mensen gestimuleerd. Anderzijds dienen dergelijke gedifferentieerde organisaties als een tegenwicht tegen een te ver gaande staatsbemoeienis, maar ook tegen andere vormen van overheersing van buitenaf. Daarom is de vrijheid van vereniging een noodzakelijke waarborg tegen de tirannie ${ }^{170}$, aldus Tocqueville, aan wie bij zijn bezoek aan Amerika de kracht van de zogeheten 'voluntary associations' was opgevallen. Naar een in de reformatorische filosofie ontwikkeld begrip kan men zeggen dat Tocqueville onderkent dat zowel de Staat als die andere samenlevingsverhoudingen hun juridische 'soevereiniteit in eigen kring' heeft, die dus nimmer absoluut kan zijn. 
In Frankrijk, waar de door de monarchie ingezette centralisatie van de staatsmacht door de revolutie alleen maar is versterkt, bestaat echter een wantrouwen tegen private corporaties. Omdat de revolutie gericht was op de definitieve afbraak van de oude structuren van het feodale en standenbestel - de oude ongedifferentieerde samenlevingsverbanden dus -, bestaat er bij de revolutionaire citoyens een algemene 'phobie des groupements' en zien ze zelfs in de oprichting van vrije maatschappelijke verenigingen een gevaar voor herleving van het oude bestel. Deze 'phobie' past trouwens ook in Rousseaus conceptie van de totalitaire democratie, die samenvalt met de samenleving en die slechts individuen - als staatsburgers - en de Staat - als de enige gemeenschap - kent. In die conceptie zijn private, niet-statelijke corporaties met een eigen rechtskring principieel ontoelaatbaar, omdat ze het individu aftrekken van het 'algemeen belang':

'Il importe donc, pour avoir bien l'énoncé de la volonté générale, qu'il n'y ait pas de société partielle dans l'état...' 'm.

Het motief van de in 1791 door de Franse Constituante aangenomen wet die ieder vorm van verbond of vergadering van arbeiders verbiedt, komt duidelijk naar voren in de toespraak van Le Chapelier tot de Constituante:

'Er kan alleen nog sprake zijn van het individuele belang van iedere burger en van het algemeen belang. Niemand zal het zijn toegestaan om in enige burger enig intermediair belang op te wekken en hem door middel van groepsbelangenvan het algemene belang te scheiden' in.

Enige tijd later worden achtereenvolgens ook corporations ouvrières, associations religieuses, associations financières nietig verklaard. Want: 'Un État vraiment libre ne doit souffrir dans son sein aucune corporation!' Dergelijke spontaan gevormde instellingen zouden moeten wijken voor het essentiële principe van de onbetwiste volkssoevereiniteit ${ }^{173}$. Zoals bekend, ontaardt de Franse revolutie in de jaren 1792-1795 in het schrikbewind van het Comité du Salut Public.

Maar ook onder de Code Civil (1804) zal de volledige verenigingsvrijheid nog niet worden erkend. Art. 291 van de Code Pénal verbiedt zelfs uitdrukkelijk de oprichting zonder toestemming der regering van verenigingen van meer dan twintig personen, ten doel hebbend op zekere dagen bijeenkomsten te houden. Niet alleen voor haar geoorloofdheid, maar daarna ook voor de vaststelling van haar rechtspersoonlijkheid is volgens de Code Civil zo'n vereniging van de overheid afhankelijk: om als rechtspersoon (zedelijk lichaam') te kunnen gelden, is nodig dat zij door de regering wordt erkend als te zijn van openbaar nut. Pas de wet van 1 juli 1901 brengt, onder afschaffing van de desbetreffende bepalingen van de Code Pénal, de vrijheid van oprichting van verenigingen, mits hun doel geoorloofd zij ('but autre que de partager des bénéfices') ${ }^{174}$. De in het Nederlandse Burgerlijk Wetboek van 1838 - dat overigens aan de Code Civil verbonden is 'als de navolging tot het model' - opgenomen titel inzake 'Zedelijke Lichamen' behoort tot de oorspronkelijke titels, die niet reeds voorkwamen in die Code ${ }^{175}$. 


\section{Het Pruisische Allgemeine Landrecht (1794)}

De grootste prestatie van het Pruisische juristendom is wel het Allgemeine Landrecht für die preussischen Staaten (ALR), waarmee voor het eerst - en waarschijnlijk tevens voor het laatst - sinds het Corpus Juris Civilis wordt beoogd nagenoeg het gehele recht te codificeren. Dit wetboek, dat op 1 juni 1794 in werking treedt, telt in totaal maar liefst 19.194 paragrafen ${ }^{176}$. Niettemin geldt het ten opzichte van de locale rechten in de verschillende Pruisische gebieden als subsidiair recht, dus als gemeenrecht ter vervanging van het Romeinse recht, dat voordien als gemeenrecht gold.

Volgens Schlosser is dit wetboek echter 'trotz dieses Umfanges und des Versuches der Lückenlosigkeit ... eine Volkstümlichkeit beschieden, wie sie andere grosse Gesetzgebungswerke einschliesslich des geltenden deutschen Bürgerlichen Gesetzbuches für sich nicht in Anspruch nehmen können' ${ }^{17}$. Hoe dit ook zij, het wetboek is vooral interessant omdat het ervan getuigt dat het is gemaakt in een overgangsperiode, een periode waarin men zich nog met één been bevindt in het feodale en standenbestel - dit wat de regeling van de verhoudingen tussen de mensen onderling betreft - en met het andere been reeds in wat men later de rechtsstaat zal noemen - namelijk waar het gaat om de regeling van de verhoudingen tussen overheid en onderdanen.

Een Inleiding over wetten en algemene rechtsbeginselen gaat aan het ALR vooraf. Deel I behandelt vervolgens de rechtsbetrekkingen tussen de individuele mensen onderling ${ }^{178}$; deel II is aan de gemeenschappen en groepen - de familie en de standen alsook de Staat - gewijd en wordt afgesloten met het criminele recht.

In hedendaagse termen kunnen we zeggen dat in deel I en in een gedeelte van deel II privaatrecht wordt gecodificeerd, terwijl het overige gedeelte van deel II publiekrecht (inclusief strafrecht) bevat. Door in zijn 'privaatrechtelijke' deel uit te gaan van de standen, en van de bestaande verschillen in rechten (en plichten) van die standen, weerspiegelt het ALR de verhoudingen binnen de feodale Pruisische samenleving. Weliswaar is men bij de opzet en indeling van het wetboek uitgegaan van de opvattingen van de Verlichting, maar niet wat de inhoud betreft ${ }^{179}$.

Dit is het grote verschil met de eerste codificatie voor de burgerlijke samenleving, de Code Civil (1905), die zal berusten op de idee van de burgerrechtelijke vrijheid en gelijkheid van alle mensen als zodanig in hun onderlinge maatschappelijke verkeer.

Een tweede verschil - dat tot uitdrukking komt in het encyclopedische en gedetailleerde karakter van de Pruisische codificatie - is dat het ALR is opgezet als een wetboek dat de rechter mechanisch zou kunnen uitvoeren. Beoogd is aan de rechter zo weinig mogelijk interpretatieruimte te geven: de rechter wordt hier inderdaad als 
'bouche de la loi' gezien. Suarez - die als hoge ambtenaar de stuwende kracht achter de codificatie is - zegt hierover:

'Es ist unstreitig ein Ubel, wenn die Rechte und Pflichten der Bürger des Staates in ihren mannigfaltigen Verhältnissen ... nicht mit Deutlichkeitund Gewissheit bestimmt sind und also diese Bestimmung bei vorfallendemStreite dem Befindendes Richters überlassen werden muss. Denn alsdann wird der Richter zum Gesetzgeber; und nichts kann der bürgerlichenFreiheit gefahrlicher sein, zumal wenn der Richter ein besoldeter Diener des Staates ... ist' "wo .

Zoals blijkt uit in de inhoud van het ALR, is echter een burgerrechtelijke vrijheid voor alle mensen nog niet realiseerbaar! ${ }^{181}$

Verlicht, ook qua inhoud, is toch vooral het 'publiekrechtelijke' deel van het ALR. De hierboven beschreven ontwikkelingen - ontpersoonlijking en juridificering van het overheidsgezag, kort: de verambtelijking - krijgen daarin gestalte. Ook getuigt het ALR reeds van de nieuwe opvatting omtrent de legaliteit van het overheidshandelen, die er op neerkomt dat in de wet niet slechts de grenzen van een overheidsbevoegdheden maar ook de grondslagen daarvan zijn vastgelegd, en dat niet zo maar de bijzondere rechten van burgers kunnen worden aangetast of aan hun verplichtingen kunnen worden opgelegd. Men zou kunnen zeggen dat in het ALR tweeërlei vrijheidsbegrip tot uitdrukking komt: enerzijds, in het 'privaatrechtelijke' deel, het voor het feodale bestel en standen'staat'wezen typische begrip van de vrijheid verbonden aan het genot van voorrechten en wel-verkregen rechten (iura regalia en iura quaesita: de 'feodale en aristocratische vrijheidsopvatting') en anderzijds, in het 'publiekrechtelijke' deel, de vrijheid van statelijke willekeur (rechtszekerheid) en de gelijkheid van iedere onderdaan ten opzichte van de overheid.

Door de invloed van de rationalistische natuurrechtsleer is de opvatting ontstaan, dat niet de blote wil van de vorst maar de 'Vernunft' bepalend is voor de inhoud van de wetten, en dat 'vernunftrechtlich' zou kunnen worden vastgesteld wat het 'bonum commune' c.q. 'die gute Polizei' eist. Door beredenering en rationele deductie zou het ware, het 'natuurlijke' recht kunnen worden gevonden en vervolgens neergelegd in de wet. De 'Vernunftstaat' is een 'wetgevingsstaat', zo merkten we reeds eerder op. Willoweit beschrijft de uitwerking van de door het rationalistische natuurrecht geïnspireerde ideeën aldus:

'Der beherrschende Einfluss vernunftrechtlicher Maximen hat schliesslich auch Wandlungen des Gesetzesbegriffs und die Entstehung des Kodifikationsgedankens zur Folge gehabt. Galt in der absolutistischen Staatlehre seit Jean Bodin der Wille des Landesherrn als Grund des Gesetzes und allein massgebend für seinen Inhalt, so erscheint jetzt der Normbefehl primâr als Ausdruck richtiger, weil gemeinwohlgebundener Politik. Darüber hinaus musste die vernunftrechtlicheVorstellung eines in sich logisch stimmigen Gesamtsystems der Rechtsordnungtiefgreifende Folgen für die Form und die Modalitâten der Rechtssetzung haben. Ein System kann adäquat nicht in einzelnen Gesetzen, sondern nur in einer umfassenden Kodifikation dargestellt werden. Lückenlosigkeit, Widerspruchsfreiheit und Berechenbarkeit wollen vorab für das ganze Werk bedacht sein, wenn es Systemcharakter erhalten soll' (curs. door de auteur; JT) ${ }^{12}$. 
Hiermee tekenen zich de contouren af van een nieuwe rechtscultuur, waarin ook de hoogste overheid zelf door de wetten is gebonden. Weliswaar is het absolute karakter van het gezag van die hoogste overheid (de vorst) nog steeds een vooraf gegeven element, dat gereguleerd wordt door het ALR, maar de gedachte is toch dat ook de - immers rationeel handelende! - vorst daardoor gebonden is. Het ALR komt neer op een wettelijke binding van het overheidsgezag, die tot voordien ongekend was. Enkele bepalingen uit het ALR verdienen in het kader van ons onderzoek de bijzondere aandacht.

In de eerste plaats zij gewezen op par. 10 van deel II, titel 17 ALR, dat de politietaak omschrijft:

'Die nöhtigen Anstalten zur Erhaltung der öffentlichen Ruhe, Sicherheit und Ordnung, und zur Abwendung der dem Publiko, oder einzelnen Mitgliedern desselben bevorstehenden Gefahr zu treffen, ist das Amt der Polizey'.

Het begrip 'politie' - dat aanvankelijk de ruime betekenis had van 'de goed geordende toestand van de gemeenschap', 'welvaartszorg' in ruime zin - heeft nu nog slechts betrekking op een onderdeel van die welvaartszorg, te weten de zorg voor de openbare orde, rust en veiligheid ${ }^{183}$. Hoewel deze bepaling slechts een algemene taakomschrijving geeft, manifesteren zich juist in de daarin besloten beperking van het politiebegrip reeds de nieuwe opvattingen omtrent wetmatigheid van bestuur (voorheen: 'politie', die meebrengen dat overheidsdwang niet uitgeoefend kan worden zonder een wettelijke bevoegdheidsgrondslag. Omdat men echter beseft dat het niet wel mogelijk is alle denkbare gevaren en mogelijkheden voor het ontstaan van gevaar voor aantasting van de openbare orde, rust en veiligheid te voorzien en daaromtrent specifieke normen te stellen, wordt de 'politie' - nu in een verengde betekenis - afgescheiden van het (overige) bestuur en wordt daarvoor volstaan met de wettelijke vastlegging van de politietaak, die dan tevens een bevoegdheidsgrondslag is voor degenen die met die taak zijn belast. Daarin is aanvankelijk óók de bevoegdheid van politie-autoriteiten besloten tot het stellen van algemene voorschriften (politieverordening), totdat er in de tweede helft van de negentiende eeuw wetgeving komt die een specifieke regeling geeft omtrent die verordeningsbevoegdheid ${ }^{184}$.

In de tweede plaats wijzen we op par. 7 van de Inleiding op het ALR, luidende:

'Ein jeder Entwurf zu einer neuen Verordnung, durch welche die besonderen Rechten und Pflichte der Bürger ${ }^{\text {tss }}$ bestimmt, oder die gemeinen Rechte abgeăndert, ergănzt oder erklärt werden sollen, muss vor der Vollziehung, der Gesetzkommission zur Prüfung vorgelegt werden".

Reeds in 1781 was met de instelling van deze (vaste) wetgevingscommissie steun gegeven aan de nieuwe cultuur van de 'Gesetzesstaat'. Geheel volgens de opvattingen van het Verlichtingsrationalisme zou deze commissie als 'Stimme der Wahrheit und des gemeinen Besten' (Suarez) ieder wetsontwerp waardoor de bijzondere rech- 
ten van burgers zouden worden geraakt danwel aan burgers verplichtingen zouden worden opgelegd, moeten beoordelen. Het wetmatigheidsbeginsel in de zin van 'Vorbehalt des Gesetzes' (Otto Mayer) - ingrepen in de vrijheid en eigendom van de burgers behoeven een wettelijke grondslag - komt in par. 7 reeds tot uitdrukking ${ }^{186}$.

Van een democratisch postulaat is nog wel geen sprake: de 'Stimme des gemeinen Besten' is niet gelijk te stellen met de volkswil (de 'volonté général' van Rousseau), maar beide begrippen zijn onmiskenbaar aan deze dezelfde traditie ontsproten: de overheid opereert onder de algemene wet, die uitdrukking geeft aan het publieke gemeenschapsbelang.

Hierbij past ook een rationalistisch-natuurrechtelijke opvatting van rechtspraak als mechanische toepassing van de wet door de rechter zonder enige interpretatie; een beroep op de doctrine of precedenten past hierin niet. Par. 6 van de Inleiding bepaalt dan ook:

'Auf Meinungender Rechtslehreroder ältere Aussprücheder Richter soll bei künftigen Entscheidungen keine Rücksicht genommen werden'.

Met het 'vernunftrechtliche' ALR zou immers zijn voldaan aan de behoefte aan 'des lois claires, qui donnent pas lieu à des interpretations' (Frederik de Grote), zodat de rechter slechts een orgaan is waardoor de wet spreekt: les juges ... ne sont que la bouche qui prononce les paroles de la loi; des êtres inanimés qui n'en peuvent modérer ni la force, ni la rigueur' (Montesquieu).

In de vierde plaats zij gewezen op de paragrafen 74 en 75 van de Inleiding op het ALR, die bepalen:

'Einzelne Rechte und Vorteile der Mitglieder des Staates müssen den Rechten und Pflichten zur Beförderung des gemeinschaftlichen Wohls, wenn zwischen beiden ein wirklicher Widerspruch (Kollision) eintritt, nachstehen. (...)

Dagegen ist der Staat denjenigen, der seine besonderen Rechte und Vorteile dem Wohle des gemeinen Wesens aufzuopferngenồtigt wird, zu entschädigengehalten.'

Deze bepalingen gaan uit van de gedachte dat degene van wie in het algemeen belang een bijzonder offer ('Sonderopfer') wordt verlangd, daarvoor een schadevergoeding ontvangt. Men kan zeggen dat ze uitdrukking geven aan het beginsel van vrijheid van statelijke willekeur en, meer in het bijzonder, aan het beginsel van gelijkheid voor de publieke lasten (de 'égalité devant les charges publiques') ${ }^{187}$.

In de vijfde plaats willen we wijzen op par. 1 van deel II, titel 14, dat een omschrijving geeft van de 'fiscus':

'Alle Arten der Staatseinkünfte, welche aus dem Besteuerungsrecht, aus dem besonderenStaatseigentum, den nutzbaren Regalien, und anderen Staatsabgaben fliessen, werden unter der Benennungder Fiskus begriffen und haben besondere Vorzugsrechte' . 
Voor het eerst zien we een wettelijke omschrijving van het fiscus-begrip. Een omschrijving waaruit blijkt dat men het oude kroondomein thans ziet als staatsdomein, en de inkomsten uit dit domein, uit belastingen en uit anderen hoofde als staatsinkomsten. De vroegere opvatting van de fiscus als het 'privaat-persoonlijke' vermogen van de vorst is vervangen door de 'publiekrechtelijke' conceptie van de fiscus als staatsvermogen, gebonden aan het publieke gemeenschapsbelang. De fiscus kan dus weliswaar worden bestempeld als de vermogensrechtelijke hoedanigheid van de staat, waaraan bepaalde bijzondere bevoegdheden verbonden zijn, maar het zou onjuist zijn de fiscus op te vatten als een 'privaatrechtelijk' instituut. Dit blijkt niet alleen uit de gegeven omschrijving van het fiscus-begrip, maar ook uit de plaats waar deze in het ALR is ondergebracht, nl. in het 'publiekrechtelijke' deel ervan. We merkten eerder op dat het een regressie betekent, wanneer men in de negentiende eeuw 'vermogensrechtelijk' veelal gaat beschouwen als synoniem voor 'privaatrechtelijk' en de fiscus als de privaatrechtelijke hoedanigheid van de overheid, in welke hoedanigheid zij ook beschikt over de privaatrechtelijke 'bevoegdheden'.

Tenslotte willen we de aandacht vestigen op par. 7 van deel II, par. 15 ALR, waarin de publieke functie van 'Land- und Heeresstrassen' wordt erkend, die gebruiksbevoegdheden van allen ten aanzien van dat publiek domein impliceren, binnen de grenzen van de functie daarvan:

'Der freie Gebrauch der Land- und Heerstrassen ist einem jeden zum Reisen und Fortbewegen seiner

Sachen gestattet'.

Ook in deze bepaling manifesteert zich de scheiding tussen imperium (publiekrechtelijke bevoegdheden) en dominium (private vermogensbelangen). 


\section{Noten bij hoofdstuk 2}

1. Overigens ook weer dankzij het geid en het talent van de derde stand! Vgl. Van Caenegem, 'Over koningen en bureaucraten', a.w., p. 173, die opmerkt dat de Frankische landbouweconomie met haar zeer zwakke productiviteit niet toeliet een stand van ambtenaren te voeden en een hoofdstad in leven te houden met een aanzienlijke niet direct productieve bevolking. Pas met de opgang van de steden en de daaraan parallelle herleving van de economie en de geldeirculatie waren in de late Middeleeuwen de economische voorwaarden aanwezig voor een 'semi-bureaucratische vorstenstaat' (Van Caenegem). De ambtenaren werden veelal uit de derde stand gerecruteerd.

2. Hieraan doet niet af dat de standen hierbij niet gedreven werden door de publieke rechtsidee, maar het gebruik van de landsheerlijke iura regalia als privat bezit zagen als een gevaar voor de eigen rechtsposities (waarin eveneens overheidsbevoegdheden werden beschouwd als private vermogensbelangen).

3. Van grote invloed is ook de grote reformatiebeweging, die vanuit een principiecl ander standpunt dan het humanisme pleit tegen de macht van de Rooms-katholieke kerk. Beide, humanisme én reformatie, zijn individualistisch. In het humanistische persoonlijkheidsideaal echter wordt de 'motor' van het menselijk handelen gezocht in de vrije denkende en scheppende menselijke persoonlijkheid zelf. Van belang in de gereformeerde idee is dat de individuele, ook niet-professioneel geschoolde, gelovige in direct contact komt met Gods Woord en zijn eigen inzicht mag volgen wat de juiste zin van dat Woord betreft. De 'motor' van het individuele menselijke handelen wordt dus niet gezocht in de menselijke persoonlijkheid zelf.

Het humanisme zal zich in de Verlichtingstijd geheel van alle kerkgeloof losmaken en het menselijk denken en handelen funderen in de autonoom en zelfgenoegzaam verklaarde menselijke ratio.

4. Vgl. Jean Bodin, 'De republica', I, 8: 'Est enim lex nihil aliud quam summae potestatis iussum' (De wet is niets anders dan het bevel van de hoogste macht). De benaming 'absolutisme' komt waarschijnlijk van de Latijnse uitdrukking 'legibus absoluta' (van de wetten los, vrijgemaakt). Op de opvattingen van Bodin gaan we hierna nog uitgebreider in.

5. En óók doordat de term 'politie' vandaag alleen nog wordt gebruikt als aanduiding voor de politieorganisatic. Aanduidingen als 'algemene politieverordening' en 'politiedwang'. waarin de oude betekenis van 'politie' nog naar voren komt, zijn inmiddels in onbruik geraakt. Op het 'ius politiae' gaan we hierna nog uitvoerig in.

6. Zie over de gehoudenheid van de koning om de 'lois fondamentales du royaume', d.w.z. de bestaande rechten en gewoonten van het land, in acht te nemen: Van Caenegem, 'Over koningen en bureaucraten', a.w., p. 69 en p. $232 / 233$.

7. Evenals trouwens vele andere overheidsposten.

8. Van Caenegem, 'Over koningen en bureaucraten', a.w., p. 67, merkt over de parlementen op dat ze 'aartsconservatief (waren) en .... heel wat hervormingen die door de regering werden gewenst (hebben) tegengehouden'.

9. De Franse koningen kennen aan hun gezag nog een goddelijk karakter toe; het 'droit divin': de koning ontleent zijn absolute recht alleen aan God en is alleen aan hem, en niet jegens zijn onderdanen, verantwoording verschuldigd. Frederik de Grote breekt met het 'droit divin' en voert tevens de godsdienstvrijheid in. Bekend is zijn uitspraak: 'In meinem Reich soll jeder nach seiner Fasson selig werden'.

10. In Pruisen wordt dit o.a. gekenmerkt door een krachtige schoolpolitiek: het onderwijs wordt tot voorwerp van staatszorg gemaakt. De Allgemeine Schulordnung van 1774 voen de algemene schoolplicht in van het $6 \mathrm{e}$ tot het $12 \mathrm{e}$ levensjaar. En het Allgemeine Landrecht für die preussischen Staaten (1794) legt 0.a. vast: 'Schulen sind Veranstaltungen des Staates'. Rond die tijd worden ook de universiteiten staatsinrichtingen. 
11. Wat in Frankrijk aan het eind van de 18e eeuw en in Duitsland aan het eind van de 19e eeuw gebeurt - het politiek mondig worden van de burgerij -, wordt in Engeland reeds aan het eind van de 17e eeuw bewerkstelligd (de 'Glorious Revolution'). Het is niet onwaarschijnlijk dat het feit dat in Engeland niet het scherpe onderscheid tussen publiek- en privaatrecht wordt gemaakt zoals dat in Frankrijk en Duitsland wordt gemaakt, mede hierin zijn verklaring vindt dat Engeland niet het gehele 'ontwikkelingspad' van de politiestaat heeft gevolgd en voltooid. Deze kwestie - hoe interessant zij ook is - zullen we niet onderzoeken.

12. Ook merkten we al op dat zulks niet wegneemt, dat zich ook onder de Republiek interessante ontwikkelingen voordoen die vergelijkbaar zijn met ontwikkelingen elders. Daarbij is o,a, te denken aan het ontstaan van het onderscheid tussen 'politie' en 'justitie', waarop hierna nog nader zal worden ingegaan.

13. Alexis de Tocqueville, 'L'Ancien régime et la Révolution', 1856, bloemlezing (in Ned. vertaling) samengesteld en ingeleid door J.M.M. de Valk, 'Over de Franse Revolutie', Kampen 1988.

14. De Valk wijst in zijn Inleiding bij Tocqueville, a.w., p. 12, op de grote gelijkenis van Tocqueville's analyse met de hedendaagse theorie van de 'revolution of rising expectations', die stelt dat revoluties niet het resultaat zijn van ondraaglijke levensomstandigheden, doch juist van een verbetering daarin die naar meer en sneller verandering doet verlangen. Tocqueville, a.w., p. 34, stelt dat, als er rond 1750 een vorst op de Franse troon had gezeten 'van het formaat en de aard van een Frederik de Grote', hij veranderingen zou hebben doorgevoerd, groter dan de revolutie heeft bewerkstelligd, en niet alleen zonder zijn troon te verliezen, maar met een aanzienlijke vergroting van zijn macht. Volgens Simon Schama, 'Burgers. Een kroniek van de Franse Revolutie', Amsterdam 1989, p. 848, ging de monarchie ten onder aan haar onvermogen om vertegenwoordigende lichamen te scheppen die het hervormingsprogramma van de Staat konden uitvoeren.

15. Tocqueville, a.w., p. 40.

16. $\mathrm{Vgl}$. B.J. de Clercq, 'Macht en principe', Tielt 1988, p. 15, die er terecht op wijst dat theorieên altijd het produkt zijn van levende mensen. levend in een bepaald tijdsbestel, erdoor geconditioneerd en erop reagerend in discussie met de gedachten van tijdgenoten en voorgangers.

17. S.W. Couwenberg. 'De omstreden staat. Ontwikkeling en problematick van de staatstheorie in de 20ste eeuw*, Alphen a/d Rijn 1974, p. 11.

18. Couwenberg, 'De omstreden staat', a.w., p. 99. Couwenberg beschouwt de dialectiek tussen het machtsmotief en het emancipatiemotief als hét centrale probleem in het denken over Staat en recht en geeft hieraan in zijn werken op indrukwekkende wijze uitwerking. Zie dez., 'Westers staatsrecht als emancipatieproces', Alphen a/d Rijn 1977: 'Modern constitutioneel recht en de emancipatie van de mens', 4 delen, Assen 1979-1984; dez., 'Recht, Staat en Maatschappij, over Gezag en Vrijheid', Zwolle 1991 (Let op de titel, waarin de dialectiek tot uitdrukking komt).

19. De opkomende Staten gaan zich juist bedienen van de religie als machtsinstrument in het kader van hun centralisatiestreven. Zoals we al opmerkten, geschiedt dit met name in de landen van de Contra-reformatie. Vgl. de door Karel V en Philips II uitgevaardigde ketter-plakkaten die de reformatie moeten bestrijden, en de in 1559 onder het bewind van Philips II verschenen bul 'super universos', die een nieuwe kerkelijke organisatie van de Nederlanden inhoudt.

20. E.J. Dijksterhuis, 'De mechanisering van het wereldbeeld', Amhem 1953; H.J. van Eikema Hommes, 'Hoofdlijnen van de geschiedenis der rechtsfilosofie', Deventer 1972, pp. 58-60, die - in navolging van de formulering van Kant - spreekt van de twee humanistische grondmotieven 'vrijheid' en 'natuur'.

21. Eerdere natuurrechtsopvattingen zochten de grondslag elders, $m . n$. in een goddelijke wereldorde (bijv. Thomas van Aquino).

22. H. Dooyeweerd, 'De vier grondthema's in de ontwikkelingsgang van het wijsgerig denken van het avondland', Philosophia Reformata 1941, pp. $161-179$ (p. 170/171), ook opgenomen in M.E. Verburg. 'Herman Dooyeweerd. Grenzen van het theoretisch denken', Baarn 1986, pp. 123-140. Dooyeweerd onderscheidt vier levensbeschouwelijke grondmotieven die als stuwende krachten de ontwikkeling van het westerse culturele en geestelijke ontwikkeling hebben beheerst (De term 'grondmotief' zal - zo vermoeden wij - ontleend zijn aan de Duitse term 'Leitmotiv'). Deze vier grondmotieven - waarvan er drie dialectisch van aard zijn, d.w.z. samengesteld uit als 'tegenpolen' tegenover elkaar staande 
motieven - zijn volgens D.: 1 . het Griekse vorm-materie-motief; 2 . het rooms-katholieke motief van natuur en genade; 3 , het humanistisch grondmotief van natuur en vrijheid; 4. het integraal christelijk motief. In elke cultuur is volgens D. zo'n grondmotief aan te wijzen dat als een geestelijke drijfkracht in de samenleving werkzaam is: '(H)et zet zijn onuitwisbaar stempel op de cultuur, de wetenschap, de sociale structuur ener periode, voor zover er inderdaad een leidende cultuurmacht is aan te wijzen, die aan de historische ontwikkeling een vaste richting geeft'. Een dergelijk grondmotief beheerst de levensen denkhouding van een denker, ook zonder dat hij er zich rekenschap van geeft. Het beheerst een denker zelfs in een hogere graad - aldus D. -, naarmate hij zich minder bewust is van zijn verborgen grondmotief.

23. S.W. Couwenberg. 'Modem constitutioneel recht en emancipatic van de mens', dl. 4: 'Dialectiek van macht en emancipatie', Assen 1984, p. 15.

24. Dooyeweerd, 'De vier grondthema's in de ontwikkelingsgang van het wijsgerig denken van het avondland', a.w., p. 171.

25. Vgl. Dooyeweerd, 'Vernieuwing en bezinning', a.w., p. 102/103.

26. We wezen er reeds op dat de anti-feodale opvarting volgens welke de vorst de overheidsmacht als een onvervreemdbaar, tén en ondeelbaar goed rechtstreeks over de onderdanen dient uit te oefenen in het algemeen belang, in ons land reeds is verdedigd door Philips van Leiden in zijn omstreeks 1355 geschreven 'Tractatus de cura reipublicae et sorte principantis'. Deze opvatting wordt door Jean Bodin uitgewerkt binnen het kader van zijn staatsabsolutistisch souvereiniteitsbegrip.

27. Van der Pot/Donner, a.w., p. 14.

28. 'Majestas est summa in cives ac subditos legibusque soluta potesta'. Hiema zal steeds worden geciteerd uit de franstalige versie van Bodins werk: J. Bodin, 'Les six livres de la république' (1576), herdruk Parijs 1984.

Ontstaan was het woord soevereiniteit reeds in de Middeleeuwen. 'Soeverein' ('superanus of 'superior') was toen nog een comparatief begrip: de 'hoogste macht' was 'hoger' in vergelijking met een 'lagere', en conflicten hadden betrekking op de legitimiteit van concurrerende aanspraken. Soeverein heette oorspronkelijk niet alleen de koning maar ook de leenman die in zijn gebied als vazal des konings gezag uitoefende. De door Bodin gegeven definitie van soevereiniteit past voor de Middeleeuwen goed bij de 'plenitudo potestatis' (volheid van macht) van de paus, die als plaatsvervanger van Christus bevoegd werd geacht over alles en allen te oordelen zonder dat hij zelf door iemand op aarde kan worden beoordeeld.

Bij de toenemende versterking van de koninklijke macht ten koste van die van de lagere heren kreeg het 'wereldlijke' begrip soevereiniteit geleidelijk steeds meer een superlatieve betekenis ('supremus'). Daardoor is 'de superior tot supremus, de superioritas tot suprema potestas ... geworden', aldus M.V. Polak, 'Pluralistische staatsleer', in: Staatswetenschappelijke opstellen aangeboden aan R. Kranenburg. Alphen a/d Rijn 1949, pp. 92-110. Vgl. ook Van Apeldoom/Leijten, a.w., p. 228.

Eerder wezen we reeds op het rapport van maart 1581, opgemaakt door vertegenwoordigers der staten der Nederlandse gewesten inzake de onderhandeling met de hertog van Anjou inzake overdracht aan hem van de landsheerlijkheid (na afzwering van Philips II), waarin bezwaar wordt gemaakt tegen opneming van het woord 'souverin' in het met Anjou te sluiten tractaat, omdat dit woord naar hun oordeel zou kunnen worden verstaan als absolute souvereiniteit. De nieuwe betekenis van het woord 'soevereiniteit' heeft dan kennelijk reeds ingang gevonden.

29. Dig. 1,3,31. Eerder merkten we al op dat deze uitspraak alleen een gevolg was van het ontbreken van instellingen die de vorst zouden kunnen dwingen zich aan de wetten te houden.

30. Overigens zou volgens Bodin de soevereiniteit - het hoogste, absolute gezag - niet alleen bij een monarch, maar ook bij een aristocratie of bij het volk zou kunnen berusten, maar Bodin laat duidelijk blijken dat een eenhoofdig gezag het meest voor de hand ligt.

31. Tussen haakjes: de Hoge Raad lijkt eveneens de 'overheid' te vereenzelvigen met de Staat (resp. zijn autonome onderdelen als gemeenten en provincies), waar hij (in o.a. het Windmill-arrest) spreekt van de 'aan de overheid' toekomende bevoegdheden 'krachtens privaatrecht'. 
32. Inzoverre als de eind-negentiende eeuwse theorie van de staatssoevereiniteit de soevereiniteit toekent aan het staatsverband zelf, is zij dus juist. $\mathrm{Zij} \mathrm{laboreert} \mathrm{echter} \mathrm{aan} \mathrm{hetzelfde} \mathrm{gebrek} \mathrm{als} \mathrm{de} \mathrm{leer} \mathrm{van} \mathrm{de}$ overheids-resp, volkssoevereiniteit, inzoverre zij geen innerlijke grenzen ziet gesteld aan die soevereiniteit.

33. Zij behoeft dus niet telkens, bij iedere troonopvolging, te worden erkend. Vgl. de praktijk die was gegroeid onder het standen'staat'wezen.

34. Vgl. Dooyeweerd, 'Vemieuwing en bezinning', a.w., p. 157: 'Het woord 'republiek' zegt niets over de regeringsvorm. Het drukt slechts uit, dat het staatswezen een publieke en geen private instelling is. (...) (D)e monarchale regeringsvorm is allerminst onverenigbaar met het wezen der republiek. Zo is onze Nederlandse staat een monarchale republiek, waarin het koninklijk gezag slechts als hoogste ambt binnen de res publica fungeert. Slechts het feit, dat juist in de monarchale regeringsvorm zich de ongedifferentieerde opvatting van het koninklijk gezag als een privaat eigendomsrecht van de vorst zo lang heeft kunnen handhaven, verklaart dat men monarchie en republiek als tegenstellingen ging zien' (curs. door auteur).

35. Bodin geeft een inventaris van negen 'echte kenmerken van soevereiniteit'. Náást de wetgevende bevoegdheid - die de kem van de soevereiniteit vormt - worden genoemd: de macht te beslissen over oorlog en vrede; benoeming en ontslag van ambtsdragers; het hoogste rechterschap; de bevoegdheid tot verlening van gratie; het recht eerbewijzen te ontvangen; de bevoegdheid belastingen te heffen; de bevoegdheid munten te slaan en maten en gewichten te ijken.

36. H.J. van Eikema Hommes, 'Hoofdlijnen van de geschiedenis der rechtsfilosofie', Deventer 1972, p. 64: 'Maar deze soevereiniteitsleer schoot haar doel voorbij, omdat zij tot een staatsabsolutistische visie op de positieve rechtsvorming leidde, waarin voor het eigen, niet tot de statelijke rechtsmacht te herleiden recht der niet-statelijke verbanden en maatschapsverhoudingen geen plaats is.' $v E H$ wijst nog op art. 3 Wet Algemene Bepalingen van 1929 (bepalende dat gewoonte geen recht geeft, tenzij de wet

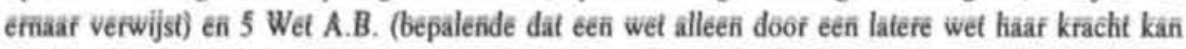
verliezen), waarin Bodins leer inzake de verhouding van wet en gewoonterecht zou zijn neergelegd (Art. 3 Wet A.B. is overigens per 1 jan. 1992 komen te vervallen). Bodins soevereiniteitsbegrip is m.a.w. functioneel in zijn tijd, maar zal niettemin een enorme invloed hebben tot in het juridisch positivisme van de 19 e en 20e eeuw, waarin zelfs de door Bodin nog geponeerde binding van de hoogste overheid aan het natuurrecht opzij wordt gezet.

37. E.H. Kossmann, 'Bodin, Althusius en Parker', in: 'Politieke theorie en geschiedenis' (Verspreide opstellen en voordrachten), Amsterdam 1987, pp. 93-110 (p. 95).

38. Ook hierin - enerzijds de onvervreemdbaarheid van een publiek domein, dat geen 'zaak in de handel' is en anderzijds de respectering van de private vermogensbelangen - manifesteert zich de scheiding van imperium (overheidsgezag) en dominium (private vermogensbelangen), die inherent is aan de doorbraak van de publieke rechtsidee.

39. Niccold Macchiavelli, 'De Heerser', Ned. vertaling van Frans van Dooren, Amsterdam 1976. In deze vertaling is niet gekozen voor de titel 'De Vorst' maar voor 'De Heerser', omdat daarmee - aldus Van Dooren - de universaliteit wordt aangegeven van het 'wilskrachtige, het energieke, het dynamische' dat in de hoofdpersoon van Macchiavelli's werk gestalte heeft gekregen.

40. Later zal men spreken van de (leer van đe) 'Staatsrăson' of 'raison d'état'. Zie F. Meinecke, 'Die Idee der Staatsräson in der neuen Geschichte', Leipzig 1924. De matiging die Macchiavelli door zijn virtugedachte aanbrengt, gaat gemakkelijk verioren: de virtu moet wijken voor de necessita, de harde politieke werkelijkheid. Zo betoogt de schrijver in het XVIIIe hoofdstuk: 'Een verstandig heerser kan noch mag zijn woord houden wanneer dit hem schade berokkent en wanneer de redenen die hem tot zijn belofte hebben gebracht, zijn weggevallen.'

41. De Clercq, a.w., p. 119.

42. Van der Pot/Donner, a.w., p. 15. 
43. De 'wetenschappelijke' bewijsvoering van Bodin is vooral historisch. Op basis van een grote hoeveelheid feitenmateriaal betreffende de meest verscheiden politieke systemen, trekt hij de conclusie dat de soevereine staatsmacht zich praktisch overal met een historische noodzaak heeft opgedrongen als de conditie voor de leefbaarheid van de samenleving.

44. Naast de 'Leviathan' is m.n. Hobbes 'De Cive' (1647) van belang voor een goed begrip van zijn politieke theorie. Zie over Hobbes 0.a.: De Clereq, a.w., pp. 132-138 (met vele literatuurverwijzingen op pp. 310/311); C.B. Macpherson, 'The Political Theory of Possessive Individualism: Hobbes to Locke', Oxford 1962; Van Eikema Hommes, 'Hoofdlijnen van de geschiedenis der rechtsfilosofie'. a.w., p. 83 e.v.; Van der Pot/Donner, a.w., pp. 17-21. In zijn geseculariseerde vorm was het denkmodel van het oorspronkelijk verdrag reeds toegepast in de calvinistische politieke theorieèn van de hugenoten die als 'monarchomachen' bekend staan - m.n. Francois Hotman (1524-1590) - en van Althusius (1557-1638). Anders dan bij Bodin is bij Althusius het volk als geheel de drager van de soevereiniteit. Zie over Althusius 0.a.: Van der Pot/Donner, a.w., p. 16/17; H.J. van Eikema Hommes, 'Die Bedeutung der Staats- und Gesellschaftslehre des Johannes Althusius für unsere Zeit', in 'Recht und Staat im sozialen Wandel. Festschrift fur Hans Ulrich Scupin zum 80. Geburtstag', Berlin 1983, pp. 211-232.

45. Dit is de vorm waarin de natuurwetten ('leges naturales') bij Hobbes optreden: niet als recel geldend natuurrecht, maar als aan de natuurwetten van de dynamica onderworpen conclusies van het redelijk denken. Hobbes onderwerpt met toepassing van de aan Galilei ontleende natuurwetenschappelijke methode ook het menselijke geestesleven aan de wetten der dynamica (beweging) en ontkent daarmee ook de wilsvrijheid van de mens. Deze methode wordt ook wel de 'resolutief-compositorische methode' genoemd. Bij deze methode wordt ervan uitgegaan, dat men een ding of verschijnsel pas kan kennen. wanneer men het in zijn elementaire bestanddelen uit elkaar heeft gehaald (resolutief) en het vervolgens. methodisch en systematisch, weer heeft opgebouwd (compositorisch). Hobbes richt deze methode zowel op de samenleving alsook op de mens zelf.

Hobbes verwerpt dus de door Descartes (1596-1650), grondlegger van de humanistische wijsbegeerte. gemaakte onderscheiding tussen enerzijds 'res extensiva' (de uitgebreide materie c.q. 'natuur', d.w.z. de gehele werkelijkheid inclusief het menselijk lichaam, maar exclusief de menselijke geest) die is onderworpen aan de a priori geldende mathematische wetten der werkelijkheid, en anderzijds 'res cogitans', die zelf niet aan die wetten is onderworpen. Later zal, in de lijn van Descartes, ook Kant trachten de menselijke wilsvrijheid te redden en te ontkomen aan de innerlijke dialectiek tussen de beide humanistische idealen, door het maken van een onderscheid tussen enerzijds 'Verstand' en 'reine Vernunft' en anderzijds de 'praktische Vemunft' (de gebied van de zedelijke vrijheid, het ideaal van de autonome persoonlijkheid).

46. Omdat de eenheid van het volk en de soevereine macht over allen pas ontstaat bij het oorspronkelijk verdrag tussen alle individuen, kan Hobbes de stichting van een Staat via dit verdrag vergelijken met Gods schepping van de mens. De absolute staatsmacht, die bij het verdrag wordt opgericht en dus buiten het verdrag zelf staat, is een 'Leviathan', dat wil zeggen: een sterfelijke God ('mortal God'), die ieder onder de onsterfelijke God vrede en rust verzekert. Op het titelblad van de eerste uitgave van de 'Leviathan' is Hobbes' staatsbeeld op fraaie wijze tot vitdrukking gebracht: een vorst die in de rechterhand een zwaard en in de linkerhand een bisschopsstaf houdt om daarmee het land te bestrijken, terwijl zijn maliēnkolder - i.p.v. uit talloze ringetjes - uit evenzovele mensen bestaat.

47. Zoals we zagen, zijn de zgn. 'leges naturales' geen natuurrecht.

48. Zie over Locke 0.a.: McPherson, a.w.; De Clercq, a.w., pp, 148-155; P.C. Westerman, 'John Locke', in: P.B. Cliteur/A.A.M. Kinneging/G.A. van der List (red.). 'Filosofen van het klassieke liberalisme', Kampen 1993, pp.47-66; Van der PotDonner, a.w., pp. 22-26; H.J. van Eikema Hommes, 'De wijsgerige grondslagen van de rechtssociologie', Deventer/Zwolle 1986, p. 11/12.

49. De Stuart-periode leidt, mede door de puriteinse revolutie (1649), de 'Glorious Revolution' (1688) en de 'Bill of Rights' (1689), tot de constitutionele beperking van de monarchie en de politieke overheersing van het parlement. De door Montesquieu in Engeland geobserveerde toestand, zal Montesquieu 
(1689-1755) inspireren bij het schrijven van het bekende hoofdstuk 6 van Boek XI ('De la constitution d'Angleterre') van zijn 'De l'Esprit des Lois' (1748).

50. Second Treatise: 'An essay concerning the true original, extent and end of civil government'), ed. Everyman's Library, Londen 1978, met inl. W.S. Carpenter. Het werk is waarschijnlijk reeds geschreven vóor 1683, maar pas in 1690 - dus nà de 'Glorious Revolution' van 1688 - gepubliceerd. De eerste 'Treatise' is een aanval op Robert Filmer's 'Patriarchia', dat geschreven was ter verdediging van het goddelijk recht van de monarchie op basis van afstamming.

51. Locke veronderstelt dat er in de natuurtoestand een natuurlijk recht op eigendom bestaat, mits iemand pas iets zijn eigendom noemt als er zijn persoonlijke arbeid aan te pas is gekomen. Dit spruit volgens Locke voort uit het feit dat ieder mens persoonlijke rechten en recht op het eigen lichaam heeft, dus ook op hetgeen door lichamelijke arbeid is voortgebracht (arbeidstheorie). De idee van de persoonlijke vrijheid wordt dus door Locke in verband gebracht met de eigendom, hetgeen verklaart waarom Locke 'property' ook gebruikt als overkoepelende term. Vgl. Locke, a.w., II, 123: De in de natuurtoestand bestaande rechtsonzekerheid dwingt de mensen tot het aangaan van het oorspronkelijk verdrag. 'to join in society with others for the mutual preservation of their lives, liberties and estates, which I call by the general name: property'. Zie ook II, 173: 'By property 1 must be understood here ... to mean that property which men have in their persons as well as goods'. De arbeidstheorie, die de eigendom relateert aan de persoonlijke arbeid, komt tot uitdrukking in art. 16 van de Franse Constitutie van 1793: 'Het eigendomsrecht is het recht van elke burger om naar willekeur ('à son gré') te genieten van en te beschikken over zijn goederen, zijn inkomen en de vruchten van zijn arbeid en inspanning'.

52. Evenals door Hobbes, wordt door Locke in het midden gelaten of er ooit ergens zo'n natuurtoestand heeft bestaan. De gedachtenconstructie van de natuurtoestand dient hem ertoe duidelijk te kunnen maken, welke de grondslagen en uitgangspunten zijn van zijn staatsidee. Zoals Hobbes' staats- en rechtsleer pas goed kan worden verstaan vanuit zijn aan de dynamica ontleende natuurwetenschappelijke methode, geldt ook voor Lockes leer dat deze eigenlijk eerst goed is te begrijpen tegen de achtergrond van zijn kentheoretische werk, zijn 'Essay Concerning Human Understanding'(1690), waarin met verwerping van de rationalistische natuurwetenschapsmethode wordt uitgegaan van het zintuiglijke (sensualisme, empirisme). Zie hierover o.a. Westerman, a.w. Tot de Britse empiristen worden naast Locke ook Berkely en Hume gerekend. Mede op basis van de inzichten van Hume zal Kant een synthese tot stand brengen tussen empirisme en rationalisme.

53. Locke, a.w.. II, 131, 135 en 163: 'For the end of government being the good of the community,... nobody in government can have a right tending to any other end; and those only are encroachments which prejudice or hinder the public good. Those who say otherwise speak as if the prince had a distinct and seperate interest from the good of the community, and was not made for it; the root and source from which spring almost all those evils and disorders which happen in kingly governments'. De consequentie die wordt verbonden aan het standpunt dat de overheidsmacht berust op vertrouwen en steeds een toevertrouwde macht ('fiduciary power') blijft, is het recht op opstand. Vgl. Locke, a.w., II, 202: 'And whosoever in Authority exceeds the Power him given by Law, ... ceases in that to be a Magistrate, and acting without Authority, may be opposed, as any other Man, who by force invades the Right of another'.

54. Staat-maatschappij is als begrippenpaar geintroduceerd door Hegel, maar materieel is de onderscheiding er al sinds Locke.

55. Van de uitvoerende macht, belast met de uitvoering van de wetten binnen de eigen samenleving. onderscheidt Locke overigens de federatieve macht, belast met de behartiging van de belangen van de gemeenschap naar buiten.

56. Locke, a.w., II, 125.

57. Locke, a.w., II, 57. Vgl, ook E.M.H. Hirsch Ballin, 'Het grondrecht op vrijheid en de wet', Alphen a/d Rijn 1989, die het 'fundamentele grondrecht op vrijheid' ziet als keerzijde van de legaliteitseis.

58. Locke, a.w., II, 158.

59. Locke, a.w., II, 160. 
60. Locke, a.w., II, 164. Als voorbeeld van gebruikmaking van het 'prerogative' noemt Locke de afbraak van het huis van een onschuldig iemand teneinde het vuur te bedwingen, wanneer het huis ernaast in brand staat (a.w., 159).

61. Dat optreden door het overheidsbestuur geboden kan zijn buiten de gevallen die uitdrukkelijk door de wetgever zijn voorzien, speelt uiteraard vooral waar het gaat om dreigend gevaar voor aantasting van de openbare orde, rust en veiligheid. In de 'polizeiliche Generalklausel' in de 'Polizeigesetze' van de Duitse Länder komt totuitdrukking dat het niet wel mogelijk is alle denkbare gevaren en mogelijkheden voor aantasting van openbare orde, rust en veiligheid te voorzien en bij (specifieke) wet te regelen, en dat het overheidsbestuur in dergelijke situaties toch moet kunnen optreden. De 'polizeiliche Generalklausel' biedt daartoe een algemene - als subsidiair bedoelde - bevoegdheidsgrondslag. Zie over deze 'Generalklausel' hierna.

62. Vgl. ook L.J. Giebels, 'Ontwikkeling van het democratisch denken', Amsterdam 1987, p. 168.

63. Vgl. Locke, a.w., II, 94: 'Government has no other end but the preservation of property".

64. Macpherson, a.w., p. 199, duidt de kern van Lockes theorie dan ook aan als 'bezitsindividualisme'

65. Hoewel Locke nergens in zijn 'Two Treatises' expliciet aangeeft, hoe ruim hij zich de kring van kiesgerechtigden denkt, mag worden aangenomen dat zijn verdediging van de 'majority rule' (meerderheid van stemmen) niet gebaseerd is op het beginsel 'one man one vote'. De 'Fundamental Constitutions for the Government of Carolina', het ontwerp voor een constitutie voor de nieuwe Amerikaanse kolonie Carolina dat in 1669 door Locke is opgesteld in zijn hoedanigheid van secretaris van de Heren Eigenaren, gaan trouwens nadrukkelijk uit van landbezit als kiesrechtkwalificatie. Kiesrecht heeft dus slechts degene die werkelijk onafhankelijk is, dat wil zeggen: degene die privé-eigendom heeft en daarover belasting betaalt (census-kiesrecht). Dit is eigenlijk een nieuwe vorm van privilegiering, maar is gerechtvaardigd in een opvatting die de vrijheid nauw verbindt met en zelfs baseert op de - zij het ruim opgevatte - eigendom. Want in tegenstelling tot standsprivileges - voorrechten door geboorte verkregen - vindt in die opvatting de eigendom zijn grondslag in de verrichte eigen arbeid. $\mathrm{V}_{\mathrm{gl}}$. ook Kant in 'Über den Gemeinspruch: Das mag in der Theorie richtig sein, taugt aber nicht für die Praxis', 1793, Frankfurt aM 1968, p. 46/47, waar wordt gesteld dat voor de hoedanigheid van staatsburger (citoyen) is vereist 'dass er sein eigener Herr (sui juris) sei, mithin irgendein Eigentum habe (wozu auch Kunst, Handwerk oder schōne Kunst, oder Wissenschaft gezāhlt werden kann), weiches ihn ernăhrt... .

66. J.J. Rousseau, 'Du contrat social, ou principes du droit politique', 1762, Ned. vertaling: 'Het maatschappelijk verdrag', Amsterdam 1947, p. 17.

67. Rousseau, a.w., I, ch. VI.

68. Rousseau, a.w., I, ch. VI.

69. Dit is - zo merkt Von Schmid op - logisch beschouwd een tegenstrijdigheid, maar is het psychologisch niet, nl. wanneer men onder 'vrijheid' niet verstaat het vermogen alles te kunnen doen en laten waartoe men fysiek in staat is, maar het daarmee geen verband houdende innerlijk vrijheidsgevoel. Voor Rousseau is de kern der menselijke persoonlijkheid niet gelegen in het rationele denken van de deterministische wetenschap, maar in het natuurlijke vrijheidsgevoel. Een staatsvolk is in staat zich zelf de wet te stellen als gevolg van zijn gevoel van samenhorigheid, die een algemene wil heeft. Deze is van grote waarde, en veel meer dan een wil van allen, omdat hij steeds op het algemeen belang gericht is. Omdat hierbij een nationaal samenhorigheidsgevoel optreedt, voelt de individuele burger zich daarbij in zijn vrijheidsgevoel niet aangetast. 'Want wie zich, zelfs aan de strengste orde, psychisch heeft aangepast, voelt zich toch innerijik vrij', aldus J.J. von Schmid, 'Het denken over staat en recht in de tegenwoordige tijd', Haarlem 1965, p. 143.

70. Rousseau, a.w., III, ch. XV.

71. Vgl. N. Reich, 'Sozialismus und Zivilrecht', Frankfurt aM 1972, p. 134. Dat het Sowjet-Russische privaatrecht op Rousseauiaanse leest was geschoeid en niet gebaseerd was op de idee van de burgerlijke vrijheid die wordt erkend en gepositiveerd, maar op de idee van de burgerlijke rechten die door de Staat aan de burgers zijn verleend, welke rechten dan ook door de burger als door een ambisdrager moeten worden uitgeoefend met inachtneming van hun doelstelling. blijkt uit art. 1 van het Sowjet-Russische Burgerlijk-Wetboek: 'De burgerlijke rechten worden door de wet beschermd, tenzij ze worden uitgeoe- 
fend in strijd met hun sociaal-economische doelstelling'. Maar dit recht was dan ook geen waar burgerlijk privaatrecht. Voor private grondeigendom is in een dergelijk bestel geen ruimte; alle grond is publiek domein. Art. 2 Wetboek van Agrarische Recht (1922) zegt dat het 'volkomen duidelijk' is dat de grondeigendom aan de Staat toebehoort, een principe dat wordt herhaald in het Burgerlijk Wetboek.

72. Waar in de Sowjet-Unie het gebruik van de grond aan anderen werd overgelaten (aan corporaties, vooral kolchozen), kreeg de grondeigendom dan ook een feodale inslag: de Staat als leenheer en de kolchozegemeenschappen als leenmannen of horigen, die voor het gebruik van het land veel méér moesten afdragen dan een 'tiende penning'. Zie V. Gsovski, 'Soviet Civil Law', 2 dl., Ann Arbor 1948/1949, p. 269. Vgl. ook Z. Szirmai, 'Schets van het Sovjet-Russische Eigendomsrecht', RMTh 1957, pp. 265-281.

73. J.P.A. Mekkes, 'Proeve eener critische beschouwing van de ontwikkeling der humanistische rechtsstaatstheorieěn', điss. Amsterdam 1940, Utrecht/Rotterdam 1940, pp. 330 e.v.

74. Die wil is - zoals we zagen - bij Rousseau de uitdrukking van een nationaal gevoel en bewustzijn van samenhorigheid, waardoor een normale samenwerking mogelijk is en de burgers zich in hun individuele vrijheidsgevoel niet aangetast voelen. Rousseau wordt dan ook wel beschouwd als de ontdekker en verkondiger van het nationale gevoel in de staatsleer.

75. A.M. Donner, 'Nederlands bestuursrecht, algemeen deel', 5e druk, Alphen a/d Rijn 1987, p. 30.

76. Volgens Donner, 'Nederlands bestuursrecht', a.w., p. 30, ontstaat de tweede betekenis waarschijnlijk als elliptische aanduiding voor de zorg voor het eerst betekende.

77. F. Fleiner, 'Institutionen des Deutschen Verwaltungsrechts', 8e druk, Tubingen 1928, p. 30/31.

78. Overigens zal Lodewijk XIV toch weer een beroep doen op een 'dominium eminens' om zijn onteigeningsmaatregelen te rechtvaardigen. Beter gezegd: van onteigening zou geen sprake zijn, omdat de vorst reeds eigenaar was uit hoofde van zijn 'dominium eminens'. En de Duitse verlichtingsfilosoof Christian Wolff verkondigt in de $18 \mathrm{e}$ eeuw, dat de vorst op grond van zijn 'dominium' eminens' over alle goederen en zijn 'potestas eminens' over alle personen, samengevat in zijn 'Ius eminens', met een beroep op het algemeen belang inbreuk kan maken op de aangeboren en verkregen rechten, maar zulks slechts in een noodsituatie. In de tijd van Wolff begint nl. de idee van de wetmatigheid van overheidsoptreden tot ontwikkeling te komen; de gedachte is dan dat - buiten de wet - slechts in noodsituaties een inbreuk op de rechten van onderdanen geoorloofd is.

79. Ók buiten de absolutistische Staten. Vgl. voor de situatie in de Republiek der Zeven Verenigde Nederlanden: R.V. Ryppenda Wierdsma, 'Politic en Justitie, Een studie over Hollandschen staatsopbouw tijdens de Republiek', diss. Leiden, Zwolle 1937.

80. Fleiner, a.w., p. 30/31.

81. Otto Mayer, 'Deutsches Verwaltungsrecht', Bd. I, le druk, Leipzig 1895, p. 246.

82. Vgl. Rijpperda Wierdsma, a.w.; dez., "Over het begrip "politie", in: Rechtshistorische opstellen aangeboden aan A.S. de Blécourt, Groningen-Batavia 1939, pp. 155-168; R.H. Hartog, 'Onrechtmatige overheidsdaden in de Republiek der Verenigde Nederlanden', Deventer 1971, p. 12/13; J. van der Poel, 'Rondom compositie en compromis. Fiscale studie in bestuurs- en strafrecht', diss. Utrecht 1942, p. $40 / 41$.

83. Waarmee dan duidelijk wordt gemaakt dat ook de rechtspraak geschiedt namens de soevereine vorst. 84. Van der Poel, a.w., p. 40/41.

85. Vgl. J, van der Poel, 'Een nieuw kleed voor het fiscaal strafrecht', TvS 1951, pp. 181-210. De 'politiewetgeving' heeft overigens niet alleen betrekking op wat later publiekrecht zal worden genoemd, maar regelt ook allerlei onderwerpen die later tot het burgerlijk recht worden gerekend. Men sla er de talloze stedelijke keuren maar op na; men denke verder aan de uitvoerige handelsrechtelijke ordonnanties van de Franse koningen.

86. Denk bijv, aan de eerder genoemde 'Constitutio Criminalis Carolina' ofwei 'Kaiser Karls V. und des Heiligen Römischen Reiches peinliche Gerichtsondnung' van 1532, die een codificatie en unificatie van het criminele recht brengt.

87. Op dit onderscheid wordt hierna nog ingegaan. 
88. Van der Poel, 'Rondom compositic en compromis', a.w., gaat in zijn belangwekkende onderzoek naar de ontwikkeling van het bestuursrecht en bet strafrecht, toegespitst op het fiscale recht, uitvoerig in op de oude betekenis van de woorden 'civiel' en 'crimineel', Aan dit onderzoek hebben we veel kunnen ontlenen.

89. Het contravenieren, d.w.z. het enkele 'tegen-komen' van (de niet-naleving van) deze administratieve voorschriften, brengt dus het opleggen der sanctie mee.

90. Th.F.M. Boey. 'Woordentolk of verklaring der voomaamste onduitsche en andere woorden in de hedendaagsche en al-oude rechtspleginge voortkomende', Den Haag 1773: Crimen: zaken uit de handelingen der mensen voorkomend tegenover zaken die door de civiele wet onder de klasse der delicten gebracht zijn.

91. Van der Poel, 'Een nieuw kleed voor het fiscale strafrecht', t.a.p., p. 184.

92. Vgl. ook Hardenberg, a.w., p. 353.

93. 'Vermogensrechtelijk' wordt hier dus niet gebruikt als synoniem voor 'burgerrechtelijk' in de modeme betekenis van dit laatste woord.

94. Joost Schomaker, 'Rechtskundige aanmerkingen over de ondonnantie (op de 25en en 50en penning) met een vooraf uit de Rechts-en Staatkunde beredeneerd vertoog over 's Lands schattingen, manier van procedeeren, enz. ', Zutphen 1754, p, 649.

95. Van der Poel, 'Een nieuw kleed voor het fiscale strafrecht', t.a.p., p. 185: 'Dit alles blijft in grote lijn zo tot ver in het revolutietijdperk'.

96. Mede gelet op het grote aantal bronnen die door Van der Poel bij zijn onderzoek zijn geraadpleegd (en weergegeven in zijn dissertatie), komt ons zijn conclusie dat de aanduiding 'civiel' wordt gebruikt voor iets dat 'op geld waardeerbaar' is, niet onjuist voor. Bij dit alles moet worden beklemtoond dat er vroeger, al evenmin als tegenwoordig, sprake is geweest van een éénduidig begrippenapparaat. Ons entbrak de tijd, zelf een uitgebreid (nader) Bnderzoek in te stellen naaf (de vêfschuivivingèn in) dê betekenis van 'civiel'. De volgende - zij het voorzichtige - conclusies zouden we echter wel durven te trekken.

In de ruimste betekenis wordt 'civiel' gebruikt als aanduiding van alle door de overheid gepositiveerde recht - in onderscheid tot het natuurrecht -, d.w.z. alle positief recht. Vgl. bijv. Hugo de Groot, die in 1625 in zijn 'De iure belli ac pacis' een onderscheid maakt tussen natuurrecht, 'ius gentium' (het volkenrecht in de zin van een op overecnkomst tussen staten berustend recht, en 'ius civile' (als aanduiding van het positieve statelijke recht, dus binnen de Staat). Hugo de Groot gaat uit van het soevereiniteitsbegrip van Bodin en kent aan de soevereine overheid de oorspronkelijke (door het natuurrecht gelegitimeerde) en exclusieve rechtsmacht tot vorming van positief recht binnen de Staat toe, zodat men kan zeggen: 'ius civile' is alle positief recht. De overlapping van de begrippen 'civiel' en 'politie' komt bijv. ó́k naar voren in het gebruik van het woord 'civiel' bij het onderscheid dat Hugo de Groot in dit werk maakt tussen politieke heerschappij ('imperium', 'ius regendi', 'dominium civile') enerzijds en privaateigendom ('dominium privatum') anderzijds.

In de wat engere betekenis wordt van het 'civiele' afgescheiden al het recht betreffende de crimina, die reeds van oudsher en ook thans - ook zonder statelijke positivering - als boos worden aangemerkt ('civiel recht' versus 'crimineel recht'). Door W. de Groot wordt 'policie' gedefiniecrd als: 'borgerlijeken standt' (dus: 'politie' = 'civiel', met afsplitsing van 'crimineel'). Zie W. de Groot, 'Inleyding tot de Practyck van den Hove van Holland', 2e druk 1667, p. 141, geciteerd bij Rypperda Wierdsma, 'Politie en justitie', a.w., p. 123.

In de nog engere betekenis wordt 'civiel' verstaan als 'op geld waardeerbaar', en wordt dus het nietvermogensrechtelijke deel van de 'politie' niet tot het 'civiele terrein' gerekend, maar wél het 'vermogensrechtelijke deel' van de 'politie'. Het lijkt ons niet onwaarschijnlijk, dat deze laatste betekenis is ontstaan doordat de gewone gerechten zich bevoegd achten te oordelen in geschillen tussen overheid en ondersaten, voorzover uit het politionele overheidsoptreden vermogensschade voor laatstgenoemden is voortgevloeid. Deze opvatting is ook ten grondslag gelegd aan art. 165 Grondwet 1815 en art. 2 Wet RO. Hier wordt hierna nog nader ingegaan. 
Ná de Franse revolutie wordt de betekenis van het begrip 'civiel' verder ingeperkt: de Code Civil van 1804 is het door de Staat gepositiveerde privaatrecht, gebaseerd op het beginsel van de burgerlijke vrijheid-in-gelijkheid: 'Aujourdui les mots droit civil et droit privé sont synonymes. Le code civil luimeme en est la preuve: toutes ses dispositions ne se rapportent qu'aux intérêts particuliers. (...) Son matière, la propriété', schrijft Locré in 1805. Daarover hierna méér. Dán ziet 'civiel' dus alleen nog wel op door de Staat gepositiveerd recht, maar alleen op dat betreffende de vermogensrechtelijke betrekkingen tussen burgers onderling in het maatschappelijk verkeer.

Zóveel is wel duidelijk, dat het begrip 'civiel' vóór het revolutietijdperk een veel ruimere betekenis heeft dan erna.

97. G.A. Struve, 'Syntagma Jurisprudentiae, secundum ordinem Pandectarum concinnatum', 3e druk 1663, Exerc. L. Lib. 49 tit. 14 XXXII: 'Ad fiscum in genere sumto vocabulo, omnis pecunia, ad usus publicos destinata refertur', Geciteerd bij B. Kempen, 'Die Formenwahlfreiheit der Verwaltung', München 1989. p. 80 . Vgl. ook Van der Poel, 'Rondom compositie en compromis', a.w., i.h.b. pp. 90-96.

98. Vgl. Van Caenegem, 'Geschiedkundige Inleiding', a.w., p. 32.

99. Zie hierover: Van der Poel, 'Rondom compositie en compromis', a.w., i.h.b. pp. 90-96.

100. Dit komt pregnant tot uitdrukking in het Preussische Allgemeine Landrecht (1794), waarover hierna méér.

101. Men kan dit 'privileges' noemen, maar die aanduiding is wat ongelukkig omdat zij pleegt te worden verbonden met de middeleeuwse bevoorrechting van feodale heren en van groepen (standen, steden. gilden etc.).

102. Óverigens đe 'financiên' ook wel, evenals de 'justitie', genoemd als aparte overheidsfunctie, te onderscheiden van de 'politie'. Óok de 'defensie' wordt veelal als aparte overheidsfunctie onderscheiden.

103. Van der Poel, 'Rondom compositie en compromis', a.w., p. 92, noemt als voorbeelden de rechten van parate executie, van legaal verband (een soort wettelijke hypotheek op de goederen der met inning belaste ambtenaren en die van de belastingschuldenaren en het recht tot vervolging ook van erfgenamen). Deze rechten van de fiscus zijn het sequeel van het recht van de Hoge Overheid. Van der Poel wijst er op dat de steden, ook al hebben zij het recht tot belastingheffing ontvangen, daarmee nog geen 'fiscaal recht' hebben gekregen. Het recht van parate executie bijv, wordt hun pas later toegekend, wanneer de praktijk de noodzakelijkheid daarvan heeft doen inzien.

Volgens Van der Poel (p. 223) worden de processen waarin de advocaat-fiscaal namens de Hoge Overheid optreedt als schuldeiser voor een boete, gerekend tot de civiele processen: hij treedt daarin wèl ratione officii, doch actione civili op.

104. We wezen hierboven reeds op de 'nalieve school', waartoe een auteur als Vegting behoort.

105. Vgl. J.Th. Buys, 'De Grondwet. Toelichting en kritiek', dl. II, Amhem 1884, p. 220. De gerechten oefenen dus hun rechtspraak uit volgens het beginsel van de justice rétenue: de vorst of zijn Raad heeft steeds de bevoegdheid om krachtens de volheid van zijn soevereiniteit rechterlijke vonnissen ongedaan te maken.

106. Zie A.J.M. Kunst, 'Historische ontwikkeling van het recht', dl. I, Zwolle 1967, p. 147/148.

107. Rijpperda Wierdsma, 'Politie en justitie', a.w., p. 157 e.v.

108. Tegenover het verwijt van de Staten dat de gewone gerechten zich onder het voorwendsel van justitie zouden bemoeien met politiezaken, is er het verwijt van die gerechten dat men 'onder dexel van politie' zaken aan de justitie tracht te onttrekken. Zie bijv, de zaak Blaeuhulk van 1615, die leidt tot een 'remonstrantie' van de Hoge Raad, waarin deze opmerkt dat het niet aan de vroedschap van Enkhuizen was om een lid van die vroedschap (Blaehulk) te straffen (ontheffing uit het ambt) wegens een puur commuun misdrij: " $t$ Is vreemt dat men onder dexel van politie dese saecke de ordinaris justitie soeckt te ontrecken, in allen schijne of daermede den staet van de lande, ofte gerustighheydt van de stadt vermenght waere. Want als sulx alhier soude verstaen werden, soo souden gheen particuliere tegens eenige regeerders der steden hem met justitie mogen behelpen, alsoo sy alle haere actien met de name van politie konnen bekleden'. Zie Rijpperda Wierdsma, 'Politie en justitie', a.w., p. 137; N. Verheij, 
'Onder dexel van politie', in: A.W. Heringa/J.G.C. Schokkenbroek/J.van der Velde (red.), " 40 Jaar Europees Verdrag voor de Rechten van de Mens', pp. 225-248.

109. Rijpperda Wierdsma, 'Politie en justitie', a.w., p. 160 e.v. Gedeputeende Staten in Friesland zijn vergelijkbaar met de Gecommitteerde Raden in Holland, gemachtigden van de Staten. Binnen de steden doen zich conflicten tussen de politionele en de justitiele overheid nauwelijks voor. Aan Rijppenda Wierdsma, a.w., p. 126, is niet gebleken 'dat de onderlinge verhouding van stedelijke administratic en stedelijken rechter een belangrijk vraagstuk heeft uitgemaakt'. Dit is vooral een gevolg van de nauwe bindingen tussen schout en schepenen (van oudsher belast met de justitie), de burgemeesters (van oudsher belast met de politie) en de vroedschappen, en van het feit dat de steden zich naar buiten als eenheid opstellen. Een vonnis van de schepenrechtbank kan - aldus Rijpperda Wierdsma - 'betrekking hebben op een onderwerp van politie'. Wanneer echter tegen zo'n vonnis voorziening bij het Gewestelijk Hof - en vervolgens eventueel bij de Hoge Raad (bevoegd voor Holland en Zeeland) wordt gevraagd, manifesteert zich de tegenstelling justitic-politie en ontstaan er conflicten.

110. Rijpperda Wiendsma, 'Politie en justitie', a.w., p. 173.

111. J. Drion, 'Administratie contra rechter tot de intrekking van het Conflictenbesluit', diss. Leiden 1950. handelsuitgave Den Haag 1958.

112. Hartog, a.w., p. 106.

113. S. van Groenewegen van der Made, 'Tractatus de Legibus Abrogatis et Inusitas in Hollandia vicinisque Regionibus', 3e druk 1669, geciteerd door Rijpperda Wierdsma, 'Politic en justitie', a.w., p. 16, nt. 1.

114. Rijpperda Wiendsma, 'Politic en justitie', a.w., p. 173.

115. L.J. van Apeldoorn, 'Het Romeinsche recht in Friesland' (Med.Kon.Ak.v. Wet., afd. letterkunde NR III, 10), Amsterdam 1940; J. Drion, a.w. p. 32; Hartog. a.w., p. 106/107. Deze jurisprudentic is wellicht mede beinnloed door de (radicaal-)Calvinistische theorieenn over het recht van verzet tegen de overheid, is ons niet bekend. In die theorieên wordt - evenals eerder door Luther - een onderscheid gemaakt tussen overheidsambt en de persoon van de bekleder van dat ambt: God heeft het ambt van de overheid ingesteld om goed te doen en kwaad te weren (Rom. 13). De ambtsbekleder ontleent zijn gezag dus aan zijn ambt, niet aan zijn persoon. Als hij in zijn ambtelijke taak tekort schiet, plaatst hij zich buiten zijn ambt en moet hij behandeld worden als gewoon persoon. En diens als gewoon persoon verrichte onrechtmatige handelingen kunnen dus door de gewone gerechten worden beoordeeld. Een vergelijkbare gedachtengang is - zoals we reeds zagen - te vinden bij John Locke (overigens van calvinistische afkomst): een overheid die de grenzen van de haar toevertrouwde bevoegdheid ('fiduciary power') overschrijdt, houdt automatisch op een overheid te zijn.

116. Hartog, a.w., p. 106.

117. Rijpperda Wierdsma, 'Politie en justitie', a.w., p. 169/170.

118. Daarop zal verderop nog door ons worden ingegaan.

119. Eerder merkten we al op, dat de positie van het Reichskammergericht - de hoogste rechterlijke instantie in het 'Heilige Rōmische Reich Deutscher Nation', 6́6k bevoegd voor Pruisen - toch al was uitgehold door talrijke privileges de non evocando en de non appellando.

120. De benaming 'de Grote' is overigens afkomstig van Voltaire.

121. Geciteend bij Fleiner, a.w., p. 9/10.

122. Geciteerd bij Van Caenegem, 'Geschiedkundige inleiding', a.w., p. 112.

123. H. Sendler, 'Friedrich der Grosse und der Müller Amold', JuS 1986, p. 759 e,v. Deze kwestie is voor Frederik ook een bevestiging, dat het procesrecht herziening behoeft. In 1781 treedt het zg. 'Corpus Juris Fridericianum' in werking, waarmee 0 .a. wordt beoogd een remedie te bieden tegen de lange duur der processen.

124. Vgl. voor Frankrijk bijv. Guyot, 'Répertoire universel et raisonné de jurisprudence civile et criminelle, canonique et bénéficiale', Paris 1775/1783, waarin bij 'police' wordt aangetekend: 'Il se dit aussi de la jurisdiction établi pour l'exercise de la Police'.

125. Fleiner, a.w., p. 33.

126. C. Bornhak, 'Preussisches Staatsrecht', Bd. II, 2 e druk, Breslau 1912, p. 464. 
127. O. Mayer, a.w., Bd. I, p. 121.

128. O. Mayer, a.w., Bd. I, p. 49.

129. Fleiner, a.w., p. 34. Interessant is de mededeling van Fleiner, dat schadevergoeding ook geboden kon zijn in gevallen waarin de overheidsmaatregel op zichzelf als rechtmatig was aan te merken. $\mathrm{Vgl}$. ook pp. 291 e.v., alwaar hij inzake 'hoheitliche Akten des Staates' betoogt: 'Das Privatrecht ist unanwendbar. Denn der rechtgemäss auftretende Staat gegenúber versagen die Vorschriften ũber unerlaubte Handlungen. Die Antwort kann allein aus Gnundsåtzen des öffentlichen Rechts abgeleitet werden. Man darf sich an der Richtigkeit dieses Satzes nicht durch die Tatsache irremachen lassen, dass in Deutschland auch nach der Einfuhrung der Verwaltungsgerichtsbarkeit die Kompetenz zur Beurteilung derartiger Schadensersatzklagen den Zivilgerichten verblieben ist'. Wat Fleiner hier zeer juist ziet, is dat overheidshandelingen op zichzelf - in abstracto - rechtmatig kunnen zijn maar tóch kunnen verplichten tot schadevergoeding, en dat zulks niet op basis van typisch burgerrechtelijke beginselen doch slechts op basis van typisch publiekrechtelijke beginselen kan worden beoordeeld. Hierbij moet m.n. gedacht worden aan het beginsel van de 'égalité devant les charges publiques'. In Deel 2 gaan we op deze problematiek nader in. Dit égalitébeginsel vindt reeds zijn uitdrukking in Par. 75 van het Preussische Allgemeine Landrecht (1794), waarover hierna méér.

130. Mayer, a.w., Bd. I, p. 51.

131. Mayer, a.w., Bd. I, p. 142.

132. Een argument dat vooral in Frankrijk wordt gebruikt tegen bemoeienis van de burgerlijke rechter met (schadeveroorzakende) overheidsmaatregelen. Vgl. E.J. Korthals Altes, 'De Staatsaansprakelijkheid volgens de jurisprudentie van den Conseil d'État', diss. Amsterdam 1923.

133. Waarbij 'burgerlijk' niet meer moet worden verstaan in de betekenis die 'burgerlijk' c.q. 'civiel' nog had vóór het revolutietijdperk. Vgl. bijv. Par. 13 van het Duitse Gerichtsverfassungsgesetz (GVG) van 27 jan. 1877, waarin de competentie van de gewone gerechten is geregeld:

'Vor die ordentlichen Gerichte gehören alle bürgerliche Streitigkeiten und Strafsachen, für welche nicht entweder đie Zustăndigkeit von Verwaltungsbehônden oder Verwaltungsgerichten begründet ist oder reichsgesetzlich besondere Gerichte bestellt oder zugelassen sind' (cursivering dzz.; JT). Par. 13 GVG geldt overigens nog steeds; de redactie heeft slechts een beperkte wijziging ondergaan: 'reichsgesetzlich' is vervangen door 'auf Grund von Vorschriften des Bundesrechts'.

134. Friedrich Carl von Savigny, 'System des heutigen Romischen Rechts', Bd. II, Berlin 1840, p. 245.

135. Vgl, voor Frankrijk: Korthals Altes, a.w.; voor Duitsland: Fleiner, a.w., en Mayer, a.w. Dergelijke constructies worden vermeden door de bekende Belgische civilist Laurent, die voorstander is van een verstrekkende overheidsaansprakelijkheid op grond van art. 1382 e.v. C.C. Z.i. mag het zwaartepunt der burgerrechtelijke aansprakelijkheid niet daarin gezocht worden, of de schade veroorzakende handeling al dan niet burgerrechtelijk is, maar of het beschadigde object een door het burgerlijk recht beschermd subjectief privaat vermogensrecht is. Laurent bestrijdt voorts de splitsing Staat-pouvoir public (of politique) en Staat-privaatrechtelijke rechtspersoon. Hij ontkent het bestaan van een tweede hoedanigheid van de Staat, omdat een private persoon particuliere belangen dient en de Staat, ook als eigenaar, als koper, als huurder, kortom altijd, handelt voor de publieke gemeenschap en dus uitsluitend voor haar - publieke - belangen. Zie Laurent, 'Principes de droit civil', 3e druk, XX, nrs. 418 e.v., en nrs. 590 e.v.

136. Deze opvatting ligt ten grondslag aan Par. 839 van het Duitse Bürgerliche Gesetzbuch (1900). Deze nu nog geldende bepaling laat goed zien, dat doelconstructies met een processuele functie - het bieden van rechtsbescherming bij de gewone rechter, waar die anders zou hebben ontbroken - uiteindelijke materieelrechtelijke consequenties krijgen, indien men zich er niet meer van bewust is dat het slechts om een doelconstructie ging.

137. In 1871 is de Conseil d'État een zelfstandige administratieve rechter geworden, nadat het eerst adviesinstantie aan de regering was. Op dit arrest wordt in Deel 2 nader ingegaan.

138. $\mathrm{Vgl}$. Korthals Altes, a.w., p. 64/65. 
139. Voor Frankrijk is deze verklaring (het onder het Ancièn Regime nog sterk privaatrechtelijk karakter der gemeenten) inderdaad gegeven door René Michoud, 'De la responsabilité des communes à raison des fautes de leurs agents'. Revue du droit public et de la science politique en France et à l'étranger 1895. p. 10 e.v. Zie hierover: Korthals Altes, a.w., p. 65/66, die ook vermeidt dat alle schrijvers over administratief recht zich tegen deze jurisprudentie te weer stellen met een beroep op de identiteit t.a.v. de aansprakelijkheid van Staat, departement en gemeente.

140. Vanaf 1871 makkt de Hoge Raad m.b.t. de vraag of (ook) de overheid uit hoofde van art. 1401 BW kan worden aangesproken terzake van onrechtmatige daad, dit onderscheid. $\mathrm{Vgl}$. $\mathrm{HR} 9$ juni 1871 , Ned.Regtspraak, deel 98, pp. 115-129 ('Stad Vlissingen'). Zie G.E. van Maanen, 'De mythe van de onrechtmatige overheidsdaad in de negentiende eeuw' (in 1996 te verschijnen bij Ars Aequi, Nijmegen), waarin een analyse wordt gegeven van de jurisprudentie van de Hoge Raad op het punt van de onrechtmatige overheidsdaad. Voornaamste conclusie is dat aansprakelijkheid van de overheid cen normale zaak was, maar dat we vanaf 1871 wel een beperking zien tot overheidshandelen 'op gelijke voet als een particulier'.

141. 'Alle twistgedingen over eigendom of daaruit voortspnitende regten, over schuldvordering of burgerlijke regten, behooren bij uitsluiting tot de kennis van de regterlijke magt'.

142. In een aantal arresten heeft de Hoge Raad de algemene competentie van de gewone rechter trouwens gebaseerd op art. 1 Wet R.O. Zie bijv. HR 24 maart 1865, Ned. Regtspraak, dl. 7, par. 49.

143. Vgl. J. Drion, a.w, Een arrest als HR 26 maart 1971, AB 1971, 135 (Verkiezingsafspraak Elsloo) past hierin, omdat in deze kwestie geen vermogensbelangen in het geding waren.

144. Hierop wordt in het volgende hoofdstuk nader ingegaan.

145. Aldus kan ook worden verklaard waarin in HR 26 maart 1971, AB 1971, 135 (Verkiezingsafspraak Elsoo) wordt overwogen dat de gewone rechter onbevoegd is - er zijn in het geheel geen vermogensbelangen in het geding -, terwijl in HR 29 mei 1896. W. 6817 (Vrouwe Elske) en HR 21 april 1898, W. 7116 (Rhedense koe) wordt geconcludeerd dat de vordering niet-ontvankelijk is - er waren weliswaar vermogensbelangen in het geding, doch het optreden van de overheid 'als zodanig' wordt niet bestreken door het burgerlijk recht en daarmee, volgens de Hoge Raad in dat arrest, ook niet door de artt. 1401 en 1402 BW Het onderscheid tussen deze twee hoedanigheden van de overheid, wordt overigens - als opgemerkt - reeds gemaakt in de jurisprudentie van de HR vanaf 1871 . Wèl kan men stellen dat de HR in de arresten van 1896 en 1898 overheidshandelen dat voordien door hem nog zou zijn omschreven als handelen 'op gelijke voet als een particulier', aanmerkt als handelen van de overheid 'als zodanig'. Ook bij de interpretatie volgens welke de artt. 1401 en 1402 BW typisch burgerrechtelijke bepaling zijn, zou in deze zaken tóch rechtsbescherming tegen het schadeveroorzakend overheidsoptreden mogelijk zijn geweest, wanneer men was uitgegaan van de opvatting zoals verwoord door de Belgische civilist Laurent (inzake art. 1382 C.C.), die - zoals we zagen - het zwaartepunt der burgerrechtelijke aansprakelijkheid niet hierin zoekt of de schade veroorzakende handeling al dan niet burgerrechtelijk is, maar of het beschadigde object een door het burgerlijk recht beschermd subjectief privaat vermogensrecht is. Vgl, bijv. HR 22 mei en 28 juni 1863, W. 2499 (Zuidplaspolder). Een dergelijk opvatting is de Hoge Raad trouwens in de 19 e eeuw vele malen gevolgd. Op de ontwikkelingen in de jurisprudentie van de Hoge Raad op het punt van de onrechtmatige overheidsdaad gaan wij in Deel II uitgebreider in.

146. Vgl. bijv. J. Oppenheim, 'Het Nederiandsch Gemeenterecht', dl. 1.4e druk, Haarlem 1913, p. 848 c.v. Krabbe spreekt in zijn interventie tijdens de vergadering van de Ned. Juristenvereniging van 1910 van de 'armelijkheid van de tegenstelling tussen den staat-fiscus en de staat-overheid', maar dit omdat hij op grond van zijn gemene rechtsleer geen wezensverschil ziet tussen private belangen en publieke belangen. Zie Hand. NJV 1910, dl. II, p. 313.

147. Maar in Duitsland gaat men althans nog niet zo ver als de Nederlandse Hoge Raad, die in het in het Burgerlijk Wetboekopgenomenonrechtmatige-daadsartikeleen bevoegdheidsgrondslag meentte kunnen zien voor 'de overheid' om publieke belangen te kunnen behartigen. $\mathrm{Vgl}$. HR 26 jan. 1990, Gst. 6914.10, AB 1990, 408 (Staat/Windmill), en - vooral - HR 18 febr. 1994, AB 1994. 415 (Kabayel). Hierover uitgebreider Deel II. Zie ook de kritische opmerkingen van E.M. Meijers op de 'leer van de 
tweehoofdige Staat' in: 'Belastingen als rechtsbegrip', opgenomen in: 'Tractatus Tributarii', opstellen aangeboden aan P.J.A. Adriani, Haarlem 1949, pp. 1-28 (p. 6).

148. $\mathrm{Vgl}$. Gerbenzon/Algra, a.w., p. 108, alwaar 0.a. wordt gewezen op het 'arrêt de règlement', een vonnis dat alle rechtsgenoten voortaan bindt.

149. $\mathrm{V}_{\mathrm{gl}}$. de verlening van stadsrechtprivileges waarbij de landsheer, doorgaans tegen een contraprestatie, aan een stad een eigen rechterlijke organisatie gaf en ook aangaf naar welk materieel recht de stad zou leven, en het staten'staat'wezen. Het Plakkaat van Verlatinge van 1581 was, zoals we zagen, gebaseerd op de gedachte dat de landsheer zijn - bij de inhuldigingseed aanvaarde - 'contractuele' verplichtingen jegens de 'staten' had geschonden.

150. Een opvatting uiteraard, die gemakkelijk in functie kan worden gesteld van versteviging van het fundament van de politiestaten en van de daaruit voortkomende natiestaten (Maar een opvatting ook, die na de definitieve vestiging van de natiestaten weer zal - moeten - worden verlaten: zo is de invloed van het Romeinse recht op de Code Civil (1804) zeer sterk). Voor Pruisen speelt bovendien een belangrijke rol, dat het Romeinse recht in de Duitse landen een betekenis heeft die het elders niet heeft. Het is $\mathrm{nl}$. het recht van het oude keizerrijk, het 'Heilige Römische Reich Deutscher Nation', waartoe ook Pruisen formeel nog behoort. De hoogste rechtbank van dit rijk - het Reichskammergericht - past 'Reichsrecht' toe, waartoe - zij het subsidiair t.o.v. de costumiere rechten - ook het Romeinse recht wordt gerekend

De Pruisische codificaties richten zich mede tegen deze subsidiaire werking van het Romeinse recht en staan daarmee ook in functie van een (verdere) losmaking van Pruisen uit het oude keizerrijk.

151. Al deze drie codices zijn het werk van de grote jurist Freiherr von Kreittmayr (1705-1790). Neemt men kennis van de inhoud van de 'Codex Maximilianeus Bavaricus Civilis', dan moet men vaststellen dat de invloed van het natuurrecht toch beperkt is gebleven: de codex is gebaseerd op het romeinsrechtelijke Institutensysteem; de codex is ingedeeld in 4 Boeken: personen-, zaken-, erf- en verbintenissenrecht).

152. $\mathrm{Zij}$ is koningin van Hongarije, koningin van Bohemen, aartshertogin van Oostenrijk en de Oostenrijkse gebiedsdelen in Noord-Italię en đe zuidelijke Nederlanden, en tevens keizerin van het 'Heilige Römische Reich Deutscher Nation'.

153. Het ABGB, dat thans nog geldt in de Staat die nu Oostenrijk wordt genoemd, is het enige, nog geldende Europese burgerlijke wetboek dat het natuurrecht uitdrukkelijk tot de rechtsbronnen rekent (Par. 7 ABGB).

154. Op dit wetboek zullen we hiema nog nader ingaan.

155. Tot de samenstelling van het ALR, dat eerst in 1794 in werking zal treden (ALR), is reeds in 1746 opdracht gegeven bij Kabinettsordre van Frederik de Grote: 'So befehlen Wir ... ein Teutsches Allgemeines Landrecht, welches sich blos auf die Vermunft und Landes-Verfassungen gründet, zu verfertigen und zu Unserer Approbation vorzulegen' (curs. dzz.; JT). In een opstel met de titel 'Dissertation sur les raisons d'établir ou d'abroger les lois' schrijft Frederik o.a.: 'Des lois précises ne donnent point lieu à la chicane, elles doivent s'entendre selon le sens de la lettre: lorsqu'elles sont vagues ou obscures, elles obligent de recourir à l'intention du législateur, et au lieu de juger des faits, on s'occupe à les définir. (...) Les juges ont deux piéges à craindre, ceux de la corruption, et ceux de l'erreur: leur conscience doit les garantir des premiers, et les législateurs des seconds: des lois claires, qui donnent pas lieu d des interprétations, y sont un premier remède, et la simplicité des plaidoyers, le second' (curs. dzz.; JT). Geciteerd bij J.H.A. Lokin/W.J. Zwalve, 'Hoofdstukken uit de Europese Codificatiegeschiedenis', Groningen 1990, p. 197/198.

156. Pas het ALR zal ook uitgebreide voorschriften op het terrein der 'politie' bevatten; zie hiema.

157. Juist in het kader van het streven der absolute vorsten naar een eenheidsstaat en de daartoe vereiste afbraak van de feodale structuren en het standenbestel - wier voorrechten bij de gerechten bescherming vinden (denk i.h.b. aan de Franse Parlementen!) - zijn de vorsten in eerste instantie overgegaan tot regulering van de 'justitie' d.m.v. unificerende en codificerende wetgeving. Maar als die wetgeving er eenmaal is, draagt deze dus weer bij aan een verzelfstandiging van de 'justitie' t.o.v. de 'politie'. 
158. In de absolutistische opvattingen geschiedt immers alle rechtspraak in naam van de soeverein en is alle positief recht gebaseerd uitdrukkelijke of stilzwijgende autorisatie van de soeverein. Daarom wordt, als eerder gezegd, de 'justitie' soms wel beschouwd als een ondendeel van de 'politie'.

159. Mayer, a.w., p. 43-45.

160. Vgl. A.Q.C. Tak/R.E. Bakker, 'De centrale rol van het willekeurverbod bij de toetsing van overheidshandelen', in: A.W. Heringa/N. Verheij (red.), 'Publiekrechtelijke bewegingen', Deventer 1990, pp. 205-218. Tak en Bakker concluderen dat 'het verbod van willekeur .... aan het legaliteitsbeginsel vooraf (gaat), in historisch opzicht en vanuit een oogpunt van rechtstheorie, maar ook, blijkens de recente jurisprudentie, vanuit het oogpunt van de rechtspraktijk'.

161. Vgl. ook de analyse van Tocqueville in zijn 'L'Ancien Régime et la Révolution', a.w.

162. Van Eikema Hommes, 'Elementaire grondbegrippen', a.w., pp. 486-488. De scheiding tussen publick overheidsgezag en privaat vermogensbelang c.q. tussen publiek- en privaatrecht betekent ook de onderscheiding tussen Staat en 'maatschappij'.

163. Het zij hier nogmaals gezegd, dat dit o.i. niet betekent dat door positivering door de Staat van het burgeriijk recht contracts-, eigendomsbevoegdheden ete. worden verleend. De rechtsmacht van de contractanten is een interne, materiele rechtsmacht. In de in het BW geregelde wettelijke rechtsvormen vindt een exteme vervlechting en integratie plaats in het door de Staat gepositiveerde burgerlijk recht, waardoor naleving van een contract zonodig kan worden afgedwongen via statelijke organen (de burgerlijke rechter; deurwaarder).

164. Geciteerd bij E. Poortinga, 'De scheiding tussen publiek- en privaatrecht bij Johan Rudolph Thorbecke (1798-1972)', Nijmegen 1987, pp. 108 en 139.

165. Alexis de Tocqueville, 'De la démocratie en Amérique', 2 delen, 1835/1840, bloemlezing (in Ned. vertaling) samengesteld en ingeleid door J.M.M. de Valk, 'De democratie in Amerika', Kampen 1990. p. 128.

166. Tocqueville, 'De democratie in Amerika', a.w., p. 95.

167. Tocqueville, 'De democratie in Amerika', a.w., p. 82.

168. Tocqueville, 'De democratie in Amerika', a.w., pp. 79, 133, 66/67, 110 en 71-74.

169. Tocqueville, 'De democratie in Amerika', a.w., p. 109/110 en p. 124/125. Vgl. ook p. 95 :

170. Tocqueville, 'De democratie in Amerika', a.w., p. 79.

171. J.J. Rousseau, 'Du Contat Social', ch. 3.

172. Geciteerd bij A.A. Zijderveld, 'Schimmen en schaduwen van de revolutie der revoluties', in: S.W. Couwenberg (red.), 'Opstand der burgers', 2e druk, Kampen 1989, pp. 39-49 (p. 45). De bedoelde wet staat bekend als de wet Le Chapelier.

173. Schama, a.w., p. 578.

174. Zie E.J.J. van der Heijden, 'Het Burgerlijk Wetboek en het vereenigingsrecht', in: Paul Scholten/E.M. Meijers (red.), 'Gedenkboek Burgerlijk Wetboek 1838-1938'. Zwolle 1938, pp. $529-557$ (p. 544/545).

175. J. van Kan, 'Het Burgerlijk Wetboek en de Code Civil', in: Paul Scholten/E.M. Meijers, a.w., pp. 243276 (p. 262/263). Oorspronkelijk is daarnaast de titel inzake Bezit, terwijl het BW voorts een 'oudHollande massa' bevat ( 0 .a. levering als vereiste voor eigendomsoverdracht, opstalrecht, erfpachtrecht, beklemrecht etc.).

176. Aanvankelijk zou het ALR reeds per 1 juni 1791 in werking treden. In de conservatieve en reactionaire kringen rond Frederik Willem II, de opvolger van Frederik de Grote, rees echter kritiek op een aantal bepalingen, die te veel zouden herinneren aan de Franse revolutic en die te liberaal en revolutionair werden geacht. Zo werd het, in het aanvankelijke wetsvoorstel voorziene, verbod van de monarchistische 'Machtsspruch' in gerechtelijke procedures geschrapt. Niettemin zal ook Frederik Willem II - die overigens weinig moet weten van het Verlichtingsrationalisme - zich in de praktijk niet aan 'Machtspruche' bezondigen. Dit is vooral toe te schrijven aan de grote invloed van de leidende figuren binnen het pruissische ambtenarendom. De stuwende kracht is met name Carl Gottlieb Suarez (= Schwartz; 1746-1798). Voorafgaande aan het ALR is, zoals eerder opgemerkt, in 1793 reeds de 'Allgemeine Gerichtsordnung für die Preussischen Staaten' (AGO) van kracht geworden, dat - voor justitiezaken beoogt processen te versnellen en partijen beter te beschermen tegen 'Verfahrenswillkür', zulks m.n. 
door invoering van de rechterlijke 'Untersuchungsgrundsatz' (waarheidsvinding van ambtswege) endoor het stellen van (kwaliteits)eisen aan rechters en advocaten.

177. Hans Schlosser, 'Grundzüge der Neueren Privatrechtsgeschichte', Se druk, Heidelberg 1983, p. 82.

178. De indeling van deel I sluit aan bij de romeinsrechtelijke indeling van Institutiones: personenrecht, zakenrecht en het recht betreffende handelingen (wilsverklaringen, overeenkomsten en ongeoorloofde handelingen).

179. In een groot aantal Pruisische gebieden komen aan de adellijke heren (de 'Gutsherren') heerlijke rechten toe, waaraan ook 'publiekrechtelijke' gezagsrechten en rechtspraakbevoegdheden jegens de op het goed woonachtige boeren verbonden zijn: 'Gutspolizei' en 'Gutsjustiz'. De horigheid van de onvrije boeren wordt door het ALR in stand gelaten; hun patromoniale bescherming door de grondeigenaar wordt in het ALR wettelijk vastgelegd. Anderzijds worden bepaalde handelingen aan de adel verboden, omdat ze niet bij deze stand zouden passen. Zo zijn bepaalde economische activiteiten voor de adel verboden. Smartegeld wegens lichamelijke verwonding kan slechts gevorderd worden door een boer of een eenvoudige burger, niet door een lid van de adel, etc.

180. Carl Gottlieb von Suarez in: H. Conrad/G. Kleinheyer (red.), 'Vortrăge über Recht und Staat', KölnOpladen 1960, p. 628.

181. De beinvloeding van Suarez door de denkbeelden van met name Locke en door de rationalistische natuurrechtsleer, komt duidelijk tot uitdrukking in een door hem in 1791 aan de kroonprins gerichte voordracht, waarin de waarborging van de 'natuurlijke vrijheid' c.q. de eigendom binnen een 'bürgerliche Gesellschaft' wordt gezien als doelstelling van de overheid: 'Dass, wenn die Menschen aus dem Stande der natürlichen Gleichheit heraustreten und sich in bürgerliche Gesellschaften unter einem gemeinschaftlichen Oberhaupte vereinigen, sie dabei keinesweg die Absicht hatten noch haben konnten, auf ihre natürliche Freiheit ganz. Verzicht zu tun und sich als Sklaven der blossen Willkûr eines unumschränkten Herrschers zu unterwerfen, sondern dass der Zweck der bürgerlichen Gesellschaft und also auch des Staates nur dahin gehen könne, den Mangeln und Unvollkommenheiten des Naturzustandes abzuhelfen und die Freiheit der einzelnen soweit einzuschrănken, als es notwendig ist, um die Freiheit aller zur Beforderung ihrer Glückseligkeit gegen Stŏrungen und Beeintrăchtigungen zu sichern. (...) Sicherheit des Eigentums und der Rechte für jeden einzelnen durch die vereinigten Kräfte aller. ungestônter Gebrauch der natürlichen Freiheit eines jeden, soweit damit die Sicherheit und Freiheit der abrigen bestehen kann. Erleichterung der Mittel und Gelegenheiten zur Beförderung des Privatwohlstandes durch Veranstaltungen zur Ausbildung des Verstandes und Herzens, wodurch allein Neigung und Bereitwilligkeit zur Erfullung der Pflichten des Wohlwollens erreicht werden kann - das sind die grossen und wichtigen Zwecke der bürgerlichen Gesellschaft, zu deren Erreichung sie dem Regenten die Macht, ihr zu befehlen, abertragen und die Disposition über ihre vereinigten Kräfte seinen Hănden anvertraut hat', Geciteerd bij: H. Coing, 'Epochen der Rechtsgeschichte in Deutschland', 4e druk, München 1981.

182. Willoweit, a.w., p. 175 .

183. Johann Stephan Putter schreef reeds in zijn in 1770 verschenen 'Institutiones iuris publici Germanici', par. 331: 'Politiae est cura avertendi mala futura; promovendae salutis cura non est proprie politiae'. Overigens is het ook in de 19 de eeuw niet ongebruikelijk de gehele overheidstaak aan te duiden als 'Polizei', met dien verstande dat een onderscheid wordt gemaakt tussen 'Sicherheitspolizei' en 'Wohlfahrtspolizei'. Vgl. Mayer, a.w., Bd. I, p. 246 e.v.

184. In het volgende hoofdstuk wordt op de verdere 'lotgevallen' van deze bepaling ingegaan.

185. Reeds het gebruik van de term 'Bürger' - i.p.v. 'Untertanen' - geeft blijk van de nieuwe opvattingen.

186. F.H. van der Burg. 'Een nieuw materieel wetsbegrip', in: 'Bestuur en norm' (Crince le Roy-bundel), pp. $57-72$ (p. 59/60), wijst er op dat de in 1887 in de Nederlandse Grondwet opgenomen regeling inzake 's Konings bevoegdheid tot vaststelling van algemene maatregelen van bestuur sterk is geinspireerd door de beschouwingen over wetgeving in materiele zin van Buys, die op zijn beurt te rade is gegaan bij Laband, wiens ideeên over wetgeving nauw verwant zijn met đie waaraan par. 7 Inl. ALR uitdrukking geeft. 
187. Na de intrekking van het ALR is de inhoud van deze bepalingen - de 'Aufopfenungsanspruch' jegens de overheid - blijven gelden als gewoonterecht, zoals bijna 200 jaar na de invoering van het ALR uitdrukkelijk wordt vastgesteld door het Bundesgerichtshof (BGH). Voor het geldend maken van deze aanspraak is niet vereist dat het overheidsoptreden waardoor de rechten van een individu worden aangetast, onrechtmatig is. Aanleiding voor deze jurisprudentie vormt het 'Nassauskiesungsurteil' van het Bundesverfassungsgericht (BVerfG 15 juli 1981, BVerfGE 58, 300), waarin is beslist dat de twee door het BGH ontwikkelde figuren van (schadevergoeding wegens) "enteignungsgleicher Eingriff en 'enteignender Eingriff niet gebaseerd kunnen worden op art. 14 lid 3 Grondwet. Het BGH is vervolgens de basis gaan zoeken in de oude algemene 'Aufopferungs' -gedachte, zoals die tot uitdrukking is gebracht in de par. 74 en 75 Inl.AL.R. 



\section{Hoofdstuk 3}

\section{De rechtsstaat}

\section{Inleiding: van politiestaat naar rechtsstaat}

De rechtsstaat is ontstaan uit - en als reactie op - de politiestaat van vóór de Franse revolutie '. Zoals we zagen, houdt de term 'politiestaat' verband met het 'ius politiae', zijnde het algemene 'natuurlijke recht' van de hoogste overheid om alle maatregelen te treffen, inclusief ge- en verboden, die in het algemeen belang nodig werden geacht. Kenmerkend voor de politiestaat, die tevens nog een standen 'staat' was, was dat vrijheid nog werd gezien als de uitoefening van voorrechten (de zgn. verkregen rechten). Daarom kon het 'ius politiae' grotendeels worden uitgeoefend in de 'rechtsvrije ruimte'. De gedachte was wél dat bestaande, verkregen rechten moesten worden gerespecteerd, althans niet zonder meer mochten worden aangetast. Toen onder Lodewijk XIV de opvatting werd verkondigd dat onteigening zonder schadevergoeding mogelijk was, beriep men zich dan ook niet op het ius politiae maar op de feodale eigendomsopvatting van het 'dominium eminens', die inhoudt dat de vorst oppereigenaar is van alle gronden en deze gronden aanvankelijk onder bepaalde voorwaarden heeft afgestaan aan anderen, die dus slechts bezitters zijn. Kenmerkend voor het feodale bestel was de koppeling tussen dominium en imperium ('overheidsgezag'): het gezagsrecht op het territoir werd beschouwd als een soort eigendomsrecht (dominium).

Als de rechtsstaat tot ontwikkeling komt, vinden de volgende gedachten ingang in de Westeuropese rechtscultuur: de wetmatigheid van bestuur (de legaliteitseis), het beginsel van de representatieve democratie en de publiekrechtelijke gelijkheid, de machtenscheiding, en de burgerlijke vrijheid en gelijkheid, tot uitdrukking gebracht in het moderne burgerlijk recht, de scheiding tussen Staat en 'maatschappij'. En in het beginsel van wetmatigheid van bestuur komt ook het beginsel van de representatieve democratie tot uitdrukking.

De post-Napoleontische periode is echter in haar eerste fase een restauratietijdperk. Zo ontstaat zowel in Frankrijk als in Nederland in 1814 een constitutionele monar- 
chie die de Grondwet slechts ziet als een beperking van het aan de vorst toekomende soevereine gezag: slechts in die gevallen waarin de Grondwet dat uitdrukkelijk eist, zou de vorst in de uitoefening van zijn gezag de medewerking behoeven van het parlement. De opsomming in de Nederlandse Grondwetten van 1814 en 1815 van een aantal bevoegdheden van de Koning wordt niet als limitatief beschouwd, maar slechts als een vaststelling dat de genoemde onderwerpen niet meer onder het provinciale ('gewestelijke') gezag maar onder het centrale gezag vallen. In de Grondwet van 1815 is weliswaar bepaald dat de wetgevende macht berust bij de Koning en de Staten-Generaal gezamenlijk, maar deze bepaling pleegt aldus te worden opgevat dat slechts in die gevallen waarin de Grondwet uitdrukkelijk een 'wet' eist, een regeling nodig is die tot stand moet worden gebracht door Koning en Staten-Generaal gezamenlijk volgens de grondwettelijke procedure. Ten aanzien van de gevallen waarin de Grondwet niet uitdrukkelijk een 'wet' eist, brengt Willem I overvloedig zijn opvatting in de praktijk dat hij als soevereine vorst eenzijdig algemeen geldende regelingen ('wetten in materiële zin') - zogenaamde algemene maatregelen van inwendig bestuur - kan maken, zonder dat hij daarvoor de machtiging van de wet in formele zin nodig heeft. Een algemene strafbedreiging op overtreding van een a.m.v.b. wordt voorzien bij de Algemene Sanctiewet van 1818 (de 'Rlankefwet') Naarmee herleeft de oude molitiectatelijke vnvatting. dat in het 'ius politiae' van de hoogste overheid ook de algemene bevoegdheid tot regelgeving is begrepen.

En van de Staten-Generaal kan zeker niet worden gezegd, dat daarin het beginsel van de representatieve democratie is verwezenlijkt. Art. 77 Grondwet 1815 bepaalt dan wel: 'De Staten-Generaal vertegenwoordigen het geheele Nederlandsche Volk', maar ze zijn zeer selectief samengesteld en kunnen bezwaarlijk als een echte volksvertegenwoordiging worden aangemerkt. De leden van de Eerste Kamer worden door de Koning benoemd uit 'de aanzienlijksten van den lande'; de leden van de Tweede Kamer worden gekozen door de leden van de verschillende Provinciale Staten. Dezen zijn verkozen door de vertegenwoordigers van drie standen, namelijk de adel (verkozen door de provinciale 'ridderschap'), de leden van de steden (verkozen door de 'regenten', dat wil zeggen: de notabelen van de steden, zelf weer getrapt gekozen door de cijnskiezers) en de leden van de 'landelijke stand' (gekozen door kiescolleges in de plattelandsdistricten). In wezen gaat het hier om heerlijke rechten, die de drie standen bij de restauratie van $1814 / 1815$ hebben herkregen ${ }^{2}$.

Het definitieve einde van zowel het feodale bestel als de standen'staat' wordt in Nederland gemarkeerd door de Grondwetsherziening van 1848 . Hierbij worden de heerlijke rechten definitief afgeschaft en wordt de standenvertegenwoordiging in de Staten-Generaal vervangen door een volksvertegenwoordiging, samengesteld op 
basis van rechtstreekse verkiezingen (zij het nog gekozen op basis van censuskiesrecht). Tevens wordt uitdrukkelijk bepaald dat de uitvoerende macht berust bij de Koning en wordt het gezag van de koning definitief 'ont-persoonlijkt' door de invoering van ministeriële verantwoordelijkheid gekoppeld aan koninklijke onschendbaarheid. Ofschoon een en ander een uitbreiding betekent van de invloed van de volksvertegenwoordiging, blijft de opvatting dat de Koning zelfstandig bevoegd is tot 'politiewetgeving' nog gehandhaafd. Nadat in de jaren 1866-1868 het parlementaire stelsel definitief is gevestigd, moet echter in 1879 in het Meerenbergarrest ${ }^{3}$ definitief gebroken worden met die opvatting. Op deze ontwikkeling, die kan worden gedefinieerd als een inperking van het politiebegrip en de aanvaarding van het beginsel van wetmatigheid van bestuur, zullen we hierna nog ingaan.

\section{Loskoppeling van dominium en imperium}

$\mathrm{Na}$ de Franse revolutie moet de feodale koppeling van imperium en (privaat) dominium definitief los worden gelaten ${ }^{4}$. De eigendom van de burger wordt uitdrukkelijk erkend als privaat dominium. Het impliceert de volstrektste beschikkingsbevoegdheid en het vrije genotsrecht over het object van de eigendom en komt aan de burgers toe, met uitsluiting van de overheid, behoudens bij of krachtens de wet gestelde beperkingen. Daarnaast kunnen er niet krachtens ongeschreven recht nog 'hoogheidsrechten' van de overheid op dat domein bestaan. Bepalingen als art. 17 van de Déclarations des Droits de l'Homme et du Citoyen van 1789 - dat spreekt van een 'droit inviolable et sacré' - en art. 625 (oud) BW zijn vooral ook te beschouwen als een reactie op de onder het 'ancien régime' nog gehuldigde leer van het dominium eminens ${ }^{5}$. De private eigendom wordt dan ook veelal wel aangeduid als de privaatrechtelijke pendant van het moderne soevereiniteitsbegrip in de publiekrechtelijke sfeer, en geldt als een pijler van de burgerrechtelijke rechtsorde en waarborg voor de volle ontplooiing van de burgerlijke vrijheid.

'Imperium' (overheidsgezag) bestaat uit aan overheidsambten toekomende bevoegdheden; het is ambtsrecht. Publiekrechtelijke bevoegdheden zijn geen 'zaken in den handel', maar zijn doelgebonden. De Franse revolutie richtte zich immers vooral ook tegen het stelsel waarin publieke bevoegdheden voorwerp van 'eigendom' of overeenkomst - en als 'zaken in den handel' overdraagbaar of verhandelbaar - konden zijn, en dus mede als private vermogensbelangen werden beschouwd. Art. 21 van de Franse Constitutie van 1795 bepaalde dan ook:

'Les fonctions publiques ne peuvent devenir la propriété de ceux qui les exercent'.

Enerzijds dus: 'privatisering' van de eigendom van de burger, anderzijds: 'publicisering' van publieke bevoegdheden (die nu niet meer worden beschouwd als private 
subjectieve vermogensrechten). Het onderscheid van publiek- en privaatrecht wordt daarmee een hoeksteen van de burgerlijk-liberale constitutie ${ }^{6}$. Daarbij past ook dat de verschillen tussen de private eigendom en het publiek domein - de publiekrechtelijke 'eigendom' - scherp(er) worden aangezet. Van het gewone, private, eigendomsbegrip verschilt het publiek domein fundamenteel, doordat daaraan nu juist niet de bevoegdheid is verbonden vrij over de zaak te beschikken en ieder ander van het gebruik van de zaak uit te sluiten.

Als Vegting tot een ander oordeel komt op basis van een historisch onderzoek waaruit hij concludeert dat ook vóór de Franse revolutie de eigendom van publiek domein werd beschouwd als 'burgerlijke' eigendom, dan maakt hij - zoals we reeds opmerkten - de grote fout het oude begrip 'burgerlijk' op te vatten in de moderne betekenis van het woord en miskent hij dat de Franse revolutie juist was gericht op een (definitieve) scheiding van 'imperium' en 'dominium', die voordien nog met elkaar vermengd waren.

Gaat men uit van de feodale opvattingen inzake het dominium eminens, dan zou men zelfs kunnen zeggen dat oudtijds alle 'eigendom' publiek domein was. De Franse revolutie reageert juist tegen dergelijke opvattingen en maakte een scherpe scheiding tussen privaat domein - dat nu werkelijk private eigendom wordt, dus los van overheidsbevoegdheden, behoudens beperkingen bij of krachtens de wet - en publiek domein. Men doet aan geschiedvervalsing door te stellen dat reeds oudtijds publiek domein werd beschouwd als gewone eigendom en daarbij uit te gaan van het huidige burgerrechtelijke eigendomsbegrip.

Ook voor het publiek domein geldt: publiek recht is publieke plicht. Kenmerkend is de (publieke) beheerstaak van het daarmee belaste overheidslichaam, waaraan is verbonden de bevoegdheid én de verplichting om te zorgen dat de zaak aan zijn publieke bestemming blijft beantwoorden ${ }^{7}$. Hardenberg spreekt van 'toebehoren' als gezagsrecht - voorheen 'hoogheidsrecht' -, dat 'buiten den handel' en als zodanig onvervreemdbaar is, en dat moet worden onderscheiden van toebehoren als privaatrechtelijke eigendom (art. 625 (oud) resp. 5:1 BW) ${ }^{8}$. De beheerstaak en de daaraan verbonden bevoegdheden vinden dus niet hun grond in een privaat subjectief eigendomsrecht. Van Maanen wijst er op dat de betekenis van art. 625 ligt in de begrenzing van de vrijheid van de eigenaar tegenover derden (niet handelen tegen de wet of rechten van anderen) en afbakening tegenover de bevoegdheden van de Staat ${ }^{9}$. Met art. 625 kan dan ook - aldus, o.i. terecht, Hardenberg en Van Maanen - geen regeling zijn gegeven van de 'publiekrechtelijke eigendom' van de Staat. De reden dat in het BW bepalingen zijn opgenomen betreffende het publiek domein als aparte vorm van toebehoren, zal hierin moeten worden gezocht dat er destijds geen sprake was van een zelfsstandige administratiefrechtelijke codificatie. 
En juist omdat het niet om echte private eigendom gaat, is voor het publiek domein de term 'toebehoren' gebruikt en is de term 'eigendom' zo veel mogelijk vermeden:

'Toebehoren' is de onbepaalderechtsbetrekkingwaarvan de inhoud afhangt van de omstandigheden, waaronder begrepen de hoedanigheid, waarin de rechthebbendetot "een zaak" staat' 10.

We merkten zoëven op dat de ontwikkeling die uitmondt in het Meerenberg-arrest, kan worden beschreven als een inperking van het oude politiebegrip ten gunste van het beginsel van wetmatigheid van bestuur. We zullen hierna echter verdedigen dat 'politiebevoegdheden' inherent zijn aan de beheerstaak ten aanzien van het publiek domein. In dit verband is ook kort na het Meerenberg-arrest gewezen jurisprudentie van de Hoge Raad inzake de vraag of Kroon, ook zonder uitdrukkelijke bevoegdheidsgrondslag in de wet in formele zin, bevoegdheden toekomen ten aanzien van publiek domein buitengewoon interessant.

\section{Het rechtsstatelijke vrijheidsbegrip; publiekrechtelijke vrijheid en burgerrechtelijke vrijheid}

De erkenning van de individuele vrijheid en van het fundamentele beginsel van de publiek- én burgerrechtelijke rechtssubjectiviteit van de mens als zodanig (het juridisch persoonlijkheidsbeginsel) - onafhankelijk van diens toebehoren tot een sociale groep, godsdienst, geslacht etc. - is een centraal element in het bewustzijn van recht en staat in de moderne tijd. Dit beginsel is de keerzijde van het beginsel van de onderscheiding van uitsluitend door het algemeen belang gereguleerd overheidsgezag ('imperium') enerzijds en privaat vermogensbelang ('dominium') anderzijds. In het persoonlijkheidsbeginsel vindt het juridisch individualiseringsproces zijn neerslag, welk proces onverbrekelijk verbonden is met het juridisch differentiatie- en integreringsproces.

Pas wanneer een wezenlijke Staat is gevestigd, die als publieke instelling met haar 'Zwangsmonopol' een eind heeft gemaakt aan de heerschappij van de ongedifferentieerde gezagskringen van het feodale en standenbestel en die alle mensen op zijn grondgebied heeft geïntegreerd in een publieke rechtsorde in een publiekrechtelijke vrijheid en gelijkheid ", bestaat óók de mogelijkheid om alle mensen binnen het staatsterritoir op voet van juridische gelijkheid in een private rechtsorde te integreren, waarin zij in hun vrije maatschappelijke verhoudingen een burgerlijke vrijheidssfeer bezitten om hun eigen private belangen na te streven, ongeacht rang, stand, status, nationaliteit, geloof etc. en ongeacht lidmaatschap van sociale groeperingen. Elk burgerlijk recht vóóronderstelt dus een publiekrechtelijke rechtsorde, op basis waarvan het kan worden erkend en gepositiveerd en zo nodig gehandhaafd. Enerzijds mogen de publiekrechtelijke en de burgerrechtelijke vrijheidssferen niet 
tot elkaar worden herleid - omdat het publiekrecht en het burgerlijk recht elk hun eigen aard hebben -, anderzijds is de éne vrijheidssfeer niet bestaanbaar zonder de andere.

$\mathrm{Nu}$ hebben we gezien dat de Franse revolutie is belast met een dubbele ideologische erfenis. Aan de Déclaration des Droits de l'Homme et du Citoyen ligt enerzijds de idee ten grondslag van de onvervreemdbare burgerlijke mensrechten - met de private eigendom als kern - ten grondslag, zoals die idee door Locke tot uitgangspunt is gemaakt van zijn natuurrechtsleer. De leer van Locke impliceert een scheiding van Staat en burgerlijke maatschappij, maar ziet de taak van de (democratische) Staat uitsluitend gelegen in de handhaving van een private rechtsorde. Het 'algemeen belang' is hier dus identiek aan de waarborging van de burgerrechtelijke vrijheid en gelijkheid ('property'), Voor onvervreemdbare staatkundige rechten voor alle burgers en voor een voldoende tegenwicht in een bestuursrechtelijke en dwingendburgerrechtelijke wetgeving te voorkoming van sociaal leed en onrecht, wordt niet gepleit $^{12}$.

Anderzijds ligt aan de Declaratie Rousseaus leer van de volkssoevereiniteit ten grondslag, die een overspanning van het beginsel van de staatkundige (publiekrechtelijke) vrijheid en gelijkheid van iedere burger impliceert en die juist niet uitgaat van een scheiding tussen Staat en maatschappij, maar van een identiteit van beide. Volgens dit vrijheidsconcept heeft vrijheid dus betrekking op de mogelijkheid tot participatie in het staatsbeleid. Van een wezenlijk burgerlijk recht, gebaseerd op het beginsel van de burgerrechtelijke vrijheid en gelijkheid in een maatschappelijk verkeer, kan geen sprake zijn. De leer van de volkssoevereiniteit brengt immers mee dat de burgers hun - specifieke - burgerlijke rechten slechts kunnen ontlenen aan de wet, als de emanatie van de wil van het soevereine volk, de 'volonté générale' die nimmer op een privaat belang maar slechts op het publiek belang ('salut public') gericht kan zijn.

Ofschoon de idee van de onvervreemdbare burgerlijke mensenrechten en van de scheiding van Staat en maatschappij en de idee de volkssoevereiniteit met elkaar op gespannen voet staan, hebben ze toch beide heilzaam gewerkt en beide hun uitwerking gekregen ${ }^{13}$. Zoals we zullen zien, zal de eerstgenoemde idee de eerste moeilijke periode van de Franse revolutie overleven en leiden tot de invoering van het moderne burgerlijk recht. 


\section{Het ontstaan van het moderne burgerlijk recht; de inperking van het begrip 'civiel': 'droit civil' = 'droit privé'}

De Code Civil is het eerste wetboek voor de moderne burgerlijke maatschappij. Door de vestiging van het staatsinstituut als res publica en de verwezenlijking van de publiekrechtelijke vrijheid en gelijkheid van elke burger, is het mogelijk geworden om op basis van de publieke rechtsorde van de Staat ook de burgerrechtelijke vrijheid en gelijkheid in het maatschappelijk verkeer van elke mens als zodanig door te voeren en te waarborgen. Dit gebeurt door statelijke positivering van het burgerlijk recht.

Uiteraard is bij de samenstelling van de Code gebouwd op koninklijke ordonnanties, gewoonterecht en - met name - het gerecipieerde Romeinse recht, dat als 'ius commune' werd beschouwd. Zo ligt aan de indeling van de Code het institutensysteem ten grondslag. Maar dit betreft toch vooral de rechtsvormen en de systematiek. In de Code is echter voor het éérst het beginsel van de burgerrechtelijke vrijheid en gelijkheid gepositiveerd.

In zijn kort na de totstandkoming van de Code verschenen commentaar op de Code brengt Locré, secretaris-generaal van de Conseil d'État, duidelijk tot uitdrukking welke uitgangspunten ten grondslag zijn gelegd aan de codificatie van het burgerlijk recht in de Code:

'Aujourd'hui les mots droit civil et droit privé sont synonymes. Le code civil lui-même en est la preuve: toutes ses dispositions ne se rapportent qu'aux intérêts particuliers. Chez les nations où la civilisation est la plus perfectionnée, il n'est point permis aux particuliers de poursuivre la punition des crimes commis contre eux; ils ne peuvent que réclamer la réparation à prix d'argent du dommage qu'ils ont reçu, parcequ'alors ils demandent seulement l'exécution de l'engagement civil que le coupable a contracté envers eux par son fait. Mais c'est la société, seule partie offensée, qui poursuit par ses officiers I'application de la peine pour la vindicte publique. Ainsi les delit, les peines, les jugements criminels, ne sont pas des matières du droit privés; ils appartiennentau droit public (...). Les différens entre particuliers et pour intérêts privés sont đonc les seules que les lois civiles sont appelés à régler. Or, ces différens et les intérêts privés en général, ont toujours pour sujet la propriété' (curs. dzz.; JT).

\section{En de slotconclusie van Locré's commentaar luidt:}

'Voila donc ce qu'est le droit civil ou privé: son object est de régler les rapports individuels, tels qu'ils existent dans l'état de société; son matière, la propriété, son principe est dans la nature; sa forme dans le droit positif (curs. dzz.; JT) ${ }^{14}$.

Uit deze citaten komt in de eerste plaats naar voren, dat een uitgangspunt van de Code is: 'droit civil' = 'droit privé': 'le code civil lui-même en est la preuve', aldus Locré. Dit moet worden gezegd, omdat - zoals we eerder zagen - het oude begrip 'civiel' of 'burgerlijk' een ruimere betekenis had en werd gebruikt als tegenstelling 
tot 'crimineel' of 'lijfstraffelijk', dit niet alleen in de Republiek der Nederlanden maar ook in Frankrijk. Vóór de Revolutie overlapte de begrippen 'politie' en 'civiel' elkaar nog gedeeltelijk, namelijk voorzover het ging om de vermogensrechtelijke aspecten van de 'politie' (het oude 'fiscale recht', dat onderdeel is van het politierecht in ruime zin en dat in zijn geheel als 'civiel' werd beschouwd).

Het revolutietijdperk brengt niet alleen een inperking op van het begrip 'civiel' - de vermogensrechtelijke aspecten van de 'politie' worden er niet meer toe gerekend; 'droit civil' wordt 'droit privé' -, maar óók van het begrip 'politie'. Van het oude 'civiele' politierecht worden de sancties op 'contraventions' en van delicten afgesplitst en, tezamen met de 'peines' wegens 'crimes' ondergebracht in het strafrecht (en daarmee bij de strafrechter). We zien dus tevens een uitbreiding van 'crimineel' tot 'strafrechtelijk': het strafrecht omvat méér dan het vroegere criminele recht; het omvat óók de overtredingen en de daarop gestelde sancties, die voorheen als 'politieel' en tevens als 'civiel' werden aangemerkt ${ }^{15}$. Dit ziet men als een consequentie van de leer van de volkssoevereiniteit, die meebrengt dat ook dergelijke sancties steeds een grondslag zouden moeten hebben in de wet (de emanatie van de 'volkswil'). Het zou de rechter - en niet de politiële overheid - moeten zijn, die als 'bouche de la loi' de desbetreffende zaken berecht. De competentie van de gewone rechter zou zich moeten uitstrekken tot civiele zaken ('civiel' in de moderne, enge betekenis) alsmede tot strafzaken (in de moderne, ruime betekenis).

Men kan de vraag stellen waarom de onderbrenging van de sancties bij contraventies en delicten, ondanks dat deze voorheen werden gerekend tot het terrein der politiële overheid, bij de (straf)rechter - de justitie dus - niet als een aantasting van het domein van het overheidsbestuur is beschouwd ${ }^{16}$. De verklaring hiervoor is deze, dat deze feiten weliswaar behoren tot het 'droit public', maar een rechterlijke kennisneming hier niet leidt tot een bemoeienis met de handelingen van de administratie, nu de represssie van deze feiten is gericht tot de overtreders en dus niet tot de administratie zelf.

Een bij de rechter tegen de overheid ingestelde vordering terzake van schade veroorzaakt door (beweerde) onrechtmatige overheidsdaad zou daarentegen - zo is de opvatting - een beoordeling door die rechter van het handelen van de overheidsadministratie zelf noodzakelijk maken en zich derhalve niet verdragen met het beginsel van de machtenscheiding. Een dergelijk geschil zou in die opvatting dan ook niet zijn aan te merken als 'civiel' (in de moderne betekenis). Locré schrijft daarom: 'Les différens entre particuliers et pour intérêts privés sont donc les seules que les lois civiles sont appelés à régler'. Niettemin is - zoals we reeds zagen - in de negentiende eeuw toch veelvuldig beproefd artikel 1382 e.v. Code Civil (de onrechtmatige-daadsartikelen) van toepassing te verklaren op overheidshandelen. 
Als het Tribunal des Conflits bij het arrest-Blanco van 8 februari $1873^{17}$ het competentieconflict tussen de burgerlijke rechter en de kort daarvoor als zelfstandige administratieve rechter aangewezen Conseil d'État beslist ten gunste van de laatste, op grond van de overweging dat de staatsaansprakelijkheid terzake van handelingen verricht in het kader van de 'service public' niet kan wordt beheerst door de beginselen die in de Code Civil zijn neergelegd voor de verhoudingen tussen burgers onderling, sluit dit duidelijk aan bij de uitgangspunten van de opstellers van de Code. De Code Civil is het voorlopige sluitstuk van het al eerder beschreven differentiatie-, individualiserings- en integreringsproces, dat heeft geleid tot een onderscheiding tussen publiek overheidsgezag en privaat vermogensrecht - en daarmee tussen publiekrecht en burgerlijk recht - en de erkenning van het beginsel van publiekrechtelijke én burgerrechtelijke rechtssubjectiviteit van iedere mens als zodanig (het juridisch persoonlijkheidsbeginsel). De Code Civil is dan de positivering door de Staat van een integrerende territoriale burgerrechtelijke rechtsorde, gebaseerd op het beginsel van de burgerrechtelijke vrijheid-in-gelijkheid en de iustitia commutativa.

Dat een wezenlijke staatsorde nodig is voor de realisering van een burgerrechtelijke rechtsorde, betekent intussen in het geheel niet dat de subjecten in het burgerrechtelijk rechtsverkeer hun bevoegdheid tot bijv. het sluiten van contracten en de beschikkings- en genotsbevoegdheden over het object van hun eigendomsrecht (of ander privaat subjectief vermogensrecht) ontlenen aan de statelijke wetgever. En ook dit komt goed tot uitdrukking in het commentaar van Locré.

Dit brengt ons bij het tweede uitgangspunt dat aan de Code Civil ten grondslag is gelegd: 'son matière, la propriété, son principe est dans la nature; sa forme dans le droit positif, zegt Locré.

Dit wetboek wordt dus gezien als een positivering (door de statelijke wetgever) van de 'natuurlijke vrijheid' van elke mens tot burgerlijke vrijheid in het maatschappelijk verkeer. Uitgegaan wordt dus van de onvervreemdbare aangeboren ('natuurlijke') mensen- en vrijheidsrechten, die in de Code worden uitgewerkt in de beginselen van de burgerrechtelijke vrijheid en gelijkheid. Met andere woorden: de rechtsmacht van burgers tot het sluiten van contracten en hun aan de 'eigendom' ('propriété', hier te verstaan in de ruime zin) verbonden vrije beschikkings- en genotsbevoegdheden zijn oorspronkelijke, 'interne' bevoegdheden, die door de statelijke positivering - dus in de rechtsvormen van de burgerlijke wet en de burgerlijke rechtspraak - 'extern' worden vervlochten in een integrerende burgerrechtelijke rechtsorde, waardoor voor de burgers ook de mogelijkheid ontstaat in geval van geschillen hun burgerlijke rechten te handhaven door inschakeling van statelijke organen (burgerlijke rechter en executerende organen) ${ }^{18}$. 
Dit uitgangspunt van de Code Civil verdient te meer de aandacht gelet op de dubbele ideologische erfenis waardoor de Franse revolutie is beïnvloed (Locke én Rousseau), waarop we hierboven reeds wezen.

Volgens de leer van de volkssoevereiniteit zou Code Civil niet kunnen worden gezien als een statelijke erkenning en positivering in de rechtsvormen van de wet (en de burgerlijke rechtspraak) van oorspronkelijke, 'natuurlijke' rechten, maar als een verlening door de Staat ( = het soevereine volk) aan zijn burgers van bevoegdheden voor het onderlinge verkeer. De burgers zouden hun - specifieke - burgerlijke rechten dan slechts kunnen ontlenen aan de wet, als de emanatie van de volkswil. Geheel in de lijn van deze leer stelt bijvoorbeeld Mirabeau, dat aan de eigendom een zuiver positiefrechtelijk karakter toekomt: de wet is dus niet alleen de rechtsvorm, doch fundeert ook de eigendom en bepaalt volledig de inhoud ervan:

'Une propriété particulière est un bien acquis en vertu des lois. La loi seule constitue la propriété, parce qu'il n'y a que la volonté politique qui puisse opérer la renonciationde tous, et donner un titre commun, un garant à la jouissance de tous' (curs. dzz.; JT) ${ }^{19}$.

Hoe tegenstrijdig de opvattingen omtrent de fundering van het eigendomsrecht zijn, komt tot uiting in artikel 17 van de Déclaration; daarin wordt namelijk juist het natuurrechtelijk karakter van de eigendom geproclameerd ('un droit inviolable et sacré').

Het is deze laatste opvatting - die uitgaat van de onvervreemdbare burgerlijke mensenrechten -, die aan de Code Civil ten grondslag wordt gelegd. Dit komt tot uitdrukking niet alleen in het commentaar van Locré, maar ook in de voorbereidende werken van de Code. Zo bestrijdt Portalis in zijn 'Livre Préliminaire' en in zijn 'Discours Préliminaire' de door Rousseau geïnspireerde opvatting omtrent de wet. In de 'Discours' merkt hij deze opvatting aan als:

'I'esprit révolutionnaire, le désir exalté de sacrifier violemment tous les droits à un but politique et de ne plus admettre d'autre considération que celle d'un mystérieux et variable intérêt d'état' ${ }^{\prime o}$.

Portalis verwerpt de opvatting dat de (burgerlijke) wet slechts een politiek instrument is om de interpersoonlijke relaties te regelen in functie van specifieke publieke belangen:

'On ne s'occupe plus de relations des hommes entre eux: on ne voit que l'objet politique et général; on cherche des confédérés plutôt que des concitoyens. Tout devient droit public. Si l'on fixe son attention sur les lois civiles, c'est moins pour les rendre plus sages ou plus justes, que pour les rendre plus favorables à eux auxquels il importe de faire goûter le régime qu'il s'agit d'établir.' 2

Portalis' eigen opvatting omtrent de wetten luidt:

'Les lois sont ou ne doivent être que le droit réduit en règles positives, en préceptes particuliers' ${ }^{n}$. 
De wetten zijn of behoren volgens Portalis niets anders te zijn dan het recht herleid tot positieve regels. Omtrent de boven-willekeurige grondslag van de wetten schrijft Portalis in het bekende art. 1, titel I van het 'Livre Préliminaire':

'Il existe un droit universel et immuable, source de toutes les lois positives; il n'est que la raison naturelle, et tant qu'elle gouverne tous les hommes'.

Portalis onderkent hier dat wetten rechtsvormen zijn, waarin boven-willekeurige materiële rechtsbeginselen worden gepreciseerd en door die positivering tot geldend (positief) en afdwingbaar recht worden ${ }^{23}$. De rechtsbeginselen dienen als kompas, terwijl de wetten als meetlat dienen, aldus Portalis in de 'Discours' ${ }^{24}$. Voor de burgerlijk wetgeving betekent dit, dat deze gebaseerd moet zijn op de constitutieve beginselen van de burgerlijke gelijkheid en vrijheid als onvervreemdbare mensenrechten. Centraal element is hierbij de eigendomsvrijheid, waaruit de andere burgerlijke vrijheden - in het bijzonder de contractsvrijheid - als het ware noodzakelijkerwijs voortvloeien. In zijn 'Exposé des Motifs' bestrijdt Portalis uitvoerig de opvattingen van 'les philosophes' (waartoe Rousseau wordt gerekend) over het zuiver positiefrechtelijke karakter van het private eigendomsrecht ${ }^{25}$.

Portalis ziet ook heel goed dat het door de Staat gepositiveerde burgerlijk recht een integrerend recht is, dat de interne materiële rechtsverhoudingen in tact laat en dat de burgerrechtelijke 'buiten-zijde' van die verhoudingen betreft. Dit blijkt bijvoorbeeld waar hij betoogt dat een huwelijk naar zijn aard niet een burgerrechtelijke overeenkomst is, en dat de niet-inachtneming van de door de burgerlijke wetgeving aan een huwelijk gestelde eisen slechts burgerlijke nietigheid met zich brengt ${ }^{26}$. Portalis maakt een principieel onderscheid tussen 'lois civiles' en 'lois politiques', en daarmee tussen burgerlijk recht en publiekrecht. En dit terecht, want een wezenlijk burgerrechtelijke rechtsorde - die naar zijn aard geen gemeenschapskarakter draagt - kan slechts bestaan in scherpe onderscheiding tot een publiekrechtelijke rechtsorde. Slechts bij erkenning van de eigen aard van het burgerlijk recht, kan dit recht een heilzaam tegenwicht bieden tegen de druk van alle publieke gemeenschapseisen. In de woorden van Portalis:

'(Les lois civiles) consolent chaque citoyen des sacrifices que la loi politique lui commande pour la cité, et le protégeant, quand il le faut, dans sa personne et dans ses biens, comme s'il était lui seul, la cité tout entière' ${ }^{\prime \prime}$.

De onderscheiding tussen 'droit civil' (= 'droit privé') en 'droit public' wordt, zoals we zagen, ook gemaakt door Locré in zijn commentaar. Gezien de aan de Code ten grondslag gelegde uitgangspunten ligt het alleen maar voor de hand, dat in de Franse doctrine en jurisprudentie een wezenlijk onderscheid wordt gemaakt tussen privaat domein en publiek domein, hoezeer ook de gebruikmaking van het woord 'propriété' in de in de Code opgenomen bepalingen omtrent dat publiek domein verwarrend 
mogen lijken. Het gaat daarbij niet om particuliere eigendom, maar om een ander soort eigendom, dat in de latere Franse doctrine en jurisprudentie als 'publiekrechtelijke eigendom' zal worden aangeduid, in onderscheiding van de 'burgerrechtelijke eigendom'. De opneming van bepaling omtrent het publiek domein in de Code Civil resp. in ons Burgerlijk Wetboek (1838) zegt op zichzelf niets omtrent de aard ervan, zoals door Hardenberg overtuigend is aangetoond ${ }^{28}$.

De Code Civil is door veel Westeuropese landen overgenomen of heeft model gestaan voor hun nationale wetgeving. Ook het Nederlandse Burgerlijk Wetboek (1838) is in belangrijke mate geënt op de Code. Ofschoon volgens Van Kan het BW qua opzet en indeling (de 'vorm') niet veel aan de Code te danken zou hebben maar des te meer aan het Ontwerp-Kemper van 1820, zijn - qua inhoud - de bepalingen van de Code, met menigvuldige grotere en kleinere wijzigingen, grotendeels wel overgenomen ${ }^{29}$. Trouwens, dat ook bij de opstelling van het Ontwerp-Kemper als uitgangspunt is genomen: 'droit civil' = 'droit privé' komt tot uitdrukking in artikel 2 van dat ontwerp, dat bepaalt:

'Onder den naam van burgerlijk regt worden begrepen al de wetten omtrent de onderlinge bevoegdheid van bijzondere personen om iets te zijn, te hebben, te doen of te laten, met het gevolg, dat de handhaving dezer bevoegdheid of wel toekenning van schadeloosstelling wegens het niet erkennen derzelve van den regter kan gevorderd worden' (curs. dzz.; JT).

Samenvattend: de Code Civil en de daarop geënte codificaties - zoals het Nederlands Burgerlijk Wetboek van 1838 - gaan uit van het beginsel van de burgerlijke vrijheidin-gelijkheid, vooral in de sfeer van eigendom, contract en vermogen; de daaruit voortvloeiende aanspraken worden gemaakt tot wettelijk beschermde bevoegdheden. Het is dus minder juist te zeggen dat de wetgever in het BW bevoegdheden heeft verleend; neen, hij erkent en positiveert een vrije burgerlijke rechtssfeer waarbinnen de burgers hun private belangen naar eigen inzicht kunnen nastreven, waardoor gewaarborgd is dat, waar zij in het maatschappelijk verkeer rechtsbetrekkingen met anderen willen aangaan, dit ook werkelijk kan geschieden op basis van de eigen vrije rechtsvormende wil en op een geordende wijze, waarbij - met uitsluiting van eigenrichting - wordt voorzien in de mogelijkheid van sanctionering van overheidswege van burgerrechtelijke verplichtingen. De basisgedachte van de makers van de Code Civil zijn dus de burgerlijke mensenrechten, die door de Code zijn gepositiveerd in de vorm van de aan de eigendom verbonden vrije beschikkings- en genotsbevoegdheid, en van de contracteerbevoegdheid. 


\section{De heerschappij van de wet en de verdere inperking van de 'politie'}

We wezen er reeds enige malen op, dat na de Franse revolutie het oude onderscheid tussen politie- en justitiezaken is bestendigd en zelfs scherper is aangezet, als tegenstelling bestuur-rechtspraak. De gewone gerechten, die - hoewel formeel nog dienaren van de soevereine vorst - reeds onder de politiestaat steeds onafhankelijker waren geworden tegenover de politiële overheid, hebben een zelfstandige positie gekregen met de constitutionele vastlegging van de machtenscheiding en van de onafhankelijkheid der rechterlijke macht. Uit de machtenscheiding wordt - zoals we zagen - anderzijds ook afgeleid, dat rechterlijke inmenging in het bestuursbeleid is uitgesloten (vgl. art. 13 van titel II van de Franse wet van 24 augustus 1790). De competentie van de rechterlijke macht strekt zich uit tot civiele zaken ('civiel' in de moderne, enge betekenis) en tot strafzaken (in de moderne, ruime betekenis, dus inclusief de contraventies en delicten). De (straf)wet wordt gezien als bron van alle strafrecht; de wetgever - die nu principieel onderscheiden wordt van de politiële overheid - is de enige die met straf kan bedreigen. En het burgerlijk recht is, op basis van het beginsel van de burgerlijke vrijheid en gelijkheid, gepositiveerd in de Code Civil. De rechterlijke macht verricht haar taak dus op basis van wat we eerder justitiewetgeving hebben genoemd (Code Civil, Code de Commerce, Dode de Procédure Civil, Code Pénal en Code d'Ínstruction Criminelle).

Wat de 'politiewetgeving' betreft, zagen we dat zich reeds onder de politiestaat het onderscheid is gaan manifesteren tussen de wetgevingsfunctie en de bestuursfunctie en dat de 'politiewetten' steeds meer werden gezien niet alleen als een beperking van een reeds bestaande bevoegdheid, maar ook als bevoegdheidsgrondslag voor de lagere overheden. Bestuur was men reeds gaan beschouwen als uitvoering van wetgeving, zij het nog steeds als uitvoering namens de Hoge Overheid, die uit kracht van zijn absolute soevereiniteit wetgeving had uitgevaardigd. Bij die soevereine Hoge Overheid zelf waren wetgevingsfunctie en bestuursfunctie dus niet van elkaar te onderscheiden: het 'ius politiae' van de vorst impliceerde juist de absolute en oorspronkelijke bevoegdheid tot rechtsvorming.

De consequentie van de doorvoering van het beginsel van de machtenscheiding en - vooral - de vervanging van de vorstensoevereiniteit ('overheidssoevereiniteit') door de volkssoevereiniteit had moeten zijn, dat voor het bestuurlijk optreden steeds een grondslag zou moeten worden geboden door de wet (wetmatigheid van bestuur). Rousseau had in zijn 'Du contract social' dan ook betoogd:

\footnotetext{
'Qu'est-ce donc le gouvernment? Un corps intermédiaire chargé de l'exécution des lois' ${ }^{30}$, en:
}

'Le cas de la dissolution de l'état peut arriver ... quand le prince n'administre plus l'état selon les lois; ... le despote est celui qui se met au dessus des lois' "3". 
De heerschappij van de wet is hier dus gebaseerd op de idee van de volkssoevereiniteit, waarbij de wet wordt gezien als de emanatie van de 'volonté général', de soevereine volkswil. Zoals we eerder zeiden, laboreert deze leer van de volkssoevereiniteit echter aan hetzelfde gebrek als de eerdere leer van de overheidssoevereiniteit, omdat beide leren geen innerlijke grenzen gesteld zien aan die soevereiniteit: de absolute vorstenwil wordt vervangen door de (gefingeerde) absolute volkswil. De rechtsstaat dient zijn democratisch karakter te ontlenen aan de toepassing van het representatiebeginsel, dat ook een onderscheiding tussen Staat en burgerlijke 'maatschappij' impliceert. Ook het beginsel van de representatieve democratie eist evenwel wetmatigheid van bestuur ${ }^{32}$.

Het beginsel van de representatieve democratie wordt echter, althans in Nederland en Duitsland, in eerste instantie nog niet verwezenlijkt. In de restauratieperiode die volgt op het revolutietijdperk is de oude opvatting, dat de soevereiniteit toekomt aan de vorst als hoogste overheid en dat het in deze soevereiniteit gefundeerde ius politiae hem ook de bevoegdheid geeft tot het stellen van ge- en verbodsvoorschriften met een abstract-generaal karakter, herleefd. Het doek over de politiestaat is nog niet geheel gevallen. Van der Woud merkt op, dat Nederland van 1813 tot 1840 een koning heeft die voor zijn regeringsbestel inspiratie zoekt bij het laat-achttiendeeeuwse model van de 'Polizei- und Wohlfahrtsstaat', 'mogelijk gesterkt door de vroeg-negentiende-eeuwse anti-revolutionaire hervormingen van de trias politica, de scheiding der machten, die in de soevereine vorst weer een machtsintegratie zochten' ${ }^{33}$.

Hoe is in de negentiende eeuw de ontwikkeling - die, als gezegd, kan worden beschreven als een steeds verder gaande inperking van de 'politie' onder gelijktijdige vestiging van de heerschappij van de wet (in formele zin) - verlopen?

Mede omdat de begripsvorming in het Nederlandse staats- en bestuursrecht zo sterk zijn beïnvloed door Duitse begrippen en theoretische opvattingen ${ }^{34}$, is het interessant na te gaan, welke de 'lotgevallen' zijn van de 'polizeirechtliche Generalklausel', zoals vervat in par. 10 van deel II, titel 17 van het Pruisische Allgemeine Landrecht (ALR) van 1794. Deze 'Generalklausel' is de eerste poging is tot normering van de politietaak; de 'politie' is hierin beperkt tot de algemene bestuurstaak tot het afweren van gevaren voor het publiek ('Gefahrenabwehr'). In deze taak wordt tevens een algemene bevoegdheid begrepen voor degenen die met die taak zijn belast, niet alleen tot het geven van 'Polizeiverfügungen' maar (aanvankelijk) $66 \mathrm{k}$ tot het stellen van algemeen bindende regels (politieverordeningen). Met deze bepaling en een bepaling als par. 7 van de Inleiding op het ALR wordt - zo merkten we op - reeds uitdrukking gegeven aan de nieuwe opvattingen omtrent wetmatigheid van bestuur (voorheen: 'politie'), volgens welke buiten het terrein van de 'Gefahrenabwehr' overheidsdwang alleen uitgeoefend kan worden volgens de wet. 
In de negentiende eeuw komt er wetgeving die een specifieke regeling geeft omtrent de verordeningsbevoegdheid van de politieautoriteiten. Dit geschiedt met name bij het Pruisische 'Gesetz über die Polizeiverwaltung' van 1850 en bij de artt. 136-145 van het Pruisische 'Gesetz über die allgemeine Landesverwaltung' van $1883^{35}$. Concrete politionele bevelen van politie-autoriteiten ('polizeiliche Befehle' of 'polizeiliche Verfügungen') behoeven echter niet te zijn gebaseerd op een specifieke wet of politieverordening, maar kunnen berusten op de 'polizeiliche Generalklausel' van par. 10 van deel II, titel 17, ALR. Wèl geeft de wet van 1883 in de artt. 132134 een omschrijving van de dwangmiddelen waarmee de politiebevelen kunnen worden gehandhaafd.

Bovendien reguleert deze wet in de artikelen 127-130 de - overigens reeds bestaande, maar summierlijk geregelde - beroepsmogelijkheden tegen 'polizeiliche Verfügungen'. Volgens deze bepalingen kan de naar aanleiding van een politionele beschikking voor het Verwaltungsgericht gebrachte klacht erop gegrond worden, 'dass der angefochtene Bescheid durch Nichtanwendung oder unrichtige Anwendung des bestehenden Rechts ... den Kläger in seinen Rechten verletze'. Hoogste beroepsinstantie is het Pruisische Oberverwaltungsgericht (OVG), een instantie die in 1875 is opgericht en die, behalve in benoeming en promotie, van de administratie geheel onafhankelijk is.

In het bekende Kreuzberg-Urteil van 16 juni 1882 was reeds een halt toe geroepen aan de extensieve opvatting van de politietaak en -bevoegdheden, die in de voorafgaande decennia was gepraktiseerd ${ }^{36}$ : het begrip 'Gefahrenabwehr' werd daarbij nogal ruim uitgelegd.

Een politieverordening die uit welstandsoogpunt de maximale bouwhoogte van bouwwerken (in Kreuzberg, Berlijn) regelt, werd door het Oberverwaltungsgericht ongeldig verklaard omdat zij niet strekte 'zur Gefahrenabwehr' maar 'zur Wohlfahrtspflege'.

Doordat tijdens de Weimarer republiek voor allerlei specifieke situaties de bevoegdheden van de politie-autoriteiten in specifieke wettelijke bepalingen worden vastgelegd, wordt de betekenis van de 'polizeiliche Generalklausel' verder beperkt en krijgt deze een subsidiair karakter. Par. 14 van het Pruisische Polizeiverwaltungsgesetz van 1931 geeft hiervan de volgende omschrijving:

'Die Polizeibehördenhaben im Rahmen der geltenden Gesetze die nach pflichtgemāssen Ermessen notwendigen Massnahmen zu treffen, um von der Allgemeinheit oder dem Einzelnen Gefahren abzuwehren, durch die die öffentliche Sicherheit oder Ordnung bedroht ist'.

Deze bepaling staat model voor bepalingen die na 1945 worden opgenomen in de 'Polizeigesetze' van de verschillende Duitse deelstaten ${ }^{37}$. Aan het Bundesverfassungsgericht is de vraag voorgelegd of de 'polizeiliche Generalklausel' voldoet aan 
het 'Bestimmtheitsgebot' (het lex certa-beginsel), een centrale rechtsstatelijke eis, welke verankerd wordt geacht in de constitutie. Volgens het Bundesverfassungsgericht is deze 'Generalklausel' echter:

'in jahrzehntelangerEntwicklung durch Rechtsprechungund Lehre nach Inhalt, Zweck und Ausmass hinreichen präzisiert, in ihrer Bedeutung geklärt und im juristischen Sprachgebrauchverfestigt' ${ }^{38}$.

Eind jaren tachtig van deze eeuw beleeft de 'polizeiliche Generalklausel' een renaissance, als grondslag om op te treden tegen bodemverontreiniging in die gevallen dat de milieuwetten zo'n basis niet bieden (omdat ze in werking zijn getreden nadat de verontreiniging heeft plaatsgevonden). Optreden op basis van de 'Generalklausel' is echter slechts mogelijk, indien en voorzover er door een verontreiniging onmiddellijke gevaren optreden voor de openbare gezondheid of veiligheid (voorbeeld: het grondwater wordt verontreinigd of dreigt te worden verontreinigd). Het politiële optreden mag dan ook niet verder gaan dan strikt nodig is om die gevaren te voorkomen of weg te nemen ${ }^{39}$.

Ook in Nederland kan de ontwikkeling, die uitmondt in het Meerenberg-arrest ${ }^{40}$, worden gedefinieerd als een uitbreiding van het materiële wetsbegrip en, annex daaraan, een inperking van het politiebegrip:

'In ons land gaat de aanvaarding van het materielle wetsbegrip gepaard met het afsterven van de opvatting, dat regelgeving ook tot de politic behoort ...',

aldus Van der Burg ${ }^{41}$. In het restauratietijdperk na de Franse overheersing wordt de politiebevoegdheid van de Koning nog ruim opgevat. Enerzijds wordt de opsomming in de Grondwetten van 1814 en 1815 van een aantal specifieke bevoegdheden van de Koning - de soevereine Vorst - veelal niet beschouwd als limitatief, maar slechts als vaststelling dat de genoemde onderwerpen voortaan niet meer onder het provinciale gezag maar onder het centrale gezag vallen. Anderzijds wordt de bepaling in de Grondwet van 1815, dat de wetgevende macht berust bij de Koning en de Staten-Generaal gezamenlijk, aanvankelijk aldus opgevat dat slechts in die gevallen waarin de Grondwet uitdrukkelijk een 'wet' voorschrijft - met name in het zgn. codificatic-artikel -, die wet moet worden tot stand gebracht door Koning en StatenGeneraal te zamen volgens de in de Grondwet aangegeven procedure. De Grondwet zou dus slechts de soevereine macht van de koning beperken in die zin dat hij slechts dan niet bevoegd zou zijn tot het stellen van algemene regelen, wanneer de Grondwet uitdrukkelijk een in samenwerking met de Staten-Generaal tot stand te brengen wettelijke regeling voorschrijft. Zodanige (codificerende) wetgeving is door art. 163 Grondwet 1815 voorgeschreven voor het burgerlijk recht en het strafrecht alsmede voor de regeling van de organisatie der rechterlijke macht ${ }^{42}$ : justitiewetgeving dus. 
Tót het Meerenberg-arrest wordt de 'politiebevoegdheid' nog zo ruim opgevat, dat de Kroon zelfs bevoegd wordt geacht om zonder grondslag in de wet (in formele zin) wetten in materiële zin tot stand te brengen (althans voor zover de Grondwet niet een wet in formele zin voorschrijft), zgn. algemene maatregelen van inwendig bestuur ${ }^{43}$. Tot kort vó6r het Meerenberg-arrest wordt door de Hoge Raad nog een expliciet onderscheid gemaakt tussen enerzijds uitvoering door de overheidsadministratie van 'wetten' en anderzijds handhaving van een 'goede politie', waartoe óók het stellen van algemene bindende regels kan behoren. Een algemene strafbedreiging op overtreding van een algemene maatregel van inwendig bestuur is voorzien bij de Algemene Sanctiewet van 1818, Stb. $12^{44}$. De verbods- en gebodsvoorschriften die met strafsanctie worden bedreigd, zouden echter door de Kroon zelf mogen worden gegeven, ook zonder machtiging door de 'wet'.

Zo wordt bij een arrest van 24 februari 1846 het Koninklijk Besluit 'rakende de vergunning ter oprigting van sommige fabrijken en trafijken' niet wegens het ontbreken van een grondslag in een wet in formele zin onverbindend geacht. Daartoe overweegt de Hoge Raad onder meer, dat bij dit besluit:

'niet is behandeld eenig onderwerp van wetgeving; doch dat, blijkens den aanhef en den inhoud, deszelfs bedoeling en strekking eeniglijk is gelegen in de bevordering en handhaving eener goede politie, alsmede in de zorg ter voorkoming van gevaar, schade en hinder voor de ingezetenen; welk een en ander tastbaar moet worden gerangschikt onder de algemeene maatregelen van inwendig bestuur, waarvan de daarstelling alzoo op de wijze, zoo als zulks bij gezegd besluit is geschied, behoort tot de grondwettige magt en bevoegdheiddes Konings' (curs. dzz.; JT) "

En bij een arrest van 24 mei 1853 wordt een algemene maatregel van bestuur, bepalende dat de oprichting van een levensverzekeringsmaatschappij alleen onder 's Konings goedkeuring geschieden kan, verbindend geacht omdat het betreft:

'een voorschrift niet van burgerlijk, maar van politieregt; dat ... is genomen in het belang van het publiek en ter voorkoming der uit die maatschappijenontstane misbruiken' (curs. dzz.; JT) *. Nog in een arrest van 23 maart 1874 wordt overwogen dat de Grondwet niet voorschrijft dat iedere algemene maatregel van inwendig bestuur, om rechtsgeldig te zijn, moet berusten op c.q. moet strekken ter uitvoering van een wet:

'(D)ie Grondwet draagt wel is waar het burgerlijk en strafrecht in zijn geheelen omvang aan de wetgevendemagt op ...., maar (bakent) de grenzen der Koninklijke magt in zaken van administratie en politie niet bepaald af ...' (curs. dzz.; JT) ${ }^{\text {}}$.

Advocaat-generaal Polis merkt in zijn - door de Hoge Raad niet gevolgde - conclusie vóor het Meerenberg-arrest o.a. op:

'(D)e Hooge Raad heeft tot dusverre altijd beslist, dat de stelling, dat een algemeene maatregel van inwendig bestuur om regtsgeldig te zijn zou moeten rusten op, en tot uitvoering strekken van eene wet, niet overeenkomt met de Grondwet van 1815 , dat die Grondwet zoodanig voorschrift niet bevat, de grenzender Koninklijkemagt in zaken van administratic en politie niet bepaald afbakent ...' 
Tot de critici van deze jurisprudentie behoort Olivier. Deze omschrijft 'politie' ('in de engere betekenis'), in navolging van Thorbecke ${ }^{48}$, als:

'de geheele inwendige regering, met uitzondering der financiën, van justitie en van defensie' " 9 , maar hij voegt eraan toe:

'Het bepalen der regten van eigendom behoort tot het gebied der wetgeving. (...) Politiewetgeving, hetzij ten opzigte van neringen en bedrijven, hetzij ten aanzien van andere takken van Staatshuishouding, is den Koning bij de Grondwet niet in het bijzonder opgedragen; zij zal dus, waar zij een algemeen rijks-belang is, volgens den algemeenen regel van art. 106 Grondwet, door de gewone wetgevendemagt, Koning en Staten-Generaal gezamenlijk, moeten worden uitgeoefend' (curs. dzz;; JT) ${ }^{\text {s. }}$.

Wat uit deze woorden goed naar voren komt is, dat het de vermogensrechtelijke sfeer van de burger - zijn 'eigen private domein', kort: zijn 'eigendom' - is die men in de negentiende eeuw met het materiële wetsbegrip beoogt te beschermen ${ }^{51}$ : voorschriften door straffen te handhaven (óók de 'contraventions de police', en niet alleen de daarop gestelde strafsancties) en (andere) ingrepen in die private eigendom zouden een uitdrukkelijke basis behoeven in de 'wet' - dat wil zeggen een regeling als bedoeld in art. 106 Grondwet (= art. 104 Grondwet 1848) - en zouden dus niet (meer) mogen plaatsvinden krachtens een algemene 'politiebevoegdheid'. Dergelijke wetten in materiële zin zouden dus slechts gesteld mogen worden door Staten-Generaal en Kroon tezamen - de wetgever als bedoeld in de Grondwet - danwel krachtens delegatie door de wetgever.

Volgens Meerenbergarrest volgt uit het stelsel van de Grondwet:

'dat de Grondwet het aan den Koning en aan den algemeenen wetgever toekomende gezag nauwkeurig onderscheidt;

dat volgens art. 104 de wetgevende magt uitgeoefend wordt door den Koning en de Staten-Generaal gezamenlijk, terwijl in de zesde afdeeling van het tweede hoofdstukde onderscheidenebestanddeelen van 's Konings magt met name worden aangegeven, en bepaaldelijk bij art. 54 den Koning geene wetgevende, maar uitvoerendemagt wordt toegekend;

Overwegende, dat wel is waar nergens eenige bepaling uitdrukkelijk voorschrijft dat algemeene maatregelen van inwendig bestuur, door den Koning te nemen, op de Grondwet of op eene wet moeten berusten, of daarvan het uitvloeisel zijn, maar dat daaruit niet volgt, dat de Koning in het algemeen de bevoegdheidzou hebben tot het uitvaardigen van dergelijke maatregelen, ook wanneer die niet steunen op eenige wet of daarvan uitvloeisels zijn;

Overwegende immers, dat ingevolge vorengemeld stelsel der Grondwet, het niet de vraag is of die bevoegdheidden Koning door eenige uitdrukkelijke bepaling ontzegd, doch of zij hem toegekend zij, en alzoo steunt op eenige directe of indirecte delegatie des wetgevers, in verband met 's Konings bevoegdheidals uitvoerende magt' s .

Eerst bij het Meerenbergarrest arrest wordt de politiestatelijke opvatting, die algemene regelgeving nog rekenende tot het domein der 'politie', verlaten en is het beginsel van wetmatigheid van bestuur - 'het beginsel van de rechtsstaat', meent Kranenburg ${ }^{33}$ - in Nederland gevestigd ${ }^{54}$. Met de oude opvatting dat de Kroon uit hoofde van zijn soevereiniteit een algemene bevoegdheid zou hebben tot 'politie- 
regelgeving' (voorzover haar de bevoegdheid niet uitdrukkelijk bij Grondwet was onthouden), moest ook wel gebroken worden nadat in 1848 uitdrukkelijk in de Grondwet was bepaald dat bij de Kroon de uitvoerende macht berust en dat de koning onschendbaar en de ministers verantwoordelijk zijn ${ }^{55}$, waarna in de jaren 1866-1868 het parlementaire stelsel definitief was gevestigd.

Bij de grondwetsherziening van 1887 wordt bepaald (art. 56), dat de Kroon weliswaar bevoegd is zelfstandig algemene maatregelen van bestuur uit te vaardigen, doch dat straf op overtreding ervan slechts kan worden bedreigd op basis van de wet in formele zin.

\section{6. 'Politie' en publiek domein; publiekrechtelijke eigendom en burgerrechtelijke eigendom}

Ook ná het Meerenbergarrest wordt echter nog in een aantal arresten het bestaan van publiekrechtelijke bevoegdheden ('politiebevoegdheden') - $66 \mathrm{k}$ die tot het stellen van algemeen bindende regels, door straffen te handhaven - zonder expliciete grondslag in de wet in formele zin aanvaard.

De verklaring hiervoor moet o.i. hierin worden gezocht, dat de desbetreffende algemene regels betrekking hebben op publiek domein. We wezen er al op dat de ontwikkeling die uitmondt in het Meerenbergarrest kan worden gedefinieerd als een uitbreiding van het materiële wetbegrip - en een daarmee annexe inperking van de algemene 'politiebevoegdheid' - en dat men met dit materiële wetsbegrip het eigen private domein van de burger - zijn 'eigendom' - wil beschermen tegen overheidsingrepen die niet hun grondslag vinden in de wet. De doorbraak van de rechtsstaatsgedachte betekent immers o.a. het (definitief) loslaten van de feodale koppeling van 'imperium' en 'dominium'. De eigendom van de burger werd uitdrukkelijk erkend als zijn 'privaat dominium', hetgeen betekent dat er niet krachtens ongeschreven recht nog 'hoogheidsrechten' van de overheid op dat domein kunnen bestaan en evenmin dat nog ingrepen in dat domein mogelijk zijn krachtens een algemene 'politiebevoegdheid'. Ook publiekrechtelijke beperkingen van de private eigendom zouden dus in beginsel steeds een uitdrukkelijke basis behoeven in de wet ${ }^{56}$. En hierbij past ook - zo merkten we reeds op - dat de verschillen tussen de burgerrechtelijke eigendom enerzijds en het publiek domein - de 'publiekrechtelijke eigendom' - scherp(er) worden aangezet.

Dit is juist gezien door Thorbecke, die - gelijk bekend - een principieel onderscheid maakt tussen zaken die een publieke functie hebben ('publiek domein') en zaken die burgerrechtelijke eigendom zijn. Wanneer een zaak bestemd is voor publiek domein, zou hiermee in de opvatting van Thorbecke de mogelijkheid van burgerrechtelijke 
eigendom op deze zaak zijn uitgesloten ${ }^{57}$. Daarmee volgt hij Franse opvattingen, zoals die verdedigd zijn door met name Proudhon ${ }^{58}$. Het Franse recht beschouwt 'le domain public' nog steeds als een aparte vorm van - niet privaatrechtelijke eigendom, die door eigen publiekrechtelijke regels wordt beheerst. Vos spreekt in 1931 - in navolging van de Franse terminologie - van 'publieke eigendom', in scherpe onderscheiding van 'private eigendom'. Met diens beschouwingen kan door ons geheel worden ingestemd:

'Publieke zaken zijn zaken, die voor den publieken dienst bestemd zijn; publieke wegen met name zijn zaken, die bestemd zijn voor het gebruik van allen, voor het algemeen verkeer, dat mede een onderdeel is van den publieken dienst. Wanneer eigendom is de volledige heerschappij over een zaak, dan is de eigendom van publieke zaken de volledige heerschappij van den Staat of andere overheidsorganen, die noodig is om zie zaken aan hare bestemming voor den publieken dienst te doen beantwoorden ${ }^{59}$ en elke inbreuk van derden op die bestemming te keeren. Er is geen reden om die volledige heerschappij over de publieke zaak niet als eigendom aan te duiden, en daar de rechten, die de overheid aan dien eigendom ontleent, een onderdeel vormen van hare bestuurstaak, dus liggen op het gebied van het publieke recht, is er ook geen reden om dezen eigendom niet aan te duiden als publieken eigendom. Die publiekeneigendom staat naast den privaten eigendom, omdat hij geheel onttrokken is aan de heerschappij van het privaat recht en geheel beheerscht wordt door de regelen van het publieke recht. (...) Publieke zaken kunnen ook, voor zoover hare publieke bestemming dit toelaat, bezwaard worden met rechten ten behoeve van particulieren, maar niet in de vorm van civielrechtelijkeovereenkomsten, doch langs den publiekrechtelijkenweg van vergunningen en concessies. (...) (D)e heerschappij van het publiekrechtelijklichaam (lost) zich op in een publieke eigendom, die uitsluitend bestaat uit bestuursbevoegdheden strekkende om de zaak aan hare publieke bestemming te doen beantwoorden, waarvan de bevoegdheid om gebruiksrechtenvan derden op de zaak van een voorafgaandevergunning afhankelijk te stellen, een onderdeel vormt' ${ }^{\prime}$.

Zien we het goed, dan aanvaardt Vos het bestaan van een algemene 'politiebevoegdheid' van de beherende overheid ten aanzien van het door haar beheerde publiek domein. En aan die 'politie' wordt ook ná het Meerenberg-arrest ook een regelgevende bevoegdheid inherent geacht.

\section{Koninklijke 'politie'regelgeving voor publiek domein}

Zo wordt in het zeer kort na het Meerenbergarrest gewezen arrest van de Hoge Raad van 30 juni 1879 de rechtsgeldigheid vastgesteld van het bij a.m.v.b. vastgestelde 'Reglement op het bevisschen der Schelde en Zeeuwse stroomen'. Daartoe overweegt de Hoge Raad:

'dat de bevaarbareen vlotbare stroomen en rivieren, als bestemd tot openbaar en algemeen gebruik. wegens die bestemming aan den Staat toebehooren,en mitsdien als staatseigendomnaar publiek regt moeten worden aangemerkt;

dat hiertegen niets afdoet, dat de bepaling omtrent dien eigendom voorkomt in het Burgerlijk Wetboek (art. 577; JT), omdat de aard van dien eigendom niet moet worden beoordeeld naar de wet waarin daarover gehandeld wordt, maar naar de bestemming der voorwerpen van eigendom; dat uit de omstandigheid, dat de bevaarbare en vlotbare stroomen en rivieren naar het publiek regt behooren aan den Staat, voortvloeit dat de Koning, als hoofd van het uitvoerend gezag, den Staat 
bij de uitoefening van zijn publiek eigendomsregtvertegenwoordigende,niet alleen de bevoegdheid bezit om het beheer daarover te regelen, maar ook om ten aanzien van het gebruik dat daarvan kan worden gemaakt, bij algemeene maatregelen van inwendig bestuur voorschriften te geven' 61 .

Dit arrest is gewezen conform de conclusie van advocaat-generaal Polis, die onder meer opmerkt dat uit het Meerenbergarrest niet mag worden afgeleid dat dergelijke regelingen niet meer mogelijk zouden zijn:

'(D)e eigendom die den Staat krachtens art. 577 BW toekomt, komt hem toe, althans voor wat betreft de in het artikel genoemde voorwerpen die, zooals de bevaarbare en vlotbare stroomen en rivieren zonder hunne bestemming te verliezen niet vatbaar zijn voor bijzonder bezit, uit kracht van zijn overheidsrecht, jure publico, zoodat het niets anders is dan eene daad van uitvoering van dit bij art. 577 BW toegekenderegt, wanneer de Koning maatregelen stelt omtrent het gebruik van die tot het publiek domein van den Staat behoorende voorwerpen. Of wil men beweren dat de onderscheiding der Fransche wet tussen publiek en privaat domein in onze wet niet bestaat, en dat alle de in art. 577 BW genoemde voorwerpen, ook die welke tot gebruik en nut van allen bestemd zijn, tot het privaat domein van den Staat behooren?' 2 .

In gelijke zin luidt een arrest van de Hoge Raad van 6 oktober 1884: krachtens het overheidsrecht van de Staat met betrekking tot het in art. 577 BW bedoelde publiek domein is de Kroon als hoofd van het uitvoerend gezag bevoegd:

'met eerbiediging van door derden verkregen burgerlijke rechten, het gebruik van zoodanig Staatseigendom, in het algemeen belang ook door algemeene maatregelen van inwendig bestuur te regelen' ${ }^{\text {as }}$.

Uitdrukkelijk stemt de Hoge Raad in met de opvatting van de kantonrechter, die de grondslag van de bevoegdheid van de Kroon gelegen zag in het overheidsrecht dat de Staat ten aanzien van het publiek domein als bedoeld in art. 577 BW toekomt. Dit verdient opmerking, omdat de rechtbank de grondslag meende te kunnen vinden in het bij art. 190 van de toenmalige Grondwet aan de Koning opgedragen oppertoezicht op de waterstaat.

Advocaat-generaal Polis reageert als volgt op het betoog van requiranten, dat de door de Hoge Raad in zijn arrest van 19 maart $1877^{64}$ aanvaarde opvatting dat de Kroon een zelfstandige bevoegdheid had het gebruik van zodanig staatsdomein via algemene maatregel van bestuur te regelen, geacht zou moeten worden te zijn verlaten mét het Meerenbergarrest van 1879 en dat in dit eigendomsrecht van de Staat niet een grondslag zou zijn te vinden voor het uitvaardigen van een algemene maatregel van bestuur:

'De opmerking toch, dat het twijfelachtig is of de Koning in eene burgerrechtelijke bepaling, waarbij de wetgever den eigendom van zekere zaken toekent, wel ooit een rechtsgrond kan hebben tot het uitvaardigen van strafverordeningen tot bescherming van den eigendom of tot regeling van het van die zaken te maken gebruik, kan niet als een argument tegen 's Raads beslissing gelden, omdat bij die opmerking is over het hoofd gezien, dat de Raad, juist omdat de rivieren en stroomen niet zijn gewoon burgerlijk eigendom van den Staat, maar aanden Staat uit kracht van zijn overheidsrecht toekomen, aanneemt dat het hoofd van het uitvoerend gezag het gebruik dat van die zaken kan gemaakt worden bij algemeenen maatregel van inwendig bestuur kan regelen. En de bewering, dat de voorschriften van het Koninklijk besluit zich niet beperkten tot de eigendommen van den Staat, 
maar ook derde eigenaren van oever, slikken en uiterwaarden aan de bepalingen van het besluit onderworpen zijn, kan ... geen gewicht in de schaal leggen, omdat bij art. 2 geene voorschriften zijn gegeven omtrent oevers, slikken en uiterwaardenniet aan den Staat toebehoorende, maar daarbij het baggeren en voor anker liggen in de rivier onder zekere omstandigheden is verboden' (curs. dzz.; JT).

De Hoge Raad leidt dus in deze arresten uit de aan de Staat opgedragen zorg voor het beheer van de bedoelde publiekrechtelijke eigendom - het 'toebehoren als gezagsrecht' (Hardenberg) c.q. 'het overheidsrecht jure publico' (Polis) - het bestaan van publiekrechtelijke bevoegdheden af, waaronder de bevoegdheid om met betrekking tot het gebruik van dat publiek domein algemene regels te stellen.

Vegting bestrijdt deze jurisprudentie:

(D)e Staat ... bezit deze bevoegdheidniet als gevolg van zijn kwaliteit van rechthebbendeop deze zaken, maar - en ditzelfde geldt voor de lagere publieke lichamen binnen den kring hunner door ons recht erkende verordeningsbevoegdheid - als wetgever. (...) Wellicht hangen ... de arresten van 30 Juni 1879 en van 1884 samen met den wensch van den Hoogen Raad den door hem sinds 1879 onontbeerlijk geachten wettelijken steun te vinden in art. $577 \mathrm{BW}^{\prime}$ 'ss,

Deze kritiek moet echter gezien worden in het licht van Vegtings opvatting, dat ook het publiek domein als 'gewone' private eigendom moet worden beschouwd. Gaat men echter uit van het eigen karakter van dit domein als publiekrechtelijke eigendom en beseft men dat het bij het Meerenberg-arrest aanvaarde materiële wetsbegrip primair is gericht op bescherming van het eigen, private domein van de burger, dan is deze jurisprudentic volstrekt begrijpelijk ${ }^{60}$. Zoals we zagen, wijst advocaatgeneraal Polis er trouwens in zijn conclusie vóor het arrest van 6 oktober 1884 uitdrukkelijk op dat in de desbetreffende algemene maatregel van bestuur opgenomen voorschriften géén betrekking hebben op de eigendommen van particulieren. Men zie in dit verband ook een arrest van 12 april 1880 , waarbij de - bij arrest van 24 mei 1853 nog rechtsgeldig geoordeelde - algemene maatregel van bestuur die de oprichting van een levensverzekeringsmaatschappij aan koninklijke goedkeuring bindt, onverbindend wordt geacht, omdat:

'de daad van oprigting van een levensverzekeringsmaatschappijle uitoefening is van een burgerlijk regt',

zodat de regeling van die uitoefening en dus ook haar beperking in het belang der openbare orde of welk ander motief ook, behoort tot de bevoegdheid der wetgevende macht ${ }^{67}$. De Hoge Raad zegt hier niet dat het gaat om een voorschrift van 'burgerlijk recht', maar om een regulering van de uitoefening van 'een burgerlijk recht'. Die regulering is echter van publiekrechtelijke aard ${ }^{68}$.

Tenslotte zij nog gewezen op een arrest van 20 oktober 1879, waarbij een algemene maatregel van bestuur die, zonder machtiging door de wetgever, voor het aanleggen van openbare vervoermiddelen op de vaart tussen Delfzijl en Groningen een concessie eist, onverbindend wordt geoordeeld. Uit dit arrest komt naar voren dat juist omdat de met het 'overheidsrecht iure publico' samenhangende beheerstaak met be- 
trekking tot publiek domein de verplichting impliceert ervoor te zorgen dat zie zaak aan zijn publieke bestemming blijft beantwoorden - zodat (in ieder geval) een normaal gebruik conform die bestemming mogelijk blijft -, de daaraan inherente bevoegdheid tot het geven van algemene politievoorschriften slechts zó ver kan gaan als nodig is voor de instandhouding van de publieke bestemming van die zaak en dus niet kan worden gebruikt om 6́ók het normale gebruik (het 'Gemeingebrauch') in algemene zin te verbieden of van een vergunning afhankelijk te stellen. Die bevoegdheid geeft, aldus de Hoge Raad:

'geen regt .... om het aanleggen van openbare vervoermiddelen op vaarwaters of wegen, die ten gerieve van het algemeen bestemd zijn, afhankelijk te stellen van het verleenen van vergunningen of concessies onder bepaalde voorwaarden, en om op deze wijze het vrije verkeer op de wateren en wegen, en het bezigen van zoodanige vervoermiddelen in het algemeen te beperken' (curs. dzz; JT) ${ }^{\infty}$.

\section{Artikel 56 van de Grondwet 1887}

Bij de herziening van 1887 wordt in de Grondwet een nieuw art. 56 opgenomen. luidende:

'Door de Koning worden algemene maatregelen van bestuur vastgesteld. Bepalingen door straffen te handhaven, worden in die bepalingenniet gemaakt dan krachtens de wet. De wet regelt de op te leggen straffen'.

In het voorstel van de Staatscommissie tot herziening van de Grondwet was gesproken van 'voorschriften ... door strafbepaling of politiedwang te handhaven', doch dit voorstel is door de regering niet overgenomen ${ }^{70}$. Hieruit is door verschillende auteurs de conclusie getrokken dat de Kroon nog wel de bevoegdheid zou bezitten algemeen bindende gedragsregelen vast te stellen, die enkel door politicdwang en niet door straf gehandhaafd worden ". Van der Burg acht deze conclusie aanvechtbaar ${ }^{72}$ : de parlementaire behandeling staat algemeen als verward te boek en kan weinig licht verschaffen in deze materie. Omdat o.i. uit de voorgeschiedenis van de grondwetsherziening naar voren komt dat met het materiële wetsbegrip (en de inperking van de 'politiebevoegdheid') is beoogd het private domein van de burger te beschermen tegen ingrepen die niet hun grondslag vinden in een met medewerking van de Staten-Generaal tot stand gebracht regeling ${ }^{73}$, achten wij die conclusie wél juist, met dien verstande dat bedoelde - zonder specifieke formeelwettelijke grondslag te stellen - te stellen algemene regels slechts betrekking zouden mogen hebben op het publiek domein. En dit wordt bevestigd door de hieronder te bespreken totstandkomingsgeschiedenis van de wet van 28 februari 1891, Stb. 69 . inzake 's Rijks Waterstaatswerken.

Wat uit de parlementaire behandeling van de grondwetsherziening in ieder geval duidelijk naar voren komt, is dat de regering zich niet wil vastleggen op het standpunt dat het politieapparaat slechts zou mogen optreden ter handhaving van de wet ${ }^{74}$, 
en dat zij niet instemt met de opvatting dat politiebevelen en andere 'bijzondere dwangmiddelen' steeds in de wet genoemd zouden moeten worden. Overigens was ook het voorstel van de Staatscommissie - waarin wél wordt gesproken van 'politiedwang' - slechts betrokken op de handhaving van 'voorschriften', niet op de concrete politiebevelen, bij niet-naleving waarvan de politiedwang als specifieke sanctie wordt toegepast. Binnen deze commissie was, met 12 tegen 4 stemmen, het voorstel van Lohman verworpen, luidende:

'Door den Koning kunnen aan particulieren geen verplichtingen worden opgelegd, dan binnen bij de wet gestelde grenzen.'

Daartegen was door de meerderheid aangevoerd dat het niet zou stroken met de opzet om slechts voor de algemene maatregelen van bestuur een regeling te treffen.

\section{De wet van 28 februari 1981, Stb. 69, inzake 's Rijks Waterstaatswerken}

Dat ook na de grondwetsherziening van 1887 nog een zelfstandige bevoegdheid van de Kroon wordt aangenomen tot vaststelling van algemeen bindende gedragsregels voor publiek domein, komt - als gezegd - naar voren bij de totstandkoming van de wet van 28 februari 1891, Stb. 69, inzake 's Rijks Waterstaatswerken.

Ten tijde van die grondwetsherziening geldt nog steeds de, telkens verlengde, Wet van 6 maart 1818 (zgn. 'Blanketwet'), die - uitgaande van de oude opvatting dat de Koning uit hoofde van zijn soevereiniteit ook de bevoegdheid bezit om zelfstandig algemeen bindende regels te stellen - de niet-naleving van bij algemene maatregelen van bestuur gestelde voorschriften van een strafsanctie voorziet.

Omdat deze wet per 1 september 1891 zou komen te vervallen, zouden al die maatregelen vanaf die datum zonder strafsanctie zijn. Om die reden dient de regering bij de Staten-Generaal een wetsvoorstel in om de Koning in staat te stellen in de voor het gehele gebied van 's Rijks Waterstaat te treffen algemene maatregelen van bestuur bepalingen op te nemen, door straffen te handhaven. Dit wetsvoorstel leidt tot de wet van 28 februari 1891 .

Neemt men kennis van de considerans van het wetsvoorstel, van de tekst van artikel 1 van de wet en van de parlementaire stukken, dan komt daaruit duidelijk naar voren dat de wetgever ervan is uitgegaan dat de wet niet bedoeld is als attributief ten opzichte van 's Konings bevoegdheid tot het stellen van algemeen bindende regels inzake het beheer van rijkswaterstaatswerken. De considerans van het (gewijzigde) wetsvoorstel luidt:

'Alzoo wij in overweging genomen hebben, dat er behoefte bestaat aan eene wet, krachtens welke door Ons in de vast te stellen algemeene maatregelen van bestuur kunnen worden opgenomendoor straffen te handhaven bepalingen ter bescherming van 's Rijks-waterstaatswerken, alsmede ter verzekeringvan het veilig en doelmatig gebruik dier werken, en dat die straffen behoorente worden geregeld bij de wet'.

De Koninklijke bevoegdheid tot het stellen van algemene politievoorschriften voor deze waterstaatswerken - publiek domein dus - wordt kennelijk vóórondersteld. 
Omdat echter voor door straffen te handhaven bepaling een wettelijke basis is vereist, wordt in verband met het vervallen van de wet van 6 maart 1818 een nieuwe wet nodig geacht.

Men zie ook artikel 1 van de wet:

'Door Ons worden, ter bescherming van 's Rijks-waterstaatswerken, alsmede ter verzekering van het doelmatig en veilig gebruik dier werken, voorzoover daarin niet door eene wet of door Ons krachtens eene wet is voorzien, bij algemeenen maatregel van bestuur vastgesteld door straffen te handhaven bepalingen ...enz.'

Hieruit komt een onderscheid naar voren tussen enerzijds de algemene maatregelen van bestuur 'waarin door Ons krachtens de wet is voorzien' en anderzijds de algemene maatregelen van bestuur die slechts in zoverre het uitvloeisel zijn van een wet - te weten de wet van 28 februari 1891 - dat daarin door straffen te handhaven bepalingen zijn opgenomen.

Ook bij de parlementaire behandeling wordt dit standpunt ingenomen door de regering en het merendeel van de kamerleden. Maar uit de omstandigheid dat dit standpunt door een aantal andere kamerleden fel is bestreden, blijkt ook dat dit standpunt niet meer als vanzelfsprekend wordt beschouwd ${ }^{75}$.

Van der Burg wijst er op dat de in de literatuur verdedigde stelling dat de Kroon nog wel de bevoegdheid heeft zelfstandige algemene maatregelen van bestuur te stellen die door politiedwang gehandhaafd zouden kunnen worden, voor de praktijk nauwelijks van enig belang is gebleken ${ }^{76}$.

Daarbij merken wij op dat dergelijke zelfstandige algemene maatregelen van bestuur, wanneer ze naar buiten werkende regels zouden bevatten ten aanzien van privaat domein van de burgers, o.i. in ieder geval ongrondwettig zouden zijn, 6́6k voorzover die regels slechts door politiedwang gehandhaafd zouden kunnen worden. Tegen zelfstandige algemene maatregelen van bestuur waarbij uit hoofde van de statelijke beheerstaak ten aanzien van publiek domein gebruiksregels worden gesteld, verzet art. 56 van de Grondwet van 1887 zich o.i. niet, althans voorzover dergelijke regels slechts door politiedwang te handhaven zijn.

De praktijk laat daarvan echter slechts een enkel voorbeeld zien ${ }^{7}$, hetgeen mede hierin zijn verklaring zal vinden in de behoefte dergelijke gebruiksregels ook door strafsancties te kunnen handhaven. De sanctie door politiedwang, zonder de sanctie door straf daarnaast, is weinig gebruikelijk. In de praktijk komt dan ook 'politieregelgeving' - zonder bevoegdheidsgrondslag in de wet - ten aanzien van publiek domein niet meer voor.

Maar betekent dit óók dat voor 'politiebestuur' in het kader van de beheerstaken ten aanzien van publiek domein, steeds een expliciete bevoegdheidsverlenende titel in de wet moet kunnen worden aangewezen? De totstandkomingsgeschiedenis van art. 
danken. Niet zo vanzelfsprekendzijn beperkingen, die uit ongeschrevenregels van het publieke recht voortvloeien. Daar echter het publieke recht niet enkel uit wettelijke voorschriften bestaat, wordt ook hier van het buitenwettelijke recht gebruik gemaakt. Ook de Hoge Raad heeft zodanige beperkingenvan het ongeschrevenrecht erkend' $\$$.

Hij verwijst dan in een noot naar het arrest van 12 januari 1923 inzake Schielands Hoge Zeedijk. Nu kan worden ingestemd met Meijers' opvatting dat het publiekrecht méér is dan wettenrecht; de verwijzing naar dit arrest is o.i. echter niet op haar plaats, omdat het daarin niet gaat om eigendom die 'tot volle' - burgerrechtelijke 'wasdom' is gekomen. Beperkingen van 'volle burgerrechtelijke eigendom' zullen o.i. hun basis moeten vinden in wettelijke voorschriften ${ }^{100}$.

Dat het overheids 'recht' - het 'toebehoren als gezagsrecht', voorheen 'hoogheidsrecht' 101 - op publiek domein primair een (publiekrechtelijke) beheersbevoegdheid, tevens plicht, is - en geen burgerlijk eigendomsrecht, dat een vrije beschikkings- en gebruiksbevoegdheid impliceert -, is reeds zeer duidelijk tot uitdrukking gebracht in een arrest van de Hoge Raad van 22 mei en 26 juni 1863, waarbij is geoordeeld dat de Zuidplaspolder onbevoegdelijk in een bij dit openbaar lichaam in beheer zijnde ringvaart een dam had aangelegd nu daardoor een openbare vaarweg was

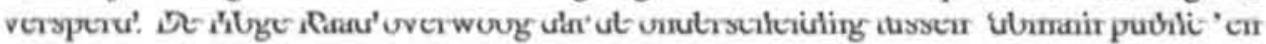
'domain privé',

'hoewel niet met name vermeld in het Burgerlijk Wetboek, niettemin niet in strijd is met eenig daaruit aangehaald artikel, en integendeel noodzakelijk volgt uit de artt. 577 tot 581 van dat wetboek, en dat, zodra deze onderscheiding vaststaat, zij noodzakelijk medebrengt, dat een dominium jure publico, ter voldoening aan de bestemming ten gebruike van het publiek, oplegt eigenaardig daaruit voortvloeijende verpligtingen, waartoe een eigenaar jure privato niet is gehouden' 102 .

Dat het bedoelde overheids'recht' op publiek domein geen privaat subjectief vermogensrecht is, is ook goed inzien door de Hoge Raad in een arrest van 29 april 1910. Dit arrest betreft een door het heemraadschap Mark en Dintel ingestelde schadevergoedingsvordering tegen het waterschap Bloemendaal, dat jegens het heemraadschap een onrechtmatige daad ex art. $1401 \mathrm{BW}$ zou hebben begaan doordat het water had onttrokken aan de rivier de Mark en Dintel en daarmee inbreuk zou hebben gemaakt op het aan het heemraadschap toekomend uitsluitend recht van beheer over die rivier. Deze vordering wordt door de Hoge Raad niet-ontvankelijk verklaard, omdat:

'de inbreuk op een publiekrechtelijk beheersrechtniet is een inbreuk op enig vermogensrechten dus niet oplevert een onrechtmatige daad die een burgerrechtelijkeverbintenis doet ontstaan, waardoor het waterschap tot schadevergoedingingevolge art. 1401 BW zou kunnen worden verplicht' ${ }^{105}$.

Dit oordeel is o.i. juist, als de Hoge Raad bedoelt te zeggen dat i.c. geen privaat vermogensrecht in het geding is. Indien de vordering niet was gebaseerd op art. 
$1401 \mathrm{BW}$ maar aangeduid als een publiekrechtelijke schuldvordering, had zij o.i. wél ontvankelijk behoren te worden verklaard.

Van een publiekrechtelijke - althans niet-burgerrechtelijke - benadering van 'toebehoren' in de zin van de artt. 575 e.v. BW geeft evenzeer blijk een arrest van de Strafkamer van de Hoge Raad van 20 juni 1927. Geoordeeld wordt dat iemand dat zonder jachtakte in de Waddenzee op pluvieren jaagde, niet handelde in strijd met de Jachtwet 1923, omdat volgens deze wet slechts het bezit van een jachtakte vereist was voor het jagen op gronden en wateren 'welke burgerrechtelijk in eigendom toebehooren aan natuurlijke of rechtspersonen' ${ }^{104}$.

Nog in 1931 besluit Vos zijn opstel over 'publiek domein' - waarin hij het als een 'onmogelijke figuur' aanmerkt dat de Staat tevens privaatrechtelijk eigenaar zou zijn van publieke zaken - met de woorden:

'(D)at ooit de Hooge Raad zou meegaan met een leer, die het de Staat mogelijk maakt de beginselen, die hem met betrekking tot een zaak als overheid krachtens publiek recht binden, als eigenaar van de zaak krachtens privaat recht weder op zij te zetten, achten wij niet goed denkbaar' 106 .

Thorbeckes opvattingen worden in de Nederlandse rechtspraktijk helaas niet (meer) gevolgd: mét de opkomst aan het eind van de vorige eeuw van de leer die het burgerlijk recht ziet als het gemene recht - verdedigd door Hamaker en, wat later, door Krabbe - kon ook de opvatting ingang vinden dat de voor de openbare dienst bestemde zaken ten dele buiten de handel zijn ${ }^{106}$.

Nadat in de tweede helft van de negentiende eeuw de publiekrechtelijke benadeling van het publiek domein heeft gedomineerd, heeft zich reeds vanaf het laatste decennium van die eeuw - mét de opkomst van de leer die het burgerlijk recht ziet als het gemene recht (Hamaker, Krabbe) - een omslag gemanifesteerd ${ }^{107}$. De door Vos nog bestreden leer is in 1941 blijkens de jurisprudentie van de Hoge Raad de heersende geworden:

'de tegenwoordig ten onzent heerschende leer, volgens welke het recht van den Staat op voor den openbaren dienst bestemde zaken zich niet onderscheidt van den privaat-eigendom van bijzondere personen op zoodanige zaken, zoodat den Staat, evenzeer als bijzondere personen, alle rechten op die zaken toekomen, voorzooverde publiekrechtelijke bestemming daarop geen inbreuk maakt', aldus procureur-generaal Berger in zijn conclusie vóor het Parlevinker-arrest ${ }^{108}$. Dit arrest en arresten als het IJsselmeerarrest, het arrest-Eindhoven/Staals en het Windmillarrest worden gezien als toepassingen van wat in Nederland de gemene rechtsleer wordt genoemd, op welke leer de twee-wegen-leer wordt gebaseerd. Daarbij is de vraag aan de orde naar het gebruik maken door 'de overheid' van 'privaatrechtelijke bevoegdheden' náást of in plaats van publiekrechtelijke bevoegdheden. In het arrest-Eindhoven/Staals luidt het: 
'dat de vooronderstelling waarvan de wetgever in 1851 t.a.v. de bestaanbaarheidvan privaatrechtelijke overeenkomsten met betrekking tot voor de openbare dienst bestemde gemeentewerken, bezittingen en inrichtingen is uitgegaan, ... niet in overeenstemming is met de thans geldende rechtsopvattingen, volgens welke aan een gemeente als eigenares van dergelijke voor de openbare dienst bestemde zaken alle bevoegdheden toekomen die het burgerlijk recht aan iedere eigenaar toekent ...., voor zover de bestemming tot die openbare dienst daardoor niet worden aangetast' ${ }^{\prime} 0$.

\section{En in het IJsselmeerarrest wordt overwogen:}

'dat ... art. 577, door den Staat ... tot eigenaar te maken van de in het artikel genoemde zaken, waartoe het Usselmeer behoort, aan den Staat t.a.v. het Usselmeer dezelfde bevoegdhedenheeft gegeven, die krachtens de artt. 625 e.v. aan iederen eigenaar van een onroerende zaak toekomen; dat daarmede onverenigbaar is dat de Staat als eigenaar van het Usselmeer tegenover zich zou moeten laten gelden een door den Staat niet in het leven geroepen bestemming van dat meer tot het opnemen van rioolwater ... welke bestemming slechts zou kunnen worden beëindigd of beperkt 'langs publiekrechtelijkeweg', waarmede het Hof blijkbaar doelt op het gebruik van publiekrechtelijke bevoegdhedenvan den Staat; (...)

dat het aan den eis ten grondslag gelegde recht op het Usselmeer, dan den Staat krachtens art. 577 toekomt, 'eigendom' is in de zin van art. 2 R.O., en een inbreuk op dat recht 'onrechtmatig' is in den zin van art. 1401 BW' 110 .

Zoals blijkt uit dit arrest, zou (o.a.) schending van die 'eigendom' een grond bieden voor een vordering uit hoofde van onrechtmatige daad ex art. $1401 \mathrm{BW}$ (Zie thans art. 6:162 $\mathrm{BW}$ ). In het Windmillarrest - waarin het gaat om publiek domein, te weten de Nieuwe Waterweg - poneert de Hoge Raad in algemene zin de opvatting, dat 'de overheid' publieke belangen ook mag behartigen 'door gebruik te maken van haar in beginsel krachtens het privaatrecht toekomende bevoegdheden, zoals aan het eigendomsrecht ontleende bevoegdheden ... of de bevoegdheid een vordering op grond van een jegens haar gepleegde onrechtmatige daad bij de burgerlijke rechter in te stellen', welke bevoegdheden alleen dan niet gebruikt mogen worden wanneer daardoor een publiekrechtelijke regeling 'op onaanvaardbare wijze (wordt) doorkruist' II'. In Deel II zullen we aangeven, waarom de opvatting dat 'de overheid' in beginsel beschikt over 'privaatrechtelijke bevoegdheden' ter behartiging van publieke belangen, en meer in het bijzonder de opvatting dat het publiek domein is te beschouwen als burgerrechtelijke eigendom, voor ons niet aanvaardbaar is. 


\section{Noten bij hoofdstuk 3}

1. Volgens Rudolph von Gneist, 'Der Rechtsstaat und die Verwaltungsgerichte in Deutschland', 2e druk, Berlin 1879, Hfdst. I, nt. 2 (p. 333), is het woord 'Rechtsstaat' in de wetenschap ingevoerd door Robert von Mohl (1799-1875), in het bijzonder door zijn 'Die Polizei-Wissenschaft nach den Grundsâtzen des Rechtsstaates', 2 din, Tübingen 1832/1833 (waaraan bij de $2 \mathrm{e}$ druk in 1844/1845 een derde deel is toegevoegd met als titel 'System der Prilventiv-Justiz oder Rechts-Polizei') en zijn 'Die Geschichte und Literatuur der Staatswissenschaften', Erlangen 1855. Dit laatste werk wijdt een heel hoofdstuk aan de 'Entstehung und Bildung des Rechtsstaates'. Zie over Von Mohl: R. Victor, 'Rechtsstaat en welvaartsstaat bij Robert von Mohl', in: 'Album Professor Fermand van Goethem', Antwerpen 1964. pp. 623-636.

2. Bij het Besluit van de Soevereine Vorst van 26 maart 1814, Stb. 46, 'houdende provisionele bepalingen wegens de toekomstige uitoefening der voormalige heerlijke regten',

3. HR 30 juni 1879, W. 4406 (Meerenberg-arrest).

4. Vgl. Herbert Krüger, 'Allgemeine Staatslehre', 2e druk. Stuttgart/Berlin/Köln/Mainz 1966, p. 329. In het begin van de 19de eeuw wordt de zgn. patrimoniele staatsopvatting nog verdedigd door Haller, die in Nederland aanvankelijk wordt gevolgd door Groen van Prinsteren. Haller ontkent de onderscheiding privaatrecht-publiekrecht, omdat alle macht van de vorst zou steunen op diens oppereigendom van het staatsterritoir. Vgl. Poortinga, a.w., p. 97/98.

5. $\mathrm{Vgl}$. Hardenberg, a.w., pp. 341-371; Van den Bergh, 'Iets over publiek- en privaatrecht', a.w., pp. 9 . 17.

6. Van den Bergh, 'Iets over publiek- en privaatrecht', a.w., p. 15.

7. B. de Goede, 'Het beheer in het waterstaatsrecht', diss. Leiden 1951, p. 42, wijst erop dat in de voorheen gebruikelijke term 'behering' de betekenis van: 'het geven van een heer' is ingesloten. Denk in dit verband ook aan de term 'heerlijke rechten'. Bij deze publiekrechtelijke beheersbevoegdheid tevens -verplichting kan echter geen sprake meer zijn van een privaat vermogensbelang van de beheerder. Bij de oude heerlijke rechten waren 'publieke' bevoegdheden en 'private' vermogensbelangen (van de 'heer') echter nog op een ongedifferentieerde wijze met elkaar vermengd.

8. Hardenberg, a.w., p. 362/363. De term 'toebehooren' kwam o.a. voor in art. 577 BW-oud, dat repte over het aan de Staat 'toebehooren' van de bevaarbare en vlotbare stromen en rivieren.

9. G. van Maanen, 'Publiek domein en twee-wegenleer', Recht en kritiek 1990, pp. 198-209 (p. 204/205).

10. Van Maanen, t.a.p., p. 204. Vgl. ook Hardenberg, a.w., p. 357.

11. Dit betekent de gelijke gelding van het publiekrecht voor alle mensen op het staatsterritoir - implicerende gelijkheid van alle burgers voor de wet; geen privileges voor bijzondere personen of groepen; gelijke verdeling van de publieke lasten over de burgers - alsmede de publiekrechtelijke status activus (actief en passief kiesrecht) voor iedere staatsburger - implicerende een representatieve democratie.

12. Dit wordt onderkend door Robert von Mohl, die er in slaagt een synthese tot stand te brengen tussen de liberale rechtsstaat en de sociale staat. Enerzijds zoekt hij waarborgen voor de individuele vrijheid tegen een almachtig staatsgezag en legt hij het er op aan aan de Staat juridische beperkingen op te leggen, waardoor staatswillekeur wordt voorkomen en rechtszekerheid wordt geboden. Maar de negatieve begrenzing die hierin gelegen is dat door het recht grenspalen zijn gesteld voor het overheidsoptreden, acht hij niet voldoende. Om de individualiteit van alle burgers tot haar ontplooiing te kunnen laten komen en aldus een wezenlijke rechtsstaat te zien ontstaan, acht hij het $66 \mathrm{k}$ nodig dat een bescherming wordt geboden tegen sociale en economische dwang en dat ook andere sociale en economische belemmeringen worden opgeruimd die deze volle ontplooiing in de weg staan. In 1833 pleit hij in zijn 'Die Polizei-Wissenschaften', a.w., reeds voor alle sociale hervormingen die vanaf de tweede helft van de 19de eeuw tot stand komen: verbetering van de materiele toestand van de fabrieksarbeider, vergoeding van arbeidsongevallen, beperking van arbeidsduur en van kinderarbeid etc. 
13. Vgl. Mekkes, a.w., pp. 330 e.v. De concepties van Locke en Rousseau komen hierin overeen, dat ze alléén de individuele burgers worden gezien, die slechts in de Staat tot gemeenschap zijn gekomen, en dus geen eigen rechtskringen van niet-statelijke gemeenschappen onderkennen. Op het grote belang van de vrije verenigingen als tegenwicht tegen de staatsmacht, is - zoals we zagen - door Tocqueville gewezen.

14. J.G. Locré, 'Esprit du Code Napoléon, tiré de la discussion', Parijs 1805 , geciteerd bij J, van der Poel, 'Rondom compositic en compromis', a.w., p. 197.

15. Dit wordt bezegeld in de Code Pénal (1810/1811) en de Code d'instruction Criminelle (1808, ingevoerd $1810 / 1811$ ). Het zal duidelijk zijn dat het begrip 'criminelle' hier, evenals het woord 'lijfstraffelijk' in art. 163 van de Nederlandse Grondwet van 1815, een ruimere betekenis heeft dan vóór de revolutie. In art. 1 Code Pénal - dat tot 1886 ook in Nederland nog van kracht zal blijven - komt overigens het oude onderscheid nog tot uitdrukking: art. 1 onderscheidt tussen contraventies, wanbedrijven (de delicten, bedreigd met 'correctioneele straffen') en misdaden (bedreigd met lijf- en onterende straf), al heeft deze onderscheiding niet meer de principiēle betekenis van voorheen. Aanvankelijk wordt dit karakterverschil nog tot uitdrukking gebracht doordat contraventies moeten worden gebracht voor de politierechter, crimes voor de criminele rechter en delicten - die een 'caractêre mixte' hebben - voor de correctionele rechter.

Overigens blijft op het terrein van de belastingen, waarschijnlijk uit pragmatische overwegingen, het oude stelsel van door de (belasting)administratie zelf op te leggen boeten bestaan. De oude terminologie 'civiel' in oude zin overleeft hier dan ook. Ook de vordering tot betaling van belasting blijft men als 'civiel' aanmerken. $\mathrm{Vgl}$. de procesregeling vervat in de artt. 246-249 Algemene Wet van 26 aug. 1822, Stb. 38, omtrent de heffing en verzekering van de Invoerrechten en Accijnzen, 0 .a. bepalende dat 'in louter civiele zaken' moet worden geprocedeerd vigs. het Wetboek van Burgerlijke Rechtsvordering. Dit vindt hierin zijn verklaring, dat men voor dergelijke zaken geen procedure bij de strafrechter wil. $\mathrm{Er}$ is echter nog geen administratieve rechter. Onder 'civiel' wordt hier verstaan het niet-poenale publiekrecht voorzover betrekking hebbend op de vermogensrechtelijke verhoudingen tussen (belasting)fiscus en burgers, i.c.: het niet-poenale belastingrecht. Dat de term 'fiscus' tegenwoordig wordt gebruikt als aanduiding van de belastingsfiscus is dus ook historisch verklaarbaar. $\mathrm{Vgl}$. ook HR $16 \mathrm{okt}$. 1876, W. 4045, waarin wordt overwogen dat de vordering tot betaling van verschuldigde accijns uit haar aard een civiele actic in de zin van art. 249 Wet van 1822 is. In HR 22 jan. 1868, W. 2978, wordt zelfs de boete wegens een overtreding (van een belastingwet) nog aangemerkt als civiel ("bloot burgerrechtelijke schadeloosstelling'). Degenen die zich ter verdediging van de gemene rechtsleer (mede) beroepen op de aanduiding van dergelijke belastinggeschillen als 'civiel' c.q. 'burgerrechtelijk' en op de competentie van de gewone rechter in dergelijke geschillen, miskennen dat deze termen hier worden gebruikt in de oude, ruime betekenis ervan. En als men later de versehillen tussen de belastingrechtspraak en andere vormen van administratieve rechtspraak wil verklaren met verwijzing naar de 'civielrechtelijke' oorsprong van de belastingrechtspraak, dan wordt die term wederom ten onrechte opgevat in de moderne, enge betekenis.

Tenslotte: de huidige ontwikkelingen om lichte overtredingen uit het strafrecht te halen en onder te brengen in het bestuursrecht (voorbeeld: lex-Mulder), zijn dus niet zo vernieuwend als wel gedacht wordt!

16. Van der Burg, 'Preventieve justitie en plaatselijke politie', a.w., p. 13, merkt op dat de toewijzing van deze zaken aan de strafrechter naar hedendaagse Nederlandse opvattingen overtuigend toeschijnt: bestraffing van strafbare feiten is rechtspraak en komt daarom toe aan de rechterijke macht. 'Daarbij gaan wij" - aldus Van der Burg - 'echter al uit van een begrip rechtspraak, dat destijds zeker nog niet vanzelf sprak'. En de contraventies en de delicten behoorden van oudsher niet tot het terrein van het criminele recht. Wel kon in het algemeen de rechter worden geadieerd, doch de desbetreffende zaken werden op de civiele wijze, niet op de criminele wijze door de rechter behandeld.

17. Tribunal des Conflits 8 febr. 1873, D. 1873.3.17 (Blanco). We gaan in hoofdstuk 2 nader in op de ontwikkelingen, ook in Frankrijk, op het punt van de onrechtmatige overheidsdaad.

18. Positivering van het burgerlijk recht is dus ook geboden i.v.m. het statelijk ' $Z$ wangsmonopol'. 
19. Geciteerd door Troplong. 'Mémoires de TAcademie Sciences Morales et Politiques, 1850, 95, aangehaald door: B. Bouckaert, 'De exegetische school', diss. Gent 1980-1981. Antwerpen 1981, p. 248.

20. P.A. Fenet, 'Recueil Complet des Travaux Préparatoires du Code Civil', Paris 1827, dl. I. p. 465, herdrukt in Osnabrück, Zeller 1968. Geciteerd door Bouckart, a.w., p. 111/112. Van de 'Discours' is een Nederlandse vertaling met toelichtingen verschenen: J.E.M. Portalis, 'Inleidingsrede', vertaald, toegelicht en besproken door Bert van Roermond, Fernand Tanghe en Harry Willekens, Zwolle 1994.

21. Fenet, a.w., p. 464 . Bouckaert, a.w., p. 452 (nt. 83) vermeldt dat de uitspraak 'Tout devient droit public' overeenkomt met de uitspraak van Lenin in 1922 n.a.v. de discussie omtrent het project voor een Code van het Contractenrecht: 'Wir erkennen nichts Privates an, für uns ist alles im Bereich der Wirtschaft offentlichrechtlich, aber nicht privat. Wir erlauben den Kapitalismus nur dem Staat, aber der Staat sind wir. Deshalb ist die Staatseinmischung in Privatrechts-Verhalltmisse und das Recht des Staates, 'Privat'-Verträge zu annulieren, $\mathrm{zu}$ erweitern. Nicht das 'corpus iuri romani' ist auf Zivilrechtsverhalltnisse anzuwenden, sondern unser revolutionäres Rechtsbewusstsein'. Aldus geciteend door $\mathrm{N}$. Reich, 'Sozialismus und Zivilrecht', Frankfurt aM 1972, p. 134.

22. Fenet, a.w., p. 476.

23. Een opvatting die door ons volledig wordt onderschreven, behoudens voorzover Portalis aan die bovenwillekeurige materiele rechtsbeginselen een eeuwig en onveranderlijk ('immuable') karakter toedenkt. Materiële rechtsbeginselen zijn constant én tegelijkertijd dynamisch, d.w.z. ze ontwikkelen en ontplooien zich in de loop van het cultuurhistorisch ontwikkelingsproces (het dynamische karakter) mét behoud van een vaste kem (het constante karakter). Zie hieromtrent uitvoerig: H.J. van Eikema Hommes, 'Relatieve constantie en dynamiek in de rechtsvorming', in: 'Recht als instrument van behoud en verandering', opstellenbundel voor J.J.M. van der Ven, Deventer 1972, pp. 27-34. Vgl. over de natuurrechtelijke inslag van 'Livre' en 'Discours Préliminaire' ook: F.A. Hayek, 'The Constitution of Liberty", London 1960, p. 195 en p. 480, nt. 9.

24. Ook de opvatting dat de rechters slechts de 'bouches de la loi' (de emanatie van de volkswil) zijn, wordt in de 'Discours' uitvoerig door Portalis betreden. Een civiele code zal z.i. noodzakelijkerwijs onvolledig zijn, zodat de rechter de wet moet interpreteren en aanvullen. Nadere positivering van de aan de Code ten grondslag liggende rechtsbeginselen zal dus door de rechter moeten plaatsvinden. Omdat het de primaire taak is van de rechter de natuurlijke rechten van de burgers te beschermen, en omdat de wetgeving ter zake onvermijdelijk lacunes zal vertonen, is het volgens Portalis de plicht van de rechter om bij lacunes een oplossing ten gronde te zoeken door terug te grijpen naar natuurrecht en gewoonterecht. De opvatting dat een civiele wetgeving volledig en exclusief zou kunnen zijn, is z.i. een waanidee omdat een op persoonlijke vrijheid en private eigendom gesteunde maatschappij onvermijdelijk een rijke diversiteit in sociale relaties ontwikkelt:

'Quoique I'on fasse, les lois positives ne sauraient jamais entièrement remplacer l'usage de la raison naturelle dans les affaires de la vie. Les besoins de la société sont si variés, la communication des hommes est si active, leurs intérêts sont si multipliés, et leurs rapports si étendus, qu'il est impossible au législateur de pourvoir à tout' (Fenet, a.w., p. 469; Bouckaert, a.w., p. 176).

25. Met name in de tweede helft van de 19 e eeuw zal echter de rechtswetenschap gevoerd worden in de banen van de zgn. 'exegetische school', die in een radicaal positivisme van niets meer wil horen dat van de wet en haar interpretatie. Men meent dan dat door de codificatie het recht kan en klaar is gepositiveerd en dat de rechtswetenschappelijke arbeid zich tot de exegese kan beperken. Zie over deze 'exegetische school' uitgebreid: Bouclaert, a.w.

26. Fenet, a.w., pp. $481-488$.

27. Fenet, a.w., p. 466; Bouckaert, a.w., p. 112.

28. Hardenberg, a.w.

29. J. van Kan, 'Het Burgerlijk Wetboek en de Code Civil', in: 'Gedenkboek Burgerlijk Wetboek 18381938, red. Paul Scholten/E.M. Meijers, Zwolle 1938, pp. 243-276, met talrijke verwijzingen.

30. J.J. Rousseau, 'Du contract social', 1762, ch. III cap. I.

31. Rousseau, a.w., ch. III. cap. X. 
32. Op het dualisme Staat-'maatschappij' gaan we in Deel II nader in.

33. A. van der Woud, 'Het lege land (De ruimtelijke orde van Nederland 1798-1848), diss. Groningen 1987, Amsterdam 1987, p. 506. Van der Woud wijst er overigens ook op, dat Willems staatsopvatting tegelijkertijd een 'privaatrechtelijke' is en hij het publiek domein beschouwt alsof het zijn privaatdomein is.

34. Zie omtrent de beinnvloeding van het Nederlandse bestuursrecht door de theorie en praktijk van het Duitse en Franse bestuursrecht: J.P. de Jong. 'Bestuursrecht van vreemde herkomst', diss. Tilburg 1988. Zwolle 1988.

35. Ook door verschillende specifieke wetten, bij voorbeeld de Reichsgewerbeordnung en de wet op de verenigingen wordt de bevoegdheid der politie verder beperkt, of ook wel uitgebreid.

36. PrOVG 16 juni 1882, E 9, 353.

37. Ook art. 28 van de Nederlandse Politiewet van 1957, letterlijk overgenomen in art. 2 van de Politiewet 1993, is ongetwijfeld mede beinvloed door de Pruisische 'Generalklausel'. Art. 2 luidt: 'De politie heeft tot taak in ondergeschiktheid aan het bevoegde gezag en in overeenstemming met de geldende rechtsregels (vgl.: 'im Rahmen der geltenden Gesetze') te zorgen voor de daadwerkelijke handhaving van de rechtsorde en het verlenen van hulp aan hen die deze behoeven'. Tot de 'daadwerkelijke handhaving van de rechtsorde' behoort blijkens art. 12 lid 1 ook de 'handhaving van de openbare orde'.

38. BVerfG 23 mei 1980, E 54, nr. 14 (p. 144/145). Door de klager was betoogd dat er sprake zou zijn van een niet 'hinreichend bestimmte Ermăchtigungsgrundlage', waardoor rechtsstatelijk-democratische beginselen, i.h.b. de 'Grundsatz der Gewaltenteilung', zouden zijn geschonden. Zoals we zagen, gaat die 'Rechtsprechung' zelfs terug tot in de vorige eeuw. Zie m.b.t. art. 28 van de Ned. Politiewet van 1957: HR 24 okt. 1961, NJ 1962, 86, AAe 1962, p. 118 (Zeijense nachtbraker); HR 12 nov. 1963, N]

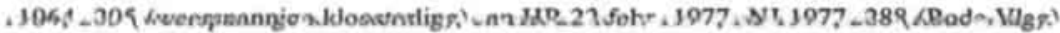

Vgl. ook EHRM 26 april 1979, NJ 1980, 146 (Sunday Times) over de uitleg van het woord 'law' en daarmee samenhangende vereisten in art. 10 lid 2 EVRM: '(T)he word 'law' in the expression 'prescribed bij law' covers not only statute but also unwritten law'. Dit, mits dit recht voldoende 'accessible' en 'foreseeable' is: 'Firstly, the law must be adequately accessible: the citizen must be able to have an indication that is adequate in the circumstances of the legal rules applicable to a given case. Secondly .... it is formulated with sufficient precision to enable the citizen to regulate his conduct'. Zie over het voor strafbepalingen uit art. 103 Abs. 2 Grundgesetz voortvloeiende 'Bestimmtheitsgebot': BVerfG 17 jan. 1978, E 47, nr. 6 (p. 120/121): 'Diese Verpflichtung dient einem doppelten Zweck. Es geht einerseits um den rechtsstaatlichen Schutz des Normadressaten: Jedermann soll vorhersehen können, welches Verhalten verboten und mit Strafe bedroht ist. Im Zusammenhang damit soll andererseits sichergestellt werden, dass der Gesetzgeber über die Strafbarkeit entscheidet: Würde die Entscheidung über die Strafbarkeit eines Verhaltens der volziehenden oder der rechtsprechenden Gewalt überlassen, so wăre dies unvereinbar mit dem Prinzip des Grundgesetzes, dass die Entscheidung über die Beschrănkung von Grundrechten oder uber die Voraussetzung einer Beschrānkung dem Gesetzgeber und nicht den anderen staatlichen Gewalten obliegt'. Bij strafbepalingen moeten strenge(re) eisen moeten worden gesteld aan de 'gesetzliche Bestimmtheit', aldus BVerfG 23okt 1985, E 71, p. 108 (p. 115).

39. Vgl. H.J. Papier, 'Empfehlen sich ergănzende gesetzliche oder untergesetzliche Regelungen der Altlasten, und welchen Inhalt sollten sie haben?', JZ 1994, pp, 810-822, met vele verwijzingen. Zie ook: 'Vorschläge zur Regelung der Altlasten im Rahmen des Bodenschutzes', Diskussionsgrundlage zum 60. Deutschen Juristentag. Munster 1994, waarin ook een uittreksel uit de zgn. 'Referenten-entwurf Bundes-Bodenschutzgesetz' is afgedrukt. Deze regeling zou moeten worden opgenomen in hett.z.t. in te voeren 'Umweltgesetzbuch-Besonderer Teil. De gedachte om, terzake van 'maatschappelijke onzorgvuldigheid jegens de Staat', op te treden op basis van het burgerrechtelijke onrechtmatige daadsartikel komt kennelijk - en terecht - in de hoofden van de Duitse juristen niet op.

40. HR 13 jan. 1879, W. 4330 (Meerenberg-arrest).

41. F.H. van der Burg, 'Preventieve justitie en plaatselijke politie', a.w., p. 71, alwaar er ook op wordt gewezen dat men in woorden als 'politieverordening' nog een herinnering vindt aan de historische opvatting, dat ook het stellen van bepaalde regelen een aangelegenheid van 'politie' was, 
42. 'Er zal worden ingevoerd een algemeen wetboek van burgerlijk regt, van koophandel, van lijfstraffelijk regt, van de zamenstelling der regterlijke magt en van de manier van procederen'.

43. Men houde in het $00 \mathrm{~g}$ dat de termen 'wet in formele zin' en 'wet in materielle zin' uit latere tijd stammen. De door de Kroon gestelde algemeen verbindende regelingen worden in de jurisprudentie van de Hoge Raad geen 'wetten (in materiele zin)' genoemd. De term 'wet' wordt gereserveerd voor regelingen afkomstig van Staten-Generaal en Kroon tezamen, dus van wat eerst later 'de wetgever in formele zin' zal worden genoemd. Pas nadat in het Meerenbergarrest de opvatting heeft gezegeviend, dat de Kroon in beginsel niet zelfstandig bevoegd is tot uitvaardiging van algemeen bindende regelingen en dat dergelijke regelingen slechts gesteld kunnen worden door Staten-Generaal en Kroon te zamen, vindt in de rechtswetenschap de term 'wet in materiele zin' ingang. Uitgangspunt wordt dat de wetgever 'in formele zin bevoegd is tot het stellen van wetten 'in materiele zin' en dat andere organen hun bevoegdheid tot het maken van 'wetten in materiele zin' dienen te ontlenen aan de wet 'in formele zin', in ieder geval voorzover het gaat om door strafsanctie te handhaven regels en regels waardoor de private eigendom wordt beperkt. Het begrip 'wet in materiele zin' is ontleend aan de Duitse rechtswetenschap (m.n. Laband) en door Buys geintroduceend in Nederland.

44. De zgn. Blanketwet. Art. 163 Grondwet 1815 (het codificatie-artikel) eiste immers een formeelwettelijke grondslag voor strafbedreiging.

45. HR 24 febr. 1846, W. 696. Vgl. ook HR 18 juni 1844, W. 506 (broodzettingsarrest), waarbij een door de Kroon afgekondigde a.m.v.b. houdende voorschriften ter voorkoming van bedrog omtrent hoedanigheid en gewicht van brood verbindend wordt geacht. Zie voorts HR 16 mei 1854, W. 1664. inzake diezelfde voorschriften.

46. HR 24 mei 1853, W. 1491.

47. HR 23 maart 1874, W. 3718. Zie voorts o.a. HR 16 mei 1854, W. 1664; HR 31 dec. 1857, W. 1833; HR 22 okt. 1861, W. 2321; HR 1 nov. 1864, W. 2644; HR 24 dec. 1867, W. 2972; HR 15 dec. 1873 , W. 3679; HR 19 maart 1877, W. 4113. Zoals kan worden afgeleid uit ná het Meerenbergarrest (1879) gewezen jurisprudentie van de HR - hierna te bespreken -, zouden de a.m.v.b.'s die aan de orde zijn in de arresten van 1857 en 1867 (Reglementen inzake beurtveren resp. inzake baggeren, graven en vissen in rivieren en langs de zeekust) vermoedelijk ook ná dit arrest verbindend zijn geoordeeld, nu ze gebruiksvoorschriften bevatten m.b.t. publiek domein. Van het in het arrest van 1873 aan de orde zijnde Reglement inzake de visserij op de Schelde en andere Zeeuwsche stromen - eveneens publiek domein - wordt bij HR 30 juni 1879 , W. 4406, wederom de rechtsgeldigheid vastgesteld.

48. Zie bijv. J.R. Thorbecke, 'Aanteekening op de Grondwet', $2 e$ herziene uitgave, 2 delen, Amsterdam 1841-1843, dl. II, p. 91, alwaar inzake de in art. 144 van de Grondwet van 1815 aan provinciale opgedragen 'inwendige policie en oeconomie' wordt aangetekend: 'Gewone inwendige politie behelst echter de binnenlandsche provincieregering niet in haren ganschen omvang, maar ... slechts, overeenkomstig met het oude gebruik, die buiten de defensie, justitie en finantiën'.

49. W.C.D. Olivier, 'Proeve over de beperkingen van den eigendom door het politie-regt', diss. Leiden 1847. In de ruimere betekenis omvat 'politie' volgens Olivier ook deze op zich zelf staande delen van de staathuishouding, en is het 'synoniem van wat men, met andere woorden, noemt administratief regt'.

50. Olivier, a.w., p. 159 en p. 182.

51. Hier zij er nogmaals op gewezen dat de term 'wet in materièle zin' pas aan het eind van de $19 \mathrm{e}$ eeuw opkomt in de Nederlandse literatuur.

52. HR 13 jan. 1879, W. 4330 (Meerenberg-arrest).

53. Kranenburg, a.w., pp. 92 e.v. en p. 349. In vergelijkbare zin: A.A.H. Struycken, 'Het wetsbegrip', in: 'Verzamelde staats- en administratiefrechtelijke opstellen', Arnhem 1918, pp. 61-69, alwaar wordt opgemerkt dat met dit arrest het pleit is beslecht ten gunste van de persoonlijke vrijheid en de modeme rechtsstaatsgedachte is verwezenlijkt.

54. Althans voorzover het niet gaat om publiek domein. Zie hierna. 


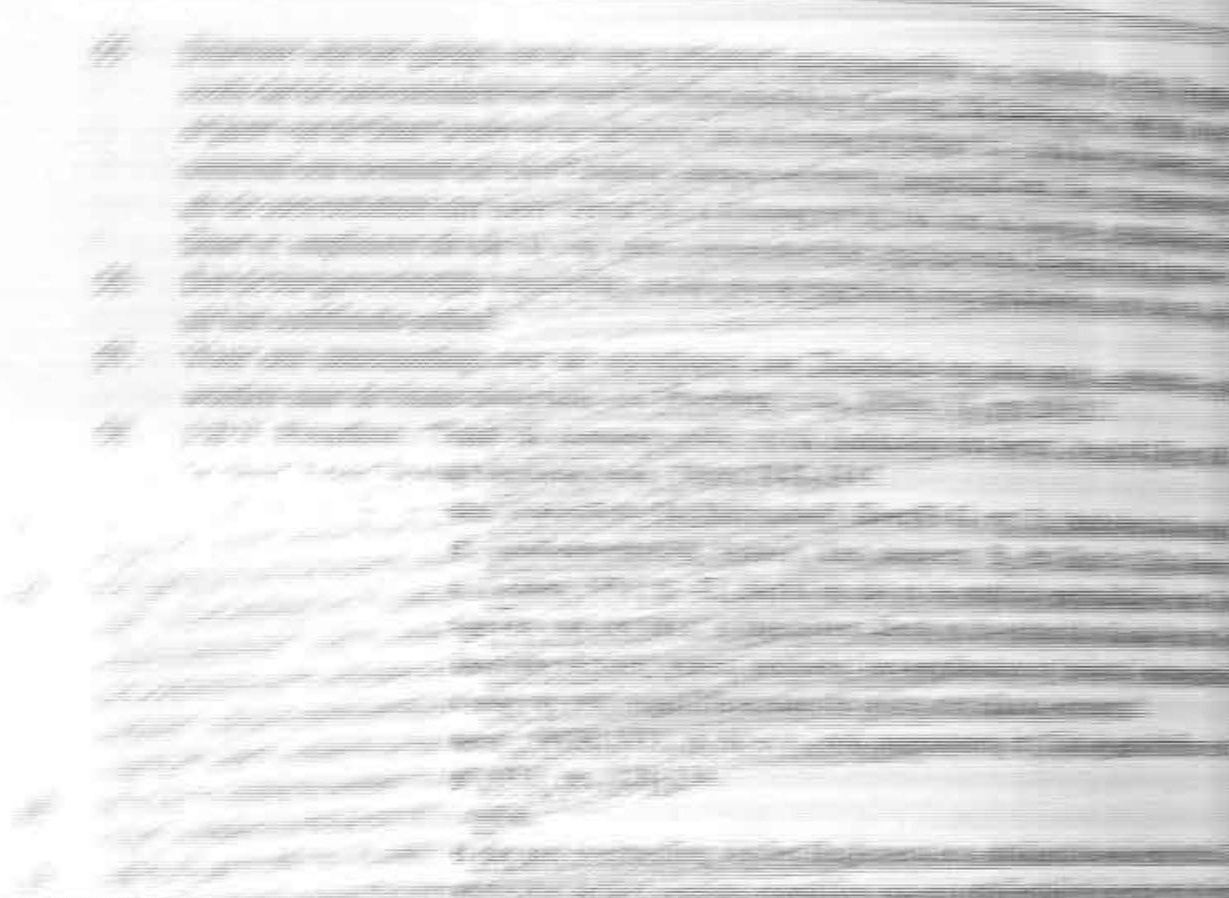

ac grunu weueiyke couilicauc-arukci vereisie gronusiag van een stralbepaling in een wet $n$ formeie zin, kon in de opvatting van adv.-gen, en H.R. echter gevonden worden in de zgn. Blanketwet van 6 maart 1818 , Stb. 12.

63. HR 6 oktober 1884, W. 5086. Zie ook nog: HR 30 juni 1879, W. 4404 (Reglement van politie voor Noordzeekanaal); HR 26 jan. 1880, W. 4477 (Reglement van politie voor het gekanaliseerd gedeelte van de Hollandse Ussel).

64. HR 19 maart 1877, W. 4113.

65. W. Vegting. 'Publiek domein en zaken buiten den handel', Alphen a/d Rijn 1946, p. 223 en p. 223, nt. 4.

66. Niet geheel juist lijkt ook de opvatting van Van der Burg. 'Preventieve justitie en plaatselijke politie', a.w., p. 70, die betoogt dat door de Hoge Raad in het grondwetsartikel betreffende het Koninklijk toezicht over de waterstaat (art. 190 Grondwet 1848) een bepaling is gezien, die aan de Koning politic en daarom ook regelgevende bevoegdheid toekent. Dit grondwetsartikel wordt door de Hoge Raad wel genoemd ter ondersteuning van zijn opvatting, doch de bevoegdheid leidt hij toch primair af uit de publieke beheerstaak van de Staat t.a.v. het desbetreffende publieke domein. In art. 190 wordt alleen bevestigd dat de Kroon het statelijk ambt is, dat terzake competent is.

67. HR 12 april 1880 , W. 4498.

68. Bij HR 24 mei 1853, W, 1491, was het desbetreffende voorschrift rechtsgeldig geacht omdat het zou zijn 'een voorschrift niet van burgerlijk, maar van politieregt'. In 1880 komt de HR niet terug van het standpunt dat het niet gaat om een voorschrift 'van burgerlijk regt', maar aanvaardt hij niet meer de opvatting dat de Kroon zelfstandig, uit hoofde van haar politiebevoegdheid, zou mogen overgaan tot (publiekrechtelijke) regulering van 'burgerlijke rechten', het private domein van de burger dus.

69. HR 20 okt. 1879, W, 4435.

70. Een tijdens de parlementaire behandeling door het kamerlid Van der Kaay ingediend amendement om de woorden 'of politiedwang' alsnog in te lassen in de tekst van art. 56, werd verworpen. Zie over de totstandkomingsgeschiedenis van art. 56 en de interpretaties die gegeven zijn aan dit grondwetsartikel: Van der Burg. 'Preventieve justitie en plaatselijke politie', a.w., pp. 71-72; dez., 'Regelgeving en bestuur', Zwolle 1993, pp. 44-45 en 153-157; C. W. van der Pot, 'Wet en Algemeene mastregel van bestuur in het Nederlandsche Staatsrecht', diss. Leiden 1916. 
71. A.F. de Savornin Lohman, 'Onze Constitutie', 4e vitgave, Utrecht 1926, p. 273 (Lohman is overigens een voorstander van opneming van de woorden 'of politiedwang' in art. 56); C.W. van der Pot, 'Handboek van het Nederlandse Staatsrecht', 6e druk, Zwolle 1957, p. 358; J.P. Oud, 'Het Constitutioneel Recht van het Koninkrijk der Nederlanden', 2 delen, Zwolle 1956-1959, dl. II, p. 207 e.v.

72. Van der Burg. 'Preventieve justitie en plaatselijke politie', a.w., p. 72/73; dez., 'Regelgeving en bestuur', a.w., p. 153-154.

73. Vgl. de woorden van Olivier: 'Het bepalen der regten van eigendom behoort tot het gebied der wetgeving' en de nog ná het Meerenbergarrest gewezen jurisprudentie van de Hoge Raad.

74. In dit verband wordt dus slechts gedacht aan een deel van de 'politie' (in materiele zin), t.w. de politietaken toevertrouwd aan de ambtenaren aangeduid als 'politie'.

75. Men zie hierover: C.H.J. Schepel, 'Wegenrecht in Nederland', diss. Groningen 1895, pp. 158-174, waar de parlementaire behandeling wordt beschreven en waar ook wordt verwezen naar de bestrijding van de opvatting van de tegenstanders van het regeringsstandpunt door de redactie van het Weekblad voor Burgerlijke Administratic, W.B.A. 2149.

76. Van der Burg. 'Regelgeving en bestuur', a.w., p. 153-154.

77. Het standaardvoorbeeld is het KB van 2 juni 1931, Stb. 237, tot regeling van de toelating van vreemde oorlogsschepen binnen het Nederlandse rechtsgebied. Het aan de zelfstandige a.m.v.b. overgelaten terrein overziende, onderscheidt Van der Pot/Donner, a.w., p. 345/346, vier categorieèn: 1 . die a.m.v.b.'s welke hun werking geheel uitoefenen binnen de bestuursorganisatie, zoals het Bezoldigingsbesluit Rijksambtenaren 1948; 2. die a.m.v.b.'s die weliswaar extern werken, maar daartoe een bijzondere sanctie niet behoeven, zoals het KB van 21 mei 1970 tot instelling van het korps van deskundigen ter beschikking voor de technische hulp aan ontwikkelingslanden; 3. de zgn. noodverordeningen, zoals de KB's van 31 juli 1914, Stb. 33, en van 26 sept. 1936, Stb. 52, beide tot verbod van gouduitvoer; 4. die a.m.v.b.'s welke uitsluitend worden gehandhaafd door feitelijke dwang (politiedwang), zoals het genoemde KB van 2 juni 1931, Stb. 237. De enorme toeneming van te regelen zaken, waarvoor de Staten-Generaal niet steeds het aangewezen orgaan zouden zijn, leidt Van der Pot, 'Wet en Algemeene maatregel van bestuur', a.w., overigens tot de opvatting dat een uitbreiding van 's Konings zelfstandige regelgevende macht nodig is tot bepaalde, ruim omschreven groepen van gevallen. In gelijke zin: A.L. de Block, 'Toeneming van de macht der Kroon', or. Tilburg 1938.

78. Zij het dat men primair dacht aan bevelen en dwangmaatregelen door het politie-apparaat.

79. 'Politiebevoegdheden' wordt hier opgevat in de oude, nume betekenis van 'bestuursbevoegdheden'.

80. HR 12 jan. 1923, W. 11060 , NJ 1923, p. 307 (Schielands Hoge Zeedijk).

81. Zie over Otto Mayer uitvoerig: J.P. de Jong. 'Bestuursrecht van vreemde herkomst', Zwolle 1988.

82. Mayer, a.w., Bd. II, p. 116.

83. Mayer, a.w., Bd. II, p. 116.

84. Mayer, a.w., Bd. II, pp. 98 e.v. Dit is de door ons al meermalen genoemde scheiding van 'imperium' en 'dominium', waarvan de erkenning van de publiekrechtelijke en burgerrechtelijke rechtssubjectiviteit van iedere mens als zodanig (het persoonlijkheidsbeginsel) de keerzijde vormt.

85. Mayer, a.w., Bd. II. p. 124.

86. Olivier, a.w., p. 209, Vgl. ook P.G.E.H. de Bieberstein, 'Proeve over zaken buiten den handel', diss. Leiden 1849, p. 21: 'Van deze (het openbaar domein van den staat) is hij geen eigenaar, alleen oefent hij zijne politiemagt daarover uit'.

87. Mayer, a.w., Bd. II, p. 124/125. Men vergelijke het reeds eerder geciteerde arrest HR 20 okt. 1879 . W. 4435, waarin wordt overwogen dat het aan de Kroon opgedragen oppertoezicht over waterstaatsweken weliswaar 'de bevoegdheid medebrengt om ... te waken tegen handelingen, waardoor aan de instandhouding en aan de bestemming dier werken voor de openbare dienst mogt worden te kort gedaan, en alzoo om ook alle misbruik dier werken te keeren', maar niet om 'op vaarwaters of wegen, die ten gerieve van het algemeen bestemd zijn ... het vrije verkeer ... in het algemeen te beperken'.

88. Mayer, a.w., Bd. 1, p. 259, waar als voor de 'Polizei' ontoegankelijke gebieden worden genoemd: het 'Privatleben' en - daarbuiten - de 'freie Bewegung', waarin het 'Recht des gemeingebrauches' t.a.v. het publieke domein is geworteld. 
32. Op het dualisme Staat-'maatschappij' gaan we in Deel II nader in.

33. A. van der Woud, 'Het lege land (De nuimtelijke orde van Nederland 1798-1848), diss. Groningen 1987, Amsterdam 1987, p. 506. Van der Woud wijst er overigens ook op, dat Willems staatsopvatting tegelijkertijd een 'privaatrechtelijke' is en hij het publiek domein beschouwt alsof het zijn privaatdomein is.

34. Zie omtrent de beïnvloeding van het Nederlandse bestuursrecht door de theorie en praktijk van het Duitse en Franse bestuursrecht: J.P. de Jong. 'Bestuursrecht van vreemde herkomst', diss. Tilburg 1988, Zwolle 1988.

35. Ook door verschillende specifieke wetten, bij voorbeeld de Reichsgewerbeordnung en de wet op de verenigingen wordt de bevoegdheid der politie verder beperkt, of ook wel uitgebreid.

36. PrOVG 16 juni 1882 , E 9, 353.

37. Ook art. 28 van de Nederlandse Politiewet van 1957, letterlijk overgenomen in art. 2 van de Politiewet 1993, is ongetwijfeld mede beïnvloed door de Pruisische 'Generalklausel'. Art. 2 luidt: 'De politie heeft tot taak in ondergeschiktheid aan het bevoegde gezag en in overeenstemming met de geldende rechtsregels (vgl.: 'im Rahmen der geltenden Gesetze') te zorgen voor de daadwerkelijke handhaving van de rechtsorde en het verlenen van hulp aan hen die deze behoeven'. Tot de 'daadwerkelijke handhaving van de rechtsorde' behoort blijkens art. 12 lid 1 ook de 'handhaving van de openbare orde',

38. BVerfG 23 mei 1980, E 54, nr. 14 (p. 144/145). Door de klager was betoogd dat er sprake zou zijn van een niet 'hinreichend bestimmte Ermăchtigungsgrundlage', waardoor rechtsstatelijk-democratische beginselen, i.h.b. de 'Grundsatz der Gewaltenteilung', zouden zijn geschonden. Zoals we zagen, gaat die 'Rechtsprechung' zelfs terug tot in de vorige eeuw. Zie m.b.t. art. 28 van de Ned. Politiewet van 1957: HR 24 okt. 1961, NJ 1962, 86, AAe 1962, p. 118 (Zeijense nachtbraker); HR 12 nov. 1963, NJ 1964, 205 (weerspannige kloosterling), en HR 22 febr. 1977, NJ 1977, 288 (Rode Vlag).

Vgl. ook EHRM 26 april 1979, NJ 1980, 146 (Sunday Times) over de uitleg van het woord 'law' en daarmee samenhangende vereisten in art. 10 lid 2 EVRM: '(T)he word 'law' in the expression 'prescribed bij law' covers not only statute but also unwritten law'. Dit, mits dit recht voldoende 'accessible' én 'foreseeable' is: 'Firstly, the law must be adequately accessible: the citizen must be able to have an indication that is adequate in the circumstances of the legal rules applicable to a given case. Secondly ... it is formulated with sufficient precision to enable the citizen to regulate his conduct'. Zie over het voor strafbepalingen uit art. 103 Abs. 2 Grundgesetz voortvloeiende 'Bestimmtheitsgebot': BVerfG 17 jan. 1978, E 47, nr, 6 (p. 120/121): 'Diese Verpflichtung dient einem doppelten Zweck. Es geht einerseits um den rechtsstaatlichen Schutz des Normadressaten: Jedermann soll vorhersehen können, welches Verhalten verboten und mit Strafe bedroht ist. Im Zusammenhang damit soll andererseits sichergestellt werden, dass der Geserzgeber über die Strafbarkeit entscheidet: Würde die Entscheidung über die Strafbarkeit eines Verhaltens der volziehenden oder der rechtsprechenden Gewalt uberlassen, so wăre dies unvereinbar mit dem Prinzip des Grundgesetzes, dass die Entscheidung über die Beschränkung von Grundrechten oder über die Voraussetzung einer Beschränkung dem Gesetzgeber und nicht den anderen staatlichen Gewalten obliegt'. Bij strafbepalingen moeten strenge(re) eisen moeten worden gesteld aan de 'gesetzliche Bestimmtheit', aldus BVerfG 23okt 1985, E 71, p. 108 (p. 115).

39. Vgl. H.J. Papier, 'Empfehlen sich ergănzende gesetzliche oder untergesetzliche Regelungen der Altlasten, und welchen Inhalt sollten sie haben?', JZ 1994, pp. 810-822, met vele verwijzingen. Zie ook: 'Vorschlige zur Regelung der Altlasten im Rahmen des Bodenschutzes', Diskussionsgrundlage zum 60. Deutschen Juristentag, Münster 1994, waarin ook een uittreksel uit de zgn. 'Referenten-entwurf Bundes-Bodenschutzgesetz' is afgedrukt. Deze regeling zou moeten worden opgenomen in het t.z.t. in te voeren 'Umweltgesetzbuch-Besonderer Teil. De gedachte om, terzake van 'maatschappelijke onzongvuldigheid jegens de Staat', op te treden op basis van het burgerrechtelijke onrechtmatige daadsartikel komt kennelijk - en terecht - in de hoofden van de Duitse juristen niet op.

40. HR 13 jan. 1879, W. 4330 (Meerenberg-arrest).

41. F.H. van der Burg. 'Preventieve justitic en plaatselijke politie', a.w., p. 71, alwaar er ook op wordt gewezen dat men in woorden als 'politieverordening' nog een herinnering vindt aan de historische opvatting, dat ook het stellen van bepaalde regelen een aangelegenheid van 'politie' was. 
42. 'Er zal worden ingevoerd een algemeen wetboek van burgerlijk regt, van koophandel, van lijfstraffelijk regt, van de zamenstelling der regterlijke magt en van de manier van procederen'.

43. Men houde in het oog dat de termen 'wet in formele zin' en 'wet in materiele zin' uit latere tijd stammen. De door de Kroon gestelde algemeen verbindende regelingen worden in de jurisprudentie van de Hoge Raad geen 'wetten (in materiêle zin)' genoemd. De term 'wet' wordt gereserveerd voor regelingen afkomstig van Staten-Generaal en Kroon tezamen, dus van wat eerst later 'de wetgever in formele zin' zal worden genoemd. Pas nadat in het Meerenbergarrest de opvatting heef gezegevierd, dat de Kroon in beginsel niet zelfstandig bevoegd is tot uitvaardiging van algemeen bindende regelingen en dat dergelijke regelingen slechts gesteld kunnen worden door Staten-Generaal en Kroon te zamen, vindt in de rechtswetenschap de term 'wet in materiêle zin' ingang. Uitgangspunt wordt dat de wetgever 'in formele zin bevoegd is tot het stellen van wetten 'in materiēle zin' en dat andere organen hun bevoegdheid tot het maken van 'wetten in materiele zin' dienen te ontlenen aan de wet 'in formele zin', in ieder geval voorzover het gaat om door strafsanctie te handhaven regeis en regels waardoor de private eigendom wordt beperkt. Het begrip 'wet in materiele zin' is ontleend aan de Duitse rechtswetenschap (m.n. Laband) en door Buys geintroduceerd in Nederland.

44. De zgn. Blanketwet. Art. 163 Grondwet 1815 (het codificatie-artikel) eiste immers een formeelwettelijke grondslag voor strafbedreiging.

45. HR 24 febr. 1846, W. 696. Vgl. ook HR 18 juni 1844, W. 506 (broodzettingsarrest), waarbij een door de Kroon afgekondigde a.m.v.b. houdende voorschriften ter voorkoming van bedrog omtrent hoedanigheid en gewicht van brood verbindend wordt geacht. Zie voorts HR 16 mei 1854, W. 1664. inzake diezelfde voorschriften.

46. HR 24 mei 1853, W. 1491.

47. HR 23 maart 1874, W. 3718. Zie voorts o.a. HR 16 mei 1854, W. 1664; HR 31 dec. 1857, W. 1833; HR 22 okt. 1861, W. 2321; HR 1 nov. 1864, W. 2644; HR 24 dec. 1867, W. 2972: HR 15 dec. 1873 , W. 3679; HR 19 maart 1877, W. 4113. Zoals kan worden afgeleid uit ná het Meerenbergarrest (1879) gewezen jurisprudentie van de HR - hierna te bespreken -, zouden de a.m.v.b.'s die aan de orde zijn in de arresten van 1857 en 1867 (Reglementen inzake beurtveren resp. inzake baggeren, graven en vissen in rivieren en langs de zeekust) vermoedelijk ook ná dit arrest verbindend zijn geoordeeld, nu ze gebruiksvoorschriften bevatten m.b.t. publiek domein. Van het in het arrest van 1873 aan de orde zijnde Reglement inzake de visserij op de Schelde en andere Zeeuwsche stromen - eveneens publiek domein - wordt bij HR 30 juni 1879, W. 4406, wederom de rechtsgeldigheid vastgesteld.

48. Zie bijv. J.R. Thorbecke, 'Aanteekening op de Grondwet', 2 e herziene uitgave, 2 delen, Amsterdam 1841-1843, dl. II, p. 91, alwaar inzake de in art. 144 van de Grondwet van 1815 aan provinciale opgedragen 'inwendige policie en oeconomie' wordt aangetekend: 'Gewone inwendige politie behelst echter de binnenlandsche provincieregering niet in haren ganschen omvang, maar ... slechts, overeenkomstig met het oude gebruik, die buiten de defensie, justitie en finantiěn'.

49. W.C.D. Olivier, 'Proeve over de beperkingen van den eigendom door het politie-regt', diss. Leiden 1847. In de ruimere betekenis omvat 'politie' volgens Olivier ook deze op zich zelf staande delen van de staathuishouding, en is het 'synoniem van wat men, met andere woorden, noemt administratief regt'.

50. Olivier, a.w., p. 159 en p. 182.

51. Hier zij er nogmaals op gewezen dar de term 'wet in materiele zin' pas aan het eind van de $19 \mathrm{e}$ eeuw opkomt in de Nederlandse literatuur.

52. HR 13 jan. 1879, W. 4330 (Meerenberg-arrest).

53. Kranenburg, a.w., pp. 92 e.v. en p. 349. In vergelijkbare zin: A.A.H. Struycken, 'Het wetsbegrip', in: 'Verzamelde staats- en administratiefrechtelijke opstellen', Amhem 1918, pp. 61-69, alwaar wordt opgemerkt dat met dit arrest het pleit is beslecht ten gunste van de persoonlijke vrijheid en de modeme rechtsstaatsgedachte is verwezenlijkt.

54. Althans voorzover het niet gaat om publiek domein. Zie hiema. 
55. Daarmee was het gezag van de vorst definitief ont-persoonlijkt c.q. ver-ambt-elijkt. Dit impliceerde reeds dat de soevereiniteit niet meer kon berusten bij de Koning, die immers nog 'slechts' als ambt - als orgaan van de Staat (waarvan de persoon van de koning de drager is) - zou kunnen fungeren. Daarmee ontstond een toestand die door Engelse auteurs wel wordt aangeduid met 'the royal impersonality'. En als de soevereiniteit niet meer berust bij de Koning en hij ook niet de hoogste gezagsdrager binnen de Staat is, impliceert dit dat hij ook geen oorspronkelijke regelgevende bevoegdheid kan hebben.

56. Dat de burgerrechtelijke regulering van de private eigendom moet geschieden door de wet, volgt reeds uit het codificatie-artikel.

57. Voor een uiteenzetting over de opvattingen van Thorbecke ter zake moge - wederom - verwezen worden naar de fraaie dissertatie van Poortinga, a.w., Hfdst. VI, pp. 207-252.

58. J.B.V. Proudhon, 'Traité đu domaine public ou du distinction des biens', 1e druk, Dijon 1834-1835; $2 \mathrm{e}$ door Victor Dumay herziene druk, Dijon 1843-1845.

59. Het gaat dus om wat men 'hoheilliche Sachherrschaft' (BverfG 42, nr. 2), 'toebehoren als overheidsgezag' (Hardenberg) of 'publiekrechtelijk beheer' kan noemen. B. de Goede, 'Het beheer in het waterstaatsrecht', diss. Leiden 1951, p. 42, merkt op dat in de oudtijds gebruikelijke term 'behering' de betekenis van: 'het geven van een heer' is ingesloten. Denk in dit verband ook aan de term 'heerlijke rechten'. Bij de oude heerlijke rechten waren 'publieke' bevoegdheden en 'private' vermogensbelangen (van de 'heer') echter nog op een ongedifferentieerde wijze met elkaar vermengd.

60. H. Vos, 'Publiek domein', WGB 1931, p. 61 e.v., ook opgenomen in: 'Uit de geschriften van mr. H. Vos', Alphen a/d Rijn 1933, pp. 128-134.

61. HR 30 juni 1879. W. 4406.

62. Problematisch was wél dat aan overtreding van het Reglement een strafsanctie was verbonden. De door het grondwettelijke codificatie-artikel vereiste grondslag van een strafbepaling in een wet in formele zin. kon in de opvatting van adv, -gen, en H.R. echter gevonden worden in de zgn. Blanketwet van 6 maart 1818, Stb. 12.

63. HR 6 oktober 1884, W. 5086. Zie ook nog: HR 30 juni 1879, W. 4404 (Reglement van politie voor Noordzeekanaal): HR 26 jan. 1880, W. 4477 (Reglement van politie voor het gekanaliseerd gedeelte van de Hollandse Ussel).

64. HR 19 maart 1877, W. 4113 .

65. W. Vegting. 'Publiek domein en zaken buiten den handel', Alphen a/d Rijn 1946, p. 223 en p. 223, nt. 4.

66. Niet geheel juist lijkt ook de opvatting van Van der Burg. 'Preventieve justitie en plaatselijke politie', a.w.. p. 70, die betoogt dat door de Hoge Raad in het grondwetsartikel betreffende het Koninklijk toezicht over de waterstaat (art. 190 Grondwet 1848) een bepaling is gezien, die aan de Koning politie en daarom ook regelgevende bevoegdheid toekent. Dit grondwetsartikel wordt door de Hoge Raad wel genoemd ter ondersteuning van zijn opvatting, doch de bevoegdheid leidt hij toch primair af uit de publieke beheerstaak van de Staat t.a.v. het desbetreffende publieke domein. In art. 190 wordt alleen bevestigd dat de Kroon het statelijk ambt is, dat terzake competent is.

67. HR 12 april 1880 , W, 4498.

68. Bij HR 24 mei 1853, W. 1491, was het desbetreffende voorschrift rechtsgeldig geacht omdat het zou zijn 'een voorschrift niet van burgerlijk, maar van politieregt'. In 1880 komt de HR niet terug van het standpunt dat het niet gaat om een voorschrift 'van burgerlijk regt', maar aanvaardt hij niet meer de opvatting dat de Kroon zelfstandig, uit hoofde van haar politiebevoegdheid, zou mogen overgaan tot (publiekrechtelijke) regulering van 'burgerlijke rechten', het private domein van de burger dus.

69. HR 20 okt. 1879, W, 4435.

70. Een tijdens de parlementaire behandeling door het kamerlid Van der Kaay ingediend amendement om de woorden 'of politiedwang' alsnog in te lassen in de tekst van art. 56, werd verworpen. Zie over de totstandkomingsgeschiedenis van art. 56 en de interpretaties die gegeven zijn aan dit grondwetsartikel: Van der Burg, 'Preventieve justitie en plastselijke politie', a.w.. pp. 71-72; dez., 'Regelgeving en bestuur', Zwolle 1993, pp. 44-45 en 153-157; C.W. van der Pot, 'Wet en Algemeene maatregel van bestuur in het Nedertandsche Staatsrecht', diss. Leiden 1916. 
71. A.F, de Savornin Lohman, 'Onze Constitutie', 4e uitgave, Utrecht 1926, p. 273 (Lohman is overigens een voorstander van opneming van de woorden 'of politiedwang' in art. 56): C.W. van der Pot, 'Handboek van het Nederlandse Staatsrecht', 6e druk, Zwolle 1957, p. 358; J.P. Oud, 'Het Constintioneel Recht van het Koninkrijk der Nederlanden', 2 delen, Zwolle 1956-1959, dl. II, p. 207 e.v.

72. Van der Burg. 'Preventieve justitie en plaatselijke politie', a.w., p. 72/73; dez., 'Regelgeving en bestuur', a.w., p. 153-154.

73. $\mathrm{V}_{\mathrm{gl}}$. de woorden van Olivier: 'Het bepalen der regten van eigendom behoor tot het gebied der wetgeving' en de nog ná het Meerenbergarrest gewezen jurisprudentie van de Hoge Raad.

74. In dit verband wordt dus slechts gedacht aan een deel van de 'politie' (in materiele zin), t.w. de politietaken toevertrouwd aan de ambtenaren aangeduid als 'politie'.

75. Men zie hierover: C.H.J. Schepel, 'Wegenrecht in Nederland', diss. Groningen 1895, pp. 158-174, waar de parlementaire behandeling wordt beschreven en waar ook wordt verwezen naar de bestrijding van de opvatting van de tegenstanders van het regeringsstandpunt door de redactie van het Weekblad voor Burgerlijke Administratie, W.B.A. 2149.

76. Van der Burg. 'Regeigeving en bestuur', a.w., p. 153-154.

77. Het standaandvoorbeeld is het KB van 2 juni 1931. Stb. 237, tot regeling van de toelating van vreemde oorlogsschepen binnen het Nederlandse rechtsgebied. Het aan de zelfstandige a.m.v.b. overgelaten terrein overziende, onderscheidt Van der PotDonner, a.w., p. 345/346, vier categorieen: 1 . die a.m.v.b.'s welke hun werking geheel uitoefenen binnen de bestuursorganisatie, zoals het Bezoldigings. besluit Rijksambtenaren 1948; 2. die a.m.v.b.'s die weliswaar extern werken, maar daartoe een bijzondere sanctie niet behoeven, zoals het KB van 21 mei 1970 tot instelling van het korps van deskundigen ter beschikking voor de technische hulp aan ontwikkelingslanden; 3. de zgn. noodverordeningen, zoals de KB's van 31 juli 1914, Stb. 33, en van 26 sept. 1936, Stb. 52, beide tot verbod van gouduitvoer; 4. die a.m.v.b.'s welke uitsluitend worden gehandhaafd door feitelijke dwang (politiedwang), zoals het genoemde KB van 2 juni 1931, Stb. 237. De enorme toeneming van te regelen zaken, waarvoor de Staten-Generaal niet steeds het aangewezen orgaan zouden zijn, leidt Van der Pot, 'Wet en Algemeene maatregel van bestuur', a.w., overigens tot de opvatting dat een uitbreiding van 's Konings zelfstandige regelgevende macht nodig is tot bepaalde, nim omschreven groepen van gevallen. In gelijke zin: A.L. de Block, 'Toeneming van de macht der Kroon', or. Tilburg 1938.

78. Zij het dat men primair dacht aan bevelen en dwangmaatregelen door het politie-apparaat.

79. 'Politiebevoegdheden' wordt hier opgevat in de oude, ruime betekenis van 'bestuursbevoegdheden'.

80. HR 12 jan. 1923, W. 11060 , NJ 1923, p. 307 (Schielands Hoge Zeedijk).

81. Zie over Otto Mayer uitvoerig: J.P. de Jong. 'Bestuursrecht van vreemde herkomst', Zwolle 1988.

82. Mayer, a.w., Bd. II, p. 116.

83. Mayer, a.w., Bd. II, p. 116.

84. Mayer, a.w., Bd. II, pp. 98 e.v. Dit is de door ons al meermalen genoemde scheiding van 'imperium' en 'dominium', waarvan de erkenning van de publiekrechtelijke en burgerrechtelijke rechtssubjectiviteit van iedere mens als zodanig (het persoonlijkheidsbeginsel) de keerzijde vormt.

85. Mayer, a.w., Bd. II, p. 124.

86. Olivier, a.w., p. 209. Vgl. ook P.G.E.H. de Bieberstein, 'Proeve over zaken buiten den handel', diss. Leiden 1849, p. 21: 'Van deze (het openbaar domein van den staat) is hij geen eigenaar, alleen oefent hij zijne politiemagt daarover uit'.

87. Mayer, a.w., Bd. II, p. 124/125. Men vergelijke het reeds eerder geciteerde arrest HR 20 okt. 1879. W. 4435 , waarin wordt overwogen dat het aan de Kroon opgedragen oppertoezicht over waterstaatsweken weliswaar 'de bevoegdheid medebrengt om ... te waken tegen handelingen, waardoor aan de instandhouding en aan de bestemming dier werken voor de openbare dienst mogt worden te kort gedaan, en alzoo om ook alle misbruik dier werken te keeren', maar niet om 'op vaarwaters of wegen, die ten gerieve van het algemeen bestemd zijn ... het vrije verkeer ... in het algemeen te beperken'.

88. Mayer, a.w., Bd. I, p. 259, waar als voor de 'Polizei' ontoegankelijke gebieden worden genoemd: het 'Privatleben' en - daarbuiten - de 'freie Bewegung', waarin het 'Recht des gemeingebrauches' t.a.v. het publieke domein is geworteld. 
89. Mayer, a.w., Bd. I, p. 264.

90. Mayer, a.w., Bd. I, p. 252.

91. Vgl. ook de eerder genoemde uitspraak BVerfG 23 mei 1980, E 54. nr. 14, volgens welke aan de 'polizeiliche Generalklausel' 'in jahrzehntelanger Entwicklung durch Rechtsprechung und Lehre nach Inhalt, Zweck und Ausmass hinreichend präzisiert, in ihrer Bedeutung geklärt und im juristischen Sprachgebrauch verfestigt ist'.

92. Vgl. ook John Locke, die onderkent dat een 'prerogative' van het overheidsbestuur om in voor de wetgever niet voorzienbare, spoedeisende situaties op te kunnen treden indien het algemeen belang dat vereist, altijd wel nodig zal zijn.

93. De omstandigheid dat Mayer spreekt van 'offentliches Eigentum', betekent niet dat hij dit domein beschouwt als eigendom in de zin van het burgerlijk recht. Hij maakt een duidelijk onderscheid tussen burgerrechtelijke eigendom enerzijds en publiekrechtelijke eigendom anderzijds, waarvoor z.i. verschillende regimes gelden. Mayer volgt daarmee de Franse terminologie.

94. Paul Guba, 'Die öffentlichrechtichen Grundlagen des Wegerechts', Leipzig 1917, p. 26.

95. Fritz Fleiner, 'Institutionen des Deutschen Verwaltungsrechts', 8e druk, Tübingen 1928, pp. 330-332. Vgl. ook p. 371 over de Wegepolizei".

96. HR 12 jan. 1923, W. 11060 , NJ 1923, p. 307 (Schielands Hoge Zeedijk).

97. HR 14 maart 1904, W. 8050 (Lantaampaal-arrest).

98. Zie voor een overzicht: J.W. van Zundert, 'Overheidsbestuur en grondeigendom', Alphen a/d Rijn 1980 , pp. 125 e.v.

99. Ontwerp voor een Nieuw Burgerlijk Wetboek, Toelichting eerste gedeelte, Staatsdrukkerij- en uitgeverijbedrijf, Den Haag 1954/1955, p. 32.

100. Zij het dat - het zij nogmaals gezegd - er altijd door de wetgever niet voorzienbare, spoedeisende gevallen zullen zijn, waarin door het overheidsbestuur moet worden opgetreden in het algemeen belang: het 'prerogative' van Locke, die het voorbeeld noemt van het noodzakelijke neerhalen van een huis teneinde het vuur te bedwingen, wanneer het aanpalende huis in brand staat. $\mathrm{Vgl}$. Locke, a.w., 159. In noodsituaties waarin spoed geboden is, zal er overigens meestentijds wel een wettelijke grondslag aanwezig zijn. Vgl. bijv. de burgermeesterlijke noodbevoegdheden in de Gemeentewet.

101. Hardenberg, a.w., p. $362 / 363$.

102. HR 22 mei en 26 juni 1863, W. 2499 (Zuidplaspolder). In gelijke zin: HR 21 juni 1872, Ned.regtspraak deel 101, pp. 195-205.

103. HR 29 april 1910, W. 9027 (Mark en Dintel-arrest). I.c. werd trouwens niet-ontvankelijkverklaring, niet onbevoegdverklaring, uitgesproken. De eis wordt dus wel gebracht onder art. 2 Wet R.O., wat illustreert dat reeds vóór HR 31 dec. 1915, W. 9947 (Guldemond/Noordwijkerhout) is aanvaard dat niet het fundamentum petendi maar het petitum/het voorwerp van geschil bepalend werd geacht voor de bevoegdheid van de gewone rechter. In de 19de eeuw was het niet anders.

104. HR 20 juni 1927. NJ 1927, p. 969. Zie ook nog het bekend Hofvijverarrest van 7 juni 1918, NJ 1918, p. 717, W. 10289.

105. Vos, a.w., p. 134.

106. Voor het publiek domein is zulks voor het eerst met kracht verdedigd door C.G. von Reeken, 'Uitoefening van private rechten op zaken met eene publieke bestemming', Themis 1893, pp. 1-66.

107. Vgl. M. Milo, 'Publiek domein in de negentiende eeuw', Recht en Kritiek 1995, pp. 166-187, waarin de opvattingen in de $19 \mathrm{de}$ eeuw worden geanalyseerd en een verklaring wordt gegeven voor de omslag. Hij wijst er op, dat het artikelen van Van Reeken uit 1893 veelal wordt gezien als het begin van de omslag in het denken over publiek domein.

108. HR 17 jan. 1941, NJ 1941, 644 (Parlevinker-arrest).

109. HR 19 jan. 1968, AB 1968, p. 585, NJ 1968, 166 (Eindhoven/Staals).

110. HR 19 jan. 1962, NJ 1962, 151, AB 1962, p. 540 (Dsselmeer-arrest, ook bekend als het arrestHuizen/Staat I).

111. HR 26 jan. 1990, AB 1990, 408, NJ 1991, 393, Gst. 1990, 6914 (Windmill). 


\section{Deel II}

Het dualisme Staat-'maatschappij' en het onderscheid tussen publiekrecht en privaatrecht 



\section{Hoofdstuk 4}

\section{Nogmaals het cultuurhistorisch differentiatie-, individualiserings- en integratieproces; het ontstaan van het dualisme Staat-'maatschappij'}

We hebben in de voorgaande hoofdstukken laten zien, dat het cultuurhistorisch proces is gekenmerkt door een steeds verder gaande 'Ausdifferenzierung' van de menselijke samenlevingsverhoudingen en, gepaard daaraan, van het recht. De gesloten feodale samenleving werd nog gekenmerkt door (meer of minder) ongedifferentieerde samenlevingsverbanden die de mens totaal, naar alle levensaspecten, omvatten. Een vrijheidssfeer van de mens als zodanig, waarbinnen private vrijheid geldt, en die een vrij maatschappelijk verkeer tussen individuen mogelijk maakt, werd nog niet erkend. De rechtspositie van de mensen was nog slechts een sequeel van de ongedifferentieerde verbanden waartoe zij behoorden. Die verbanden bezaten ook nog brokken overheidsmacht over hun leden als private vermogensrechten, die vererfbaar, overdraagbaar en beleenbaar zijn ('zaken in den handel', de zgn. heerlijke rechten, de regalia majora). Er was dus sprake van een vermenging van 'imperium' ('overheidsbevoegdheden') en 'dominium' (private vermogensbelangen). In dit bestel ontmoette men geen burgerlijk recht, geen publiekrecht, geen bedrijfsrecht etc.

Vanaf het einde van de Middeleeuwen kwam de moderne staatsidee tot doorbraak, voor het éérst in de stedelijke rechtskringen en daarna - via de tussenvorm van het standen'staat'wezen - in de opkomst van de gecentraliseerde 'politiestaten'. De term 'politiestaat' houdt verband met het 'ius politiae', zijnde de algemene bevoegdheid van de hoogste overheid om alle maatregelen te treffen, inclusief ge- en verbodsvoorschriften, die in het algemeen belang (het 'bonum commune', 'die gute Polizei') nodig worden geacht. De politiestaat was res publica - publieke instelling - en was door zijn monopolisering van de gewapende macht ('Zwangsmonopol') in staat geleidelijk om een eind te maken aan de heerschappij van ongedifferentieerde verbanden van het feodale en standen'staat'wezen en om daarmee al zijn leden gelijkelijk tot onderdanen te maken van het - nu als ambt beschouwde - overheidsgezag ("ontpersoon-lijking', 'ver-ambt-elijking' van overheidsgezag) in een publiekrechtelijke gelijkheid (vrijheid van statelijke willekeur). 
Het cultuurhistorische ontwikkelingsproces leidde dus tot (a) een concentratie in het staatsverband van de voorheen her en der bij niet-statelijke, ongedifferentieerde verbanden aanwezige 'overheidsrechten', onder (b) gelijktijdige afbraak van die ongedifferentieerde verbanden en daarmee (c) een vrijmaking van individuen uit die verbanden. Het cultuurhistorisch differentiatieproces is dus tegelijkertijd een individualiseringsproces en een proces van integratie (door de Staat als res publica).

Als kern van het 'ius politiae' werd de (absolute) en oorspronkelijke bevoegdheid van de hoogste overheid tot wetgeving beschouwd. De codificatie en unificatie van het recht was een instrument van deze overheid tot versteving van haar gezag. Deze codificatie had in eerste instantie met name betrekking op het terrein der 'justitie' ('justitiewetgeving'). Ofschoon de gerechten nog steeds werden beschouwd als de dienaren van de soevereine vorst, leidde dit mede tot een verdere, feitelijke verzelfstandiging van de 'justitiële overheid' ten opzichte van de 'politiële overheid". Mede onder invloed van de zeventiende- en achttiende-eeuwse rationalistische natuurrechtstheorieën - die uitgingen van een 'natuurlijke vrijheid' van de mens als zodanig en van een rationalistisch wetsbegrip: de wet als uitdrukking van wat de 'Vernunft' eist - werd ook de statelijke gezagsuitoefening zelf steeds meer een door wetten gereguleerde bevoegdheidsuitoefening. Geleidelijk ontstond er daarmee ook een scheiding tussen de wetgevingsfunctie en de bestuursfunctie - tussen 'politiewetgeving' en 'politiebestuur' -, waarbij bestuur steeds meer werd beschouwd als uitvoering van - de nog steeds door de hoogste overheid uit krachte van zijn soevereiniteit gegeven - wetgeving. Mede aan de hand van het Pruisische Allgemeine Landrecht van 1794 lieten we zien, dat de nieuwe wetgevingscultuur ertoe leidde dat 'politie' (verder) werd verengd tot een onderdeel van de totale overheidstaak, namelijk dat deel dat naar zijn aard niet kan worden gereguleerd door specifieke wettelijke regels, te weten de handhaving van de openbare orde en rust en de bescherming tegen gevaren. Wetgeving was echter nog steeds een attribuut van de (soevereine) hoogste overheid: wetgeving werd gezien als een door die overheid zelf gestelde begrenzing van het haar 'van nature' toekomende 'ius politiae' ('Selbstbindung'). Met de doorbraak van de rechtsstaatsidee vonden de volgende gedachten ingang in de Westeuropese rechtscultuur: het representatiebeginsel, de machtenscheiding en het beginsel van wetmatigheid van bestuur (als uitdrukking van het representatiebeginsel, het beginsel van de machtenscheiding en als waarborg voor de individuele vrijheid). De opvatting werd nu, dat de wet niet alleen de overheidsbevoegdheid begrenst maar tegelijkertijd vestigt: 'The end of law is not to abolish or restrain, but to preserve and enlarge freedom' (Locke). De heerschappij van de wet (in formele zin) kon echter in de loop van de negentiende eeuw eerst worden gerealiseerd mét de definitieve aanvaarding van het beginsel van de representatieve democratie. En dit impliceerde ók dat, annex aan de doorvoering van de heerschappij van de wet, 
de 'politiebevoegdheid - waarvoor geen specifieke wettelijke grondslag nodig werd geacht - verder werd ingeperkt (vgl. Meerenberg-arrest van 1879).

Juist door de vestiging van de moderne Staat als wezenlijke publieke territoriale rechtsgemeenschap bekleed met het 'Zwangsmonopol', onder gelijktijdige afbraak van de vroegere ongedifferentieerde rechtskringen, was er náást de Staat ruimte gekomen voor een eigen terrein van 'natuurlijke', vrije relaties tussen individuen, waarbinnen zij naar eigen inzicht hun private belangen konden behartigen, en voor de totstandkoming op basis van dat vrije maatschappelijke verkeer van gedifferentieerde ('maatschappelijke') corporaties. Tevens was op basis van de publieke rechtsorde van de Staat ook een positivering mogelijk van een integrerende burgerrechtelijke rechtsorde die is gebaseerd op de beginselen van de iustitia commutativa en de burgerlijke vrijheid en gelijkheid van de mensen als zodanig in hun onderling maatschappelijk verkeer '. Het fundamentele beginsel van de publiek- én burgerrechtelijke erkenning van de rechtssubjectiviteit van iedere mens als zodanig is de keerzijde van de scheiding van de scheiding van publiek overheidsgezag en privaat vermogensbelang. Daarmee is de koppeling van 'imperium' (overheidsbevoegdheden) en (privaat) 'dominium' (private vermogensrechten) definitief losgelaten. Enerzijds is de eigendom van de burger erkend als zijn private eigendom, behoudens beperkingen bij of krachtens de wet. Anderzijds zijn overheidsbevoegdheden niet meer te beschouwen als private vermogensbelangen. 'De fransche omwenteling was inzonderheid een strijd tegen het stelsel, publieke regten in bijzondere eigendom te houden (bezitten)', schrijft Thorbecke ${ }^{2}$. Dit impliceerde ook dat een principieel onderscheid moest worden gemaakt tussen enerzijds privaat domein en anderzijds publiek domein. De op de gemene rechtsleer (burgerlijk recht = 'gemeen recht') gebaseerde opvatting, die ook het publiek domein in beginsel beschouwt als burgerlijk eigendom, dient dan ook te worden afgewezen. We wezen er ook op, dat het beeld dat auteurs als Hamaker, Krabbe en Vegting - adepten van die gemene rechtsleer - schetsen van de historische rechtsontwikkeling vertekend is.

Sinds Locke kunnen Staat en 'maatschappij' dus worden beschouwd als twee van elkaar te onderscheiden sferen ${ }^{3}$; annex aan de scheiding Staat-'maatschappij' - de scheiding tussen res publica ('imperium') en societas civilis (sine imperio) - is de principiële onderscheiding tussen publiek en privaatrecht. Tegenover de Staat als de publieke rechtsgemeenschap is komen te staan de 'maatschappij' ('society', 'Gesellschaft'), als de 'Inbegriff' voor het gehele niet-statelijke terrein van het op de behartiging van private belangen gerichte relaties tussen individuen en (gedifferentieerde) niet-statelijke gemeenschappen. Men kan dus zeggen dat de onderscheiding tussen Staat en 'maatschappij' haar juridische doorwerking vond in een principieel onderscheid tussen publiek- en privaatrecht. 
Daarbij werd het beginsel van de heerschappij van de wet aanvankelijk primair gezien als een waarborg voor de individuele vrijheid en de rechtszekerheid en tegelijkertijd als een uitvloeisel van het beginsel van de machtenscheiding. Pas in de tweede helft van de negentiende eeuw werd, mét de uitbreiding van het kiesrecht, de wet ook steeds meer de uitdrukking van het beginsel van de representatieve democratie.

Böckenförde omschrijft dit ontwikkelingsproces dat leidde tot de scheiding Staat'maatschappij', als volgt:
'(A)us der herrschaftlich-politisch durchformtenund geschichtetenGesellschaft (societas civilis cum imperio) des Mittelalters und der frühen Neuzeit (entsteht) auf der einen Seite die einheitliche und umfassende, gegenüber ihren individuellen Trăgern verselbstăndigte Staatsgewalt, auf der anderen Seite die einheitliche neue Gesellschaft (societas civilis sine imperio) der dieser Staatsgewalt Unterworfenen. (...) Der organisatorische Ausbau der einheitlichen Staatsgewalt bringt nicht nur eine Konzentrierung und Erweiterung der politische Herrschaftsrechte zu einer umfassenden poli- tischen Entscheidungsgewaltund die Verselbständigungund 'Objektivierung'dieser Entscheidungs- gewalt gegenüberder Person und dem Belieben des Monarchen, es bringt auch eine Bindung und Begrenzungdieser Entscheidungsgewalt. (...) Diese Bindung und Begrenzungerfolgt durch die Auf- stellung und Verbindlichmachung grundlegender Staatszwecke; diese Staatszwecke begleiten die Frrichtuge und den Aushav der Stastgoewalt von Anfage an' 4

In de eerste fase van de rechtsstaatsidee - die van de vroeg-liberale rechtsstaat, zoals die zijn constitutionele uitwerking ontving in de Amerikaanse en Franse constituties en verklaringen voor de mensenrechten - was deze eenzijdig gericht op waarborging van de sfeer van het burgerlijk recht, dus van de beginselen van de burgerlijke vrijheid en gelijkheid en - in het bijzonder - de private eigendom. Zo was voor Kant het publiekrechtelijk georganiseerde staatswezen slechts gericht op verschaffing van de vormen, door de publiekrechtelijk georganiseerde wetgeving en rechtspraak in de 'status civitatis', voor de oorspronkelijk in de 'status naturalis' gedachte materie van het burgerlijk recht ${ }^{5}$. Dit past geheel in Lockes vroeg-liberale staatsidee, waarin Staat en 'maatschappij' van elkaar worden gescheiden, maar de Staat alleen ten doel heeft om via algemene wetgeving de tot burgerlijke vrijheid-in-gelijkheid gepositiveerde 'natuurlijke vrijheid' alsmede de private eigendom te beschermen en de in de natuurtoestand ontbrekende rechtszekerheid te verschaffen. In de woorden van Böckenförde:

'(Die) Begrenzung und Zweckbindung der staatlichen Entscheidungsgewalt(und damit des Staates selbst) gegenüber den einzelnen und der Gesellschaft erfolgt in der Französischen Revolution und durch die bürgerliche Freiheitsbewegung in einer spezifischen Weise, die den Charakter der Gesellschaft als Enwerbsgesellschaft begründet. Die tragenden Elemente sind die Herstellung und Gewährleistungder (bürgerlichen)Rechtsgleichheit, der allgemeinenErwerbs- und Vertragsfreiheit, der Freizugigkeit und der garantie des erworbenen Eigentums. Die Fesseln des Bürgerlichen Erwerbs, die für die alte Gesellschaft durch das stāndisch und korporativ gebundene Berufs", Gewerbe-, Eigentums- und auch persōnlicheRecht, das seine Erscheinungsform im 'Privileg' hatte. 
bestimmend waren, werden beseitigt. Sie werden ersetzt durch ein neues, auf die Verwirklichung der Rechtsgleichheit, Erwerbs- und Vertragsfreiheit usw. abzielendes allgemeines Recht, dessen Ausgangs- und Bezugspunkt die freie, selbstbestimmende und erwerbsorientierte Einzelpersōnlichkeit ist. Durch die Schaffung und Gewährleistung dieser neuen 'bürgerlichen' Rechtsordnung setzt der Staat die Gesellschaft in den Erwerb und zum Erwerb frei; sie wird im spezifischen Sinn 'bürgerliche Gesellschaft' (curs. door auteur) 6 .

Omdat de enkeling ná de afbraak van de ongedifferentieerde verbanden onbeschermd was binnen de 'maatschappij' en deze eenzijdige gerichtheid op de private, individuele vrijheid vooral voor de arbeidende bevolking tot grote sociale ellende en armoede voerde - de 'sociale kwestie' -, werd op de nieuwe sociale ongelijkheid en onvrijheid in de tweede helft van de negentiende eeuw gereageerd in de vorm van staatsinterventie door sociale wetgeving op het gebied van kinderbescherming, veiligheid, ziekte, ongevallen, ouderdom, werkloosheid, volkshuisvesting etc. Deze wetgeving was een publiekrechtelijk complement van de burgerlijke wetgeving, die ook zelf aan de nieuwe verhoudingen werd aangepast (wetgeving inzake het arbeidscontract, faillissement etc.).

In deze tweede fase van de rechtsstaatsidee werden de doeleinden van de Staat niet meer uitsluitend gezien in bescherming van de burgerlijke vrijheid en private eigendom, maar werd aanvaard dat de Staat alle mogelijke publieke belangen mag behartigen, mits binnen het kader van een algemene (publiekrechtelijke) wetgeving.

Het denken over de verhouding van Staat en 'maatschappij' is in deze periode vooral geïnspireerd door de rechts- en staatsfilosofie van Hegel en die van Lorenz von Stein. Terwijl bij Locke en Kant de Staat nog geheel in dienst was gesteld van de vrije 'maatschappij', heeft - zo merkt Van Eikema Hommes op ${ }^{7}$ - Hegel goed heeft gezien dat de administratieve wetgeving van de Staat ('die Polizei') het noodzakelijke complement moet zijn van het vrije burgerlijke rechtsverkeer, in het bijzonder om de positie van de 'armen' te beschermen. Maar omdat de verhouding tussen 'bürgerliche Gesellschaft' en Staat bij Hegel niet dualistisch maar dialectisch wordt gedacht - met de Staat als hoogste synthese - en de betoogtrant van Hegel bovendien nogal duister is, kon zijn filosofie ook gebruikt - zo men wil: misbruikt worden als onderbouwing voor totalitaire staatsopvattingen ${ }^{8}$. Lorenz von Stein maakt in navolging van Hegel scherp onderscheid tussen 'bürgerliche Gesellschaft' en Staat, maar ziet de Staat, anders dan Hegel, niet als de hogere helft van de samenleving. Bij hem is er sprake van een echt dualisme:

'Staat und Gesellschaftsind die beiden Lebenselemente aller menschlichenGemeinschaft. (...) Inhalt des Lebens der menschlichen Gemeinschaft (müsse) ein bestăndiger Kampf des Staats mit der Gesellschaft, der Gesellschaft mit dem Staat sein' ?

Lorenz von Stein ziet scherp, dat het algemeen belang het leidende beginsel van de Staat is: 'Träger der Harmonie aller Interessen' ${ }^{10}$. Dit impliceert dat de Staat niet alleen gehouden is tot het creëren van de juridische voorwaarden voor een vrij maat- 
schappelijk verkeer, maar 6 ók tot publiekrechtelijke wetgeving op sociaal terrein, als noodzakelijk complement van de burgerrechtelijke wetgeving, en tevens tot realisering van een representatieve democratie, de 'staatsbürgerliche Freiheit'. De deelname van de volksvertegenwoordiging aan de wetgeving, ziet Lorenz von Stein dan ook als een wezenlijk kenmerk van het wetsbegrip. Hij beseft dat 'maatschappij' en 'Staat' niet mogen samenvallen, omdat daarmee de vrijheid om in het maatschappelijk verkeer de eigen, private belangen na te streven, verloren zou gaan. De volksvertegenwoordiging is een 'ausgleichendes Prinzip zwischen Staat und Gesellschaft', 'das staatliche Organ des Volkes und das völkische des Staates' "I. Het dualisme Staat-'maatschappij' betekent dus dat er weliswaar een 'Wechselbeziehung' tussen beide is: enerzijds creëert de Staat de voorwaarden voor het maatschappelijk verkeer door burgerlijke wetgeving met als complement publiekrechtelijke wetgeving op sociaal terrein en anderzijds is het volk betrokken bij het proces van de statelijke rechtsvorming, maar dit geschiedt op basis van de instandhouding van de onderscheiding.

Toen in de tweede helft van de negentiende en het begin van de twintigste eeuw ook het kiesrecht werd uitgebreid, kon door de wetgeving ook uitdrukking worden gegeven aan het beginsel van de representatieve democratie. Ieder mens was daarmee erkend niet alleen als bourgeois maar ook als citoyen:

'An die Stelle einer strikten Trennung im Sinne des vielberufen 'Dualismus' von Staat und Gesellschaft trat eine verfahrensmässig und institutionell ausgeformte Wechselbeziehung zwischen Staat und Gesellschaft auf der Grundlage ihrer organisatorisch-institutionellen Unterscheidung' ${ }^{12}$. Geen strikte scheiding tussen beide dus, maar wèl een principiële onderscheiding, ondanks alle wederzijdse vervlechtingen. Böckenförde schrijft:

'Solange auf der einen Seite alle hoheitliche Herrschafts- und politische Entscheidungsgewalt bei einer Organisationkonzentriert bzw, von ihr delegiert ist, auf der anderen Seite das Zusammenleben der einzelnen auf der Grundlage von Freiheit und Gleichheit als ein in sich niet-politisches geordnet ist, ist immer die Struktur von Staat und Gesellschaft als zwei nebeneinanderstehenden Ordnungszusammenhăngen real vorhanden, mögen so viele Wechselwirkungen zwischen beiden bestehen wie immer" "13.

Dit nieuwe dualisme vond zijn uitdrukking in een principieel onderscheid tussen publiekrecht en burgerlijk recht. Het beginsel van wetmatigheid van bestuur werd juist gezien tegen de achtergrond van dit dualisme. Jeand'Heur merkt terecht op:

'(D)er Gesetzesvorbehalt(wurde) vor dem Hintergrund eines Staatsverständnis entwickelt, welches die Sphären Staat und Gesellschaft strikt trennte. Die verfassungs- und demokratietheoretische Grundstruktur unserer Rechtsordnung hat ... allein der Staat als unmittelbaren Adressaten solcher Verfassungsnormen und -prinzipien gewähtt, die eine unkontrollierte Beschneidung individueller oder gesellschaftlicher Rechtspositionenverhindern sollen' ${ }^{4}$. 


\section{'Vermaatschappelijking van de Staat'?}

Mede onder invloed van het juridisch positivisme had de rechtsstaatsidee vanaf het einde van de negentiende eeuw echter steeds meer een in hoofdzaak formeel-juridisch karakter aangenomen, in die zin dat men de wetgeving, de grondrechten, de administratieve rechtspraak etc. ging beschouwen als slechts formele-organisatorische grenzen van de staatsmacht. Het normlogische systeem van Hans Kelsen, bijvoorbeeld, kent geen principieel onderscheid tussen publiek- en privaatrecht, naar hun materiële aard. Duguit meent een 'socialisering' van alle recht te kunnen constateren, waardoor het klassieke burgerlijk recht en publiekrecht zouden worden vervangen door één 'droit social' ${ }^{15}$. Bij Krabbe - vertegenwoordiger van de psychologische variant van de leer van de rechtssoevereiniteit - is te lezen dat in deze leer het dualisme Staat-'Gesellschaft' wordt opgeheven, zodat 'alle Gewalt, auch die des Staates, vom Rechte hergeleitet wird und also die Gemeinschaft als die einzige Quelle des Rechts zu gelten hat', zijnde de 'Gemeinschaft' de 'vom Rechte geordnete Zusammenhang zwischen den Menschen', welk recht voortspruit uit het rechtsbewustzijn ${ }^{16}$. Krabbes definitie van het recht luidt:

'Het recht is een psychologischverschijnsel en is in zijn oorsprongeven originair als elk ander stuk van ons geestelijk leven. Het is een product van het ons eigene rechtsgevoel of rechtsbewustzijn, dat onafhankelijk van onzen wil werkt, dien wil beheerscht en waanit alle normen, voorzoover zij rechtsnormen zijn, ontspringen' $"$.

Krabbes leer impliceert een verwerping van een principieel verschil tussen publieke en private belangen en tussen publiek- en privaatrecht ${ }^{18}$. Het burgerlijke recht is volgens Krabbe het gemene recht, op de basis waarvan ook de Staat zijn taken kan volbrengen; het bestuursrecht is ten opzichte van het burgerlijk recht het aanvullings- c.q. uitzonderingsrecht, dat aan staatsorganen bijzondere bevoegdheden verleent: het is 'een verlengstuk van het burgerlijke recht' ${ }^{19}$.

Mede onder invloed van opvattingen als de evengenoemde, meent menigeen thans te mogen concluderen dat er geen principieel onderscheid meer bestaat tussen privaat- en publiekrecht, want 'zowel met behulp van privaatrechtelijke als van bestuursrechtelijke instrumenten kunnen algemene belangen behartigd worden' ${ }^{20}$. Tussen de rechtsbetrekkingen in de beide rechtsgebieden zou ook hierom geen relevant verschil meet zijn aan te wijzen, omdat de rechtsbetrekkingen tussen overheid en burger meer horizontaal zouden zijn geworden en er sprake zou zijn van een 'wederkerige rechtsbetrekking'.

In de toelichting bij het in 1987 gepubliceerde voorontwerp voor de eerste tranche van een Algemene wet bestuursrecht wordt, evenals in de memorie van toelichting bij het in 1989 bij de Tweede Kamer ingediende wetsvoorstel, de betrekking bestuur-burger gekarakteriseerd als een wederkerige rechtsbetrekking ${ }^{2 t}$. Neemt men kennis van de literatuur van de laatste jaren ${ }^{22}$, dan blijkt echter dat de weder- 
kerigheidsconceptie in vrij korte tijd nogal populair is geworden. Kennelijk geeft het velen een warm gevoel, wanneer hun wordt voorgespiegeld dat het moderne overheidsbestuur geen 'Hoheitsverwaltung' of Obrigkeitsverwaltung' meer is doch dat dit bestuur 'wederkerig' en 'horizontaal' met de burger omgaat ${ }^{23}$.

Eén en ander wordt in verband gebracht met enerzijds de sterke uitbreiding van de overheidsactiviteiten sinds het begin van deze eeuw (de opkomst van de sociale Staat) - een ontwikkeling die wel beschreven wordt als 'vermaatschappelijking van de staat' en een daarmee gepaard gaande 'horizontalisering van de bestuursbetrekkingen' 24 - en anderzijds de opkomst van private organisaties die zich (mede) met de behartiging van publieke belangen bezig zouden houden ${ }^{25}$. In het privaatrecht zou zich een gelijksoortige ontwikkeling hebben voorgedaan: door de 'vermaatschappelijking van het privaatrecht' zou de 'autonomie van het rechtssubject' sterk zijn gerelativeerd: 'Het nieuwe privaatrecht houdt aldus meer rekening met de niet zelden .. verticale verhoudingen tussen bestuur en burger' ${ }^{26}$. Samenvattend worden al deze ontwikkelingen ook wel beschreven als 'osmose' ${ }^{27}$ tussen Staat en 'maatschappij', en tussen publiekrecht en privaatrecht ${ }^{28}$. Het gevolg van deze ontwikkelingen zou daarom zijn, dat tussen de rechtsbetrekkingen in het publiek- en het privaatrecht 'geen relevant verschil' meer zou zijn aan te wijzen ${ }^{29}$. En de conceptie van de 'wederkerige rechtsbetrekking' zou behulpzaam kunnen zijn bij het analyseren van de klassieke grenzen tussen deze rechtsgebieden.

Terecht wordt er op gewezen dat het vanaf het einde van de achttiende eeuw voorgestane dualisme Staat-'maatschappij' zijn juridische doorwerking vond in een principieel onderscheid tussen publiek- en privaatrecht ${ }^{30}$ en wordt het beginsel van wetmatig bestuur plaatst tegen de achtergrond van die scheiding.

Is de stelling juist, dat dit dualisme thans is losgelaten, met als gevolg dat 'de overheid' is geworden tot een actor te midden van een pluraliteit van burgers en belangen' " ${ }^{11}$ binnen één rechtsorde die bestaat uit 'complexen van rechtsbetrekkingen' met 'wederzijdse rechten en plichten', zodat de 'wederkerige rechtsbetrekking' inderdaad kan fungeren als 'gemeenschappelijk concept' op basis waarvan 'niet (meer) gerechtvaardigde verschillen' 32 tussen de rechtsgebieden kunnen worden opgeruimd?

Aan een discussie over de betekenis van het dualisme Staat-'maatschappij' in een democratische sociale rechtsstaat is grote behoefte: de zin en functie van een principieel onderscheid tussen publiek- en privaatrecht heeft inderdaad alles te maken met het ontstaan van dit dualisme aan het einde van de achttiende eeuw en het begin van de negentiende eeuw. De consequenties die verbonden worden aan de 'wederkerigheidsconceptie' zijn belangrijk. Zo zou zij niet alleen gevolgen moeten 
hebben voor het non-contentieus bestuursrecht, maar ook voor de opzet van contentieus bestuursprocesrecht ${ }^{33}$. En omdat deze conceptie in verband wordt gebracht met het (verder) vervagen van de grenzen tussen Staat en 'maatschappij' en - annex daaraan - van het onderscheid publiekrecht-privaatrecht ${ }^{34}$, wordt ook gepleit voor een relativering van het beginsel van wetmatigheid van bestuur ${ }^{35}$, het aanvaarden van ongeschreven zorgplichten van de burger jegens 'de maatschappij' - met 'de overheid', als 'zaakwaarnemer' van de 'collectieve belangen' van die 'maatschappij' 36 - en de wettelijke vastlegging van die zorgplichten (vgl. art. 1.1a Wet milieubeheer). Dit laatste wordt dan beschouwd als niet mér dan een codificatie van de jurisprudentie van de Hoge Raad, waarin de maatschappelijke zorgvuldigheidsnorm ó́k wordt aangelegd op het handelen van burgers waardoor zgn. publieke belangen worden geschaad, waarbij die codificatie aan het daardoor voor de overheid bestaande instrumentarium slechts zou toevoegen dat die zorgplichten niet meer alleen 'privaatrechtelijk' doch ook 'bestuursrechtelijk' kunnen worden gehandhaafd ${ }^{37}$. De nieuwe artikelen 3:305b en 3:305a BW sluiten áán bij deze ontwikkelingen in de jurisprudentie.

Deze jurisprudentie, die ook een vérgaande relativering betekent van het beginsel van wetmatigheid van overheidsbestuur, is van zo principiële betekenis omdat men daarin een bevestiging kan zien van het loslaten van het dualisme Staat-'maatschappij' en - annex daaraan - van het principiële onderscheid tussen publiekrecht en privaatrecht. In het volgende hoofdstuk bespreken we deze jurisprudentie: kan het door de Hoge Raad ingenomen standpunt dat 'de overheid' publieke belangen, behalve via de publiekrechtelijke weg, 'ook mag behartigen door gebruik te maken van haar in beginsel krachtens het privaatrecht toekomende bevoegdheden' ${ }^{38}$, en dat die onrechtmatigheid óók gelegen kan zijn in maatschappelijke onzorgvuldigheid jegens 'de overheid' ${ }^{39}$, worden aanvaard?

In hoofdstuk 6 geven we rekenschap van onze visie inzake de rol van de Staat in de rechtsvorming en de relatie tussen de statelijke - dat wil zeggen de publiekrechtelijke en burgerrechtelijke - rechtsvorming en de niet-statelijke rechtsvorming (de rechtsvorming binnen de 'maatschappij'). Om de vraag te kunnen beantwoorden, hoe ver de rechtsbekwaamheid van 'de overheid' c.q. de publiekrechtelijke rechtspersonen als bedoeld in art. 2:1 BW in het burgerrechtelijk verkeer werkelijk reikt, en welke de verhouding is tussen het publiekrechtelijke en het privaatrechtelijke handelen van 'de overheid', geven we ook aan wat naar ons oordeel de betekenis, de zin, is van de burgerrechtelijke rechtspersoonlijkheid van openbare lichamen. We zullen aangeven, waarom het dualisme Staat-'maatschappij' o.i. constitutief is voor een ware rechtsstaat - en derhalve niet los mag worden gelaten - en dat publieke belangen eerst door 'de overheid' te behartigen belangen zijn, wanneer deze belangen op basis van publiekrechtelijke rechtsvorming als zodanig zijn aangewezen. 
In de hoofdstukken 7 en 8 bespreken we art. 3:305b resp. art. 3:305a BW, die - als gezegd - aansluiten bij ontwikkelingen in de jurisprudentie en die aan publiekrechtelijke rechtspersonen resp. aan maatschappelijke organisaties (verenigingen en stichtingen) de algemene bevoegdheid verlenen ten behoeve van 'andere personen' zgn. civiele gebods- en verbodsacties te entameren, óók ter behartiging van zgn. publieke belangen. 


\section{Noten bij hoofdstuk 4}

1. Vgl. ook M. Hariou, 'Précis de Droit Administratief, 5e đruk, Paris 1943, p. VIII: 'L'existence d'un droit administratif de puissance publique est, par une sorte de loi de compensation, la condition de I'existence d'un droit civil purgé de toute inégalité sociale'.

2. Geciteerd naar Poortinga, a.w., pp. 108 en 139.

3. Staat-'maatschappij' is als begrippenpaar geintroduceerd door Hegel (of beter: Hegel ging uit van de drieslag: gezin-burgerlijke maatschappij-Staat). De onderscheiding is er echter al sinds Locke.

4. E.-W. Bockenforde, 'Die Bedeutung der Unterscheidung von Staat und Gesellschaft im demokratischen Sozialstaat der Gegenwart', in: 'Staat, Gesellschaft, Freiheit', Frankfurt am Main 1976, pp. 185-220 (p. 187-189), ook opgenomen in de bundel 'Staat und Gesellschaft', Darmstadt 1976, pp. 395-431. recent herdrukt in: dez., 'Recht, Staat, Freiheit', Frankfurt aM 1991, pp. 395-431. Op dit opstel - dat ook vele literatuurverwijzingen bevat - wordt hierna nog uitvoerig ingegaan. De bundel 'Staat und $\mathrm{Ge}$ sellschaft' bevat, behalve het opstel van B., nog een groot aantal andere klassieke teksten over de verhouding Staat-Gesellschaft.

5. L. Kant, 'Grundlegung zur Metaphysik der Sitten', 306 en 313: '(Das offentliche Recht) enthalt nicht mehr oder andere Pflichten der Menschen unter sich, als in jenem (t.w. het privaatrecht in de 'status naturalis'; JT) gedacht werden kōnnen; die Materie des Privatrechts ist ebendieselbe in beiden. Die Gesetze des letzteren (t.w. het publiekrecht; JT) betreffen nur die rechtliche Form ihres Beisammenseins (Verfassung), in Ansehung deren diese Gesetze notwendig als offentliche gedacht werden müssen. (...) (D)die Gesetze über das Mein und Dein im Naturzustande (enthalten) ebendasselbe, was die im bürgerlichen vorschreiben, sofern dies nach reinen Vernunftbegriffen gedacht wird: nur das im letzteren die Bedingungen angegeben werden, unter denen jene zur Ausübung ... gelangen' (curs. dzz.; JT)

6. Bōckenforde, a.w., p. 189/190.

7. H.J. van Eikema Hommes, 'De wijsgerige grondslagen van de rechtssociologie', a.w., p. 172.

8. Een goed voorbeeld is het nationaal-socialistisch gekleurde werk van Karl Larenz, 'Rechts- und Staatsphilosophie der Gegenwart', 2e druk, Berlin 1935. Vanwege zijn verheerlijking van 'de Staat' als 'zuivere vorm des menschen' - vgl. R.A.V. van Haersholte, 'De Staat als zuivere vorm des menschen', diss. Leiden 1946 - wordt Hegel veelal beschouwd als geestelijke vader van totalitaire staatsopvattingen (Zoals trouwens Rousseau veelal wordt beschouwd als de geestelijke vader van de totalitair-democratische staatsopvattingen. Vgl. J.L. Talmon, 'The Origins of Totalitarian Democracy', London 1952; dez., 'The myth of the nation and the vision of revolution', London 1981). Volgens auteurs als Donner en Meuwissen zou men Hegel daarmee onrecht doen. Zie D.H.M. Meuwissen, 'Recht en vrijheid', Inleiding in de rechtsfilosofie, Utrecht/Antwerpen 1982, pp. 51-56; C.W. van der Pot/A.M. Donner, 'Handboek van het Nederlandse Staatsrecht', 10e druk, Zwolle 1977, p. 41. Op het misbruik door Larenz van Hegels filosofie wordt gewezen door H.H. Jakobs, 'Karl Larenz und der Nationalsozialismus', JZ 1993, pp. 805-815.

9. Lorenz von Stein, 'Geschichte der sozialen Bewegung in Frankreich von 1789 bis auf unsere Tage', Bd. I: Der Begriff der Gesellschaft, Leipzig 1850, (heruitgave: G. Salomon, München 1921, herdruk Darmstadt 1959), p. XXXI en XLIII.

10. Lorenz von Stein, 'Gegenwart und Zukunft der Rechts- und Sozialwissenschaften Deutschlands', Sturtgart 1876, p. 144 (cursivering door de auteur).

11. Lorenz von Stein, 'Zur preussischen Verfassungsfrage', 1852, herdruk Berlijn 1941, p. 35/36. Vgl. dez., 'Die Verwaltungslehre', 2e druk, Stuttgart 1869, p. 89.

12. Bökenforde, a.w., p. 191.

13. E.W. Bockenforde, 'Lorenz von Stein als Theoretiker der Bewegung von Staat und Gesellschaft zum Sozialstaat', in: Staat, Gesellschaft, Freiheit, Frankfurt am Main 1976, pp. 146-184 (p. 176, nt. 24).

14. Bernd Jeand'Heur, 'Von der Gefahrenabwehr als staatiche Angelegenheit zum Einsatz privater Sicherheitskräfte', Verwaltungsarchiv 1994, pp. $107-136$ (p. 120). 
15. Léon Duguit, 'Le droit social, le droit individuel et les transformations de I'État', Paris 1911; dez., 'Les transformations générales du droit privé depuis le Code de Napoléon'. Paris 1912; dez., 'Les transformations du droit public', Paris 1921.

16. H. Krabbe, 'Kritische Darstellung der Staatslehre', Den Haag 1930, p. 315/316.

17. H. Krabbe, Interventic, in: HNJV 1914-II, p. 132.

18. Zie bijv. H. Krabbe, 'De moderne staatsidee', Den Haag 1915, pp. 84-90, pp. 104-107.

19. Zie bijv. H. Krabbe, 'Administratieve rechtspraak', Groningen 1901, p. 103.

20. Aldus M. Kobussen, 'De vrijheid van de overheid', diss, Tilburg, Zwolle 1991.

21. TK 1988-1989, 21.221, nr. 3, p. 11 e.v.

22. Een overzicht is te vinden bij Gribnau, t.a.p.

23. Vgl. bijv. H.G. Lubberdink, 'De Awb: hoedster van de individuele vrijheid?', in: J.L. Boxum e.a. (red.), 'Aantrekkelijke gedachten', Deventer 1993, pp. 131-139. Volgens Lubberdink impliceertde visie van de Awb-wetgever, dat de 'hoheitliche Verwaltung' voltooid verleden tijd is: 'Het bestuur is niet 'die hoheitliche Verwaltung' die in haar wijsheid beslissingen over de burger uitstort. De ruimte die de wetgever het bestuur moet laten, mag niet eenzijdig door het bestuur worden ingevuld. Daarbij geldt dat niet het bestuur bepaalt wat het belang van de burger is, maar dat de burger dat zelf bepaalt'.

24. Stout, a.w., p. 2 .

25. Zo betoogt R.M. Unger, 'Law in Modern Society, Toward a Citicism of Social Theory', New York 1976. dat de moderne Staat niet meer 'a neutral guardian of the social order' is en dat ook private organisaties macht zijn gaan uitoefenen die traditioneel geacht wordt het prerogatief van de overheid te zijn. Daarmee verdwijnen z.i. de grenzen tussen Staat en maatschappij, terwijl ook private organisaties zich steeds meer bezig houden met publieke belangen.

26. J.H. van Kreveld, 'De wisselwerking tussen publiek- en privaatrecht. Een uitdaging voor juristen van beide zijden', in: J.H.F. Peters, M.H. Kobussen (red.), 'Bestuursrecht en nieuw BW', Zwolle 1988, p. 71 .

27. G.A. van Poelje, 'Osmose. Een aanteekening over het elkander doordringen van de beginselen van openbuar bestuur en particulier beheer', Alphen a/d Rijn 1931, 2e druk 1959.

28. Men denke ook aan de in zwang gekomen aanduiding 'gemengde rechtsleer'.

29. A.F.M. Brenninkmeijer, 'Harmonisatie van procesrecht', HNJV 1991, p. 68.

30. René Foqué, 'De ruimte van het recht', oratie Rotterdam 1992, Amhem 1992, p. 24; Gribnau, t.a.p., p. 93.

31. Gribnau, t.a.p., p. 93.

32. Gribnau, t.a.p., p. 95.

33. TK 1991-1992, 22,495, nr. 3, pp. 33-35, waar wordt betoogd dat de ontwikkeling die ertoe heeft geleid dat de verhouding tussen overheid en burger in toenemende mate wordt gezien als een wederkerige rechtsbetrekking, 'ook van invloed (is) op het bepalen van de doelstellingen en de vormgeving van het bestuursprocesrecht' en dat in de verdere toekomst 'denkbaar is dat, zoals dat ook in het burgerlijk procesrecht het geval is, de rechtsbetrekking ex nunc de inzet van de procedure wordt, waarbij ook aan het betrokken bestuursorgaan een actie toekomt'.

34. Vgl. Gribnau, t.a.p.

35. Zie bijv. H. Stout, 'De betekenissen van de wet', diss. Amsterdam 1994, Zwolle 1994, 0.a. pp. 164 en 247; Lubberdink, a,w., p. 137.

36. Zie bijv. P.C.E. van Wijmen, 'Samenloop van bestuursrecht en burgerlijk recht bij onrechtmatige daad', in: H.J.A.M. van Geest e.a., 'Bestuursrecht aan de horizon' (bundel t.g.v. de 80-ste verjaardag van prof.mr. S.F.L. van Wijnbergen), Zwolle 1994, pp. 135-148; dez., 'Bescherming van natuur-en milieuwaarden in rechte; de verdediging van collectieve goederen', M\&R 1994/9, pp. 234-243; Anke Kruisinga, 'De vervuiler betaalt?', Recht en Kritiek 1994, pp. 27-45.

37. Bekendste voorbeeld: art. 1. Ia Wet milieubeheer (Wmb), waarin een zorgplicht van de burger 'jegens het milieu' is vastgelegd.

38. HR 26 jan. 1990, Gst. 6914.10, AB 1990, 408 (Windmill).

39. HR 9 febr. 1990, NJ 1991, 462, AB 1990, 409 (Staat/Van Amersfoort). 


\section{Hoofdstuk 5}

\section{De overheidsactie uit onrechtmatige daad, ook voor publieke belangen. Ontwikkelingen in de jurisprudentie van de Hoge Raad}

\section{Inleiding}

In dit hoofdstuk bespreken we ontwikkelingen in de jurisprudentie van de Hoge Raad, die de eis van de zorgvuldigheid in het maatschappelijk verkeer - waarvan Paul Scholten nog zei dat hier niet staat 'individu tegenover gemeenschap .... doch individu tegenover individu' ' - 6 ók is gaan aanleggen op de verhouding tussen private (rechts)personen en de overheid die optreedt in het kader van de behartiging van publieke belangen. Het principiële onderscheid tussen Staat en 'maatschappij' en daarmee ook tussen publiek- en privaatrecht, wordt daarmee losgelaten, hetgeen ook een relativering impliceert van de eis van wetmatigheid van bestuur, een eis die - zoals we zagen - kan worden gezien tegen de achtergrond van het dualisme Staat'maatschappij'. Dit komt duidelijk naar voren in de recente jurisprudentie, waarin wordt gesteld dat 'de overheid' publieke belangen, behalve langs de publiekrechtelijke weg, in beginsel ook mogen behartigen 'door gebruik te maken van haar in beginsel krachtens het privaatrecht toekomende bevoegdheden, zoals aan het eigendomsrecht ontleende bevoegdheden, de bevoegdheid een overeenkomst naar burgerlijk recht te sluiten of de bevoegdheid een vordering op grond van een jegens haar gepleegde onrechtmatige daad bij de burgerlijke rechter in te stellen ${ }^{2}$, waarbij de onrechtmatigheid jegens 'de overheid' óók hierin gelegen kan zijn dat het handelen van de burger aantasting van een (ongeschreven) publiek belang en daarmee strijd met een ongeschreven zorgvuldigheidsnorm impliceert ${ }^{3}$. Terwijl voorheen nog gesproken werd van de 'zorgvuldigheid die in het maatschappelijk verkeer betaamt jegens eens anders persoon of goed', wordt thans aangenomen dat er ook ongeschreven zorgvuldigheidsnormen kunnen gelden in de verhouding tussen burger en overheid die optreedt ter behartiging van ('ongeschreven') publieke belangen. Omgekeerd is aanvaard dat maatschappelijke verbanden - zoals milieuorganisaties kunnen opkomen voor publieke belangen via acties uit hoofde van onrechtmatige daad, die hierin gelegen zou zijn dat door aantasting van het publieke belangen het door zo'n verband behartigde belang zou zijn geschonden ${ }^{4}$. 
Had het toepasselijk achten van art. 1401 BW (oud) op de overheid ('als zodanig') aanvankelijk een rechtsbeschermingsfunctie, thans is art. 1401 resp. art. 6:162 BW geworden tot een wapen van 'de overheid' tégen de burger. De principiële betekenis van de recente jurisprudentie, waarbij wordt aanvaard dat aantasting van - zelfs 'ongeschreven' - publieke belangen is te kwalificeren als onzorgvuldigheid in het maatschappelijk verkeer jegens 'de overheid', is nog niet of althans onvoldoende onderkend. Aan discussies over de betekenis van de onderscheiding van Staat en 'maatschappij' in een democratische sociale rechtsstaat, zoals die zijn gevoerd in de na-oorlogse Duitse literatuur ${ }^{\text {s }}$, bestaat in Nederland kennelijk weinig behoefte. Het antwoord op de vraag, hoe deze jurisprudentie moet worden beoordeeld, is echter - zoveel is wel duidelijk - mede ervan afhankelijk, of men vasthoudt aan deze onderscheiding.

\section{De rechtsontwikkeling in Frankrijk op het punt van de onrechtmatige overheidsdaad}

Dat het toepasselijk achten van art. $1401 \mathrm{BW}$ op het onrechtmatig overheidsoptreden te maken had met het ontbreken van (algemene) administratiefrechtelijke rechtspraak hier te lande, moge blijken uit een vergelijking met de rechtsontwikkeling die zich heeft voorgedaan in Frankrijk. In het eerste hoofdstuk wezen we er reeds op dat ook uit de totstandkomingsgeschiedenis van de Code Civil naar voren komt, dat de artt. 1382 e.v. van de Code - waaraan de artt. 1401 e.v. BW (oud) zijn ontleend - zijn geschreven voor interpersoonlijke verhoudingen. Het burgerlijk recht werd beschouwd als een door de Staat gepositiveerd recht voor de maatschappelijke betrekkingen, welk recht het onderling private verkeer tussen de burgers betreft die daarbij juridisch op voet van gelijkheid staan, en dat aan de burgers de vrijheid laat hun eigen private belangen naar eigen inzicht na te streven. Het burgerlijk recht is - zoals reeds meermalen werd betoogd - gebaseerd op de beginselen van de burgerlijke vrijheid-in-gelijkheid en de iustitia commutativa. Overduidelijk blijkt dit uit de door ons in het eerste hoofdstuk reeds geciteerde woorden van Locré, secretaris van de Conseil d'État, in zijn kort na de inwerkingtreding van de Code verschenen en aan Napoléon opgedragen commentaar:

'Voila donc ce qu'est le droit civil ou privé: son object est de régler les rapports individuels, tels qu'ils existent dans l'état de société; son matière, la propriété, son principe est dans la nature; sa forme dans le droit positif "

Niettemin zijn er in de negentiende eeuw in Frankrijk (en daarbuiten) belangrijke auteurs op burgerrechtelijk terrein alsook enkele administratiefrechtelijke auteurs, die de toepasselijkheid van de artt. 1382 e.v. van de Code op de Staat aannamen, hetzij absoluut, hetzij beperkt (waarbij dan veelal een onderscheid wordt gemaakt 
tussen de Staat 'als overheid' en de Staat 'als privaat-rechtspersoon') ${ }^{7}$. Vermelding verdient $o . i$. de door ons in het eerste hoofdstuk reeds genoemde opvatting van de Belgische civilist Laurent, die overheidsaansprakelijkheid op grond van art. 1382 e.v. van de Code mogelijk acht. Zijns inziens mag het zwaartepunt der burgerrechtelijke aansprakelijkheid niet daarin gezocht worden, of de schade veroorzakende handeling al dan niet burgerrechtelijk is, maar of het beschadigde object een door het burgerlijk recht beschermd subjectief privaat vermogensrecht is.

Vermelding verdient ook zijn bestrijding van de splitsing Staat-pouvoir public (of politique) en Staat-privaatrechtelijke rechtspersoon. Laurent ontkent het bestaan van de tweede, omdat een private persoon particuliere belangen dient en de Staat, zelfs als eigenaar, als koper, als huurder, kortom altijd, handelt voor de publieke gemeenschap en dus uitsluitend voor haar - publieke - belangen.

Bij de auteurs op administratiefrechtelijk terrein gaat René Jacquelin het verst ${ }^{8}$. Jacquelin vraagt zich af, of de bevoegdheid van de Conseil d'Etat - die tot 1872 immers nog niet is aangewezen als zelfstandige administratieve rechter - en de onbevoegdheid van de gewone rechter wel in overeenstemming zijn met het beginsel van de machtenscheiding. Óf wat de Conseil doet, is rechtspreken, of het is ' $t$ niet. Is het wél rechtspraak, dan is hier een administratief orgaan belast met een functie die alleen de rechterlijke macht toekomt. Is het géén rechtspraak, dan is er dus ook geen sprake van administratieve rechtspraak. Jacquelin is dan ook van oordeel dat, waar het gaat om de beoordeling van beweerde onrechtmatige overheidsgesties, de uitsluiting van de burgerlijke rechter niet verdedigd mag worden met een beroep op de machtenscheiding 'puisqu'il en est la violation'. Zuiver in de leer acht hij het Belgische systeem, waarin de burgerlijke rechter bevoegd is wanneer het gaat om inbreuken op private rechten door de administratie, zij het dat de machtenscheiding in elk geval beoordeling van de zgn. 'actes d'autorité' c.q. de 'puissance publique' uitsluit.

Gedurende geruime tijd achtte ook de hoogste burgerlijk rechter - het Cour de Cassation - de overheid uit hoofde van art. 1384 jo. art. 1384 Code Civil aansprakelijk voor onrechtmatig handelen waardoor private vermogensrechten worden aangetast, óók als het bij dit overheidshandelen gaat om zgn. 'faits de service' ?

Zo oordeelt een arrest van het Cour du Cassation van 19 dec. 1854 ('arrêt-administration des postes') inzake de competentie van de burgerlijke rechter o.a.:

'(C)ette compétence est générale (...) A l'égard de ces employés (des administrations publiques; JT), l'action exercée contre eux a son principe dans le droit commun et doit être jugée par les principes de ce droit. Si cette action par sa nature réagit contre l'administration elle-même, et peux amener des condamnationsenvers elle comme responsabledu fait des ses agents, cette responsabilité n'est aussi que la conséquence du droit commun; les administrationspubliques, comme représentant l'Etat ne sont pas à l'abri des poursuites judiciaires qui ont pour objet de faire établir et déclarer 
cette responsabilité et de faire reconnaitre les conséquences légales qui en découlent ..etc.' (curs. dzz.; JT) ${ }^{10}$.

De toepasselijkheid van de artt. 1382 e.v. van de Code op onrechtmatige handelingen van de administratie wordt hier gebaseerd op wat men de leer van het gemene recht ('droit commun') zou kunnen noemen.

De competentie van de burgerlijke rechter wordt echter betwist door de Conseil d'État. Bij het beroemde arrest-Blanco van 8 februari 1873 beslecht het Tribunal des Conflits de strijd ten gunste van de administratieve rechter ". Dit conflictenhof is kort daarvoor, bij wet van 24 mei 1872, ingesteld als afzonderlijke conflictenrechter; bij diezelfde wet is de Conseil d'État - voordien, ook in administratieve geschillen, nog college van advies aan de regering ('justice rétenue') - aangewezen als zelfstandige administratieve rechter. Bij art. 9 van die wet is bepaald:

'Le Conseil d' État statue souverainement sur les recours en matière contentieuse administrative, et sur les demandes d'annulation pour excès de pouvoir formées contre les actes des diverses autorités administratives:

Bij het arrest-Blanco wordt beslist:

'Considérant que la responsabilité qui peut incomber à l'État pur les dommages causés aux particuliers par le fait des personnes qu'il emploie dans le service public, ne peut être régie par les principes qui sont établis dans le Code civil pour les rapports de particulier à particulier;

Que cette responsabilitén'est ni généraleni absolue; qu'elle a ses règles spéciales qui varient suivant les besoins du service et la nécessité de concilier les droit d'État avec les droits privés'.

Omdat het dus gaat om een 'matière contentieuse administrative' is niet de burgerlijke rechter maar de administratieve rechter - de Conseil d'État - bevoegd kennis te nemen van dergelijke geschillen met de overheid. De argumentatie van het Tribunal des Conflits sluit aan bij het uitgangspunt van de Code Civil, die - zoals we zagen - door de opstellers ervan is bedoeld als een wetboek dat de regels voor het onderlinge verkeer tussen de burgers behelst (het 'maatschappelijke verkeer').

De grondslag voor de staatsaansprakelijkheid terzake van schade toegebracht in het kader van de 'service public' is in deze visie niet te vinden in de Code Civil (de artt. 1382 e.v.), maar in het ongeschreven recht. De jurisprudentie van de Conseil d'État zou steeds meer worden geleid door het typisch - op de iustitia distributiva gebaseerde - publiekrechtelijke beginsel van de égalité devant les charges publiques. Bijzondere vermelding verdient het arrest van de Conseil d'État van 14 jan. 1938, inzake de melkfabriek 'La Fleurette'. In dit arrest wordt voor het eerst schadeaansprakelijkheid van de Staat erkend in verband met schending van de égalité bij de uitvaardiging en uitvoering van wetgeving. Een wet had het bereiden van room verboden, welke niet uitsluitend uit melk samengesteld was. Dit geschiedde teneinde de afzet van melkprodukten te verhogen. In het bijzonder werd in deze wet verboden 
het bereiden van een produkt genaamd 'gradine', hetwelk in geen enkel opzicht schadelijk was, doch waarin ook aardnootolie verwerkt werd. De fabriek 'La Fleurette' had zich speciaal toegelegd op het maken van bedoelde 'gradine' en zag zich dus door het verbod bijzonderlijk benadeeld. De Conseil d'État overweegt dat noch uit de wet noch uit haar wordingsgeschiedenis noch uit enige andere omstandigheid valt af te leiden, dat de wetgever de benadeelde een schade zou hebben willen doen lijden, welke hij normaliter niet zou hebben te lijden. Het betreft hier het opleggen van een last in het algemeen belang en derhalve zou de staatsgemeenschap deze last hebben te dragen. Omdat door de wettelijke maatregel een beperkte groep van producenten bijzonder - onevenredig - zou worden getroffen, zou de daardoor veroorzaakte schade door de Staat moeten worden vergoed:

'Considérant ... que rien, ni dans le texte même de la loi ou dans ses travaux préparatoires, ni dans le texte même de la loi ou dans ses travaux préparatoires, ni dans l'ensemble des circonstances de l'affaire, ne permet de penser que le législateur a entendu faire supporter à l'intéressée une charge qui ne lui incombe pas normalement;

que cette charge, créée dans un intérêt général, droit supportée par la collectivité;

qu'il suit de là que la societé La Fleurette est fondée à demander que l'État soit condamné à lui payer une indemnité en réparation du préjudice par elle subi....' 1 .

Zien we het goed, dan moet de eerste overweging verstaan worden in het licht van het verbod tot toetsing van de wet in formele zin. Evenals in Nederland werd - en wordt ${ }^{13}$ - in Frankrijk nog steeds uitgegaan van de onschendbaarheid van de wet in formele zin $^{14}$.

In zijn jurisprudentie waarin sprake was van het égalitébeginsel, heeft de Conseil d'État zich niet beroepen op een geschreven tekst.

Overigens is in de Franse literatuur al vroeg gezocht naar een wettelijke ondergrond, die voor het publiekrecht een algemene regel voor de overheidsaansprakelijkheid zou kunnen stellen. Zo verdedigt een auteur als Teissier, dat art. 1382 Code Civil slechts de uitdrukking is van een algemeen principe dat zonder de Code ook zou gelden, zodat art. 1382 zou zijn te beschouwen als een algemene regel die geldt zowel voor het burgerlijk recht als het publiekrecht, met dien verstande dat men in het publiekrecht van die regel alles los maakt wat aan speciale regels aan art. 1382 wordt vastgeknoopt (zoals de competentie van de burgerlijke rechter) en aldus zou moeten worden ingevuld dat de schadevergoedingsplicht afhankelijk wordt gesteld van de vraag of er sprake is van 'un préjudice exceptionnel dépassant les risques normaux que le législateur a entendu laisser à sa charge'. De algemene regel van art. 1382 zou voor het publiekrecht niet toestaan, 'qu'un citoyen souffre plus que les autres des actes de la puissance publique réputés accomplis dans l'intérêt de tous' ${ }^{15}$. Andere auteurs ${ }^{16}$ menen een geschreven constitutionele basis te kunnen vinden in art. 13 van de Déclaration des Droits de l'homme et du citoyen van 3-14 september 1791: 
'Pour l'entretien de la force publique et pour les dépenses d'administration, une contribution commune est indispensable; elle doit être également répartie entre tous les citoyens, en raison de leurs facultés'.

Het égalitébeginsel kan, meer indirect, ook worden afgeleid uit de artikelen 3 en 5 van de Constitutie van 24 juni 1793, die de 'égalité devant la loi' en de 'égalité d'accès de tous aux emplois publics' beogen te waarborgen. De égalité wordt verstoord telkenmale wanneer een burger onevenredig in zijn rechtsbelangen is benadeeld ten gevolge van de functionering der services publics. De Staat is dan gehouden het evenwicht te herstellen door een schadevergoeding. Dit 'principe d'égalité devant les charges publiques' is vervolgens ook neergelegd in art. 59 van de Acte additionel van 1815 bij het Handvest van 1814 , de préambules van de Constitutie van 1848 en die van 1946 en in art. 2 van de Constitutie van 1958, die namelijk uitdrukkelijk verwijst naar de Déclaration van 1789.

Het 'principe d'égalité' (gelijkheidsbeginsel), waarvan het 'principe d'égalité devant les charges publiques' een typisch publiekrechtelijke verbijzondering is, wordt daarnaast gerekend tot de 'principes généraux du droit' waaraan de rang van constitutionele regels wordt verbonden, hetgeen impliceert dat dit beginsel ook in acht moet worden genomen bij overheidsgesties die niet door geschreven positiveringen van dit beginsel worden bestreken ${ }^{17}$.

In 1927 doet Paul Duez naar aanleiding van de jurisprudentie van de Conseil d'État inzake overheidsaansprakelijkheid de uitspraak:

'Qu'il s'agisse de la responsabilité pour faute, qu'il s'agisse de la responsabilité pour risque, I'inspiration ne vient pas du droit civil: les théories inclues dans les arrêts sont des théories autonomes reflectant les idées du droit public' ${ }^{*}$.

Deze conclusie van Duez is o.i. juister dan die van Gaston Jèze, die betoogt:

'En droit public français on n'appliquepas les textes mêmes de Code civil - on s'inspire seulement des idées générales qui justifient ces textes en les combinant avec les nécessités du fonctionnement régulier et continu de services publiques' ${ }^{19}$.

Dit betoog van Jèze wordt met instemming geciteerd door Kranenburg. Kranenburg merkt op dat de Franse oplossing gelukkiger is dan die welke in de Nederlandse literatuur door meerderen is verdedigd, namelijk dat het burgerlijk recht wordt beschouwd als het gemene recht, waarop het publiekrecht voortdurend inbreuk maakt, maar dat daardoor niet terzijde wordt gesteld ${ }^{20}$. Als Kranenburg betoogt dat er geen principiële tegenstelling bestaat tussen publiek- en privaatrecht, dan doelt hij op het bestaan van algemene, gemeenschappelijke rechtsbeginselen ${ }^{21}$. Nu moge het niet onjuist zijn dat allerlei regels en rechtsbeginselen gemeenschappelijk zijn aan publiek- en burgerlijk recht, zulks neemt niet weg dat beide een typische eigenaard hebben. Beide rechtsgebieden kunnen hun eigen typische rechtsbeginselen; bovendien krijgen de algemene rechtsbeginselen - bijvoorbeeld het rechtszekerheidsbeginsel - in elk rechtsgebied hun typische verbijzondering. Inzoverre zou men, nl. 
voorzover het gaat om algemene rechtsbeginselen, kunnen spreken van 'gemeenschappelijk', 'gemeen recht', mits men deze term niet - zoals in de Nederlandse literatuur gebruikelijk is - direct koppelt aan het burgerlijk recht. Men zou dus kunnen zeggen dat de jurisprudentie van de Conseil d'État mede geïnspireerd werd door algemene rechtsbeginselen die ó́k aan het burgerlijk recht ten grondslag liggen, maar hun eigen typische verbijzondering krijgen in het publiekrecht. Aldus opgevat is het betoog van Gaston Jèze niet onjuist. Onjuist is echter de door Kranenburg - mede op basis van de Franse jurisprudentie - getrokken conclusie, dat het principiële onderscheid tussen publiekrecht en burgerlijk recht verloren is gegaan.

In Frankrijk, zowel als in Duitsland, is de bevoegdheid van de burgerlijke rechter in beginsel afhankelijk van het al dan niet toepasselijk zijn van materieel burgerlijk recht. Fritz Fleiner vat in 1906 de ontwikkeling in Frankrijk heel treffend als volgt samen:

'Aus der Unzustảndigkeitdes Zivilgerichtes in allen Angelegenheitender ôffentlichen Verwaltung schloss die Praxis auf die Unaufwendbarkeitdes Zivilrechtes ${ }^{2}$.

Ofschoon deze ontwikkeling aansluit bij de bedoelingen van de wetgever van de Code Civil, is - zo kan men concluderen - de aanwezigheid van algemene administratieve rechtspraak in Frankrijk beslissend geweest.

\section{Nederland: art. 1401 BW als 'uitwijkmethode' in het belang van de rechtsbescherming}

Dat in Nederland de ontwikkeling anders is verlopen dan in Frankrijk, vindt voor een belangrijk deel zijn oorzaak in de afwezigheid van algemene administratieve rechtspraak. Waar de burger onrecht werd aangedaan door de overheid, moest hij daartegen bescherming zoeken bij de gewone rechter.

Reeds toen hier te lande nog de Code Civil van kracht was, werden de artikelen 1382 e.v. van de Code - betreffende de onrechtmatige daad - in de jurisprudentie óók op onrechtmatig overheidsoptreden van toepassing geacht ${ }^{23}$. Daarin kwam geen verandering toen het Burgerlijk Wetboek werd ingevoerd en de artt. 1382 e.v. van de Code werden vervangen door de artt. 1401 e.v. BW. Hierbij speelde een belangrijke rol dat men hier in het restauratietijdperk nog in sterke mate vasthield aan oud-Vaderlandse rechtsopvattingen. Zo kan gewezen worden op de ruime inhoud die het begrip 'burgerlijk' c.q. 'civiel' oudtijds had ${ }^{24}$.

Bovendien was er veel kritiek op het Franse conflictenstelsel dat hier ten tijde van de Franse overheersing had gegolden: men wenste bescherming bij een rechter tegen aantasting van het particulier vermogen, en dat betekende: de gewone rechter, want 
een aparte administratieve rechter was er nog niet ${ }^{25}$. Een doctrinair onderscheid tussen privaatrechtelijke en publiekrechtelijke geschillen werd hierbij niet gemaakt. Poortinga wijst er op dat ook de totstandkoming van het Nederlandse Conflictenbesluit in 1822 en de ter uitvoering daarvan genomen KB's in de periode 1822 1844 niet zijn verdedigd met behulp van het onderscheid tussen publiek- en privaatrecht, en dat het ook in de literatuur vóór 1840 niet gangbaar was het conflictenstelsel in verband te brengen met dit onderscheid ${ }^{26}$.

Pas als het er aan het eind van de vorige eeuw naar uitziet dat algemene administratieve rechtspraak zou worden geïntroduceerd - op basis van de voorstellen van de commissie-Kappeyne van de Coppello - is de Hoge Raad hierin kennelijk enige tijd van oordeel dat de tijd was gekomen om zich terug te trekken van het terrein van de onrechtmatige overheidsdaad. Zoals Van der Hoeven terecht opmerkt ${ }^{27}$, zijn de bekende arresten van 29 mei 1896 ('Vrouwe Elske') ${ }^{28}$ en van 21 april 1898 ('Rhedense koe') ${ }^{29}$, die in vele uiteenzettingen van de historie van de jurisprudentie over de onrechtmatige overheidsdaad tot uitgangspunt worden genomen, vormden veeleer een incident dan een voortzetting van een bestaande jurisprudentielijn.

Meer dan eens is namelijk in de loop van de negentiende eeuw met succes een beroep gedaan op de gewone rechter terzake van schade veroorzaakt door overheidsoptreden. Een sprekende voorbeeld is het in hoofdstuk 1 reeds genoemde arrest van de Hoge Raad van 26 juni 1863, waarbij de Zuidplaspolder schadevergoedingsplichtig werd geoordeeld wegens de schade die deze aan een schipper had toegebracht, door een dam te leggen in een bij dit openbaar lichaam in beheer zijnde ringvaart en daarmee deze openbare vaarweg te versperren. Het cassatiemiddel, dat de artt. 1401 en 1402 BW onjuist waren toegepast, werd door de Hoge Raad verworpen met de overweging:

'dat art. $1401 \mathrm{BW}$ toekent vergoeding der schade, toegebragt, door elke onregtmatige daad; dat daaronder is begrepen elk ook door een openbaar bestuur gepleegdedaad, waartoe het is onbevoegd en waardoor het schade heeft veroorzaakt, hoedanige onbevoegdheiden geleden schade in casu zijn uitgemaakt, en dat dus gezegd artikel terecht is toegepast; dat hetzelfde geldt ten aanzien van art. 1402 BW, hetwelk heeft eene even algemeene strekking en alleen vordert nalatigheid of onvoorzigtigheid en door een van beide veroorzaakte schade, terwijl èn nalatigheid èn daardoor geleden schade door het Hof zijn aangenomen... ${ }^{30}$.

Zien we het goed, dan getuigt dit arrest van een opvatting die verwantschap vertoont met de eerder genoemde opvatting van de Belgische civilist Laurent, die het zwaartepunt van de aansprakelijkheid ex art. 1382 e.v. Code Civil niet daarin gelegen zag, of de schade veroorzakende handeling al dan niet burgerrechtelijk is, maar of het beschadigde object een door het burgerlijk recht beschermd subjectief privaat vermogensbelang is. 
Waarschijnlijk in de verwachting dat het spoedig zal komen tot invoering van administratieve rechtspraak, wijst de Hoge Raad de arresten van 1896 en 1898 .In het arrest van 1898 wordt over een overheidsdaad die 'zuiver en alleen' gegrond zou zijn in het publiekrecht, geoordeeld:

'dat de al dan niet rechtmatigheid van zoodanigedaad van het openbaargezag als in deze heeft plaats gehad uitsluitend aan het publiekrecht kan worden getoetst, en niet kan worden beoordeeld naar de bepalingen van het burgerlijk recht, als regelende de rechten en verplichtingen van bijzondere personen' 31

Hiervan komt de Hoge Raad in het Pothuisarrest van 1901 al weer terug ${ }^{32}$. En sinds het Ostermanarrest van $1924{ }^{33}$ wordt art. 1401 BW algemeen geacht betrekking te hebben op schade veroorzaakt door zowel privaatrechtelijk als publiekrechtelijk onrecht, met dien verstande dat het in 1919 aanvaarde onrechtmatigheidscriterium van de onzorgvuldigheid in het maatschappelijk (!) verkeer slechts toepasbaar wordt geacht op het verkeer tussen burgers onderling (met inbegrip van de overheid 'als bijzonder persoon').

Wat de bevoegdheid van de gewone rechter betreft, staat sinds het arrest-Guldemond/Noordwijkerhout ${ }^{34}$ al vast, dat die bevoegdheid niet wordt bepaald door de aard van het rechtsstelsel waarop de rechtsbetrekking tussen eiser en gedaagde is gebaseerd (het fundamentum petendi) c.q. de aard van de gepleegde handeling ${ }^{35}$, maar door de aard van het door die handeling aangetaste subjectieve recht c.q. rechtsbelang waarin eiser wenst te worden beschermd (het voorwerp van het geschil, het objectum litis).

Anders dan in Frankrijk (alsook Duitsland) is de bevoegdheid van de Nederlandse burgerlijke rechter dus niet gekoppeld aan de toepasselijkheid van materieel burgerlijk recht; hij is de algemeen bevoegde - gewone - rechter. De enkele omstandigheid dat de onderliggende rechtsverhouding van publiekrechtelijke aard is, leidt dus niet tot een onbevoegdverklaring ${ }^{36}$. Hieruit volgt dat, waar de bevoegdheid van de gewone rechter wordt aangenomen, dit niet automatisch toepasselijkheid van burgerlijk recht impliceert. De bevoegdheidsvraag is te onderscheiden van de vraag of materieel burgerlijk recht van toepassing is.

Wellicht ware het dus denkbaar geweest dat de Hoge Raad de grondslag voor de aansprakelijkheid wegens onrechtmatig handelen door de overheid (althans voor het onrechtmatig handelen door de overheid 'als zodanig') niet had gezocht in art. 1401 BW maar - evenals de Franse Conseil d'État dat deed - in het ongeschreven recht. Uit een oogpunt van rechtsbescherming behoeven er op zichzelf geen bezwaren te bestaan tegen het toepasselijk achten van art. $1401 \mathrm{BW}$ op het onrechtmatig overheidsoptreden; wèl heeft de omstandigheid dat de gewone rechter ook bij de beoordeling van bestuursgesties sterk redeneerde vanuit een privaatrechtelijk begrippenapparaat belemmerend gewerkt op de (theoretische) ontwikkeling van het bestuurs- 
recht. Thorbecke sprak al van het 'burgerlijk rechtsoog' van de gewone rechter. Thorbecke was overigens géén tegenstander van rechtspraak terzake van geschillen van bestuur, maar achtte het wèl onjuist de burgerlijke rechter te belasten met de beslechting van dergelijke geschillen. $\mathrm{Hij}$ was voorstander van een strenge scheiding tussen burgerlijke rechtspraak en administratieve rechtspraak ${ }^{37}$.

Van der Hoeven zegt over dit 'burgerlijk rechtsoog' o.m. het volgende:

'(De gewone rechter) moest ..., wanneer hij geroepen werd geschillen te beslissen die tussen organen van het openbaar bestuur enerzijds en particulieren anderzijds waren gerezen over de al dan niet rechtmatigheid van overheidshandelen, in belangrijke mate de oplossing zoeken in het privaatrecht. Dat gold met name wanneer algemene begrippen van rechtssystematiek en ongeschreven rechtsbeginselenom toepassing vroegen. Eensdeels was dit het gevolg van de overwegendcivielrechtelijke oriëntatie en praktijk van de rechterlijke macht, anderzijds van het ontbreken van een algemene leer van het bestuursrecht. Maar de belangrijkste oorzaak moet wel worden gezocht in de omstandigheid, dat de beslissing altijd moest vallen in een burgerlijk geding, tussen partijen die als eiser en gedaagde in beginsel als rechtens gelijk te behandelen en te beoordelen tegenover elkaar stonden. Als het gedaagde overheidsorgaaneen verweer wilde voeren op basis van het principiêle onderscheid tussen partijen - en daartoe geen expliciete wettelijke grondslag kon aanwijzen - dan moest de rechter, wanneer hij het verweer meende te moeten honoreren, daartoe een oplossing zoeken in het civielrechtelijke kader. En, omgekeerd, wanneer hij het door een overheidsorgaan gedane beroep op zjin bjizondere positie verwierp, diende dit evenzeer te geschieden in datzelfde kader' ${ }^{38}$.

Dit denken 'in het civielrechtelijke kader' leidt er veelal toe dat de litigieuze rechtsverhoudingen als civielrechtelijk worden geduid, óók door bestuursjuristen. Zo schrijft Hirsch Ballin:

'De toegang tot de rechter is ... gegeven doordat de open normen van art. 1401 BW en art. 1395 BW, die de administratiefrechtelijke normen waarnaar de onrechtmatigheid of onverschuldigdheid beoordeeld moet worden, op een privaatrechtelijkerechtsbetrekking betrekken, ${ }^{39}$.

Waar het gaat om (bijvoorbeeld) de terugvordering van onverschuldigd betaalde subsidies, sociale uitkeringen of ambtelijk salaris is het o.i. onjuist te spreken van een privaatrechtelijke rechtsbetrekking. De oorsprong van de terugvordering ligt dan immers in het publiekrecht; daaraan doet niet af de omstandigheid dat de civiele rechter zich op grond van art. 2 Wet RO (oud) in beginsel bevoegd achtte het geschil te beoordelen. Ten Berge lijkt echter dezelfde fout te maken als Hirsch Ballin, als hij naar aanleiding van het Willemse-arrest ${ }^{40}$ opmerkt dat men dit arrest zó kan interpreteren:

'dat de vermogensrechtelijke rechtsbetrekking (onverschuldigde betaling) tussen Willemse en de Nieuwe Algemene Bedrijfsvereniging, welke vermogensrechtelijke rechtsbetrekking uiteindelijktot de competentie van de burgerlijke rechter behoort, werd bepaald door voorafgaandebestuursrechtelijke vragen die dan ook eerst voorafgaandbeantwoord moeten worden door de daartoe door de wetgever aangewezen administratieve rechter' " .

Gezien het onderscheid dat hier wordt gemaakt tussen 'vermogensrechtelijk' en 'bestuursrechtelijk', lijkt het erop dat het begrip 'vermogensrechtelijk' wordt gebruikt als synoniem voor 'privaatrechtelijk'. 
Wat hier over het hoofd wordt gezien, is dat (a) de competentie van de gewone rechter alsmede de van-toepassing-verklaring van deze BW-bepalingen zeggen nog niets zeggen over het karakter van de rechtsbetrekking, en (b) dat 'vermogensrechtelijk' geen synoniem is voor 'privaatrechtelijk', zoals trouwens ook de rechtshistorie bewijst ${ }^{42}$. Wat echter nog weer eens wordt aangetoond, is het nauwe verband tussen het ontbreken van administratieve rechtspraak en het ontstaan van de gemene rechtsleer.

Dat de jurisprudentie van de gewone rechter inzake de onrechtmatige overheidsdaad een op rechtsbeschermingsoverwegingen gebaseerd noodconstructie was (en is), wordt ook door Van der Hoeven beklemtoond:

'Aanvankelijkbij wijze van uitwijkmethode omdat de wetgever op het gebied van de administratieve rechtspraak volstrekt in gebreke bleef, heeft de burgerlijke rechter op basis van artikel 1401 van het Burgerlijk Wetboek een zeer eervolle jurisprudentie gebouwd, die echter - dat moet men niet vergeten - in wezen zeer oneigenlijk is. Tijdens de discussie aan het begin van deze eeuw over administratieve rechtspraak heeft men aan een dergelijke jurisprudentie in het geheel niet gedacht. (..)

Die oplossing, hoeveel waardering zij ook verdient, is niet ideaal en niet adequaat' $\theta$.

Van der Hoeven bepleit administratieve rechtspraak óók voor schade-acties tegen de overheid, omdat het overheidshandelen moet worden beoordeeld naar een ander soort criteria dan die welke worden gehanteerd in een rechtsstrijd tussen twee gelijkwaardige partijen.

\section{Toepassing van de maatschappelijke zorgvuldigheidsnorm op overheidshandelen?}

Dat de toepasselijkverklaring van art. 1401 BW op onrechtmatig overheidshandelen 'slechts' een uit rechtsbeschermingsoverwegingen nodig geachte 'uitwijkmethode' was, wordt niet uit het oog verloren door auteurs als Dooyeweerd, Stellinga, Kranenburg, Meijers, Van Maarseveen en Van der Hoeven. Zij beseffen dat de 'strijd met de zorgvuldigheid die in het maatschappelijk verkeer betaamt ten aanzien van eens anders persoon of goed' een typisch materieel burgerrechtelijk onrechtmatigheidscriterium is, dat niet past op de verhouding tussen overheid en burgers, en dat de beoordeling van dit handelen dient te geschieden aan de hand van eigen, publiekrechtelijke beginselen.

De formulering van Molengraaf luidt trouwens:

'Hij die anders handelt dan in het maatschappelijkverkeer den eenen mensch tegenover den anderen betaamt, anders dan met het oog op zijn medeburgers (!) behoort te handelen, is verplicht de schade te vergoedendie derden daardoor lijden' (cursivering en uitroeptekendzz.; JT) ".

En Paul Scholten zegt over de toepasselijkheid van deze zorgvuldigheidsnorm:

'dat hier niet staat individu tegenover gemeenschap, waarbij de enkeling de steun van het recht behoeft tegenover de alles onder haar macht brengende overheid en voor de laatste nauwkeurig de 
grenzen van haar inmenging moeten worden aangegeven, doch individu tegenover individu, gelijken tegenover elkaar, waarbij het recht geen enkele reden heeft den een boven den ander te stellen en iedere grond ontbreekt om wat onrecht is te dulden terwille van de noodzakelijkheidvan waarborgen tegen machtsmisbruik' 4s.

Volgens Dooyeweerd kan slechts een theorie die geen oog heeft voor de eigen aard van het burgerlijk recht resp. het publiekrecht:

'in 't geheel geen begrip toonen voor de zeer principieele onderscheiding ... tusschen de onrechtmatige daad in het maatschappelijk verkeer en intern verbands-onrecht, dat de overheid als zoodanig aan haar onderdanentoevoegt' ${ }^{*}$.

Ook Meijers meent dat men het publiek onrecht niet kan brengen onder het onrechtmatigheidscriterium van de maatschappelijke onzorgvuldigheid. Na eerst te hebben opgemerkt dat het:

...,niet waarschijnlijk (is), dat onze wetgever bij art. $1401 \mathrm{BW}$ aan verder onrecht dan burgerlijk onrecht gedacht heeft ....'

beklemtoont hij:

'Het is practisch niet doenlijk de schadevergoedingsplichtin het publiek recht op gelijke wijze te behandelenals in het burgerlijk recht. Ook om deze reden kan art. $1401 \mathrm{BW}$ niet op gelijke wijze het publieke onrecht naast het burgerlijk onrecht omvatten' $A$.

Toewijzing van een schadevergoedingsactie tegen de overheid wegens een handelen 'in strijd met de noodige zorgvuldigheid voor de goederen en personen der burgers' acht Meijers dan ook uitgesloten. In zijn noten bij het Strooppot-arrest en bij het Meerboei-arrest ${ }^{48}$ geeft hij ervan blijk in te stemmen met deze arresten, waarbij overheidsaansprakelijkheid wegens handelen dat in de zin van art. $1401 \mathrm{BW}$ indruist tegen de zorgvuldigheid welke in het maatschappelijk verkeer betaamt tegenover eens anders persoon of goed, wordt afgewezen waar het een handelen door de overheid 'als zodanig' betrof ${ }^{49}$.

Zolang nog een onderscheid wordt gemaakt tussen het optreden van de overheid 'als zodanig' en de overheid 'als bijzonder persoon, optredende op gelijke voet als de burger in het maatschappelijk verkeer', is het geheel consequent dat het onrechtmatigheidscriterium van de maatschappelijk onzorgvuldigheid ook wordt toegepast op het optreden van de overheid in laatstgenoemde hoedanigheid. Als echter dit onderscheid tussen de twee hoedanigheden van 'de overheid' wordt verlaten ${ }^{50}$ - en zulks geheel terecht: de overheid is immers altijd overheid -, wordt niettemin de maatschappelijke onzorgvuldigheid als toetsingsmaatstaf voor overheidsoptreden niet losgelaten. Integendeel, in het zesde Voorste Stroom-arrest en in het Jochemsarrest gaat de Hoge Raad de kant uit van het aanleggen van de maatschappelijke zorgvuldigheidsnorm aan de overheid in het kader van de uitoefening van de 'service public'. Zo wordt in het zesde Voorste Stroom-arrest overwogen: 
'dat de Gemeente dusdoendecen gedragslijn volgde, welke wel is waar van uit het oogpunt der door haar te behartigen gemeentebelangen volkomen gerechtvaardigden zelfs geboden kon zijn, doch waarvan tegenover den eigenaar van een bedreigd perceel de eventueele nadelige gevolgen, die daaruit voor dezen mochten voortvloeien, voor haar rekening behooren te komen;

dat de Gemeente dan ook niet, in de verhouding tot dezen eigenaar, indien de gekozen maatregel falt en de overlast, als gevolg van de besparing van uitgaven voor de gemeente, niet wordt opgeheven, met vrucht kan beweren aan hare verplichting de zorgvuldigheidin acht te nemen, welke in het maatschappelijkverkeer t.a.v. diens eigendom betaamde, te hebben voldaan' 5!

Een vergelijkbare overweging is opgenomen in het Jochemsarrest ${ }^{52}$. De strekking en uitslag van deze arresten zijn o.i. volkomen juist ${ }^{53}$. Materieel gezien betreft het in deze arresten overheidsaansprakelijkheid wegens schending van het - op de iustitia distributiva gebaseerde - égalitébeginsel bij het, in het kader van de uitoefening van een publieke taak, aantasten van de goederen van derden. Zo luidt het in het Jochemsarrest, dat de gedragslijn van de gemeente, die was gekozen:

'in het belang van de watervoorziening harer bevolking en ter ontkoming aan de bezwaren, welke een andere wijze van watervoorziening zou medebrengen,.... weliswaar vanuit het oogpunt der gemeentelijke belangen volkomen gerechtvaardigd of zelfs geboden kon zijn, doch waarvan zij tegenover de eigenaren der bedreigde percelen eventueele nadeelige gevolgen voor hare rekening behoorde te nemen' (curs. dzz.; JT).

Kranenburg - goed op de hoogte met de jurisprudentie van de Franse Conseil d'État - merkt naar aanleiding van het zesde Voorste Stroomarrest op, dat de nadelige gevolgen van het desbetreffende overheidsoptreden voor rekening van de gemeente behoorden te komen,

'omdat de slechte risico's van de functioneering van den publieken dienst niet ten laste van den enkeling, maar van de gemeente behooren te komen; anders zou de gelijkheid der burgers m.b.t. de publieke lasten zijn verbroken' 's.

Maar dan is - zo vervolgt Kranenburg - de verdere overweging inzake de maatschappelijke zorgvuldigheidsnorm niet houdbaar:

'(D)ie formule is hier niet van toepassing. Er is hier geen sprake van het gewone maatschappelijke verkeer; als ik een publiekedienst doe functioneeren, ben ik als zoodanigéénling, en mijn gedraging als overheid is niet een gedraging in het 'maatschappelijk verkeer'. (...) De billijkheid is in 's Hoogen Raads beslissing meer te waarderen dan de logica. Overdaad schaadt; met zijn laatste overweging is de H.R. slachtoffer geworden van zijn vroegere averechtse dogmatische constructie'.

Over de jurisprudentie van de Conseil d'État, met name het in 1938 verschenen arrest inzake La Fleurette, merkt Dooyeweerd op dat het daarin allerminst gaat om kleurloze algemene rechtsbeginselen, maar om de toepassing van het typisch publiekrechtelijke beginsel van de evenredigheid ten aanzien van de publieke lasten, een beginsel dus dat geworteld is in de eigen innerlijke aard van het publiekrechtelijke verband ${ }^{55}$. 
Men zou over de genoemde arresten kunnen zeggen dat de Hoge Raad in juiste intuîtie goed heeft begrepen dat het égalitébeginsel hier in het geding was, maar zó vast zit in een 'privaatrechtelijk begrippenapparaat', dat hij de materiële toetsing aan dit beginsel formeel aankleedt als toetsing aan de maatschappelijke zorgvuldigheidsnorm, ofschoon deze voor inter-persoonlijke relaties bedoelde - op de iustitia commutativa gebaseerde - norm naar haar aard incompatibel is met het - op de iustitia distributiva gebaseerde - égalitébeginsel. De door Kranenburg en ook Van Maarseveen ${ }^{36}$ o.i. terecht gekritiseerde overweging, kan men zien als een goed voorbeeld van wat een ongedifferentieerd en nivellerend gebruik van rechtstermen kan worden genoemd. Dit leidt er gemakkelijk toe dat de eigen aard van zowel het égalitébeginsel als van de maatschappelijke zorgvuldigheidsnorm wordt miskend, en heeft er mede aan bijgedragen dat in de huidige jurisprudentie van de Hoge Raad (zie hierna) de '(maatschappelijke) zorgvuldigheid' is gaan fungeren als een clichébegrip, een container-begrip, en de 'maatschappij' kennelijk wordt opgevat als een totaal-structuur, waarbinnen geen principieel onderscheid meer bestaat tussen de publieke gemeenschapsverhoudingen en de burgerlijke maatschapsverhoudingen.

Het denken vanuit een 'privaatrechtelijk begrippenapparaat' leidt ook tot de nogal geforceerde constructies van J. Drion ${ }^{57}$ en Bregstein ${ }^{58}$, die zoeken naar een verklaring waarom een overheidshandelen dat gerechtvaardigd - ja zelfs geboden - is, tevens onrechtmatig zou kunnen zijn en dus zou verplichten tot schadevergoeding. Volgens Drion zou de door de Hoge Raad aanvaarde schadevergoedingsplicht van de overheid aldus moeten worden gezien, dat de onrechtmatigheid niet zit in de inbreukhandeling op zichzelf, maar in de combinatie van deze handeling en het niet voor rekening nemen van de schadelijke gevolgen die er voor bepaalde personen uit voortvloeien. Drion is verweten dat zijn systeem zou zijn te herleiden tot de regel: Gij moet de schade vergoeden, omdat Gij de schade niet hebt vergoed ${ }^{59}$. Volgens Bregstein zou de inbreukhandeling zelf onrechtmatig zijn, maar gerechtvaardigd worden wanneer aan twee eisen is voldaan: a. de handeling strekte ter behartiging van een meerderwaardig publiek belang (de 'rechtvaardigingsgrond in wording') en b. de overheid is bereid de schadelijke gevolgen voor haar rekening te nemen.

Van den Bergh meent dat de Hoge Raad een 'hoogst gevaarlijke weg' is ingeslagen en bestrijdt de opvattingen van Drion én Van den Bergh. Van den Bergh acht een logische contradictie aanwezig: 'Een daad is of gerechtvaardigd ò zij is dat niet'. Wellicht kan men beter spreken van een vicieuze cirkel: als men stelt dat een overheidsdaad als gevolg van schadevergoeding rechtmatig is, waarin is dan - nu die daad rechtmatig is - de rechtsgrond voor de vergoeding gelegen? De kritiek van Van den Bergh op Drion en Bregstein is terecht: hun opvattingen zijn inderdaad te beschouwen als een 'logische contradictie'. Maar al deze opvattingen, óók die van Van den Bergh, berusten op een burgerrechtelijke denkwijze, die ervan uitgaat dat 
een overheidsdaad hetzij rechtmatig hetzij onrechtmatig is en die miskent dat de voor inter-persoonlijke relaties tussen particulieren ontworpen regel van art. 1401 (oud) resp. art. 6:162 BW niet zonder meer toepassing is op overheidsdaden, mede gezien hun 'erga omnes'-karakter.

Dat hier de iustitia distributiva en het daarop gebaseerde égalitébeginsel in het geding zijn, werd reeds heel goed beseft door Thorbeckes leerling Olivier, die er in zijn dissertatie uit 1847 (de eerste in de Nederlandse taal) op wees dat de schadevergoedingsplicht voor de overheid terzake van eigendomsbeperkingen en onteigening, hierop rust:

'dat de last, ten gevalle van het publiek te dragen,... niet gelijkelijk over alle leden der gemeente is omgeslagen, doch op de schouders van slechts enkele leden drukt' ${ }^{\omega}$.....) 'Met welk regt kan hij (t.w. 'een lid der gemeente"; JT) op schadevergoedingaanspraak maken? Omdat het offer hier geheel en al ten laste komt van één enkel lid der gemeente. Trof de schade allen gezamenlijk, er zou geene vergoeding behoevengegevente worden, even weinig als men den burgers de belastingenvergoedt, welke men hun oplegt. Maar waar men van een enkel lid het offer vordert van zijn regt. omdat het nu juist zoo uitkomt, dat zijn regt onbestaanbaar is met het belang des geheelen ligchaams, daar is ook de gemeente verpligt de schade te vergoeden, welke dat lid door zijn offer geleden heeft. Men vergoedt de schade, .... omdat ... een publieke last niet uitsluitend ten laste dier eigenaars zou gebragt worden, wier eigendommen toevallig juist in de rigting van het aan te leggen werk liggen' ${ }^{61}$,

Hiermee wordt al fraai aangegeven, waarom men bij de beoordeling van overheidsdaden veelal zal moeten differentiëren.

Van Maarseveen wijst er op dat men daarom bij de toetsing van overheidsdaden aan art. 1401 BW een onderscheid moet maken in de onrechtmatigheid ${ }^{62}$ :

'Een onderscheid nl. in wat men zou kunnen noemen absolute en relatieve onrechtmatigheid. Een overheidshandelen is absoluut gezien onrechtmatig, indien het bijvoorbeeld indruist tegen een positieve rechtsregel. Een overheidshandelenkan een relatieve onrechtmatigheidvertonen, wanneer de belangen van een bijzonder persoon erdoor gekrenkt worden. Het een is mogelijk zonder het ander. Een handelen moge, om 's-Hogen Raads formulering te gebruiken, in het algemeen gerechtvaardigd, ja zelfs geboden zijn, in een bepaald opzicht, nl. tegenover de nadeellijdende particulier kan het onrechtmatig zijn'.

Die onrechtmatigheid is gelegen in de omstandigheid dat men de publieke dienst 'strekkende ten bate van velen, laat werken op kosten van enkelen, dat men dus een deel van de nadelen onevenrediglaat drukken op een enkeling of een kleine groep. Er is strijd met de norm van de evenredigheid in de verdeling van de openbare lasten, een norm die, hoewel ongeschreven, zijn neerslag heeft gevondenin vele wetten. In het geval van de Voorste Stroom werkt de overheid alleen relatief gezien onrechtmatig en de grond van de schadeplichtigheid is de schending van het rechtsbeginsel van de égalité devants les charges publiques'.

De relatieve onrechtmatigheid van het handelen kan op zichzelf geen grond zijn tot het geheel verbieden van de handeling, maar wél voor schadevergoeding van de speciale schade. De publieke dienst draait op kosten van allen, niet van de toevallige enkeling:

'Het onderscheid in absolute en relatieve onrechtmatigheid is niet te maken voor de gewone onrechtmatige daad, omdat daarbij slechts de relatieve zijde naar voren komt, het handelen komt 
alleen maar ter sprake, zoals dit zich voordoet tussen beide partijen, de daad op zichzelf is indifferent'.

Nu kan men zeggen dat de onrechtmatigheid als bedoeld in art. $1401 \mathrm{BW}$ (oud) resp. art. 6:162 BW per definitie 'relatief' is. Wellicht wordt ons nu tegengeworpen, dat we niets nieuws vertellen. Dat het onderscheid tussen absolute en relatieve (on)rechtmatigheid van overheidsdaden echter wordt miskend, blijkt toch uit al die gekunstelde constructies die zijn bedacht om de schadevergoeding wegens - wat men noemde - 'rechtmatige overheidsdaad' in te passen in art. 1401 (oud) resp. art. 6:162 BW Deze miskenning komt reeds naar voren in het gebruik van de term 'schadevergoeding wegens rechtmatige overheidsdaad' ${ }^{63}$, die een 'logische contradictie' inhoudt. Men onderkent niet of onvoldoende dat men, wanneer men in dit verband spreekt van 'rechtmatige overheidsdaad', het heeft over de absolute rechtmatigheid, niet over de relatieve, met andere woorden: dat een overheidsdaad in absolute zin gerechtvaardigd, maar relatief onrechtmatig kan zijn.

Steeds houde men in het oog dat de toepasselijkverklaring op overheidsgesties van art. 1401 (oud) BW een 'uitwijkmethode' was. Terwijl de privaatrechtelijke onrechtmatige daad een verstoring is in het evenwicht van private rechtsbelangen die gepaard gaat met schending van de maatschappelijke zorgvuldigheidsnorm - een verstoring dus van de typisch burgerrechtelijke (commutatieve, maatschappelijke) evenredigheid $-{ }^{64}$, betreft de publiekrechtelijke onrechtmatige daad een verstoring in het evenwicht van de rechtsbelangen in het licht van het typisch publiekrechtelijke beginsel van het algemeen belang c.q. de publiekrechtelijke (distributieve) evenredigheid. Deze evenredigheid vereist de 'égalité devant les charges publiques' ${ }^{\text {os }}$ en mag niet worden verward met de zorgvuldigheid in het maatschappelijk verkeer. Bij de toepassing van art. 6:162 BW op de publiekrechtelijke onrechtmatige daad - de onrechtmatige overheidsdaad - zal dus, ter beantwoording van de vraag of van een 'inbreuk op een subjectief recht' kan worden gesproken, het égalitébeginsel moeten worden gehanteerd. Wanneer een privaat subjectief recht of rechtsbelang onevenredig wordt aangetast - 'onevenredig' in het licht van de iustitia distributiva c.q. de 'égalité devant les charges publiques' - zal o.i. gesproken kunnen worden van 'inbreuk' op des burgers recht (of rechtsbelang), hetgeen relatieve onrechtmatigheid oplevert. Het Leffers-arrest biedt daarvan een goed voorbeeld. Het gaat in dit arrest dus niet om schadevergoeding wegens rechtmatige overheidsdaad en evenmin om schadevergoeding wegens - in absolute zin - onrechtmatige overheid. Neen, dit arrest betreft (de erkenning van de mogelijkheid van) schadevergoeding wegens relatieve onrechtmatigheid, namelijk jegens een naar verhouding kleine groep van varkensmesters, onder wie Leffers ${ }^{66}$. En de relativiteitseis is hier gefundeerd in het égalitébeginsel ${ }^{67}$. 
Schending van een positieve rechtsregel - strijd met de rechtsplicht van de overheid - zal doorgaans absolute onrechtmatigheid opleveren, zij het dat die 'absolute onrechtmatigheid' op zichzelf nog niet leidt tot onrechtmatigheid en aansprakelijkheid in de zin van art. 6:162 BW Daarvan is 'pas' sprake als die absolute onrechtmatigheid schade voor een of meer bepaalde personen tot gevolg heeft, dus resulteert in een onrechtmatigheid jegens die personen ${ }^{68}$.

'Relatieve onrechtmatigheid' impliceert dus dat een - in absolute zin niet onrechtmatige - daad jegens één of meer bepaalde personen wél onrechtmatig is. Daarmee is ook aan de relativiteitseis ex art. 6:163 BW voldaan. Dit algemene relativiteitsvereiste speelt echter een aparte rol, waar absolute onrechtmatigheid in het geding is.

\section{5. 'Omdraaiing': onrechtmatige daad ex art. 1401 resp. art. 6:162 BW jegens 'de overheid'}

Wanneer niet meer het historisch besef aanwezig is dat de toepasselijkverklaring van art. $1401 \mathrm{BW}$ op overheidshandelen een noodconstructie was in het belang van de rechtsbescherming van de burgers was, leidt dit tot de al geconstateerde 'omdraaiing': als de burger terzake van onrechtmatige overheidsdaad een vordering uit hoofde van art. 1401 resp. art. 6:162 BW kan instellen tegen de overheid, dan zou toch - omgekeerd - de overheid ook acties moeten kunnen entameren tegen burgers die handelen in strijd met publiekrechtelijke voorschriften of die zich 'maatschappelijk onzorgvuldig' jegens 'de overheid' gedragen?

G.J. Scholten betoogt in zijn noot onder het Rijksweg 12-arrest:

'Zoals in het algemeen men tegen publiekrechtelijk onrecht, door de overheid begaan, beschermd wordt door art. $1401 \mathrm{BW}$ als er maar schade is of dreigt, is er reden publiekrechtelijkelichamen beschermd te achten door art. 1401 als men bij het plegen van een onrechtmatige daad daardoor schade veroorzaaktaan een publiekrechtelijklichaam dat bijv. politie of brandweer extra moet laten optreden. Het is redelijk aan te nemen dat de overtreden norm (niet veilig rijden enz.) niet alleen beschermt wie zij direct op het oog heeft, maar ook het openbaar lichaam dat de belangen behartigt van die direct beschermde personen juist tegen schade door overtreding van die norm' ${ }^{*}$.

Ook Bloembergen hanteert in zijn conclusie vóór het Magnus-arrest de 'omdraaiingsconstructie', waar hij betoogt:

'dat art. 1401 (6:162) sedert het Osterman-arrest van 1924 is uitgegroeid tot een bepaling die het privaatrecht én het publiekrecht omspant (met als gevolg dat de burgerlijke rechter overal als restrechter kan optreden en dat er dus altijd een rechter is). Als dat zo is, valt moeilijk in te zien waarom er na vijftig jaar opeens belangen zouden moeten zijn die niet door art. 1401 worden beschermd' $x$. 
Wat hier uit het oog wordt verloren, is dat het in het civiele delictenrecht niet gaat om schending van publieke rechtsbelangen, maar om inbreuken op private rechtsbelangen in het burgerlijk rechtsverkeer. Als 'uitwijkmethode' was het van toepassing verklaren van art. 1401 (oud) resp. 6:162 BW op de onrechtmatige overheidsdaad nog aanvaardbaar, omdat daarmee bescherming werd geboden tegen aantasting door de overheid van private rechtsbelangen ${ }^{71}$.

In de opvatting van Scholten en Bloembergen zou art. 1401 resp. 6:162 BW echter niet meer alleen strekken ter bescherming van private rechtsbelangen maar mede ter bescherming van publieke rechtsbelangen, en aldus een procesbevoegdheid van 'de overheid' impliceren om terzake van aantasting van die publieke rechtsbelangen een actie uit hoofde van onrechtmatige daad te entameren. Ten principale is dit aanvaard door de Hoge Raad in het Windmill-arrest, waarin hij overweegt dat 'de overheid' publieke belangen, behalve langs de publiekrechtelijke weg, ‘ók mag behartigen door gebruik te maken van haar in beginsel krachtens het privaatrecht toekomende bevoegdheden, zoals ... de bevoegdheid een vordering op grond van een jegens haar gepleegde onrechtmatige daad bij de burgerlijke rechter in te stellen' 72 . En reeds het enkele 'handhavingsbelang' kan - zo blijkt uit recente, hierna nog te bespreken jurisprudentie - legitimeren tot zo'n vordering. Dit betekent tevens een loslaten van de Limmen/Houtkoop-formule.

\subsection{Het loslaten van de Limmen/Houtkoop-formule}

Wanneer Houtkoop dreigt een bloembollenschuur in gebruik te nemen als opslagplaats voor zijn onderneming in kappersartikelen, zulks in strijd met het in de gemeentelijke bouwverordening opgenomen verbod om percelen te gebruiken in afwijking van de daaraan bij het bestemmingsplan gegeven bestemming, vordert de gemeente Limmen in kort geding een verbod van overtreding van de bouwverordening op straffe van een dwangsom.

Nadat het Gerechtshof zich onbevoegd heeft verklaard tot beoordeling van de vordering, wordt het daartegen ingestelde cassatieberoep door de Hoge Raad verworpen. Omdat de gemeente haar vordering heeft doen steunen op een volgens haar uit art. $1401 \mathrm{BW}$ voor haar voortvloeiend recht, heeft het Hof weliswaar ten onrechte een onbevoegdverklaring uitgesproken. Doch zulks kan niet tot cassatie leiden, omdat het Hof de vordering had moeten afwijzen (en de gemeente bij een desbetreffende wijziging van het dictum van 's Hofs arrest uiteraard geen belang heeft). Daartoe overweegt de Hoge Raad:

'dat het enkele feit dat Houtkoop zich zal schuldig maken aan die door de Gemeente van hem verwachte overtreding, nog niet betekent dat Houtkoops onrechtmatigegedraging alsdan zal kunnen worden beschouwd als een door Houtkoop tegenover de Gemeente gepleegde onrechtmatige daad: (...) 
dat ... het algemene belang dat voor elk overheidslichaamis betrokken bij de naleving van de door dat lichaam uitgevaardigdewettelijke voorschriften op zich zelf niet behoort tot de belangen welke art. 1401 BW beoogt te beschermen',

en dat de gemeente in het desbetreffende geval:

'niet heeft gesteld dat voor haar enig ander belang dreigt te worden geschondendan het algemeen belang dat bedoelde voorschriften worden nageleefd' (cursivering dzz.; $\mathrm{JT}$ ) ${ }^{n}$.

Volgens Bloembergen zou de Hoge Raad met de Limmen/Houtkoop-formule geen gelukkige greep hebben gedaan. Evenals Nieuwenhuis meent hij dat het in dit arrest in wezen gaat om de bestaanbaarheid van een privaatrechtelijke naast een publiekrechtelijke weg en dat de zaak beter afgedaan had kunnen worden met een dáárop afgestemde motivering dan met het nu gebruikte 'machtswoord' ${ }^{74}$. Volgens Frenk heeft de Hoge Raad met de 'inmiddels beruchte passage' antwoord willen geven op de vraag of overtreding door Houtkoop van het planologisch gebruiksvoorschrift jegens de gemeente onrechtmatig is. Wil een gemeente of andere overheid kunnen betogen dat de overtreding van een door haar uitgevaardigd voorschrift jegens haar onrechtmatig is (relativiteit), dan zal zij - aldus Frenk - door de overtreding getroffen moeten worden in een belang dat het desbetreffende voorschrift beoogt te dienen ${ }^{75}$.

De opvatting van Bloembergen, Nieuwenhuis en Frenk lijkt ons onjuist: in zijn arrest heeft de Hoge Raad o.i. slechts tot uitdrukking gebracht, dat van een civielrechtelijke onrechtmatige daad in de zin van art. $1401 \mathrm{BW}$ slechts sprake kan zijn, wanneer er sprake is van de aantasting van een individueel c.q. privaat rechtsbelang van een ander in strijd met de dit rechtsbelang beschermende rechtsnormen. Het desbetreffende voorschrift strekte ter bescherming van een publiekrechtelijk belang, hierin gelegen dat niet zou worden gehandeld in strijd met de door een bestemmingsplan (-oude stijl) aan een perceel gegeven bestemming. En ook bij de handhaving van dit voorschrift door het gemeentebestuur was uiteraard slechts een publiekrechtelijk belang in het geding. Nu geen privaat rechtbelang in het geding was, kon a fortiori overtreding van dit voorschrift geen onrechtmatige daad in de zin van art. $1401 \mathrm{BW}$ jegens de gemeente opleveren ${ }^{76}$. Dat publieke belang is per definitie nimmer een eigen belang - in de zin van een subjectief privaat rechtsbelang - van 'de overheid'.

Vooral vanaf het einde van de tachtiger jaren is de Limmen/Houtkoop-formule - het vereiste van een 'art. 1401 BW-belang' - steeds verder uitgehold. Dat door 'de overheid' via een onrechtmatige daadsactie ex art. $1401 \mathrm{BW}$ in beginsel óók publieke belangen kunnen worden behartigd, wordt door de Hoge Raad in algemene zin tot uitdrukking gebracht in het Windmill-arrest ${ }^{7}$. 
Aanvankelijk werd nog een 'art. 1401 BW-belang' vereist, welk vereiste bij schadevergoedingsvorderingen zonder meer aanwezig werd geacht. Zo wordt in het arrestStaat/Van Amersfoort overwogen dat:

'Het afzonderlijk - naast het vereiste dat jegens de overheid onrechtmatig is gehandeld - eisen van een door ant. 1401 beschermd belang is niet op zijn plaats wanneer de overheid schadevergoeding vordert op grond van een tegenover haar gepleegdeonrechtmatige daad' $n$.

Dat het vereiste van een art. 1401 resp. 6:162-belang niet apart gesteld behoefde te worden, komt waarschijnlijk doordat het zich naar 's Hogen Raads oordeel oploste in de vragen naar schade, onrechtmatigheid en relativiteit. En die onrechtmatigheid jegens 'de overheid' kan óók gelegen zijn in 'onzorgvuldigheid' van de burger ten opzichte van 'de overheid' als behartiger van bepaalde - ook 'ongeschreven' - publieke belangen. Omdat door de Hoge Raad kennelijk wordt aanvaard dat art. 1401 BW niet alleen strekt ter bescherming van private rechtsbelangen maar 6 ók van aan de zorg van 'de overheid' toevertrouwde publieke belangen - i.c. het 'ongeschreven' belang van 'een zo schoon mogelijk milieu', in het bijzonder bodemsanering -, heeft hier materieel gezien de Limmen/Houtkoop-formule haar betekenis verloren. Enige voorwaarde is nog dat aan de behartiging van een publiek belang 'vermogensnadeel' voor 'de overheid' is verbonden, maar aan die 'voorwaarde' wordt gemakkelijk voldaan.

Ook bij gebods-en verbodsvorderingen kan een art. 1401 resp. 6:162-belang reeds spoedig aanwezig werd geacht vanwege het 'vermogensnadeel' dat voor 'de overheid' verbonden is aan de toepassing van publiekrechtelijke bevoegdheden. Zo wordt in het Benckiser-arrest aanvaard dat de Staat zich niet alleen beroept op het 'algemeen belang' bij de naleving van de milieuwetgeving op zichzelf, maar ook op het 'concrete belang' hierin bestaande dat het opruimen van de bodemvervuiling omvangrijke kosten voor de Staat kan veroorzaken ${ }^{79}$. En in het arrest-Staat/Magnus wordt overwogen dat voor de beantwoording van de vraag, of langs publiekrechtelijke weg een vergelijkbaar resultaat kan worden bereikt als langs de privaatrechtelijke weg van de onrechtmatige-daadsactie:

'niet (moet) worden geabstraheerd van het aspect van de kosten, met name voor zover dit hierin bestaat dat bij de toepassing van bestuursdwangde overheid voorshandsde kosten van de opgelegde maatregel zelf moet dragen en dat deze kosten voor rekening van de overheid blijven, als achteraf verhaal onmogelijk blijkt te zijn' $\$$.

Naar het ons voorkomt, heeft hiermee in feite de kritiek op de Limmen/Houtkoopformule van Bloembergen en Nieuwenhuis - die, zoals we zagen, betoogden dat het in wezen zou gaan om de bestaanbaarheid van een privaatrechtelijke naast een bestaande publiekrechtelijke weg - gezegevierd. 
Wanneer in het Kabayel-arrest deze formule definitief ten grave werd gedragen - en vervangen door de eis van 'voldoende belang' (zonder voldoende belang komt niemand een rechtsvordering toe) -, is dit dan ook niet meer opzienbarend. In casu betreft het een door de Staat op art. 6:162 BW gegronde vordering strekkende tot verkrijging van een bevel tot ontruiming door de familie Kabayel van het - niet bij de Staat in eigendom zijnde - asielzoekerscentrum 'Moorheide' in de gemeente Schinnen. Op gebruikmaking van dat centrum zouden de Kabayels volgens de Staat geen aanspraak 'op grond van de Regeling Opvang Asielzoekers (ROA) meer maken, een regeling die ertoe strekt dat de minister voorziet in de noodzakelijke middelen van bestaan en de opvang van asielzoekers die nier over voldoende middelen beschikken. De Hoge Raad verwerpt - anders dan het Hof - het betoog dat de Staat niet enig civielrechtelijk belang had ingeroepen waarin de Staat bescherming wilde verkrijgen, en overweegt daartoe:

'De Staat heeft aan zijn vordering ten grondslag gelegd dat Kabayel c.s. jegens hem onrechtmatig handelen doordat zij zonder recht of titel verblijven in de bij hen in gebruik zijnde (woon-)ruimten van het asielzoekerscentrum' Moorheide'. Daarmee was de bevoegdheidvan de burgerlijke rechter gegeven, nu het hier om een 'schuldvordering' in de zin van art. 112 Grondwet gaat. Noch voor deze bevoegdheid. noch voor de ontvankelijkheid van de op art. 6:162 BW gegronde vordering, strekkende tot het verkrijgen van een bevel, is vereist dat de Staat aan die vordering een 'civielrechtelijk belang' ten grondslag legt. Nodig is slechts dat voldaan wordt aan de eis van een voldoende belang, zoals deze eis tot uiting is gebracht in art. 3:303 BW Een voldoende belang is gegeven met het in de onderhavige vordering naar zijn aard besloten liggende belang van de Staat bij het wederom ter beschikking komen van de door Kabayel c.s. in het asielzoekerscentrum gebruikte ruimten, waarop zij naar het oordeel van de Staat geen aanspraak op grond van de ROA meer hebben en die anders niet ter beschikking zouden kunnen worden gesteld van andere asielzoekers, die aan de ROA jegens de Staat wèl een aanspraak op opvang kunnen ontlenen' 8 .

Een voldoende (proces)belang in de zin van art. 3:303 BW kán een 'vermogensbelang' zijn, met name wanneer door 'de overheid' in het kader van de behartiging van (ongeschreven) publieke belangen een schadevordering is ingesteld. Bij gebodsof verbodsacties, strekkende tot 'privaatrechtelijke' handhaving van publiekrechtelijke voorschriften of zelfs - zoals in de Kabayelcasus - van in een rijksbijdrageregeling verwoord 'beleid', kan ook het 'handhavingsbelang' reeds voldoende belang in de zin van art. 3:303 BW opleveren.

Een 'voldoende belang' ex art. 3:303 BW kan in de opvatting van de Hoge Raad zelfs gelegen zijn in vermogensnadelen voor 'de overheid', die niets te maken hebben met het publieke belang dat het overtreden wettelijk voorschrift beoogt te dienen. In casu ging het om de permanente bewoning van een zomerhuis in strijd met de bestemmingsplanvoorschriften. Omdat een belang ex art. 3:303 BW voldoende is, zou volgens de Hoge Raad het Gerechtshof geen blijk hebben gegeven 
van een onjuiste rechtsopvatting door te wijzen op de gevolgen van het permanent gebruik van zomerhuizen, te weten:

'het vervallen van inkomsten van de woonforensenbelasting waartegen extra inkomsten van de algemene uitkering uit het gemeentefondsniet opwegen, extra druk op de ambtelijke en bestuurlijke organisatie in voorkomend geval door aanvragen om bijstandsuitkeringen, extra bouwaanvragen alsmede hiermee samenhangendebezwaarschriftenproceduresen controles door bouw- en woningtoezicht, extra verontreiniging van het oppervlaktewater, extra gebruik van de toevoerwegen en een beroep op de plaatselijke krappe woningmarkt' $n$.

Dit alles doet zeer gezocht aan en komt er op neer, dat er altijd wel 'vermogensnadelen' voor 'de overheid' aanwezig kunnen worden geacht. Met het planologisch belang dat de overtreden bestemmingsplanvoorschriften beogen te dienen, hebben deze 'kosten' geen (direct) verband. In dit arrest worden de met handhaving van publiekrechtelijke voorschriften gedienden belangen ondergebracht onder de 'eigen', 'private' vermogensbelangen van 'de overheid'.

Het doorkruisingscriterium moge hierbij enige waarborg bieden tegen onaanvaardbare doorkruising van het publiekrecht; een voldoende waarborg biedt het zeker niet,

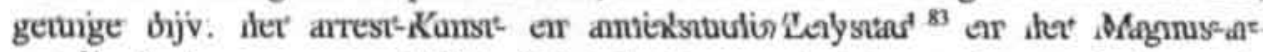
rest ${ }^{84}$. Zoals we zagen, blijkt uit het laatste arrest dat naar het oordeel van de Hoge Raad ook bij de (niet-)gebruikmaking van een door de wet verleende publiekrechtelijke bevoegdheid - bestuursdwang - een financieel 'eigen' belang van 'de overheid' in het geding kan zijn, dat legitimeert tot het volgen van de 'privaatrechtelijke' weg.

Waar het gaat om civiele verbods- of gebodsacties speelt 'vermogensnadeel voor de overheid zelf' dus nog wel een rol, maar niet in het kader van de beoordeling of er sprake is van een 'art. 6:162 BW-belang' - deze eis is immers gesneuveld - en ook niet zozeer bij de beoordeling of is voldaan aan de eis van een 'art. 3:303 BWbelang', alswel ter beantwoording van de vraag of door gebruikmaking van een publiekrechtelijke regeling een - mede uit een oogpunt van 'kosten' voor 'de overheid' - vergelijkbaar resultaat kan bereiken als door gebruikmaking van de 'privaatrechtelijke weg' (de doorkruisingsproblematiek). We zouden dus kunnen zeggen dat de vraag of er sprake is van 'vermogensnadeel voor de overheid zelf' niet meer fungeert als een positief criterium - nl. ter beantwoording van de vraag of de 'privaatrechtelijk weg' voor 'de overheid' überhaupt openstaat -, maar als een negatief criterium - nl. ter beantwoording van de vraag of het bewandelen van de in beginsel voor 'de overheid' openstaande 'privaatrechtelijke weg' een doorkruising oplevert van de publiekrechtelijke weg. Is er een publiekrechtelijke weg doch zou die, vergeleken met de 'privaatrechtelijke weg', 'vermogensnadeel voor de overheid' kunnen 
opleveren, dan biedt - vide het Magnus-arrest - die publiekrechtelijke weg geen 'vergelijkbaar resultaat' en is 'dus' van doorkruising geen sprake.

De nieuwe jurisprudentie betekent dat, in de visie van de Hoge Raad, art. 6:162 BW niet meer alleen de private rechtsbelangen binnen de private vrijheidssferen in het burgerlijke maatschappelijke rechtsverkeer beschermt, doch ók geschreven én ongeschreven publieke belangen die 'de overheid' zich is gaan aantrekken. Dit is o.i. een 'Umwertung aller Werte' en een ontwrichting van de structuur van zowel het burgerlijk recht als het publiekrecht.

Het gaat nu niet meer een gebruik van art. 1401 resp. art. 6:162 BW als basis - bij wijze van uitwijkmethode - voor rechtsbescherming ten behoeve van de burger, maar om het gebruik van dit artikel als wapen tegen de burger. Deze omdraaiing is onaanvaardbaar; ze is een staatsrechtelijke ironie. Stel dat zich in Nederland dezelfde ontwikkeling had voorgedaan als in Frankrijk en de overheidsaansprakelijkheid dus niet was gebaseerd op art. 1401 BW maar op het ongeschreven recht, zou de Hoge Raad dan ook een in beginsel bestaande algemene 'bevoegdheid', zonder wettelijke basis, van 'de overheid' hebben aangenomen om ter behartiging van openbare belangen acties tegen de burger te entameren? Waarschijnlijk niet. En als de Hoge Raad het wél had aangenomen, dan had zulks een storm van kritiek in de juridische vakpers tot gevolg gehad: de aanvaarding van zo'n 'ius politiae' zou men strijdig hebben geacht met de rechtsstatelijke legaliteitseis, in verband met het ontbreken van een specifieke bevoegdheidsgrondslag en in verband met het lex certabeginsel. $\mathrm{Nu}$ is - uitzonderingen daargelaten ${ }^{85}$ - die kritiek uitgebleven, zulks waarschijnlijk om de enkele reden dat op het desbetreffende overheidsoptreden het etiket 'privaatrechtelijk' is geplakt: kennelijk wordt niet (meer) beseft dat het BW geen zelfstandige bevoegdheden ter behartiging van publieke belangen kan verlenen.

\subsection{Oprekking van de zorgvuldigheidsnorm}

De grond voor onrechtmatigheid jegens 'de overheid' wordt ook gezocht in 'onzorgvuldigheid' van de burger ten opzichte van belangen die 'de overheid' zich - ook zonder wettelijke grondslag - is gaan aantrekken. Zie bijvoorbeeld het arrest-Staat/ Shell van 30 september 1994, waarin de Hoge Raad 'ten aanzien van het veroorzaken van bodemvervuiling door het in strijd met hetgeen in het maatschappelijk verkeer betaamt (doen) storten of ten vervoer geven van afvalstoffen' nagaat of ten tijde van die handelingen 'de zorgvuldigheidsnorm tegenover de overheid' is geschonden en er derhalve sprake is van een onrechtmatige daad jegens de overheid ${ }^{86}$. Dat de onrechtmatigheid jegens 'de overheid' kan worden gevonden in 'maatschappelijke onzorgvuldigheid' door het toebrengen van schade aan door 'de overheid' behartigde publieke belangen, zou als een contradictio in terminis moeten worden aangemerkt 
wanneer men Staat en 'maatschappij' als twee verschillende grootheden beschouwt en de 'strijd met de zorgvuldigheid die in het maatschappelijk verkeer betaamt ten aanzien van eens anders persoon of goed' ziet als een typisch materieel burgerrechtelijk onrechtmatigheidscriterium, dat beschermt tegen aantasting in het maatschappelijk verkeer van private rechtsbelangen en dat dus naar zijn aard niet past op de verhouding tussen overheid en burgers. Men kan o.i. niet volhouden dat de overheid, die optreedt ter behartiging van publieke belangen, opereert in het maatschappelijk verkeer. Wèl bestaan er, vooral als gevolg van de bestuursrechtelijke normstelling, vele vervlechtingen tussen 'maatschappelijke belangen' met publieke belangen. Die vervlechtingen betreffen echter de externe, publiekrechtelijke zijde van die 'maatschappelijke belangen' en maken die belangen dus niet tot publieke belangen. Wanneer Van Wijk betoogt:

'dat de administratiefrechtelijke normen ... eigenlijk deze functie hebbendat zij nader omlijnen de zorgvuldigheiddie in het maatschappelijk verkeer betaamt ten aanzien van eens anders persoon of goed' $"$,

drukt hij zich onzes inziens dan ook ongelukkig uit ${ }^{88}$.

Wellicht voelt de Hoge Raad zelf aan, dat er iets wringt. Want ofschoon ook art. 6:162 lid 2 spreekt van '(een doen of nalaten in strijd met) hetgeen volgens ongeschreven recht in het maatschappelijk verkeer betaamt', gebruikt de Hoge Raad vervolgens het algemene begrip 'ongeschreven zorgvuldigheidsnormen', welke dus ó́k kunnen gelden in de verhouding burgers-overheid. In algemene zin geeft de Hoge Raad aan, wanneer sprake is van onrechtmatigheid doordat is gehandeld in strijd met 'ongeschreven zorgvuldigheidsnormen':

'Of van zodanig handelen sprake is, hangt - in abstracto - daarvan af of de dader anders heeft gehandeld dan hij had moeten doen teneinde geen schade toe te brengen aan een bepaald belang van een ander dat hij had behoren te ontzien, waartoe dan ook mede is vereist dat hij dat belang kende of had behoren te kennen. Dergelijke normen strekken aldus uitsluitend ter bescherming van belangen van anderen waarop de dader bedacht had moeten zijn.

Schendt hij een belang van een ander waarop hij niet bedacht behoefde te zijn, dan is derhalve niet voldaan aan het relativiteitsvereiste, zodat het mogelijk is te zeggen dat de dader niet onrechtmatig heeft gehandeld jegens die ander; men kan dan evenwel even goed, zo niet beter, zeggen dat de dader (in zoverre) niet onrechtmatig heeft gehandeld (...) In zoverre bestaat een nauwe samenhang tussen onrechtmatigheiden relativiteitsvereiste ${ }^{\prime 8}$.

En van schending van een 'ongeschreven zorgvuldigheidsnorm die uitsluitend strekken ter bescherming van een belangen van de overheid' is volgens de Hoge Raad sprake, wanneer 'een belang ... tot een belang van de overheid is geworden doordat zij het zich is gaan aantrekken' ${ }^{90}$ en de 'dader' nà het tijdstip waarop 'hij dat belang kende of behoorde te kennen', 'door met dat belang onvoldoende rekening te houden' ${ }^{1}$, 'schade' toebrengt aan dat belang. Waar dat belang gelegen is in de sanering van bodemvervuiling, wordt dat tijdstip door de Hoge Raad in beginsel 
vastgesteld op 1 januari 1975, zowel voor zover het gaat om eigen terrein van de vervuiler als voor zover het andermans terrein betreft. Die schade zal gelegen kunnen zijn in 'vermogensnadeel voor de overheid zelf. Zo wordt in het arrestStaat/Van Wijnbergen van 24 april 1992 overwogen:

'dat, wil er sprake zijn van een door het onzorgvuldig veroorzakenvan bodemverontreiniging jegens de overheid gepleegde onrechtmatige daad waaraan deze op de voet van art. 1401 (oud) BW resp. art. 6:162 BW een recht op schadevergoeding kan ontlenen, op het tijdstip van dit veroorzaken voldoendeduidelijk moet zijn dat daardoor niet alleen het aan de zorg van de overheid toevertrouwde algemeen belang van een zo schoon mogelijk milieu wordt geschaad, maar ook vermogensnadeel voor de overheid zelf ontstaat of dreigt te ontstaan ...' (cursivering dzz.; JT) ${ }^{n}$.

Zien we het goed, dan zal het begrip 'schade aan een belang van de overheid' in de opvatting van de Hoge Raad ruimer kunnen worden geïnterpreteerd dan alleen als 'vermogensnadeel voor de overheid zelf'. Zoals naar voren komt uit het Kabayelarrest, kan het óók gaan om 'schade' aan een - in een rijksbijdrageregeling verwoord - 'beleid' van 'de overheid' 93 .

Het in de opvatting van de Hoge Raad kenmerkende aspect van 'ongeschreven zorgvuldigheidsnormen', in vergelijking met geschreven normen, wordt naar voren gebracht in het arrest-Staat/Van den Brink, dat van dezelfde datum is als het arrestStaat/Shell:

'(I)n het kader van dit type onrechtmatige daad, het handelen in strijd met de wet, dient te worden vastgesteld of de wettelijke norm strekt tot bescherming tegen de schade zoals de benadeelddie heeft geleden. Het strookt met het karakter van geschreven rechtsregels dat daarbij - anders dan het geval is bij handelen in strijd met ongeschreven zorgvuldigheidsnormen, die uitsluitend strekken ter bescherming van belangen waarop de dader bedacht moest zijn - niet afzonderlijk behoeft te worden vastgesteld dat de dader bedacht was of behoorde te zijn op de belangen van de benadeeldedie de geschondennorm beoogde te beschermen' ${ }^{\text {rq }}$.

In tegenstelling tot geschreven normen, die 'een gedraging (kunnen) verbieden ongeacht het gevolg of gevaar ervan', strekken ongeschreven zorgvuldigheidsnormen dus 'altijd ter voorkoming van schade aan iemands persoon of vermogen' 95 . Ze kunnen niet bestaan los van een concrete (dreigende) belangenaantasting: 'de belangen van anderen zijn immer bij de vaststelling van de ongeschreven norm betrokken' ${ }^{96}$. Zo'n belang moet kenbaar zijn geweest alvorens een verplichting kan worden aangenomen om het gedrag aan te passen in verband met dat belang. 'Vastgesteld moet worden dat gedaagde het betreffende belang kende of behoorde te kennen'; 'eerst dan kan er sprake zijn van een plicht tot zorg voor dat belang', aldus Bauw, die dit kenmerkende aspect van de zorgvuldigheidsnorm aanduidt als de eis van de 'voorzienbaarheid van de belangenaantasting'. Bij toepassing van 'ongeschreven zorgvuldigheidsnormen' jegens 'de overheid' is het echter problematisch een tijdstip aan te wijzen vanaf hetwelk het betrokken belang voor de 'rechtsgenoten' duidelijk had moeten zijn: 
'In tegenstelling tot de belangen die traditioneel in het privaatrecht bescherming vinden, bestaat bij het belang van de overheid dat hier in het geding is onzekerheid omtrent het tijdstip waarop dit daadwerkelijkgeacht kan worden te hebben bestaan. Rechtens gewaarborgdebelangen als eigendom of lichamelijke integriteit zijn 'van alle tijden' en daarmee behoorde men dan ook zeker vór 1 januari 1975 rekening te houden. Een belang dat eerst een belang wordt op het moment dat de overheid het zich aantrekt is echter van wezenlijk andere aard, vanwege het ongewisse karakter ervan. Men zal ergens toch een moment moeten aanwijzen vanaf welke het belang voor de rechtsgenoten die het aangaat kenbaar moet zijn geweest. Wat is anders de toetssteen voor de bepaling van de zorgvuldigheid van het gedrag van degenen die, naar later blijkt, een inbreuk op dit belang hebben gemaakt' $n$.

\subsection{Het regressieve karakter van de recente jurisprudentie}

\section{Artikel 6:162 BW als para-wettelijke 'Generalklausel'; 'Meerenberg' revisited}

De vraag is inderdaad: wanneer is een bepaald belang te beschouwen als 'een aan de zorg van de overheid toevertrouwd algemeen belang' c.q. wanneer kan worden gezegd dat een belang 'tot een belang van de overheid is geworden doordat zij het zich is gaan aantrekken'?

Volgens de Hoge Raad zou er van 'onzorgvuldigheid' en 'derhalve' van 'onrechtmatigheid' jegens 'de overheid' sprake zijn vanaf het tijdstip, dat duidelijk was dat die overheid zich een bepaald belang heeft aangetrokken en er voor die overheid vermogensnadeel ontstaat 'of dreigt te ontstaan' doordat dat belang wordt geschonden ${ }^{98}$. Maar verdraagt het zich met de rechtsstaatsgedachte dat de overheidsadministratie zich, zonder specifieke bevoegdheidsgrondslag, een bepaald belang aantrekt en alleen daardoor al een legitimatie verkrijgt om ter zake van dat belang een vordering in te stellen? Ten tijde van de politiestaat werd nog uitgegaan van een 'natuurlijk' recht van de hoogste overheid om al datgene te doen, wat zij met het oog op het bonum commune nodig achtte (het 'ius politiae'). Deze opvatting werd verlaten bij het Meerenbergarrest ${ }^{99}$. De ontwikkeling die uitmondde dit arrest, definieerden wij in hoofdstuk 3 als een uitbreiding van het materiële wetsbegrip en - analoog daaraan - een inperking van de 'politie' in de zin van 'Generalklausel': zonder publiekrechtelijke bevoegdheidsgrondslag kan er geen sprake meer zijn van 'een aan de zorg van de overheid toevertrouwd algemeen belang'.

Terecht overweegt de Duitse constitutionele rechter, het Bundesverfassungsgericht, in een uitspraak van 31 oktober 1984:

'Die Erfullung offentlicher Aufgaben durch juristische Personen des offentlichen Rechts vollzieht sich in aller Regel nicht in Wahrnehmung unabgeleiteter ursprünglicher Freiheiten, sondern aufgrund von Kompetenzen, die vom positiven Recht zugeordnet und inhaltlich bemessen und begrenzt sind' 100 .

En met die wettelijke bevoegdheidsgrondslag is ook de democratische legitimatie van het overheidsoptreden, ook in ons land, gegeven. Het burgerlijke recht - het recht 
dat gebaseerd is op de beginselen van de burgerlijke vrijheid (een 'unabgeleitete und ursprüngliche Freiheit') en de iustitia commutativa - kan naar zijn aard geen zelfstandige bevoegdheidsgrondslagen bieden ter behartiging van publieke belangen.

Wij stemmen in met Maurer, waar hij de vraag behandelt of de burgerrechtelijke regeling betreffende zaakwaarneming ('Geschäftsführung ohne Auftrag'; Par. 677 e.v. BGB) ook - al dan niet analoog - zou kunnen fungeren als bevoegdheidsgrondslag voor de overheid. Maurer betoogt:

'Die Bürgerlich-rechtlichenGoA-Vorschriften gehen - wie das bürgerliche Recht überhaupt - von der Privatautonomie des einzelnen aus und regeln die unterschiedlichen Interessen, wenn jemand freiwillig aus Hilfsbereitschaft für einen andern tătig wird. Die Verwaltung wird dagegen entsprechenddem Grundsatz der Gesetzmässigkeit der Verwaltung durch die Gesetze bestimmt und gebunden. Wenn sie auf Grund einer gesetzlichen Ermàchtigung handelt, liegt schon deshalb kein GoA vor, weil sie nicht 'ohne Auftrag' tătig wird. Andererseits schliesst đie Gesetzmalssigkeitaus, dass die Verwaltung dort, wo gesetzlicheBefugnisse und Zuständigkeitenfehlen, unter Berufung auf die GoA in den Rechtskreis des Bürgers oder die Zustăndigkeit eines anderen Verwaltungsträgers übergreift. Daran ândert auch Par. 679 BGB nichts, der eine auftragslose Geschăftsfuhrung für zulässig erklărt, wenn sie der Erfullung einer im ôffentlichen Interesse liegenden Pflicht đes Geschäftsherrndient. Denn sonst würde die gesetzlicheZustăndigkeitsordnung durch eine paragesetzliche Generalklausel unterlaufen, zumal die Verwaltung ohnehin nur im öffentlichen Interesse tătig wird und tătig werden darf (curs. dzz.; JT) ${ }^{\text {to! }}$.

Doordat de Hoge Raad heeft aanvaard dat art. 6:162 BW voor 'de overheid' als bevoegdheidsgrondslag kan dienen voor de behartiging van publieke belangen, is deze bepaling voor 'de overheid' gaan fungeren als een para-wettelijke 'Generalklausel' die het nieuwe 'ius politiae' fundeert. Deze algemene bevoegdheid is volgens de Hoge Raad slechts in zóverre beperkt, dat gebruikmaking ervan niet mag leiden tot een doorkruising van bij specifieke publiekrechtelijke regeling aan 'de overheid' toegekende bevoegdheden. We wijzen ook op de grote gelijkenis met het 'doorkruisingscriterium' dat de Hoge Raad hanteerde vóór het Meerenbergarrest, toen dit rechtscollege immers aannam dat de Koning slechts dàn niet bevoegd werd geacht om op basis van zijn algemene politiebevoegdheid algemeen bindende regels uit te vaardigen voorzover de Grondwet uitdrukkelijk een wet in formele zin voorschreef, m.a.w. indien er sprake zou zijn van een doorkruising van de Grondwet. 'Meerenberg' revisited?

\section{Vermenging van publiek belang en subjectief privaat vermogensbelang}

Dat de jurisprudentie van de Hoge Raad als een regressie is aan te merken, komt - behalve uit het vermengen van de statelijke sfeer met de maatschappelijke sfeer en, annex daaraan, het loslaten van de eis van een specifieke bevoegdheidsgrondslag naar voren uit de verbinding die hij legt tussen 'imperium' en 'dominium'. De vermenging van 'imperium' (overheids'bevoegdheden') en 'dominium' ('privaat' 
subjectief vermogensrecht) was kenmerkend voor het feodale bestel, waarin overheids'bevoegdheden' nog werden gezien als private vermogensbelangen. De doorbraak van de rechtsstaatsidee ging gepaard met een definitieve loskoppeling van imperium en dominium: publieke competentiebevoegdheden ('imperium') kunnen nog slechts uitgeoefend worden in het algemeen belang op basis van een positivering door de algemene wet, die ook de democratische legitimatie verschaft. Dat er bij een overheidsambt en een overheidsbevoegdheid geen privaat vermogensbelang meer in het geding kan zijn, werd duidelijk uitgedrukt in het al eerder geciteerde artikel 21 van de Franse Constitutie van 1795:

'Les fonctions publiques ne peuvent devenir la proprietté de ceux qui les exercent'.

Deze scheiding van 'imperium' en 'dominium' betekende - zoals we eerder zagen $66 \mathrm{k}$ een loslaten van de theorie van het dominium eminens, waarin de hoogste Overheid nog werd gezien als een oppereigenaar van alle gronden binnen zijn territoir, die ten aanzien van die gronden 'overheidsrechten' had uit hoofde van dat dominium eminens, waarbij die 'overheidsrechten' tevens werden gezien als privaat bezit ${ }^{102}$. De eigendom van de burger - hier genomen in de ruime zin van 'property', includerende al zijn private subjectieve vermogensrechten - moest nu worden erkend als privaat dominium, dat aan de burger toekomt met uitsluiting van de overheid, behoudens bij of krachtens de wet gestelde beperkingen. Deze eigendom staat in nauw verband met - en is basis voor - de private vrijheid. $\mathrm{Zij}$ heeft - in de woorden van het Bundesverfassungsgericht ${ }^{103}$ - als functie te dienen 'als Grundlage privater Initiative und in eigenverantwortlichem privatem Interesse von Nutzen zu sein' en wordt gekenmerkt door 'Privatnützigkeit und grundsätzliche Verfügungsbefugnis des Eigentümers über den Eigentumsgegenstand’.

Bepalingen als art. 17 van de Franse Déclaration des droits de l'homme et du citoyen en art. 625 BW (oud) waren een reactie op de oude theorie van het dominium eminens. Omgekeerd zijn publieke bevoegdheden en óók de overheids'rechten' op publiek domein geen 'zaken in den handel', geen private vermogensbelangen meer. Dit alles is een noodzakelijk gevolg van de doorbraak van de publieke rechtsstaatsidee en de daaraan verbonden scheiding van imperium en dominium.

Maar wat doet nu de Hoge Raad in het arrest Staat/Van Wijngaarden ${ }^{104}$ ? Hij aanvaardt niet alleen dat een 'ongeschreven' publiek belang - d.w.z. een belang dat 'de overheid' zich zonder bevoegdheidsgrondslag is gaan aantrekken - een titel kan opleveren voor een ingreep in de private eigendom ${ }^{105}$, maar construeert 6́ók de aantasting van een dit 'ongeschreven' publiek belang tot een eigen - 'privaat' vermogensnadeel van 'de overheid', welk eigen vermogensbelang door de aantaster had behoren te worden ontzien. Dat naar het oordeel van de Hoge Raad ook bij de gebruikmaking van een door de wet verleende publiekrechtelijke bevoegdheid 
- bestuursdwang - terzake van de schending van wettelijke voorschriften die een bepaald publiek belang ter behartiging aan 'de overheid' toevertrouwen, een eigen vermogensbelang van 'de overheid' in het geding kan zijn, blijkt uit het arrestStaat/Magnus ${ }^{106}$, waaruit we reeds citeerden.

Het gaat hier om het type onrechtmatige daad, bestaande uit de schending van een geschreven rechtsnorm, waarbij 'slechts' behoeft te worden vastgesteld of die norm strekt tot bescherming tegen de schade die de benadeelde - hier: de Staat - heeft geleden of zal lijden en waarbij - anders dan bij schending van een ongeschreven zorgvuldigheidsnorm - niet afzonderlijk behoeft te worden vastgesteld of de dader bedacht was of behoorde te zijn op de belangen van de benadeelde die de geschonden norm beoogt te beschermen ${ }^{107}$.

Kennelijk neemt de Hoge Raad dus aan dat door publiekrechtelijke - bevoegdheidsverlenende - voorschriften niet slechts de belangen van burgers worden beschermd, maar tevens eigen vermogensbelangen van 'de overheid' zelf.

En als eenmaal wordt aanvaard dat 'de overheid' voor publieke belangen als eigen (vermogens)belangen kan opkomen via een onrechtmatige-daadsactic, dan wordt vervolgens aangenomen dat die overheid zonder specifieke wettelijke bevoegdheidsgrondslag - evenals private belangenorganisaties - ó́k voor de belangen van 'andere personen' zou moeten kunnen opkomen.

In de memorie van toelichting bij het wetsvoorstel collectief actierecht, dat leidde tot een nieuw artikel $3: 305 \mathrm{~b}$ BW, dat aan publiekrechtelijke rechtspersonen de 'bevoegdheid' geeft om ten behoeve van 'andere personen' gebods- en verbodsacties in te stellen ${ }^{108}$, wordt met verwijzing naar o.a. dit arrest-Staat/Van Amersfoort betoogd:

'De publiekrechtelijke rechtspersoon die voor zijn eigen belangen opkomt heeft deze bepaling niet nodig. Het wetsvoorstel beoogt derhalve geen invloed uit te oefenen op de vraag wanneer een onrechtmatige daad ook jegens de overheid onrechtmatig is. Het eigen belang bij een op onrechtmatige daad gebaseerdevordering - eventueel ook een vordering tot schadevergoeding- is dan immers gegeven' 109 .

De door de overheid in een rechtsstaat te behartigen publieke gemeenschapsbelangen zijn echter nimmer eigen belangen in de zin van private belangen, zoals de burger die kan behartigen in het burgerrechtelijke rechtsverkeer. Zo men wil kan men zeggen: de 'eigen' belangen van de overheid zijn per definitie publieke gemeenschapsbelangen.

Dat bij de behartiging van publieke gemeenschapsbelangen geen schade in de zin van een eigen - subjectief privaat - vermogensbelang in het geding kan zijn, is in oudere jurisprudentie ook door de Hoge Raad nog goed ingezien, getuige bijvoorbeeld het eerder reeds genoemde Mark-en-Dintel-arrest van 29 april 1910: 
'dat ... de inbreuk op een publiekrechtelijkbeheersrechtniet is een inbreuk op enig vermogensrecht (bedoeld zal zijn: privaat vermogensrecht; JT) en dus niet oplevert een onrechtmatige daad die een burgerrechtelijke verbintenis doet ontstaan, waardoor het waterschap tot schadevergoeding ingevolge art. $1401 \mathrm{BW}$ zou kunnen worden verplicht' 110 .

De Hoge Raad verwierp overigens ook de - door het Gerechtshof wél geaccepteerde - 'vertegenwoordigingsconstructie', inhoudende dat ook een inbreuk zou zijn gemaakt op de onder de hoede van het heemraadschap staande vermogensrechten zijner ingelanden, wier belang zou meebrengen dat het rivierwater op een bepaald peil werd gehouden en niet door onbevoegdheden werd afgetapt. De Hoge Raad overwoog:

'dat toch, al moge het waar zijn dat het heemraadschap... zijn beheersrecht uitoefent in het belang van de ingelanden, dat recht, evenals de andere rechten die het heemraadschapals zoodanig heeft, toekomt aan het publiekrechtelijklichaam alleen, en niet aan hen in wier belang het is in het leven geroepen - zoodat ook inbreuk op dat recht, ofschoon tevens benadeelendede belangender ingelanden, niet is een krenking van de rechten van dezen doch van het heemraadschap.'

\section{Het Kabayelarrest: alle sluizen open}

Wellicht heeft de Hoge Raad aangevoeld dat de behartiging door 'de overheid' van publieke belangen geen privaat (vermogens)belang van die overheid mag zijn. Maar in plaats van zijn ten principale onjuiste uitgangspunt - namelijk dat 'de overheid' in beginsel zou beschikken over zelfstandige privaatrechtelijke 'bevoegdheden' ter behartiging van publieke belangen - te verlaten, heeft hij de eis van een privaat belang uitdrukkelijk laten vallen en deze in het Kabayelarrest vervangen door de eis van 'voldoende belang', zoals omschreven in art. 3:303 BW (zonder voldoende belang komt niemand een rechtsvordering toe) ${ }^{\prime \prime \prime}$. Daarmee lijken alle sluizen te zijn opengezet voor wat nog steeds 'privaatrechtelijke' handhaving genoemd wordt. Dit belang kán een vermogensbelang zijn - nl. bij schadevorderingsacties -, doch bij gebods- of verbodsacties strekkende tot 'privaatrechtelijke' handhaving van publiekrechtelijke voorschriften of zelfs - zoals in de Kabyelcasus - van in een rijksbijdrageregeling verwoord 'beleid', kan reeds het 'handhavingsbelang' een voldoende belang in de zin van art. 3:303 BW opleveren. We wezen er al op, dat het doorkruisingscriterium hierbij zeker geen voldoende waarborg biedt. Zo blijkt uit het Magnus-arrest ${ }^{112}$, dat naar het oordeel van de Hoge Raad ook bij de (niet)gebruikmaking van een door de wet verleende publiekrechtelijke bevoegdheid - bestuursdwang - 'financiële nadelen' voor 'de overheid' in het geding kunnen zijn, die betekenen dat de publiekrechtelijke weg geen 'vergelijkbaar resultaat' oplevert en die daarom legitimeren tot het volgen van de 'privaatrechtelijke' weg.

En zoals we reeds zagen, heeft de Hoge Raad in een arrest van 7 oktober 1994 laten blijken, dat een 'voldoende belang' ex art. 3:303 BW zelfs gelegen kan zijn in 
vermogensnadelen voor de overheid, die geen direct verband hebben met het publieke rechtsbelang dat het overtreden wettelijk voorschrift beoogt te dienen ${ }^{113}$.

Dat van het één het ander komt, blijkt wel uit het nieuwe artikel 3:305b BW. In zijn noot onder het Kabayelarrest in de A.B. betoogt G.A. van der Veen dat het begrijpelijk is dat de Hoge Raad het vereiste van art. 6:162 BW-belang c.q. concreet (vermogens)belang heeft laten vallen, waarbij hij er o.a. op wijst dat óók private belangenorganisaties nást 'een algemeen belang als het behoud van het milieu' niet een concreet belang behoeven te stellen, en dat voorts de wetgever door de nieuwe artikelen 3:305a en 3:305b BW de zin aan dit belangvereiste zou hebben ontnomen. Aan de aanvaarding van de mogelijkheid dat private organisaties via cen art. 1401 resp. art. 6:162 BW-actie kunnen opkomen voor een publiek belang, wordt simpelweg de conclusie verbonden dat 'a fortiori' $66 \mathrm{k}$ 'de overheid' dat zou moeten kunnen. Als dat laatste eenmaal is aanvaard, wordt uit de omstandigheid dat private organisaties bij hun behartiging van publieke belangen geen concreet belang behoeven te stellen, afgeleid dat 'logischerwijs' ók 'de overheid' dat niet zou behoeven te doen. En als private organisaties, behalve voor publieke belangen - die ze als hun 'eigen' belangen behartigen -, voor de belangen van 'andere personen' moeten kunnen opkomen, zouden toch ook overheidslichamen, behalve voor hun 'eigen' belangen, voor de belangen van 'andere personen' moeten kunnen opkomen (de nieuwe artikelen 3:305a en 3:305b BW).

De vraag of de behartiging van het algemeen belang in een rechtsstaat niet een exclusieve zaak van de overheid is, wat 'openbare' c.q. 'publieke belangen' zijn - of beter: wie dit bepaalt -, wat het onderscheid is tussen 'publieke' en 'collectieve belangen' wordt bij een dergelijke grensvervaging niet meer gesteld ${ }^{114}$.

\section{Tweewegenleer en doorkruisingsproblematiek}

Thans nog enkele woorden over het zgn. 'doorkruisingscriterium', waarin de Hoge Raad een waarborg wil zien tegen onaanvaardbare doorkruising van het publiekrecht. Dit criterium is - zoals bekend - geformuleerd in het Windmill-arrest ${ }^{115}$ : in geval aan 'de overheid' bij een publiekrechtelijke regeling ter behartiging van zekere belangen bepaalde bevoegdheden zijn toegekend, is - wanneer die regeling daarin zelf niet uitdrukkelijk voorziet - ter beantwoording van de vraag of zij die belangen óók mag behartigen door gebruikmaking van haar 'in beginsel krachtens het privaatrecht toekomende bevoegdheden', beslissend of daardoor de publiekrechtelijke regeling 'op onaanvaardbare wijze' zou worden doorkruist. Of zich zo'n onaanvaardbare doorkruising voordoet, dient dan o.m. te worden bepaald door: a. de inhoud en strekking van de publiekrechtelijke regeling; de wijze waarop en de mate waarin die regeling de belangen van burgers beschermt; $c$. het door de overheid te bereiken resultaat. 
Het Windmill-arrest is, vooral in publiekrechtelijke kringen, in eerste instantie redelijk positief ontvangen. Zulks ten onrechte. Het arrest erkent in algemene zin de - in de gemene rechtsleer gefundeerde - tweewegenleer en neemt als uitgangspunt dat 'de overheid' 'in beginsel' zou beschikken over 'privaatrechtelijke bevoegdheden' ter behartiging van publieke belangen. Het zal duidelijk zijn geworden, dat o.i. reeds dit uitgangspunt, dat ten principale als onjuist moet worden aangemerkt.

Dat de tweewegenleer alsook het doorkruisingscriterium hun basis vinden in de gemene rechtsleer wordt duidelijk, indien men kennis neemt van een in 1934 door een commissie uit het Nederlands Instituut voor Volkshuisvesting en Stedebouw uitgebracht rapport. Deze commissie bestond uit o.a. J. Kruseman, F.J.A. Huart en F.G. Scheltema, allen aanhangers van de leer die het burgerlijk recht ziet als het gemene recht, waarop het publiekrecht uitzondering c.q. aanvulling vormt ${ }^{116}$. In het rapport gaf de commissie haar antwoord op de vraag, of een 'privaatrechtelijke regeling' van bebouwingsvoorschriften in overeenkomsten betreffende verkoop of uitgifte in erfpacht van gemeentegronden, resp. in exploitatieovereenkomsten met particulieren betreffende de medewerking der gemeente tot het bouwrijp maken van particuliere gronden, juridisch aanvaardbaar is.

Aanleiding tot instelling van deze commissie vormde o.a. de circulaire van de minis-

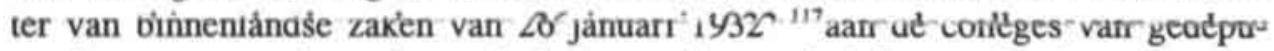
teerde staten, waarin er de aandacht op werd gevestigd dat regeling langs burgerrechtelijke weg van hetgeen krachtens de Woningwet 1901 publiekrechtelijke geregeld moest worden, in strijd was met deze wet en te kort deed aan de waarborgen welke deze wet aan derden gaf. Bedoelde handelwijze was volgens de minister bedenkelijk, omdat aldus publieke rechtsbelangen tot onderwerp van koophandel werden gemaakt, waarbij bijvoorbeeld de belangen der volkshuisvesting op meer dan één wijze in het gedrang kwamen. Aan de colleges van gedeputeerde staten werd dan ook verzocht hierop toe te zien bij hun ingevolge art. 228 gemeentewet te nemen goedkeuringsbesluiten, zodat door de Kroon geen vernietiging van deze besluiten wegens strijd met de Woningwet zou behoeven plaats te vinden. Bij Koninklijke Besluiten van 7 juli 1932, Stb. 329, AB 1932, p. 855 (Amsterdam), en van 13 februari 1933, Stb. 43 (Rockanje), werden inderdaad goedkeuringsbesluiten betreffende gemeentelijke besluiten tot het aangaan van een koopovereenkomst resp. een exploitatieovereenkomst, waarin een 'privaatrechtelijke bebouwingsregeling' was opgenomen, vernietigd ${ }^{118}$. 


\section{De genoemde commissie gaf daarentegen als háár standpunt:}

'(E)r moet ... van uitgegaan worden, dat het privaatrecht ook voor de Overheid algemeene gelding heeft en dat deze voor de vervulling van haar taak dus ook privaatrechtelijkeovereenkomstenkan aangaan, tenzij de betreffende publiekrechtelijke regeling kennelijk bedoelt het daarin behandelde onderwerp geheel aan de heerschappij van het privaatrecht te onttrekken. M.a.w. in het algemeen staat aan de Overheid zoowel de publiekrechtelijke als de privaatrechtelijkeweg open, tenzij de eerste bepaaldelijk is voorgeschreven of althans uit het systeem der wet of het verband der wetsbepalingenmoet worden afgeleid, dat het volgen van dien weg verplicht wordt gesteld. Een verdere mogelijkheid is nog dat de wet door een uitdrukkelijk voorschrift naast den publiekrechtelijkenweg ook den privaatrechtelijken open laat, al dan niet onder bepaalde voorwaarden, gelijk b.v. in art. 146 der Gemeentewet (intercommunale regelingen) en art. 1 jo. 134 der Ambtenarenwet (privaatrechtelijke arbeidsovereenkomsten) het geval is. Met een algemeenheid is dit vraagstuk derhalve niet op te lossen; in elk voorkomend geval zal moeten worden nagegaan, of en in hoeverre de daarop betrekking hebbende regeling den privaatrechtelijken weg verspert' 110 .

Dit is, in ietwat andere bewoordingen, ook het standpunt dat de Hoge Raad zo'n 56 jaar later zal vertolken in het Windmill-arrest!

Het is vervolgens interessant te bezien, tot welke conclusie de commissie in 1934 kwam bij toepassing van het 'doorkruisingscriterium' op het aan deze commissie voorgelegde vraagstuk, namelijk of 'privaatrechtelijke regeling' van planologische bebouwings- en gebruiksvoorschriften op gespannen voet staat met de Woningwet 1901. Dit is zo interessant, omdat de Hoge Raad in 1991 bij het arrest-Kunst- en Antiekstudio/Lelystad ${ }^{120}$ is gesteld voor in wezen dezelfde vraag: moet een 'privaatrechtelijke regeling' van planologische gebruiksvoorschriften in strijd worden geacht met de Wet op de Ruimtelijke Ordening? ${ }^{121}$.

De commissie oordeelde dat de Woningwet 1901, voor de vaststelling van de eisen waaraan moest worden voldaan bij het oprichten van gebouwen (artt. 1 en 2), van een bouwverbod (art. 35), van een uitbreidingsplan (art. 36), van bebouwingsvoorschriften (art. 39) en van voorschriften inzake de aard van de bebouwing en het gebruik van gronden in de bebouwde kom (art. 43),

'een bepaalde wijze van totstandkoming heeft voorgeschreven, ter waarborging van de belangen zoowel van de volkshuisvestingals van belanghebbenden.

Daaruit meent de Commissie de gevolgtrekkingte mogen maken, dat bepalingen, die in wezen zijn voorschriften, als bedoeld in de artt. 1,2, 39 en 43, regelingen, die in wezen zijn een bouwverbod of een uitbreidingsplan, niet mogen worden tot stand gebracht, zonder dat de daarvoor wettelijk voorgeschreven formaliteiten in acht zijn genomen. (...) Ook als eigenares van den grond zal de gemeente de door de Wet voorgeschreven formaliteiten niet mogen veronachtzamen' in .

Wat dit laatste betreft, was overigens een minderheid der commissie - bestaande uit Scheltema en P. Bakker Schut - een ander oordeel toegedaan ${ }^{123}$.

De conclusie van de Hoge Raad is in 1991 regressiever dan die van de commissie - althans de meerderheid daarvan - in 1934! Ofschoon de waarborgen waarmee de totstandkoming van planologische bebouwings- en gebruiksregelingen door de Wet 
Ruimtelijke Ordening zijn omkleed, uitgebreider zijn dan die waarmee de totstandkoming van vergelijkbare maatregelen onder vigeur van de Woningwet 1901 waren omgeven, neemt de Hoge Raad in het arrest-Kunst en Antiekstudio/Lelystad namelijk het algemene standpunt in,

'dat de Wet Ruimtelijke Ordening niet in de weg staat aan het opnemen van voorwaarden omtrent grondgebruik in overeenkomsten, ook niet als door of krachtens de voorwaarden in bepaalde gevallen gebruik van de grond wordt beperkt of verboden, resp. kan worden beperkt tot verboden dat volgens het vigerende bestemmingsplan in het algemeen geoorloofd is'.

Opmerkelijk is dat de Hoge Raad de argumentatie voor zijn standpunt, behalve in een 'reeds tientallen jaren bestaande praktijk', zoekt in het stilzwijgen van de wetgever omtrent de toelaatbaarheid van die praktijk bij de totstandkoming van de Wet Ruimtelijke Ordening ${ }^{124}$. Zelfs wanneer we de huidige jurisprudentie van de Hoge Raad vergelijken met de opvatting van gemene rechtsleer-adepten, zoals die naar voren komt in het rapport van 1934, dan betekent die jurisprudentie dus geen vooruitgang; integendeel.

De conclusie dient te zijn, dat het door de Hoge Raad gekozen uitgangspunt - namelijk dat 'de overheid' 'in beginsel' zou beschikken over 'privaatrechtelijke bevoegdheden' ter behartiging van publieke belangen - onjuist is, en dat het doorkruisingscriterium zeker geen voldoende waarborg is gebleken tegen 'onaanvaardbare doorkruising' van het publiekrecht, getuige bij voorbeeld het arrest-Kunst- en antiekstudio/Lelystad en het Magnus-arrest. Blijkens het laatste arrest kan immers naar het oordeel van de Hoge Raad reeds de omstandigheid dat aan de gebruikmaking van publiekrechtelijke bevoegdheid financiële risico's zijn verbonden, betekenen dat de publiekrechtelijke weg niet een 'vergelijkbaar resultaat' oplevert als de privaatrechtelijke.

\section{Algemene zorgplichten van de burger voor 'collectieve belangen' van 'de maatschappij'; de Staat als zaakwaarnemer van deze belangen}

Als eenmaal de grenzen tussen Staat en 'maatschappij' niet meer aanwezig worden geacht en aanvaard wordt dat 'de overheid' als 'privaatrechtelijke' behartiger van publieke belangen mag optreden tegen burgers en niet-statelijke organisaties die op een onzorgvuldige wijze met zulke belangen zijn omgegaan, dan is de stap niet meer zo groot om in het kader van een 'permanente' ${ }^{125}$, 'dynamische, zich steeds ontwikkelende' ${ }^{126}$, rechtsbetrekking tussen overheid en burger 'met wederzijdse rechten en plichten', ongeschreven maatschappelijke zorgplichten van de burger ten opzichte van publieke belangen te aanvaarden. Illustratief is het betoog van Van Wijmen, die meent dat de maatschappelijke zorgvuldigheidsnorm in de relatie burger/overheid enerzijds wordt ingevuld door de algemene beginselen van behoorlijk 
bestuur en anderzijds wordt ingekleurd via 'algemene beginselen van behoorlijk burgerschap', als pendant van eerstgenoemde beginselen ${ }^{127}$. Zo noemt hij als 'burgerschapspendant' van het algemeen beginsel van behoorlijk bestuur van het verstrekken van de juiste inlichtingen: 'het beginsel ener adequate informatieverschaffing, onder andere bij het aanvragen van een vrijstelling of vergunning' ${ }^{128}$. Elders noemt hij als burgerschapsplicht 'de gehoudenheid om collectieve belangen te eerbiedigen en in stand te houden' ${ }^{129}$.

\section{Codificatie van zorgplichten en écartering van het 'doorkruisingscriterium'}

De wettelijke vastlegging van een algemene zorgplicht voor het milieu (art. 1. 1a Wet milieubeheer) kan in die visie worden beschouwd als 'slechts' de codificatie van een reeds bestaande ongeschreven maatschappelijke zorgplicht ${ }^{130}$, met als 'voordeel' dat die plicht nu niet meer alleen privaatrechtelijk doch ook via bestuursrechtelijke sancties zou kunnen worden gehandhaafd ${ }^{131}$. Dat aan deze bepaling de opvatting ten grondslag ligt dat 'de overheid' in beginsel beschikt over 'privaatrechtelijke bevoegdheden' ter behartiging van publieke belangen, i.c. het 'milieubelang', en dat deze bepaling is bedoeld als een algemene grondslag om via bestuursrechtelijke sancties op te kunnen treden wegens 'milieubenadeling' in die gevallen waarin geen specifieke voorschriften zijn overtreden, blijkt uit het derde lid. Daarin staat dat het bepaalde in het eerste en tweede lid 'de uit het burgerlijk recht voortvloeiende en de mogelijkheid van rechtspersonen als bedoeld in art. 1, Boek 2, van het BW, om uit dien hoofde in rechte op te treden', onverlet laat. De bedoeling van dit artikellid is om het doorkruisingscriterium via een machtswoord van de wetgever buiten spel te zetten ${ }^{132}$.

De Staat als zaakwaarnemer voor de 'collectieve belangen' van de 'maatschappij'; écartering van de relativiteitseis?

In het kader van de wijziging van de Wet Bodembescherming ${ }^{133}$ wilde de regering voor 'gevallen van ernstige verontreiniging' het zowat enige obstakel dat nog op die 'privaatrechtelijke weg' gelegen is, te weten de - toch al sterk uitgeholde relativiteitseis, ook nog écarteren ${ }^{134}$, hetgeen volgens de regering 'slechts' zou leiden tot een overdracht van verhaalsrechten van benadeelden aan de Staat, resulterende in een 'doelmatige bundeling van verhaalsrechten in handen van de overheid' ${ }^{135}$. Het creëren van een vrijwel onbegrensde verhaalsactie sui generis is echter door de Eerste Kamer niet geaccepteerd ${ }^{136}$.

Het laten vallen van de relativiteitseis is o.i. echter de uiterste consequentie van de aanvaarding dat 'de overheid' in het kader van de behartiging van publieke belangen burgers kan aanspreken wegens maatschappelijke onzorgvuldigheid. Als men de grenzen tussen 'Staat' en 'maatschappij', tussen 'publiek' en 'privaat', laat weg- 
vallen en bovendien aanneemt dat er van maatschappelijke onzorgvuldigheid reeds sprake is indien 'de overheid' zich een bepaald belang heeft aangetrokken - zéker wanneer de behartiging ervan aan die overheid geld kost ${ }^{137}$-, dan wordt ieder door 'de overheid' - ook zonder wettelijke basis - aan zich getrokken 'maatschappelijk belang' tevens tot een 'publiek belang'. Wanneer de Staat aldus geworden is tot de waarnemer van de belangen van de georganiseerde 'maatschappij', kan uiteraard de eis niet meer gesteld worden dat een daad ook jegens de Staat onrechtmatig is.

Deze 'zaakwaarnemings-' c.q. 'vertegenwoordigingsconstructie' is inderdaad verdedigd in de literatuur: 'de overheid' zou ter behartiging van publieke belangen onrechtmatige-daadsacties moeten entameren, omdat zij via zo'n actie zou opkomen voor de 'gebundelde belangen van burgers'. Het 'vertegenwoordigingsargument' is reeds te vinden in de noten van G.J. Scholten onder het Rijksweg 12-arrest ${ }^{138}$ en het Zuidpoolarrest ${ }^{139}$. In zijn noot onder het Zuidpoolarrest stelt Scholten:

'Een openbaar lichaam heeft ook een zekere vertegenwoordigende functie'.

En in zijn noot onder het Rijksweg 12-arrest betoogt Scholten, dat de overtreden norm ook het openbaar lichaam beschermt dat de belangen behartigt van de door die norm beschermde personen, juist tegen schade door overtreding van die norm. Deze benadering lijkt ook de Hoge Raad te volgen: zoals we reeds aangaven bij onze bespreking van het arrest-Staat/Magnus, gaat de Hoge Raad er kennelijk van uit dat door wettelijke normen tevens eigen (vermogens)belangen van 'de overheid' zelf worden beschermd. Deze opvatting - die een vermenging impliceert van 'imperium' en 'dominium' - kritiseerden we reeds uitvoerig. Naar aanleiding van het Kabayelarrest ${ }^{140}$ merkt Simon terecht op:

'dat ernstig kan worden betwijfeld of in de zaak Kabayel is voldaan aan het relativiteitsvereiste. De opvang van asielzoekersstrekt ter bescherming van asielzoekers, niet ter beschermingvan het (financiële) belang van de overheid. Hiertoe dienen $\mathrm{o} . \mathrm{m}$. de bepalingen aangaande de belastingheffing' ${ }^{141}$.

Wellicht ging de Hoge Raad er van uit dat aan de relativiteitseis is voldaan, om reden dat de Staat mede optrad als 'waarnemer' van de belangen van 'andere asielzoekers (dan de Kabayels; JT), die aan de ROA jegens de Staat wèl een aanspraak op opvang kunnen ontlenen' en dat de Kabayels jegens die andere asielzoekers onrechtmatig handelden door het 'zonder recht of titel verblijven in de bij hen in gebruik zijnde (woon-)ruimten van het asielzoekerscentrum 'Moorheide'? Een vergelijkbare benadering wordt gekozen door hen die stellen dat vervuiling van eigen terrein onrechtmatig - want maatschappelijk onzorgvuldig - zou zijn jegens 'de maatschappij' en dat de Staat de vordering zou kunnen instellen als waarnemer van de georganiseerde maatschappij ${ }^{142}$. Exemplarisch is het volgende betoog van Kruisinga:

'(G)ezegd (kan worden) dat door schending van de zorgvuldigheidsnorm de onrechtmatigheid jegens een derde reeds gegeven is. De zorgvuldigheidsnormimpliceert immers dat de vervuiler zijn 
gedraging achterwege had moeten laten wegens het te verwachtennadeel voor derden. Daarbij doet niet ter zake of de vervuiler wist welke derde in concreto door de verontreinigingschade zou leiden. Gesteld kan dan worden dat als een vervuiler de zorgvuldigheidsnorm overtreedt, de verontreiniging onrechtmatig jegens eenieder, dus ook jegens de overheid is.(...) (D)at het gehele leefmilieu belang heeft bij een schone bodem, de zorg voor een schone bodem is derhalve een algemeen belang. De overheid die de bodem saneert behartigt het algemeen belang bij een schone bodem. De eigenaar die ten tijde van de vervuiling wist of behoordete weten dat door zijn handelen het algemeen belang van een schone bodem zou worden geschaad, heeft onzorgvuldiggehandeld' 16 .

$\mathrm{Om}$ te voldoen aan het onrechtmatigheidscriterium van de onzorgvuldigheid in het maatschappelijk verkeer is kennelijk niet (meer) nodig dat het gaat om onzorgvuldigheid van de een persoon ten aanzien van eens anders persoon of goed; voldoende is 'onzorgvuldigheid' 'jegens een ieder', d.w.z. 'de maatschappij', 'dus' ook 'jegens de overheid'. De 'collectieve belangen' van 'de maatschappij' worden hier getransformeerd tot 'publieke rechtsbelangen', te behartigen door 'de overheid'.

\section{Relativering van het beginsel van wetmatigheid van bestuur}

Waar wordt aanvaard dat 'de overheid' ook tegen burgers kan optreden terzake van beweerde schending van ongeschreven zorgplichten resp. van gecodificeerde algemene zorgplichten (vgl. art. 1.1 a Wmb), moet zulks welhaast automatisch leiden tot een relativering van de eis van wetmatigheid van bestuur. De 'Gesetzesvorbehalt' is, zoals we zagen, juist ontwikkeld op basis van een staatsbegrip dat Staat en 'maatschappij' resp. publieke en private rechtsbelangen c.q. publiek- en privaatrecht strikte wilde scheiden ${ }^{144}$.

In een recente dissertatie wordt aan de geconstateerde 'horizontalisering' van de - door 'wederzijdse afhankelijkheid' - gekenmerkte, verhouding tussen overheid en burger' dan ook de conclusie verbonden, dat volstaan zou kunnen worden met een 'open bevoegdheid' van het bestuur.

De betekenis van de wet als adequate rechtsstatelijkheidswaarborg zou grotendeels zijn vervallen: in plaats van de wet zou het ongeschreven recht - met name de beginselen van behoorlijk bestuur - de rechtmatigheid van het overheidsoptreden garanderen. Het besturen met privaatrechtelijke 'bevoegdheden' wordt dan ook niet als problematisch ervaren. Immers:

'Aan de strekking van het legaliteitsbeginselwordt voldaan wanneer de privaatrechtelijke bevoegdheidsuitoefening aan dezelfdebeperkingenen voorwaardenis gebondenals overheidsoptreden langs de publiekrechtelijke weg. In dit verband is het onderscheid tussen het privaatrecht en het publiekrecht op de achtergrond geraakt. Het onderscheid is alleen nog van betekenis waar het de waardering van de betrokken belangen betreft. In dit opzicht kan de door de wetgever aangeduide publiekrechtelijke weg als een geheel van 'geprioriteerde belangen' worden beschouwd waaraan in beginsel niet kan worden gederogeerd.

Geconstateerd kan worden dat de strekking van het legaliteitsbeginsel in het positieve recht wordt gerealiseerd. De overheid is in beginsel voor wat betreft haar 'gehele' optreden gebonden aan de algemene beginselen van behoorlijk bestuur' (curs. dzz.; JT) ${ }^{145}$. 
Een relativering van het beginsel van wetmatigheid van bestuur is ook de consequentie die Lubberdink verbindt aan de wederkerigheidsconceptie. In zijn opvatting zou de Awb-wetgever daarom nog niet ver genoeg zijn gegaan in de uitwerking van deze conceptie. Hij bepleit een overheidsbestuur dat met de burgers 'meedenkt' en meent dat aan de besluitvorming door democratische gelegitimeerde organen niet langer het gezag toekomt, dat er nu nog aan wordt toegekend:

'Zo niet reeds met een beroep op de vrijheid van het individu gerechtvaardigdzou kunnen worden dat afwijking van democratisch tot stand gekomen regels in een concreet geval mogelijk moet zijn, kunnen bij de democratische legitimatie zelf van de regels vraagtekens worden gezet of meer algemeen bij de democratische legitimatie van de politieke besluitvorming' ${ }^{106}$.

Van enige beduchtheid voor de overheids-Leviathan, die men aan banden wilde leggen door invoering van het beginsel van wetmatigheid van overheidsoptreden, lijkt in deze beschouwingen nauwelijks nog sprake te zijn. Gezien het Kabayelarrest is die beduchtheid er kennelijk ook niet bij de Hoge Raad ${ }^{147}$. De Duitse constitutionele rechter waarschuwt tegen de met burgers 'meedenkende' overheid, die zich 'in privaatrechtelijke hoedanigheid' opwerpt als zaakwaarnemer van hun belangen:

'Eine 'Vertretung', wie hier ausgesprochenwürde eine gefährliche Einbruchstelle in die Individualfreiheit eroffnen; die grundrechtlich verbürgten Freiheiten sollen prinzipiell nicht von der Vernunfthoheit offentlicher Einrichtungenverwaltet werden' is .

Grondrechtenbeperking op grond van 'maatschappelijke zorgvuldigheid' jegens 'de overheid'?

Een consequentie van de aanvaarding door de Hoge Raad van ongeschreven 'maatschappelijke zorgvuldigheidsplichten' van de burgers jegens 'de overheid' en van, annex daaraan, de relativering van het wetmatigheidsbeginsel zou óók kunnen zijn dat, waar het desbetreffende overheidshandelen kan leiden tot een beperking van grondrechten, het grondwettelijk beperkingenkader kan worden 'opgeblazen'. Volgens het grondwettelijk stelsel is de tussenkomst van de wetgever in formele zin vereist voor beperking van de daarin geformuleerde klassieke grondrechten ${ }^{149}$. Verder mogen beperkingen in een aantal gevallen alleen gesteld worden met het oog op bepaalde doelen (doelcriteria) ${ }^{150}$. Tenslotte zijn in enkele gevallen procedureeisen gesteld, namelijk waar het gaat om de beperking van het huisrecht (art. 12 lid 2) ${ }^{151}$ en vrijheidsontneming (art. 15 leden 2 en 3 ).

In commentaren op het HIV-arrest van 18 juni 1993 is erop gewezen, dat dit arrest niet uitsluit dat door de Hoge Raad zal worden aanvaard dat 'de overheid' de voor grondrechtsbeperking vereiste formeel-wettelijke grondslag onder omstandigheden óók zou kunnen vinden in art. 1401 (oud) resp. 6:162 BW ${ }^{152}$. De Hoge Raad aanvaardt hier dus dat art. 1401 (oud) resp. 6:162 BW - en via deze bepaling ongeschreven maatschappelijke zorgvuldigheidsnormen - als wettelijk grondslag kan fungeren voor beperking van grondrechten, 'in elk geval tussen burgers onderling'. Aldus wordt niet uitgesloten, dat door de burger jegens 'de overheid' - als be- 
hartiger van aan zich getrokken publieke belangen - in acht te nemen ongeschreven 'maatschappelijke zorgvuldigheidsnormen' zouden kunnen fungeren als beperkingsgrondslag. Dan zou het grondwettelijk beperkingenstelsel worden ondergraven en zou - in de woorden van Leenen - 'de beschermende werking van de grondrechten tegenover de overheid boterzacht worden' ${ }^{153}$.

Uit het feit dat we de kritiek op het HIV-arrest delen, mag overigens niet worden afgeleid dat we de door de HR verrichte belangenafweging en de uitkomst van het arrest onjuist achten. Waar de Hoge Raad zich o.i. echter te weinig van bewust is geweest, is dat de in de Grondwet gepositiveerde grondrechtsnormen zijn toegespitst op de verhouding tussen overheid en burgers, zoals ook blijkt uit de beperkingsclausules. Maar dit neemt niet weg dat aan grondrechtsnormen algemene rechtsbeginselen ten grondslag kunnen liggen, die weliswaar in die normen zijn gepositiveerd voor de verhouding tussen overheid-burgers maar die als rechtsbeginselen ook op eigen wijze tot uitdrukking behoren te komen in burgerrechtelijke verhoudingen. En dat geldt o.i. zeker ook voor het aan art. 11, waaraan het algemene rechtsbeginsel van de menselijke persoonlijkheid ten grondslag ligt, zoals dat wordt verdiept door het beginsel van de menselijke waardigheid ${ }^{154}$. Nu het i.c. ging om een verhouding tussen burgers onderling, was het o.i. juister geweest wanneer de Hoge Raad niet zou hebben gesproken van een 'bij of krachtens de wet' geoorloofde beperking van de positieve grondrechtsnorm ex art. 11 Grondwet.

Dat de benadering van de Hoge Raad het reële gevaar in zich bergt, dat ook de nietinachtneming van de 'maatschappelijke zorgvuldigheidsnorm' jegens 'de overheid' via een civiele actie kan leiden tot beperking door die overheid van grondrechten, blijkt uit de Kabayel-casus. Simon wijst er op, dat in die casus de toewijzing van de vordering van de Staat ertoe zal kunnen leiden dat er, via art. 6:162 BW, op grondslag van de ongeschreven 'publiekrechtelijke betamelijkheid', inbreuk wordt gemaakt op het huisrecht en het recht op privacy van de Kabayels ${ }^{155}$. Een ongeschreven maatschappelijke zorgvuldigheidsnorm is inherent gebrekkig als beperkingsgrondslag, zo merkt Simon terecht op.

Intussen doet de aanvaarding door de Hoge Raad in een arrest van 22 januari 1993, dat óók de regering - en daarmee de Staat - aanspraak heeft op "het zowel in de Grondwet als in internationale verdragen neergelegde recht op vrijheid van meningsuiting' ${ }^{156}$, vrezen dat ingeval van 'botsing' van een grondrecht van een burger - bijv. het grondrecht op privacy - met zo'n aan 'de overheid' toekomend grondrecht, in het belang van realisering van het laatstgenoemde grondrecht een rechtvaardiging aanwezig kan worden geacht voor beperking van het eerstgenoemde grondrecht. Het standpunt van de Hoge Raad, dat óók de Staat aanspraak zou maken op een grondrecht als de vrijheid van meningsuiting, is o.i. terecht bestreden door Kort- 
mann ${ }^{157}$, Verhey ${ }^{158}$ en Hins ${ }^{159}$. Kortmann schrijft dat het 'juister en consistenter zou zijn ... vast te houden aan het beginsel dat grondrechten niet gelden voor de overheid, noch als rechtspersoon, noch als ambt'. In hoofdstuk 4 zullen wij aangeven, waarom het juist is vast te houden aan de heersende leer, waarin een principiële afwijzing van grondrechtsbescherming voor publiekrechtelijke rechtspersonen uitgangspunt is, 6́6k waar optreden 'in burgerrechtelijke hoedanigheid'. 


\section{Noten bij hoofdstuk 5}

1. Paul Scholten. 'Molengraaf en de onrechtmatige daad', RM 1931, p. 399, ook opgenomen in 'Verzamelde geschriften van Paul Scholten', dl. IV, Zwolle 1951, p. 207 e.v. (p. 211).

2. HR 26 jan. 1990, Gst. 6914.10, AB 1990, 408, NJ 1991, 393 (Windmill), en HR 9 juli 1990, Gst. 6914.11 (De Pina/Helmond).

3. Vgl. HR 24 april 1990, NJ 1991, 462 (Staat/Van Amersfoort), en HR 24 april 1992, NJ 1993, 643 (Staat/Van Wijngaarden).

4. HR 18 dec. 1992, NJ 1994, 139, Gst. 6970.5, M\&R 1993/4, 24, TVVS 1993/3, p. 75, AA 1993/9, p. 664 (Kuundersarrest).

5. Vgl. het fraaie opstel van E.-W. Bockenforde, 'Die Bedeutung der Unterscheidung von Staat und Gesellschaft im demokratischen Sozialstaat der Gegenwart', a.w. Zie ook nog: H.H. Rupp. 'Die Unterscheidung von Staat und Gesellschaft', in: J. Issensee/P. Kirchhof (red.), 'Handbuch des Staatsrechts der Bundesrepublik Deutschland', Band I, Heidelberg 1987, pp. 1187-1223.

6. Locré, a.w.

7. Zie voor een overzicht: Korthals Altes, 'De staatsaansprakelijkheid volgens de rechtspraak van den conseil d'Etat in Frankrijk', a.w., m.n. pp. 11-37.

8. R. Jacquelin, 'Principes dominants du contentieux administratif. genoemd door Korthals Altes, a.w.

9. Optreden van de overheid 'als zodanig' dus. Wel wordt aanvankelijk alleen een aansprakelijkstelling van de ambtenaar persoonlijk mogelijk geacht. De redenering is dan dat, waar de ambtenaar onrechtmatig handelt, dit handelen niet geschiedt op naam van de overheid en de ambtenaar dus a.h.w. 'privaatrechtelijk' handelt. Een vergelijkbare opvatting ligt ten grondslag aan Par. 839 van het Duitse Bürgerliche Gesetzbuch. Voor zo'n burgerlijke vordering was in Frankrijk ingevolge art. 75 van de Grondwet van het jaar VII aanvankelijk voorafgaande autorisatie đoor de Conseil d'État nodig.

10. Cour du Cassation van 19 dec. 1854 (Administration des postes), geciteerd door Korthals Altes, a.w., p. $12 / 13$.

11. Tribunal des Conflits 8 febr. 1873, D. 1873.3.17 (Blanco).

12. Conseil d'Etat 14 jan. 1938, opgenomen in M. Long, P. Weil en G. Braiband, 'Les grands arrêts de la jurisprudence administrative', 8 e druk, 1984, nr. 59. Het Leffersarrest (HR 18 jan. 1991, AB 1991, 241, NJ 1991, 638, tB/S rubr. Burg, r., nr. 1) vertoont met dit Franse arrest grote overeenstemming, met dit verschil dat het in het Leffersarrest gaat om (mogelijke) onevenredige schade veroorzaakt door de uitvaardiging en toepassing van een wet in materiēle zin, niet tevens zijnde een wet in formele zin.

13. Strikt genomen geldt in Frankrijk ook thans nog de onschendbaarheid van de wet in formele zin. 'In strikte zin', want volgens de Grondwet van 1958 (die ten grondslag ligt aan de Vijfde Republiek) worden organieke wetten vóor hun afkondiging op hun grondwettigheid getoetst door de Conseil Constitutionel. Andere wetten kunnen met het oog op een dergelijke toetsing aan de Conseil Constitutionel worden voorgelegd door de president, de eerste minister, een van beide kamervoorzitters of (minimaal) zestig leden van de Assemblée of Senaat (art. 61 Grondwet). Een ongrondwettig verklaarde wet of wetsbepaling mag niet worden afgekondigd (art. 62 le al, Grondwet). Ten tijde van het arrest 'La Fleurette' uit 1938 was $66 \mathrm{k}$ voorafgaande toetsing van parlementaire wetten nog ondenkbaar (onschendbaarheid van de 'volonté général'!). Maar wat thans getoetst wordt door de Conseil Constitutionel, is nog geen wet.

14. Het komt ons voor dat de in HR 14 april 1989. NJ 1989, 469 (Harmonisatiewet-arrest) verwoorde opvatting correspondeert met die van de Conseil d'Etat, zoals die - zij het meer impliciet - naar voren komt in het arrest 'La Fleurette'. De Hoge Raad overwoog in dit arrest, dat de rechtspraak is gaan aanvaarden dat strikte toepassing van de wet onder omstandigheden zozeer kan indruisen tegen fundamentele rechtsbeginselen dat zij achterwege moet blijven. Hierbij zou een 'wezenlijk verschil' bestaan tussen: 
'enerzijds: het in bepaalde (groepen van) gevallen buiten toepassing laten van een wetsbepaling in verband met daarin niet verdisconteerde omstandigheden (in de regel: de wijze waarop de overheid is opgetreden) in strijd zou komen met een fundamenteel rechtsbeginsel, en anderzijds: het wegens zulk een strijd buiten toepassing laten van een wetsbepaling op grond van omstandigheden welke bij haar totstandkoming in de afweging zijn betrokken, dus in gevallen waarvoor zij nu juist is geschreven. Het eerste raakt niet aan de verbindende kracht van de betrokken bepaling en staat de rechter ingevolge voormelde jurisprudentie vrij; het tweede ontneemt echter aan die bepaling haar verbindende kracht en is de rechter ingevolge art. 120 Grondwet verboden' (curs. dzz.; JT). En het égalitébeginsel is - zo merken wij op - zo'n fundamenteel rechtsbeginsel.

15. Teissier, 'De la Responsabilité de la Puissance publique', nos. 52 en 147, Paris 1909.

16. Vgl. bijv. R. Jacquelin, 'Le droit social et la réparation des dommages en régions envahies', Paris 1917; L. Michoud, 'La théorie de la personnalité morale', dl. II, Paris 1909, pp. 260 e.v.

17. Zie over de ontwikkeling van de 'principes généraux du droit': R.M. van Male, 'Rechter en bestuurswetgeving', diss. Tilburg, Zwolle 1988, pp. 115 e.v. De Conseil Constitutionnel heeft in grote lijnen de methode van toetsing aan het 'principe d'égalité' door de Conseil d'État overgenomen. $V_{g i}$. M. de Villiers, 'Le principe d'égalité dans la jurisprudence du Conseil Constitutionnel', Revue Administrative 1984, p. 39.

18. Paul Duez, 'La Responsabilite de la Puissance Public (en dehors du contrat)', Paris 1927, p. 60-61.

19. Gaston Jèze, 'Les principes généraux du droit administratif. dl. III, 3e druk, Paris 1925, p. 161.

20. R. Kranenburg. 'De grondslagen der rechtswetenschap', Se druk, Haarlem 1955, p. 80.

21. De opvattingen van Kranenburg zijn op dit punt dus genuanceerder dan die van zijn leermeester Krabbe, die van mening was dat het 'gemene recht' (= burgerlijk recht) waaraan de overheid is onderworpen. hetzelfde is als wat tussen particulieren geldt, met dien verstande dat het bestuursrecht aan de overheid aanvullende, bijzondere bevoegdheden zou verschaffen.

22. F. Fleiner, 'Über die Umbildung zivilrechtlicher Institute durch das öffentliche Recht', Tübingen 1906 , p. 5 .

23. Zie het uitvoerige jurisprudentie-overzicht door C.W. de Vries in Themis 1917, pp. 337-361.

24. 'Civiel' c.q. 'burgerlijk' werd oudtijds gebruikt als tegenstelling tot 'crimineel' c.q. 'lijfstraffelijk'. Het begrip 'civiel' overlapte toen het begrip 'politie' (de bestuurstaak), nl. voorzover het ging om de vermogensrechtelijke aspecten van de 'politie'. Dit vermogensrechtelijke deel van de 'politie' werd aangeduid met 'fiscus'. Zie hierover de uiteenzettingen in hoofdstuk 2.

25. J. Drion, 'Administratie contra rechter tot de intrekking van het Conflictenbesluit', diss. Leiden 1950.

26. Poortinga, a.w., p. 89.

27. Van der Hoeven, 'De drie dimensies', a.w., p. 143/144.

28. HR 29 mei 1896, W. 6817, Gst. 2338, WBA 2460 (Vrouwe Elske).

29. HR 21 april 1898, W. 7116, Gst. 2436, WBA 2559 (Rhedense koe).

30. HR 22 mei en 26 juni 1863, W. 2499 (Zuidplaspolder).

31. HR 21 april 1898, W. 7116, Gst. 2436, WBA 2559 (Rhedense koe).

32. HR 10 mei 1901, W. 7606 (Pothuisarrest).

33. HR 20 nov. 1924, NJ 1925, p. 89, W. 11293, Gst. 3835 (Ostermann I).

34. HR 31 dec. 1915, W. 9947, NJ 1916, p. 406; AB-klassiek, le druk, nr. 3, m.nt. J.B.J.M. Ten Berge.

35. Zie bijv. HR 10 april 1987, AB 1987, 326, NJ 1988, 148, m.nt. W.H. Heemskerk (GCN-Nieuwegein 1), waarin wordt overwogen dat 'nu GCN aan haar vordering een verbintenis tot schadevergoeding en derhalve een schuldvordering ... ten grondslag (heeft) gelegd, ... daarmede de bevoegdheid van de burgerlijke rechter op grond van art. 2 Wet RO (is) gegeven. Hieraan doet niet af dat het gaat om schadevergoeding wegens niet-nakoming van een gemeenschappelijke regeling die het hof terecht heeft gekarakteriseerd als een publiekrechtelijke overeenkomst'.

In het kader van de ontvankelijkheidstoetsing - waarbij het criterium is of een met voldoende waarborgen omklede administratieve rechtsgang openstaat - speelt de vraag naar het karakter van het overheidsoptreden wél een rol, $\mathrm{nl}$. indien de toegang tot die administratieve rechtsgang afhankelijk is 
van het publiekrechtelijke karakter van een rechtshandeling van de overheid (vgl. art. 8:1 lid 1 jo. art. 1:3 Awb).

Een afwijkend oordeel inzake de bevoegdheidsgrondslag van de gewone rechter is overigens ingenomen door P. Zonderland, 'Het kort geding, in het bijzonder tegen de overheid', diss. Leiden 1954, 2e druk, Zwolle 1992. Zonderland ziet in art. 1 Wet RO een opdracht aan de gewone rechter van alle rechtsmacht, bij andere wettelijke bepalingen niet aan anderen opgedragen. Zie bijv. HR 24 maart 1865 . W. 2681, waarbij de bevoegdheid van de gewone rechter kennis te nemen van een actie tot terugvordering van (beweerdelijk onverschuldigd betaalde) belastingen $0 . \mathrm{m}$. werd gebaseerd op art. 1 Wet RO.

36. Dit standpunt werd reeds ingenomen onder de werking van de Grondwet van 1815 en zijn art. 165 , vóordat dit in 1848 werd gewijzigd. Dat de rechterlijke macht reeds in het tijdperk na de totstandkoming van de Grondwet van 1815 haar bevoegdheid ruim opvatte, blijktuit de jurisprudentie gepubliceerd door C.W. de Vries, t.a.p. Na 1848 werd de bevoegdheid gebaseerd op het ongewijzigd gebleven art. 2 Wet RO, zij het dat de bevoegdheid een aantal malen ook wel (mede) is gegrond op art. 1 Wet RO.

37. Zie hierover uitgebreid: Poortinga, a.w., hfdst. VIII (pp. 253-291). Poortinga, a.w., p. 288/289. vermeldt een in 1860 door Thorbecke gehouden pleidooi om de beslissing van geschillen van bestuur "af te zonderen van het dagelijksch of actief bestuur, le omdat de eerste de natuurlijke taak is van een collegie, zooals het laatste die van een individu, $2 e$ opdat niet de bestuurder, bij geschil over zijne handeling, zelf als regter beslisse; of zijne eigene bestissing formere'. Zie we het goed, dan correspondeert dit in sterke mate met de voorstellen die in Pruisen zouden worden geformuleerd door Von Gneist. welke voorstellen zouden leiden tot een stelsel dat we thans een tussen- of mengvorm van administratief beroep en administratieve rechtspraak zouden noemen. Dit stelsel zou in de loop van de tijd zou uitgroeien tot een volwaardig systeem van administratieve rechtspraak. Waar F.A.M. Stroink, 'Rechterlijke organisatie en rechtspraak in beweging', Zwolle 1993, p. 56, schrijft dat Thorbecke 'niets (moest) hebben van wat wij tegenwoordig administratieve rechtspraak noemen', is dit dan ook o.i. niet gelukkig geformuleerd. Hij moest niets hebben van burgerlijke rechtspraakt.a.v. overheidshandelingen.

38. Van der Hoeven, 'De drie dimensies', a.w., p. 155/156. Zie ook pp. 144 en 154:

'Criteria ontleend aan de rechtsverhouding tussen burgers onderling moesten worden geadapteerd aan de rechtsverhouding tussen administratie en burger, een relatie die deels geheel andere aspecten heeft.' In dezelfde zin P. de Haan/Th.G. Drupsteen/R. Fernhout, 'Bestuursrecht in de sociale rechtsstaat', 3e druk, Deventer 1986, deel 1, p. 4:

'Een gevolg van het ontbreken van een algemene administratieve rechtspraak is, dat het bestuursoptreden zich in Nederland op sommige punten niet los heeft kunnen maken van het privaatrecht. De jurisprudentie van de Hoge Raad rond onderwerpen als de overheidseigendom en de overheidsovereenkomst gaat uit van de opvatting van het privaatrecht als het gemene recht. Het privaatrecht geldt niet alleen in de verhoudingen tussen burgers maar ook in de verhouding tussen overheid en burgers, tenzij het publiekrecht daaraan derogeert. Deze leer werkt gunstig met het oog op de bevoegdheid van de gewone rechter om kennis te nemen van geschillen over overheidsoptreden in de vorm van een contract of op basis van eigendom. Ze biedt echter onvoldoende mogelijkheden om rekening te houden met de bijzondere positie van de overheid.'

39. E.M.H. Hirsch Ballin, 'Het grondrecht op behoorlijke rechtspraak in het Nederlandse administratieve recht', HNJV 1983-I, 2e stuk, p. 43/44.

40. HR 26 juni 1964, NJ 1965, 2 (Willemse-arrest).

41. Noot J.B.J.M. ten Berge bij HR 25 nov. 1977 (Loosdrechtse Plassenschap) in: F.H. van der Burg e.a.(red.), 'AB klassiek', 1e druk, Zwolle 1991, nr. 11, p. 100/101.

42. Zie over de totstandkomingsgeschiedenis van art. 2 R.O., i.v.m. art. 165 Grondwet 1815 , en de eerste jurisprudentie inzake deze bepalingen: De Vries, t.a.p., J. Drion, a.w.

43. Interventie VAR-vergadering 1989 over 'Overheidsaansprakelijkheid, administratieve en burgerlijke rechter’, VAR-reeks 103, Alphen a/d Rijn 1990, pp. 12-16. 
44. W.L.P.A. Molengraaff, 'De 'oneerlijke concurrentie' voor het forum van den Nederlandschen rechter, tevens een bijdrage tot de uitlegging van art. 1401 BW en van de wet op de handels- en fabrieksmerken', RM 1887, p. 386. Zoals bekend, heeft dit artikel een wezenlijke invloed uitgeoefend op het totstandkomen van de bekende jurisprudentie van de Hoge Raad inzake de zorgvuldigheidsnorm sinds 1919.

45. P. Scholten, 'Molengraaf en de onrechtmatige daad', RM 1931, p. 399, ook opgenomen in 'Verzamelde geschriften van Paul Scholten', dl. IV, Zwolle 1951, p. 207 e.v. (p. 211).

46. H. Dooyeweerd, 'De Wijsbegeerte der Wetsidee', dl. III, a.w., p. 620.

47. E.M. Meijers, 'De onrechtmatige overheidsdaad', dl. II, WPNR 1925, 2884, p. 241-244.

48. HR 29 juni 1928, NJ 1928, p. 1138 (Strooppot-arrest), en HR 5 mei 1933, NJ 1933, p. 875 (Meerboeiarrest), beide met noot van Meijers. Zijn noot bij het eerste arrest wordt besloten met de opmerking: 'Een administratieve rechtspraak, die eigen administratief recht kan toepassen en vormen, blijt nog steeds een eisch van goede rechtsbedeeling.'

49. In het Meerboei-arrest wordt, anders dan in het Strooppot-arrest, overheidsaansprakelijkheid wegens maatschappelijke onzorgvuldigheid aangenomen, omdat de overheid hier zou hebben deelgenomen aan het maatschappelijk verkeer 'op gelijken voet als een bijzonder persoon'. In de casus van het Strooppotarrest zou de overheid echter hebben opgetreden 'als zoodanig'. N.a.v. HR 20 dec. 1940, NJ 1941, 365 (Stamboekvaarzen-arrest), is door sommigen betoogd - o.a. in de Gemeentestem, nr, 4659 - dat de Hoge Raad hier de maatschappelijke zorgvuldigheidseis zou hebben gesteld, in een situatie waarin de overheid niet op de voet van 'bijzonder persoon' was opgetreden. Zie echter de noot van Meijers onder dit arrest in de NJ, waarin door hem wordt beklemtoond dat het i.c. aantasting van eigendom betreft (schending van een subjectief recht dus), hetgeen de overheid niet vrijstaat, zolang geen bijzonder rechtsvoorschrift haar dit veroorlooft.

50. Zij het dat de Hoge Raad nooiv sxpliciet yav het in het Strooppot-ansest sa het. Mestoei-ancest gemaakte onderscheid is afgestapt.

51. HR 19 maart 1943, NJ 1943, 312 (zesde Voorste Stroom-arrest).

52. HR 18 febr. 1944, NJ 1944/45, 226 (Jochemsarrest, ook bekend als het Duinwaterleidingsarrest en als het wateronttrekkingsarrest).

53. Wèl merken wij op dat de vraag naar de publiekrechtelijke bevoegdheidsgrondslag in deze jurisprudentie helaas niet aan de orde is gekomen. Voor ingrepen in de private eigendom is immers steeds een uitdrukkelijke bevoegdheidsgrondslag in de wet nodig.

54. R. Kranenburg, 'De ontwikkeling der rechtspraak betreffende de staatsaansprakelijkheid', in: 'Studiën over Recht en Staat', 3e druk, Haarlem 1946, pp. 190-225 (p. 222/223).

55. H. Dooyeweerd, 'Over de methode van begripsvorming in de rechtswetenschap', Een nadere critische beschouwing van Prof. Mr. R. Kranenburg's De Grondslagen der Rechtswetenschap, Juridische Kennisleer en Methodologie (4e druk, Haarlem 1952), RMTh 1953, pp. 298-339 (pp. 306 en 310). Dooyeweerd kritiseert hier o.a. de in Kranenburgs boek verdedigde 'eenvormige opvatting van het evenredigheidsprincipe als 'wet van het rechtsbewustzijn", welk principe door Kranenburg omschreven wordt met de formule 'zoveel lust en onlust als waarvoor hij de voorwaarden heeft geschapen, komen aan hem (nl. de rechtsgenoot) toe'. Kranenburg gooit aldus het publiekrechtelijke evenredigheidsbeginsel (de iustitia distributiva) en het burgerrechtelijke evenredigheidsbeginsel (de iustitia commutativa) op één hoop, hetgeen o.i. merkwaardig is omdat hij blijkens zijn kritiek op zesde Voorste Stroomarrest toch wel oog had voor de typische eigengeaardheid van de publiekrechtelijke evenredigheid.

Dooyeweerd wijst er op 'dat het juridisch evenredigheidsprincipe, dat op zich zelve nog een abstract. zgn. 'puur modaal' karakter draagt, voor de verschillende rechtssferen zeer verschillende typisering aanneemt, bv. in het publiek recht een andere dan in het burgerlijk privaatrecht. Aristoteles' onderscheiding tussen verdelende en ruilgerechtigheid met haar verschillende evenredigheidsmaatstaf geeft van dieper inzicht blijk dan Kranenburg's uniforme conceptie', die 'toch moeilijk rekenschap geven (kan) van bv. het publiekrechtelijk beginsel: 'belasting naar draagkracht' of van het publiekrechtelijk evenredigheidsprincipe'. 
56. H.Th.J.F. van Maarseveen, 'Een opmerking over de onrechtmatige overheidsdaad', NJB 1954, pp. 914 920.

57. J. Drion, 'Een nieuwe koers in 's hogen raads jurisprudentie over de onrechtmatige daad', WPNR 1947 , nrs. 3992-3996.

58. M.H. Bregstein, 'De arresten van de hoge raad van 19 maart 1943 en 18 februari 1944 en het leerstuk van de onrechtmatige daad', RMTh 1951, p. 273.

59. R.J. Polak, 'Aanspraak en aansprakelijkheid uit onrechtmatige daad', p. 95, en P.A.N. Houwing in zijn noot onder HR 19 dec. 1952, NJ 1953, 642.

60. W.C.D. Olivier, 'Proeve over de beperkingen van den eigendom door het politie-regt', diss. Leiden 1847, p. 216.

61. Olivier, a.w., p, 13/14.

62. Van Maarseveen, t.a.p.

63. Zie bijv. Asser-Hartkamp, 'Handleiding tot de beoefening van het Nederlands burgerlijk recht, Verbintenissenrecht. Deel III. De verbintenis uit de wet', 8e druk, Zwolle 1990, nr. 18a-d.

64. Vgl. G.E. van Maanen, 'Onrechtmatige Daad. Aspecten van de ontwikkeling van een omstreden leerstuk', diss. Groningen 1986, Deventer 1986, die stelt dat van een in de zin van art. 1401 resp. 6:162 BW onrechtmatige wetsovertreding resp. inbreuk op een subjectief recht pas kan worden gesproken indien de gedraging maatschappelijk onzorgvuldig is. De vormen 'inbreuk op een recht' en 'strijd met een wettelijk voorschrift' hebben - aldus Van Maanen - een heuristische, bij het recht zoekende helpende, functic en op zichzelf geen legitimerende functie. Voor art. 6:162 BW acht hij de volgende omschrijving (p. 229) dan ook beter dan die welke is gekozen door de wetgever: 'Als onrechtmatige daad wordt aangemerkt een doen of nalaten in strijd met hetgeen volgens geschreven en ongeschreven recht in het maatschappelijk verkeer betaamt'.(Het inbreuk-criterium is in deze omschrijving weggelaten, omdat het in de eerste plaats ziet op het gevolg van bepaald onzorgvuldig gedrag. In de wettelijke omschrijving is dit criterium - dat als gezegd verwijst naar het gevolg van gedrag - geplaatst naast twee vormen van - geschreven en ongeschreven - onrechtmatig gedrag). In vergelijkbare zin Van Eikema Hommes, 'De elementaire grondbegrippen', a.w., p. 312/313, die de 'formalistische opvatting der onrechtmatigheid' kritiseert en betoogt dat slechts een materieel onrechtmatigheidsbegrip aanvaardbaar is, dat eist dat er sprake is van aantasting van een privaat rechtsbelang van een ander in strijd met de dit rechtsbelang beschermende rechtsnorm, t.w. een (geschreven of ongeschreven) maatschappelijke zorgvuldigheidsnorm.

65. En daarnaast óók de 'égalité d'accès de tous aux emplois publics' en de 'égalité devant les services publiques'. Zie voor een bespreking van de Franse jurisprudentie inzake de beginselen: C.A.J.M. Kortman, "'Égalité" en 'défense"', diss. Nijmegen 1971, Alphen a/d Rijn 1971, m.n. pp. 16-37. Interessant in dit verband is ook de jurisprudentie van het Duitse Bundesverfassungsgericht inzake het 'Verhăltnismässigkeitsprinzip', dat in de constitutie besloten wordt geacht. Zie o.a. Jürgen Schwarze, 'Europāisches Verwaltungsrecht', Bd. II, Baden-Baden 1988, pp. 669-674.

66. HR 18 jan. 1991, AB 1991, 241, NJ 1991, 638, tB/S 1991, rubriek Burg. r. nr. 1 (Leffers-arrest, ook bekend als Swill-arrest en als Varkensmesters-arrest). In zijn naschrift in $\mathrm{B} / \mathrm{S}$ maakt A.Q.C. Tak terecht ook dit onderscheid tussen absolute en relatieve onrechtmatigheid. Overigens is in casu relatieve onrechtmatigheid jegens Leffers niet aanwezig geacht.

67. Dat immers eist dat bepaalde burgers niet, in verhouding tot alle anderen, onevenredig worden getroffen.

68. HR 24 jan. 1969, NJ 1969, 316, AB 1969, p. 194, AA 1969, p. 266 (Pocketbooks-II) biedt een voorbeeld van absolute onrechtmatigheid die resulteerde in aansprakelijkheid ex art. 1401 (oud) BW. Overwogen werd dat de Staat onrechtmatig had gehandeld door bij de Vestigingsbeschikking boekverkopersbedrijf 1958 een verbod te stellen op een handeling die ingevolge de norm van art. 7 Grondwet niet mag worden verboden. We kunnen dit aanmerken als 'absolute onrechtmatigheid'. Dit leidde in casu tot aansprakelijkheid in de zin art. 1401 BW, omdat de procederende boekverkopers (Van Tuyl en De Bron) ten gevolge van de uitvaardiging en uitvoering van die ministeriêle regeling emstige schade en verliezen hadden geleden. We zouden kunnen zeggen dat hier, ten opzichte van deze boekverkopers, 
de overtreding van de norm (art. 7 Grondwet) die mede strekte ter bescherming van hun rechtsbelangen, een schending van het égalitébeginsel opleverde.

Omgekeerd kan, zoals we zagen, een overheidsdaad die in absolute zin niet onrechtmatig is, leiden tot relatieve onrechtmatigheid en tot aansprakelijkheid ex art. 6:162 BW. Een voorbeeld is de 'Swillregeling', die aan de orde is in het Leffers-arrest. 'Relatieve onrechtmatigheid' impliceert dat een - in absolute zin niet onrechtmatige - daad jegens één of meer bepaalde personen wél onrechtmatig is. Daarmee is ook de relativiteit in de zin van art. 6:163 BW gegeven. Dit algemene relativiteitsvereiste speelt echter - zoals we zagen -een aparte rol, waar absolute onrechtmatigheid in het geding is.

69. HR 19 dec. 1975, NJ 1976, 280 (Rijksweg 12-arrest).

70. HR 22 okt. 1993, AB 1994, 1 (Staat/Magnus-arrest).

71. Bloembergen verdraait dus de jurisprudentie, wanneer hij stelt dat 'moeilijk (valt) in te zien waarom et na vijftig jaar opeens belangen zouden moeten zijn die niet door art. 1401 worden beschermd'. In de desbetreffende jurisprudentie ging het steeds om bescherming van private rechtsbelangen.

72. HR 26 jan. 1990, Gst. 6914.10, AB 1990, 408 (Windmill/Staat).

73. HR 9 nov. 1973, NJ 1974, 91 (Limmen/Houtkoop).

74. A.R. Bloembergen, bespreking van Asser-Harkamp, 'Verbintenissenrecht', dl. III, 7e druk, Zwolle 1986, NJB 1987, pp. 631-633; J.H. Nieuwenhuis, 'Welke belangen worden beschermd door art. 1401 BW?', WPNR 1987, 5821, pp. 145 e.v.

75. N. Frenk, 'Kollektieve akties in het privaatrecht', diss. Utrecht 1994, p. 67-69.

76. In HR 28 juni 1985, NJ 1986, 356, BR 1986, p. 121 (Claas-Van Tongeren) wordt overwogen dat zo'n planologisch gebruiksvoorschrift wèl 'mede strekt ter bescherming van de belangen van belanghebbenden' (omwonenden) en is - indien de onrechtmatigheid eenmaal vaststaat - een door die omwonenden gevraagd verbod in een bodemprocedure in beginsel zonder meer toewijsbaar. Overigens kan men zich afvragen of de geciteerde overweging wel zo gelukkig is: het betrokken voorschrift strekte ter bescherming van een publiek belang; dat daardoor ók private rechtsbelangen (van omwonenden) worden beschermd, is daarvan een reflex.

77. HR 26 jan. 1990, Gst. 6914.10, AB 1990, 408 (Windmill).

78. HR 9 febr. 1990, NJ 1991, 462, AB 1990, 409 (Staat/Van Amersfoort).

79. HR 14 april 1989, AB 1989, 486, NJ 1990, 712 (Benckiser/Staat).

80. HR 22 okt. 1993, AB 1994, 1 (Staat/Magnus).

81. HR 18 febr. 1994, AB 1994, 415 (Staat/Kabayel).

82. HR 7 okt. 1994, AB 1995, 47 (Nieuwveen/Van Schaik).

83. HR 8 juli 1991, AB 1991, 659, NJ 1991, 691 (Kunst- en antiekstudio/Lelystad).

84. HR 22 okt. 1993, AB 1994, 1 (Staat/Magnus).

85. H.J. Simon, A.Q.C. Tak, 'Het BW als 'zwart gat'. NTBR 1994/8, pp. 173-180; H.J. Simon, 'Publiekrecht en burgerlijk recht', WPNR 1994, 6156, pp. 753-764; A.Q.C. Tak, J.M.H.F. Teunissen, 'Wie zorgt er voor de rechtsstaat. Een voortgezet debat', Recht en Kritiek 1994, pp. 340-354.

Verwonderd vragen we ons af, hoe het mogelijk is dat veel auteurs, waar het gaat om overheidsoptreden waarop het etiket 'publiekrechtelijk' is geplakt, strenge wetspositivisten blijken te zijn, maar wél uitgaan van een volledige privaatrechtelijke handelingsbekwaamheid voor 'de overheid', implicerende o.a. de 'bevoegdheid' om onrechtmatige-daadsacties ter behartiging van publieke belangen te voeren, dus zonder enige specifieke wettelijke grondslag. Zie bijv. P.J.J. van Buuren en F.C.M.A. Michiels, 'Bestuursdwang', Zwolle 1989, p. 19: 'Een zo ingrijpende wijze van overheidsoptreden als bestuursdwang behoor in een rechtsstaat op een uitdrukkelijke wettelijke grondslag te berusten'. Zie daartegenover: P.J.J. van Buuren, 'Twee-wegenleer is niet van de baan', NJB 1991, p. 1501-1503, en F.C.M.A. Michiels in NTB 1991, p. 97.

86. HR 30 sept. 1994, BR 1995, p. 42 (Staat/Shell).

87. H.D. van Wijk, 'Hoofdstukken van administratief recht', 2e druk, Den Haag 1972, p. 7. 
88. H.J. van Eikema Hommes, 'Hoofdlijnen der rechtssociologie en de materiele indelingen van publieken privaatrecht', Zwolle 1975, p. 65/66, merkt n.a.v. de geciteerde uitlating van Van Wijk op dat daarmee de typische geaardheidsverschillen tussen administratief recht en burgerlijk recht worden miskend.

89. HR 30 sept. 1994, BR 1995, p. 42, (Shell/Staat), onder 3.8.4.

90. HR 30 sept. 1994 (Shell/Staat) onder 3.6.2.

91. HR 30 sept. 1994 (Shell/Staat) onder 3.6.2.

92. HR 24 april 1992, NJ 1993, 643 (Staat/Van Wijngaarden).

93. HR 18 febr. 1994, AB 1994, 415 (Staat/Kabayel c.s.).

94. HR 30 sept. 1994, RvdW 1994, 188c (Staat/Van den Brink).

95. Hofman-Drion-Wiersma, 'Het Nederlands verbintenissenrecht', Tweede Gedeelte, Groningen 1959, p. 89 e.v.

96. Noot E. Bauw bij HR 30 sept. 1994 (Shell/Staat) in BR 1995, pp. $42-53$ (p. 51).

97. Bauw, t.a.p., p. 51 .

98. HR 24 april 1992, NJ 1993, 643 (Staat/Van Wijngaarden).

99. HR 13 jan. 1879, W. 4330 (Meerenberg).

100. BVerG 31 okt. 1984, E. 68, nr. 6. De clausule 'in aller Regel' is waarschijnlijk toegevoegd met het oog op die publiekrechtelijke rechtspersonen die als zelfstandige, van de Staat onafhankelijke instellingen 'unmittelbar einem durch bestimmte Grundrechte geschüzten Lebensbereich zugeordnet sind', m.n. de universiteiten (wetenschaps- en onderzoeksvrijheid) en openbare omroepinstellingen (omroepvrijheid, onderdeel van de vrijheid van meningsuiting). Die onafhankelijkheid jegens de Staat is nodig voor de realisering van die grondrechten en impliceen dat de taakuitoefening door deze instellingen niet (volledig) gestuurd mag worden door de Staat.

101. H. Maurer, 'Allgemeines Verwaltungsrecht', 9e drk, München 1994, p. 709 e.v. Wèl erkent Maurer dat er met name in noodsituaties sprake kan zijn van een 'öffentlich-rechtliche Geschäftsfühnung ohne Auftrag', een figuur die ook door het Bundesverfassungsgericht en het Bundesverwaltungsgericht is erkend. De bevoegdheidsgrondslag zal in het (ongeschreven) publiekrecht moeten kunnen worden gevonden, niet in het Bürgerliches Gesetzbuch. Wordt een dergelijk grondslag aangenomen, dan kunnen ook in het BGB inzake de burgerrechtelijke zaakwaameming neergelegde regels analogisch worden toegepast. Maurer kritiseert de jurisprudentie van het Bundesgerichtshof, waarin is aanvaard dat onder omstandigheden de overheid op basis van de BGB-bepalingen betreffende burgerrechtelijke zaakwaarneming kan komen tot een verhaal van kosten gemaakt bij de behartiging van aan haar toevertrouwde publieke belangen. Het BGH neemt nl. aan dat er óók van GoA sprake kan zijn wanneer de zaakwaarnemer bij de behartiging van eigen belangen tegelijkertijd de belangen van een ander behartigt, en trekt daaruit de conclusie dat ook de overheid publieke belangen en tegelijkertijd de belangen van een burger kan behartigen. Maurer schrijft: 'Dass der BGH in diesen Fallen keine öffentiich-rechtliche, sondern eine privatrechtliche GoA annimmt, mindert die Bedenken nicht, sondern zeigt die Fragwürdigkeit der Konstruktion besonders deutlich. Ein und dieselbe Tätigkeit einer Behörde wird danach nicht nur als gesetzlich gebotene Erfüllung einer hoheitlichen Aufgabe des eigen Zustăndigkeitsbereich und als freiwillige Wahrnehmung von fremden Geschäften eines Bürgers qualifiziert, sondern auch dem ôffentlichen Recht und dem Privatrecht zugeordnet'.

De vraag of 'de overheid' de bij de uitoefening van een haar opgedragen publieke taak gemaakte kosten langs burgerrechtelijke weg mag verhalen, kwam aan de orde in de casus die leidde tot het Brandweerkostenarrest (HR 11 dec. 1992, AB 1993, 301). De Hoge Raad volstond met de conclusie dat, 'nu verhaal langs publiekrechtelijke weg is uitgesloten op voormelde aan het openbaar belang ontleende gronden, .... kostenverhaal langs privaatrechtelijke weg zou neerkomen opeen onaanvaardbare doorkruising van deze publiekrechtelijke regeling'. De vraag of ubberhaupt een beroep kan worden gedaan op zaakwaarneming ex art. 6:198 BW en, zo ja, of voldaan is aan het door deze bepaling gestelde criterium dat 'eens anders belang' is waargenomen (náást het aan 'de overheid' toevertrouwde publieke belang), kon de Hoge Raad daarmee laten liggen. O.i. kan, waar sprake is van publieke 
taakvervulling door 'de overheid', van burgerrechtelijke zaakwaameming per definitie geen sprake. Aldus ook G. Verburg. 'De vrijwillige zaakwaarneming', diss. Amsterdam 1949, i.h.b. pp. 182-185.

102. Nog de natuurrecht- en politiestaat-filosoof Christiaan Wolff (1679-1704) aanvaardde de patrimoniële staatsvorm, waarin de overheidsmacht als privaat bezit aan de vorst toekwam. Hij construeerde een 'ius eminens', een 'oppereigendom' van de vorst om al datgenen te doen wat in het algemeen belang nodig werd geacht alsmede een stelsel van 'natuurlijke verplichtingen', waarbij een subjectief recht slechts werd beschouwd als 'Freiheit zur Pflichterfullung'.

103. Zie 0.a. BVerfG 8 juli 1982, E 61, nr. 10.

104. HR 24 april 1992, NJ 1993, 643 (Staat/Van Wijngaarden).

105. In het arrest-Staat/Van Wijngaarden ging het immers om eigen terrein van Van Wijngaarden.

106. HR 22 okt. 1993, AB 1994, 1 (Staat/Magnus).

107. Vgl. HR 30 sept. 1994, NJB 1994, RvdW 1994, 188c (Staat/Van den Brink).

108. TK 1991-1992, 22.486, nr. 3, p. 33. De artt. 3:305a en 3:305b BW worden hierna nog besproken.

109. HR 9 febr. 1990, NJ 1991, 462, AB 1990, 409 (Staat/Van Amersfoort).

110. HR 29 april 1910, W. 9027 (Mark en Dintel).

111. HR 18 febr. 1994, AB 1994, 415 (Kabayel c.s.).

112. HR 22 okt. 1993, AB 1994, I (Staat/Magnus).

113. HR 7 okt. 1994, AB 1995, 47 (Nieuwveen/Van Schaik).

114. De artikelen 3:305a en 3:305b BW worden hiema nog uitvoerig besproken.

115. HR 26 jan. 1990, Gst. 6914.10, AB 1990, 408 (Windmill/Staat).

116. 'Rapport van de commissie, ingesteld door den stedebouwkundigen Raad van het Nederlandsch Instituut voor Volkshuisvesting en Stedebouw, tot onderzoek van de vraag, of en in hoeverre privaatrechtelijke regeling van bebouwing geoorloofd moet worden geacht', afgedrukt in 'Gemeentebestuur' van augustus 1934, pp. 351-378.

117. Afgedrukt in Tijdschrift voor Volkshuisvesting 1932, p. 60, en S\&J-editie Woningwet 1901, 6e druk 1957, p. 362.

118. De opvatting van de Kroon correspondeerde met die van Vos en van Lietaert Peerbolte. Vgl. H. Vos, 'Overheidsrecht krachtens overeenkomst', WGB 1933, p. 97 e.v., ook opgenomen in: dez., 'Uit de geschriften van mr. H. Vos', Alphen a/d Rijn 1933, pp. 84-87. Vgl. L. Lietaert Peerbolte, 'De Woningwet', Alphen a/d Rijn 1932, p. 50: 'Nu de Woningwet aangeeft hoe de bestemming van gronden geregeld moet worden, en hoe bepaald moet worden, aan welke eischen bij het bouwen moet worden voldaan, zijn dergelijke overeenkomsten naar mijne meening in strijd met de wet. De wet verbiedt haar niet ipsis verbis, maar een uitdrukkelijk verbod is voor strijd met de wet niet noodig'. Vgl. ook p. 199. waar wordt gesproken van 'de helaas veld winnende praktijk bij privaatrechtelijke overeenkomst te regelen, wat in wezen publiekrechtelijk is', van 'do-ut-des-gedoe' en van 'een spel van macht en handigheid'. Lietaert Peerbolte was destijds Directeur-Generaal der Volksgezondheid.

119. Rapport, t.a.p., p. $366 / 367$ (curs. door commissie). Voor nadere uiteenzetting en verdediging van dit standpunt verwijst de commissie hier naar F.J.A. Huart, 'Misbruik van burgerlijk recht door de administratie', in: Staatrechtelijke opstellen aangeboden aan Krabbe, dl. II, p. 181 e.v., en F.G. Scheltema, 'De Zaken der openbare lichamen', in: Nederlandsch Bestuursrecht', Alphen a/d Rijn 1933, p. 115 e.v.

120. HR 8 juli 1991, AB 1991, 659, NJ 1991, 691 (Kunst- en antiekstudio/Lelystad).

121. Zoals bekend, is de Woningwet 1901 - die ook de grondslag bood voor gemeentelijke maatregelen op het terrein van de ruimtelijke ordening - per 1 augustus 1965 vervangen door de Woningwet 1962 - alleen regelende de volkshuisvesting-sec - en de Wet Ruimtelijke Ordening - waarin de ruimtelijke ordening werd ondergebracht -.

122. Rapport, t.a.p., p. $367 / 368$. Wel was de commissie van oordeel dat, voorzover in bepaalde gevallen van bijzondere aard de behoefte zich zou doen gevoelen uit te gaan boven de voorschriften die ingevolge de Woningwet konden worden gesteld, de gemeente zou mogen trachten 'dit meerdere' langs privaatrechtelijke weg vastgelegd te krijgen, zij het dat de gemeente haar tegenpartij niet krachtens haar publiekrechtelijke bevoegdheid zou mogen dwingen tot zo'n privaatrechtelijke regeling. Dat zou volgens de commissie neerkomen op détournement de pouvoir. 
123. Rapport, t.a.p.. p. 374/375 (Minderheidsnota). Hun conclusie was 'dat de Woningwet niet bedoelt, de privaatrechtelijke bevoegdheden der gemeente als eigenares te elimineeren; is deze eigenares, dan zal zij - naast de bevoegdheden, te ontleenen aan Woningwet, bouwverordening, enz. - alle bevoegdheden aan haar eigendomsrecht kunnen ontleenen, die iedere eigenaar daaraan kan ontleenen:

124. De redenering lijkt te zijn 'zwijgen is instemmen'. Stel dat al zou mogen worden aangenomen de wetgever indertijd stilzwijgend heeft ingestemd met bedoelde praktijk - quod non -, dan nog is het merkwaardig dat de Hoge Raad zich zo gebonden acht aan een 'stilzwijgende instemming' die meer dan 30 jaar oud is. Men vergelijke dit arrest met HR 19 jan. 1968, AB 1968, p. 585, NJ 1968, 166 (Eindhoven/Staals), waarin de Hoge Raad zelfs m.b.t. de door de wetgever bij de totstandkoming van de gemeentewet van 1851 uitdrukkelijk verwoorde opvatting t.a.v. de niet-bestaanbaarheid van privaatrechtelijke overeenkomsten m.b.t. publiek domein, oordeelde dat die opvatting 'niet in overeenstemming is met de thans geldende rechtsopvattingen, volgens welke aan een gemeente als eigenares van dergelijke voor de openbare dienst bestemde zaken als bevoegdheden toekomen die het burgerlijk recht aan iedere eigenaar toekent...'

125. Vgl. R.M. van Male, 'Onvoltooid recht. Over rechtsbetrekking, bestuursrecht en bestuursprocesrecht', oratie Rotterdam, Zwolle 1993. p. 22, die het onjuist acht te stellen 'dat rechtsbetrekkingen door een wet, beschikking of overeenkomst tot stand worden gebracht. Zij bestaan steeds daar waar subjecten met elkaar samenleven en zijn naar hun aard onvoltooid:

126. Gribnau, t.a.p.. p. 92.

127. P.C.E. van Wijmen, 'Samenloop van bestuursrecht en burgerlijk recht bij onrechtmatige daad', in: H.J.A.M. van Geest e.a., 'Bestuursrecht aan de horizon' (bundel t.g.v. de 80-ste verjaardag van prof. mr. S.F.L. baron van Wijnbergen), Zwolle 1994, pp, 135-148 (p. 145/146).

128. Aldus ook Van Male, a.w., p. 20/21, die spreekt van op de justiciabelen nustende plichten.

129. P.C.E. van Wijmen, 'Bescherming van natuur- en milieuwaarden in rechte; de verdediging van collectieve goederen', M\&R 1994/9, pp. 234-243 (p. 243).

130. Zie bijv. P.C.E. van Wijmen, 'Zorgplicht in natuur- en milieuwetten', M\&R 1991, p. 1, en N.S.J. Koeman, 'Bodembescherming en bodemsanering', Zwolle 1987, p. 190.

131. C.J. Bastmeijer, 'De algemene zorgplicht in de Wet milieubeheer', M\&R 1993, p. 466. Onder de titel 'Recht ist, was der Umwelt nũtzt? Over zorgplichtbepalingen, civiele acties en tweewegenleer', NJB 1994, pp. 605-616, gaven we samen met A.Q.C. Tak een kritische beschouwing n.a.v, deze wettelijke zorgplichtbepaling. Daarin wordt er op gewezen dat art, 1.1a Wmb op gespannen voet staat met het lex certa-beginsel ('Bestimmtheitsgebot') en wordt de aan deze bepaling ten grondslag liggende opvatting gekritiseerd, dat 'de overheid in beginsel zou beschikken over zelfstandige privaatrechtelijke bevoegdheden ter behartiging van publieke belangen, i.c. het 'milieubelang'.

132. Immers, als er een algemene bevoegdheid bestaat tot toepassing van bestuursrechtelijke sancties wegens 'milieubenadeling', zal zich nagenoeg altijd de mogelijkheid van 'doorkruising' voordoen. Lid 3 van art. 1.1a Wmb neemt niet weg, dat wanneer specifieke milieuvoorschriften zijn overtreden, het doorkruisingscriterium zich tegen een civiele actie door 'de overheid' kàn verzetten. Ook dit wordt kennelijk nog als 'lastig' ervaren. Door het tijdschrift 'Handhaving' (maart/mei 1994, p. 34/35) is uit de mond van het plaatsvervangend hoofd van de Afdeling bodemsanering van het ministerie van VROM opgetekend, dat n.a.v. het Magnus-arrest (HR 22 okt. 1993, AB 1994, 1) de vraag is gerezen 'of je als overheid niet te veel beperkingen hebt' en dat er nu 'een discussie gaande (is) of je niet in het Hoofdstuk handhaving van de Wel milieubeheer moet opnemen dat de weg van het civielrecht te allen tijde openstaat, parallel aan de zorgplicht die in deze wet is opgenomen en waarbij de mogelijkheid van het civielrecht nadrukkelijk onverlet is gelaten'.

133. Kamerstukken 21.556

134. Zie de oorspronkelijke - door de regering voorgestelde - tekst van art. 47 lid 5 van de uitbreidingswet: 'Voor de toepassing van dit artikel is niet vereist dat op het tijdstip waarop de oorzaak van de verontreiniging of de aantasting zich heeft voorgedaan reeds jegens de overheid onrechtmatig werd gehandeld'. De bepaling van art. 47 van de uitbreidingswet is overigens in de herziene Wet Bodembescherming genummerd als artikel 75 . 
135. UCV Vaste Commissie voor Milieubeheer TK, 18 maart 1993, pp. 19-28.

136. Zie E.C.M. Wagemakers, 'Artikel 47 van de Wet Bodembescherming', NJB 1994, pp. 1029-1034.

137. $\mathrm{Vgl}$. het Benckiserarrest. Maar wat kost géén geld?

138. HR 19 dec. 1975, NJ 1976, 280 (Rijksweg 12).

139. HR 26 mei 1978, NJ 1978, 615 ('Zuidpool').

140. HR 18 febr. 1994, AB 1994, 415 (Staat/Kabayel c.s.)

141. H.J. Simon, 'Publiekrecht en burgerlijk recht', WPNR 1994, 6156, pp. 753-757 (p. 756, nt. 36).

142. $\mathrm{Vgl}$. punt 6 van de conclusie adv.gen. Koopmans voor het arrest-Staat/Van Amersfoort, waar hij overigens wijst op de 'moeilijkheid' van deze benadering. Zie reeds $P$. Verloren van Themaat, 'Economisch recht, sociaal recht en economische orde', Alphen a/d Rijn 1982, p. 107: 'In beginsel lijkt het denkbaarde eis van maatschappelijke zorgvuldigheid ook tot aansprakelijkheid jegens de gehele gemeenschap uit te breiden. Aan gemeenschapsorganen zou dan een civiele actie uit onrechtmatige daad kunnen worden toegekend, zoals reeds op beperkte schaal gebeurt ten gunste van vertegenwoordigers van groepsbelangen'.

143. Anke Kruisinga, 'De vervuiler betaalt?', Recht en Kritiek 1994, pp. $27-45$ (p. 31 en p. 32 ).

144. $\mathrm{Vgl}$. Jeand'Heur, La.p., p. 120.

145. H. Stout, 'De betekenissen van de wet', diss. Amsterdam 1994, Zwolle 1994, p. 164. Vgl. ook p. 247. Dergelijke opvattingen bevestigen, wat A.Q.C. Tak schrijft in zijn inleiding tot E.C.H.J. van der Linden, A.Q.C. Tak (red.), 'Bestendig en wederkerig', Deventer 1995, p. 3/4: 'De bevoegdheidsvraag lijkt 'uit', de wetmatigheidsleer (bevoegdheidsleer) is ingenuild voor een rechtmatigheidsleer (controleleer), zo lijkt het'.

146. Lubberdink, a.w., p. 137.

147. HR 18 febr, 1994, AB 1994, 415 (Staat/Kabayel c.s.).

148. BVerfG 8 juli 1982, E 61, nr. 10, p. 104. Bij de term 'Vernunfthoheit' gaan de gedachten uit naar de pruisische 'Polizeistaat', waarin de verlichte vorst het als zijn taak zag op basis van zijn 'ius politiae' volgens eigen rationeel oordeel en inzicht ('Vernunfthoheit') het algemeen belang (de 'gemeine Polizei') te bevorderen.

149. Delegatie van de beperkingsmogelijkheid door de wetgever in formele zin aan een 'lager' overheidsorgaan is alleen mogelijk, als een grondwettelijke bepaling een van de begrippen 'bij of krachtens de wet', 'de wet stelt regels' of 'de wet kan regels stellen' gebruikt.

150. Met name in die gevallen waarin delegatie aan een 'lager' overheidsorgaan mogelijk is gemaakt.

151. Ingevolge art. 12 is vereist: voorafgaande legitimatie en mededeling van het doel van het binnentreden alsmede uitreiking aan de bewoner van een schriftelijk verslag van het binnentreden.

152. HR 18 juni 1993, NJCM-bulletin 1993, pp. 786 e.v., Tijdschrift voor Gezondheidsrecht 1993, p. 368 e.v. (HIV-arrest). Zie ook H.J. Simon, 'Publiekrecht en burgerlijk recht', WPNR 1994, 6156, pp. 753757 (р. 756).

153. Noot H.J.J. Leenen bij het arrest in Tijdschrift voor Gezondheidsrecht 1993, p. 368 e.v. Vergelijkbare kritiek wordt geuit door L. Verhey in zijn noot in NJCM-bulletin 1993, p. 786 e.v.

154. Vgl. A.K. Koekkoek, 'De betekenis van grondrechten voor het privaatrecht', WPNR 1985, nr. 5742, pp. 385-389, nr. 5743, pp. 405-412, nr. 5744, pp. 425-434; dez., 'De onderlinge verhouding van grondrechten', preadvies Calvinistische Juristenvereniging mei 1985.

155. H.J. Simon, 'Publiekrecht en burgerlijk recht', WPNR 1994, 6156, pp. 753-757 (p. 756 ).

156. HR 22 jan. 1993, AB 1993, 198, NJCM-bulletin 1993, p. 410 e.v.

157. C.A.J.M. Kortmann, 'Vrijheid van meningsuiting voor de regering?', NJB 1993, p. 333 e.v.

158. L. Verhey, 'Vrijheid van meningsuiting voor de regering?', NJCM-bulletin 1993, p. 410 e.v.

159. W. Hins, 'Uitingsvrijheid voor de Staat?!', Mediaforum 1993, p. 37. 


\section{Hoofdstuk 6}

\section{Het juridisch pluralisme. De constitutieve betekenis van het dualisme Staat-'maatschappij'. De rol van de Staat in de rechtsvorming}

\section{Het bloot rechtspositivistische karakter van de 'twee-wegen- jurisprudentie' van de Hoge Raad}

De recente jurisprudentie van de Hoge Raad is in wezen zeer rechtspositivistisch. Voor het rechtspositivisme dat het recht ziet als 'nur die Form ... für irgendwelche Inhalte' en de Staat als 'nur das Mittel ... zur Realisierung irgendwelcher sozialer 'Zwecke' (Kelsen), zijn er geen wezensverschillen tussen publiek- en privaatrecht. Met deze formalistische beschouwingswijze hangt ook de opvatting samen, dat alle positief recht afkomstig zou zijn van de overheid ${ }^{1}$. Deze opvatting impliceert dat men bijvoorbeeld ook de 'privaatrechtelijke bevoegdheid' van contractspartijen om binnen hun kring (positief) recht te vormen, moet herleiden tot de wet (het BW) en dat dus het BW 'privaatrechtelijke bevoegdheden' zou verlenen: 'alle recht is in deze zin overheidsrecht' (Kortmann). Omdat men bij deze formalistische beschouwingswijze geen wezenlijk materieel onderscheid kan zien tussen publiek- en privaatrecht, moet tevens worden geconcludeerd dat 'de overheid' haar 'privaatrechtelijke bevoegdheden' óók kan gebruiken ter behartiging van 'publieke belangen'.

Als de Hoge Raad als zijn opvatting geeft dat 'de overheid' publieke belangen, behalve via de publiekrechtelijke weg, 'ook mag behartigen door gebruik te maken van haar in beginsel krachtens het privaatrecht toekomende bevoegdheden, zoals aan het eigendomsrecht ontleende bevoegdheden, de bevoegdheid een overeenkomst naar burgerlijk recht te sluiten of de bevoegdheid een vordering op grond van een jegens haar gepleegde onrechtmatige daad bij de burgerlijke rechter in te stellen' ${ }^{2}$, en dat die onrechtmatigheid óók gelegen kan zijn in maatschappelijke onzorgvuldigheid jegens 'de overheid' die optreedt in het kader van de behartiging van publieke belangen $^{3}$, dan geeft hij er blijk van de materiële verschillen tussen publiek- en privaatrecht niet te zien en slechts oog te hebben voor de rechtsvormen zoals die zijn neergelegd in het BW.

Als het BW aan 'de overheid' bevoegdheden zou verlenen ter behartiging van publieke belangen, rijst de vraag, wat eigenlijk het 'privaatrechtelijke' is aan die 
bevoegdheden. En we wezen er al eerder op dat de opvatting dat het BW 'privaatrechtelijke bevoegdheden' verleent, óók zou moeten betekenen dat ook private (rechts)personen hún privaatrechtelijke bevoegdheden ontlenen aan de wetgever. Dat zou een staatsabsolutistisch standpunt zijn.

De Hoge Raad hanteert in wezen slechts een formeel bevoegdheidsbegrip en miskent daarmee dat elke formele bevoegdheid slechts kan bestaan binnen een materiële competentiesfeer, die wordt bepaald door de eigen aard van de desbetreffende samenlevingsverhouding: alle positief recht ontstaat door de juridische vormgeving door competente rechtsorganen aan materiële rechtsbeginselen, binnen de grenzen van hun materiële rechtskring. Een wezenlijke rechtsstaatsconceptie gaat o.i. uit van een pluraliteit van eigen-geaarde samenlevingskringen, met alleen een eigen materiële rechtssfeer met voor die rechtssfeer typische materiële rechtsbeginselen. In navolging van Dooyeweerd menen we, dat niet alleen tussen publiekrecht en privaatrecht, maar ook tussen algemeen privaatrecht - het door de Staat gepositiveerde burgerlijk recht - en bijzonder privaatrecht - het eigen interne recht van niet statelijke levenskringen (door Dooyeweerd 'niet-burgerlijk privaatrecht' genoemd) een principieel onderscheid worden gemaakt, ondanks alle vervlechtingen tussen deze rechtskringen.

Het publiekrecht is typisch publiekrechtelijk gemeenschapsrecht, een publiek ius commune dat uitdrukking geeft aan het publieke gemeenschapskarakter van het staatsverband en dat beheerst wordt door het typisch publiekrechtelijke beginsel van het algemeen belang (de iustitia distributiva) en niet dienstbaar mag worden gemaakt aan specifieke persoonlijke of groepsbelangen.

Het burgerlijk recht is naar zijn aard een privaat ius commune, dat de algemene voorwaarden creëert voor een vrij maatschappelijke verkeer op voet van de burgerlijke gelijkheid en dat beheerst wordt door de iustitia commutativa en dienstbaar is aan de behartiging van private belangen. Naar zijn aard draagt het burgerlijk recht geen gemeenschapskarakter.

Het burgerlijk recht kan worden onderscheiden van het bijzondere privaatrecht, zijnde het eigen recht van de niet-statelijke samenlevingskringen, dat door het burgerlijk recht extern wordt geïntegreerd in een burgerrechtelijke rechtsorde. Dooyeweerd is op basis van zijn filosofie gekomen tot een pluralistische visie op de onderscheidene samenlevingskringen en op de rechtswerkelijkheid, waarin de eigengeaardheid en eigen materiële rechtssfeer van zowel het staatsverband als van alle andere pluriforme samenlevingskringen worden erkend ${ }^{4}$. Juist omdat zijn theorie van de structuurprincipes van de Staat en van de andere samenlevingsstructuren een 'model' levert voor een werkelijk pluriforme samenleving en grote perspectieven biedt voor een adequatere en scherper geformuleerde theoretische visie op de aard van en de onderlinge verhoudingen tussen de onderscheidene samenlevingsstructuren 
- ook naar hun rechtsaspect - dan in gangbare theorieën gebruikelijk is ${ }^{5}$, is het $0 . \mathbf{i}$. toelaatbaar deze theorie te hanteren als 'bloot' paradigma ${ }^{6}$.

Zowel in de eigen aard van de Staat als in die van de andere, niet-statelijke samenlevingssferen ligt een begrenzing voor het staatsoptreden. De Staat kan worden gekarakteriseerd als de publieke rechtsgemeenschap van overheid en onderdanen binnen een bepaald territoir, op de grondslag van de monopolistische organisatie van de gewapende macht ('Zwangsmonopol'). Bij de Staat speelt de publieke rechtsfunctie de leidende rol; anders gezegd: de Staat is instituut van het algemeen belang (res publica), hetgeen betekent dat binnen het staatsverband alle bijzondere individuele en groepsbelangen evenwichtig moeten worden geharmoniseerd en geîntegreerd in dat algemeen belang (iustitia distributiva), onder eerbiediging van de eigen interne rechtssferen van individuen en niet-statelijke samenlevingskringen. Men kan dus 6́6k zeggen: de bestemmingsfunctie van de Staat - die de eigen aard van dit verband bepaalt - is gelegen in (de behartiging van het algemeen belang.

Met zijn unieke structuur als territoriale, met het 'Zwangsmonopol' beklede publieke rechtsgemeenschap, waarin alle mensen en niet-statelijke collectiviteiten binnen het staatsterritoir zijn geïntegreerd, hangt unieke (juridische) integreringsvermogen van de Staat samen. De algemene rechtsvormende taak van de Staat openbaart zich primair in de totstandbrenging van een eigen publiek verbandsrecht (het publiekrecht), een integrerend publiek ius commune dat op basis van de leidende beginselen van het algemeen belang en van de publiekrechtelijke vrijheid en gelijkheid, de publieke gemeenschapsstructuur van de Staat tot uitdrukking brengt. Dit integreringsvermogen manifesteert zich vervolgens óók in de totstandbrenging en instandhouding van een integrerend privaat ius commune, het burgerlijk recht. Alvorens hier nader op in te gaan, willen we eerst nog eens stil staan bij de vraag welke de relatie is tussen materiële rechtsbeginselen en positief recht, en tussen materiële competentiesfeer en formele bevoegdheden.

\section{Materiële rechtsbeginselen en positief recht; algemene en typische rechtsbeginselen; materiële competentiesfeer en formele bevoegdheden}

Dooyeweerd wijst op het onderscheid tussen de rechtsvormen waarin recht wordt gepositiveerd en het materiële karakter van het gepositiveerde recht, dat bepaald wordt door de daaraan ten grondslag liggende materiële rechtsbeginselen. Enerzijds zijn materiële rechtsbeginselen nog geen geldend recht: zij geven een bepaalde richting aan en behoeven concretisering (positivering); slechts positief recht is geldend recht. Anderzijds wordt bij een verabsolutering van de element van de positivering miskend dat de vóor-positieve, boven-willekeurige grondslag van alle positieve recht is 
gelegen in materiële rechtsbeginselen ${ }^{7}$. Alle positieve recht kan slechts ontstaan door juridische vormgeving (= positivering) in formele rechtsbronnen aan materiële rechtsbeginselen door competente rechtsorganen binnen hun materiële rechtsgebied. Materiële rechtsbeginselen fungeren dus als materiële ontstaans- en geldingsbronnen ('rechtsgronden') voor de inhoud van positieve rechtsnormen. In de ontstaansvormen van positief recht (rechtsbronnen in formele zin) zijn de op deze rechtsvorming gerichte wilsverklaringen van de daartoe competente rechtsorganen (= rechtshandelingen) essentieel ${ }^{8}$. Materiële rechtsbeginselen moeten door deze rechtsorganen (rechtsvormers) worden gevonden ('rechtsvinding') en worden gepositiveerd tot geldend recht. Kortom: alle positief recht ontstaat in formele rechtsbronnen, zijnde de juridische ontstaansvormen waarin materiële rechtsbeginselen door daartoe competente rechtsorganen worden gepositiveerd. Die rechtsbeginselen vormen de inhoud van de juridische vormgeving door de competente rechtsorganen:

'(R)echtsbeginselen (zijn) los van de competente rechtsvorming geen geldend recht, terwijl omgekeerd de juridische vormgeving onafhankelijkvan de materiële rechtsbeginselen, geen bindend positief recht voortbrengt'"

Spreken we over bevoegdheden tot rechtsvorming, dan moeten we een onderscheid maken tussen formele bevoegdheden en materiële bevoegdheidssfeer. Een formele bevoegdheid kan slechts bestaan binnen een materiële bevoegdheidssfeer, die bepaald en begrensd wordt door de typische eigen aard van de desbetreffende samenlevingskring. Zo'n samenlevingskring is óók een eigen rechtskring. Als er binnen één materiële rechtskring een hiërarchie bestaat van hogere en lagere trappen van rechtsvorming, dan is de rechtsvorming door het hoogste rechtsvormende orgaan de formele geldingsgrond van afgeleide (gedelegeerde) vormen van (formele) bevoegdheid binnen het materiële rechtsgebied van het verband. De rechtsvormende bevoegdheid van het hoogste orgaan is een materiële, omdat zij slechts wordt afgebakend door de materiële bevoegdheidssfeer van de desbetreffende samenlevingskring zelf. Lagere rechtsvormende organen hebben dus een formele bevoegdheid, een afgeleide bevoegdheid dus, die ontstaat door de rechtsvorming door een daartoe bevoegd hoger rechtsvormend orgaan en daardoor dus (ook) formeel-juridisch is afgepaald ${ }^{10}$. Elke rechtsvormende bevoegdheid vóóronderstelt dus een materiële rechtsmacht, die gegrond is in de typische eigen structuur van de desbetreffende samenlevingskring.

Deze materiële rechtsmacht drukt zich uit in voor die rechtskring typische materiële rechtsbeginselen. Rechtsbeginselen kunnen dus worden onderscheiden in algemene ('modale') rechtsbeginselen, die gegrond zijn in de algemene ('modale') aard van het rechtsaspect en daarom in alle rechtskringen een rol spelen - zij het dat ze binnen elke rechtskring hun typische verbijzondering krijgen ${ }^{11-}$, en typische 
rechtsbeginselen, die dus gegrond zijn in de typische aard van de onderscheiden samenlevingsstructuren. Zo zijn de typisch publiekrechtelijke rechtsbeginselen gegrond in de eigen structuur van de Staat als publieke territoriale rechtsgemeenschap op de basis van het 'Zwangsmonopol'; zij beheersen de samenstelling, inrichting en bevoegdheden van de overheidsorganen en de rechtsverhouding tussen overheid en burgers. De inhoud van het positieve recht binnen een rechtskring wordt dus bepaald door typische rechtsbeginselen en de - voor die rechtskring typisch verbijzonderde - algemene rechtsbeginselen.

Hier kan nog gewezen worden op het onderscheid tussen constitutieve en regulatieve rechtsbeginselen ${ }^{12}$. Constitutieve rechtsbeginselen zijn rechtsbeginselen die inherent zijn aan elke rechtsorde. Ze bepalen de structuur van het recht als zodanig en zijn onontbeerlijk voor het ontstaan en voortbestaan (de 'constitutie') van elke rechtsorde; worden ze genegeerd, dan is er geen sprake van recht meer ('nonrecht'). Deze beginselen zijn bepalend voor het rechtsbegrip; dit begrip moet naar zijn aard de algemeen geldige kenmerken van elke - ook de primitieve - rechtsorde bevatten, ook wanneer deze niet aan de ideële kenmerken van de rechtsidee beantwoordt ${ }^{13}$. De regulatieve rechtsbeginselen - vaak rechtsethische principes of beginselen van de juridische moraal genoemd - vóoronderstellen de constitutieve rechtsbeginselen en ontsluiten, verdiepen en verfijnen op basis van de cultuurhistorische ontwikkeling het rechtsleven in de richting van het morele aspect ${ }^{14}$. Kenmerkend is hun concretiserend en individualiserend karakter: ze krijgen in concreto positieve gestalte met het oog op alle juridisch relevante, bijzondere omstandigheden van het individuele geval. Daarom kunnen ze alleen onder algemene en vage termen als 'redelijkheid en billijkheid' worden gebracht, die als 'Generalklauseln' fungeren als 'Einbruchstellen' van de juridische moraal ${ }^{15}$. De onderscheiding tussen constitutieve en regulatieve rechtsbeginselen kruist die van modale en typische rechtsbeginselen ${ }^{16}$.

Terwijl het rechtsbegrip betrokken is op de constitutieve structuurmomenten van het rechtsaspect, moet de rechtsidee betrokken worden op de regulatieve structuurmomenten. De rechtsidee - idee der gerechtigheid, rechtsovertuiging - fungeert dus op basis van het rechtsbegrip en verdiept en ontsluit dit ${ }^{17}$.

Ook de constitutieve rechtsbeginselen mogen niet star en statisch worden opgevat. Rechtsbeginselen zijn niet kant en klaar gegeven, maar openbaren hun juridische zin in de loop van de cultuurhistorische ontwikkeling steeds rijker en dieper. Tussen rechtsbeginselen en positieve rechtsnormen bestaat een voortdurende wisselwerking: die rechtsnormen zijn positiveringen van boven-positieve rechtsbeginselen, maar de betekenis van die rechtsbeginselen krijgt ook steeds nieuwe accenten door de werking van die positieve rechtsnormen in de praktijk. Sterker nog, beginselen kunnen alleen vanuit die praktijk begrepen worden. Men kan zeggen dat de constitutieve 
rechtsbeginselen in hun voortdurende wisselwerking met de juridische positivering en onder leiding van de regulatieve rechtsbeginselen steeds meer verdiept en ontsloten worden. Van Eikema Hommes spreekt dan ook van 'relatieve constantie én dynamiek der materiële rechtsbeginselen' respectievelijk van 'relatieve constantie én dynamiek in de juridische positivering' door competente rechtsorganen, welke beide - materiële rechtsbeginselen én rechtsvorming - elkaar wederzijds veronderstellen ${ }^{18}$. In de woorden van Cliteur - die de bron van die beginselen gelegen ziet in de cultuur - hebben die beginselen een 'relatieve duurzaamheid': 'ze zijn niet van alle plaatsen en tijden maar ... zijn verbonden met de liberale rechtsstaat' ${ }^{19}$. Een en ander betekent een verwerping niet alleen van het blote rechtspositivisme, dat zich vastklampt aan de ontstaansvormen van recht, maar ook van de a-historische speculatie van de traditionele natuurrechtsleer, die uitgaat van eeuwige ('invariante') en concrete natuurrechtsnormen en die het positieve recht afschrijft ${ }^{20}$.

Juist omdat de ontstaans (-en bestaans)vormen van positief recht op zichzelf nog niets prejudiciëren omtrent het materiële ('typische') karakter van het gepositiveerde recht, kunnen in die rechtsvormen verschillende materiële rechtskringen met elkaar vervlochten zijn, steeds met respectering van de eigen rechtssfeer van de onderscheiden rechtskringen ${ }^{21}$. Die rechtsvormen zijn als het ware de knooppunten van de vervlechtingen van onderling onherleidbare, materiële rechtskringen. De publieken burgerrechtelijke integrering van het niet-statelijke maatschaps- en gemeenschapsrecht vóoronderstelt juist de eigen aard en onherleidbaarheid van al deze rechtskringen en laat ze intact ${ }^{22}$.

\section{Het burgerlijk recht als integrerend privaat ius commune}

Men zou zelfs kunnen zeggen dat het burgerlijk recht naar zijn aard alleen 'vervlechtingsrecht' is. Het burgerlijk recht - het algemene privaatrecht, het private ius commune - is een door de Staat in de juridische ontstaansvormen van wetgeving en burgerlijke rechtspraak gepositiveerd en door staatsorganen gehandhaafd (statelijk 'Zwangsmonopol') integrerend recht voor maatschapsbetrekkingen, dat gebaseerd is op de leidende beginselen van de iustitia commutativa en de burgerlijke vrijheid en gelijkheid. Het is in die ontstaansvormen extern vervlochten zowel met het staatsrecht als met het interne recht van de niet-statelijke samenlevingsverhoudingen (maatschapsverhoudingenen gemeenschapsverhoudingen). Het burgerlijk recht vóóronderstelt dus zowel de territoriale publieke rechtsorde van de staatsgemeenschap, als het interne recht van die niet-statelijke samenlevingsverhoudingen.

In de eerste plaats is het burgerlijk recht in zijn juridische ontstaansvormen van wetgeving en burgerlijke rechtspraak extern vervlochten met het staatsrecht, inzo- 
verre dit laatste de wijze regelt waarop de wetgeving in formele zin tot stand komt en burgerlijke rechtspraak instelt en organiseert ${ }^{23}$. Die ontstaansvormen - wetgeving en rechtspraak - zeggen op zichzelf niets omtrent het materiële karakter van het daarin gepositiveerde recht; dit karakter is afhankelijk van de materiële rechtsbeginselen die via die ontstaansvormen worden gepositiveerd en die gefundeerd zijn in de typische structuren van de desbetreffende samenlevingskringen. Een wet is een ontstaansvorm van recht; dat de totstandkoming van een wet wordt geregeld door het staatsrecht (onderdeel van het publiekrecht), zegt dus nog niets over haar inhoud. De inhoud ervan kan zijn staats- en bestuursrecht, straf- en strafprocesrecht, burgerlijk recht en burgerlijk procesrecht.

In de tweede plaats is het burgerlijk recht (het algemene privaatrecht) in die juridische ontstaansvormen van wetgeving en burgerlijke rechtspraak extern vervlochten met het interne recht van de niet-statelijke samenlevingskringen (intern maatschapsrecht en intern gemeenschapsrecht), met eerbiediging van de eigen typische rechtssfeer van die kringen. Zo wordt de interne contractssfeer vó́rondersteld door het burgerlijk contractenrecht. Of en zo ja, met wie en wanneer wordt gecontracteerd en welke inhoud wordt gegeven aan het contract, is een zaak van de daartoe materieel competente contractspartijen binnen hun maatschapsverhouding. Hun competentie tot vorming van intern contractenrecht is niet een door de wet gedelegeerde, maar een oorspronkelijke materiële rechtsmacht. Die contractsvrijheid wordt door de wet in formele zin erkend - niet: verleend - en gepositiveerd en daarmee extern - naar haar burgerrechtelijke kant - geïntegreerd in het burgerlijk recht. Over de in art. 1374 BW (oud) opgenomen regel dat overeenkomsten partijen binden, hen 'tot wet strekken', merkte Paul Scholten terecht op, dat de inhoud van deze bepaling 'niet de wet, doch de wil van partijen' gaf ${ }^{24}$. De bepalingen van het BW beogen de burgerlijke vrijheid en gelijkheid te waarborgen en stellen vast aan welke burgerrechtelijke eisen de inhoud van een contract moet voldoen om burgerlijke rechtskracht te verkrijgen, zodat een naar burgerlijk recht afdwingbare verbintenis ontstaat en men deze bij rechtsstrijd zodanig voor een onafhankelijke, burgerlijke rechter en met inschakeling van statelijke executieorganen geldend kan maken (statelijk 'Zwangsmonopol') ${ }^{25}$. Daardoor kan worden gewaarborgd dat waar de mens in het maatschappelijk verkeer rechtsbetrekkingen met anderen aangaat, dit ook werkelijk kan geschieden in vrijheid en op een geordende wijze. Wèl hebben de niet-statelijke levenskringen er aanspraak op dat hun belangen beschermd worden tegen de expansiezucht van andere belangen en dat hun de ruimte wordt gelaten zich te kunnen ontwikkelen. Daarom behoort de rechtsstaat - de publieke rechtsgemeenschap - juridische kaders te bieden tegen deze expansie. Zo heeft de wetgever zich, omdat de burgerlijke vrijheid en gelijkheid in een aantal gevallen leidde tot feitelijke onvrijheid van sociaal en economisch zwakkeren (huurders, 
arbeiders etc.), genoodzaakt gevoeld tot het stellen van allerlei beschermende bepalingen teneinde hun menselijke (vol)waardigheid in het maatschappelijk verkeer te waarborgen. Maar de omstandigheid dat de wetgever veelal begrenzingen stelt die in acht moeten worden genomen (dwingende wetsbepalingen, openbare orde en goede zeden etc.), wil een contract (ook) burgerlijke rechtskracht kunnen verkrijgen, neemt niet weg dat de rechtsmacht van contractspartijen een oorspronkelijke is. Daarom kunnen we inderdaad zeggen dat het burgerlijk recht 'vervlechtingsrecht' is ${ }^{26}$. In de woorden van Dooyeweerd:

'Zijn zinstructuur is een onzelfstandige, daar het burgerlijk recht eenerzijds de gelding van het interne staatsrecht en anderzijds die van het niet statelijk-recht onderstelt, dat het in diens enkaptische functies in het staatsverband tot burgerrechtelijke eenheid wil brengen. (...) Het burgerlijk recht kan slechts de niet-statelijke rechtsvorming aan 'einheitliche' rechts-voorwaarden binden voor hare gelding bij den burgerlijke rechter, en deze rechtsvoorwaarden kunnen naar de interne structuur van het burgerlijk recht, nimmer een buiten-rechtelijke bestemmingsfunctie bezitten. Zoo zijn de bindingen tusschen burgerlijk recht en niet-burgerlijk recht wederkeerig. Het burgerlijk recht onderstelt het niet-statelijk recht en het interne staatsrecht, het brengt het nietstatelijk recht tot burgerlijke eenheid, doch is anderzijds in zijn competentiesfeergebondendoor het niet-burgerlijkrecht (het interne staatsrechten het niet-statelijk recht). De juridischeontstaansvormen zijn de knooppuntendeze enkaptischebindingen' ${ }^{p}$.

Het burgerlijk recht is dus geen gemeenschapsrecht maar een door de Staat gepositiveerd, integrerend maatschapsrecht: het regeit dus de maatscriapsbietreḱkingen (naar hun burgerrechtelijke zijde) tussen gecoördineerde rechtssubjecten, die daarin niet als leden van een gemeenschap fungeren en waarin de individuen en rechtspersoonlijkheid bezittende sociale verbanden op voet van gelijkheid aan het maatschappelijk verkeer deelnemen ${ }^{28}$. Het moet worden onderscheiden van zowel het interne maatschapsrecht als het interne gemeenschapsrecht, dat door het burgerlijk recht wordt geïntegreerd en daarmee extern wordt vervlochten. Er is niet slechts een eigen interne materiële rechtskring van gemeenschappen - een 'interne gemeenschapsvrijheid' -, maar evenzeer een interne maatschappelijke vrijheid, met name de contractsvrijheid. Ook het interne recht van niet-statelijke gemeenschappen (gezinnen, vennootschappen, vrije verenigingen, kerken etc.) is niet afgeleid van de Staat; hun eigen intern-materiële rechtssfeer is slechts 'extern' vervlochten met het door de Staat gepositiveerde burgerlijk recht, het algemene privaatrecht. Zo kent - om maar één voorbeeld te noemen - een bedrijfsverband een interne rechtssfeer die gekwalificeerd wordt door de typische bestemmingsfunctie van deze (niet-statelijke) gemeenschap in het economisch aspect. Dit interne recht is van een andere aard dan het gemeenschapsrecht van het staatsverband, van kerkverbanden, van vrije verenigingen etc., etc.

Wel heeft elke gemeenschap heeft ook zijn externe rechtsverhoudingen, namelijk inzoverre het met andere samenlevingsverhoudingen vervlochten is. $\mathrm{Bij}$ de oprichting van zgn. maatschappelijke verbanden zoals vennootschappen, spelen de gekozen externe ('maatschappelijke') doelstellingen zelfs een beslissende rol; de doelstellin- 
gen van deze verbanden zijn - anders dan bij de institutionele verbanden - mede of zelfs primair gericht op het optreden in het maatschappelijk verkeer ${ }^{29}$. Voor zover op basis van de burgerlijke wetgeving aan verbanden rechtspersoonlijkheid is toegekend, kunnen ze naar burgerlijk recht als zodanig - als zelfstandige juridische eenheden (rechtssubjecten) - deelnemen aan het maatschappelijk verkeer.

\section{De betekenis van de rechtspersoonlijkheid naar burgerlijk recht}

Wat is nu de betekenis, de zin, van de burgerrechtelijke rechtspersoonlijkheid? Deze vraag moet worden beantwoord, omdat waar in het Windmill-arrest gesproken worden van aan 'de overheid' 'in beginsel krachtens het privaatrecht toekomende bevoegdheden', alleen kan zijn gedoeld op de openbare lichamen die volgens art. 2:1 BW rechtspersoonlijkheid bezitten en die volgens art. 2:5 BW, evenals 'private rechtspersonen', voor het (burgerlijk) vermogensrecht met een 'natuurlijke' persoon gelijk staan: aan de toekenning van die burgerrechtelijke rechtspersoonlijkheid wordt kennelijk de vérgaande conclusie verbonden, dat hun burgerrechtelijk handelen niet aan banden is gelegd en dat zij beschikken over een burgerrechtelijke 'Vollhandlungsfähigkeit', ó́k ter behartiging van publieke belangen. Uit het voorgaande is duidelijk geworden, dat wij deze opvatting niet kunnen delen. Om de vraag te kunnen beantwoorden hoe ver de handelingsbekwaamheid van deze publiekrechtelijke rechtspersonen in het burgerrechtelijk verkeer werkelijk reikt en welke de verhouding is tussen het publiekrechtelijk en het privaatrechtelijk handelen van 'de overheid', zullen we moeten nagaan wat de zin is van de toekenning aan openbare lichamen van de burgerrechtelijke rechtspersoonlijkheid en van een bepaling als art. 2:5 BW. Daartoe zullen we eerst een verklaring moeten geven voor het verschijnsel van de rechtspersoonlijkheid qua talis, en meer algemeen: van de rechtssubjectiviteit als zodanig ${ }^{30}$.

Rechtssubjectiviteit betreft het fungeren van de mens of van een verband-als zodanig binnen samenlevingsverhoudingen, beschouwd naar het juridisch aspect van die verhoudingen: het is een juridische subjectsfunctie. Waar een verband-als zodanig, als zelfstandige juridische eenheid, in dergelijke verhoudingen kan fungeren, wordt die rechtssubjectiviteit aangeduid als rechtspersoonlijkheid ${ }^{31}$.

Teneinde de in art. 2:1 BW bedoelde openbare lichamen, de in art. 2:2 BW bedoelde kerkgenootschappen en de in art. 2:3 bedoelde maatschappelijke verbanden in de gelegenheid te stellen om (ook) naar burgerlijk recht in hun externe maatschapsbetrekkingen als zelfstandige juridische eenheid (rechtssubject in het burgerrechtelijk verkeer) te kunnen fungeren, reikt het BW hun de externe organisatievorm van de rechtspersoonlijkheid naar burgerlijk recht aan. Teneinde de rechtszekerheid in het burgerrechtelijk verkeer te waarborgen heeft de wetgever de verkrijging van deze rechtspersoonlijkheid door laatstbedoelde verbanden wèl afhankelijk gesteld van 
preventieve controle, terwijl die rechtspersoonlijkheid pas tegenover derden werkt na publicatie van de oprichtingsakte ${ }^{32}$. Voorts geeft het BW een aantal organisatieregels waaraan een verband moet voldoen om burgerrechtelijke rechtspersoonlijkheid te kunnen verkrijgen en al zodanig in het burgerrechtelijk verkeer op te kunnen treden. Het zijn algemene organisatieregels die voor de onderscheidene vormen van burgerrechtelijke rechtspersoonlijkheid gelden, waarbij de wetgever is uitgegaan van een zekere vergelijkbaarheid in organisatiestructuur die bestaat binnen resp. verenigingen, stichtingen en vennootschappen. Niet hun ontstaan en voortbestaan als verbanden danken zij echter aan de burgerlijke wetgeving, wèl hun ontstaan en voortbestaan als rechtspersoon naar burgerlijk recht. Niet de op basis van die statelijke wetgeving erkende rechtspersoonlijkheid naar burgerlijk recht is bepalend voor de materiële aard van het interne organisatierecht; het is omgekeerd: die rechtspersoonlijkheid is niets anders dan de extern-burgerrechtelijke organisatievorm van een verband met een eigen vermogen, die een reële intern-juridische verbandsorganisatie en zekere gedragsnormen binnen het rechtspersoonlijkheid bezittend verband vóóronderstelt ${ }^{33}$.

In wezen ligt het bij deze private organisaties niet anders dan bij de op grond van art. 2:1 BW met rechtspersoonlijkheid beklede openbare lichamen - de zgn. publiekrechtelijke rechtspersonen -, waarover Asser-Van der Grinten terecht betoogt dat hun 'structuur en inrichting in het publiekrecht is geregeld' - dus in het interne (publieke) verbandsrecht! - en dat 'deze organisaties in het civiele recht ... als rechtspersoon (worden) erkend op grond van de activiteiten die in het kader van deze organisaties worden ontwikkeld ${ }^{34}$. Het interne organisatierecht is bij een openbaar lichamen-rechtspersoon naar zijn aard publiekrecht; bij een met burgerrechtelijke rechtspersoonlijkheid bekleed niet-statelijk verband is het daarentegen (bijzonder) privaatrecht.

Verder kunnen we opmerken dat er niets bijzonders aan de hand is, wanneer men constateert dat de publiekrechtelijke rechtsvorming - de rechtsvorming binnen het publiekrechtelijke verband dus - plaatsvindt door overheidsorganen ('ambten') terwijl in het burgerlijk-vermogensrechtelijk verkeer wordt opgetreden door openbare lichamen-rechtspersonen. Bij de niet-statelijke verbanden die met burgerrechtelijke rechtspersoonlijkheid zijn bekleed, doet zich immers een vergelijkbare situatie voor. Binnen een bepaald verband hebben de leden - in hun hoedanigheid van leden van dat verband - te maken met het interne verbandsrecht zoals dat gepositiveerd wordt door verbandsorganen ${ }^{35}$. Dit geldt zowel voor het staatsverband en de autonome statelijke sub-verbanden (provincies, gemeenten etc.) als voor de niet-statelijke - private - verbanden (vrije verenigingen, bedrijven etc.). Terwijl dus binnen de interne rechtskring van een verband de rechtsvorming geschiedt door verbandsorganen, treedt in het burgerrechtelijk verkeer ('extern') het verbandsgeheel - als rechtspersoon - op ${ }^{36}$. Omdat zo'n verband ook als rechtspersoon uiteraard slechts 
kan handelen door middel van zijn organen, vertegenwoordigen bepaalde organen de organisatie naar buiten - in het burgerrechtelijk verkeer -, zulks op basis van hun door het interne verbandsrecht bepaalde positie binnen die organisatie. Daarbij worden de door een orgaan-vertegenwoordiger binnen de grenzen van zijn formele competenties verrichte rechtshandelingen toegerekend aan die rechtspersoon.

Hoe ver reikt nu de aan die rechtspersoonlijkheid verbonden (burgerrechtelijke) rechts- en handelingsbekwaamheid? ${ }^{37}$. Terwijl overheidsorganen ('ambten') beschikken over specifieke - publiekrechtelijke - bevoegdheden die hun uitdrukkelijk op basis van de (Grond)wet zijn toegekend, wordt aan de toekenning aan openbare lichamen van de burgerrechtelijke rechtspersoonlijkheid en van de daaraan verbonden 'Vollhandlungsfähigkeit' veelal de conclusie verbonden dat het privaatrechtelijke handelen van deze 'publiekrechtelijke rechtspersonen' niet aan banden is gelegd. En deze handelingsbekwaamheid zou, omdat het burgerlijk recht het 'gemene recht' zou zijn, 6́6k kunnen worden aangewend ter behartiging van publieke belangen (vide het Windmill-arrest). Zo noemt Konijnenbelt als 'fundamenteel verschil' bij de kwestie of het gaat om een publiekrechtelijke danwel een privaatrechtelijke overheidshandeling:

'Gaat het om een publiekrechtelijke rechtshandeling, dan zal daarvoor normaliter een grondslag in een wettelijk voorschrift moeten kunnen worden aangewezen, zo wil het legaliteitsbeginsel. Voor privaatrechtelijke rechtshandelingen, doorgaans gebaseerd op eigendomsrecht of contractsvrijheid, eventueel op een combinatie van de twee, geldt het omgekeerde: die rechtshandelingenkunnen in beginsel vrijelijk worden verricht, het recht kan in bijzondere gevallen hooguit beperkingen bevatten' 38 .

\section{En Hennekens betoogt:}

'In de bestuurswetgeving gaat het om publiekrechtelijke bevoegdheden en plichten. Het privaatrechtelijk handelen is tot nu toe door de wetgever niet aan banden gelegd, ieder openbaar lichaam kan privaatrechtelijk in het verkeer optreden ter behartiging van zijn taken' 39 .

Vraagt men nu naar de grondslag van die algemene burgerrechtelijke handelingsbekwaamheid, dan kan in de bloot positivistische beschouwingswijze worden volstaan met een verwijzing naar art. 2:5 BW, dat 'wat het vermogensrecht betreft' rechtspersonen - privaatrechtelijke én publiekrechtelijke - met 'een natuurlijke persoon' gelijk stelt, 'tenzij uit de wet het tegendeel voortvloeit'. Zo reageert Bloembergen op de op het Windmill-arrest geuite kritiek, dat 's Hogen Raads opvatting dat 'de overheid' in beginsel beschikt over 'krachtens het privaatrecht toekomende bevoegdheden' ter behartiging van publieke belangen ${ }^{40}$, met het betoog 'dat het wettelijk stelsel meebrengt dat aan de overheid deze bevoegdheden toekomen' ${ }^{41}$. Art. 2:1 BW kent aan een groot aantal overheidslichamen rechtspersoonlijkheid toe. Uit lid 3 van art. 2:1 in relatie met art. 2:5 vloeit - aldus Bloembergen - voort: 'dat in beginsel ieder vermogensrechtaan een overheidslichaamkan toekomen en - via art. 3:32 dat zo'n lichaam elke privaatrechtelijke rechtshandeling kan verrichten. Bovendien kan zo'n lichaam in bepalingen als art. 6:162 en 6:203 zowel 'hij die' ('degene die') als 'een ander' zijn, 
enz., enz, Kortom, op deze manier is de overheid als rechtssubject het privaatrecht binnengesluisd en is het overheidsprivaatrechtgegeven'.

En daarbij zou de doorkruisingsformule ervoor zorgen, dat het publiekrecht niet op onaanvaardbare wijze wordt doorkruist.

We hebben er al eerder op gewezen dat de opvatting dat het BW 'privaatrechtelijke bevoegdheden' verleent, ook impliceert dat óók private (rechts)personen hún privaatrechtelijke bevoegdheden ontlenen aan de (burgerlijke) wetgever, hetgeen o.i. een staatsabsolutistisch standpunt is. Het moge duidelijk zijn geworden, dat die opvatting door ons niet wordt aanvaard.

Art. 2:5 BW erkent inderdaad dat de in art. 2:1 BW bedoelde publiekrechtelijke verbanden, evenals de met rechtspersoonlijkheid beklede private verbanden, als zelfstandige juridische eenheden kúnnen fungeren in het burgerlijk-vermogensrechtelijk verkeer ${ }^{42}$. Het BW erkent en positiveert ${ }^{43}$ daarmee in algemene zin de rechtsbekwaamheid en handelingsbekwaamheid (dus het vermogen om actief rechtsvormend aan dat verkeer deel te nemen door het sluiten van contracten, het instellen van rechtsvorderingen etc.) van 'natuurlijke' personen ${ }^{44}$ én burgerrechtelijke rechtspersonen. Maar daarbij dient te worden onderkend, dat de door het BW gegeven regeling van de 'Vollrechtsfähigkeit' en 'Vollhandlungsfähigkeit' noodzakelijkerwijs een formele en externe is. Men dient nl. goed in het oog te houden, dat (1) rechtssubjectiviteit - en dus ook rechtspersoonlijkheid - als zodanig nimmer een absoluut karakter draagt, maar steeds een relatieve juridische subjectsfunctie is, dat (2) het burgerlijk recht naar zijn aard 'vervlechtingsrecht' is, en dat (3) die relatieve juridische subjectsfunctie zich bij rechtspersoonlijkheid bezittende verbanden slechts kan voordoen in een noodzakelijke correlatie van externe maatschapsen interne verbandsverhoudingen. We lichten dit toen.

Ten eerste: absolute rechtssubjectiviteit c.q. absolute handelingsbekwaamheid, waardoor een enkeling of rechtspersoon tot alles bevoegd is wat niet door een wetsbepaling uitdrukkelijk is uitgesloten, bestaat niet. Rechtssubjectiviteit als zodanig heeft niet een starre, 'absolute' inhoud, maar is een relatieve figuur. De mens fungeert in allerlei sociale betrekkingen van zowel maatschaps- als gemeenschapsaard ${ }^{45}$. Bezien naar het rechtsaspect van deze betrekkingen betekent dit dat hij als rechtssubject fungeert in evenzovele materiële rechtskringen als er maatschaps- of gemeenschapsbetrekkingen zijn waarbinnen hij optreedt. Omdat het typische karakter van die rechtssubjectiviteit telkens wordt bepaald door de typische eigen aard van de desbetreffende materiële rechtskring, kunnen we zeggen dat er evenzovele typen van rechtssubjectiviteit zijn als er materiële rechtskringen zijn waarin concrete enkelingen (of verbanden) als rechtssubjecten optreden. Anders gezegd: een enkeling of een verband heeft evenzovele rechtssubjectiviteiten - d.w.z. evenzovele specifieke juridische subjectsfuncties -, als er materiële rechtskringen 
zijn waarin hij fungeert. Als we zeggen dat de rechtssubjectiviteit qua talis geen absoluut maar een relatief karakter draagt, dan bedoelen we dus steeds: relatief tot de rechtsnormen van het typische rechtsgebied waarin een enkeling of verband als rechtssubject fungeert ${ }^{46}$. Ook de door het BW erkende en gepositiveerde 'Vollrechtsfähigkeit' en 'Vollhandlungsfähigkeit' zijn dus per definitie relatief en ontlenen hun karakter aam de typische aard van dit rechtsgebied. In navolging van Fabricius ${ }^{47}$ spreekt Kempen dan ook van 'relative Vollrechtsfähigkeit':

'(Es) gilt ...., einen ganz wesentlichen Aspekt nicht aus den Augen zu verliehren: Auch die vollrechtsfahigen Rechtssubjeckte sind nicht unbeschränkt oder 'absolut' rechtsfahig in dem Sinne, dass sie tatsächlichoder potentiell alle Rechte ausübenund alle Rechtspflichtenübernehmenkönnten. (...) In dem Begriff der Voll-Rechtsfahigkeitist also immer auch die Relativitat der Rechtsfahigkeit angelegt; auch die Vollrechtsfahigkeit ist relative Rechtsfahigkeit. (...) Ob Voll- oder Teilrechtsfahigkeitvorliegt, ist ... keineswegs ... eine Frage der Quantităt, sondern ausschliesslich eine Frage der Qualităt. Es kommt nicht darauf an, zu ermitteln, wieviele Rechtssätze einem Rechtssubjekt zugeordnet sind. Entscheidend ist vielmehr, ob einem bestimmten Rechtssubjekt die (nur durch bestimmte Merkmale eingeschrănkte) Făhigkeit zuerkannt ist, generell Träger von Rechtssătzen zu sein' a

Ten tweede: als we constateren dat (ook) in het burgerlijk recht de rechtssubjectiviteit en handelingsbekwaamheid relatief zijn en hun karakter ontlenen aan de typische aard van dit rechtsgebied, dan moeten we vervolgens vaststellen dat het burgerlijk recht naar zijn aard 'vervlechtingsrecht' is en - in de woorden van Dooyeweerd - een 'onzelfstandige zinstructuur' heeft: het is een integrerend extern maatschapsrecht dat via de burgerrechtelijke ontstaansvormen van wetgeving en burgerlijke rechtspraak extern is vervlochten met de interne materiële rechtskringen van maatschaps- en gemeenschapsaard, die het vóóronderstelt. Zo berust - zoals we reeds opmerkten - het sluiten van een overeenkomst op een materiële competentie van de contracterende partijen binnen hun maatschapsbetrekking - welke competentie dus niet berust op bevoegdheidsverlening door de (burgerlijke) wet - en krijgt deze overeenkomst slechts in haar structuurvervlechting met het door de Staat gepositiveerde burgerlijk recht een externe, burgerrechtelijke zijde. Anders gezegd: de door de (burgerlijke) wet gegeven regeling van de handelingsbekwaamheid betreft de externe, burgerrechtelijke keerzijde van de binnen interne maatschapsbetrekkingen bestaande bevoegdheden tot rechtsvorming, i.c. die tot het sluiten van een contract.

Als dus het BW voor het burgerlijk-vermogensrechtelijk verkeer de rechts- en handelingsbekwaamheid van enkelingen en rechtspersoonlijkheid bezittende verbanden erkent, geeft het noodzakelijkerwijs slechts een generale, externe, 'formele' regeling van die rechtsbekwaamheid en die handelingsbekwaamheid. Pawlowski schrijft dan ook:

'Die Fähigkeit, Träger von Rechten und Pflichten zu sein, soll allen Rechtssubjekten, unterscheidslos zukommen ...Das ist aber nur möglich, wenn man diese Fähigkeit rein formal 
- abstrakt - versteht und von jeder Beziehungauf konkrete Făhigkeitenabsieht. (...) Dieser Begriff der Rechtsfâhigkeitmuss sich also auf jeder Beziehung auf einzelne Fähigkeiten enthalten...' (curs. dzz; JT)".

Gelet op zijn karakter kàn het burgerlijk recht de omvang en inhoud van die rechtsbekwaamheid en handelingsbekwaamheid niet concreet regelen door positivering van specifieke subjectieve rechten en plichten resp. van specifieke bevoegdheden tot het verrichten van bepaalde burgerrechtelijke rechtshandelingen ${ }^{50}$, doch moet het het vermogen van enkelingen en van (rechtspersoonlijkheid bezittende) verbanden om 'wat het (burgerlijk) vermogensrecht betreft' (art. 2:5 BW) drager te zijn van de door dit burgerlijk recht erkende en gepositiveerde subjectieve rechten en plichten resp. hun vermogen om actief rechtsvormend op te treden in algemene zin erkennen en kan het deze rechts- en handelingsbekwaamheid slechts formeel omschrijven. Het burgerlijk recht verleent geen 'privaatrechtelijke bevoegdheden', maar erkent ze en positiveert ze met zijn formele regeling van de 'Vollhandlungsfähigkeit' naar hun burgerrechtelijke kant.

Ten derde: waar een verband, bij voorbeeld door het sluiten van een overeenkomst met een derde, komt te staan in een maatschapsbetrekking - die naar haar externjuridisch zijde wordt geïntegreerd in het burgerlijk recht -, doet het dit noodzakelijkerwijs in onverbrekelijke samenhang met zijn intern-juridische verbandsverhoudingen. De eigen typische aard van een maatschappelijk verband, zoals die (nader) is gevormd door de gekozen doeleinden ervan, is niet alleen bepalend voor de materiële afgrenzing van het interne verbandsrecht, maar óók voor de omvang van de functies der rechtspersoonlijkheid naar burgerlijk recht. Deze doeleinden verbinden de interne verbands- en externe maatschapsfuncties met elkaar. Binnen het geldingsgebied van het burgerlijk recht kan een verband slechts rechts- en handelingsbekwaam zijn voor zover dit met zijn aard strookt. Dit betekent dat de burgerrechtelijke 'Vollrechtsfähigkeit' en 'Vollhandlungsfähigkeit' van de met rechtspersoonlijkheid beklede maatschappelijke verbanden materieel nader bepaald wordt door hun doeleinden. Hun burgerrechtelijke handelingsbekwaamheid is een doelgebonden handelingsbekwaamheid ${ }^{51}$. Van der Grinten merkt inzake de gelijkstelling in art. 2:5 BW van rechtspersonen met 'natuurlijke' personen voor het vermogensrecht op:

'De gelijkstelling van een rechtspersoonmet een natuurlijkepersoon voor wat betreft het vermogensrecht moet niet in absolute zin worden verstaan. De mens is in beginsel autonoom in zijn handel en wandel. (...) Waar de rechtspersoon een doelorganisatie is, zullen de rechtshandelingenvan de rechtspersoondienstig moeten zijn aan het doel van de rechtspersoon. (...) Het doel heeft voor de rechtspersoon normatieve betekenis. De organen van de rechtspersoon en zij die voor de rechtspersoon handelenzijn gebondenaan het doel, behoudensde mogelijkheid van wijziging van het doel. Het doel van de rechtspersoon begrenst haar werkterrein en haar activiteiten. Met de aard en het karakter van een rechtspersoon kunnen bepaalde handelingen in strijd zijn ${ }^{32}$. 
Ook voor de burgerrechtelijke rechtssubjectiviteit en handelingsbekwaamheid van de in art. 2:1 BW bedoelde openbare lichamen, zal moeten gelden dat de door het BW gegeven regeling een formele en externe is. Een belangrijk verschil tussen het staatsverband en de maatschappelijke verbanden is intussen, dat de doeleinden van de laatsten mede of zelfs primair zijn gericht op het optreden in het maatschappelijk verkeer ('maatschappelijke doeleinden'). Inherent aan het karakter van de Staat als institutaire territoriale publieke rechtsgemeenschap is echter, dat de staatsdoeleinden primair intern werken, dus binnen het staatsverband resp. zijn autonome subverbanden. Deze doeleinden ('publieke rechtsbelangen') worden binnen de grenzen van de competentiesfeer van de Staat vastgesteld op basis van de (Grond)wet, waartoe specifieke (publiekrechtelijke) bevoegdheden worden toebedeeld aan overheidsorgaan. Deze door publiekrechtelijke rechtsvorming vastgestelde doeleinden werken ook 'extern' en bepalen materieel de omvang en inhoud van de door het BW slechts formeel omschrevenhandelingsbekwaamheid vanopenbare lichamen-rechtspersonen. Zoals we later nog nader zullen toelichten, betekent dit dat hun fungeren in het burgerrechtelijk verkeer steeds dient te geschieden, niet ter (zelfstandige) behartiging van publieke belangen - want de behartiging van publieke rechtsbelangen is een zaak van publiek verbandsrecht en dient te geschieden op basis van publiekrechtelijke bevoegdheden -, maar waar dat nodig is in het kader van de uitoefening van de steeds ter bereiking van specifieke doelstellingen verleende - publiekrechtelijke bevoegdheden.

Samenvattend kunnen we stellen: het burgerlijk recht verleent geen bevoegdheden - zoals de Hoge Raad kennelijk meent in het Windmill-arrest -, maar erkent deze teneinde een vrij en geordend maatschappelijk verkeer te waarborgen. A fortiori verleent het burgerlijk recht aan 'de overheid' geen bevoegdheden ter behartiging van publieke belangen. De behartiging van publieke belangen - beter: publiekrechtelijke belangen ${ }^{53}$ - dient te geschieden binnen het publieke gemeenschapsrecht (het publiekrecht) door de daartoe bevoegde overheidsorganen. Openbare lichamen kunnen 'extern' fungeren in het burgerrechtelijk verkeer, maar dit slechts in onverbrekelijke samenhang met de behartiging van publieke rechtsbelangen, welke laatste moet geschieden op basis van publiekrechtelijke bevoegdheden. De burgerrechtelijke handelingsbekwaamheid van openbare lichamen is een annexe handelingsbekwaamheid, die inhoudelijk wordt bepaald door het publiekrecht.

\section{Het juridisch pluralisme; 'samenleving' en 'maatschappij' zijn geen totaal-structuren}

Het ware rechtspluralisme erkent dat de samenleving niet een totaal-structuur is, maar bestaat uit allerlei eigen-geaarde maatschaps- en gemeenschapsverhoudingen 
met eigen interne rechtssferen, hoezeer deze rechtssferen ook extern vervlochten zijn in de integrerende rechtsorde van het burgerlijk recht. En de menselijke rechtssubjectiviteit kan in geen enkele van die rechtskringen geheel opgaan, óók niet in die van het publiekrecht of het burgerlijk recht. De mens heeft allerlei specifieke juridische functies, al naar gelang de materiële rechtskring waarin hij fungeert.

'Maatschappij' plaatsen we steeds tussen aanhalingstekens: de 'maatschappij' is geen totaal-structuur; de universalistische opvatting over de 'maatschappij' als één organische gemeenschap wordt door ons afgewezen. Met de term 'maatschappij' wordt slechts gedoeld op alle eigen-geaarde niet-statelijke (private) samenlevingsverhoudingen van maatschaps- én gemeenschapsaard, die slechts extern met elkaar - en met het staatsverband - zijn vervlochten ${ }^{54}$. Als wij de eigen zelfstandige positie van de niet-statelijke gemeenschappen náást de staatsgemeenschap zo nadrukkelijk onderstrepen, betekent dit overigens volstrekt niet dat wij aansluiten bij de opvatting van die gemeenschapsdenkers die betogen dat die niet-statelijke gemeenschappen de 'hoekstenen van de samenleving' zijn, met verwerping van de opvatting dat het individu of de Staat dat zouden zijn ${ }^{55}$. Gemeenschappen zijn geen 'zelfstandige personen' met een eigen 'ik-heid', die kunnen denken, voelen etc.; zij hebben geen bestaan in zichzelf. Maar zij zijn ook geen ficties, maar realiteiten; zij zijn geen bijkomstigheid van het wezen van de mens: zonder gemeenschappen kan een mens niet bestaan. Hij is uit zijn aard 'non solus'; een abstract in-dividu bestaat niet. Een gemeenschap wortelt in de menselijke persoonlijkheid, die zich naar een bepaald aspect daarvan uitdrukt in die gemeenschap. De mens gaat in geen enkele gemeenschap op, óók niet in het staatsverband: binnen een bepaalde gemeenschap: binnen een bepaalde gemeenschap treedt hij op naar een specifieke gemeenschapszijde van zijn persoonlijkheid. Van Haersolte schrijft:

'Denkt men den mensch, dan denkt men noodzakelijkerwijze ook 'gemeenschap', wijl deze een onmisbaar moment in het begrip 'mensch' is. (...) De staat is ... niet de uiteindelijke gemeenschap, de gemeenschapder gemeenschappen.(...) In den staat ... treedt hij op als staatsburger. In de kerk daarentegen ... fungeert hij als lidmaat der kerke. In de provincie, in de gemeente, in het waterschap, in voetbalclub, kegelclub, beroepskring, gezin, echtpaar en liefdesverhouding keert de mensch even zoo vele andere aspecten van zichzelf naar buiten. Telkens is hij zichzelf; doch omdat hij telkens op een andere manier zichzelf is, is hij nooit zichzelf heelemaal, nooit heelemaal zichzelf, en is ieder van die aspecten toch ook weer een masker (persona). Met 'persona' bedoelen wij dan ook allereerst den mensch zoals hij onder een bepaald aspect optreedt (...). Kortom, in iedere gemeenschap is de mensch drager eener andere qualiteit; de functie wisselt, doch de drager blijft als drager al dier functies steeds dezelfde' 's .

En naast zijn fungeren als lid van allerlei gemeenschappen, fungeert de mens in allerlei maatschapsbetrekkingen. Al die gemeenschaps- en maatschapsverhoudingen hebben een eigen, niet van de Staat afgeleide, maar door hun typische eigen-aard bepaalde rechtskring, náást de integrerende rechtsorde van het burgerlijk recht en die van het publiekrecht. Al die samenlevingsverhoudingen (statelijke en niet- 
statelijke c.q. private) zijn gelijkwaardig, vóoronderstellen elkaar en houden elkaar in evenwicht: maatschaps- en private gemeenschapsverhoudingen zijn geen verhoudingen binnen het staatsverband. Dat zou een 'Gleichschaltung' betekenen van alle pluriforme samenlevingsverhoudingen binnen een alomvattende staatsorde. Ook van een hiërarchische relatie tussen Staat en 'maatschappij' kan geen sprake zijn. Maar er is ook geen 'strikte scheiding' tussen die samenlevingsverhoudingen en tussen hun rechtskringen, maar van een strikte onderscheiding: de rechtskringen zijn op allerlei wijzen met elkaar vervlochten (niet: vermengd), maar deze vervlechting is extern en laat de interne rechtssferen intact. In het rechtsverkeer tussen individuen en groepen valt weliswaar te onderscheiden tussen het rechtsverkeer binnen gemeenschappen (gemeenschapsrecht) en dat tussen individuen en gemeenschappen onderling (maatschapsrecht), maar dat rechtsverkeer is ondenkbaar zonder de correlatie van gemeenschaps- en maatschapsrecht. Zo is de individuele private vrijheid en een vrij, maatschappelijk verkeer de basis voor de vorming van de vrije, gedifferenticerde maatschappelijke corporaties, terwijl die corporaties na hun oprichting in het maatschappelijk verkeer fungeren op basis van hun interne gemeenschapsverhoudingen. Een sfeer van persoonlijke vrijheid buiten de verhoudingen van institutaire verbanden en een vrij maatschappelijk verkeer, kon echter pas worden verwezenlijkt na het ontstaat van een modern staatsverband, dat de oude ongedifferentieerde verbanden afbrak en de publieke overheidscompetenties in zich verenigde (scheiding van imperium en dominium). Vrije maatschappelijke betrekkingen en gedifferentieerde niet-statelijke gemeenschappen vóóronderstellen dus ook de aanwezigheid van een publieke rechtsgemeenschap, die als instituut van het algemeen belang een unieke integreringsfunctie heeft ten opzichte van de niet-statelijke rechtskringen. De juridische differentiatie, waarbij talrijke rechtskringen ontstaan, vindt dus haar keerzijde in een juridische integratie van alle niet-statelijke samenlevingskringen, met behoud van hun eigen aard, in het publiekrecht en het burgerlijk recht, waarbij de Staat ook juridische kaders behoort te bieden ter bescherming van de belangen van samenlevingskringen tegen de expansiezucht van anderen (de 'markt', commercialisering etc. etc.) ${ }^{57}$.

Onjuist is het betoog van Foqué, dat - zoals hij het noemt - 'het dualisme staatsamenleving' samenhangt met een 'étatisch denken' en dat dit dualisme:

'wordt gekenmerkt door een strikte scheiding tussen beide polen, die tevens in een hiërarchische verhouding top-down tot elkaar staan. Het publiekrecht representeert de verticale dimensie en het privaatrecht de horizontale dimensie (...) Boven bevindt zich de staat en beneden de samenleving' 's.

In de eerste plaats kan er binnen zo'n 'étatisch denkmodel' van zelfstandige rechtskringen geen sprake zijn, doch is elke bevoegdheid en elk subjectief recht een door de Staat verleende bevoegdheid; dan kan er óók van een dualisme geen sprake zijn. 
In de tweede plaats is 6́ók de Staat een eigen-geaarde samenlevingsstructuur, en wel de publiekrechtelijke gemeenschap. Ter onderscheiding van Staat kan men beter spreken van 'maatschappij' - als aanduiding van alle niet-statelijke samenlevingsverhoudingen - dan van 'samenleving'. Ongelukkig is een ook een term als 'maatschappelijk middenveld', omdat daarmee het bestaan van een 'top-down' relatie tussen overheid en individuen - met daartussen niet-statelijke gemeenschappen wordt gesuggereerd.

Onjuist is ób de veel voorkomende opvatting, dat alle recht afkomstig is van de Staat. Zo identificeert - om één voorbeeld te noemen - Schindler 'recht' met 'Staat', waar hij betoogt dat men in plaats van 'Gesellschaft' ('maatschappij') beter van het 'Ausserstaatliche, resp. wenn vom Recht ausgegangen wird, vom Ausserrechtlichen' kan spreken ${ }^{59}$.

Staat en 'maatschappij' vóóronderstellen elkaar wederzijds en zijn noodzakelijk op elkaar betrokken, maar dat betekent niet dat het geen van elkaar te onderscheiden grootheden zijn. Dat het dualisme Staat-'maatschappij' - en de erkenning van alle eigen-geaarde rechtssferen van gemeenschaps resp. maatschapskarakter in die 'maatschappij' - en daarmee ook de erkenning van een principieel onderscheid tussen publiek- en privaatrecht (en tussen algemeen en bijzonder privaatrecht) constitutief is voor een ware rechtsstaat, leert ook de geschiedenis ${ }^{60}$.

We behoeven maar te wijzen op de doctrine die in Duitsland na 1933 Staat en maatschappij wilde vereenzelvigen in de éne 'volksgemeenschap', waarin ook alle recht zou zijn geworteld ('Recht ist, was dem Volke nützt'). Dit impliceerde dat het onderscheid tussen publiek- en privaatrecht ten prooi moest vallen aan een 'Gleichschaltung des Rechts' en een 'Gemeinrecht der Volksgemeinschaft' zou ontstaan ${ }^{61}$. Het Bürgerliche Gesetzbuch zou daarom niet meer gebouwd moeten zijn op de individuele burgerlijke vrijheid van 'die Person, der abstrakte gleiche Träger von Rechten und Pflichten', maar op de 'Volksgenosse, ... der als Glied der Gemeinschaft eine ganz bestimmte Rechts- und Pflichtenstellung hat' ${ }^{62}$. Waar Slagter in zijn dissertatie met instemming citeert uit een in 1940 gepubliceerd wetsontwerp van een commissie van de Akademie für Deutsches Recht, met o.a. de volgende bepaling:

'Rechtswidrig handelt immer, wer gröblich gegen anerkannte Grundsätze des völkischen Zusammenlebens verstösst',

ziet hij o.i. niet dat daarmee niet gedoeld wordt op de norm betreffende de onzorgvuldigheid in het maatschappelijk verkeer en dat het 'völkische Zusammenleben' als alomvattend is bedoeld ${ }^{63}$.

Men kan ook kijken naar het privaatrecht van de voormalige Sowjet-Unie om vast te stellen, dat het ontbreken van dit principieel onderscheid inherent is aan een 
vereenzelviging van Staat en maatschappij. Het uitgangspunt van het SowjetRussische Burgerlijk Wetboek was niet gelegen in het beginsel van de burgerlijke vrijheid die door het burgerlijk recht wordt erkend en gepositiveerd en op de daarmee verband houdende bestemmingsvrijheid van de subjectief gerechtigde ten aanzien van het object van zijn subjectieve rechten - idee die ten grondslag ligt aan de Westeuropese codificaties -, maar op de Rousseauiaanse idee dat burgerlijke rechten door de wetgever aan de burgers zijn verleend ${ }^{64}$. De burgers moest zijn burgerlijke rechten dan ook uitoefenen zoals dat van een ambtsdrager mag worden verwacht, nl. met inachtneming van de doelstelling van die rechten. Uitgangspunt van de doctrine was immers de principiële overeenstemming tussen de belangen van de individuele mens en die van de Staat. Art. 1 van het Burgerlijk Wetboek bepaalde dan ook:

'De burgerlijke rechten worden door de wet beschermd, tenzij ze worden uitgeoefend in strijd met hun sociaal-economische doelstelling'.

Maar dit was naar zijn aard geen burgerlijk recht, althans niet het burgerlijk recht dat inherent is aan een rechtsstaat. Pawlowski formuleert de betekenis van het principiële onderscheid dat de moderne westerse rechtsorde kent tussen de twee 'Verfassungstypen öffentliches Recht und Privatrecht' als volgt:

'Die Anerkennung des Privatrechts und die damit gegebene Anerkennungder subjektiven Entscheidung des einzelnen Rechtsgenossen schliesst ... die totalitäre Demokratie Rousseauscher Prägung aus, wie sie im sowjetrussischen Recht verwirklicht ist; sie entspricht damit der Idee des Rechtsstaates. Das Privatrecht gewährleistet sozusagen einen 'staatsfreien Raum', in dem der einzelne (die Minderheit) nicht majorisiert werden kann, in dem er nicht verpflichtet ist, nach den Zielen zu streben, die die Mehrheit seiner Mittbürger verfolgt. Das Privatrecht ist also das Rechtsgebiet, auf dem der einzelne Rechtsgenosse nach seinen persönlichen Vorlieben und Neigungen handeln und entscheiden kann, mit dessen Hilfe er seine persönlichen Ziele auch dann verfolgen kann, wenn sie von der Mehrheit seiner Mitbürger nicht geteilt werden'.

Daarentegen correspondeert - aldus Pawlowski - het publiekrecht met de 'Idee der Demokratie'; het betreft:

'das Verhalten der Rechtsgenossenauf den Gebieten, auf denen die nach den allgemein anerkannten Grundsãtzen der Rechtsgemeinschaft handeln sollen, d.h. in denen sie als Amtsträger handeln sollen; es ist Amtsrecht' ${ }^{\text {ss. }}$.

Kenmerkend voor zowel de nationaal-socialistische als de totalitair-communistische doctrine was dat ze slechts één gemeenschap kenden - de Staat c.q. 'volksgemeenschap' c.q. 'socialistische maatschappij' - en slechts individuen als leden daarvan. Dan kan er geen principieel onderscheid meer kan worden gemaakt tussen 'statelijke' ('publiekrechtelijke') belangen enerzijds en 'maatschappelijke' belangen anderzijds, maar kan nog slechts gesproken worden van 'publieke' belangen. Foqué, die het dualisme Staat-'maatschappij' en de daarmee annexe scheiding tussen publiek- en privaatrecht verwerpt, spreekt dan ook van een 'publieke ruimte', zijnde 'de wereld van cultuur, architectuur, wetenschappen en kunst, en van instituties, 
staat en recht', een ruimte die gekenmerkt wordt door 'duurzaamheid' en door 'openbaarheid en pluraliteit van belangen', binnen welke ruimte de overheid één van de actoren is 'te midden van een pluraliteit van burgers en belangen', 'zij het met specifieke taken en verantwoordelijkheden, in vaak complexe netwerken van rechtsbetrekkingen' ${ }^{66}$. Foqué maakt de fout te denken, dat door de constructie van zo'n amorfe 'publieke ruimte' het subject wordt beschermd 'niet alleen in zijn negatieve vrijheid, freedom from, maar ook in zijn positieve vrijheid, freedom to, in zijn participatie aan de gemeenschappelijke zaak' ${ }^{67}$. Opmerkelijk dat een beroep wordt gedaan wordt op Tocqueville, die in zijn 'De la démocratie en Amérique' een beschrijving zou geven van:

'de toestand die is ontstaan door de eenzijdige bescherming van de negatieve vrijheid van het individu en door een geëxalteerde autonomie van het subject. Hij schetst de maatschappij daar als een onoverzienbaremassa mensen zonder publieke identiteit die allen op elkaar zijn gaan lijken en alleen nog maar aandacht voor zichzelf hebben' $a$.

Zoals we eerder zagen, zoekt Tocqueville de verklaring hiervoor vooral in de idee van de volkssoevereiniteit én het ontbreken van niet-statelijke gemeenschappen (met name vrije verenigingen), waarin de mensen zich kunnen ontplooien volgens hun diepste overtuigingen en die een 'buffer' zijn tegenover een te ver gaande bemoeienis door het staatsgezag én door andere machten. Hij kritiseert niet 'de eenzijdige bescherming van de negatieve vrijheid van het individu', maar juist het eenzijdige streven naar sociale gelijkheid, met als gevolg dat er van de individuele c.q. maatschappelijke vrijheid weinig meer overblijft. Wat Tocqueville in zijn analyse duidelijk maakt, is juist dat er een scheiding moet zijn tussen het 'statelijke' en het 'maatschappelijke', en dat mensen niet alleen fungeren binnen de staatsgemeenschap maar daarnaast ook in allerlei niet-statelijke ('private') gemeenschappen. Foqué ziet kennelijk maar één gemeenschap - die van de 'publieke ruimte' - en géén dualisme Staat-'maatschappij'. Als hij spreekt van 'pluraliteit', dan heeft deze term in juridische zin niets te betekenen.

Anderzijds dient ook gewaakt te worden tegen overspanning van de gedachte der individuele burgerrechtelijke vrijheid, zoals die bestond ten tijde van de negentiendeeeuwse liberale rechtsstaat (de 'nachtwakerstaat') en die tot schrijnende sociale onvrijheid en ongelijkheid leidde (de 'sociale kwestie').

De Staat dient niet alleen rechtsstaat - zowel formeel als materieel; zie hierna - en democratische Staat te zijn, maar ook 'Sozialstaat'. De door de ontwikkeling van de 'Sozialstaat' toegenomen vervlechtingen tussen Staat en 'maatschappij' betekenen allerminst, dat het onderscheid tussen beide zijn rechtvaardiging heeft verloren ${ }^{69}$. Een markteconomie kan alleen tot optimale ontplooiing komen en iedereen voorspoed brengen als zij fungeert bij een sociale rechtsstaat, die de grondrechten - waaronder de vrijheid van private eigendom en ondernemerschap - respecteert en 
toeziet op de naleving van concurrentieregels, maar die ók zorgt voor een fysieke infrastructuur (wegen, spoorwegen) en sociale voorzieningen en goed onderwijs etc. voor een ieder garandeert. De superioriteit van een dergelijk bestel tegenover dat van samenlevingen die deze onderscheiding niet kenden en óók het economisch leven werd bestierd door de Staat ${ }^{70}$.

De sociale verworvenheden van de afgelopen eeuw zijn sinds het laatste decennium weer één voor één op de tocht komen te staan door een ideologie die kan worden samengevat in de woorden: de Staat is slecht, de markt is goed. De taken en bevoegdheden van de Staat zouden tot een minimum moeten worden teruggebracht, zodat het mechanisme van de vrije markt zich optimaal kan ontplooien. Sociale zekerheidsvoorzieningen - die niet langer worden beschouwd als teken van vooruitgang - en allerlei andere activiteiten worden overgeheveld van de publiekrechtelijke naar de private sector. Michel Albert constateert een veramerikanisering van de Europese samenlevingen in al haar geledingen, die heeft geleid tot een nieuwe fase in de 'relatie van het kapitalisme met de Staat': het 'Rijnlandse model' van de sociale markteconomie, dat zich kenmerkt door sociale zekerheid, gemeenschapszin binnen de bedrijven en investeren op de lange termijn, verliest ondanks zijn sociale én economische superioriteit sedert de jaren tachtig geleidelijk terrein aan het neoliberale (neo-Amerikaanse) model ". Dit model kenmerkt zich door een 'iedervoor-zich-individualisme', met tegelijkertijd een achteruitgang en/of commercialisering van het niet-economische gemeenschapsleven in de 'maatschappij': vakbonden, verenigingen enz. ('economisme').

De door Albert gegeven omschrijving van deze nieuwe fase: 'kapitalisme in plaats van de Staat', is o.i. treffend, omdat te constateren valt dat óók binnen de overheid typisch publiekrechtelijke beginselen verdrongen dreigen te worden door de voor het bedrijfsleven typische economische beginselen ${ }^{72}$. Terwijl Lenin predikte: 'Für uns ist alles im Bereich der Wirtschaft öffentlichrechtlich, aber nicht privat' (étatisme), zou men nu - enigszins gechargeerd - kunnen zeggen dat de leuze van de huidige marktdenkers is: 'Für uns ist alles wirtschaftlich, auch im Bereich des Staates' (economisme). Ook dit is een miskenning van de eigen aard van het staatsverband als publieke rechtsgemeenschap. Het optreden van de overheid behoort te zijn gekwalificeerd door de publieke rechtsfunctie: de Staat is géén bedrijf, evenmin als hij een zedenmeester of een geloofsgemeenschap (scheiding van kerk en Staat) is. Uiteraard dient de overheid zo zuinig mogelijk te opereren, maar economische principes mogen niet de publiekrechtelijke beginselen overwoekeren. Dat de Staat instituut van het algemeen belang is, betekent óók dat alle bijzondere individuele en groepsbelangen tot hun recht moeten kunnen komen, hetgeen niet alleen een normatieve begrenzing van de staatsmacht impliceert maar óók de opdracht tot het bieden van juri- 
dische kaders tegen overheersing van de mensen, bij voorbeeld door de economische belangen van 'de markt'.

\section{Publiekrechtelijke rechtsvorming}

\section{Het beginsel van het algemeen belang: representatie en non-identificatie}

De Staat karakteriseerden we als de territoriale institutionele publieke rechtsgemeenschap van overheid en onderdanen, bekleed met het 'Zwangsmonopol'. De Staat is instituut van het algemeen belang (res publica).

Het beginsel van het algemeen belang eist dat alle bijzondere individuele en groepsbelangen worden erkend en met elkaar geharmoniseerd en geïntegreerd in dat algemeen belang, zulks onder erkenning van de eigen interne rechtssfeer van individuen en niet-statelijke gemeenschappen. In dit leidende beginsel liggen reeds besloten: het beginsel van de scheiding van 'imperium' en 'dominium', het beginsel dat de Staat slechts recht kan (en moet) vormen dat een voor een ieder geldend ius commune is, de eerbiediging van een eigen rechtssfeer van niet-statelijke levenskringen, het non-identificatiebeginsel en het representativiteitsbeginsel.

Een representatieve democratie is immers de beste waarborg is voor zowel een integrale belangenafweging als voor handhaving van een 'vrije maatschappij'. Het beginsel van het algemeen belang en, meer in het bijzonder, het representatiebeginsel eisen enerzijds dat alle burgers worden gerepresenteerd - als staatsburgers ('homines publici') - en anderzijds dat de private sfeer van alle burgers erkend en gewaarborgd wordt. In het Rousseauiaanse model van de totalitaire democratie is er voor het individu slechts een sfeer als staatsburger onder de wet van de algemene wil ('alles ist öffentlichrechtlich'); er is dan geen sprake meer van representanten en gepresenteerden, maar van identiteit tussen Staat en 'maatschappij'. Slechts als het dualisme 'Staat' en 'maatschappij' wordt erkend en in stand wordt gelaten, betekent individuele en maatschappelijke vrijheid niet alleen (medewerkings)vrijheid in het democratische proces (vrijheid 'in de Staat'; staatkundige vrijheid-in-gelijkheid) maar ook vrijheid tegenover de Staat. In de woorden van Böckenförde:

'Einerseits wird die demokratische Willensbildung und Mitwirkungsfreiheit für die Entscheidungen der OrganisationseinheitStaat durchgeführt, der Staat wird 'demokratischer' Staat, auf der andern Seite wird die Begrenzung und Funktionsreduzierungder Staatsgewalt im Hinblick auf die individuelle und gesellschaftlicheFreiheit, die in der Unterscheidungvon Staat und Gesellschaft angelegt ist, beibehalten. Die Freiheit wird also 'doppelt genäht' : zur politischen Freiheit der Mitwirkung und Mitbeteiligung aller an den Entscheidungender Staatsgewalt tritt hinzu die bürgerliche Freiheit der einzelnen und der Gesellschaft vor bestimmten Zugriffen der Staatsgewalt überhaupt. Eben diese Konstituierung und zugleich Einbindung des demokratischen Prinzips um der doppelten Sicherung der Freiheit willen ist es, für die sich das Gundgesetzentschiedenhat, wenn es die Demokratie als rechtsstaatliche, freiheitliche Demokratie verfasst (Art. $20 \mathrm{II}$ und 28), die Grundrechteauch für den 
Gesetzgeberverbindlich macht (Art. 1 III) und ihren Kerngehalt für unantastbar erklärt (Art. 19 II, 79 III) $* n$.

Totalitaire tendensen zitten echter ook besloten in de huidige cultus van de vrije markt, waarbij de Staat de neiging heeft zich te identificeren met de economische sector ('alles ist wirtschaftlich'). Een ware private sfeer voor allen is slechts mogelijk wanneer er ook een werkelijk publieke sfeer bestaat, waarin alle bijzondere rechtsbelangen worden erkend en de Staat het als zijn roeping ziet de publiekrechtelijke randvoorwaarden te creëren om het goed fungeren van een vrije 'maatschappij' mogelijk te maken ${ }^{74}$.

Het beginsel van het algemeen belang en het representatiebeginsel impliceren juist een verbod van dienstbaarstelling van de Staat aan specifieke individuele en groepsbelangen (waaronder ook de eigen belangen van overheidspersonen: scheiding van 'imperium' en 'dominium'): de Staat mag zich niet met bepaalde individuen of groepen resp. met bepaalde levensbeschouwelijke opvattingen identificeren (het 'non-identificatiebeginsel'). Dit betekent ook een verbod van privilegiering van bepaalde individuen of groepen, om in plaats van of naast de overheid ter behartiging van 'algemene belangen' in te dringen in de rechtssfeer van anderen. Dat zou ook in strijd zijn met het gelijkheidsbeginsel en een niet-gelegitimeerde bemoeienis betekenen met de private sfeer van die individuen of groepen, waarin wordt ingebroken ter behartiging van de belangen van andere individuen of groepen. In de woorden van Böckenförde:

'Eines der konstituierendenPrinzipien des modernen Staates ist das Prinzip der Nichtidentifikation bzw. Neutralität (...) Durch den zunehmenden Abbau bestehender Indentifikation ist der Staat zum Wegbereiterder individuellenFreiheit und im eigentlichenSinn zum gemeinsamenHaus aller Untertanen und Bürger geworden. Aus der Nichtidentifikation bezieht er daher in hohem Masse seine Legitimität. Nun besteht aber die Nichtidentifikationnicht nur darin, dass der Staat keine Besonderheit, keinen partikulären materiellen Gehalt zum Inhalt seiner Allgemeinheit macht, sondern ebenso darin, dass die Besonderheit sich entfalten kann, in Freiheit gesetzt ist' 75 .

Herbert Krüger brengt het principiële onderscheid tussen publiekrecht en burgerlijk recht rechtstreeks in verband met het beginsel van de representatieve democratie en het non-identificatiebeginsel. Na te hebben opgemerkt dat de 'Interessentheorie' - die ter bepaling van het onderscheid uitgaat van de aard van de in het publiekresp. burgerlijk recht te behartigen belangen - 'im Ansatz ... richtig' is, omdat zij uitgaat van een materieel criterium en niet van de docr de overheid gekozen rechtsvormen, betoogt Krüger dat echter:

'vielmehr der Sinn der Unterscheidung (ist), den repräsentativen Charakter des Amtes zu sichern', zodat 'der Unterschied zwischen beiden Normenartennur in ihrem Verhăltnis zur Idee der Repräsentation gesucht werden (kann). (...) Das Öffentliche Recht kennzeichnetsich ... als jene Normenart, für die eine Wahl zwischen Repräsentationund Nicht-Repräsentationnicht in Betracht kommt, die 
vielmehr durch die Idee der Reprãsentation determiniert ist. Ist aber der Staat in Ämtern und Gesetzen als Reprâsentation der Staatlichkeit der Gruppe zu verstehen, dann ist die Folgerung unabweislich, dass er ausschliesslich in den Formen der Öffentlichen Rechts zu handeln vermag' ${ }^{\mathrm{r}}$.

En:

'(D)ie Ausbildung und Durchsetzung eines Öffentlichen Rechts und dessen Entgegensetzung zu einem nunmehr reinen Privatrecht (erweist sich) als einer der Vorgänge, mittels dessen man den repräsentativen Charakter des Modernen Staates herausgearbeitet hat. (...) (D)as Gesetz des sich nicht identifizierenden Staats (bedarf) der Privatautonomie zur Behauptung seines repräsentativen Charakters: Wie es erst aus der Dialektik von Reprăsentierenden und Repräsentantenentsteht, so lässt es sich auch nur in dieser Dialektik erhalten' $\pi$.

Het grootste bezwaar van de formalistische opvatting die ter bepaling van het onderscheid publiek- en burgerlijk recht slechts ziet naar de vormen en die meebrengt dat de overheid 'in burgerrechtelijke hoedanigheid' in beginsel ter behartiging van publieke belangen gebruik zou mogen maken van de burgerrechtelijke rechtsvormen, is dan ook dat deze een 'Entrepräsentierung' van het overheidshandelen impliceert:

'Verknüpft man daher das Öffentliche Recht ausschliesslich mit einer bestimmten Form staatlichen Handelns, dann heisst das nichts anderes als zum mindestendie Möglichkeiteröffnen, alles staatliche Handeln, das nicht in Befehlen, Zwingen und Strafen besteht, der Bindung des Öffentlichen Rechts zu entziehen und in den Bereich eines bindungslosen Privatrechts zu verlagern'. Deze theorie 'Iăuft... jedenfalls im Ergebnis daraus hinaus, weite und wichtige Bereiche des staatlichen Handelns zu enträpresentierenund damit von der Nötigung zur Richtigkeit zu entbinden. (...) Das (dieses) aber dem Sinn und der Funktion der Unterscheidung zwischen Öffentlichem und Privatem Recht schnurstracks zuwiderläuft, bedarf keiner Ausführung mehr' ${ }^{n}$.

De vraag van Krüger luidt dan ook: waarop baseert de heersende leer eigenlijk de these, dat de Staat in privaatrechtelijke hoedanigheid (als 'Fiskus') in beginsel de vrijheid zou hebben gebruik te maken van het burgerlijk recht? G.J. Scholten heeft gelijk, wanneer hij er op wijst dat 'een openbaar lichaam ...ook een zekere vertegenwoordigende functie (heeft)' ${ }^{79}$ : het beginsel van de representatieve democratie is typerend voor de moderne rechtsstaat. Maar waar Scholten kennelijk in die 'vertegenwoordigende functie' van een openbaar lichaam kennelijk een legitimatie ziet voor gebruikmaking door dat lichaam van zgn. privaatrechtelijke bevoegdheden, miskent hij dat de zin van het onderscheid tussen publiekrecht en privaatrecht mede gelegen is in de idee van de representatie en non-identificatie en dat 'de overheid' derhalve niet vrijelijk gebruik zal mogen maken van het privaatrecht.

Het is dan ook onjuist te stellen dat 'de overheid' voor haar publieke taakvervulling gebruik zou mogen maken van zgn. 'privaatrechtelijke bevoegdheden', omdat zij dan zou optreden als waarnemer c.q. vertegenwoordiger van 'gebundelde belangen van burgers' (de achterliggende gedachte bij het hierna nog te bespreken art. 3:305b BW). De overheid mag niet worden geidentificeerd met de burgers; haar optreden wordt beheerst door het beginsel van het algemeen belang, hetgeen betekent dat zij die burgers - alle leden van de publieke rechtsgemeenschap - slechts kan represen- 
teren op basis van een afweging en harmonisatie van bijzondere rechtsbelangen in het licht van het algemeen belang. Deze rechtsvormende taak is naar haar aard publiekrechtelijk. Aan overheidsorganen kunnen slechts bevoegdheden zijn toebedeeld uit hoofde van het algemeen belang, niet uit hoofde van individuele of private groepsbelangen die immers juist in dat algemeen belang zijn geharmoniseerd. Men zou dus kunnen zeggen dat, waar 'de overheid' optreedt ter behartiging van publiekrechtelijke belangen, de relatie met de bijzondere rechtsbelangen een indirecte is ${ }^{80}$. Dit is onderkend door het Bundesverfassungsgericht, die de opvatting verwerpt dat een overheidslichaam in rechte zou kunnen optreden als vertegenwoordiger ('Sachwalter') van individuele burgers en aldus zou kunnen opkomen voor hun grondrechten:

'Der Umstand allein, dass eine juristische Person des ôffentlichen Rechts öffentliche Aufgaben, also Aufgaben im Interesse der Allgemeinheit wahrnimmt, macht sie nicht zum grundrechtsgeschuttzten 'Sachwalter' des Einzelnen bei der Wahrnehmungseiner Grundrechte, mag die Erfullung der offentlichen Aufgaben auch die Verwirklichung seiner Grundrechte (möglicherweisemittelbar) forderlich sein, wie đas bei der Daseinsvorsorge mōglich ist' (onderstreping dzz.; JT) ".

Dit college is dan ook van oordeel dat de taakvervulling door 'de overheid' dient te geschieden op basis van door het positieve recht toevertrouwde (en begrensde) bevoegdheden, publiekrechtelijke bevoegdheden dus. Waar zij niet optreedt op basis van dergelijke bevoegdheden, treedt zij dus buiten de 'Bereich der Wahrnehmung öffentlicher Aufgaben'. Ook 'in privaatrechtelijke hoedanigheid' kan zij zich - a fortiori - niet opwerpen als representant van bepaalde burgers:

'Verlässt die juristische Person des öffentlichen Rechts den Bereich der Wahrnehmung öffentlicher Aufgaben, so besteht noch weniger Grund sie als 'Sachwalterin' des privaten Einzelnen anzusehen. Grundsätzlich ist davon auszugehen, dass der Bürger selbst seine Grundrechte wahrnimmt und etwaige Verletzungen geltend macht. Eine 'Vertretung', wie hier ausgesprochen, würde eine gefährlicheEinbruchstellein die Individualfreiheiteröffnen; die grundrechtlichverbürgtenFreiheiten sollen prinzipiell nicht von der Vernunfthoheit öffentlicher Einrichtungen verwaltet werden' (curs. van BVerG; JT) ${ }^{82}$.

\section{Materiële competentiesfeer en formele bevoegdheden}

Eerder maakten we reeds een onderscheid tussen materiële competentiesfeer en formele bevoegdheden. Dit onderscheid moet ook worden gemaakt, wanneer we spreken over bevoegdheden tot publiekrechtelijke rechtsvorming. De materiële competentiesfeer van het staatsverband wordt bepaald door zijn karakter als publieke rechtsgemeenschap, als instituut van het algemeen belang. Binnen die materiële competentiesfeer ontstaat positief recht door de juridische vormgeving (= positivering) door de competente rechtsorganen van dat verband. De hoogste rechtsvormende organen binnen het staatsverband zijn de Grondwetgever en - met inachtneming van de Grondwet - de wetgever (regering en Staten-Generaal; art. 81 Grondwet). Hún rechtsvormende bevoegdheid wordt in beginsel slechts bepaald en afge- 
bakend door de materiële competentiesfeer van het staatsverband ${ }^{83}$. De rechtsvorming - het stellen van positief recht - door deze organen bestaat mede hierin, dat bevoegdheden tot nadere rechtsvorming worden toevertrouwd aan 'lagere' organen binnen het staatsverband, die op basis daarvan veelal weer bevoegd zijn tot bevoegdheidstoedeling aan nog 'lagere' organen ('Stufenbau', gelede normstelling). Andere publiekrechtelijke rechtsvormers dan de (Grond)wetgever hebben dus een formele bevoegdheid, een afgeleide ('gedelegeerde') bevoegdheid dus, die ontstaat door de rechtsvorming door een daartoe bevoegd 'hoger' rechtsvormend orgaan ${ }^{84}$. Afgeleide (formele) competenties hebben een positiefrechtelijke grondslag. Publiekrechtelijke bevoegdheden van andere organen dan de (Grond)wetgever zullen dus herleidbaar moeten zijn tot een (Grond)wettelijke grondslag (wetmatigheid van bestuur), zij het dat die - afhankelijk van de aard van de materie - ruim geformuleerd kan zijn.

\section{Wetmatigheid van bestuur}

Eerder wezen we er reeds op dat de eis van wetmatigheid van bestuur ('Vorbehalt des Gesetzes' en 'Vorrang des Gesetzes') tot ontwikkeling is gekomen tegen de achtergrond van het dualisme Staat-'maatschappij' ${ }^{85}$. De betekenis van deze eis wordt door Giacometti zeer beknopt in één zin samengevat; deze eis volgt - aldus Giacometti - uit de machtenscheiding en beoogt tegelijkertijd:

'dem Bürger Freiheit, Gleichheit und damit Gerechtkeit sowie Rechtssicherheit gegenüber dem Staat zu gewăhrleisten... sowie eine mittelbare Demokratie der Verwaltung (zu) verwirklichen' ${ }^{86}$.

Aldus wordt tweeërlei vrijheidswaarborg ten opzichte van de Staat geboden: in de eerste plaats wordt de status activus van de burger, dat wil zeggen: om in zijn hoedanigheid als 'homo publicus' te participeren in de publieke zaak (de res publica) op basis van vrije meningsuiting, informatieverschaffing en door uitoefening van zijn actief en passief kiesrecht, zulks in het kader van de representatieve democratie ('vrijheid in de Staat', 'publiekrechtelijke vrijheid' van alle staatsburgers). In de tweede plaats wordt door de legaliteitseis gewaarborgd - mits uiteraard (ook) de wetgever de grenzen van de materiële competentiesfeer van het staatsverband in acht neemt - , dat beperkingen van staatswege van de eigen rechtssfeer van individuen en niet-statelijke gemeenschappen herleidbaar moeten zijn tot de algemene wet, die dus tevens de democratische legitimatie biedt ('vrijheid jegens de Staat', 'private vrijheid' van alle mensen). Laat men het dualisme Staat-'maatschappij' los, dan moet ook de wetmatigheidseis en daarmede tevens het representativiteits- en het nonidentificatiebeginsel alsmede het principiële onderscheid tussen publiek- en privaatrecht - hun betekenis verliezen.

Iedere bestuursbevoegdheid moet dus zijn terug te voeren op een wettelijke grondslag, die echter - afhankelijk van de aard van de materie - ruim geformuleerd kan 
zijn. De eis van wetmatigheid van bestuur mag niet zó worden verstaan, dat voor de rechtsgeldigheid van door een bestuursorgaan verrichte handelingen altijd noodzakelijk is dat de bevoegdheden daartoe door een wetgever exact omschreven en uitdrukkelijk zijn toegekend, en dat dus bij het ontbreken van een uitdrukkelijke (specifiek-wettelijke) bevoegdheidsgrondslag zonder meer moet worden aangenomen dat bestuursbevoegdheden ontbreken; wél behoeven ingrepen in het private domein van de burger in beginsel steeds een specifieke wettelijke grondslag ${ }^{57}$. Een bevoegdheidstoekenning kán ook besloten worden geacht in een bepaalde veelomvattende taak die aan een bestuursorgaan ter behartiging is opgedragen, bijv. tot het nemen van incidentele beslissingen in gevallen waarin onverwijld optreden noodzaak is ${ }^{88}$. En zo zijn aan de beheerstaak ten aanzien van publiek domein een 'politiebevoegdheid' (tevens zijnde verplichting) inherent - tot het verrichten van feitelijke én rechtshandelingen - teneinde ervoor te kunnen zorgen dat die zaak aan haar publieke functie blijft beantwoorden. Zoals we eerder betoogden, is die bevoegdheid gefundeerd in het 'overheidsrecht' op publiek domein en strekt ze ter waarborging van het 'Recht auf Gemeingebrauch' (Otto Mayer) van iedere mens als zodanig; de titel tot rechtsvorming is dus dit 'overheidsrecht' zelf ${ }^{8 \%}$. Ontkent men het bestáán van een dergelijke bevoegdheid, dan miskent men óók het 'Recht auf Gemeingebrauch' van allen. Deze bevoegdheid komt toe aan dat orgaan het staatsverband (of statelijk subverband), waaraan die beheerstaak - op basis van de wet! - ter behartiging is opgedragen ${ }^{90}$. Men pleegt etikettenzwendel wanneer men een bevoegdheid tot het verlenen van toestemming tot niet-functioneel gebonden gebruik ('bijzonder gebruik') wél aanvaardt, maar bij het ontbreken van een specifiek-wettelijke bevoegdheidsverlening op die bevoegdheid het etiket 'privaatrechtelijk' plakt.

\section{'Algemeen belang' en 'publiekrechtelijke belangen'}

Het vorenstaande impliceert dat het algemeen belang als leidend beginsel van het publiekrecht niet gelijk gesteld dient te worden aan de specifieke publieke rechtsbelangen die de staatsorganen dienen te behartigen. De aanwijzing van deze publieke belangen en de toedeling van de formele bevoegdheid tot behartiging daarvan geschiedt door het tot deze rechtsvorming (positivering) bevoegde hogere staatsorgaan - primair door de (Grond)wetgever - op basis van een afweging van de bijzondere rechtsbelangen en van eventueel reeds eerder aangewezen publieke rechtsbelangen. De door staatsorganen te behartigen publieke rechtsbelangen kunnen immers wisselen naar gelang van de historische omstandigheden waaronder de overheid haar taak heeft te vervullen ${ }^{91}$.

Wat de specifieke, door de overheid te behartigen belangen betreft, verdient het ook aanbeveling om - in plaats van publieke belangen - te spreken van publieke rechtsbelangen c.q. publiekrechtelijke belangen. Daarmee wordt duidelijker aangegeven dat het niet de overheidsadministratie zelf is die bepaalt welke belangen zij heeft te 
behartigen, maar dat een belang eerst dan een door de overheid te behartigen belang is, indien dit belang door een daartoe bevoegd hoger staatsorgaan ter behartiging is opgedragen aan die administratie en daartoe bevoegdheden zijn verleend. Essentieel is hier het beginsel van de (representatieve) democratie.

Böckenförde heeft er op gewezen dat, indien men het democratiebeginsel in acht wil nemen en de grenzen tussen Staat en 'maatschappij' ('Gesellschaft') niet volledig wil laten vervloeien, een principieel onderscheid moet worden gemaakt tussen enerzijds 'staatliche' c.q. 'öffentlich-rechtliche Aufgaben' en anderzijds 'gesellschaftliche Aufgaben' ${ }^{2}$. Daarmee wordt niet ontkend dat er binnen de 'maatschappij' door individuen en niet-statelijke verbanden allerlei taken worden verricht, waarbij een gemeenschappelijk (collectief) belang - als aanduiding van de parallelle belangen van een aantal personen - in het geding is. Böckenförde spreekt hier van 'öffentliche Aufgaben'. Maar daarmee zijn het nog geen statelijke c.q. publiekrechtelijke taken:

'(N)icht in Abrede (wird) gestellt, dass innerhalb der Gesellschaft in vielfaltiger Weise ôffentliche

Aufgaben ... wahrgenommen werden und auch Privatpersonen, wie etwa beim Milch- oder Lebensmittelhandel, Träger solcher öffentlicher Aufgaben sein können. Aber es folgt ... daraus noch kein Übergang in den staatlichen oder offentlich-rechtlichen Bereich' $*$.

De heantwording van de vraag. welke publieke taken tot publiekrechtelijke taken verklaard moeten worden, is een zaak van de democratisch gelegitimeerde wetgever, waarbij deze de grenzen van de eigen rechtssfeer van individuen en niet-statelijke levenskringen moet respecteren. Zo vervullen bijvoorbeeld de pers en de kerken 'öffentliche Aufgaben', die echter maatschappelijke belangen ${ }^{94}$ moeten blijven en dus niet door de Staat mogen worden overgenomen en tot publiekrechtelijke belangen gemaakt mogen worden. Dit impliceert:

'(Z)um Ausgangs- und Bezugspunkt verfassungsrechtlicher Betrachtung (nimmt man) nicht das Materiell-Öffentliche und die (materiell) öffentlichen Aufgaben ...., wie es heute zunehmend geschieht, sondern die Gegenüberstellung von staatlichen und gesellschaftlichen Aufgaben (und damit die Unterscheidungvon Staat und Gesellschaft). (...) Die entscheidendeFrage ist ..., ob eine öfentliche Aufgabe durch die Verfassung oder durch eine im Rahmen der Verfassung getroffene Entscheidungdes demokratischenGesetzgeberszu einer staatlichen Aufgabe erklärt und entsprechend organisiert ist' *

Daarbij is de beoordelingsruimte van de wetgever uiteraard niet onbeperkt:

'Es gibt etliche offentliche Aufgaben, die notwendig staatliche Aufgaben sind, wie z.B. Rechtspflege, Polizei, Sicherung nach aussen. Es gibt daneben eine breite Skala öffentlicher Aufgaben, die zu staatlichen Aufgaben erklärt werden können, aber keineswegs müssen, die daher als staatliche und gesellschaftliche Aufgaben nebeneinander wahrgenommen werden können (z.B. Schule und Bildung); es gibt schliesslich einen Bereich durchaus öffentlicher oder öffentlich relevanter Aufgaben, deren Inanspruchnahme als staatliche Aufgaben kraft grundrechtlicherVerbürgerung ausgeschlossen ist, die also der Gesellschaft allein vorbehalten sind (z.B. Pressewesen, religiös-weltanschauliches Bekenntnis)' ${ }^{\prime \text {. }}$. 
Men kan het ook zo zeggen: er zijn staatsdoeleinden die noodwendig voortvloeien uit de eigen typische structuur van de publiekrechtelijke gemeenschap, die wordt beheerst door het leidende rechtsbeginsel van het algemeen belang. We kunnen dit de primaire staatsdoeleinden kunnen noemen ${ }^{97}$. Daartoe behoort de inrichting van een publieke rechtsorde op basis van het 'Zwangsmonopol'. Dit impliceert de inrichting van politie en leger tot handhaving van binnenlandse orde en buitenlandse veiligheid. Daartoe behoort tevens het tot stand brengen en houden van een integrerende burgerrechtelijke rechtorde - teneinde een onderling maatschappelijk verkeer van individuen en gemeenschappen, op basis van de beginselen van de iustitia commutativa en de burgerlijke vrijheid en gelijkheid te waarborgen ${ }^{98}$ - alsmede de inrichting van een wetgevende, uitvoerende en onafhankelijke rechtsprekende macht ten dienste van de publieke en burgerrechtelijke rechtsbedeling (statelijk 'Zwangsmonopol'!). Maar óók behoort daartoe de totstandbrenging en het beheer van publiek domein, reeds omdat zonder publiek domein kunnen de private eigendom en de private vrijheid van iedere mens als zodanig niet tot gelding kunnen komen ${ }^{99}$.

\section{Ook de sociale Staat is gebonden aan de materiële en formele rechtsstaatsidee}

Naast de primaire, 'noodzakelijke', staatsdoeleinden zijn er staatsdoeleinden die men secundaire staatsdoeleinden kan noemen, $t$.w. de staatsdoeleinden die afhangen van het cultuur-historische ontwikkelingsniveau van de samenleving en van politieke opportuniteit. In de moderne Staat - die sociale rechtsstaat is geworden - behoren hiertoe bijv. de verschaffing van een minimum levensniveau op basis van de sociale wetgeving, huisvesting, onderwijs, zorg voor het milieu, steun aan de pers etc. Deze secundaire doeleinden zijn dus historisch variabel - en zijn in de Nederlandse Grondwet van 1983 deels vastgelegd in de vorm van sociale grondrechten -, maar moeten wèl altijd worden nagestreefd binnen de structurele grenzen van de typische aard van de Staat ${ }^{100}$. Dit betekent dat de Staat zich slechts met de publiekrechtelijke kant van de gekozen doeleinden bezig mag houden en de eigen interne rechtssfeer van de betrokken niet-statelijke samenlevingskringen moet respecteren. Het gaat om doeleinden die - in de woorden van Böckenförde - tot 'staatlichen Aufgaben erklärt werden können, aber keineswegs müssen, die daher als staatliche und gesellschaftliche Aufgaben nebeneinander wahrgenommen werden können'. Het betreft hier 'maatschappelijke belangen' die een vervlechting met publiekrechtelijke belangen vertonen. Deze vervlechting betreft wederom de externe, publiekrechtelijke kant en maakt die 'maatschappelijke belangen' dus niet tot publiekrechtelijke belangen. Voorzover bepaalde maatschappelijke activiteiten uit een oogpunt van algemeen belang door de Staat worden gesubsidieerd, betekent dit dus niet dat ze daarmee publiekrechtelijk worden. Ten onrechte meent Van Kreveld, dat gesubsidieerde activiteiten op welzijnsterrein door het aandeel dat de overheid daarin in financieel opzicht neemt, geleidelijk tot overheidstaken zijn geworden. Hij betoogt zelfs: 
'De verstatelijkte 'particuliere' instellingen zijn in wezen overheidsinstellingen" ${ }^{101}$.

Daarin ziet hij de rechtvaardiging - ja zelfs de plicht - van de overheid om aan de subsidieverlening vergaande voorschriften te verbonden, en om ze om te bouwen tot zelfstandige bestuursorganen. Deze opvattingen zijn terecht gekritiseerd door J. Donner $^{102}$ en De Haan ${ }^{103}$. Donner wijst er o.a. op, dat ten tijde van de onthoudingsstaat talloze activiteiten op particulier initiatief (armenzorg, welzijn, onderwijs) werden ondernomen en, door de lage belastingtarieven, ook door particulieren geheel zelf bekostigd konden worden. De gewijzigde opvattingen omtrent de staatsonthouding en de ontwikkeling der denkbeelden betreffende belastingheffing en overheidslebingen leidden echter tot steeds hogere belastingen en daardoor tot een steeds verdergaande beperking van de mogelijkheden van particulieren om aan allerlei activiteiten financieel bij te dragen. Gelden die voorheen door particulieren aan bepaalde activiteiten beschikbaar konden worden gesteld, bereikten sommige van die activiteiten nu door tussenkomst van de fiscus in de vorm van subsidie.

Van Kreveld verliest uit het oog, dat de grondgedachte van subsidiëring is - of althans behoort te zijn - dat een 'maatschappelijke' activiteit aanspraak op financiële ondersteuning van staatswege verdient omdat deze activiteit een publiekrechtelijke vervlechting vertoont. De subsidiëring heeft een publiekrechtelijk karakter, doch de gesubsidieerde activiteit blijft op zichzelf een 'maatschappelijke', zij het in externe publiekrechtelijke vervlechting ${ }^{104}$. Dat betekent dat de overheid niet door het stellen van subsidievoorschriften de eigen verantwoordelijkheid van de particulier voor de gesubsidieerde, 'maatschappelijke' activiteiten kan uithollen of zelf teniet doen. Bij een 'verstatelijking' heeft de subsidie echter geen zin meer en ligt het voor de hand, dat de Staat zelf de bewuste activiteiten ter hand neemt. Te vér gaande subsidievoorschriften werken juist de verstatelijking in de hand. Böckenförde betoogt:

'Die Frage einer gezielten staatlichen Förderung bzw. Subvention stellt sich nicht in Hinblick auf die öffentliche Relevanz, sondern im Hinblick auf die Verantwortung des Staates für die Erhaltung gesellschaftlicher Freiheit, wozu heute in einem gewissen Umfang auch die Garantie der sozialen Voraussetzungender Freiheit gehôrt' ${ }^{105}$.

Dit is o.i. enigszins ongelukkig uitgedrukt: juist omdat bij de behartiging van een 'maatschappelijk' belang tevens een publiekrechtelijk belang - een 'öffentliche Relevanz' - aanwezig wordt geacht, vindt subsidiëring plaats.

Maar de bedoeling is duidelijk: het desbetreffende belang blijft een 'maatschappelijk' belang, zij het in externe publiekrechtelijke vervlechting. De rechtsstaat die tevens sociale Staat is, ziet het als zijn roeping, de publiekrechtelijke randvoorwaarden te creëren om het goed fungeren van een vrije 'maatschappij' op terreinen als ruimtelijke ordening, woningbouw, onderwijs, gezondheidszorg, sociale zekerheid etc. mogelijk te maken en om, voorzover er door de botsing van belangen publiek onrecht zou ontstaan, niet-statelijke levenskringen in staat te stellen in vrijheid en naar eigen inzicht aan hun eigen taak toe te komen. Men kan mét Faber constateren, dat 
de moderne bestuurstaak gekenmerkt wordt door de algemene zorg voor de 'maatschappelijke' infrastructuur ('Infrastrukturverwaltung') ${ }^{106}$. Mannheim heeft er al op gewezen dat het karakter van de moderne 'maatschappij', waarin de noodzaak tot afstemming van belangen van individuen en groeperingen groter dan ooit is, planning noodzakelijk maakt. In een rechtsstaat dient dit 'planning for freedom' te zijn, dat wil zeggen: een planning die de gunstigst mogelijke voorwaarden schept voor het private initiatief ${ }^{107}$. De Staat 'helpt' hier 'de maatschappij'; hij dient zich niet in haar plaats te stellen en mag niet treden in de persoonlijke levenssferen van individuen en in de interne sferen van school, bedrijf, school, universiteit, kerk, gezin. De Staat kan slechts opereren tot aan de rand van deze sferen, tot aan de grens tussen het eigen erf van de niet-statelijke samenlevingskringen en het publieke erf met het oog op de publieke voorwaarden voor het fungeren van deze pluriforme kringen binnen de integrerende statelijke rechtsorde mogelijk blijft.

Uit het in Artikel 20 Abs. 1 Grundgesetz neergelegde 'Sozialstaatprinzip' vloeit volgens het Bundesverfassungsgericht voort, dat de Staat in ieder geval ervoor moet zorgen dat een menswaardig bestaan mogelijk is en blijft. De wetgever heeft de verplichting 'sich um einen erträglichen Ausgleich der widerstreitenden Interessen und um die Herstellung erträglicher Lebensbedingungen .... zu bemühen' ${ }^{108}$. Gezien de omvang en onbepaaldheid van dit beginsel is echter '(lediglich) zwingend ..., dass der Staat die Mindestvoraussetzungen für ein menschenwürdiges Dasein seiner Bürger schafft' ${ }^{109}$.

Al de genoemde doeleinden moeten worden verwezenlijkt 'in der Weise des Rechts' ${ }^{110}$, d.w.z. de materiële publiekrechtelijke beginselen die inherent zijn aan de typische eigen aard van de Staat - en dus met respectering van de interne sferen van niet-statelijke samenlevingskringen -, terwijl ook positivering door de wetgever nodig is. Er bestaat dus geen tegenstelling tussen de rechtsstaatsidee en de idee van de sociale staat.

In de eerste plaats geldt de wetmatigheidseis óók op het terrein van de Leistungs- en Infrastrukturverwaltung (het formele element van de rechtsstaatsidee), zij het dat de wettelijke grondslag - afhankelijk van de aard van de materie ${ }^{111}$ - ruim geformuleerd kan zijn en zich beperkt tot de aanwijzing van enig belang als publiekrechtelijk belang. Het Bundesverfassungsgericht oordeelt terecht, dat het in Artikel 20 Abs. 1 Grundgesetz vastgelegde 'Sozialstaatsprinzip' 'einen Gestaltungsauftrag an den Gesetzgeber (enthält)' 112 .

In de tweede plaats tast de externe, publiekrechtelijke vervlechting van 'maatschappelijke belangen' met publiekrechtelijke belangen, de interne sfeer van de nietstatelijke samenlevingsverhoudingen niet aan. De grenzen van de eigen materiële competentiesfeer en die van andere niet-statelijke rechtskringen moeten worden gerespecteerd (het materiële element van de rechtsstaatsidee). Het is dan ook gevaar- 
lijk te stellen, dat in de moderne sociale Staat de maatschappij is 'verstatelijkt' en dat, omgekeerd, de Staat is 'vermaatschappelijkt'. Het veel gebruikte beeld van de 'osmose' is o.i. dan ook ongelukkig; beter is het te spreken van externe vervlechting van correlerende niet-statelijke en statelijke belangen. De grenzen vervloeien echter volledig wanneer men, uitgaande van een formeel en leeg karakter van begrippen en -beginselen, overheid en burgers beide beschouwt als 'actoren' in een 'door openbaarheid en door pluraliteit van belangen' gekenmerkte 'publieke ruimte', welke ruimte 'bij uitstek de ruimte van het recht' is en waarin 'het individu niet meer als een volstrekt autonoom rechtssubject (wordt) geconceptualiseerd' ${ }^{113}$. Dan zijn er echter ook geen principiële beperkingen meer gesteld aan de staatsmacht en zijn er ook geen principiële grenzen meer tussen door de Staat en door niet-statelijke ('maatschappelijke') verbanden en individuen behartigde 'publieke belangen'.

\section{Böckenförde merkt op:}

'Geht man davon aus, dass Staat und Gesellschaft 'ineinanderfallen', der Staat 'Selbstorganisation der Gesellschaft' wird, so wird die politische Willensbildung, prinzipiell gesehen, weder ein 'staatlicher' noch ein 'gesellschaftlicher', sondern ein einfach 'offentlicher' Vorgang, wodurch beliebige Reglementierungen durch den Staat und beliebige Einfluss- und Autonomieansprüche durch gesellschaftliche Bildungen, und damit eine fortschreitende Parzellierung der einheitlichen politischen Entscheidungsgewaltlegitimiert werden' " 1 .

Als niet meer wordt onderscheiden tussen 'publieke' belangen en publiekrechtelijke - dat wil zeggen door de wetgever aangewezen - belangen, dan is een interne rechtssfeer van individuen en niet-statelijke verbanden tegenover de Staat niet meer gewaarborgd, terwijl die rechtssfeer eveneens kan worden aangetast door andere individuen en niet-statelijke verbanden, die zich aldus zelfstandig willen inzetten voor de behartiging van een bepaald 'publiek belang'. En als voor de behartiging van publieke belangen geen grondslag in de wet meer nodig is, verliest ook het beginsel van de representatieve democratie (de vrijheid in de Staat) zijn betekenis. Noch het democratiebeginsel noch het 'Sozialstaatprinzip' impliceren dus noodzakelijkerwijs het loslaten van het dualisme Staat-'maatschappij'. Integendeel, het 'Sozialstaatprinzip' is geen 'Gegenprinzip' van dit dualisme, maar ondersteunt het juist. De moderne Staat moet als sociale Staat de publieke voorwaarden creëren voor een vrije maatschappij:

'Der Staat ist ... ganz im Sinne der ursprünglichenZuordnung von Staat und Gesellschaft, gemäss seiner Funktion als Garant der freien Gesellschaft und ihre Grundverfassung,zur Intervention, zum gezielten Einsatz seiner hoheitlichen Regulierungsmacht gehalten, um die Gesellschaft vor ihrer Selbstzerstörung zu bewahren. (...) Das Grundgesetz hat solchem Umschlag in die Ununterscheidbarkeit von Staat und Gesellschaft vorbeugenwollen; es hat dem Sozialstaat nicht einfach freies Feld eröffennet, sondern - bewusst - Rechtsstaat und Sozialstaat nebengeordnet,d.h. in ein Verhăltnis rechtlicher Verknūpfungund wechselseitiger Begrenzunggestellt. Die auf Daseinsvorsorge, sozialen Ausgleich und soziale Umverteilung zielenden sozialstaatlichen Aktivităten, zu denen Gesetzgeber und Verwaltung ermächtigtund aufgerufensind, dispensierennicht von der Anforderungdes Rechtsstaats, insbesondereseinen Freiheitsverbürgungen für Individuenund Gesellschaft; sie müssen sich in den Rahmen rechtsstaatlicher Gewährleistungen und Begrenzungen einfügen. Das Grundgesetz 
hat ebenso wie für die Realisierung des demokratischenPrinzips auch für die staatliche Antwort auf die 'soziale Frage', die es als verfassungsrechtliches Gebot statuiert, die Unterscheidungvon Staat und Gesellschaft fest- und offengehalten' "is.

Dit moet bij voorbeeld betekenen dat ook de in de Duitse Grondwet opgenomen 'Sozialstaatklausel' (artt. 20 Abs. 1 en 28 Abs. 1) op zichzelf aan 'de overheid' geen bevoegdheid kan geven om in te grijpen in de vrijheidssfeer van burgers en maatschappelijke verbanden. Hierboven werd er reeds op gewezen dat algemeen is aanvaard dat de in de Duitse Grondwet opgenomen grondrechten weliswaar, mede in verband met de 'Sozialstaatklausel', ook verplichtingen inhouden voor de Staat om actief bij te dragen aan de realisering van die grondrechten, doch dat zulks primair een opdracht behelst aan de democratisch gelegitimeerde wetgever. Deze moet 'de overheid' daartoe de nodige bevoegdheden verlenen; enkel op grondrechten kunnen geen overheidsbevoegdheden gebaseerd worden.

Samenvattend: een publiek belang is eerst een publiekrechtelijk d.w.z. statelijke belang, wanneer dit belang als zodanig is aangewezen op basis van een beslissing van de democratisch gelegitimeerde wetgever. Hierbij geldt zowel een materieel criterium (het belang moet passen bij de publiekrechtelijke bestemmingsfunctie; de eigen private sfeer van individuen en groepen moet worden erkend en gewaarborgd) als een formeel criterium (de aanwijzing en positivering van dat belang door een daartoe competent orgaan).

\section{'Algemeen belang' en 'publiekrechtelijke belangen' versus 'eigen belang' en collectieve belangen'}

Wat nu opvalt in vele beschouwingen - en ook in jurisprudentie - waarin een lans wordt gebroken voor civiele 'algemeen belang-acties' ${ }^{116}$, is het ongedifferentieerde, 'nivellerende' gebruik van termen als 'algemeen belang', 'algemene belangen', 'openbare belangen', 'collectieve belangen', 'eigen belang van de overheid' etc. worden gebruikt en dóór elkaar worden gebruikt. Gesproken wordt ook van behartiging door private belangenorganisaties van 'een algemeen belang als het behoud van het milieu' 117 .

Er is slechts het algemeen belang, het leidende beginsel in het publiekrecht, dat we eerder in positieve zin omschreven als het beginsel van de iustitia distributiva, dat eist dat alle bijzondere belangen van individuen en groepen worden erkend, afgewogen en geharmoniseerd in dat algemeen belang. En daartoe is slechts de Staat als publiekrechtelijk territoriaal verband in staat.

We kunnen dan ook niet instemmen met de centrale stelling van een in 1988 verschenen opstellenbundel met de titel 'Publiek domein (De veranderende balans tussen staat en samenleving)'. Deze stelling luidt: 
'dat zaken van algemeen belang niet uitsluitend vanuit de overheid behartigd (behoren te) worden. Daarmee wordt afstand genomen van de idee - nog steeds prominent aanwezig in de huidige verzorgingsstaatdiscussie - dat slechts de overheid in staat zou zijn het algemeen belang te behartigen' "'s.

Koekkoek neemt in zijn opstel in deze bundel o.i. terecht afstand van het ruime begrip 'publiek domein', zoals die elders in de bundel wordt gehanteerd:

'(P)ubliek domein' (kan) beter gereserveerd ... worden voor het terrein waar de overheid, als hoedster van het algemeen belang een taak heeft' "'.

Vervolgens spreekt Koekkoek niet meer van 'publiek domein', maar van 'overheidszorg'.

'Publiekrechtelijke belangen' zijn de specifieke belangen die door de wetgever als door de overheid te behartigen belangen zijn aangewezen, en is dus niet hetzelfde als 'collectieve belangen'. 'Collectieve belangen' zouden we willen omschrijven als de met elkaar corresponderende belangen van een groter aantal individuen en/of sociale collectiviteiten. Verburgh hanteert een ruimere omschrijving en onderscheidt collectieve acties in groepsacties en algemeen belang-acties ${ }^{120}$. Onder groepsacties verstaat hij collectieve acties waarbij de personen om wier belangen het gaat zijn te individualiseren, zij het wellicht - door de kwantiteit - met de grootste moeite. Algemeen belang-acties noemt hij de acties waarbij de personen om wie het gaat niet zijn te individualiseren, omdat het belangen betreft van een zo algemeen karakter, dat zij een facet vormen van vrijwel ieders bestaan. Daarbij merkt hij op dat de grens tussen beide soorten acties vaag en vloeiend is. Het zal duidelijk zijn geworden, dat wij het ongewenst achten om 'algemeen belang' gelijk te stellen met 'collectieve belangen'. Dergelijke belangen kúnnen publiekrechtelijke belangen worden, maar pas als ze als zodanig door de wetgever zijn aangewezen en daartoe aan de overheid de benodigde publiekrechtelijke bevoegdheden zijn toegekend.

De overheid heeft nimmer eigen belangen - althans niet in de zin van private (vermogens)belangen - zoals de memorie van toelichting bij het wetsvoorstel collectief actierecht wil doen geloven ${ }^{121}$, met een verwijzing naar o.a. het arrest-Staat/Van Amersfoort ${ }^{12}$. Beslist onjuist is ook het door ons reeds besproken arrest 'StaatMagnus', waarin de Hoge Raad kennelijk aanneemt dat door publiekrechtelijke - bevoegdheidsverlenende - voorschriften tevens eigen - 'private' - vermogensbelangen van 'de overheid' zelf worden beschermd ${ }^{123}$. Hier worden de structuurverschillen tussen publiekrecht en burgerlijk recht uit het oog verloren en vindt weer een vermenging plaats van 'imperium' (overheidsmacht) en 'dominium' (privaat subjectief vermogensbelang), die zo kenmerkend was voor het feodale bestel. 


\section{Nogmaals: 'politie' en publiek domein}

Een ware private sfeer voor allen is slechts mogelijk wanneer er ook een werkelijk publieke sfeer bestaat, zo schreven we eerder. In zijn 'Handleiding tot de kennis van het administratief regt in Nederland' schrijft De la Bassecour Caan onder het kopje 'Politieregt ten aanzien der wegen':

'Het is van het grootste gewigt, dat er goede middelen van gemeenschap bestaan, want waar deze ontbreken of onvoldoendezijn, wijkt het vertier en is geen handel mogelijk ${ }^{124}$.

De wegen zijn uit hunnen aard bestemd ten publieke nutte, ten dienste van een ieder, die daarvan gebruik maakt. Derhalve behooren zij, met betrekking tot den grond, in eigendom toe aan allen of aan niemand. Door hunne bestemming zijn zij zaken buiten den handel' (curs. door auteur; JT) ${ }^{13}$.

En voor een (negatieve) omschrijving van 'publiek domein' verwijst hij naar art. 2 van Franse Wet van 1 december 1790 'relative aux Domaines nationaux' (Deze omschrijving is later overgenomen in art. 531 Code Civil):

'Les chemins publics, les rues et places des villes, les fleuves et rivières navigables, les rivages, lais et relais de la mer, les ports, les havres, les rades. etc., et en général toutes les parties du territoire national, qui ne sont pas susceptibles d'une propriété privée, sont considérées comme des dépendances du domaine public'.

De Staat is - aldus De la Bassecour Caan - van de goederen welke tot nut en ten dienste van het algemeen strekken, geen eigenaar maar oefent daarover 'alleen politiemagt' uit ${ }^{126}$. Ook Olivier wijst er op, dat de Staat geen 'bijzondere eigendom' kan hebben ten aanzien van de ten openbare nutte bestemde zaken. De in art. $577 \mathrm{BW}$ (oud) genoemde bevaarbare en vlotbare stromen en rivieren met hun oevers zijn - aldus Olivier - het uitsluitend en onvervreemdbaar eigendom van de Staat:

'Uitsluitend omdat zij, uit den aard der zaak, tot gemeen gebruik van allen en een iegelijk dienen, en het niet in de magt van éénen behoort te zijn, te beschikkenover wat aan allen toebehoort; onvervreemdbaar, omdat de staat, de rivieren en stroomen niet bezit als een domein iure privato, maar krachtens zijne regeeringsbevoegdheid,krachtens zijn verpligting om toe te zien en te zorgen, dat aan de regten van het publiek geene afbreuk wordt gedaan' (curs. door auteur; JT) ${ }^{12}$.

Olivier gebruikt dus wel de term 'eigendom' als aanduiding voor het recht van de Staat op het publiek domein, maar hij onderscheidt dit principieel van de burgerrechtelijke eigendom ${ }^{128}$. Ook in de toelichting op het voorstel dat leidde tot de Franse Wet van 1 december 1790 worden de hier bedoelde zaken als 'une veritable propriété' aangemerkt, maar wél als 'propriété publique'. En daar wordt aan toegevoegd:

'(L)a nation ... exerce incontestablementsur elles (t.w. 'ces choses'; JT) les droits de souveraineté qui dérivent de la suprématie territoriale' 12 .

We wezen er in Deel 1 op dat onder de politiestaat 'soevereiniteit' en 'politie' onlosmakelijk aan elkaar waren geklonken. Voorts wezen we er op, dat met de Franse revolutie de in de leer van het 'dominium eminens' besloten vermenging van 'imperium' ('publieke' bevoegdheden) en privaat 'dominium' definitief moest worden verlaten: het overheidsgezag op het territoir werd niet langer beschouwd als een soort 'private' eigendom, waarin ook de gezagsbevoegdheden zijn gefundeerd ${ }^{130}$. 
Dat betekende dat de verschillen tussen privaat domein (burgerrechtelijke eigendom) enerzijds en publiek domein (publiekrechtelijke eigendom) scherp(er) moesten worden aangezet. Burgerrechtelijke eigendom is gebonden aan de typisch burgerrechtelijke beginselen van de iustitia commutativa en de burgerlijke vrijheid en gelijkheid, en impliceert de volstrektste beschikkingsbevoegdheid en het vrije genotsrecht over het object van de eigendom, behoudens uitdrukkelijk door de democratisch gelegitimeerde wetgever gestelde begrenzingen. Dit betekende dat er daarnaast niet krachtens een 'dominium eminens' of een algemene 'politiebevoegdheid' nog 'hoogheidsrechten' van de overheid op dat domein konden bestaan: ook publiekrechtelijke beperkingen op de private eigendom zouden dus in beginsel steeds een uitdrukkelijke wettelijke basis behoeven. We beschreven in dit verband de ontwikkeling die uitmondde in het Meerenbergarrest van 1879, waaruit naar voren komt dat men het private domein van de burger - zijn 'eigendom' - wilde beschermen met de uitbreiding van het materiële wetsbegrip. We bespraken ook ná dit arrest gewezen jurisprudentie, waaruit blijkt dat aan het publieke domein nog 'politiebevoegdheden' inherent werden geacht. Kenmerkend is - in de woorden van Otto Mayer - enerzijds 'das Recht auf Gemeingebrauch' van allen, binnen de grenzen die bepaald worden door de publieke functie, en anderzijds 'die Polizei der öffentlichen Sache', welke laatste ertoe strekt te voorkomen dat aan de publieke functie afbreuk wordt gedaan ${ }^{13 !}$. De 'heerschappij van het publiekrechtelijk lichaam over de publieke zaak' lost zich - aldus Vos - op in 'een publieke eigendom, die uitsluitend bestaat in bestuursbevoegdheden, strekkende om de zaak aan hare publieke bestemming te doen beantwoorden, waarvan de bevoegdheid om gebruiksrechten van derden op de zaak van een voorafgaande vergunning afhankelijk te stellen, een onderdeel vormt' ${ }^{132}$.

De door Vos in 1931 nog als 'onmogelijk' aangeduide opvatting, dat de Staat privaatrechtelijk eigenaar zou zijn van publieke zaken, werd echter bij het Parlevinkerarrest ${ }^{133}$ aanvaard als de 'ten onzent heerschende leer, volgens welke het recht van den Staat op voor den openbaren dienst bestemde zaken zich niet onderscheidt van den privaat-eigendom van bijzondere personen' ${ }^{134}$. In dit arrest wordt het toelaatbaar geacht dat voor het parlevinken op het Merwedekanaal, nást een publiekrechtelijke vergunning krachtens het Algemeen reglement van politie voor rivieren en Rijkskanalen, door het Domeinbestuur (namens de Staat) een civielrechtelijke overeenkomst wordt gesloten strekkende tot verlening van een 'privaatrechtelijke vergunning' voor dit bijzonder gebruik van het kanaal tegen een contraprestatie van een jaarlijks aan de Staat te betalen vergoeding. Het was precies deze handelwijze van het Domeinbestuur, die door Vos is bestreden. Vos is weliswaar van mening dat publieke zaken, voor zover de publieke functie dit toelaat, kunnen worden bezwaard met gebruiksrechten ten behoeve van particulieren, 'maar niet in 
de vorm van civielrechtelijke overeenkomsten, doch langs de weg van vergunningen en concessies'. De bevoegdheid om zodanige gebruiksrechten van een voorafgaande vergunning of concessie afhankelijk te stellen, zou in de visie van Vos onderdeel zijn van 'de heerschappij van het publiekrechtelijk lichaam' (de publieke eigendom). Gaat men uit van deze - o.i. juiste - visie, dan zou de vergunningsregeling in het Algemeen reglement moeten worden beschouwd als een lex specialis ten opzichte van dit algemene beheers'recht'. De vraag in de Parlevinker-casus had dan ook moeten luiden: staat het de Staat vrij het parlevinken, behalve van een publiekrechtelijke vergunning krachtens dit reglement, ó k nog krachtens zijn algemene beheerstaak afhankelijk te stellen van een publiekrechtelijke toestemming waaraan een financieel voorschrift is verbonden ${ }^{135}$.

Het Parlevinkerarrest en latere arresten als het IJsselmeerarrest, het arrestEindhoven/Staat en het Windmillarrest, worden gezien als toepassingen van wat in Nederland de gemene rechtsleer wordt genoemd, op welke leer de twee-wegenleer wordt gebaseerd. Daarbij is de vraag aan de orde naar het toepassen door de overheid van 'privaatrechtelijke bevoegdheden' náást of in plaats van publiekrechtelijke bevoegdheden. Het zal duidelijk zijn dat het $0 . i$. juister ware geweest, wanneer de Hoge Raad desbetreffende casus had behandeld in het kader van een publiekrechtelijke twee-wegenleer.

Dergelijke jurisprudentie zegt méér over het 'burgerlijk regtsoog' (Thorbecke) van de gewone rechter dan over het karakter van het publiek domein en van het burgerlijk recht. Uit deze jurisprudentie komt in het geheel niet naar voren, waarom de opvatting juist zou zijn, dat het publiek domein 'zich niet onderscheidt van de privaat-eigendom'. Ook hier wreekt zich het rechtspositivistische karakter van deze jurisprudentie: om na te gaan, ó en zo ja, in welke opzichten, publiek domein en private eigendom van elkaar verschillen, zou toch een onderzoek moeten worden ingesteld naar de materiële, inhoudelijke aard van beide vormen van 'eigendom', en meer algemeen: naar de materiële, inhoudelijke structuurverschillen tussen publieken privaatrecht, c.q. de materiële aard van de menselijke samenlevingsverhoudingen waarbinnen deze vormen van eigendom fungeren.

\section{Het Bundesverfassungsgericht over publiek domein ${ }^{136}$}

Van een materiële benadering geeft wél de jurisprudentie van de Duitse constitutionele rechter, het Bundesverfassungsgericht, blijk. Zijn uitspraken betreffende het publiek domein zijn juist zo belangwekkend vanwege de door deze rechter gehanteerde argumenten, de overwegingen waarop deze uitspraken zijn gebaseerd. In dit verband kan in de eerste plaats gewezen worden op de jurisprudentie met betrekking tot de in Artikel 14 Grundgesetz vervatte 'Eigentumsgarantie'. Deze bepaling luidt: 
'1. Das Eigentum und das Erbrecht werden gewăhrleistet. Inhalt und Schranken werden durch die Gesetze bestimmt.

2. Eigentum verpflichtet. Sein Gebrauch soll zugleich dem Wohle der Allgemeinheit dienen.

3. Eine Enteignung ist nur zum Wohle der Allgemeinheit zulāssig. Sie darf nur durch Gesetz oder auf Grund eines Gesetzes erfolgen, das Art und Ausmass der Entschãdigung regelt (...)'.

'Eigentum' (en ook 'Enteignung') moet blijkens de jurisprudentie ruim worden uitgelegd, en ziet in ieder geval op de subjectieve private vermogensrechten in ruime zin ('vermögenswerte Rechte'), zoals die zijn erkend en gepositiveerd door het burgerlijk recht. Verder is van belang dat het in Artikel 2 Abs. 1 Grundgesetz erkende juridisch persoonlijkheidsbeginsel mede de 'allgemeine Handlungsfreiheit' waarborgt - als 'Auffangsgrundrecht' -, die blijkens de jurisprudentie met name ook de vrije beschikking over het eigen vermogen, de handelingsvrijheid in het economisch verkeer en - meer algemeen - de contractsvrijheid omvat, één en ander voor zover niet reeds beschermd door Artikel 14. Deze eigendom - en de daarmee correlate vrije beschikkings- en genotsbevoegdheid van de subjectief gerechtigde over het object van zijn subjectief vermogensrecht - alsmede de contracts- en testeervrijheid behoren tot het kernbestand van het burgerlijk recht:

'Art. 14 GG will das Eigentum so schützen, wie das bürgerliche Recht und die gesellschaftliche Anschauungenes geformt haben. (...) Die verfassungsrechtliche Gewăhrleistungbesteht hinsichtlich der durch die Rechtsordnung anerkannten einzelnen Vermögensrechte. (...) Art. 2 Abs. 1 GG gewährleistet die allgemeine Handlungsfreiheit. Hierzu zählt neben der Freiheit im wirtschaftlichen Verkehr ... auch die Vertragsfreiheit' 137 .

Deze 'eigendom' wordt - aldus het Bundesverfassungsgericht in een vaste jurisprudentie - gekenmerkt door:

'Privatnützigkeitund grundsătzlicheVerfügungsbefugnis des Eigentumersüberden Eigentumsgegenstand. (...) Es soll im als Grundlage privater Initiative und in eigenverantwortlichemprivaten Interesse von Nützen sein' 138 .

Omdat de 'Privateigentum' in nauw verband staat met de burgerlijke vrijheid en een constituerend element is van de burgerlijke rechtsorde, mogen staatsorganen bij hun publiek- en burgerrechtelijke 'Ausformung' van de private eigendom (vormgeving!) ${ }^{139}$ niet zo ver gaan dat deze eigendom zodanig wordt uitgehold dat van private eigendom niet meer kan worden gesproken (= 'Enteignung'), terwijl bij deze 'Ausformung' ook steeds de 'Verhältnismässigkeitsgrundsatz' ${ }^{140}$ in acht moet worden genomen. Daarom ook heeft Artikel 14 in de opvatting van het Hof ook een institutionele inslag, in die zin dat het het bestaan en voortbestaan van de 'Privateigentum' als rechtsinstituut ('Rechtsinstitut', 'Rechtseinrichtung') vooropstelt:

'Art. 14 Abs. 1 Satz 1 GG gewährleistet das Privateigentum sowohl als Rechtsinstitut wie auch in seiner konkreten Gestalt in der Hand des einzelnen Eigentümers. Das Eigentum ist ein elementares Grundrecht, das in einem inneren Zusammenhang mit der Garantie der persönlichen Freiheit steht. Ihr kommt im Gesammtgefügeder Grundrechtedie Aufgabe zu, einen Freiheitsraum im vermögensrechtlichen Bereich sicherzustellen und ihm dadurch eine eigenverantwortliche Gestaltung des Lebens zu ermöglichen. Die Garantie des Eigentums als Rechtseinrichtungdient der Sicherungdieses Grundrechts' ${ }^{141}$. 
Hier kan nog aan worden toegevoegd dat, terwijl aanvankelijk nog werd aangenomen dat 'öffentlich-rechtlich begründete vermögenswerte Positionen' nimmer zouden zijn aan te merken als 'Eigentum' en daarom zouden vallen buiten de grondwettelijke bescherming van Artikel 14, in latere jurisprudentie is aanvaard dat deze bescherming $606 \mathrm{k}$ kan gelden 'wenn der ein subjektiv-öffentliches Recht begründende Sachverhalt dem Einzelnen eine Rechtsposition verschafft, die derjenigen des Eigentümmers entspricht'. Dit is het geval bij aanspraken uit hoofde van sociale verzekeringen, dit ondanks het feit dat bij met name de verplichte sociale verzekeringen de 'freie Verfügungsbefugnis' ten aanzien van het object van het publieke subjectieve recht ontbreekt ${ }^{142}$.

Ondanks de ruime betekenis van 'Eigentum' in Artikel 14, ligt het gelet op de functie van de 'Eigentumsgarantie' - bescherming van (in ieder geval) de door 'Privatnützigkeit' en 'grundsätzliche Verfügungsbefugnis' gekenmerkte 'Privateigentum' echter niet voor de hand, dat óók zaken met een publieke functie (zoals openbare wegen) daardoor worden bestreken. In de 'Sassbach-Entscheidung' van het Bundesverfassungsgericht van 8 juli 1982 luidt het dan ook:

'Soweit gemeindliches Eigentum der Erfullung öffentlicher Aufgaben gewidmet ist, kommt ein

Grundrechtsschutzohnehin von vornherein nicht in Betracht' ${ }^{\text {10? }}$.

Het publieke domein is naar zijn aard geen burgerrechtelijke eigendom, ook al noemt men het zo. In zijn uitspraak inzake het Hamburger Deichordnungsgesetz overweegt het Bundesverfassunsgericht dan ook dat, als het karakter van dergelijke zaken wordt geformaliseerd, doordat de door de wetgever worden bestempeld tot 'öffentliches Eigentum' en - ook formeel - onttrokken aan het burgerlijk recht, niet kan worden gesproken van een aantasting van het door Artikel 14 gewaarborgde rechtsinstituut van de 'Privateigentum':

'Werden Sachen dieser Art, wenn sie sich in der Hand des Staates befinden, grundsătzlich aus der Privatrechtsordnung herausgenommen und einer ausschliesslich öffentlich-rechtlichen Sachherrschaft unterstellt, die man als 'öffentliches Eigentum' bezeichnet, so liegt darin jedenfalls dann keine Schmälerung des durch Art. 14 Abs. 1 GG gewährleistetenRechtsinstituts, wenn diese Sachen einem besonderen öffentlichen Zweck gewidmet sind und im Hinblick auf diese Zweckbindung die private Verfügungsbefugnisganz oder weitgehend ausgeschlossen ist' 14 .

In de tweede plaats zij gewezen op de jurisprudentie van het Bundesverfassungsgericht met betrekking tot Artikel $74 \mathrm{Nr}$. 1 jo. Artikel 72 Grundgesetz, met name op een uitspraak van 10 maart $19766^{145}$. Deze uitspraak maakt nóg duidelijker, waarom publiek domein geen burgerrechtelijke eigendom is. In deze uitspraak ging het om de vraag, of het Hamburgse Wegegesetz in strijd was met genoemde artikelen van het Grundgesetz, waarin is neergelegd dat (o.a.) de wetgeving op het terrein van het burgerlijk recht behoort tot de zgn. concurrerende bevoegdheden. Dit betekent dat voor zover de Bond van een concurrerende bevoegdheid gebruik heeft 
gemaakt, de deelstaten niet meer bevoegd zijn. In het Hamburgse Wegegesetz worden de aan de stad toebehorende wegen uitdrukkelijk gekwalificeerd als 'öffentliches Eigentum' mét de bepaling dat het burgerlijk recht daarop niet toepasselijk is (Zie Par. 4 Abs. 1 Wegegesetz). In casu was een burger op grond van de aansprakelijkheidsbepaling in deze wet door de stad Hamburg aangesproken tot vergoeding van de door hem aan een openbare weg toegebrachte schade. Het door hem tegen het 'Kostenbescheid' bij de administratieve rechter ingestelde beroep werd tot in hoogste instantie - het Bundesverwaltungsgericht - afgewezen. Toen hiertegen door betrokkene vervolgens een Verfassungsbeschwerde werd ingediend, moest door het BVerfG de vraag worden beantwoord of sprake was van een schending van het grondrecht ex Artikel 2 Abs. 1 Grundgesetz. Dit grondrecht verbiedt, aldus het Hof:

'Eingriffe der Staatsgewalt, die nicht rechtsstaatlichsind. Insbesonderedarf ein Bürger nur aufgrund solcher Vorschriften mit einem Nachteil belastet werden, die formell und materiell der Verfassung gemalss sind und deshalb zur verfassungsmăssigenOrdnung gehôren'.

Door betrokkene was aangevoerd dat het Hamburgse Wegegesetz, in het bijzonder de daarin opgenomen schadevergoedingsregeling, in strijd kwam met Artikel $74 \mathrm{Nr}$. 1 jo. Artikel 72 Grundgesetz, omdat met het Bürgerliches Gesetzbuch (BGB) zou zijn beoogd een uitputtende regeling te geven voor alle 'Sachen' (par. 90 BGB) en de stad Hamburg haar wetgevende bevoegdheid ${ }^{146}$ zou hebben overschreden door in haar Wegegesetz de aan deze stad toebehorende openbare wegen te kwalificeren als 'öffentliches Eigentum' en te onttrekken aan het regime van het burgerlijk recht. fet Bundesverfassungsgericht dacht er anders over en overwoog dat het de deeIstaten weliswaar ingevolge Artikel $74 \mathrm{Nr} .1$ Grundgesetz niet is toegestaan burgerrechtelijke normen te stellen die afwijken van het Bürgerliches Gesetzbuch, maar dat de in het Wegegesetz van Hamburg opgenomen regeling inzake 'öffentliches Eigentum' - inclusief de aansprakelijkheidsbepaling voor schaden veroorzaakt aan zodanig eigendom - niet is aan te merken als regeling van 'burgerlijk recht' (in de zin van Artikel $74 \mathrm{Nr}$. 1 Grundgesetz en van het BGB). Het is immers, aldus het Hof, zonder meer duidelijk:

'dass die Rechtsverhăltnisse an den öffentlichen Strassen sich in dieses Konzept nicht einordnen lassen. Diese für den allgemeinen Verkehr geschaffene und hierfür gewidmete sowie für seine Zwecke unterhaltene Verkehrsfläche ist in tatsāchlicher Hinsicht durch Besonderheitengeprägt, die mit dem Wesen und der Funktion des bürgerlichen Rechts kaum noch einen Zusammenhang aufweisen. Die öffentlicheStrasse kann als Verwaltungsleistungweder mit dem für das Privatrecht und keineswegs allgemein geltenden Sachbegriff des Par. 90 BBG noch mit dem Eigentumsbegriff des BGB sachgerecht erfasst werden, sondern fordert ihrer Funktion nach eine vom bürgerlichen Recht abweichendeRegelung der 'Sachherrschaft'. Ihr Inhalt wird durch das ôffentlich-rechtliche, auf die Allgemeinheit ausgerichtete Element bestimmt. (...) Das öffentliche Eigentum begründet eine "hoheitliche Sachherrschaft' "

'Hoheitliche Sachherrschaft' is o.i. het best te vertalen als: publiekrechtelijk(e) beheer c.q. beheerstaak. De conclusie moest dan ook luiden: 
'Die Beschreibungder Sachherrschaftūber die Strasse als 'Eigentum' - das im übrigen durch seine Fremdnùtzigkeit gekennzeichnet ist - lâsst nicht den Schluss zu, dass es sich hier um bürgerliches Recht im Sinne der Kompetenzzuteilung handelt. Dem Bund kommt demgemăss eine Gesetzgebungszustăndigkeitfür die Strassen der Lănder nicht zu'.

Het in de competentienorm van Artikel $74 \mathrm{Nr}$. 1 Grundgesetz gebruikte begrip 'bürgerliches Recht' moet worden geïnterpreteerd in het licht van een lange rechtshistorische ontwikkeling. Bij de totstandkoming van het BGB is - aldus het BVerfG gebroken met opvattingen zoals die tot uitdrukking kwamen in oudere codificaties, waarin het privaatrecht 'noch am Modell einer umfassenden Sozialordnung orientiert war, in dem Öffentliches und Privates miteinander verwoben waren'. Die 'Sozialordnung' werd - zo merkten wij eerder op - nog gekenmerkt werd door een ongedifferentieerde vermenging van 'imperium' ('overheidsrechten') en 'dominium', hetgeen ook tot gevolg had dat overheidsrechten nog werden beschouwd als privaat bezit en als 'zaken in den handel'. Ten tijde van de totstandkoming van het BGB:

'gewann die Vorstellung, privates und öffentliches Recht seien zwei sich prinzipiell ausschliessende Rechtsgebiete, praktische und entscheidungserhebliche Bedeutung. (...) Bürgerliches Recht wurde wesentlich als die Ordnung der Individualverhältnisseverstanden. Die Beziehungendes einzelnen zu den öffentlichen Einrichtungen bewegten sich prinzipiell ausserhalb des bürgerlichen Rechts'. Ofschoon het Bundesverfassungsgericht de conclusie van het Bundesverwaltungsgericht - nl. dat de stad Hamburg met de gewraakte bepalingen van haar Wegegesetz haar wetgevende bevoegdheid niet had overschreden - onderschreef, was zijn motivering een principieel andere dan die van de hoogste administratieve rechter.

Het Bundesverwaltungsgericht ${ }^{147}$ had $\mathrm{nl}$., in aansluiting aan de jurisprudentie van de hoogste civiele rechter (het Bundesgerichtshof) ${ }^{148}$, voorop gesteld dat ervan moest worden uitgegaan 'dass das Bürgerliche Gesetzbuch das Eigentum auch nach öffentlichem Recht, nicht nur nach privatem Recht abschliessend hätte regeln können' (curs. dzz.; JT). Het begrip 'Sache' in Par. 90 BGB zou ook de publieke eigendom includeren. Omdat evenwel het BGB niet een uitputtende regeling van de publieke eigendom bevat, zou het ingevolge Artikel 3 van het Einführungsgesetz BGB de deelstaten niet zijn verboden een eigen regeling te geven van de publieke eigendom. Van deze mogelijkheid zou door de Hamburgse wetgever gebruik zijn gemaakt.

Het BVerfG oordeelde daarentegen dat de gewraakte bepalingen reeds hierom aanvaardbaar waren, omdat openbare wegen geen 'Sache' en geen 'Eigentum' zijn in de zin van het BGB en het Wegegesetz derhalve geen regeling behelst van 'bürgerliches Recht' als bedoeld in Artikel 74 Nr. 1 Grundgesetz. De overwegingen van het Bundesverfassungsgericht in deze uitspraak zijn van principiële aard; zij zijn niet toegesneden op - alleen - het Hamburgse Wegegesetz.

De Hamburgse wetgever achtte de rechtsgrond voor aansprakelijkheid voor schaden veroorzaakt aan een openbare weg dan ook niet gelegen in een jegens de stad Ham- 
burg gepleegde onrechtmatige daad (Par. 823 e.v. BGB), bestaande uit schending van subjectief (privaat) eigendomsrecht van de stad. De aansprakelijkheid was daarentegen in het leven geroepen met het oog op de instandhouding van de publieke bestemming van de weg; beschadiging van een weg kan nl. afbreuk doen aan de functie van de weg. De aansprakelijkheid is 'objektbezogen', niet 'subjektbezogen':

'Die Haftung ist objektbezogen; sie ist die Kehrseite davon, dass die offentliche Hand eine für die Allgemeinheit bestimmte Verwaltungsleistung zur Verfügung stellt. Ist das Schutzgut bei der Sachbeschädigungnach BGB die Erhaltung des subjektiven Eigentumsrechts des Geschãdigten, so steht hier die Aufrechterhaltung und Sicherung der öffentlichen Zweckbestimmung im Vordergrund, der die Verkehrsanlagedient. Die Beschãdigungeines öffentlichen Verkehrswegs ist geeignet, seine Funktion zu beeintrăchtigen. Die Legitimation für die Haftung der Schãdigers liegt hier zunăchst nicht darin, dass er in unzulässiger Weise in den 'Rechtskreis des Eigentümers' eigengedrungenist, sondern beruht auf die Öberlegung, dass derjenige, der eine Verwaltungsleistung in Anspruch nimmt, damit zugleich die Pflicht ábernimmt, einen etwa hierbei entstandenen Schaden auszugleichen. Nach Par. $823 \mathrm{ff}$. BGB ist die einem Dritten gegenüber begangene 'unerlaubteHandlung' der Rechtsgrundfür die Schadenshaftung dagegen steht im Strassenrechtdie Tatsache der Beschädigung einer öffentlichen Einrichtung als solche im Vordergrund' (curs. dzz.; JT) ${ }^{14}$.

Men vergelijke in dit verband óók het eerder genoemde arrest van de Hoge Raad van 29 april 1910, waarin hij overweegt dat 'de inbreuk op een publiekrechtelijk beheersrecht niet is een inbreuk op enig vermogensrecht en oplevert een onrechtmatige daad die een burgerrechtelijke verbintenis doet ontstaan' ex art. 1401 (oud) BW ${ }^{150}$.

De uitspraak yan het BYerfG is des te opmerkeljiker omdat alleen Hamburg principieel gekozen had voor invoering van het instituut 'öffentliches Eigentum', terwijl in de wegenwetten van de andere deelstaten werd uitgegaan van de leer van de 'modifizierte Privateigentum' c.q. de 'dualistische Rechtsstatus' van openbare wegen (en andere zaken met een publieke bestemming) ${ }^{15 !}$. De opvattingen van Otto Mayer, die - mede met een beroep op de Franse theorie van het 'domaine public' een krachtig pleidooi heeft gehouden voor een zuiver publiekrechtelijke benadering van het publiek domein, hebben zich onvoldoende kunnen doorzetten. Faber spreekt in dit verband van de 'Erfolglosigkeit einer richtigen Theorie', die z.i. te meer merkwaardig is nu deze theorie 'spätestens nach dem Zweiten Weltkrieg durch die Bedeutungszunahme des Verwaltungsrechts eigentlich Auftrieb hätte erhalten müssen' ${ }^{152}$. Wellicht wordt de verklaring hiervoor reeds door Otto Mayer zelf gegeven: 'Juristen sind meist konservative Leute' ${ }^{153}$. Als dit juist is, dan behoren althans de Hamburgse wetgever en het BVerfG niet tot die categorie.

$\mathrm{Nu}$ het Bundesverfassungsgericht in zijn uitspraak over het Hamburgse Wegegesetz zo uitdrukkelijk overweegt dat het bij de rechtsverhoudingen ten aanzien van openbare wegen niet gaat om burgerlijk recht, ziet hij zich kennelijk genoodzaakt ook iets te zeggen over de Wegegesetze van de andere deelstaten. Deze wetten worden door het Hof - zo zou men kunnen zeggen - 'verfassungskonform' uitgelegd. Volgens het Hof zou de Hamburgse regeling $\mathrm{nl}$.: 
'nur unwesentlich (abweichen) vom gemeindeutschenWegerecht ..., das nach herrschender Auffassung von einem dualistischen Rechtsstatus ausgeht: Das bürgerlich-rechtlicheEigentum am Strassengrund bleibt zwar formell bestehen, wird aber durch Vorschriften des öffentlichen Rechts überlagert und beschränkt. Trotz des theoretischen Unterschieds ist beiden Systemen gemeinsam, dass der Strassengrund in der Wirklichkeit einer allgemeinen Aufgabe dient und einer ôffentlich-rechtlichen Ordnung unterstellt wird, um eine sachgerechte Nutzung der Strasse durch die Allgemeinheit zu ermōglichen. Die Zustăndigkeit des Landesgesetzgebersfür die dualistische Regelung ist aber nie zweifelhaft gewesen' (curs. dzz.; JT).

Deze overweging kan o.i. ook aldus worden samengevat: de 'eigendom' van publiek domein is - gezien zijn aard en functie - geen 'gewone', burgerrechtelijke eigendom, ook al noemt men het zo. Het gaat om een 'toebehoren als overheidsgezag'; niet om een 'toebehoren als privaatrechtelijke eigendom'. Reeds daaruit zou men toch de conclusie moeten trekken dat de overheid ten aanzien van het publiek domein niet beschikt over de vrije beschikkings- en genotsvrijheid die zo kenmerkend is voor de burgerrechtelijke eigendom.

privaatrechtelijke 'bevoegdheden' zoals die verbonden zijn aan de private eigendom. En met de o.i. juiste opvatting van het Bundesverfassungsgericht, dat de rechtsgrond voor verhaal van schade toegebracht aan publiek domein niet gelegen is in een schending van subjectief (privaat) eigendomsrecht van de overheid als eigenaar, maar in aantasting van de publieke bestemming, is evenmin verenigbaar dat de overheid een actie uit hoofde van onrechtmatige daad zou kunnen entameren op de grond dat zij in een eigen vermogensbelang zou zijn geraakt ${ }^{154}$. De overheid heeft geen 'eigen' belangen; zij dient slechts publieke gemeenschapsbelangen te behartigen, zoals het belang dat gemoeid is met de instandhouding van de bestemming van publiek domein.

Opmerking verdient nog, dat ook in het standaardwerk van Kodal/Krämer, 'Strassenrecht', waarin geopteerd wordt voor de zgn. 'gemischtrechtliche Konstruktion' (d.w.z. de leer van de 'dualistische Rechtsstatus'), wordt toegegeven dat de door o.a. Otto Mayer, Krüger ${ }^{155}$, Bartlsperger ${ }^{156}$ en het Bundesverfassungsgericht op deze leer geuite kritiek uit rechtstheoretisch oogpunt juist is:

'Der Kritik an der gemischtrechtlichen Konstruktionder öffentlichenStrassen ist aus rechtstheoretischer Sicht zuzustimmen. (...) (D)ie Belassung einer begrenzten bürgerlich-rechtlichen Sachherrschaft in der geltenden Rechtsordnung (ist) eine Zweckmässigkeitsentscheidung. Sie macht es überflüssig, ein vollständiges Sortiment öffentlicher Rechtsregeln aufzustellen und erlaubt es, auf die Normen des Privatrechts zurūckzugreifen'(curs. door auteurs; JT) ${ }^{15}$.

De opvatting van Kodal/Krämer is, kortom, gebaseerd op pragmatisme. Dit standaardwerk vermeldt zelf de hiertegen door Bartlsperger ${ }^{158}$ - o.i. terecht - geuite kritiek:

'Gegen Erwägungender Zweckmässigkeit bei der Strassengesetzgebung anstelle einer ausschliesslich systemgerechtenGestaltung nach rechtstheoretischenVorstellungenwendet sich Bartlsperger mit 
dem Zweifel, "ob bei allen Vorzûgender Verwaltungspragmatikder Pragmatismus als Rechtsprinzip und Gesetzgebungsmaximeeine Legitimation beanspruchenkann"”.

Als in Nederlandse literatuur wordt opgemerkt dat het Nederlandse recht zich aanvankelijk niet, doch in de loop der tijden wèl heeft aangesloten bij de Duitse benadering van de 'modifizierte Privateigentum' c.q. 'dualistische Rechtsstatus' en er daarvoor voor wordt gepleit om ook voor de rubricering van openbare zaken zoveel mogelijk aansluiting te zoeken bij het Duitse recht ${ }^{159}$, zou er wèl bij moeten worden vermeld dat die benadering door de Duitse constitutionele rechter - o.i. terecht - is gekritiseerd en dat die kritiek in de gezaghebbende literatuur, in ieder geval vanuit rechtstheoretisch oogpunt, wordt onderschreven. Men doet - ook hier aan 'Etikettenschwindel', wanneer met spreekt van '(modifizierte) Privateigentum'.

\section{De fiscusleer als rechtsbeschermingsconstructie}

Bij onze bespreking van de negentiende-eeuwse fiscusleer wezen wij er reeds op, dat deze leer geconstrueerd is met het oog op de rechtsbescherming van de burger: door de Staat-fiscus aan te merken als de Staat 'in privaatrechtelijke hoedanigheid' en óók door het publiek domein te beschouwen als privaatrechtelijke eigendom kon, toen adequate administratieve rechtspraak nog ontbrak, de burgers rechtsbescherming worden geboden bij de gewone gerechten. Juist omdat in Duitsland de competentie van de burgerlijke rechter in beginsel was (en is) gekoppeld aan het burgerrechtelijke karakter van het geschil ${ }^{160}$, kon in de laatste decennia van de vorige eeuw - toen de administratieve rechtspraak nog geen algemeen karakter had - de leer van de 'modifizierte Privateigentum' van publieke zaken ingang vinden.

'(M)itgewirkt hat ... das Bestreben, die Kompetenzzur Beurteilung von Streitsachen der erwähnten Art der ordentlichen Gerichten zu erhalten',

schrijft Fleiner ${ }^{161}$. We merkten al op dat in Duitsland de overheid die gebruik makkt van burgerrechtelijke rechtsvormen, nog steeds als 'Fiskus' wordt aangeduid. Dat de Duitse staatsrechtbeoefenaren zich in de negentiende eeuw nauwelijks hebben bezig gehouden met de vraag naar de legitimatie van het 'fiscale handelen' van de overheid, vindt ook volgens Püttner waarschijnlijk zijn oorzaak in het ontbreken van volwaardige administratieve rechtsbescherming. Waar door de overheid 'fiscaal' werd opgetreden, betekende dit dat de gewone rechter bevoegd werd geacht te beoordelen of door dit optreden de vermogensbelangen van de burger onrechtmatig werden aangetast, zodat de 'fiscale beschouwingswijze' voor de burger een 'voordeel' betekende:

'Man konnte nămlich im 19. Jahrhundert davon ausgehen, dass der Staat, wenn er sich des Privatrechts bedient, vom Thron der Hoheitsgewalt herabsteige und sich auf die gleiche Stufe mit den Bürgern begebe; die Wahl des Privatrechts bedeutete einen Nachteil (t.w. voor de Staat; JT), der insbesonderein der Unterwerfungunter die Rechtsprechungder Gerichte zum Ausdruck kam (Fiskus als Prügelknabe des Staates). Die Verfassung konnte sich bei dem Ziel, die Bürgerfreiheit zu 
schützen, auf die Begrenzung der als weit unangenehmerempfundenen Hoheitsgewalt des Fürsten beschränkenund den freiwilligen Verzicht auf die Hoheitsgewalt als willkommenes Zusatzgeschenk ohne Verfassungsschutzentgegennehmen"16.

Mét de uitbouw van de administratieve rechtspraak is echter volgens Püttner:

'das privatrechtliche Auftreten des wirtschaftlich erstarkten Staates aus einer Wohltat zur Plage geworden; seitdem heisst es, der 'Flucht von Staat und Gemeinden in das Privatrecht' (Fleiner) angemessen zu begegnen' 16 .

De oude fiscusleer is kennelijk hardnekkig: aan een voor procesrechtelijke doeleinden geconstrueerde leer worden materieelrechtelijke consequenties verbonden.

In Nederland bestond en bestaat er (ook) uit een oogpunt van rechtsbescherming echter geen noodzaak het publiek domein te behandelen als private eigendom. In Nederland is immers de bevoegdheid van de gewone rechter niet gekoppeld aan het al dan niet burgerrechtelijke karakter van het toepasselijke materiële recht.

Naar aanleiding van het Isselmeerarrest suggereert Hardenberg, dat de daarin gekozen burgerrechtelijke benadering van 'toebehoren' in de artikelen 575 e.v. (oud) BW door de Hoge Raad nodig zou kunnen zijn geacht, omdat dit college - z.i. ten onrechte - uitging van een zuiver burgerrechtelijke opvatting van het begrip 'geschillen over eigendom of daaruit voortspruitende burgerlijke rechten' in art. 2 Wet R.O. en daarom zocht naar een formulering waarin de bevoegdheid van de gewone rechter ligt besloten ${ }^{164}$. Indien het geschil tussen Staat en gemeente als een zuiver publiekrechtelijke aangelegenheid was beschouwd, had de gewone rechter zich - volgens die 'burgerrechtelijke opvatting' - onbevoegd moeten verklaren, tenzij tevens van inbreuk op enig burgerlijk recht gesproken zou kunnen worden. In dit arrest oordeelt de Hoge Raad, anders dan het Hof, dat de Staat als (burgerrechtelijk) eigenaar van het Isselmeer van de gemeente Huizen zou kunnen eisen dat deze geen ongezuiverd rioolwater op het IJsselmeer loost:

'dat immers art. 577, door den Staat ... tot eigenaarte maken van de in het artikel genoemdezaken, waartoe het Usselmeer behoort, aan den Staat t.a.v. het Usselmeer dezelfde bevoegdhedenheeft gegeven, die krachtens de artt. 625 e.v. aan iederen eigenaar van een onroerende zaak toekomen; dat daarmede onverenigbaar is dat de Staat als eigenaar van het Usselmeer tegenover zich zou moeten laten gelden een door den Staat niet in het leven geroepen bestemming van dat meer tot het opnemen van rioolwater ... welke bestemming slechts zou kunnen worden beêindigd of beperkt 'langs publiekrechtelijkeweg', waarmede het Hof blijkbaar doelt op het gebruik van publiekrechtelijke bevoegdhedenvan den Staat; $(\ldots)$

dat het aan den eis ten grondslag gelegde recht op het Usselmeer, dan den Staat krachtens art. 577 toekomt, 'eigendom' is in de zin van art. 2 R.O., en een inbreuk op dat recht 'onrechtmatig' is in den zin van art. $1401 \mathrm{BW}$ ' 16 .

Hardenberg is van opvatting dat het begrip 'eigendom' in art. 2 Wet R.O. ziet op alle vormen van 'toebehoren', dus zowel op burgerrechtelijke als op publiekrechtelijke eigendom, zodat de rechterlijke bevoegdheid geen probleem had behoeven te zijn ${ }^{166}$. Deze opvatting komt ons niet onjuist voor, omdat deze bepaling blijkens haar totstandkomingsgeschiedenis ó́k uitging van de ruime, oud-Vaderlandse bete- 
kenis van 'civiel' c.q. 'burgerlijk'. Zo is óók het begrip 'schuldvordering' in art. 2 steeds ruim uitgelegd, in die zin dat daaronder ook publiekrechtelijke schuldvorderingen zijn begrepen ${ }^{167}$.

Dit ligt o.i. echter anders voor art. $1401 \mathrm{BW}$, zodat bij een zuiver publiekrechtelijke benadering van het geschil de vraag had moeten rijzen of de Staat ontvankelijk was in zijn vordering, omdat bij die benadering niet had kunnen worden uitgegaan van een inbreuk op een subjectief privaat vermogensrecht van de Staat. Men vergelijke het Mark en Dintel-arrest! Maar wanneer de Staat zijn vordering van de Staat niet had gebaseerd op art. $1401 \mathrm{BW}$ maar op (antasting van) het 'dominium iure publico', had o.i. ook de ontvankelijkheid geen probleem behoeven op te leveren.

Omgekeerd zou bij op art. 1401 (thans 6:162 BW) gebaseerde vorderingen van burgers die zich beroepen op aantasting van hun private vermogensbelangen door de onjuiste uitvoering door de Staat (of zijn lagere corporaties) van zijn publieke beheerstaak, een zuiver publiekrechtelijke benadering van het publiek domein evenmin aan ontvankelijkheid in de weg behoeven te staan. Men zie, bij voorbeeld, het arrest van 22 mei en 26 juni $1863^{168}$.

In Nederland gold en geldt dus niet het rechtsbeschermingsargument, dat wél speelde in Duitsland. Jurisprudentie als het Parlevinkerarrest, het IJsselmeerarrest en het arrest-Eindhoven/Staals, zegt méér over het 'burgerlijk regtsoog' (Thorbecke) van de gewone rechter dan over het karakter van het publiek domein en van het burgerlijk recht. Sterker nog, de privaatrechtelijke benadering van het publiek domein heeft ertoe geleid dat de rechtsbescherming van de burger in het nauw wordt gebracht, nu publiekrechtelijke waarborgen door de privaatrechtelijk opererende overheideigenaar opzij kunnen worden gezet ${ }^{169}$. Het opschrift van de kritische bespreking door Sens van het arrest-Eindhoven/Staals luidt dan ook: 'Geld breekt wet' ${ }^{170}$.

\section{Het subjectief recht op publiek domein en de daarin gefundeerde 'politie'bevoegdheid}

Naar aanleiding van het Rijksweg 12 -arrest ${ }^{171}$ merkt Poortinga terecht op dat in dit arrest een (burgerrechtelijk) eigendomsrecht van de Staat ten aanzien van de weg geen rol speelt ${ }^{172}$. In dit arrest staat, evenals in het 'Attican Unity'-arrest van 7 februari $1986^{173}$ en de 'Long Lin'-uitspraak van de Afdeling bestuursrechtspraak van 10 april $1995^{174}$, de beheerstaak van de Staat ten aanzien van zaken met een publieke functie centraal. De Staat was in de desbetreffende casus ongetwijfeld tot optreden bevoegd én verplicht, óók zonder specifieke wettelijke bevoegdheidsgrondslag. De bevoegdheidsgrondslag kan o.i. echter niet gevonden worden in art. 1401 (oud) resp. 6:162 BW. Waarin dan wèl? 
De titel is o.i. gelegen in het 'recht' van het openbaar lichaam op publiek domein ('het toebehoren als gezagsrecht'), dat we mét Stellinga zouden willen aanmerken als een publiekrechtelijk subjectief recht ${ }^{175}$.

Een overeenkomst met het subjectief burgerrechtelijk eigendomsrecht is hierin gelegen, dat beide vormen van eigendomsrecht een gebruiksbevoegdheid van de subjectief gerechtigde ten aanzien van het object van dat recht meebrengt. De inhoud van een subjectief recht wordt bepaald door de typische aard van het rechtsobject en die van de rechtskring waarbinnen het subjectief recht fungeert. Terwijl echter het burgerrechtelijke eigendomsrecht een - met het burgerrechtelijke vrijheidsbeginsel verband houdende - typische eigen aard heeft en gekenmerkt wordt door exclusiviteit en niet-doelgebondenheid ${ }^{176}$, is het subjectief recht van een openbaar lichaam op publiek domein een subjectief recht van een publieke rechtsgemeenschap op een publiekrechtelijke gebonden rechtsobject: het wordt bepaald door de publiek functie van dat object. Men kan zeggen dat alle mensen als zodanig subjectieve 'deelrechten' op dit domein hebben, welke rechten een gebruiksbevoegdheid van elke mens als zodanig ten aanzien van die zaak impliceren (binnen de grenzen die voortvloeien uit de functie van dit domein) ${ }^{177}$. Dit is wat Otto Mayer het 'Recht auf Gemeingebrauch' van iedere mens als zodanig, als 'Ausfluss der allgemeinen Freiheit' noemde ${ }^{178}$.

Naar aanleiding van het Usselmeerarrest en het Windmillarrest is opgemerkt dat deze arresten onder vigeur van het nieuw BW niet meer aldus gewezen zouden kunnen worden, omdat dit wetboek de eigendom van de ondergrond en niet die van het water - de zee, de Waddenzee en openbare vaarwateren (artt. 5:25 en 5:27 BW) als uitgangspunt neemt en dit water ook niet is aan te merken als 'zaak' in de zin van art. 3:2 BW, omdat het niet 'een voor menselijke beheersing vatbaar stoffelijk object' is ${ }^{179}$. Maar daaruit blijkt slechts een te meer, dat de privaatrechtelijke benadering van publieke zaken niet voldoet. Openbaar water niet vatbaar is niet vatbaar voor menselijke beheersing zoals bedoeld in die bepaling, voor private beheersing. De omstandigheid dat het geen object kan zijn van een privaat subject (eigendoms)recht, neemt niet weg dat het wel degelijk een rechtsobject is, en wel een publiekrechtelijk gebonden rechtsobject, een rechtsobject dat een publieke functie heeft en dat daartoe ook beheerd moet worden. Zulks geldt overigens niet alleen voor openbaar water, maar ók voor openbare wegen. In de reeds besproken uitspraak van 10 maart 1976 zegt het Bundesverfassungsgericht hierover:

'Die offentliche Strasse kann als Verwaltungsleistung weder mit dem für das Privatrecht und keineswegs allgemein geltenden Sachbegriff des Par. 90 BGB noch mit dem Eigentumsbegriff des BGB sachgerechterfasst werden, sondern fordert ihrer Funktion nach eine vom bürgerlichen Recht abweichende Regelung der 'Sachherrschaft' ${ }^{150}$. 
Ofschoon, zoals we eerder opmerkten, subjectieve rechten niet verward mogen worden met juridische competentiebevoegdheden ${ }^{181}$, zijn subjectieve rechten in het algemeen wél correlaat met zekere competentiebevoegdheden. Zo heeft hij die een subjectief burgerrechtelijk eigendomsrecht heeft op een landgoed, de bevoegdheid om zijn eigendomsrecht te vervreemden of te bezwaren, of om eenzijdig rechtsregels te stellen voor ieder aan wie hij een zeker gebruik daarvan wil toestaan ${ }^{182}$, of ook om alle anderen het gebruik te ontzeggen. De titel tot rechtsvorming is hier het subjectieve recht zelf ${ }^{183}$.

Ook met de subjectieve rechten van de Staat resp. zijn statelijke sub-verbanden op publiek domein correleren o.i. zekere competentiebevoegdheden. Voor deze bevoegdheden is, zoals voor alle publiekrechtelijke bevoegdheden, kenmerkend dat ze steeds tevens een publieke plicht inhouden en dat ze meer in het bijzonder bepaald worden door de publieke bestemming van dat domein. In casu gaat het om (publiekrechtelijke) beheersbevoegdheden die tevens de plicht inhouden ervoor te zorgen dat het publieke domein steeds aan zijn functie blijft beantwoorden onder evenwichtige afweging en harmonisatie van alle daarbij in aanmerking komende rechtsbelangen (beheersplicht), juist ook om te verzekeren dat het 'Gemeingebrauch' van allen (binnen de door de publieke functie bepaalde grenzen) mogelijk blijft. Het publiek domein legt, 'ter voldoening aan de bestemming ten gebruike van het publiek ... eigenaardig daaruit voortvloeijende verpligtingen (op), waartoe een eigenaar jure privato niet is gehouden' ${ }^{24}$, hetgeen betekent dat de beheerder 'niet alleen geregtigd, maar ook gehouden is tot alle handelingen, die noodzakelijk zijn voor een juiste en doelmatige uitoefening van zijn taak' ${ }^{185}$. Daarom ook is 'de inbreuk op een publiekrechtelijk beheersrecht niet ... inbreuk op enig vermogensrecht' ${ }^{186}$, dat wil zeggen: een privaat vermogensrecht. En daarom ook wordt deze eigendom niet gekenmerkt door exclusiviteit en was in het BW bepaald dat zij 'buiten den handel' is.

De titel voor de 'Polizei der öffentlichen Sache' (Otto Mayer) is gelegen in het subjectieve recht op publiek domein zelf c.q. de publiekrechtelijke subjectieve 'deelrechten' van allen op dit domein. Ontkent men het bestáán van dergelijke bevoegdheden - die immers juist strekken ter verzekering van het 'Gemeingebrauch' -, dan miskent men o.i. ook het 'Recht auf Gemeingebrauch' van allen. Tussen deze 'Polizei' en het recht van een ieder op 'Gemeingebrauch' bestaat een nauwe relatie. De 'Polizei der öffentlichen Sache' reikt dan ook niet verder dan nodig is om ervoor te zorgen, dat de zaak aan zijn publieke bestemming blijft beantwoorden en het 'Gemeingebrauch' van allen te waarborgen ${ }^{187}$. Degene die gehinderd wordt in zijn 'Recht auf Gemeingebrauch' heeft daarom ook aanspraak op bescherming door de 'Polizeigewalt'.

Omdat het recht op publiek domein een subjectief recht van een gemeenschap is, zullen bedoelde 'politiebevoegdheden' uiteraard moeten worden uitgeoefend door 
één of meer rechtsorganen van die gemeenschap. Een zodanige bevoegdheid komt toe aan het orgaan van het staatsverband (of statelijk sub-verband) waaraan de beheerstaak - en dit op basis van de wet! - ter behartiging is opgedragen ${ }^{188}$.

Wij menen dan ook dat ook in recente jurisprudentie niet ten onrechte is aanvaard, dat aan het recht op publiek domein (weg, water) zekere bestuursbevoegdheden zijn verbonden, zonder dat daartoe een specifieke wettelijke grondslag in het leven was geroepen ${ }^{189}$. In een recente uitspraak ontvangt de Afdeling bestuursrechtspraak o.i. terecht het beroep tegen een door de minister van verkeer en waterstaat gegeven verbod tot het binnenvaren van de Nederlandse territoriale wateren door het Chinese zeeschip 'Long Lin', omdat deze beslissing is aan te merken als een beschikking in de zin van art. 2 lid 1 Wet Arob en dus niet als een rechtshandeling naar burgerlijk recht:

'Enig als zodanig aanwijsbaar publiekrechtelijk voorschrift ter uitvoering waarvan het besluit is genomen, is geen vereiste om een beschikking in de zin van art. 2 aan te nemen. Naar door verweerders bij pleidooi is gesteld, is de Staat beheerder van de Nederlandse territoriale wateren. De Staat, en daarmee verweerder, acht zich in dit verband verplicht ervoor zorg te dragen dat het vaarwater aan zijn bestemming beantwoordt. Het vorenstaande betekent dat het bestreden besluit is genomen ter uitvoering van verweerders publiekrechtelijke taak. (...) De Staat der Nederlandenen daarmee verweerder ontleent de bevoegdheid tot het opleggen van een verbod in beginsel aan de soevereiniteit van de Staat' 190 .

Wél menen wij dat het legaliteitsbeginsel eist, dat tot algemene regelgeving - 'politiewetgeving' - (nog) slechts de wetgever bevoegd is. En voor beperkingen van (de deel-rechten op) het 'normaal gebruik' (dus functioneel gebonden gebruik) is, evenals voor ingrepen in het eigen, private domein van de burgers, is steeds een specifiek-wettelijke grondslag nodig.

Men pleegt echter etikettenzwendel wanneer men een bevoegdheid tot het verlenen of weigeren van toestemming tot 'bijzonder gebruik' (niet-functioneel gebonden gebruik) - dus gebruik 'über den Gemeingebrauch hinaus' (Otto Mayer) - wél aanvaardt, maar bij het ontbreken van een specifiek-wettelijke grondslag daarop het etiket 'privaatrechtelijk' plakt. Vos wijst er op dat de bevoegdheid om dergelijk bijzonder gebruik van een voorafgaande toestemming afhankelijk te stellen, onderdeel is van 'de heerschappij van het publiekrechtelijk lichaam' ${ }^{191}$. Gaat men uit van deze visie, dan had de Hoge Raad de casus die bij voorbeeld aan de orde waren in het Parlevinkerarrest en het Windmillarrest moeten behandelen in het kader van een publiekrechtelijke twee-wegenleer. In de Parlevinkercasus had dan de vraag moeten luiden, of de Staat het parlevinken, behalve van een vergunning ingevolge het Algemeen reglement van politie voor rivieren en kanalen, óók nog krachtens zijn aan het subjectief recht op het desbetreffend publiek domein gerelateerde algemene 'politiebevoegdheid' afhankelijk mocht stellen van een publiekrechtelijke toestem- 
ming waaraan een financieel voorschrift is verbonden. En indien dit al mogelijk zou kunnen worden geacht, zou zo'n financieel voorschrift uitsluitend mogen strekken ter bescherming van de door de publieke beheerstaak gediende belangen, hetgeen ook een winstverbod impliceert: het publiek domein is geen 'zaak in den handel'.

Naar aanleiding van het Rijksweg 12-arrest, het 'Attican Unity'-arrest en de 'Long Lin'-uitspraak merkten we al op, dat de Staat in de desbetreffende casus o.i. tot optreden bevoegd én verplicht was, ook zonder specifiek-wettelijke bevoegdheidsgrondslag. Inzake vraag of ook verhaal mogelijk is van de kosten, schade of voordeel welke zo'n bevoegdheidsuitoefening oplevert, indien geen wettelijke regeling is getroffen voor dat verhaal, betoogt Simon o.i. terecht, dat de rechtsgeldigheid van dat verhaal afhankelijk is van de regels die kunnen worden afgeleid van het typisch publiekrechtelijke, in de iustitia distributiva gefundeerde égalitébeginsel, als het beginsel dat ziet op de evenredige verdeling van de lasten en 'lusten' binnen de publieke rechtsgemeenschap. Het égalitébeginsel dat ziet op de evenredige verdeling van de 'lusten' is het spiegelbeeld van het beginsel van de 'égalité devant les charges publiques' ${ }^{192}$. Een vergoeding voor 'normaal' gebruik ('Gemeingebrauch') van een publieke zaak zal in beginsel moeten berusten op een formeel-wettelijke grondslag. Het niet-functioneel gebonden gebruik ('bijzonder gebruik; gebruik 'über den Gemeingebrauch hinaus') kan echter op grond van de ten aanzien van die zaak bestaande 'politiebevoegdheid' gebonden worden aan het vereiste van toestemming, waarbij het égalitébeginsel wordt gepositiveerd door daaraan een gebruiksvergoeding te koppelen ${ }^{193}$, voorzover althans de publiekrechtelijke regelgever niet een specifieke regeling heeft getroffen die zulks uitsluit ${ }^{194}$.

Ook de vergoeding van schade en kosten, ontstaan door gebruik 'über den Gemeingebrauch hinaus' vindt haar materiële rechtsgrond in het égalitébeginsel en kan met gebruikmaking van deze bevoegdheid worden gevorderd. Zo konden in de Rijksweg 12-casus de kosten die verbonden waren aan de opruimings- en herstelwerkzaamheden die uit hoofde van de beheerstaak van de Staat moesten worden verricht, worden verhaald op de veroorzakers. Dit kostenverhaal kan echter niet worden gebaseerd op een onrechtmatige daad in de zin van art. 1401 (oud) resp. 6:162 BW, zoals de Hoge Raad meent in het desbetreffende arrest. De omstandigheid dat aan het optreden van de Staat kosten waren verbonden, 'veroorzaakt ... door het verkeersongeval en dus ook door het onzorgvuldig rijden van Bodde dat de oorzaak van dat ongeval was', brengt niet mee dat de Staat daardoor getroffen was in een privaat subjectief recht of rechtsbelang dat valt onder de bescherming van art. 1401, een 'eigen materieel belang' zoals advocaat-generaal Berger het uitdrukte. 


\section{De paradox van de legaliteitseis}

Het zicht op het ware karakter van een dergelijke geldvordering en - meer algemeen - op dat van de met de publiekrechtelijke eigendom verband houdende bevoegdheden, wordt o.i. vertroebeld niet alleen door het 'burgerlijk regtoog' van de gewone rechter (Thorbecke) maar ook door de wetspositivistische instelling van veel aanhangers van de gemene rechtsleer.

Enerzijds bestaat de neiging het bestaan van publiekrechtelijke bevoegdheden - hier: tot het verlenen of weigeren van toestemming tot 'bijzonder gebruik' van publiek domein, tot uitvaardiging van een verbod tot binnenvaren van territoriale wateren, tot kostenverhaal etc. - slechts aan te nemen voorzover daarvoor een specifieke wettelijke basis bestaan. Zo noemt Van der Veen in zijn noot de 'Long Lin'-uitspraak 'niet zo verstandig:

'Mij lijkt het beheer de eigenlijke basis van de weigering, maar de vraag is dan welke grondslag het beheer heeft. Publiekrechtelijke grondslagen lijken afwezig. Verweerder noch Afdeling bestuursrechtspraak noemen specifieke wettelijke voorschriften. Het is hoogst onwaarschijnlijk dat de Afdeling bestuursrechtspraakin deze eerste publiekrechtelijketaak-uitspraakover de territoriale zee een ongeschreven publiekrechtelijk beheersregime heeft willen genereren, zoals dat bijv, gezien wordt door L. Hardenberg, 'De 'eigendom' van de Staat', in: C. Streefkerk/H. Faber (red.), Ter recognitie, Hilversum 1987, p. $369^{\prime}$ '19,

Anderzijds is men in vele gevallen tóch genegen een bevoegdheid te aanvaarden, mits die maar als 'privaatrechtelijk' wordt gekwalificeerd. Het publieke domein wordt dan als gewone, burgerrechtelijke eigendom gekarakteriseerd en geldvorderingen worden gebaseerd op een onrechtmatige daad ('jegens de overheid') ex art. 6:162 BW. De rechtsgrond voor de bevoegdheidsuitoefening wordt dus gezocht in die eigendom en/of art. 6:162 BW. Van der Veen betoogt dan ook:

'De grondslag van het beheer zal dus wel privaatrechtelijkzijn, hetgeen het BW kan bevestigen. In navolging van het in 1981 ingevoerde art. 576a BW (oud) stelt art. 5:25 BW dat de bodem en territoriale zee (en van de Waddenzee)eigendom is van de Staat. Uit die eigendom zou de grondslag van de toegangsweigering afgeleid kunnen worden. Met een analoge toepassing van HR 19 jan. 1962 , NJ 1962, 151, m.nt. JHB, AB 1962, p. 540 (Huizen/De Staat) ... zou de Staat als eigenaar alle bevoegdheden hebben om aantastingen van de territoriale zee te voorkomen, slechts beperkt door de in de uitspraak genoemde verdragsartikelen'.

Waarom is dus in deze visie de rechtsgrondslag 'privaatrechtelijk'? Omdat een publiekrechtelijke grondslag ontbreekt, want die zou alleen gevonden kunnen worden in een specifiek wettelijk voorschrift! En die in de 'burgerrechtelijke eigendom' en in art. 6:161 BW gefundeerde 'privaatrechtelijke' bevoegdheden zouden óók mogen worden gebruikt ter behartiging van publieke belangen. Hennekens schrijft:

'De eigendomsbevoegdheid kan een basis bieden om inbreuken van derden te weren. (...) (D)e aan het burgerlijk recht te ontlenen bevoegdheid (biedt) een goede gelegenheid voor maximale competenties tot een optimale behartiging van de zorg voor deze zaken. ${ }^{1 \%}$.

'Maximale competenties'! En wanneer onder het nieuw BW niet meer de mogelijkheid bestaat het openbaar water te beschouwen als 'zaak' en als burgerrechtelijke 
eigendom ${ }^{197}$ - en dus de 'privaatrechtelijke bevoegdheden' ter behartiging van publieke belangen niet (meer) gebaseerd kunnen worden op de eigendom ex art. 5:1 BW, eventueel in combinatie met art. 6:162 B.W, worden die bevoegdheden alléén nog gebaseerd op artikel 6:162 BW. Men zie bij voorbeeld het Wrakkenwet-arrest, waarin de Hoge Raad de gemene rechtsleer volledig lijkt te omarmen met zijn overweging:

'dat ... de regeling van de Wrakkenwet niet ertoe strekt een bepaalde, in het gemene recht bestaande grondslag voor aansprakelijkheid van de eigenaar van het gezonken voorwerp, op voorhand uit te sluiten' 1 .

Zoals we eerder betoogden, is art. 6:162 BW gaan fungeren als een para-wettelijke 'Generalklausel', op grond waarvan zelfs inbreuken door 'de overheid' van het private domein van de burger mogelijk zijn zonder specifiek-wettelijke bevoegdheidsgrondslag. Een 'civielrechtelijk belang' is niet nodig. Men zie het Kabayelarrest ${ }^{199}$ en het arrest Van Schaik/Nieuwveen ${ }^{200}$. Men kan dit de paradox van de legaliteitseis noemen, die juist (mede) strekt ter bescherming van de burgerlijke vrijheid: men eist voor het bestaan van publiekrechtelijke bevoegdheden steeds een specifiek-wettelijke grondslag en gaat, bij het ontbreken daarvan, toch een bevoegdheidsgrondslag zoeken, die ment dan meent te kunnen vinden in het BW. Als echter de Hoge Raad in het Windmill-arrest - waarin het gaat om publiek domein, te weten de Nieuwe Waterweg - overweegt dat 'de overheid' publieke belangen ook mag behartigen 'door gehruik te maken van has in hegineel krarhtene het grivast. recht toekomende bevoegdheden, zoals aan het eigendomsrecht ontleende bevoegdheden .... of de bevoegdheid een vordering op grond van een jegens haar gepleegde onrechtmatige daad bij de burgerlijke rechter in te stellen' ${ }^{201}$, dan maakt hij niet alleen geen principieel verschil (meer) tussen burgerrechtelijke eigendom en publiekrechtelijke eigendom, maar postuleert hij in feite tevens een algemene bevoegdheid van 'de overheid' om ter behartiging van publieke belangen acties te entameren tegen burgers, met name om te komen tot 'kostenverhaal'.

Dit 'ius politiae' gaat - als gezegd - veel verder gaat dan de bevoegdheid als vervat in de Duitse 'polizeiliche Generalklausel', die immers slechts gegeven is voor uitzonderingssituaties, waarin met het oog op gevaren voor de openbare orde, veiligheid of gezondheid onmiddellijk optreden geboden is. En een consequentie van de vermenging van de rechtssfeer van het publiekrecht met die van het burgerlijk recht is óók, dat de uit de pre-revolutionaire periode stammende beschouwing van overheidsbevoegdheden als eigen (private) vermogensbelangen is teruggekeerd.

Historisch gezien betekent de genoemde jurisprudentie een regressie, want de doorbraak van de rechtsstaatsidee in de vorige eeuw impliceerde - zoals we reeds meermalen aangaven - een scheiding van 'imperium' en 'dominium', van 'publiek' en 'privaat', van 'publiek domein' en 'privaat domein', welk privaat domein beschermd werd door het materiële wetsbegrip. Dit betekende een inperking van de politiebe- 
voegdheid ten faveure van de heerschappij van de wet (het legaliteitsbeginsel), een ontwikkeling die in 1879 is bezegeld in het Meerenbergarrest.

\section{Verwerping van de ambtentheorie}

Volgens Hennekens zou het (publiekrechtelijke) beheer van een openbare zaak los staan van het rechthebbende zijn: het beheer wordt uitgeoefend door een ambt, terwijl de eigendom berust in handen van de (rechts)persoon naar civielrecht ${ }^{202}$. Deze laatste zou echter beschikken over 'maximale competenties tot een optimale behartiging van de zorg voor deze zaken' ${ }^{203}$. Het hier gemaakte onderscheid is gebaseerd op de ambtentheorie, zoals die door met name Logemann is ontwikkeld ${ }^{204}$.

Aanhangers van de zgn. ambtentheorie plegen in navolging van Logemann een 'fundamenteel', 'wezenlijk' en 'scherp onderscheid' te maken tussen enerzijds de overheidsorganen (ambten) - belast met publiekrechtelijke rechtsvorming op basis van publiekrechtelijke bevoegdheden - en anderzijds de openbare lichamen-rechtspersonen naar burgerlijk recht ${ }^{205}$, die beschikt over privaatrechtelijke bevoegdheden. Daarbij wordt zelfs gesteld dat, publiekrechtelijk bezien, een 'openbaar lichaam', slechts een 'ambtenorganisatie' ${ }^{206}$, een 'gemeenschappelijk dak' van ambten ${ }^{207}$, een 'ambtenkring' c.q. 'organisatorisch verband van ambten' ${ }^{208}$ is en in het publiekrecht 'geen grote rol van betekenis' ${ }^{209}$ speelt. Deze ambtentheorie is dóór en dóór positivistisch en moet met haar uitsluitend formele competentiebegrip het overheidsorgaan (ambt) juridisch los denken van de publieke rechtsgemeenschap - het openbaar lichaam, dat er publiekrechtelijk bezien 'niet als noodzakelijkheid' (Logemann) zou zijn - en een 'wezenlijk onderscheid' maken tussen de publiekrechtelijke 'overheidsbevoegdheden (die) verbonden zijn aan het ambt' (Stroink/ Steenbeek) en de 'privaatrechtelijke bevoegdheden' van het openbaar lichaamrechtspersoon naar burgerlijk recht. En die privaatrechtelijke handelingsbekwaamheid is niet beperkt. Zo noemt Konijnenbelt het een 'fundamenteel verschil' bij de kwestie of het gaat om een publiekrechtelijke danwel een privaatrechtelijke overheidshandeling:

'Gaat het om een publiekrechtelijkerechtshandeling, dan zal daarvoor normaliter een grondslag in een wettelijk voorschrift moeten kunnen worden aangewezen, zo wil het legaliteitsbeginsel. Voor privaatrechtelijke rechtshandelingen, doorgaans gebaseerd op eigendomsrecht of contractsvrijheid, eventueel op een combinatie van de twee, geldt het omgekeerde: die rechtshandelingenkunnen in beginsel vrijelijk worden verricht, het recht kan in bijzondere gevallen hooguit beperkingen bevatten' 210 ,

\section{En Hennekens betoogt:}

'In de bestuurswetgeving gaat het om publiekrechtelijke bevoegdheden en plichten. Het privaatrechtelijk handelen is tot nu toe door de wetgever niet aan banden gelegd, ieder openbaar lichaam kan privaatrechtelijk in het verkeer optreden ter behartiging van zijn taken. Er zijn slechts regels 
gesteld omtrent de vraag welk orgaan bevoegd is besluiten te nemen ter zake van privaatrechtelijke aangelegenheden en of er toezicht nodig is' 21.

Maar omdat de ambtentheorie door haar formalistische beschouwingswijze geen wezenlijk materieel onderscheid ziet tussen publiek- en privaatrecht resp. tussen publieke en private rechtsbelangen, moet zij tevens concluderen dat het openbaar lichaam-rechtspersoon zijn 'privaatrechtelijke bevoegdheden' óók kan gebruiken ter behartiging van publieke belangen. En dat 'privaatrechtelijke handelen is tot nu toe door de wetgever niet aan banden gelegd'. Er zou dus wél een 'fundamenteel', 'wezenlijk' en 'scherp onderscheid' bestaan tussen de overheid-ambt enerzijds en de overheid-openbaar lichaam-rechtspersoon anderzijds, maar niet wat de aard van de door deze twee 'overheidspersonen' te behartigen belangen betreft! En als Hennekens in verband met het publiek domein een wezenlijk onderscheid maakt tussen enerzijds het met het publiekrechtelijk beheer van een openbare zaak belaste ambt en anderzijds de '(rechts)persoon naar civiel recht', die zou beschikken over 'maximale competenties tot een optimale behartiging van de zorg voor deze zaken', dan luidt onze vraag: wat voor 'zorg' is dit dan wel, als het geen beheer is?

Gaat men uit van een 'fundamenteel onderscheid' tussen ambten en openbare lichamen, dan zou óók een financiële aansprakelijkstelling terzake van schadeveroorzakende publiekrechtelijke gedragingen van een ambt problematisch moeten zijn. Een ambt is immers geen zelfstandig vermogensrechtelijk subject. Niettemin worden deze gedragingen in de jurisprudentie toegerekend aan het openbaar lichaam dat het 'overkoepelend dak' vormt - wij zouden zeggen: waartoe het ambt behoort -, en wordt dat lichaam financieel aansprakelijk geacht ${ }^{212}$. Ook waar het betreft de niet-uitbetaling van een door een ambt krachtens zijn publiekrechtelijke bevoegdheid toegekende subsidie, zal de begunstigde zich met zijn actie moeten wenden tot het lichaam. En waar een door een ambt vastgestelde bestuursrechtelijke dwangsom wordt verbeurd, komt deze toe aan het openbaar lichaam waartoe het ambt behoort ${ }^{213}$.

De Hoge Raad wenst in het Windmill-arrest de kunstmatige scheiding tussen de twee 'overheidspersonen' ambt en openbaar lichaam kennelijk echter niet te maken en spreekt in algemene zin van 'de overheid', die enerzijds ingevolge publiekrechtelijke regelingen beschikt over 'bepaalde bevoegdheden' ter behartiging van publieke belangen, maar aan wie anderzijds in beginsel ' $k$ rachtens het privaatrecht' bevoegdheden ter behartiging van publieke belangen zouden toekomen. Dit laatste, tenzij gebruikmaking van die 'privaatrechtelijke bevoegdheden' een onaanvaardbare doorkruising zou opleveren van die publiekrechtelijke regelingen.

Als het echter juist zou zijn - quod non - dat ambten 'scherp' moeten worden onderscheiden van openbare lichamen-rechtspersonen, zou het 'logisch gezien' onaan- 
vaardbaar zijn de twee overheidsbegrippen te versmelten tot éen begrip 'overheid'. Als men, met andere woorden, aanneemt dat de privaatrechtelijke bevoegdheden toekomen aan een andere 'persoon' (het openbaar lichaam-rechtspersoon) dan aan de publiekrechtelijke 'persoon' (het ambt), dan is niet in te zien hoe gebruikmaking van de privaatrechtelijke bevoegdheden door de éne 'persoon' zou kunnen leiden tot doorkruising van de publiekrechtelijke bevoegdheden van de andere, daarvan 'scherp' te onderscheiden publiekrechtelijke 'persoon'. Van het bewandelen van twee wegen door eenzelfde 'persoon' kan dan niet worden gesproken. Evenmin kan er derhalve sprake zijn van een doorkruisingsproblematiek. Men kan spreken van een 'logische contradictie' in de ambtentheorie, zoals die in Nederland verbonden is met de gemene rechtsleer.

Maar als men - zoals de Hoge Raad kennelijk doet in het Windmill-arrest - géén 'wezenlijk' onderscheid maakt tussen beide 'overheidspersonen', dan rijst de vraag hoe het te verklaren is dat de wetgever aan 'de overheid' (de ambten) welbewust slechts specifieke publiekrechtelijke bevoegdheden heeft toegekend ter behartiging van bepaalde belangen, terwijl diezelfde overheid daarnást nog zou beschikken over algemene, niet gespecificeerde - van het etiket 'privaatrechtelijk' voorziene bevoegdheden ter behartiging van allerlei, ook 'ongeschreven' publieke belangen.

De Haan c.s. verwerpt o.i. terecht de beschouwingswijze van aanhangers van de ambtentheorie, volgens welke een openbaar lichaam slechts een 'ambtengroep' is. Hij wijst er op dat met die beschouwingswijze onvoldoende wordt onderkend, dat een openbaar lichaam primair is te beschouwen als een zelfstandige publiekrechtelijke gemeenschap van personen, mét organen ${ }^{214}$. En elders merkt De Haan het op basis van de ambtentheorie gemaakte onderscheid tussen het beheerder van openbare zaken en het 'rechthebbende' zijn, als onhoudbaar aan ${ }^{215}$. In ander verband is Logemanns staatsbegrip door Couwenberg reeds als 'sterk geformaliseerd en daarmee verschraald' gekarakteriseerd: Logemanns wetspositivistische benadering reduceert de Staat tot een strikt formele organisatie van publieke functies (ambten) en miskent het materiële karakter van het staatsverband als gemeenschap ${ }^{216}$. Ook Stellinga oefent in zijn bespreking van de 'Algemene rechtsleer' van M.M. van Praag ${ }^{217}$ kritiek uit op diens ambtentheorie:

'Deze theorie, wellicht terug te voeren tot de oude onderscheidingstaat-fiscus en staat-Overheid, is evenals deze onhoudbaar. Men kan dit in kort bestek even demonstreren aan een andersoortige rechtspersoonals de vereniging. Ook deze vormt zelf recht, het interne verenigingsrecht. Neemt de schrijver hier dan ook twee verenigingen aan? Natuurlijk zien we het verschil tussen de staat en andere rechtspersonen wel in, maar het is de vraag, of de schrijver wel oog heeft voor het feit dat de staat als levensverband tot op zekere hoogte ook juridisch op één lijn staat met verbandenals de kerk, het gezin etc. Dit tweeledige staatsbegrip ligt ten grondslag aan vele uiteenzettingen van de schrijver, die mede daardoor reeds haar onhoudbaarheid in zich dragen' 21. 
Oók voor privaatrechtelijke rechtspersonen (zoals verenigingen, vennootschappen, stichtingen) geldt: de drager van subjectieve burgerlijke rechten en subjectieve rechtsbelangen is het verband zelf. De bevoegdheden om, hetzij binnen de organisatie zelf hetzij in het maatschappelijk verkeer, rechtsvormend op te treden, komen toe aan organen van die (rechtspersoonlijkheid bezittende) organisatie. Elke organisatie - of dit nu het staatsverband is of een willekeurig maatschappelijk verband (vereniging, vennootschap etc.) - kan nu eenmaal slechts handelen door zijn organen. Wanneer het bestuur van een tennisvereniging regels uitvaardigt inzake de wijze van gebruikmaking door haar leden van bij haar in eigendom zijnde tennisvelden, zegt men toch 66 k niet dat de handelingen van dat bestuur los staan van het eigendomsrecht van de vereniging? Over een dergelijke benadering zou terecht worden opgemerkt, dat zij werkelijkheidsvreemd is.

Voor het publiek domein ligt dit niet anders. Het publiekrechtelijke subjectief recht op publiek domein is steeds een recht van een openbaar lichaam, terwijl de in dit subjectief recht gefundeerd bevoegdheden zijn op basis van het interne publiekrechtelijke organisatierecht toevertrouwd aan organen van die verbanden ('ambten'). Er is geen principiële scheiding te maken tussen het openbaar lichaam en zijn organen ('ambten') en het overheidsrecht op publiek domein is geen private doch publiekrechtelijke eigendom.

Op de inamsequtmtis var de Ntedtriandse gemene rechtsiler - die, als gezegu', pleegt te worden gecombineerd met de ambtentheorie -, wordt ook gewezen door Meijers. Deze merkt op dat de beschouwingswijze van de gemene rechtsleer, die uitsluitend let op uiterlijke kenmerken en zich bedient van 'zuiver juridisch-technische criteria' en daarmee 'langzaam maar zeker de structuur van het publieke recht ondergraaft', zich moet wreken bij een zo belangrijke onderscheiding als die in publiek- en privaatrecht:

'Wij zien dan ook in dit land verschillende correcties op de leer aangebracht, alle bestemd om het verband tussen rechtsregel en zijn sociale betekenis weer te herstellen. Men onderwerptb.v. aan de overheid toebehorendegoederen aan alle regels, die het privaatrecht voor de eigendomopstelt, maar men weigert dit te doen, wanneer daardoor de bestemming die de zaak in het algemeen belang ontvangen heeft, niet verwezenlijkt kan worden' 219 .

Bij een consequente doorvoering van de gemene rechtsleer, die immers het bestuursrecht slechts ziet als een door de wetgever gewild bijzonder recht dat het (al)gemene recht aanvult of daarop uitzonderingen maakt, zou immers overal waar zulke wetgeving ontbreekt steeds het burgerlijk recht van toepassing moeten achten. Hierop is ook door Van der Hoeven gewezen:

'(D)e opvatting dat het gemene recht (= het burgerlijk recht; JT) het primair bindende recht is, 66k voor de overheid, en dat afwijking daarvan als 'inbreuk' moet worden beschouwd, (is) moeilijk verenigbaar ... met het aanvaardenvan ongeschrevenbestuursrecht. Wie ervan uitgaat dat het recht een logisch, in zichzelf gesloten geheel van normen vormt - en die opvatting ligt ten grondslag aan 
het primaat van het 'gemene recht' - kan wettelijk vastgelegde inbreuken op het gemene recht aanvaarden, omdat wetgeving zèlf van het systeem deel uitmaakt. Maar voor ongeschreven 'inbreuken' geldt dat niet: zulks inbreukenstrijden - alweer: in die opvatting - met het wezen van de rechtsorde zelf 20 .

F.G. Scheltema is dan ook consequent, waar hij betoogt dat ook op het publiek domein het burgerlijk recht steeds van toepassing is, behalve voor zover daarvan bij publiekrechtelijke regeling uitdrukkelijk wordt afgeweken ${ }^{22 !}$.

Hét principiële bezwaar tegen de ambtentheorie is, dat zij in wezen slechts een formeel competentiebegrip kent en daardoor niet ziet dat elke formele competentie bepaald en begrensd wordt door een materiële competentiesfeer, die op haar beurt bepaald wordt door de aard van de desbetreffende rechtskring, in casu door het publiekrecht: het recht van de publieke rechtsgemeenschap. Doordat zij slechts het formele moment van de rechtsvorming (door 'ambten') beziet, stelt de ambtentheorie niet het staatsverband en zijn autonome sub-verbanden (de 'openbare lichamen') vóórop als publiekrechtelijke verbanden met eigen rechtsvormende organen binnen een materiële competentiesfeer, maar neemt zij - omgekeerd - de rechtsvormende organen (de 'ambten') als uitgangspunt van haar betrachting. En omdat naar positief publiekrecht de rechtsvorming geschiedt door ambten, moet zij concluderen dat juridisch de openbare lichamen - het staatsverband en zijn sub-verbanden dus - 'geen grote rol van betekenis spelen' en slechts 'ambtengroepen' c.q. 'gemeenschappelijk dak' van ambten vormen.

Door haar miskenning van een materiële competentiesfeer van de Staat én daarmee ook die van andere niet-statelijke samenlevingskringen, moet de ambtentheorie ook alle positief recht herleiden tot de overheid. 'Alle positieve recht is te herleiden tot de overheid', aldus - bij voorbeeld - Kortmann, die de attributie van bevoegdheden aan ambten door de constitutie zelfs een 'creatio ex nihilo' noemt ${ }^{222}$.

Bij haar uitééndenken van ambt en openbaar lichaam kan deze theorie ook niet verklaren, wat de zin is van de rechtspersoonlijkheid (naar burgerlijk recht) van openbare lichamen ${ }^{223}$ en wat de omvang is van de functies is van die rechtspersoonlijkheid. 


\section{Noten bij hoofdstuk 6}

1. Deze opvatting is wijd verbreid. Zo betoogt C.A.J.M. Kortmann, 'Constitutioneel recht', Deventer 1990, p. 4: '(I)n de westerse staten bestaat recht niet zonder overheid. Alle positieve recht is te herleiden tot de overheid, hetzij op grond van uitdrukkelijke rechtsschepping, hetzij op grond van al dan niet stilzwijgende erkenning. Alle recht is in deze zin overheidsrecht, of het gaat om staatsrecht, bestuursrecht, strafrecht of burgerlijk recht. Het typerende van het staatsrecht als onderdeel van het Nederlandse positieve recht is dat het altijd betrekking heeft op relaties waarbij de overheid is betrokken. Het onderwerpt de overheid in die relaties aan het recht. Weliswaar kan ook in het privaatrecht de overheid .... aan het recht zijn onderworpen, doch het privaatrecht regelt niet slechts de betrekkingen tot de overheid, doch ook en vooral tussen 'gewone' natuurlijke personen en rechtspersonen. Bovendien zijn staat, provincies, provincies, gemeenten, enz. niet aan het privaatrecht onderworpen in hun kwaliteit van overheid, van bevoegd gezag, doch in hun - min of meer toevallige kwaliteit van rechtspersoon naar privaatrecht'. Burkens krijgt $0 . i$. niet ten onrechte associaties met Kelsens 'reine Rechtslehre' en wijst op de 'kennelijke allergie' van het handboek voor enigerlei gerechtigheidsconceptie: 'het is positief recht wat de klok slaat', Zie M.C. Burkens, Bespreking van: P.P.T. Bovend'Eert/C.A.J.M. Kortmann, 'Inleiding constitutioneel recht', Deventer 1993, in RMTh 1995, pp. 21-23, in welke bespreking Burkens ook ingaat op Kortmanns handboek. 'Maar Kelsen was' - aldus Burkens - 'tot zodanig positivisme gemotiveerd omdat hij ideologisering van het recht vreesde, in de toenmalige situatie duidelijk niet zonder grond', Ook F.A.M. Stroink/J.G. Steenbeek, 'Inleiding in het staats- en administratief recht', 3e druk, Alphen a/d Rijn 1989, pp. 27 e.v., beperken vorming van positief recht tot de rechtsvorming door daarvoor bestemde overheidsorganen: 'overheidsbevoegd-

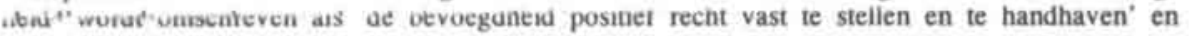
'bevoegdheid' als 'een wettelijk toegekend vermogen om rechtsgevolgen te bewerkstelligen'.

2. HR 26 jan. 1990, Gst, 6914,10, AB 1990, 408 (Windmill).

3. HR 9 febr. 1990, NJ 1991, 462, AB 1990, 409 (Staat/Van Amersfoort).

4. P.B. Cliteur, 'Conservatisme en cultuurrecht', diss, Leiden 1989, Amsterdam 1989, i.h.b. pp. 294-338, meent dat Dooyeweerds materiële rechtsstaatsleer en zijn opvattingen over materiële rechtsbeginselen een universele betekenis hebben, een betekenis die het wenselijk maakt dat men ook in niet-gereformeerde kring hiervan kennis neemt. In Trouw van 8 okt. 1994, p. 19, schrijft hij: 'Dooyeweerd is een filosoof die recht wil doen aan de variëteit in de werkelijkheid. (...) Dooyeweerd is ... de filosoof van de pluriforme samenleving. Dit kan ook door een humanist, een christen en een islamiet volkomen worden onderschreven'. Ofschoon Cliteur Dooyeweerds opvatting over het boven-willekeurig karakter van rechtsbeginselen en van de structuurprincipes vande onderscheidene samenlevingsvormen deelt - en diens leer van de rechtsstaat zelfs superieur acht aan wat men daarover leert in de handboeken van het Nederlands staatsrecht - , kan hij vanuit zijn humanistische levensvisie uiteraard niet aanvaarden dat ze boven-willekeurig zijn in de zin van transcendentaal: als 'vorgegeben' in de letterlijke zin, d.w.z. als beginselen neergelegd in een kosmische scheppingsorde. Voor de fundering ervan zoekt Cliteur aansluiting bij Hayek, die spreekt van 'long-term principles'. Ze zijn boven-willekeurig in die zin dat ze als vrucht van een langdurig proces uitstijgen boven de wijsheid van een bepaalde generatie. Ze zijn dus inderdaad niet gemaakt, zoals een handwerksman een tafel heeft gemaakt: 'Die beginselen zijn product van menselijk handelen, maar niet van een bepaald ontwerp. (...) Zij zijn niet van alle plaatsen en tijden maar ... verbonden met de liberale rechtsstaat'. En evenals J.F. Glastra van Loon, 'Dooyeweerd in gesprek met de filosofie', in: J. de Bruin (red.), 'Dooyeweerd herdacht', Amsterdam 1995, pp. 95-113 (p. 112/113), acht Cliteur het een grote verdienste van Dooyeweerd, dat deze de betekenis van het cultuurhistorisch ontsluitingsproces onder de aandacht heeft gebracht. $\mathrm{Vgl}$. ook Cliteur, a.w., p. 345/346, alwaar wordt ingegaan op de opvatting van Gijssels, dat het natuurgetrouwer zou zijn te poneren dat de mens en de mensheid permanent nieuwe samenlevingsvormen creèren die naar hun oordeel beter beantwoorden aan hun tijd-en plaatsgebonden noden. Zie J. Gijssels, 'Onherleid- 
bare rechtskringen en rechtswetenschap', Ned. Tijdschrift voor rechtsfilosofie en rechtstheorie', 1980 , pp. 42-66. Cliteur merkt op dat het hier als richtsnoer aangedragen criterium - de tijd-en plaatsgebonden noden van een samenleving - volkomen faalt tegenover een pervertering van het rechtssysteem. Door humanistische filosofen als Glastra van Loon en Cliteur wordt er op gewezen dat men Dooyeweerds grondstelling, $\mathrm{nl}$. dat elke vakwetenschappelijke begrips-en theorievorming afhankelijk is van een wijsgerige totaliteitsidee die op haar beur verankerd is in een 'arehimedisch punt' (grondmotief), niet behoeft te onderschrijven om toch de andere grondstellingen van zijn filosofie te kunnen aanvaarden. Ook voor Roos lijdt het, ondanks zijn kritick op de grondslagen van deze filosofie (m.n. de zgn. transcendentale denkkritiek en de transcendentaal-empirische methode), geen twijfel dat deze filosofie zich in veel sterkere mate dan andere (rechts)filosofieên voor rechtstreekse toepassing in het recht leent. Zie N.H.M. Roos, 'Dooyeweerd', in: T.J. Veen/P.C. Kop (red.), 'Zestig juristen. Bijdragen tot een beeld van de geschiedenis der Nederlandse rechtswetenschap', Zwolle 1987, pp. 397. 402.

5. Zoals bekend, heeft ook de Amerikaanse politiek filosoof Michael Walzer zich in zijn 'Spheres of justice. A defence of pluralism and equality', New York 1983, sterk gemaakt voor een (onder) scheiding van samenlevingsverhoudingen ('structural pluralities') met eigen rechtvaardigheidssferen ('spheres of justice'). Rechtvaardigheid in een tiberaal-westerse samenleving is - aldus Walzer - 'sfeergebonden': 'In any differentiated society, justice will make for harmony only if it first makes for separation. Good fences make just societies' (a.w., p. 319). In het onderwijs gelden andere rechtvaardigheidscriteria dan op de markt of in het gezin. Volgens Walzer kunnen samenlevingsvraagstukken worden opgelost door te bepalen in welke sfeer ze moeten worden gesitueerd en welke rechtvaardigheidscriteria daar nu precies gelden. 'Good fences' zijn volgens Walzer een garantie voor een rechtvaardige samenleving en een waarborg tegen een indringing in de eigen sfeer door andere sferen, i.h.b. ook de Staat. Dit doet denken aan Dooyeweerds beginsel van de soevereiniteit in eigen kring. De filosofie van Walzer is echter een 'interpretatiefilosofie', d.w.z. een filosofie die normatieve beginselen afleidt uit bestaande gewoontes, tradities en praktijken. Bovendien is in deze filosofie noch het sferenbegrip noch de plaats van het recht behoorlijk en systematisch uitgewerkt. Zie over de theorie van Walzer: P. van den Berg. M. Trappenburg (red.), 'Lokale rechtvaardigheid; de politieke theorie van Michael Walzer', Zwolle 1994. Zie voor een vergelijking tussen Dooyeweerds wijsgerige sociologie en Walzers theorie: J.W. Skilen, R. McCarthy (red.), 'Political Order and the Plural Structure of Society', Georgia 1991. De relevantie van Dooyeweerds theorie voor de politieke theorie is recentelijk aangetoond door: J.P. Chaplin, 'Pluralism, Society and the State: The Neo-Calvinist Political Theory of Herman Dooyeweerd (1894-1977)', PhD Dissertation, University of Londen 1993.

Vgl. ook Roel van Duijn, 'Voeten in de aarde', Amsterdam 1984, die zich beroept op het beginsel van de soevereiniteit in eigen kring als nuttig beginsel voor de opbouw van een vrije samenleving. juist omdat dit beginsel een nevenschikking van de onderscheidene samenlevingsverhoudingen inhoudt. Dit is iets anders dan het subsidiariteitsbeginsel, dat juist een ondergeschiktheid van de ene kring aan de andere impliceert.

Verder zij op de zekere gelijkenis die bestaat tussen Dooyeweerds opvattingen en die van de rechtsfilosoof H. Henkel, a.w., i.h.b. pp. 269-296, waar deze een analyse geeft van de onderscheidene 'Sozialstrukturen' en hun verhouding tot het recht. Hij ziet binnen deze structuren 'innere ontlogische Gesetzmåssigkeiten' ('Gesetzstrukturen') - dus: 'normatieve structuurprincipes'! -, die ook voor de statelijke wetgever 'Vorgegebenheiten' zijn. Deze gelijkenis behoeft niet te bevreemden, als men bedenkt dat Henkel zijn rechtsfilosfie bouwt op Hartmanns 'Schichtenlehre', die gelijkenis vertoont met de aspectentheorie van Dooyeweerd. Enigszins denken aan de theorie van de soevereiniteit in eigen kring doet ook de 'autopoietische theorie' van de Duitse rechtssocioloog Gunther Teubner. Zie over deze theorie o.a.: H.D. Stout, J. Stoop. 'Het falen van de wet. Een inleiding tot het autopoietische denken van Gunther Teubner'; dez., 'Autopoiese aan de Maas' (vraaggesprek met Teubner); dez., Recensie van Teubners 'Recht als autopoietisches System', RegelMaat 1991, pp. 3/4, 5-9 en 28-31; H.D. Stout, 'De betekenissen van de wet', diss. Amsterdam, Zwolle 1994, pp. 201-205; N.J.H. Huls, H.D. Stout (red.), 'Reflexies op reflexief recht', Zwolle 1992, waarin op pp. 71-84 in Nederlandse 
vertaling ook een paper van Teubner is opgenomen onder de titel 'Reflexief recht: de kracht van nietstatelijk recht'. Zie ook nog: P. van den Berg, M. Trappenburg, a.w., p. 102/103, waar gewezen wordt op de thematische verwantschap tussen Teubner, Walzer en Hayek.

6. T.S. Kuhn, 'The structure of Scientific Revolutions', Chicago 1962, Ned. vert. 'De structuur van wetenschappelijke revoluties'. Meppel 1987. Als bekend, is een paradigma het (gemeenschappelijk) apriorische uitgangspunt van de (normale) wetenschapsbeoefening in een bepaalde periode. Kuhns paradigma-leer is 'slechts' een descriptieve: Kuhn is er op uit na te gaan, hoe de wetenschap feitelijk bedreven wordt. Hij stelt wel vast dat wetenschappelijke theorieèn (mede) bepaald worden door de heersende levens- en wereldbeschouwing (het 'grondmotief') en dat wetenschappelijke revoluties - die ertoe leiden dat een paradigame 'instort' en een nieuwe theorie tot paradigma wordt - verbonden zijn met (o.a.) veranderingen in 'wordviews'.

7. Een vergelijkbaar standpunt wordt, als bekend, ingenomen door R. Dworkin. Ook hij wijst er op dat rechtsbeginselen en positieve rechtsregels een verschillend karakter hebben en ieder hun eigen rol vervullen in het recht. Hij wijst er op dat beginselen vooral een richtinggevende functie hebben, zonder dat ze bij voorbaat een bepaalde beslissing door het tot rechtsvorming competente rechtsorgaan dicteren. Ook wijst hij er op dat er een voortdurende wisselwerking is tussen beginselen en positieve rechtsregels: regels moeten worden toegepast in het ligt van de daaraan ten grondslag liggende beginselen, maar die beginselen winnen zelf ook weer aan betekenis door de toepassing van die regels in de juridische praktijk. Zie over verschillende bijdragen aan het themanummer van Ars Aequi okt. 1991 over 'Rechtsbeginselen', o.a. A. Soeteman, 'Hercules aan het werk. Over de rol van rechtsbeginselen in het recht', pp. 744-756; P.W. Brouwer, 'Rechtsbeginselen en rechtspositivisme', pp. 757-772; K. Raes, 'Rechtsbeginselen en de morele eenheid van het recht', pp. 773-784.

8. $\mathrm{Vgl}$. H. Dooyeweerd, 'Het juridisch wilsbegrip en de juridisch-normatieve uitlegging van rechtshandelingen', in: 'Speculum Langemeijer', Zwolle 1973, pp. 29 e.v. (p. 40): 'Niet alleen de overeenkomst, maar ook de wet, de amvb, de verordeningen van publiekrechtelijke lichamen, vonnissen, statuten en reglementen van verenigingen, volkenrechtelijke tractaten, enz., zijn in formele zin rechtshandelingen in de zin van op rechtsvorming gerichte wilsverklaringen van daartoe competente rechtsorganen'. Een onderscheid kan nog worden gemaakt tussen uitdrukkelijke en stilzwijgende ontstaansvormen van recht. De ordenende juridisch wil kan uitdrukkelijk of direct worden geopenbaard in gesproken of geschreven woorden, bijv. een wet in formele zin, een tractaat, een testament, een contract etc., of stilzwijgend (indirect) via concludente rechtsvormende gedragingen, zoals bestuurspraktijk, constante rechtspraak, gebruiken of gebruikelijke bedingen, en in het algemeen alle vormen van zgn. gewoonterecht. De gewoonte is geen juridische ontstaansvorm van positief recht, maar een kenbron van indirect gevormd recht. Het 'gewoonterecht' ontstaat binnen de onderscheiden rechtskringen door 'indirecte' (stilzwijgende) vormen, d.w.z. rechtsvormende wilsverklaringen, welke uit de feitelijke, constante gedragingen van een competent rechtsvormer worden geconcludeerd.

9. H.J. van Eikema Hommes, 'Hoofdlijnen der rechtssociologie en de materiēle indelingen van publieken privaatrecht', Zwolle 1975, p. 52. Dez., in: G.J. Scholten/D.F. Scheltens/H.J. van Eikema Hommes, 'Rechtsbeginselen', 2e druk, Zwolle 1983, pp. 33-69 (p. 51): '(Materiēle rechtsbeginselen) verschaffen de innerlijke gelding of de materiële rechtskracht aan de rechtsnormen en in samenhang met de formele rechtskracht, die op de juridische vormgeving gegrond is'.

10. Deze situatie doet zich voor binnen het staatsverband ('Stufenbau', 'gelede normstelling'), maar zal bij niet-statelijke gemeenschappen niet vaak voorkomen.

11. Hét algemene rechtsbeginsel, dat dus voor alle soorten recht geldt, maar steeds typisch gekleurd wordt door de eigen aard van het rechtsgebied waarbinnen het wordt gepositiveerd. Men vergelijke de korte beroepstermijnen in het bestuursprocesrecht met de , naar verhouding. lange verjarings- en vervaltermijnen in het burgerlijk recht.

12. Dit onderscheid is vooral door Van Eikema Hommes uitgewerkt. Vgl. Van Eikema Hommes in: 'Rechtsbeginselen', a.w.

13. Binnen de modale rechtsbeginselen kan nog worden onderscheiden tussen elementaire en samengestelde rechtsbeginselen, waarop we hier niet nader ingaan. 
14. Dat regulatieve rechtsbeginselen de constitutieve rechtsbeginselen vóoronderstellen, impliceert dat zij slechts kunnen fungeren op de grondslag van de laatste. Zo veronderstelt de juridische redelijkheid en billijkheid in het burgerlijk contractenrecht het constitutieve beginsel der rechtszekerheid, dat veelal tot uitdrukking wordt gebracht in het adagium: pacta sunt servanda. Die rechtszekerheid heeft 'nogal te lijden van de redelijkheids- en billijkheidspsychose van de moderne "rechtsvinding", aldus - 0.1 . niet ten onrechte - H.J. van Eikema Hommes, 'Detranscendentaal-empirische methode. Haar betekenis voor de juridische vakwetenschappen', Ars Aequi 1979, pp. 719-730 (p. 725).

15. Van Eikema Hommes, 'De elementaire grondbegrippen', a.w., p. 511/512.

16. Er zijn dus modaal-constitutieve rechtsbeginselen en typische-constitutieve rechtsbeginselen en er zijn modaal-regulatieve en typisch-regulatieve rechtsbeginselen.

Modaal-constitutieve rechtsbeginselen zijn de beginselen die door de algemene modale structuur van het rechtsaspect zijn gegeven, zonder welke er geen rechtservaring mogelijk is (bijv. de rechtszekerheid, het subjectieve recht en zijn onderseheid met de juridische competentiebevoegdheden ete.).

Tot de typisch-constitutieve rechtsbeginselen behoren o.a. het beginsel van de burgerlijke vrijheid in gelijkheid en het beginsel van de iustitia commutativa, als de noodzakelijke en algemeen geldige basis van het moderne burgerlijk recht.

Tot de modaal-regulatieve rechtsbeginselen behoort in de eerste plaats het beginsel van de menselijke waardigheid, dat richting geeft aan het tot gelding brengen van constitutieve rechtsbeginselen - i.h.b. aan het juridische persoonlijkheidsbeginsel - en ze verdiept en verfijnt.

Typisch-regulatieve rechtsbeginselen in het modeme contractenrecht zijn de beginselen van goede trouw, redelijkheid en billijkheid, die o.a. hun neerslag hebben gevonden in het beginsel van de toerekenbare schijn bij de juridische wilsovereenstemming.

17. $\mathrm{Vgl}$. H. Dooyeweerd, 'De Theorie van de Bronnen van het Stellig Recht in het licht der Wetsidee', Inleiding voor vergadering Vereeniging voor Wijsbegeerte des Rechts 17 dec. 1932, p. 16: 'De zin (van een modaal aspect, zoals het rechtsaspect; JT) 'in gesloten functie' wordt ... door het begrip, de zin 'in verdiepte functie' door de idee omvat'.

18. H.J. van Eikema Hommes, 'Relatieve constantie en dynamiek in de rechtsvorming', in: Recht als instrument van behoud en verandering, opstellen aangeboden aan J.J.M. van der Ven, Deventer 1972 , pp. 27-34.

19. Cliteur, a.w., p. 324

20. Met deze 'derde weg' wordt een middenpositie ingenomen tussen het natuurrechtsdenken en het rechtspositivisme. Aldus ook Cliteur, a.w., en S.W. Couwenberg. 'Gezag en vrijheid. Inleiding in de constitutionele rechts- en ontwikkelingstheorie', Zwolle 1991, i.h.b. pp, 172 e.v.

21. Ook de in het burgerlijk recht geregelde organisatievormen (stichting, n.v, etc.) prejudiciêren dus op zichzelf nog niet de materielle aard van de organisatie die voor zijn zelfstandige optreden in het burgerrechtelijke verkeer is bekleed met burgerrechtelijke rechtspersoonlijkheid. Zo komt het nogal eens voor, dat door de Staat of zijn sub-verbanden stichtingen worden opgericht teneinde bepaalde publiekrechtelijke taken te kunnen vervullen (bijv. subsidieverlening). Omgekeerd is de publiekrechtelijke inrichting van de rijksuniversiteiten een publiekrechtelijke vorm, waarin Staat en universiteit, met behoud van hun typische eigenaard, enkaptisch vervlochten zijn. Een universiteit, 66k een rijksuniversiteit, is géen 'stuk Staat', want zij vindt haar bestemmingsfunctie niet in het juridische aspect - zoals de Staat, wiens bestemmingsfunctie een (publiek)rechtelijke is - maar in het morele aspect. Naar haar aard is zij een door liefde tot de wetenschap gekwalificeerde gemeenschap van docenten en studenten, die is gefundeerd in een organisatie van wetenschappelijk onderwijs en onderzoek. Zij is dus niet alleen geen 'stuk Staat' maar óók geen bedrijf, wat betekent dat de voor staatsverband resp. bedrijfsverbanden typische beginselen niet van toepassing zijn. Vgl. Van Eikema Hommes, 'Hoofdlijnen der rechtssociologie en de materiêle indelingen van publiek- en privaatrecht', a.w., p. 22.

22. H. Coing. 'Grundzüge der Rechtsphilosophie', 3e druk, Berlin/New York 1976, p. 272/274, merkt terecht op: 'Der Staat ist keineswegs das einzige soziale Gebilde, innerhalb dessen es positives Recht gibt. Es gibt das Völkerrecht, das als ũberstaatliche Ordnung Recht zwischen den Staaten setzt; es gibt das Kirchenrecht, das innerhalb der organisierten Religionsgesellschaften Geitung besitzt. Aber auch 
innerhalb von Gruppen sehr viel geringer Relevanz und Dignităt existieren eigene Ordnungen: so in Vereinen, Gesellschaften, Untemehmungen. Es gibt eine Vielfalt von Rechtsgemeinschaften, Rechtskreisen, die nebeneinander stehen. Mat hat die Ordnungen dieser nichtstaatlichen Rechtsgemeinschaften als Sozialrecht dem staatlichen Recht gegenübergestellt.

Innerhalb dieser verschiedenen Rechtskreisen kommt allerdings dem staatlichem Recht eine besondere Stellung zu, wiel der modeme, nach dem Prinzip der Souveränitât aufgebaute Staat innerhalb seiners Gebietes das Z wangsmonopol in Anspruch nimmt und weitgehend ... auch durchgesetzt hat. Angesichts dieses Zwangsmonopols haben andere, nicht staatlich gesetzte Ordnungen nur dann eine wirkliche Geltungschance, wenn das staatliche Rechts sie anerkannt. (...) In der Tat ist die Bedeutung dieses gesellschaftich geschaffenen Rechts ausserordentlich. (...) Die Bestimmung seiner Grenzen im Verhalitnis zur staatichen Rechtsordnung ist eines der grossen Probleme der Rechtsbildung in der modernen freiheitlichen Demokratie'.

Vgl. ook W. Krawietz, 'Recht ohne Staat? Spielregeln des Rechts und Rechtssystem in Normen- und Systemtheoretischer Perspektive', Rechtstheorie 1993, pp. 81-133 (p. 126-127): 'Es wăre ... absurd, per definitionem als Recht nur das staatliche Recht anzusehen, denn dass hiesse, dass nur das vom Staat gesetzte oder doch irgendwie abgeleitete Recht diesen Namen verdiente. (...) Aber auch die nichtstaatlichen Rechtsgemeinschaften, wie Vereine, Gewerkschaften, Verbànde und Unternehmungen, ganz zu schweigen von den Kirchen, erzeugen eigenständiges autonomes Recht. Dieses genuin gesellschaftliche Recht gehört selbstverständlich zum positiven Recht, darf aber nicht mit dem formalen staatlichen Recht identifizien werden. Die pluralistischen gesellschaftlichen Krafte ... bilden kein einheitliches, in sich koharentes oder gar widerspruchfreies System der Rechrsquelen und können - wenn überhaupt - nur partiell durch das staatliche Recht beeinflusst, reguliert und gesteuert werden. (...) In Wirklichkeit ist die Rechisondnung in der modemen Gesellschaft ... keive Henanchie vow Rechusnormen, sondern erine Heterarchie diverser sozialer Regelsysteme des Rechts'.

23. Dat ook cultuurhistorisch bezien, het burgerlijk recht onverbrekelijk samenhangt met de territoriale publieke rechtsorde lieten we reeds eerder zien. We beschreven het cultuurhistorisch differentiërings-, individualiserings- en integratieproces, dat leidde tot afbraak van de vroegere ongedifferentieerde gemeenschappen, de scheiding van enkel door het beginsel van het algemeen belang gereguleerde overheidsmacht (imperium) en privaat vermogensbelang (dominium), en - als keerzijde - de erkenning van het persoonlijkheidsbeginsel. Daarmee werd enerzijds een vrije ontplooiing van de mens mogelijk en kon een vrij maatschappelijk verkeer ontstaan, waarin de enkelingen zelfstandig hun private doeleinden kunnen nastreven en op basis waarvan ook het ontstaan van vrije - gedifferentieerde maatschappelijke corporaties mogelijk is, en kon anderzijds op basis van de territoriale publieke rechtsorde van de Staat een integrerende burgerlijke rechtsorde op basis van de burgerlijk vrijheid en gelijkheid worden ingesteld.

24. Asser-Scholten, 'Algemeen deel', 3e druk, Zwolle 1974, p. 16. Overigens ware het o.i. preciezer om, i.p.v. 'wil van partijen', te spreken van 'rechtsvormende wil van partijen'. Vgl. ook J.H. Nieuwenhuis, 'Drie beginselen van contractenrecht', diss. Leiden, Deventer 1979.

25. Dit uitgangspunt is in het per 1 jan. 1992 in werking getreden nieuw BW gehandhaafd. Art. 6:1 BW bepaalt weliswaar: 'Verbintenissen kunnen slechts ontstaan indien dit uit de wet voortvloeit', maar daarmee kan slechts zijn bedoeld dat voor het burgerlijk recht een verbintenis - afdwingbaar naar burgerlijk recht - ontstaat indien dit uit de wet voortvloeit. Art. 6:213 omschrijft een overeenkomst heel algemeen als 'een meerzijdige rechtshandeling, waarbij een of meer partijen jegens een of meer andere een verbintenis aangaan': art. 6:217 lid 1 BW zegt: 'Een overeenkomst komt tot stand door een aanbod en de aanvaarding daarvan'. In art. 3:33 BW is omschreven wat kenmerkend is voor een rechtshandeling: 'Een rechtshandeling vereist een op een rechtsgevolg gerichte wil die zich door een verklaring heeft geopenbaard'. Dit rechtsgevolg - het verkrijgen van burgerrechtelijke rechtskracht - treedt in concreto eerst in, wanneer aan de in de wettelijke rechtsvormen van artt. 6:213 en 6:217 W.W. neergelegde rechtsfeitomschrijving is voldaan. Daarin is echter de rechtsmacht van partijen te contracteren - de contracteervrijheid ('Abschlussfreiheit' en 'Inhaitsfreiheit') - vóorondersteld: als burgers een contract sluiten - dus als sprake is van met elkaar corresponderende op contractsvorming 
gerichte wilsverklaringen - en de wettelijke gremzen in acht worden genomen (dwingende wetsbepalingen, openbare orde etc.), verbindt de burgerlijke wet dasraan het rechtsgevolg dat de verbintenis burgerrechtelijke rechtskracht krijgt.

26. Overigens is niet alles wat in het BW staat, maar zijn materiele aard burgerlijk recht. Zo bevat Boek 1 van het BW allerlei bepalingen van publiekrecht (bijv. de artt. 1:16 e.v.: instructies aan de ambtenaar

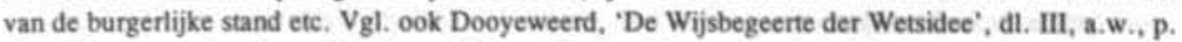
596: 'Het zgn. naleve formalistisch positivisme klampt zich vast aan de juridische ontstaanswormen van het recht, waaronder het de staatswet tot hoogste geldingsbron verheft en ziet in 't geheel niet, dat juist in deze ontstaansvormen het fundamenteele probleem der enkaptische structuurverlichtingen tusschen materieel verschillende competentiesferen schuilt. Het gaat eenvoudig uit van het politieke dogma, dat de 'staatswil" de eenige geidingsbron is van het recht, dat de staat een juridisch onbegrensde 'Kompetenz-Kompetenz' bezit'.

27. H. Dooyeweend, 'De Theorie van de Bronnen van het Stellig Recht in het licht der Wetsidee', Inleiding voor de vergadering van de Vereeniging voor Wijsbegeerte des Rechts 17 dec. 1932, p. 25/26.

28. Zie bijv. Dooyeweerd, 'Het juridisch wilsbegrip en de juridisch-normatieve uitleg van rechtshandelingen', a.w., pp. 44-48, waar ook opgemerkt wordt dat men de termen 'gemeenschap' en 'maatschap' dus niet dooreen mag gebruiken. $\mathrm{Vgl}$. dez., 'Verkenningen in de wijsbegeerte, de sociologie en de rechtsgeschiedenis', a.w., p. 110: 'Onder gemeenschapsbetrekkingen verstaan wij al die sociale relaties warin de mensen als leden van een geheel zijn gevoegd; onder maatschapsverhoudingen daarentegen die, waarin de mensen, resp. de gemeenschappen onderling, niet tot een geheel verbonden zijn, maar gecoōrdineerd naast of zelfs tegenover elkander in de samenleving optreden ('t zij in samenwerking en onderlinge aanvulling, ' $t$ zij in neutrale verhouding, ' $t$ zij in strijdpositie)'.

29. Verbanden zijn georganiseerde (niet-natuurlijke) gemeenschappen; ze bezitten een organisatie die hun een min of meer continu bestaan verschaft, onafhankelijk van de levensduur van zijn leden of het aanen aftreden van bestuursleden. Ze kunnen worden onderscheiden van de zgn. natuurlijke gemeenschappen, zoals huwelijk, gezin en familie, die een typisch biotische fundering hebben en op een gegeven moment ophouden te bestaan. Binnen de categorie van de verbanden kan worden onderscheiden tussen de institutionele verbanden en de vrije, niet-institutionele verbanden, ook wel maatschappelijke verbanden genoemd. Omdat ze ontstaan op basis van het vrije maatschappelijke verkeer - mogelijk geworden door het ontstaan van een sfeer van persoonlijke vrijheid ná de afbraak van de vroegere ongedifferentieerde samenlevingsverbanden -, worden ze maatschappelijke verbanden genoemd. $\mathrm{Ze}$ ontstaan in dat verkeer door een vrij contract ('Vereinbarung') en berusten op vrije toe- en uittreding van leden, en bestaan na die oprichting als verbanden. Een institutioneel verband is een verband dat zijn leden voor hun gehele leven of een aanzienlijk deel daarvan, tot op zekere hoogte onafhankelijk van hun individuele wil samenbindt. Tot de institutionele verbanden behoren de Staat en - althans voor de gelovigen - de kerk. Een mens wordt in het algemeen staatsburger door geboorte, hoewel er ook andere wegen bestaan om de nationaliteit te verkrijgen. Geen staatsburger kan geheel naar eigen wil zijn nationaliteit veranderen.

30. De beantwoording van deze vragen is uiteraard afhankelijk van de kijk die men heeft op de menselijke samenlevingsverhoudingen en van het rechtsbegrip dat men aanhangt. Zie hierover: $\mathrm{H}$. Dooyeweerd, 'Grondproblemen in de leer der Rechtspersoonlijkheid', Ee. critische beschouwing n.a.v. Dr H.J. Wolff's standaardwerk 'Organschaft und juristische Person', Bnd. I(1933)', Themis 1937, pp. 199-263, pp. $367-421$, waarin de $z \mathrm{gn}$. functionele verbandstheorie wordt verdedigd.

31. De aanduiding 'rechtspersoonlijkheid', die is ontstaan op basis van een beschouwing die in een menselijk samenlevingsverband de (juridische) fictie kon zien van een 'natuurlijke persoon' moet overigens als minder gelukkig worden beschouwd. Die gemeenschappen zijn geen 'zelfstandige personen' met een eigen 'ik-heid', die kunnen denken, voelen etc. Wanneer men zegt dat een samenlevingsverband een eigen handelingssfeer etc. heeft, kan dit niets anders betekenen dan de handelingssfeer etc. van de mensen verenigd in een bepaalde verbandseenheid. Maar evenmin zijn die gemeenschappen ook geen ficties (dus ook geen juridische ficties), doch realiteiten: het gaat om reelle, meer of minder duurzame samenlevingsverhoudingen die door mensen tot een eenheid zijn gevormd en 
waarvan die mensen als leden - steeds naar een specifieke gemeenschapszijde van hun menselijke persoonlijkheid - deel uitmaken. En omdat het juridisch aspect slechts éen van de aspecten is van de volle werkelijkheid en de rechtssubjectiviteit dus niet mag worden vereenzelvigd met de 'natuurlijke mens' - zij betreft 'slechts' zijn fungeren in allerlei samenlevingsverhoudingen, bezien naar het juridisch aspect -, fungeren ook samenlevingsverbanden - die immers door mensen geconstitueerd worden - niet alleen als rechtssubject.

32. Voor de zgn. verenigingen 'met beperkte rechtsbekwaamheid' en voor stichtingen is bepaald, dat ze eerst als rechtspersoon kunnen optreden, wanneer de oprichting geschiedt bij notariële akte (stichtingen kunnen overigens 6 ók worden opgericht bij openbaar testament) en de oprichtingsakte aan zekere wettelijke eisen voldoet (artt. 2:27 en 2:286 BW). Preventieve controle wordt hier dus uitgeoefend door de notaris als ambtenaar. Voor naamloze en besloten vennootschappen ontstaat de rechtspersoonlijkheid eerst na een ministeriele verklaring van geen bezwaar op de oprichtingsakte (artt. 2:62 en 2:175 BW). Bij al deze rechtspersonen werkt de rechtspersoonlijkheid pas tegenover derden na publicatie van de oprichtingsakte (artt. 2:29, 2:289, 2:69 en 2:180 BW). Met deze voorschriften wordt de rechtszekerheid gediend, omdat derden aldus kennis kunnen nemen van het doel der rechtspersoonlijkheid, van de organen die bevoegd zijn extern namens het verband op te treden, en van de omvang van het maatschappelijk kapitaal resp. het afgescheiden vermogen). Met de eis van preventieve controle wordt meer in het bijzonder beoogd een zekere bescherming te bieden van derden tegen het gevaar van een mogelijk misbruik van de rechtspersoonlijkheidsvorm door enkelingen die haar zouden kunnen aanwenden om op naam van de rechtspersoon privé-belangen te behartigen, maar de aansprakelijkheid voor de daaruit voortvloeiende schulden bij de rechtspersoon te leggen. Door de verkrijging van rechtspersoonlijkheid afhankelijk te stellen van preventieve controle heeft de wetgever dus zoveel

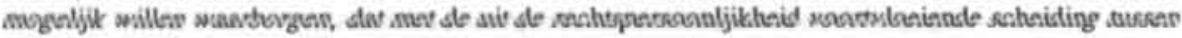
corporatief vermogen en privé-vermogen(s) geen ongeoorloofde doelen worden nagestreefd. Vgl. Van Eikema Hommes, 'De samengestelde grondbegrippen', a.w., p. 149. Wat het toezicht op het functioneren van rechtspersonen betreft, kan nog gewezen worden op de door Boek 2 BW (artt. 20 en 21: vgl. ook artt. 298 en 299) aan het Openbaar Ministerie verleende bevoegdheid ontbinding van de rechtspersoon te vorderen wanneer de rechtspersoon verboden is, deze bij zijn oprichting of in zijn statutaire regeling niet aan de wettelijke eisen voldoet of wanneer de rechtspersoon in ernstige mate in strijd met de statuten handelt.

33. Asser-Van der Grinten, 'De rechtspersoon', 5e druk, Zwolle 1980, p. 32/33, drukt zich dan ook nogal ongelukkig en zelfs onjuist uit, waar wordt gesteld: 'Iedere rechtspersoon is een georganiseerd geheel, waarvan de organisatie wordt bepaald door de wet en eventueel door het ongeschreven recht en voorts in het bijzonder door de eigen statuten en reglementen (...) De rechtspersoon heeft krachtens de wet een interne organisatie. (...) Het is denkbaar, dat de organisatie van een rechtspersoon geheel in wettelijke bepalingen is vervat' (curs. dzz.; JT)'. Welbeschouwd zou dit betekenen dat een menselijk samenlevingsverband zijn ontstaan en voortbestaan - dus niet alleen de rechtspersoonlijkheid naar burgerlijk recht - alsook zijn bevoegdheid tot het, binnen de door de wet overgelaten ruimte, positiveren van intern verbandsrecht (statuten en reglementen) ontleent aan de wetgever. Het zal duidelijk zijn, dat de opvatting dat een rechtspersoon zijn interme organisatie heeft krachtens de wet, door ons niet kan worden aanvaard.

Wij tekenen nog aan dat, wanneer aan een organisatie geen burgerrechtelijke rechtspersoonlijkheid toekomt, er toch goede redenen kunnen zijn te erkennen dat 'een zelfstandige deelname aan het administratiefrechtelijke verkeer' (Vz.AR 26 maart 1981, tB/S IV, p. 262) door die organisatie als zodanig tot de mogelijkheden dient te behoren. We stemmen dan ook in met de kritiek van P. Nicolai,, 'De rechtspersoon in artikel 7 Wet Arob', NJB 1988, pp. 183-187, op de Arob-rechter, die veelal niet bereid was een als appellant optredende groep als rechtspersoon in de zin van art. 7 Wet Arob aan te merken omdat de rechtspersoonlijkheid in de zin van Boek $2 \mathrm{BW}$ ontbrak. De omstandigheid dat een organisatie als zodanig geen rechtssubject is binnen de ene rechtskring, betekent niet automatisch dat dat geen rechtssubject kan zijn binnen de andere rechtskring.

34. Asser-Van der Grinten II, a.w., pp. 134 en 29. 
35. L.J.A. Damen, 'De assistent-kampbeheerder die graag ambtenaar had willen zijn' (noot bij Pr.Rb. Amsterdam 13 april 1994. Awb 94/947/V). AAe 1995, pp. 290-296, wijst er terecht op dat de term 'publiekrechtelijke rechtspersoon' dient te worden vermeden als aanduiding voor 'overheidsorgaan' c.q. 'ambt', zoals we bepleit is door aanhangers van de zgn. ambtentheorie. Zoals het verwarrend is voor overheidsorganen de term 'publiekrechtelijke rechtspersonen' te gebruiken, zou het toch $6 \delta \mathrm{k}$ misleidend zijn de intern-rechtsvormende organen van private verbanden aan te duiden als 'privaatrechtelijke rechtspersonen'.

36. Nemen we als voorbeeld iemand die lid is van een sportvereniging en daarnaast, als exploitant van een winkel in sportartikelen, dergelijke artikelen verkoopt aan die vereniging. Als lid van die vereniging - dus binnen de vereniging - heeft hij (o.a.) te maken met de organen van die vereniging, en met het inteme verenigingsrecht zoals dat door die organen is gepositiveerd. Als hij als winkelier sportartikelen verkoopt aan die vereniging, treedt hij echter op als rechtssubject in het burgerrechtelijk verkeer en heeft hij te maken met het verbandsgeheel dat als rechtspersoon 'extern' - dus eveneens als rechtssubject in het burgerrechtelijk verkeer - optreedt. Hij heeft niet één 'rechtssubjectiviteit', maar allerlei specifieke juridische subjectsfuncties, al naar gelang de materiele rechtskring waarin hij fungeert: hij fungeert als lid van het staatsverband en van statelijke sub-verbanden, en kan daarnaast ook fungeren als lid van allerlei niet-statelijke gemeenschappen. Bovendien fungeen hij ook buiten gemeenschapsbetrekkingen ( $\mathrm{nl}$, in maatschapsbetrekkingen) en kan hij, náást en buiten zijn lidmaatschap van een verband, tegenover dat verband ook als derde optreden en met dat verband in een burgerrechtelijke rechtsbetrekking staan.

37. Onder rechtsbekwaamheid verstaan we de hoedanigheid om binnen een bepaalde rechtskring - hier: die van het burgerlijk recht - op te treden als drager van subjectieve rechten, van subjectieve rechtsbelangen (zoals vrijheid, eer, lichamelijke integriteit etc.) en van subjectieve rechtsplichten. A.Q.C. Tak, 'Overheid en privaatrecht', Alphen a/d Rijn 1979, p. 281, maakt nog een onderscheid tussen 'rechtsbekwaamheid' - als aanduiding van het vermogen, de potentie, om in het algemeen subject, drager van subjectieve rechten en plichten te zijn - en 'rechtsbevoegdheid' - als aanduiding van de geoorloofdheid om subject, drager, van concrete subjectieve rechten en plichten te zijn. Zien we het goed, dan correspondeert deze onderscheiding met het in Duitse literatuur gemaakte onderscheid fussen 'Vollrechtsfahigkeit' en 'Teilrechtsfahigkeit'. O. Bachof, 'Teilrechtsfahige Verbände des offentlichen Rechts', AōR 1958, pp. 208-279 (p. 264), schrijft: 'Teilrechtsfahigkeit entsteht durch 'Einzelzuweisungen von Rechten und Pflichten'. En H. Maurer, a.w., p. 469, zegt: 'Wăhrend im Falle der Vollrechtsfähigkeit die Rechtsfahigkeit' allgemein angenommen werden kann und nur die Anwendbarkeit der fraglichen Rechtsnorm im einzelnen festzustellen ist, muss im Falle der Teilrechtsfahigkeit zunăchst die besondere Zlwweisung der fraglichen Rechte und Pflichten geprüft werden' (curs. dzz.; JT). Met 'Teilrechtsfahigkeit' wordt dus gedoeld op (een complex van) specifiek toegewezen 'rechtsbevoegdheden'. Het vermogen om in het burgerlijk vermogensrecht als 'natuurlijke' persoon of als rechtspersoon drager te zijn van private subjectieve rechten, rechtsbelangen en plichten wordt door het BW in algemene zin erkend en gepositiveerd, en is dus een 'Vollrechtsfahigkeit'.

Rechtsbekwaamheid en rechtsbevoegdheid enerzijds kunnen worden onderscheiden van handelingsbekwaamheid en handelingsbevoegdheid anderzijds. (Rechts)handelingsbekwaamheid kan worden omschreven als het in algemene zin bestaande vermogen om binnen een bepaalde rechtskring actief rechtsvormend op te treden, en (rechts)handelingsbevoegdheid als een concrete, specifieke bevoegdheid om binnen een bepaalde rechtskring rechtsvormend op te treden, dus de competentiebevoegdheid om een concrete rechtshandeling te verrichten. We zouden ook kunnen spreken van 'Vollhandlungsfähigkeit' resp. van 'Teilhandlungsfahigkeit'.

Dit onderscheid loopt parallel met het eerder gemaakte onderscheid tussen de materiële competentiesfeer van een bepaald verband, die de rechtsvormende competentie van het hoogste verbandsorgaan bepaalt en welke competentie we dus 'handelingsbekwaamheid' kunnen noemen, en de formele competenties van de lagere rechtsvormende organen, die we als 'handelingsbevoegdheden' kunnen aanduiden. 
Subjectieve rechten moeten dus worden onderscheiden van rechtsvormende bevoegdheden: de contracteerbevoegdheid van burgers, de regelgevende bevoegdheid van de wetgever etc. zijn geen subjectieve rechten. Wél zijn subjectieve rechten in het algemeen correlaat met zekere rechtsvormende bevoegdheden: $z o$ impliceen bijv, de eigendom van een grondstuk de bevoegdheid van de eigenaar om (het object van) zijn eigendomsrecht te vervreemden of te bezwaren, of om eenzijdig rechtsregels te stellen voor ieder aan wie hij een zeker gebruik daarvan wil toestaan. Omgekeerd kunnen door gebruikmaking van rechtsvormende bevoegdheden (bijv. door contractsluiting) nieuwe subjectieve rechten ontstaan.

38. H.D. van Wijk/W. Konijnenbelt/R.M. van Male, 'Hoofdstukken van administratief recht', 9e druk, Utrecht 1994. p. 459.

39. H.Ph.J.A.M. Hennekens, 'De Kaderwet bestuur in verandering', Gst. 1994, nr. 6997.1. pp. 521-530 (p. 527, 1e kolom).

40. A.Q.C. Tak, 'Publiek domein, Overheidscontract en rechterlijke wetshandhaving', NTB 1990, pp. 265 270 (p. 269).

41. A.R. Bloembergen, 'Overheidsprivaatrecht: schets van een algemeen deel', WPNR 1992, nr. 6074 (themanummer 'De overheid in het privaatrecht twintig jaar later'), pp. 950-957 (p. 953).

42. We spreken hier van 'burgerlijk vermogensrecht', omdat 'vermogensrecht' geen synoniem is voor 'burgerlijk recht'. Er bestaat ook een publiekrechtelijk vermogensrecht. L. van Praag. 'Op de grenzen van publick- en privaatrecht', Den Haag 1923, heeft hier terecht op gewezen. Het is een veel voorkomende misvatting. dat vermogensrechtelijke overheidsgedragingen steeds burgerrechtelijke gedragingen zijn, en wel van het openbaar lichaam-rechtspersoon naar burgerlijk recht. Zo zijn de uit de verhouding tussen de overheid en haar ambtenaren voortvloeiende verhoudingen óók van vermogensrechtelijke, 'maar hier nog niet van burgerrechtelijke aard', zoals ady gen. Besier terecht opmerkt in zijn conclusie vóór HR 29 jan. 1926, NJ 1926, p. 231 (Staat/Kok). Als art. 2:5 BW spreekt van 'wat het vermogensrecht betreft', kan uiteraard slechts gedoeld zijn op het burgerlijk vermogensrecht.

43. $\mathrm{Vgl}$. art. 3:32 lid $1 \mathrm{BW}$ : 'Iedere natuurlijke persoon is bekwaam tot het verrichten van rechtshandelingen, voor zover de wet niet anders bepaalt', en art. 2:5 BW: 'Een rechtspersoon staat wat het vermogensrecht betreft, met een natuurlijke persoon gelijk, tenzij uit de wet het tegendeel voortvloeit'.

44. Voor de volledigheid merken we nog op, dat de burgerrechtelijke handelingsbekwaamheid van 'natuurlijke' personen in het algemeen is gebonden aan de burgerlijke meerderjarigheid. Vgl. art. 1:234 lid 1 en art. 3:32 lid 2 BW. De minderjarige kan overigens wel bevoegd zijn tot het verrichten van concrete rechtshandelingen. $\mathrm{Vgl}$. art. 2:234 leden 2 en $3 \mathrm{BW}$. Ook de onder curatele gestelde is handelingsonbekwaam voor zover de wet niets anders bepaalt (art. 1:234 lid 1 BW). Minderjarigen en onder curatele gestelden zijn wèl rechtsbekwaam (zij kunnen zelfstandig drager zijn van subjectieve rechten, rechtsbelangen en plichten), maar niet in algemene zin handelingsbekwaam. Daarom moeten er wettelijke vertegenwoordigers - ouders, voogden, curators - zijn, die in het burgerlijk rechtsverkeer de rechtsmacht bezitten om rechtshandelingen te verrichten in de plaats van en op naam van deze handelingsonbekwamen.

45. In de sociologie wordt dit wel aangeduid als 'roldifferentiatie'.

46. Ook voor het bestaan van rechtspersoonlijkheid kan men dus niet de eis stellen, dat desbetreffende organisaties in elk opzicht, dus voor alle soorten van rechtsnormen, eindpolen van subjectieve toerekening kunnen zijn: zulke organisaties bestaan niet. In dit verband wijze we nog eens op onze eerdere opmerking dat, indien een organisatie de burgerrechtelijke rechtspersoonlijkheid ontbeert, zulks op zichzelf niet behoeft te betekenen dat het in het publiekrechtelijke verkeer ook niet als zelfstandige juridische eenheid zou kunnen optreden, i.h.b. bij het aantekenen van bezwaar en beroep. Vgl. art. 8:1 jo. art. 1:3 Awb.

47. F. Fabricius, 'Relativităt der Rechtsfahigkeit', München/Berlin 1963.

48. B. Kempen, 'Die Formenwahlfreiheit der Verwaltung', München 1989, p. 67/68. 
49. H.-M. Pawlowski, 'Allgemeiner Teil des BGB', 2e druk, Heidelberg 1983, p. 47/48, die overigens evenenals Bachof en Kempen 'Rechtsfahigkeit' lijkt te gebruiken in de ruime betekenis, in die zin dat daaronder begrepen wordt zowel wat wij onder rechtsbekwaamheid als wat wij onder handelingsbekwaamheid verstaan.

50. Vgl. Logemann, a.w., p. 115. Wat de rechtspersonen betreft, geeft het BW alleen een beperking voor de vereniging ex art. 2:30 BW, t.w. de vereniging waarvan de statuten niet zijn vastgelegd bij notariele akte. Naar burgerlijk recht kan deze vereniging gaan registergoederen verwerven en geen erfgenaam zijn (Bovendien zijn bestuurders naast de vereniging hoofdelijk aansprakelijk voor schulden uit rechtshandelingen verricht tijdens hun bestuur).

51. Anders dan voor een verband zijn voor de 'natuurlijke' persoon zijn maatschapsbetrekkingen niet de noodzakelijke keerzijden van de gemeenschapsbetrekkingen, waarin hij $60 k$ verkeert. De omvang van de menselijke rechtssubjectiviteit en handelingsbekwaamheid in het burgerrechtelijk verkeer is niet afhankelijk van specifieke doeleinden.

52. Asser-Van der Grinten all, a.w., p. 58/59.

53. Op het onderscheid tussen 'publieke' en 'publiekrechtelijke belangen' komen we hierna nog terug.

54. De omwentelingen is Oost-Europa hebben daar het bewustzijn vergroot van het grote belang bij het herstel van een van de statelijke sfeer te onderscheiden 'civil society'. Men zie hierover o.a. bijdragen aan de in juli 1990 aan het Institut fur die Wissenschaften vom Menschen te Wenen gehouden conferentie over 'Centraal-Europa op weg naar de democratie' op, welke gedeeltelijk zijn afgedrukt in: P. Dekker (red.), 'Civil Society', Rijswijk, Sociaal en Cultureel Planbureau 1994, pp. 35-39. Leszek Kolakowski (pools filosoof, thans werkzaam in Oxford) merkt in zijn bijdrage op, dat de uitdrukking 'civil society' in minstens drie betekenissen wordt gebruikt: ten eerste wordt in Rousseauiaanse geest de maatschappij ermee tegenover de oorspronkelijke natururtoestand geplaatst; ten tweede wordt de burgerlijke maatschappij in Hegeliaanse zin tegenover de Staat geplaatst, en dan wordt ermee gedoeld op alle individuele en groepsverhoudingen buiten de statelijke; ten derde wordt 'civil society' ook nog gebruikt in de (vage) betekenis van: gemeenschap van de burgers, en wel de burgers die een zintuig hebben voor de res publica. Het zal duidelijk zijn, dat wij de aanduiding 'maatschappij' gebruiken in de tweede betekenis. Jerzy Szacki (socioloog aan de universiteit van Warschau) wijst er in zijn bijdrage terecht op, dat het belangrijkste aan het Civil society-concept het tegenover elkaar stellen van het maatschappelijke domein en het statelijke is.

55. Zie voor een overzicht van het zgn. communitarisme (niet te verwarren met communisme): B. van Klink, P. van Seters en W. Witteveen, 'Gedeelde normen? Gemeenschapsdenken en het recht', Zwolle 1993: Dekker (red.), a.w..

56. R.A.V. van Haersolte, 'De staat als zuivere vorm des menschen', Zwolle 1946, pp, 198, 202 en 256.

57. Vgl. ook Walzer, a.w., die uitgaat van een pluralisme aan 'spheres of justice' in hedendaagse samenlevingen en die de publieke samenlevingssfeer beschrijt als de sfeer die de onderlinge verhouding van de andere sferen reguleert. Ook wijst hij er op dat in een pluralistische 'civil society' politieke, noch economische, noch culturele belangen etc. mogen overheersen. Al de verschillende 'settings of good life' dienen - met respect voor elkaars grenzen - te floreren binnen de 'civil society', die Walzer beschrijt als 'setting of settings'. Zie M. Walzer, 'The idea of civil society', Dissent 1991, pp. 293. 304.

58. René Foqué, 'De ruimte van het recht', a.w., p. 25. De term 'samenleving' gebruikt Foqué, waar wij de term 'maatschappij' zouden gebruiken. Immers, ook de Staat is een samenlevingsverhouding.

59. D. Schindler, 'Verfassungsrecht und soziale Struktur', Zürich 1944, p. 61/62.

60. Zie ook de politiek-filosofische geschriften van de Franse filosoof Claude Lefort, die betoogt dat de politieke idee van democratie - in tegenstelling tot het totalitarisme - vasthoudt aan het onderscheid tussen Staat en maatschappij als waarborg voor de vrijheid van de burgers in de sfeer van het maatschappelijke. Zie o.a. Claude Lefort, 'Essays sur le politique', Paris 1986; dez., 'Het democratisch tekort: Over de noodzakelijke onbepaaldheid van de democratie', Amsterdam-Meppel 1992 (vertaling in het Nederlands van enkele artikelen). Zie over de politieke theorie van Lefort: A. van der Putte, 'Macht en maatschappij. Cl. Lefort over democratic en totalitarisme', Tijdschrift voor Filosofie 1987 
(49), pp. 396-433; D. Loose, 'Van de ene democratie naar de andere. Over vrijheid en gelijkheid n de politieke filosofie van Alexis de Tocqueville en Claude Lefort', in: L. Heyde en H. Visser (nd.), 'Filosofie en Democratie', Tilburg 1990; Herman van Erp, 'Het politieke belang', Amsterdam 194, pp. $42-44$.

61. Vgl. E. Molitor, 'Über offentliches Recht und Privatrecht', Karlsruhe 1949.

62. Dit is o.a. verkondigd door Karl Larenz, 'Rechts- und Staatsphilosophie', 2e druk, Berlin 1935; ez., 'Rechtsperson und subjektives Recht; Zur Wandlung der Rechtsbegriffe', in: 'Grundlagen der nuen Rechtswissenschaft', Berlin 1935. Vgl, ook H.H. Jakobs, 'Karl Larzen und der Nationalsozialismus', JZ 1993, pp. 805-813, warin een aantal opstellen van Larenz uit de periode na 1933 woden besproken. In 1942 verscheen een ontwerp voor 'Grundregeln' en een nieuw Boek I ('Der Volksgeiosse') van een nieuw BGB, een 'Volksgesetzbuch' dat het oude 'individualistische' BGB zou moten vervangen. De eerste van deze 'Gnundregeln' luidde: 'Oberstes Gesetz ist das Wohl des deutschen Volkes'.

63. W.J. Slagter, 'De rechtsgrond van de schadevergoeding bij onrechtmatige daad', diss. Leiden 1952, p. 26.

64. Ook de in de Grondwet vastgelegde grondrechten werden niet beschouwd als - door de grondwetgwer erkende en gepositiveerde - materielle vrijheidssferen tegenover de Staat, maar als door de Saat verleende rechten die het karakter hadden van sociale functies, d.w.z. als rechten die in dienst var de samenleving - hier inderdaad beschouwd als totaal-structuur - en 'dus' in dienst van het algemen belang uitgeoefend dienden te worden. $\mathrm{Zij}$ mochten dan ook slechts worden uitgeoefend, voor zover daardoor de belangen van de 'socialistische maatschappij' niet werden geschaad. Zie bijv. art. 59 ran de Sowjet-grondwet van 1977: 'De uitoefening door burgers van hun persoonlijke vrijheidsrechter is onverbrekelijk verbonden aan de nakoming van hun plichten. Burgers van de USSR zijn verplichide grondwet van de USSR en sowjet-wetten in acht te nemen, te voldoen aandemaatstavandirgoldarvoor socialistisch gedrag alsmede de eer en waardigheid van het Sowjet-burgerschap hoog te houden. Dat een eigen sfeer van niet-statelijke gemeenschappen niet werd erkend, blijkt ook uit een bepaling als art. 67 van die Grondwet, waarbij ouders werden verplicht hun kinderen op te voeden 'tot eervol lid van de socialistische maatschappij'.

65. Hans-Martin Pawlowski, 'Allgemeiner Teil des BGB', 2e druk, Heidelberg 1983, p. 6 (cursiveringen door de auteur).

66. Foqué, 'De ruimte van het recht', a.w., pp. 31 e.v.

67. Foqué, 'De ruimte van het recht', a.w., p. 33.

68. Foqué, 'De ruimte van het recht', a.w., p. 26/27 en p. 32/33.

69. Vgl. ook H. van Erp, 'Het politieke belang', Amsterdam 1994, p. 44/45, die enerzijds wijst op de taak van de Staat om de privacy van de burgers te beschermen tegen de zich gestaag uitdijende informatiemaatschappij. maar anderzijds ook op de noodzaak tot beteugeling van de Staat bij zijn drang tot controle: 'De scheiding van staat en maatschappij wordt zo een voorwaarde voor de privacy en vrijheid van de burgers tegen een naar totalitarisme neigende samenleving van allemaal gelijken. De totalitaire staat legt zichzelf geen beperkingen op in zijn wil om te weten wat er in de individuen omgaat en kent geen grenzen in zijn behoefte aan centralisering van informatie'.

70. Vgl. de uitspraak van Lenin: 'Wir erkennen nichts Privates an, für uns ist alles im Bereich der Wirtschaft offentlichrechtlich, aber nicht privat. Wir erlauben den Kapitalismus nur dem Staat, aber der Staat sind wir'. Geciteerd door N. Reich. 'Sozialismus und Zivilrecht', Frankfurt aM 1972, p. 134.

71. M. Albert, 'Capitalisme contre capitalisme', Paris 1991, Ned. vert.: 'Kapitalisme contra kapitalisme', Amsterdam 1992. Albert onderscheidt drie fasen in de relatie tussen kapitalisme en staat: (1) de fase van het kapitalisme contra de staat (ca. 1791-1891), de 'nachtwakerstaat' dus, (2) de fase van het kapitalisme gestuurd door de staat, de fase van de sociale staat dus (1891-1981), (3) de fase van het kapitalisme in plaats van de staat (vanaf 1981, de opkomst van de 'Reagonomics' en het 'Thatcherisme'). De analyse van Albert vertoont overigens gelijkenis met die van J.K. Galbraith, 'The culture of contentment', Boston 1990. Galbraith constateert de opkomst van een nieuwe professionele klasse, die gekenmerkt wordt door een 'cultuur van tevredenheid' (nl. met zichzelf), die zich o.a. uit in het 
toeschrijven van armoede en sociale achterstanden van anderen aan persoonlijke factoren en in een selectieve kijk op de overheid, die eerder als last dan als zegen wordt gezien.

72. Hetgeen zich o.a. manifesteert in de behoefte van overheidsbureaucratieèn aan te duiden als 'concern' of als 'bedrijf, en de vroegere juristen-in-algemene-dienst als 'concemjurist'. Nogal gemeenten hebben een nieuw organisatiemodel geintroduceerd, waarbij zgn. 'produktgroepen' zijn ingesteld: een 'produktgroepmilieu' (produkten: milieuvergunningen, gedoogverklaringen, bestuursdwange.d.), een 'productgroep bevolking' (produkten: paspoorten, rijbewijzen e.d.). enz. De vroegere ambtenaren worden nu aangeduid als 'medewerkers van produktgroep $\mathrm{X}$ ', In een dergelijke cultuur wordt ook het publiek domein gemakkelijk weer een 'zaak in den handel'.

73. Bockenforde, 'Die Bedeutung der Unterscheidung von Staat und Gesellschaft', a.w., p. 198.

74. Wat heeft men aan zijn private vrijheid zonder een publiek domein: openbare en goed onderhouden wegen, spoorwegen, groenvoorzieningen en zonder een publieke handhaving van de veiligheid ete.? En hoe is individuele ontplooiing voor elke burger zonder voor allen openstaande onderwijsvoorzieningen, sociale zekerheid, een minimumloon ete.? We behoeven maar te denken aan de verpaupering van het publieke domein in de meeste grote steden in Amerika, de teloorgang van het openbaar vervoer in dat land (onderhoud levert immers niets op in de vorm van directe geldelijke winst), de toenemende sociale ongelijkheid en het ontstaan van ghetto's voor 'nieuwe armen' en tegelijkertijd van door particuliere beveiligingsdiensten beschermde luxe woongetto's voor de 'nieuwe rijken', die gekenmerkt worden door een 'culture of contentment'. Dit alles is o.i. toch vooral een gevolg van de vereconomisering van het gehele leven, ó́k van de Staat.

75. E.-W. Bökenforde, 'Das Grundrecht der Gewissensfreiheir', in: 'Staat, Verfassung, Demokratie', Frankfurt aM 1991, pp. 200-263 (p. 226).

76. Herbert Krüger, 'Allgemeine Staatslehre', 2e druk, Stuttgart-Berlin-Köln-Mainz 1966, p. 323.

77. Krüger, a.w., p. $319 / 320$.

78. Krüger, a.w., p. 320.

79. Noot in NJ 1978, 615 (Zuidpoolarrest).

80. De overweging in HR 28 juni 1985, NJ 1986, 356, BR 1986, p. 121 (Claas/Van Tongeren), dat cen publiekrechtelijk voorschrift zoals een bij een bestemmingsplan behorend gebruiksvoorschrift (i.c. art. 352 bouwverordening-oud), 'mede strekt ter bescherming van de belangen van belanghebbenden als Claas c.s.' , achten wij dan ook - als eerder opgemerkt - minder gelukkig. Een dergelijk voorschrift strekt ter bescherming van publieke gemeenschapsbelangen (publiekrechtelijke belangen). Dat aldus ook bijzondere belangen worden beschermd, is hiervan een reflex.

81. BVerfG 8 juli 1982, E 61, nr. 10, p. 103/104. In het verleden verwierp trouwens ook de Hoge Raad een dergelijke vertegenwoordigings-constructie bij door de overheid geêntameerde art. 1401 BW-acties, getuige het al besproken Mark-en-Dintel-arrest van 29 april 1910, W. 9027.

82. BVerfG 8 juli 1982, E 61, nr. 10, p. 104.

83. De begrenzingen die voortvloeien uit internationale verdragen en uit het E.G.-recht, laten we hier buiten beschouwing.

84. $\mathrm{Vgl}$. in dit verband ook de belangwekkende beschouwingen van H.J. Simon, 'Publiekrecht of privaatrecht? (Een geschiktheidsonderzoek a.d.h. van het nutsmaximalisatiebeginsel toegespitst op het gebruik van het privaatrecht door het bestuur)', diss. Amsterdam 1993, Zwolle 1993, i.h.b. pp. 113 e.v., waar hij ook een onderscheid maakt tussen de materiële bevoegdheidsvraag en de formele bevoegdheid. De materiële bevoegdheidsvraag omschrijft hij als het vereiste van evenwichtigheid (p. 119): 'Evenwichtigheid heeft betrekking op door de overheid te maken belangenafwegingen en de door haar te kiezen criteria voor het maken van keuzen. Bij beslissingen terzake dient de overheid te letten op noodzakelijkheid, subsidiariteit (onmisbaarheid) en proportionaliteit'. Meer in het bijzonder bespreekt Simon o.a. het égalitébeginsel en het rechtszekerheidsbeginsel. Als wij schrijven dat de materielle competentiesfeer van het staatsverband wordt bepaald door de eigen aard ervan als publieke rechtsgemeenschap en dat het leidende rechtsbeginsel hierbij dat van het algemeen belang c.q. de iustitia distributiva is, dan zitten we - als we het goed zien - op dezelfde lijn. Zoals we meermalen betoogden, eist immers het algemeen belang een afweging van alle bijzondere rechtsbelangen van alle niet-statelijke 
levenskringen, welke belangen evenwichtig worden geharmoniseerd en geĭntegreerd in dat algemeen belang, zulks onder eerbiediging van de eigen, interne rechtssfeer van die niet-statelijke sameslevingskringen. We merkten ook reeds op, dat dit beginsel van de iustitia distributiva (o.a.) de églité devant les charges publiques impliceert.

85. Vgl. Bernd Jean d'Heur, t.a.p., p. 120.

86. Z. Giacometti, 'Allgemeine Lehren des rechtsstaatlichen Verwaltungsrechts. Allgemeines Verwalturgsrecht des Rechtsstaates', Zürich 1960, p. 228.

87. In beginsel: we wijzen nogmaals op het reeds door Locke erkende 'prerogative' van het overheidibestuur om in voor de wetgever niet voorzienbare, spoedeisende situaties op te kunnen treden indienhet algemeen belang dat eist.

88. Vgl. ook HR 7 febr. 1986, NJ 1987, 477 ('Attican Unity'), en de conclusie van adv,-gen. BiegmanHartogh voór dat arrest.

89. Vgl. de burgerrechtelijke eigendom, waarin eveneens een beschikkingsbevoegdheid - doch een vrie van de subjectief gerechtigde is gefundeerd en die een vrije genotsbevoegdheid van die gerechtigde impliceert. Het 'overheidsrecht' op publiek domein ('publiekrechtelijke eigendom') omschreven we als een publiekrechtelijk subjectief recht, waarin eveneens een beschikkingsbevoegdheid - maar sen gebonden (nl. aan de publieke functie van dat domein) - is gefundeend en die een gebruiksbevoegdteid van allen impliceert. Omdat het een publiekrechtelijk subjectief recht is van een publiekrechtelijk gemeenschap (de Staat of een statelijk sub-verband), hebben alle mensen als zodanig publiekrechtelije subjectieve 'deel-rechten' op dit domein, welke deel-rechten een 'Recht auf Gemeingebrauch' meebrengen. Omdat het een subjectief recht van een gemeenschap is, zal de in dit recht gefundecrde beschikkingsbevoegdheid moeten worden uitgeoefend door één of meer rechtsvormende organen ran die gemeenschap.

We merkten eerder ook al op, dat beperkingen van dit (deel-)recht op 'normaal gebruik' (Ius functioneel gebonden gebruik) steeds een specifiek-wettelijke grondslag behoeven. Dit recht vindt een verdragsrechtelijke bescherming in art. 12 BUPO-verdrag (bewegingsvrijheid). Ook voor beperkingen van bepaalde soorten 'bijzonder gebruik' (niet-functioneel gebonden gebruik) kàn overigens een specifieke wettelijke basis zijn vereist, m.n. wanneer dit uit grondrechts- en verdragsbepalingen voortvloeit. Gesteld bijv. dat betogingen op bepaalde publieke plaatsen is aan te merken als 'bijzonder gebruik', is voor de beperking ervan een specifiek-wettelijke grondslag nodig (art. 9 Grondwet).

90. Voorbeeld: de beheerstak van de gemeente t.a.v. binnen haar grondgebied liggende wegen (met uitzondering van de wegen die door Rijk, provincie of waterschap: vgl. art. 16 Wegenwet) is ingevolge art. 160 Gemeentewet ter behartiging opgedragen aan B. en W. ('Het dagelijks bestuur van de gemeente berust bij het college van burgemeester en wethouders ...'), O.i. is hier aan zowel het 'rechtspostulaat' als aan het 'democratisch postulaat' voldaan; vgl. F.W. ter Spill/A.Q.C. Tak, 'Onwetmatig bestuur', preadvies VAR LXXXVI, Alphen a/d Rijn 1981.

91. Althans voorzover het gaat om de zgn. 'secundaire staatsdoeleinden', te onderscheiden van de zgn. 'primaire staatsdoeleinden' - $\mathrm{t}$. $\mathrm{w}$. de doeleinden die noodwendig voortvloeien uit het ' $Z$ wangsmonopol' van de Staat, en die welke te maken hebben met zijn integratiefunctie. Zie over dit onderscheid tussen 'primaire' en 'secundaire staatsdoeleinden' hierna en (uitgebreider) hoofdstuk 3.

92. E.-W. Bőckenforde, 'Die Bedeutung der Unterscheidung von Staat und Gesellschaft', a.w.

93. Bôckenforde, 'Die Bedeutung der Unterscheidung von Staat und Gesellschaft', a.w., p. 202.

94. 'Maatschappelijke' zal hier moeten worden verstaan in de ruime zin van: de belangen van niet-statelijke samenlevingsverhoudingen, d.w.z. de belangen van maatschapsverhoudingen én niet-statelijke gemeenschappen.

95. Böckenforde, 'Die Bedeutung der Unterscheidung von Staat und Gesellschaft', a.w., p. 202.

96. Böckenforde, 'Die Bedeutung der Unterscheidung von Staat und Gesellschaft', a.w., p. 202/203.

97. Vgl. ook Van Eikema Hommes, 'De wijsgerige grondslagen van de rechtssociologie', a.w., p. 157. Men denke ook aan de huidige discussie over de vraag, wat de 'kerntaken' van de overheid zijn.

98. Die integrering is - als eerder betoogd - extern, hetgeen betekent dat de interne sferen van de nietstatelijke levenskringen gerespecteerd moeten worden. 
99. Simpel voorbeeld: wat heeft men aan de (private) eigendom van een auto, als er geen openbare wegen zouden zijn?

100. Vgl. Van Eikema Hommes, 'De wijsgerige grondslagen van de rechtssociologie', a.w, p. 157.

101. J.H. van Kreveld, 'In hoeverre mogen en moeten bij het verienen van subsidie voorwaarden worden gesteld?', preadvies NJV 1977, CVII, deel 1, 2e stuk, Zwolle 1977, pp. $59-153$ (p. 100).

102. J. Donner, 'De vrijheid van het bijzonder wetenschappelijk onderwijs', Zwolle 1978, pp. 109-112.

103. P. de Haan, 'Over de vervlechting van publiek- en privaatrecht', in: 'Regel en praktijk', bundel opstellen aangeboden aan prof. mr. S.F.L. baron van Wijnbergen, Zwolle 1979, pp. $39-62$ (p. 58/59).

104. Voor een goed begrip: onder 'subsidiëring' verstaan wij hier niet de verlening van financiele uitkeringen aan (andere) overheidslichamen.

105. Bōckenforde, 'Die Bedeutung der Unterscheidung von Staat und Gesellschaft', a.w., p. 203.

106. H. Faber, 'Verwaltungsrecht', 2e druk, Tubingen 1989, m.n. pp. 43 en 158-162, alwaar wordt onderscheiden tussen de zgn. negatieve (voorbeeld: milieuhygiëne) en positieve (voorbeelden: ruimtelijke ordening, onderwijs, verkeer en vervoer) Infrastrukturverwaltung. 'Infrastruktur' moet hier dus worden verstaan in de ruime zin, en niet alleen als fysieke infrastruktuur (aanleg wegen e.d.).

107. Karl Mannheim, 'Man and society in an age of reconstruction', London 1940, p. 6. Mannheim onderscheidt tussen vrijheid zonder planning - die in de modeme samenleving slechts tot onvrijheid kan leiden -, planning zonder vrijheid - die regelrecht voert tot de totalitaire staat - en planning for freedom. Vgl. over 'planning zonder vrijheid': BVerfG I maart 1979, E 50, nr. 26, p. 353, waar gesproken wordt van de 'planmalssige Formung und Organisation durch den Staat nach den Massstäben eines von der herrschenden Gruppe diktierten Wertsystems, wie sie den totalitären Staat der Gegenwart kennzeichnet' en welke onverenigbaar is met het 'Prinzip freier Assoziation und Selbstbestimmung'.

108. BVerfG 19 dec. 1951, E 1. p. 97 (p. 105).

109. BVerfG 29 mei 1990, E 82, p. 60 (p. 80) (Steuerfreies Existenzminimum).

110. Friedrich Julius Stahl, 'Die Philosophie des Rechts', Bd. II, Heidelberg 1846, p. 137/138: 'Der Staat soll Rechtsstaat sein, das ist seine Losung und ist auch in Wahrheit der Entwicklungstrieb der neueren Zeit. Er soll die Bahnen und Grenzen seiner Wirksamkeit wie die freie Sphăre seiner Bürger in der Weise des Rechts genau bestimmen und unverbrüchlich sichern (...) Dies ist der Begriff des Rechtsstaates, nicht etwa dass der Staat bloss die Rechtsordnung handhabe ohne administrative Zwecke, oder vollends bloss die Rechte der Einzelnen schütze, er bedeutet überhaupt nicht Ziel und Inhalt des Staates, sondern nur Art und Charakter dieselben zu verwirklichen' (curs. dzz.; JT).

111. Naar mate het overheidsoptreden 'ingrijpende' is, zal de wettelijke bevoegdheidsgrondslag specifieker moeten zijn. Vgi. HR 22 juni 1973, AB 1973, 187, AAe 1973, p. 457 (Fluorideringsarrest) en de jurisprudentie van het Bundesverfassunsgericht inzake de 'Wesentlichkeitstheorie'.

112. BVerfG 29 mei 1990, E 82, p. 60 (p. 80) (Steuerfreies Existenzminimum).

113. Foqué, 'De ruimte van het recht', a.w., pp. 31-39; Gribnau, t.a.p., p. 93.

114. Böckenförde, 'Die Bedeutung der Unterscheidung von Staat und Gesellschaft', a.w., p. 199/200.

115. Bōckenförde, 'Die Bedeutung der Unterscheidung von Staat und Gesellschaft', a.w., p. 204 en p. 206.

116. Vgl. bijv. N. Frenk, 'Kollektieve akties in het privaatrecht', diss. Utrecht 1994.

117. Zie bijv, de noot van G.A. van der Veen onder HR 18 febr. 1994, AB 1994, 415 (Staat/Kabayel c.s.).

118. A.M.J. Kreukeis en J.B.D. Simonis (red.), 'Publiek domein. De veranderende balans tussen staat en samenleving', Meppel-Amsterdam 1988.

119. A.K. Koekkoek, 'Overheidsorganisatie en overheidszorg: een rechtsvergelijkende verkenning', in: Kreukels, Simonis (red.), 'Publiek domein', a.w., pp. 30-56 (p. 33).

120. M.J.P. Verburgh, 'Privaatrecht en kollektief belang' 2 e druk, oratie Utrecht 1974, Zwolle 1975, p. 9.

121. TK 1991-1992, 22.486, nr. 3, p. 33.

122. HR 9 febr. 1990, NJ 1991, 462, AB 1990, 409 (Staat/Van Amersfoort).

123. HR 22 okt. 1993, AB 1994, 1 (Staat/Magnus). Vgl. ook het door ons eveneens reeds besproken arrest HR 24 april 1992, NJ 1993, 643 (Staat/Van Wijngaarden), waarin de aantasting van een ('ongeschreven') publiek belang wordt geconstrueerd tot een eigen vermogensbelang van 'de overheid', dat 
door de aantaster had behoren te worden ontzien op 'straffe' van overtreding van de maatschappijke zorgvuldigheidsnorm.

124. De la Bassecour Caan citeert in dit verband nog uit het 'Dictionnaire de I'Economie Polique' (publicatiedatum en -plaats niet vermeld), waar inzake de 'voies de communication' wordt vereld: 'Établir, perfectionner les voies de communication d'un pays, c'est augmenter le rayon dans quel peuvent s'effectuer ses échanges, c'est diminuer le prix de revient de la plupart de ses produits,'est done contribuer puissamment à la richesse', en naar een gezegde van J.B. Say: 'La facilité qu'o les hommes de communiquer entre eux, est le premier fondement de la société'.

125. J.J. de la Bassecour Caan, 'Handleiding tot de kennis van het administratief regt in Nederland', 2e uk, Den Haag 1865-1866, DI. 1, p. 169.

126. De la Bassecour Caan, a.w., p. 127.

127. Olivier, a.w., p. 208, alwaar er ook nog op wordt gewezen dat de redactie van art. 538 Code Civilzter is dan die van art. 577 BW i.v.m. de in eerstgenoemd wetsartikel voorkomende zinsnede 'qui neont pas susceptibles d'une propricté privete'.

128. Ook Thorbecke gebruikt de term 'eigendom' voor het publieke domein. Zie hierover: Poortinga, w.; Van Maanen, 'Publiek domein en twee-wegenleer', t.a.p., p. 207 nt. 31.

129. Geciteerd bij Vegting. 'Publiek domein en zaken buiten den handel', a.w., p. 144/145.

130. In de eerder genoemde toelichting op het wetsvoorstel dat leidde tot de Franse wet van 1 dec. 90 . wordt i.v.m. de 'propriété publique' vermeld: 'Ce domaine éminent, qui ne differe de la puisnce publique, qui comme la cause differe de son effet, lui (t.w. aan de natie; JT) assure la propriette dicte de toutes les portions de ce territoire, qui, par leur nature ou leur destination, ne peuvent apparter à personne en particulier et de celles encore qui demeurent vacantes et sans maitre'. De 'leer' vahet dominium eminens wordt hier echter niet meer verstaan in de oude betekenis: er wordt een onderseid gemaakı tussen 'propriété privée' en 'propriété publique', en alléén de laatste wordt 'domaine émint' genoemd, 'terwyi kènmerkend daarvoor de 'puissance publique' acht.

131. Mayer, a.w., Bd. II, p. 124/125: '(so) dass die Sache dabei im ganzen ihrem Zwecke möglichst erhalten und dienstlich bleibt', Vgl. ook dez., a.w.., Bd. I, p. 259, waaruit blijkt dat het 'Recht des gemeingebrauches' zelf niet kan worden aangetast op basis van 'die Polizei'.

132. Vos, a.w., p. 134. Vos doelt hier uiteraard op rechten van derden t.b.v. bijzonder gebruik, dus gebruik dat het 'Gemeingebrauch' te buiten gaat. Met verwijzing naar Frankrijk betoogt H.Ph.J.A.M. Hennekens, 'Openbare zaken naar publiek- en privaatrecht', Zwolle 1993, p. 11, dat daar de 'antieigendomsleer' terrein heeft verloren en 'momenteel ... over het algemeen (wordt) aangenomen dat eigendom ook op zaken van het publiek domein van toepassing is. Deze eigendom wordt door eigen regels beheerst, doch als eigendom blijft dit recht erkend'. Hennekens maakt hier o.i. dezelfde vergissing als Oppenheim, 'Nederlandsch Gemeenterecht', 5e druk, a.w., dl. I, p. 715/716, die verwijst naar Hariou, waar deze schrijft 'que les dépendences du domaine public sonts des objets de propiriété'. Vos wijst er n.a.v. deze opmerking van Oppenheim op dat 'propriété' hier niet betekent 'propriété' in privaatrechtelijke zin, maar 'propriéte' in de publiekrechtelijke betekenis: 'propriété administrative' of 'offentliches Eigentum' zoals het wordt genoemd door Otto Mayer. Terwijl Vegting, 'Publiek domein en zaken buiten den handel', a.w., in zijn rechtshistorisch onderzoek de grote fout maakt het moderne burgerrechtelijke eigendomsbegrip terug te projecteren in de tijd en daarbij 'eigendom' c.q. 'propriété' steeds burgerrechtelijk op te vatten, maken Oppenheim en Hennekens - in rechtsvergelijkende onderzoekjes - een vergelijkbare fout, nl. het geven van de in Nederland gebruikelijke enge - burgerrechtelijke - betekenis aan het Franse begrip 'proprietté'. Als wordt betoogt dat in Frankrijk de 'anti-eigendomsleer' terrein heeft verloren, wordt dus o.i. ten onrechte gesuggereerd dat de leer is verlaten dat publiek domein geen voorwerp van burgerrechtelijke eigendom kan zijn.

133. HR 17 jan. 1941. NJ 1941, 644 (Parlevinker).

134. De woorden zijn van adv.gen. Berger in zijn conclusie vóór het arrest.

135. En zo'n voorschrift mag uitshuitend strekken ter bescherming van de door de algemene, publieke beheerstaak gediende belangen, hetgeen ook een winstverbod impliceert: het publiek domein is geen 'zaak in den handel'. 
136. Het onderstaande is voor een belangrijk deel reeds gepubliceerd in een door ons samen met A.Q.C. Tak geschreven artikel 'Wie zorgt er voor de rechtsstaat? Een voortgezet debat', Recht en Kritiek 1994, pp. 340-354.

137. BVerfG 19 okt. 1983, E 64, nr. 14, p. 209/210 (betriebliche Altersversorgung).

138. BVerfG 12 juni 1979, E 52, nr. 1, p. 30 . Zie ook BVerfG 8 juli 1984, E 61, nr. 10, met vele verwijzingen naar eerdere jurisprudentie.

139. BVerfG 18 dec. 1968, E 24, nr. 28, p. 396 (Hamburger Deichordnungsgesetz).

140. Vgl. BVerfG 1 maart 1979, E 50, nr. 26, p. 341; BverfG 1 juli 1981, E 58, nr. 4; BVerfG 14 juli 1981 , E 58, nr. 5.

141. BVerfG 18 dec. 1968, E 24, nr. 28, p. 367 (Hamburger Deichordnungsgesetz).

142. Vgl. BVerfG 28 febr. 1980, E 53, nr. 17. Doorslaggevend argument om dergelijke aanspraken te erkennen als 'Eigentum', is de 'personale Bezug' van deze aanspraken.

143. BVerfG 8 juli 1982, E 61, nr. 10, p. 108 (Sassbach). In deze uitspraak gaat het om de vraag, of een gemeente zich in haar hoedanigheid als eigenaar van zgn. privaat domein, gelijk een burger, op het grondrecht van Art. 14 kan beroepen. Blijkens het 'ohnehin von vornherein' in het hier opgenomen citaat is een dergelijk beroep in ieder geval niet mogelijk, voor zover het gaat om publiek domein, en dit omdat dit naar zijn aard wezenlijk verschilt van de private eigendom. Ook als eigenaar van zgn. privaat domein kan - aldus het Hof - een gemeente zich niet beroepen op Art. 14, omdat de door Art. 14 beschermde 'Eigentum' als functie heeft te dienen 'als Grundlage privater Initiative und in eigenverantwortlichem privatem Interesse von Nutzen zu sein'. Deze functie heeft de eigendom nu juist niet, waar zij in handen is van de overheid. Kortom, ook t.a.v. het zgn. private domein van de overheid geldt dat deze gebonden is aan en in functie staat van de door die overheid te vervullen publieke taken. De omstandigheid dat deze eigendom 'privatrechtliche - also als Privateigentum - ausgestaltet' is, doet daaraan volgens bet $\mathrm{H}$ of dus aiets af.

144. BVerfG 18 dec. 1968, E 24, nr. 28, p. 390 (Hamburger Deichordnungsgesetz), Verworpen werd dan ook de stelling van de klagers dat, nu Art. 14 het instituut van de Privateigentum waarborgt, deze instituutsgarantie zou zijn geschonden ('Mit der begrifflichen Verschmelzung von hoheitlicher Sachherrschaft und Eigentum zu einem öffentlichen Eigentum werde einen Fremdkörper innerhalb der geltenden Rechtsordnung geschaffen').

145. BVerfG 10 maart 1976, E 42, nr. 2 (Hamburger Wegegesetz).

146. De algemene grondslag voor de wetgevende bevoegdheid van de deelstaten is vervat in art. 70 GG: '1. Die Laander haben das Recht der Gesetzgebung, soweit dieses Grundgesetz nicht dem Bunde Gesetzgebungsbefugnisse verleiht.

2. Die Abgrenzung der Zuständigkeit zwischen Bund und Lăndem bemisst sich nach den Vorschriften dieses Grundgesetzes über die ausschliessliche und die konkurrierende Gesetzgebung. "

Art. 72 bepaalt dat de Lånder wetgevingsbevoegdheid hebben op de terreinen van de concurrerende wetgeving, zolang en voor zover de Bund van zijn wetgevingsbevoegdheid op deze terreinen geen gebruik heeft gemaakt. Art. 74 geeft aan welke terreinen behoren tot de concurrerende wetgevingsbevoegdheden.

147. BVerwGE 27, 131 .

148. BGHZ 9, 373.

149. BVerfG 10 maart 1976, E 42, nr. 2, p. $34 / 35$ (Hamburger Wegegesetz).

150. HR 29 april 1910. W. 9027 (Mark en Dintel).

151. Als gezegd, vertoont deze leer in belangrijke mate gelijkenis met de leer die in de Nederlandse doctrine en jurisprudentie wordt aangehangen: het burgerlijk recht blijft op dergelijke zaken in beginsel van toepassing, voor zover de publieke bestemming zich daartegen niet verzet.

152. Heiko Faber, 'Verwaltungsrecht', 2e druk, Tübingen 1989, p. 154/155.

153. Mayer, a.w., Bd. 2, p. 44.

154. Zoals in de MvT bij wetsvoorstel collectieve acties, met een verwijzing naar o.a. HR 19 dec. 1975, NJ 1976, 280 (Rijksweg 12), wordt betoogd. Zie TK 1991-1992, 22.486, nr. 3, p. 33/34.

155. Krüger, 'Allgemeine Staatslehre', a.w., p. 329 
156. Bartlsperger, 'Strassenrecht', DVBI. 1979, p. 1 e.v.

157. Kodal/Krilmer, 'Strassenrecht', 4 e druk, München 1985, pp. 135-159 (p. 159).

158. Bartlsperger, t.a.p., p. 8.

159. Hennekens, 'Openbare zaken naar publiek- en privaatrecht', a.w., p. 40.

160. Vgl. Par. 13 Gerichtsverfassungsgesetz van 27 jan. 1877: 'Vor die ordentlichen Gerichten gehôren alle bärgerliche Streitigkeiten und Strafsachen, für welche nicht entweder die Zuständigkeit von Verwaltungsbehörden oder Verwaltungsgerichten begruindet ist oder reichsgesetzlich (thans: 'auf Grund von Vorschriften des Bundesrechts'; JT) besondere Gerichte bestellt oder zugelassen sind'.

161. Fleiner, 'Institutionen des Deutschen Verwaltungsrechts', a.w., p. 357.

162. G. Püttner, 'Die offentlichen Unternehmen', Stuttgart/München/Hannover 1985, p. 79/80.

163. Puttner, a.w., p. 80.

164. Art. 2 Wet R.O. is overigens per 1 jan. 1994 ingetrokken.

165. HR 19 jan. 1962, NJ 1962, 151, AB 1962, p. 540 (Usselmeer-arrest, ook bekend als het arrestHuizen/Staat I).

166. Hardenberg, a.w., p. 367, alwaar nog wordt opgemerkt dat zulks ook door het Hooggerechtshof - de voorganger van de Hoge Raad - bij herhaling is uitgemaakt.

167. Vgl. o.a. HR 23 juni 1989, AB 1989, 551, NJ 1991, 673 (GCN/Nieuwegein II). De competentie had overigens $606 \mathrm{k}$ kunnen worden gebaseerd op art. 1 Wet R.O., zoals met name in de tweede helft van de 19de eeuw veelvuldig is geschied. Zie bijv. HR 24 maart 1865, Ned. Rechtspraak deel 79, par. 49, pp. 396-414.

168. HR 22 mei en 26 juni 1863, W. 2499 (Zuidplaspolder). In gelijke zin: HR 21 juni 1872, Ned.Regtspraak dl. 101, pp. 195-205.

169. Zie het arrest-Eindhoven/Staals: aanvaard werd dat de gemeente a) voor de ingebruikgeving van de gemeentegrond een huursom bedong i.p.v. de bij art. 275 gemeentewet (oud) geregelde precariobelasting en b) het verlenen van de $0 . g . v$. de APV vereiste publiekrechtelijke vergunning afhankelijk stelde van het sluiten van het privaatrechtelijke huurcontract.

170. J.B. Sens, 'Geld breekt wet', TvO 1968, pp. 146-149. Sens kan zich overigens verenigen met de opvatting, dat aan de gemeente als eigenares van openbare zaken alle bevoegdheden toekomen, die het burgerlijk recht aan iedere eigenaar toekent. Zie ook zijn proefschrift 'Eigendom van zaken, voor den openbaren dienst bestemd', Nijmegen 1934. Hij acht het echter onjuist dat, nu de gemeentewet een precariobelasting mogelijk maakt, in plaats daarvan een huursom wordt bedongen.

171. HR 19 dec. 1975, NJ 1976, 151 (Rijksweg 12-arrest).

172. E. Poortinga. 'De figuur van de onrechtmatige daad jegens de overheid en art. 21 Interimwet Bodemsanering', AAe 1987, pp. 319-327.

173. HR 7 febr. 1986, NJ 1986, 477 ('Attican Unity').

174. AbRS RvS 10 april 1995, AB 1995, 498 ('Long Lin').

175. J.R. Stellinga, 'Grondtrekken van het Nederlandse Staatsrecht', Zwolle 1953, p. 71. Vgl. ook: dez., 'Bevoegdheden en verplichtingen, subjectieve rechten en schulden van de overheid en van de onderdanen', RMTh 1949, pp. 445-454; dez., 'De overgang van rechten en verplichtingen uit administratieve rechtsbetrekkingen', TvO 1958, pp. 241-243.

176. Vgl. Van Maanen, t.a.p., p. 207.

177. Subjectieve rechten (i.c. deel-rechten) impliceren, als juridische reflex van deze rechten, steeds de subjectieve rechtsplichten van derden om deze rechten niet wederrechtelijk te storen. $\mathrm{Vgl}$. Stellinga, 'Bevoegdheden en verplichtingen, subjectieve rechten en schuiden van de overheid en van de onderdanen', t.a.p.

178. De Wegenwet heeft (o.a.) een wettelijke positivering van deze 'deel-rechten', nl. t.a.v. openbare wegen, gebracht. In de vastlegging in mensenrechtenverdragen van het persoonlijke recht op bewegingsvrijheid (vgl. art. 12 BUPO-verdrag) kan men (o.a.) een verdragsrechtelijke waarborging van dergelijke 'deelrechten' zien. 
179. Hennekens, 'Openbare zaken naar publiek-en privaatrecht', a.w., p. 61. Zie ook adv.-gen. Mok in zijn conclusie (punt 3.2.) vóór het Windmill-arrest, waar hij zegt in het midden te laten, of de Staat onder vigeur van het nieuw BW zich als (burgerrechtelijk) eigenaar niet meer tegen lozingen in openbaar vaarwater zal kunnen verzetten, waarbij hij echter opmerkt dat men voor een andersluidende opvatting steun zou kunnen zoeken in de artt. 5:21 en 5:40 van het nieuw BW. G.A. van der Veen stelt in zijn noot onder de 'Long Lin'-uitspraak van de Afdeling bestuursrechtsprak van 10 april 1995, AB 1995. 498, dat de grondslag voor het verbod van toegang tot de territoriale wateren gevonden zou kunnen worden in de eigendom van de bodem van de territoriale zee. Wilde het schip 'Long Lin' dan gebnik maken van de zeebodem?, zo luidt onze vraag. Blijkens de recente jurisprudentie is niet onwaarschijnlijk zou overigens een in de burgerrechtelijke eigendom gefundeerde bevoegdheid niet eens meer nodig zijn: 'de overheid' zou immers de bevoegdheid hebben op basis van alleen ant. 6:162 BW acties te entameren!

180. BVerfG 10 maart 1976, E 42, nr. 2, p. 32 (Hamburger Wegegesetz).

181. Zo zijn de regelgevende bevoegdheid van de wetgever en de in het BW erkende contractsbevoegdheid geten subjectieve rechten, maar juridische competentiebevoegdheden. Zoals Stellinga, 'Bevoegdheden en verplichtingen, subjectieve rechten en schulden van de overheid en van de onderdanen', t.a.p.. opmerkt, kan men bijv. niet zeggen dat de wetgever een subjectief recht heeft, waarvan 'regelgeving' het object is.

182. Weliswaar heeft de eigenaar geen rechtsgezag over degenen voor wie die rechtsregels uitvaardigt - pas bij het betreden van het goed aanvaardt men die rechtsmacht -, maar hij is krachtens zijn rechtstitel geheel eenzijdig bevoegd de gestelde regels te veranderen. Voorbeeld ontleend aan: $\mathbf{H}$. Dooyeweerd, 'Encyclopaedie der rechtswetenschap, Vervolg', Collegedictaat, ongedateerd (waarschijnlijk eind 50er jaren), p. 42/43. Een bepaling als art. 461 Wetboek van Strafrecht knoopt overigens bij die bevoegdheid aan.

183. Dergelijke competentiebevoegdheden doen zich dus weliswaar voor in verbinding met een subjectief recht (i.c. het burgerrechtelijke eigendomsrecht), maar zijn zelf geen subjectief recht. $\mathrm{V}_{\mathrm{gl}}$. Van Eikema Hommes, 'De samengestelde grondbegrippen', a.w., p. 199, die verwijst naar de opmerking van A. Thon, 'Rechtsnorm und subjektives Recht', 1878, dat zo min de kracht om een steen te werpen tot de steen zelf behoort, de bevoegdheid tot vervreemding of bezwaring van het eigendomsrecht tot dit recht zelf kan worden gerekend. Overigens kunnen door gebruikmaking van competentiebevoegdheden nieuwe subjectieve rechten worden gevestigd. Wie bijv. met een garagist contracteert over de reparatie van zijn auto, verwerft een subjectief recht (t.w. een persoonlijk recht) op de prestatie (rechtsobject) van die garagist.

184. HR 22 mei en 26 juni 1863 , W. 2499 (Zuidplaspolder).

185. HR 12 jan. 1923, W. 11060 , NJ 1923, p. 307 (Schielands Hoge Zeedijk).

186. HR 29 april 1910, W. 9027 (Mark en Dintel).

187. 'Om toe te zien en te zorgen, dat aan de regten van het publiek geen afbreuk wordt gedaan', aldus Olivier, a.w., p. 209. '(Diese Polizei geht) bloss dahin, den fortbestehenden Gemeingebrauch so zu ordnen und zu leiten, dass die sache dabei im ganzen ihrem Zwecke möglichst erhalten und dienstlich bleibt', aldus Mayer, a.w., Bd. II, p. 124/125.

188. Voorbeeld: de beheerstaak van de gemeente t.a.v. de binnen haar grondgebied liggende openbare wegen (met uitzondering van de wegen die door Rijk, provincie of waterschap worden onderhouden; vgl. art. 16 Wegenwet) is ingevolge art. 160 Gemeentewet ter behartiging opgedragen aan B. en W. ('Het dagelijks bestuur van de gemeente berust bij het college van burgemeester en wethouders...'). Het is o.i. minder juist te zeggen dat bedoelde bevoegdheden kunnen worden afgeleid uit de beheerstaak ex art. 16 Wegenwet jo. art. 190 Gemeentewet. Neen, de titel is het subjectieve recht op publiek domein, en de bevoegdheden worden uitgeoefend door het door genoemde wetsartikelen aangewezen bestuursorgaan. 
189. Zie 0.a. ARRS 28 febr. 1980, Gst. 1980, nr. 6625.8 (weigering uitweg Laren) en de jurisprudente genoemd door Hennekens in zijn naschrift bij Vz.ARRS 12 mei 1992, Gst. 1992, nr. 6960.2. Zie voor een geval waarin m.b.t. staatsnatuurmonumenten (i.c. Krammer-Volkerak en Zoommeer) de bevoegdheid wordt aangenomen tot het verlenen of weigeren van een vergunning voor het verrichten van bepaalde inbreuken op het natuurmonument: Vz.ARRS 6 mei 1991, AB 1992, 414, met instructieve noot H.J. Simon. In HR 7 febr. 1986, NJ 1986, 477 ('Attican Unity") luidt het: "Nu de Staat de bevoegdheid tot het geven van het onderhavige verbod aan zijn soevereiniteit over de Nederlandse territoriale wateren ontleent en dit verbod (nl. tot het binnenvaren van die wateren door de 'Attican Unity': JT) is gegeven door of namens ambtenaren onder wier toezicht en beheer het betrokken gedeele van die wateren is gesteld, kan ... het ontbreken van enig wettelijk voorschrift waarop de bevoegdheid van de ambtenaren die het verbod in feite hebben gegeven, specifiek kan worden gebaseerd, niet leiden tot de slotsom dat het verbod niet bevoegd is gegeven'. Men zie ook de instructieve conclusie van adv. gen. mevrouw Biegman-Hartogh: in de veelomvattende beheerstaak mogen 'aan een bepaald staatsorgaan toegekende, specifieke bevoegdheden, bijv. tot het nemen van incidentele, geen uitstel duldende beslissingen - ook impliciet - begrepen worden geacht'.

190. AbRS 10 april 1995, AB 1995, 498 ('Long Lin').

191. Vos, a.w., p. 134. Vgl. ook Guba, a.w., p. 26.

192. Dit laatste beginsel eist dat men de publieke lasten, strekkende ten dienste van allen, niet laat werken op kosten van de toevallige enkeling. Indien er inderdaad sprake is van zo'n 'Aufopferung' bij bepaalde individuen of groepen, is dit beginsel de materièle rechtsgrond voor schadevergoeding verschuldigł door 'de overheid'. Bij het andere égalitébeginsel gaat het, omgekeerd, om - wat men met Simon zou kunnen noemen - 'Aufopferung zijdens de algemeenheid'. We verwijzen voor een uitstekende behandeling van deze problematiek naar de scherpe analyse van H.J. Simon, 'Financiēle voorwaarden en voorschriften', NTB 1994, pp. 149-164.

193. Financiēle voorwaarden komen in twee vormen voor: als betalingsverplichting opgenomen in een voorschrift bij een begunstigende beschikking, en als voorwaarde vóoraf om een gunstige beschikking te kunnen nemen. Bij de tweede vorm gaat het om een overeenkomst waarbij een bestuursorgaan een bepaalde gebruikmaking van een publiekrechtelijke bevoegdheid afhankelijk stelt van een bepaalde financiële prestatie zijdens de belanghebbende. Zo'n bevoegdhedenovereenkomst is onmiskenbaar een publiekrechtelijke overeenkomst. Wanneer - zoals in de 'Long Lin'-casus - een bevoegdhedenovereenkomst niet tot stand komt en het bestuursorgaan om die reden een begunstigend besluit weigert, kan de administratieve recht bij de beoordeling van laatstgenoemd besluit indirect ook een oordeel geven over de aanvaardbaarheid van de door het bestuursorgaan noodzakelijk geachte - maar niet tot stand gekomen - bevoegdhedenovereenkomst. Zie verder Van Wijk/Konijnenbelt/Van male, a.w., pp. 309 . 311 , waar de vraag behandeld wordt welke rechter bevoegd is bij geschillen i.v.m. (1) het aangaan of juist niet aangaan van de overeenkomst, (2) de uitvoering of niet-uitvoering ervan door het bestuursorgaan, en (3) de uitvoering of niet-uitvoering door de belanghebbende. De vraag of een financieel beschikkingsvoorschrift toelaatbaar is en, zo ja, wat de maximale omvang is van de op te leggen financięle last, alsmede de zgn. publiekrechtelijke twee-wegenleer, komen aan de orde in ARRS 30 aug. 1985, AB 1986, 243 (Rabobank Stompwijk Zoeterwoude). In AbRS 10 april 1995, AB 1995. 498 ('Long Lin') - waarin het niet gaat om een financieel beschikkingsvoorschrift maar om een financièle voorwaarde vóóraf (bevoegdhedenovereenkomst, en wel: een garantieovereenkomst) - wordt in wezen dezelfde beperking gesteld aan de hoogte van het bedrag als in ARRS 30 april 1985, met dien verstande dati.p.v, (de eis dat met de financiele voorwaarde) 'een rechtstreekse bijdrage wordt geleverd aan de doelstelling van de wettelijke bepaling waarop de vergunning of vrijstelling rust' zal moeten worden gelezen 'een rechtstreekse bijdrage wordt geleverd in de (mogelijke) kosten die de Staat - uit hoofde van zijn taak ervoor te zorgen dat het vaarwater aan zijn bestemming blijft beantwoorden - moet maken wegens werkzaamheden ter voorkoming van door belanghebbende veroorzaakte aantasting van die bestemming'. Wel menen wij dat de AbRS de garantieovereenkomst ten onrechte duidt als een 'overeenkomst naar privaatrecht'. 
194. Simon, 'Financiēle voorwaarden en voorschriften', t.a.p., p. 161/162, betoogt dat een toestemming voor niet-functioneel gebonden gebruik - en de daaraan gekoppelde 'lastenoplegging' - haar (primaire) rechtsgrond vindt in het 'vermogensrecht'. Men kan o.i. het publiekrechtelijk subjectief recht t.a.v. publiek domein aanmerken als een vermogensrecht, mits men in aanmerking neemt dat het geen privaat doch een publiek vermogensrecht is.

195. AbRS 10 april 1995, AB 1995, 498, m.nt. G.A. van der Veen. $V_{g l}$. ook de kritiek van Hennekens op jurisprudentie van de Arob-rechter, waarin uit de beheerstaak t.a.v. openbare wegen en wateren bevoegdheden van het bestuur $66 \mathrm{k}$ tot optreden tegen burgers zijn afgeleid: H.Ph.J.A.M. Hennekens, 'Openbare zaken naar publick- en privaatrecht', Zwolle 1993, i.h.b. p. 139/140, en naschrift bij Vz.ARRS 12 mei 1992, Gst. 1990, nr, 6960.2.

196. Hennekens, 'Openbare zaken naar publiek- en privaatrecht', a.w., p. 11/12.

197. Zoals we zagen, komt Van der Veen in zijn noot in AB 1995, 498, zelfs met de gewrongen constructie om de 'privaatrechtelijke bevoegdheid' tot ontzegging aan het schip 'Long Lin' van de toegang tot de territoriale wateren te funderen in de eigendom van de zeebodem.

198. Vgl. ook HR 14 okt. 1994, AB 1995, 48 (Wrakkenwet-arrest). De stelling van adv.-gen. Bloembergen in zijn conclusie, dat 'uit de geschiedenis blijkt dat de wetgever (bij de redactie van art. 9 van de Wrakkenwet van 1885; JT) alleen maar aan de klassieke grondslag heeft gedacht' (waarbij B. doelt op art. $1401 \mathrm{BW}$ ) komt ons overigens bepaald onjuist voor, mede gezien de opvattingen die destijds nog bestonden omtrent het publick domein. Trouwens, ook in de parlementaire stukken wordt nergens gesproken van art. $1401 \mathrm{BW}$.

199. HR 18 febr. 1994, AB 1994, 415 (Kabayel).

200. HR 7 okt. 1994, AB 1995, 47, BR 1995, p. 256 (Van Schaik/Nieuwveen).

201. HR 26 jan. 1990, AB 1990, 408, NJ 1991, 393, Gst. 1990, 6914 (Windmill-arrest). Zoals blijkt uit bijv, het Usselmeerarrest zou (o.a.) schending van de 'eigendom' van de Staat een grond bieden voor een vordering uit hoofde van onrechtmatige daad ex art. 1401 (oud) resp. 6:162 BW.

202. Hennekens, 'Openbare zaken naar publiek- en privaatrecht', a.w., p. 139/140.

203. Hennekens, 'Openbare zaken naar publiek- en privaatrecht', a.w., p, 11/12.

204. J.H.A. Logemann, 'Over de theorie van een stellig staatsrecht', Leiden 1948.

205. H.Ph.J.A.M. Hennekens/H.J.A.M. van Geest/F. Fernhout, 'Decentralisatic', 2e druk, Nijmegen 1993 , p. 19 ('wezenlijk onderscheid'); F.A.M. Stroink/J.G. Steenbeek, 'Inleiding in het staats- en administratief recht', 3e druk, Alphen a/d Rijn 1989, p. 37 ('scherp onderscheid'): Van Wijk/Konijnenbelt/Van Male, a.w., p. 459 ('fundamenteel verschil'). Zie ook W.G. Vegting. 'Het Algemeen Nederlands Administratiefrecht', dl. I, Alphen a/d Rijn 1954, pp. 174-178, die het overheidsorgaan i.p.v. als 'ambt' liever aanduidt als 'publiekrechtelijke rechtspersoon'.

206. Logemann, a.w., p. 84.

207. Stroink/Steenbeek, a.w., p. 35.

208. Hennekens/Van Geest/Fernhout, a.w., p. 19.

209. Hennekens/Van Geest/Fernhout, a.w., p. 20.

210. Van Wijk/Konijnenbelt/Van Male, a.w., p. 459.

211. H.Ph.J.A.M. Hennekens, 'De Kaderwet bestuur in verandering', Gst. 1994, nr. 6997.1, pp. 521-530 (p. 527, 1e kolom).

212. Vgl. HR 6 april 1979, AB 1979, 356, AAe 1980, p. 250 (Knabbel en Babbel), waarbij de gemeente aansprakelijk werd geoordeeld voor gedragingen van een wethouder. Vgl. ook de aantekening van A.Q.C. Tak bij HR 1 mei 1987, tB/S rubriek jurisprudentie burgerlijke rechter, nr. 3 (Van Daalen/Aerle-Rixtel), die opmerkt dat naar nieuw BW deze aansprakelijkheid kan worden gebaseerd op art. 6:162 BW, m.n. de toerekening naar verkeersopvattingen. F.A.M. Stroink, 'Het leerstuk der Deconcentratie', diss. Utrecht 1978. Den Haag 1978, pp. 17-19. pleit ervoor om, in daartoe aangewezen gevallen, aan ambten vermogensrechtelijke rechtspersoonlijkheid toe te kennen, zodat financiēle aansprakelijkstelling van deze ambten mogelijk wordt. $0 . \mathbf{i}$. is dit toch weer een blote constructie, die nodig blijkt te zijn bij de formalistische beschouwingswijze van de ambtentheorie met haar strenge onderscheid tussen ambt en openbaar lichaam. 
213. Vgl. art. 5.3..2, lid 1, wetsvoorstel Derde Tranche Algemene wet bestuursrecht.

214. P. de Haan/Th.G. Drupsteen/R. Fernhout, 'Bestuursrecht in de sociale rechtsstaat', 3e druk, dl,, Deventer 1986, p. 116.

215. P. de Haan, Bespreking van Hennekens, 'Openbare zaken naar publiek- en privaatrecht', in RMh 1994. pp. 129-135 (p. 134).

216. S.W. Couwenberg, 'De omstreden staat. Ontwikkeling en problematiek van de staatstheorie in de $20 \mathrm{e}$ eeuw', Alphen a/d Rijn 1974, p. 44/45.

217. M.M. van Praag. 'Algemene rechtsleer', Alphen a/d Rijn 1949.

218. J.R. Stellinga, TvO 1949, p. 549.

219. Meijers, 'Belastingen als rechtsbegrip', a.w., p. 8. Maar 66k de structuur van het burgerlijk recht woit o.i. door die beschouwingswijze ondermijnd, want 'burgertijk recht' dat aan 'de overhe' bevoegdheidsgrondslagen zou bieden tot zelfstandige behartiging van publieke belangen is naar zijn aad geen burgerlijk recht meer.

220. Van der Hoeven, 'De drie dimensies', a.w., p. 166.

221. F.G. Scheltema, 'De zaken der openbare lichamen', in: 'Nederlandsch Bestuursrecht', Alphen a/d Ra 1932, pp, 115-134.

222. Kortmann, 'Constitutioneel recht', a.w., pp, 4 en 21 . Zoals we zagen, knijgt Burkens in zijn besprekig in RMTh 1995, pp. 21-23, associaties met Kelsens 'reine Rechtslehre'. Op de beïnvloeding va Logemann door Kelsen wordt gewezen door H. van den Brink in zijn biografie van Logemann : 'Zestig juristen', Zwolle 1987, pp. $324-327$ (p. 326). Dat de ambtentheorie is beinnloed door it radicale rechtspositivisme van Kelsen, blijkt nog het duidelijkst uit de geschriften van M.M. van Prat.

223. $\mathrm{Vgl}$. Kortmann, 'Constitutioneel recht', a.w., p. 4, die betoogt dat de kwaliteit van rechtspersoon nar privaatrecht 'min of meer toevallig' is. 


\section{Hoofdstuk 7}

\section{Een algemene overheidsactiebevoegdheid in het Burgerlijk Wetboek: artikel 3:305b BW}

Het reeds genoemde wetsvoorstel collectief actierecht heeft geleid tot opneming in het BW van nieuwe artikelen 3:305a en 305b. Art. 3:305b geeft aan publiekrechtelijke rechtspersonen de algemene bevoegdheid om ten behoeve van 'andere' personen zgn. civiele gebods- en verbodsacties te entameren (Voor de publieke rechtspersoon die voor zijn 'eigen belangen' opkomt, zou deze bepaling volgens de memorie van toelichting niet nodig zijn). Art. 305 b BW luidt:

'1. Een rechtspersoonals bedoeld in art. 1 van Boek 2 kan een rechtsvordering instellen die strekt tot bescherming van de belangen van andere personen, voor zover hem de behartiging van deze belangen is toevertrouwd.

2. De leden 2 tot en met 5 van art. 305 a van dit Boek zijn van overeenkomstigetoepassing'.

Volgens de memorie van toelichting ' zou voor de vraag wat de taakstelling van een overheidslichaam inhoudt, onder meer aansluiting kunnen worden gezocht bij de instellingsregeling ${ }^{2}$ en de sociale grondrechten. Uit de verwijzing in lid 2 naar art. 305a, leden 2-5, BW vloeit voort dat aldus aan openbare rechtspersonen de bevoegdheid wordt gegeven ten behoeve van 'andere personen' gebods- en verbodsacties in te stellen. Impliciet blijkt dit uit art. $305 \mathrm{a}$, lid 3, dat luidt:

'Behoudens voorzover een vereniging uitsluitend ten behoeve van haar leden optreedt, kan een rechtsvorderingals bedoeld in lid 1 niet strekken tot schadevergoedingte voldoen in geld.'

Als gezegd, benadrukt de memorie van toelichting, met verwijzing naar o.a. het arrest-Staat/Van Amersfoort, dat het bij art. 3:305b gaat om de bescherming van de 'belangen van andere personen'. De publiekrechtelijke rechtspersoon die voor 'zijn eigen belangen' opkomt zou volgens de memorie van toelichting deze bepaling niet nodig hebben: wanneer een onrechtmatige daad 'ook jegens de overheid onrechtmatig' is, zou 'het eigen belang' bij een op onrechtmatige daad gebaseerde vordering 'immers' gegeven zijn ${ }^{3}$.

In de eerste plaats wijzen we erop dat de overheid nimmer eigen belangen in de zin van private belangen heeft. De overheid heeft slechts publieke gemeenschapsbelangen - publiekrechtelijke belangen - te behartigen; welke als zodanig zijn aan 
te merken, wordt bepaald door de (Grond)wetgever, die daartoe aan het overheidsbestuur de benodigde publiekrechtelijke bevoegdheden verleent. Daarmee wordt, behalve aan het rechtszekerheidsbeginsel en het gelijkheidsbeginsel, ook voldaan aan het publiekrechtelijke beginsel van de representatieve democratie. Dán kan men zeggen dat de overheid voor de gemeenschap optreedt als 'waarnemer' van die - als openbaar aangemerkte - belangen. Het is niet de administratie die uitmaakt welke belangen als gemeenschapsbelangen moeten worden behartigd, d.w.z. via 'privaatrechtelijke weg'. Eventueel kan men zeggen: de 'eigen' belangen van de overheid zijn per definitie publieke gemeenschapsbelangen en dus door de wetgever als zodanig aangemerkte belangen.

Dat de overheid in een rechtsstaat slechts publieke gemeenschapsbelangen mag behartigen, betekent ó́k dat zij niet gelijk mag worden gesteld met maatschappelijke verbanden en dus niet voor de private belangen van bepaalde personen - 'andere personen' - mag opkomen, zoals art. 3:305b wil toestaan. De overheid mag zich zeker niet met een deel van haar burgers identificeren.

Het opkomen voor de private belangen van bepaalde 'andere personen' zou ook in strijd zijn met het gelijkheidsbeginsel en een miet-gelegitimeeru'e bemoeienis met de private sfeer betekenen.

Want tegen wie zouden de belangen van de in art. 3:305b bedoelde 'personen' moeten worden beschermd door publiekrechtelijke lichamen? Bedoeld kan slechts zijn dat deze rechtspersonen de belangen van bepaalde burgers of bepaalde maatschappelijke verbanden beschermen tegen de (vermeende) aantasting van die belangen door andere burgers of maatschappelijke verbanden. Wij wezen er eerder al op, dat dit in strijd is met het non-identificatiebeginsel.

Het van overheidswege beschermen van de belangen van bepaalde (groepen van) personen of bepaalde maatschappelijke verbanden, is slechts aanvaardbaar waar zulks in het belang van de publieke rechtsgemeenschap wordt geacht (Om een voorbeeld te noemen: dat de Algemene Bijstandswet een recht op bijstand toekent aan personen zonder inkomen of met een inkomen beneden een bepaald niveau, is omdat het een publiek gemeenschapsbelang wordt geacht dat een minimaal bestaansniveau voor alle burgers is gewaarborgd). Het beschermen van de belangen van bepaalde (groepen van) personen is dan een publiek gemeenschapsbelang en - in die betekenis - een 'eigen belang' van de overheid. Zo overwoog het Bundesverfassungsgericht terecht met betrekking tot de toekenning van subsidies van overheidswege: 'Die Gewährung von Subventionen muss - schon aus Gleichheitsgründen - gemeinwohlbezogen sein' (curs. dzz.; JT) 4 . 
Van der Hoeven, die 'publieke taakvervulling' definieert als 'de vervulling van de krachtens de rechtsorde opgedragen taak ter behartiging van één of meer aspecten van het algemeen belang', merkt op:

'Onder omstandighedenis het zeer wel mogelijk - en het komt herhaaldelijkvoor - dat het algemeen belang samenvalt met een of meer private belangen, juister gezegd: dat het oordeel omtrent dat wat het algemeen belang inhoudt, afkomstig van hem die door de rechtsorde tot het stellen van dat oordeel bevoegd is verklaard, inhoudt dat bepaalde private belangen zullen worden gediend. De beslissing bijv., om bepaalde belastingtarievente verlagen dient staatsrechtelijk te steunen op een oordeel omtrent dat, wat het algemeen belang vergt en niet op de behoefte bepaaldeprive-personen te bevoordelen- al kan die bevoordelingdaarvan wel het gevolg zijn' (curs, dzz.; JT) '.

In dit verband moge ook uit de reeds eerder besproken uitspraak van het Bundesverfassungsgericht van 2 mei 1967 worden geciteerd. Daarin werd geoordeeld dat de Landesversicherungsanstalt Westfalen zich ook niet in de hoedanigheid van 'Sachwalter' c.q. 'Vertreter' van de door haar gebundelde belangen van verzekerden kon beroepen op hun grondrechten. Immers:

'Die der Beschwerdeführerin zur Verfügung stehende Mittel ... sind nicht für die Wahmehmung der Vermögensinteressender jeweiligen Versichertenoder Beitragspflichtigenbestimmt, sondernzur Erfüllung ihrer sozialstaatlichenAufgabe, die die Beschwerdefuhrerinim Interesse der Gemeinschaft als "verlängerter Arm' des Staates erfullt", d.w.z. 'als Trägerin vom Staat übertragener Aufgaben und vom Staat verliehene Befugnisse' (curs. dzz.; JT) ${ }^{6}$.

Deze opvatting is o.i. volkomen juist. Het beginsel van de representatieve democratie en de legaliteitseis - welk eis mede beoogt uitdrukking te geven aan eerstgenoemd beginsel - impliceren dat er bij de takvervulling door de overheid géén sprake is van een - in de woorden van het Bundesverfassungsgericht - 'unmittelbarer Bezug zum Menschen' ?. Behartigd worden de rechtsbelangen van een publieke rechtsgemeenschap, waarvan elke mens als zodanig op gelijk voet met alle anderen deel uitmaakt.

Een vonnis als dat van de president van de rechtbank 's-Gravenhage van 16 januari 1990 inzake Noordwijkerhout/Bonte is o.i. dan ook onjuist. Bij dit vonnis wordt een door de gemeente Noordwijkerhout op grond van art. 1401 BW (oud) gevorderd verbod tot (verdere) overtreding van een parkeerexcessenverordening ingewilligd op grond van de overweging:

'Het door eiseres ingeroepen belang - bescherming van het woonmilieu van omwonenden, voorkoming van (parkeer)overlast voor publiek - behoort tot de belangen die art. $1401 \mathrm{BW}$ beoogt te beschermen. Aan eiseres, belast met de behartiging van algemene belangen, komt het recht toe om voor genoemd belang op te komen'

Met deze overweging kan reeds hierom niet worden ingestemd, omdat de "bescherming van het woonmilieu' een belang van bepaalde personen - omwonenden - was, 
hetgeen niet per definitie een door de overheid te behartigen publiek gemeenschapsbelang is.

In de tweede plaats merken we op dat de memorie van toelichting suggereert, dat een publiekrechtelijke rechtspersoon ter behartiging van 'zijn eigen belang' - dat, als gezegd, slechts een publiekrechtelijk belang kan zijn - zonder meer civiele gebods- en verbodsacties kan instellen. Ten tijde van het verschijnen van de memorie van toelichting was dit een onjuiste interpretatie van de jurisprudentie van de Hoge Raad. In de arresten-Staat/Van Amersfoort en Staat/Benckiser ging het om schadevergoedingsacties. Blijkens het arrest-Benckiser stond de 'Limmen/Houtkoop'-doctrine ${ }^{9}$ in ieder geval nog in zoverre overeind, dat de bescherming van het 'algemeen belang' dat is betrokken bij de naleving van publiekrechtelijke normen, op zichzelf geen grond kan vormen voor een civiele gebods- of verbodsactie vanwege de overheid.

Kennelijk is met art. 3:305b mede beoogd de laatste weerstanden die 'Limmen/Houtkoop' opwierp tegen een algemene civiele actiemogelijkheid terzake van handhaving van publiekrechtelijke normen uit de weg te ruimen, mits de overheid zich maar tegelijkertijd opwerpt als de behartiger van de belangen van 'andere personen'. Zou art. 3:305 b indertijd reeds hebben gegolden, dan zou de gemeente Limmen een civiele verbodsactie hebben kunnen entameren tegen Houtkoop, op de grond dat deze door de overtreding van bestemmingsplanvoorschriften de belangen van zijn buren schond, welke belangen de gemeente wenste te beschermen (náást het algemeen belang dat betrokken was bij de naleving van het bestemmingsplan) ${ }^{10}$.

Overigens is de Limmen/Houtkoop-formule door de Hoge Raad reeds (kort) vóór de inwerkingtreding van artikel 3:305b BW ten grave gedragen, namelijk bij het hierboven reeds besproken Kabyel-arrest, dat - zoals we aangaven - alle sluizen open zet voor civiele acties terzake van beweerde aantasting van publieke belangen, waarbij die aantasting zelfs gelegen kan zijn in schending van de 'maatschappelijke zorgvuldigheid jegens de overheid': een 'civielrechtelijk belang' is niet vereist; nodig is nog slechts een 'voldoende belang' als bedoeld in art. 3:303 BW ${ }^{11}$. Frenk trekt uit het Kabayel-arrest niet ten onrechte de conclusie, dat nu door de Hoge Raad is aanvaard dat ook de schending van 'publieke belangen' jegens 'de overheid' onrechtmatig in de zin van art. 6:162 BW kan zijn:

'Artikel 6:162 BW biedt derhalve voor de overheid een grondslag voor het behartigen van publieke belangen' 12 .

Deze opvatting, volgens welke art. 6:162 BW aan 'de overheid' een zelfstandige grondslag zou bieden ter behartiging van 'publieke belangen', hebben we hierboven reeds uitvoerig bestreden. En de 'strijd met de zorgvuldigheid die in het maatschappelijk verkeer betaamt jegens eens anders persoon of goed' is - zo merkten we op - 
een typisch materieel burgerrechtelijk onrechtmatigheidscriterium, dat naar zijn aard niet past op de publiekrechtelijke verhouding tussen overheid en burgers.

Tenslotte: uit algemene taakstellingen zoals vervat in de sociale-grondrechtsartikelen, vloeien nog geen concrete bestuursbevoegdheden jegens burgers voort. Waar wordt ingegrepen in de uitoefening van de aan particulieren toekomende private rechten, behoeft dit een specifieke wettelijke basis ${ }^{13}$. Ook de 'sociale Staat' is - zo merkten we reeds op - gebonden aan de materiële én formele rechtsstaatsidee. In dit verband zouden we nog willen wijzen op de bij de Grundgesetznovelle van 27 oktober 1994 in een nieuw Artikel 20a Grundgesetz opgenomen staatsdoel-bepaling milieubescherming:

'Der Staat schützt auch in der Verantwortung für die künftigen Generationen die natürlichen Lebensgrundlagenim Rahmen der verfassungsmässigen Ordnung durch die Gesetzgebungund nach Massgabe von Gesetz und Recht durch die vollziehende Gewalt und Rechtsprechung' ".

Door de uitdrukkelijke vermelding van de 'Gesetzesvorbehalt' wordt de 'Systemkonformität' van deze nieuwe bepaling buiten twijfel gesteld. Zou deze 'Vorbehalt' niet zijn opgenomen, dan zou hij niettemin gelden en kunnen worden afgeleid uit het in Artikel 20 verankerde 'Rechtsstaatsprinzip'. Voor de in de Nederlandse Grondwet vastgelegde sociale grondrechten kan dit niet anders zijn.

Voorzover ter behartiging van publiekrechtelijke belangen wordt ingegrepen in de eigen sfeer van burgers, dient zulks dus te geschieden op basis van verleende én begrensde - dus specifieke - bevoegdheden. Met art. 3:305b BW is echter, in de woorden van Frenk:

'aan een vrij ruime groep overheidslichamen een algemene bevoegdheid gegeven om in civilibus voor groeps- en algemene belangen op te komen, dat wil zeggen een bevoegdheiddie niet beperkt is tot specifieke rechtsgebieden. Wel dient het behartigen van deze belangen aan het eisende overheidslichaamte zijn toevertrouwd' (cursivering door auteur; JT) ${ }^{15}$.

Dit laatste levert echter geen problemen op: volgens de memorie van toelichting kan immers onder meer aansluiting worden gezocht bij de sociale grondrechten.

Kennelijk waren de opstellers van art. 3:305b echter van mening dat de genoemde rechtsstatelijke eisen hiervoor niet gelden, nu hierop het etiket 'privaatrechtelijk' c.q. 'in civilibus' is geplakt. Maar wat is er eigenlijk 'privaatrechtelijk' aan de door die bepaling gecreëerde bevoegdheid om 'algemene belangen' te behartigen? Het is niet meer dan 'Etikettenschwindel', wanneer deze bevoegdheid 'privaatrechtelijk' wordt genoemd.

In de literatuur wordt betoogd dat in art. 3:305 b aan publiekrechtelijke rechtspersonen een 'gelijke bevoegdheid' wordt gegeven als aan de belangenorganisaties bedoeld in art. $3: 305 \mathrm{a}^{16}$. Ook die - hierna nog te bespreken - bepaling moet wor- 
den afgewezen. Maar de door art. 3:305a BW aan belangenorganisaties verleende bevoegdheid is in ieder geval nog in zoverre beperkt, dat het moet gaan om de behartiging van de specifieke belangen die zij ingevolge hun statuten behartigen. Voor de bevoegdheid ex art. 3:305b geldt een dergelijke begrenzing niet, want deze bevoegdheid zou in ieder geval mogen worden gebruikt ter behartiging van al die belangen welke door sociale grondrechten worden gedekt. Kortom, het gaat om een bevoegdheid die aan geen enkele andere (rechts)persoon toekomt. Door art. 3:305b is aan 'de overheid' als een soort super-belangenorganisatie een algemene, nietgelimiteerde bevoegdheid verleend om via verbods- en gebodsacties in te dringen in de particuliere sfeer van burgers en de eigen kring van maatschappelijke verbanden, telkens waar zij dit nodig oordeelt ter bescherming van (één of enkele?) andere burgers of andere maatschappelijke verbanden.

Volgens Frenk zou mét art. 3:305b BW worden voldaan aan de eis dat er sprake moet zijn van bevoegdheidverlenende regelgeving, wil de overheid ter behartiging van een door een sociaal grondrecht bestreken belang kunnen ingrijpen in de rechtssfeer van burgers ${ }^{17}$. De verlening van een zo algemene 'bevoegdheid' komt echter in feite neer op herstel van het oude ius politiae, met alleen dit verschil dat thans de

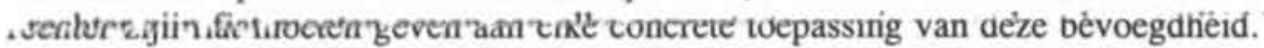
We wezen er trouwens al eerder op dat de Hoge Raad, door art. 1401 (oud) resp. art. 6:162 te beschouwen als een algemene bevoegdheidsgrondslag voor 'de overheid' biedt tot entameren van gebods- en verbodsacties ter behartiging van publieke belangen, in feite weer de opvatting aanvaardt die bij het Meerenbergarrest ${ }^{18}$ werd verlaten, namelijk dat 'de grenzen der Koninklijke magt in zaken van administratie en politie niet bepaald (afgebakend zijn)' ${ }^{19}$, behoudens in die gevallen waarin de Grondwet uitdrukkelijk een wet in formele zin eist (en de Grondwet dus door gebruikmaking de Kroon van zijn ius politiae zouden worden doorkruist).

Art. 3:305b BW voegt er alleen nog aan toe, dat 'de overheid' die algemene bevoegdheid om in civilibus te ageren óók kan gebruiken om op te komen voor de belangen van bepaalde (groepen van) burgers, groepsbelangen dus.

Als Frenk betoogt dat het opmerkelijke van art. 3:305b BW is:

'dat overheidslichamenbinnen hun overheidstaak' - die, zoals we zagen, ruim is op te vatten - 'de bevoegdheid verkrijgen als representant van getroffen burgers de burgerlijke rechter te adiēren' (cursivering dzz.: $\mathrm{JT}$ ) ${ }^{20}$,

miskent hij dat met deze wel zeer algemene bevoegdheidsgrondslag van democratische representatie geen sprake kan zijn ${ }^{21}$. Wil men al van representatie spreken, dan gaat het toch veeleer om een representatie zoals deze werd opgevat in de 'Polizeistaat' van de verlicht absolute vorst. Maar die beschouwde zich tenminste nog als representant van zijn gehele volk. Bij art. 3:305b BW gaat het daarentegen om representatie door overheidslichamen van specifieke (groepen van) burgers. 
$\mathrm{Na}$ de opkomst van de rechtsstaat zijn het leidende beginsel van algemeen belang, de beginselen van volksrepresentatie en non-identificatie en de eis wetmatigheid van bestuur nauw met elkaar verbonden begrippen geworden: elk optreden van de overheid moet zijn gekwalificeerd door het leidende beginsel van het algemeen belang, dat eist dat alle bijzondere rechtsbelangen evenwichtig worden geharmoniseerd en geïntegreerd in dat algemeen belang, en dat dus ook een verbod inhoudt van dienstbaarstelling van de Staat aan specifieke individuele en groepsbelangen (beginsel van de non-identificatie).

De conclusie moet zijn dat deze beginselen door art. 3:305b BW worden geschonden - het overheidshandelen wordt juist 'enträpresentiert' (Krüger) -, terwijl deze bepaling óók op gespannen voet staat met het non-identificatiebeginsel ${ }^{22}$. Ook het burgerlijk recht wordt door deze bepaling ontwricht; dit recht kàn naar zijn aard aan 'de overheid' geen 'bevoegdheden' verlenen ter behartiging van 'algemene belangen'. Omdat door art. 3:305b BW de zowel voor het publiekrecht als het burgerlijk recht constitutieve rechtsbeginselen op grove wijze worden geschonden, menen we dat art. 3:305b BW is te beschouwen als non-recht ${ }^{20}$ : de wetgever is niet almachtig en dient de grenzen van de materiële rechtsmacht van de Staat - die gekwalificeerd wordt door zijn publiekrechtelijke bestemmingsfunctie - en de structuurverschillen tussen publiek- en burgerlijk recht in acht te nemen.

Art. 3:305b BW is het (voorlopige?) sluitstuk van een ontwikkeling die werd ingezet toen aan het eind van de vorige eeuw en het begin van deze eeuw de zgn. gemene rechtsleer werd aanvaard. Deze leer heeft enerzijds geleid tot een 'privatisering' van publiekrecht - voorbeeld: de beschouwing van het publiek domein als 'gewone' private eigendom - en anderzijds tot een 'publicisering' van privaatrecht - voorbeeld: de toekenning aan 'de overheid' van zgn. 'privaatrechtelijke' bevoegdheden ter behartiging van publieke belangen -, waarbij zowel de eigen aard van het publiekrecht als van het privaatrecht worden miskend.

Een bepaling als 3:305b BW getuigt van een sterk formalistische en (vermeend) pragmatische benadering van het recht en van een geringe belangstelling voor de materiële grondslagen van elk positief recht: alle positief recht kan slechts ontstaan door de juridische vormgeving (positivering) door competente rechtsorganen van de materiële rechtsbeginselen die inherent zijn aan de desbetreffende rechtskring.

Deze formalistische benadering leidt er toe dat men meent te mogen concluderen dat er geen principieel onderscheid (meer) is tussen privaat- en publiekrecht, want 'zowel met behulp van privaatrechtelijke als van bestuursrechtelijke instrumenten kunnen algemene belangen behartigd worden' ${ }^{24}$. 


\section{Noten bij hoofdstuk 7}

1. TK 1991-1992, 22.486, nr. 3, p. 34.

2. Als voorbeeld van $z 0^{\prime} n$ 'instellingsregeling' wordt genoemd: art. 128 van de per 1 jan. 1994 ingetrokken gemeentewet, luidende: 'De gemeentebesturen kunnen de belangen hunner gemeenten van hare ingezetenen bij Ons, bij de Staten-Generaal en bij de Staten der provincie, waartoe zij behooren, voorstaan.' Men kan deze bepaling bezwaarlijk als een 'instellingsregeling' betitelen. Reeds in de oudere commentaren op de oude gemeentewet werd art. 128 beschouwd als een - overbodige - vastlegging van het petitierecht van gemeentebesturen. In het in 1980 gepubliceerde voorontwerp voor een nieuwe Gemeentewet was deze bepaling, in gemoderniseerde redactie, overgenomen in art. 115. In per 1 jan. 1994 in werking getreden nieuwe Gemeentewet komt zij niet meer voor.

3. TK 1991-1992, 22.486, nr. 3, p. 33.

4. BVerfG 8 juni 1988, E 78, p. 250 (Fehlbelegungsabgabe).

5. J. van der Hoeven, 'De magische lijn. Verkenningen op de grens van publiek- en privaatrecht', in: 'Honderd jaar rechtsleven. Feestbundel NJV 1970', pp. 201-219, ook opgenomen in: dez., 'Staatsrecht en bestuursrecht. Opstellen van Mr. J. van der Hoeven', Zwolle 1984, p. 177-196 (p. 193/194). Vgl. onze eerdere opmerkingen over 0.a. HR 28 juni 1985, NJ 1986, 356, BR 1986, p. 121 (Claas/Van Tongeren), dat de hierin opgenomen overweging dat een bij een bestemmingsplan behorend gebruiksvoorschrift 'mede strekt ter bescherming van de belangen van belanghebbenden al Claas c.a.' minder gelukkig is. Een dergelijk voorschrift strekt ter bescherming van publieke gemeenschapsbelangen. Dat daardoor óók bijzondere belangen worden beschermd, is daarvan een reflex.

6. BVerfG 2 mei 1967, E 21 , nr. 46 , p. $378 / 379$ en p. 374.

7. Reden waarom publiekrechtelijke rechtspersonen zich niet op grondrechten kunnen beroepen.

8. Pres.Rb. 's-Gravenhage 16 jan. 1990, KG 1990, 78 (Noordwijkerhout/Bonte). Vgl. ook Hof Amhem 8 juni 1993, KG 1993, 375, waarbij werd ingewilligd een door de gemeente Deventer, ter bescherming van de belangen van omwonenden, gevraagd bevel tot sluiting van een pand waar soft drugs werden verkocht.

9. HR 9 nov. 1973, NJ 1974, 91 (Limmen/Houtkoop).

10. Dit is ook de opvatting van N. Frenk, 'Kollektieve akties in het privaatrecht', diss. Utrecht 1994, p. 76 (Frenk was overigens als ambtenaar ten departemente nauw bij het wetgevingsproces betrokken).

11. HR 18 febr. 1994, AB 1994, (Kabayel).

12. Frenk, a.w., p. 75 en p. 127, nt. 100.

13. Reeds in 1847 schreef Olivier, a.w., p. $275 / 276$, over de in art. 226 Grondwet 1840 vervatte 'sociale grondrechtsbepaling', waarbij 'als eene zaak van hoog belang ... het armbestuur ... aan de aanhoudende zorg der Regering' werd opgedragen, reeds Olivier, a.w. p. 275/276: 'Daaruit zal men toch wel niet de gevolgtrekking kunnen maken, dat de grondwet dezen tak van Staatshuishouding aan de medewerking der vertegenwoordiging heeft willen onttrekken, om dien uitsluitend aan den Koning op te dragen. (...) Over de regten der regering (de bevoegdheden tot 'tusschenkomst' in particuliere rechten; JT) bij de haar bevolen zorg wordt in art. 226 niets bepaald. $\mathrm{Zij}$ zorgt dus binnen de grenzen harer grondwettige bevoegdheid. (...) Men bestuurt niet ... naar de regels van het natuurregt, maar naar die van het stellig regt. (...) De wet moet aanwijzen, in welke gevallen en op welke wijzen dat regt van tusschenkomst zal uitgeoefend worden'.

In de Duitse literatuur wordt zelfs door degenen die bepleiten dat (ook) de Staat zich kan beroepen op grondrechten, beklemtoond dat de wettelijke bevoegdheidstoedeling niet met een beroep op grondrechten verruimd kan worden. Zie bijv. K.-A. Bettermann, 'Juristische Personen des öffentlichen Rechts als Grundrechtsträger', NJW 1969, p. 1321 e.v., i.h.b.p. 1326: 'Eine Kompetenzüberschreitung kann nicht durch Berufung auf ein Grundrecht gerechtfertigt, eine vom Staat verfügte Kompetenzănderung nicht durch Berufung auf ein materielles Grundrecht abgewehrt werden'. 
14. Zie over deze grondwetsherziening: R. Samwalt, 'Die Reform des Grundgesetzes', NJW 1994, pp. 3313-3320. De grondrechtencatalogus in de Duitse Grondwet bevatte - andersdan de Nederlandse (bijv. in art. 21) - voorheen nog geen sociale grondrechten. Zoals blijkt uit de Verfassungsbeschwerde die leidde tot BVerfG 7 juni 1977. E. 45, nr. 2, was het echter niet ondenkbaar zijn dat burgers het recht op drinkwatervoorziening, of meer algemeen: het recht op een schoon milieu, baseerden op Art. 2 Abs. 1 (algemene handelingsvrijheid), eventueel in verband met de in Art. 20 Abs. I vastgelegde 'Sozialstaatklausel'.

15. Frenk, a.w., p. 128/129.

16. Niels Frenk, 'Kent Nederiand een 'governmental action?', NTB 1993/4, pp. 145-155 (p. 149).

17. Niels Frenk, 'Kent Nederland een 'governmental action?', t.a.p., p. 154/155.

18. HR 13 jan. 1879 , W. 4330 (Meerenberg).

19. HR 23 maart 1874, W. 3718.

20. Frenk, a.w., p. 128.

21. Vgl. onze eerdere kritiek op G.J. Scholten, die in zijn noot in NJ 1978, 615 (Zuidpoolarrest) betoogt dat 'een openbaar lichaam ... ook een zekere vertegenwoordigende functie (heeft)' en daarin een legitimatie ziet voor gebruikmaking door dat lichaam van zgn. privaatrechtelijke bevoegdheden.

22. H. Dooyeweerd, 'De verhouding van individu en gemeenschap rechtswijsgeerig bezien'. Ned. Tijdschrift voor Wijsbegeerte en Psychologie dec. 1946, aft. 2, pp. 5-12 (p. 12), schrijf:

'(D)e stormloop tegen de grondslagen van het burgerlijk recht (gaat) steeds gepaard met een principieclen aanval op de modeme staatsidee, die op een scherpe onderscheiding van publiek- en privaatrecht gebouwd is en op het beginsel der salus publica in zijn scherpe onderscheiding van alle groepsbelang'.

23. We stemmen dus in met Van Eikema Hommes. Deze gaat ervan uit dat een wettelijke regeling die in strijd komt met de regulatieve beginselen van de rechtsidee (beginselen van juridische billijkheid, redelijkheid e.d.) wel onrechtvaardig, 'unrichtiges' recht is, maar haar karakter van geldend recht behoudt. Daarentegen heeft een regeling die in strijd komt met constitutieve rechtsbeginselen, het karakter van non-recht. Vgl. Van Eikema Hommes. 'Hoofdlijnen van de geschiedenis der rechtsfilosofie', a.w., pp. 219. Dit standpunt komt dicht in de buurt van Radbruch's opvatting dat grove schending van het 'übergesetzliche Recht' het positieve recht tot onrecht maakt.

24. Aldus M. Kobussen, 'De vrijheid van de overheid", diss. Tilburg, Zwolle 1991. 



\section{Hoofdstuk 8}

\section{Behartiging van 'publieke belangen' door maatschappelijke organisaties: artikel 3:305a BW}

\section{Nieuwe Meer}

Wanneer men er van uitgaat dat het dualisme Staat-'maatschappij' moet worden losgelaten en dat de grenzen tussen 'publiekrechtelijke belangen' en 'maatschappelijke belangen' c.q. collectieve belangen zijn vervloeid, aanvaardt men een 'publieke ruimte' (Foqué) waarin enerzijds 'de overheid' op 'privaatrechtelijke' basis publieke belangen kan vervullen en anderzijds dat ook niet-statelijke verbanden - zoals milieuorganisaties - 'publieke belangen' kunnen behartigen door het aanspannen van privaatrechtelijke acties tegen andere particulieren die deze belangen zouden aantasten.

Baanbrekend was in dezen het Nieuwe Meer-arrest, waarin wordt overwogen dat weliswaar de enkele doelomschrijving van een rechtspersoon deze nog niet bevoegd maakt om bij de burgerlijke rechter een vordering in te stellen ter zake van de aantasting van de belangen waarvan zij blijkens die doelomschrijving de behartiging op zich heeft genomen, maar daarop uitzonderingen denkbaar zijn. Zo'n uitzondering deed zich i.c. volgens de Hoge Raad voor, nu:

'de belangen die bij een vordering als de onderhavige - in wezen strekkende tot het verkrijgen van een verbod tot verdere aantasting van het milieu - betrokken zijn zich (lenen) tot een 'bundeling' als door het optreden in rechte van de milieuverenigingen tot stand is gebracht; bij gebreke van de mogelijkheid van een zodanige bundeling zou integendeeleen efficiènte rechtsbeschermingtegen een dreigende aantasting van deze belangen - die in de regel grote groepen burgers te zamen raken, terwijl de gevolgen van een dergelijke aantasting ter aanzien van ieder van die burgers zich vaak moeilijk laten voorzien - niet onaanzienlijk kunnen worden bemoeilijkt' '

De hier door de milieuverenigingen gebundelde belangen behoren volgens de Hoge Raad:

'tot de soort die valt onder de bescherming die art. $1401 \mathrm{BW}$ bedoelt te bieden; zulks geldt mede voor het in de onderhavige zaak meespelende belang om niet door zonder vergunning uitgevoerde gedragingen, als door de milieuverenigingen aan de gemeente verweten, de .... mogelijkheid te verliezen om in een vergunningsprocedure krachtens de Wet algemene bepalingen milieuhygiêne met gebruikmaking van de daarbij gegeven waarborgen tijdig voor de voormelde belangen op te komen'. 
Bij de Wet algemene bepalingen milieuhygiëne was aan 'een ieder' (en uitdrukkelijk ó́k aan privaatrechtelijke belangenorganisaties) de mogelijkheid gegeven tot het instellen van bezwaar en beroep tegen milieubeslissingen. Deze wettelijk geboden inspraak- en beroepsmogelijkheden worden volgens de Hoge Raad gefrustreerd, wanneer een milieuvereniging niet in civiel kort geding zouden kunnen opkomen tegen gedragingen, waarvan zij menen dat deze ten onrechte zonder vergunning plaatsvinden en die in beginsel kunnen leiden tot aantasting van de belangen waarvoor die vereniging blijkens haar doelomschrijving opkomt:

'Dit brengt tevens mee dat het niet op zijn plaats zou zijn om in een geval als het onderhavige nadere eisen voor de ontvankelijkheidte stellen, zoals bijv. terzake van representativiteitof feitelijke werkzaamheden.

Aanvaard wordt dus de mogelijkheid dat een maatschappelijk verband in een civiele procedure opkomt voor een belang dat geen eigen, privaat belang is. Het is o.i. een blote redeneertruc wanneer men de actiebevoegdheid van zo'n organisatie baseert op de stelling 'behartiging van het algemeen milieubelang is voor een milieuvereniging met een dergelijke doelstelling behartiging van haar eigen belang' ${ }^{2}$. Drupsteen omschrijft de betekenis van het Nieuwe Meer-arrest juister:

'Het Nieuwe Meer-arrest opent ... de mogelijkheidom in een civiele procedurealgemenemisstanden aan de kaak te stellen, zonder dat daarbij sprake behoeft te zijn van een aantasting van een concreet, eigen belang van de eiser' (curs. dzz; JT) 's.

Onzes inziens mag evenwel niet over het hoofd worden gezien, dat een civiele procesmogelijkheid in dit arrest juist geboden werd geacht om te voorkomen dat de bestuursrechtelijke - ingevolge de Wet algemene bepalingen milieuhygiëne - aan de betrokken milieuorganisaties toekomende - inspraak- en beroepsmogelijkheden zouden worden gefrustreerd door de betrokken overheidsinstantie zelf. Deze procedure was er op gericht, de overheid ertoe aan te zetten de wettelijk voorgeschreven procedures te volgen.

'Eigen belang' = 'collectief belang' = 'belangen van (alle) andere personen' = 'algemeen belang' = 'eigen belang'

Het nivellerende denken leidt er - ook hier - echter toe dat de in dit arrest neergelegde opvatting wordt veralgemeniseerd. Zo betoogt Frenk, dat één van de redenen om 'algemeen belang-akties' aan te moedigen, is:

'dat een algemeen belang-aktieslechts in kwantitatiefopzicht van een groepsaktieverschilt. Waarom zou een kollektieve aktie wel mogelijk zijn indien daarmee wordt opgekomen voor een belang dat slechts een bepaalde groep aangaat, en niet indien het een belang betreft dat ons ieder raakt? Dit nog even afgezien van het feit dat het onderscheidtussen beide vaag is en de rechter onder omstandigheden voor het probleem kan stellen dat hij moet beslissen of het belang waarom bescherming wordt gevraagd een groeps- of algemeen belang is' 4 . 


\section{En Van Nispen betoogde reeds in 1978:}

'De overheid wordt niet langer gezien als het instituut dat exclusief bepaalt wat het algemeen belang vergt en hoe dat moet worden behoed's

Hierboven zal reeds duidelijk zijn geworden, dat door ons niet kan worden aanvaard dat er geen principieel verschil is tussen 'algemeen belang' en 'publiekrechtelijke belangen' enerzijds en 'groepsbelang' c.q. collectief belang anderzijds. Als Frenk betoogt:

'Met de erkenning van het kollektief aktierecht is ... de aktieradius van het civiele recht vergroot, immers zonder deze akties is het niet mogelijk normen te handhavendie de belangenvan vrijwel een ieder, of zo men wil de gemeenschapals geheel, beogen te beschermen'"

miskent hij de eigen aard van zowel het publiekrecht als van het 'civiele recht', dat als burcht der burgerrechtelijke vrijheid-in-gelijkheid juist bestemd is 'een heilzaam tegenwicht te bieden tegen den overmachtigen druk der gemeenschapseischen in het rechtsleven' 7 . Als het civiele recht er mede toe zou strekken het 'algemeen belang' te behartigen, wordt het ontwricht en is het geen civielrecht meer doch is het geworden tot een ongedifferentieerd recht.

Het nivellerende denken gaat echter verder: als reeds niet-statelijke organisaties, zoals milieuverenigingen, via een civiele actie mogen opkomen voor 'publieke belangen', dan zou 'de overheid' dat toch zeker - 'a fortiori' - ó́k mogen? Mede gelet op het Nieuwe Meer-arrest overwoog het Haagse Hof in de Benckiser-casus dat:

'niet goed (valt) in te zien, waarom milieuverenigingende weg naar de rechter wel zouden mogen bewandelen... en de Staat niet' " .

Als dan een civiele 'bevoegdheid' voor 'de overheid' om via een art. 1401 resp. art. 6:162 BW-actie op te komen voor 'publieke belangen' eenmaal in algemene zin is aanvaard ', wordt vervolgens geredeneerd: als belangenorganisaties via zo'n actie kunnen opkomen voor een publiek belang zonder dat zij daarbij een concreet art. 1401 (6:162)-belang behoeven te stellen, ligt het voor de hand dat het vereiste van een concreet belang óók niet aan 'de overheid' wordt gesteld. Zoals we zagen, heeft kennelijk de Hoge Raad gemeend deze conclusie inderdaad te moeten trekken ${ }^{10}$.

En als eenmaal is geaccepteerd dat - zoals advocaat-generaal Koopmans het uitdrukt in zijn conclusie vóór het Kuundersarrest " - "dankzij de Nieuwe-Meerjurisprudentie' particuliere milieuorganisaties voor de burgerlijke rechter in het krijt kunnen treden ten behoeve van 'het algemeen belang, ... dezelfde belangen ... als die welke door de overheid worden behartigd', wordt een dergelijke actiebevoegdheid voor particuliere organisaties al gauw óók aanwezig geacht voor andere 'publieke belangen' dan het milieubelang. De Hoge Raad overweegt in dat arrest dan wel dat de door hem aanvaarde uitzondering op de regel dat de doelomschrijving van een rechts- 
persoon deze niet zonder meer bevoegd maakt een civiele vordering in te stellen ter zake van aantasting van de blijkens die doelomschrijving behartigde belangen, wordt gerechtvaardigd doordat het gaat om ecologische belangen die een 'bundeling' vergen, maar zoals het nieuwe art. 3:305a BW laat zien is een uitbreiding van deze actiebevoegdheid van particuliere organisaties tot allerlei andere 'belangen ... als die welke door de overheid worden behartigd' niet tegen te houden.

\section{Artikel 3:305a BW}

\section{Artikel 3:305a, eerste lid, BW luidt:}

'1. Een stichting of vereniging met volledige rechtsbevoegdheidkan een rechtsvordering instellen die strekt tot bescherming van gelijksoortige belangen van andere personen, voorzover zij deze belangen ingevolge haar statuten behartigt.

2. Een rechtspersoon als bedoeld in lid 1 is niet ontvankelijk, indien hij in de gegeven omstandigheden onvoldoendeheeft getracht het gevorderde door het voeren van overleg met de gedaagde te bereiken.

3. Een rechtsvordering als bedoeld in lid 1 kan niet strekken tot schadevergoedingte voldoen in geld.

4. Een gedraging kan niet ten grondslag worden gelegd aan een rechtsvordering als bedoeld in lid

1, voor zover degene die door deze gedraging wordt getroffen, daartegen bezwaar maakt.

5. Een rechterlijke uitspraak heeft geen gevolg ten aanzien van een persoon tot bescherming van wiens belang de rechtsvordering strekt en die zich verzet tegen werking van de uitspraak ten opzichte van hem, tenzij de aard van de uitspraak meebrengt dat de werking niet slechts ten opzichte van deze persoon kan worden uitgesloten' ${ }^{12}$.

Uit de wetsgeschiedenis komt naar voren, dat de woorden 'belangen van andere personen' in het eerste lid ruim moeten worden uitgelegd: het kan gaan om een onbepaalbare, zeer grote groep van personen. Uitdrukkelijk verworpen ${ }^{13}$ werd de opvatting zoals naar voren gebracht in het advies van de Sociaal-Economische Raad over het voorontwerp van wet. De Sociaal-Economische Raad had het criterium dat het gaat om 'belangen van anderen', als volgt geïnterpreteerd:

'Het collectieve vorderingsrecht zoals dat in het wetsartikel wordt 'geconstrueerd', heeft tot doel om met één vordering op te komen tegen een gedraging die - althans naar de mening van de vorderende organisatic - onrechtmatig is jegens de (identieke) belangen van een min of meer grote groep 'anderen' (dat wil zeggen anderendan de vorderendeorganisatie) en die daardoor aan elk van die anderen de mogelijkheid geeft om zèlf een 'normale' vordering wegens onrechtmatige daad in te stellen: de collectieve vordering 'bundelt' als het ware die potentiele individuele vorderingen, die overigenswel als zodanigmogelijk blijven. Essentieel is derhalvedat die individuele vorderingsrechten bestaan' (curs. dzz.; JT) ${ }^{14}$.

\section{Volgens Frenk zijn 'geruststellende woorden' op hun plaats:}

'Kenmerkend voor een algemeen belang is dat het een belang betreft bij de bescherming waarvan wij allen profijt hebben. $\mathrm{Zo}_{0}$ is, om een voorbeeld te noemen, het belang van een schoon milieu bij uitstek een algemeen belang omdat dat ons ieder aangaat. Een kollektieve aktie waarbij derhalve 
wordt opgekomen voor een algemeen belang is bij uitstek een aktie waarbij de bescherming van de belangen van personen centraal staat' (curs. dzz.; JT) ${ }^{\text {is. }}$.

Maar bij een zó ruime uitleg heeft de clausule 'belangen van andere personen' uiteraard geen zin meer. Dat de wetgever niettemin deze clausule heeft opgenomen, zal hiermee te maken hebben dat hij althans formeel de relatie van het door art. 3:305a (en art. 3:305b) geregelde actierecht met het burgerlijk recht wilde handhaven. Het burgerlijk recht beoogt - aldus de memorie van toelichting - nu eenmaal uitsluitend rechtsverhoudingen tussen personen te regelen ${ }^{16}$. Ook hier is o.i. de aanduiding 'etikettenzwendel' op haar plaats: van burgerlijk recht is hier materieel geen sprake meer.

\section{Representatie door 'opt-out' systeem?}

En een statutaire doelomschrijving is reeds voldoende om op te komen voor de 'gelijksoortige belangen van andere personen': noch de representativiteitseis noch de eis van feitelijke werkzaamheid wordt als ontvankelijkheidsvoorwaarde gesteld. Door de wetgever is in art. 3:305a BW aanvaard, dat stichtingen en andere organisaties enkel uit hoofde van de door hen gekozen doelomschrijving bevoegd zijn om wegens (beweerde) onrechtmatige daad ex art. 6:162 acties te entameren ter bescherming van de 'belangen van andere personen', waaronder een 'algemeen belang'. Met een beroep op de jurisprudentie waarin deze eis soms niet zou zijn gesteld, wordt in de memorie van toelichting de keuze verdedigd dat in het wetsvoorstel de representativiteitseis niet is te vinden ${ }^{17}$.

Volgens Frenk is echter de door de wetgever gemaakte keuze, dat de representativiteitseis in het geheel niet als ontvankelijkheidsvoorwaarde wordt gesteld, mede verdedigbaar omdat er een aantal waarborgen is opgenomen, die moeten voorkomen dat tegen iemands zin voor zijn belangen wordt opgekomen. Daarbij zou, náást de in het tweede lid opgenomen verplichting om voorafgaande aan een civiele actie overleg te voeren met de gedaagde teneinde het gevorderde te bereiken, de in het vijfde lid aan 'een persoon tot bescherming van wiens belang de vordering strekt' gegeven mogelijkheid van belang zijn om zich aan de gevolgen van de procedure te onttrekken, door zich te verzetten tegen de werking van de uitspraak ten opzichte van hem ${ }^{18}$. Zo'n 'systeem' wordt wel een 'opt-out' systeem genoemd, in tegenstelling tot een 'opt-in' systeem, waarin individuen alleen dán geacht kunnen worden door de organisatie te zijn vertegenwoordigd wanneer zij vooraf hebben kenbaar gemaakt dat zij door die organisatie vertegenwoordigd willen worden ${ }^{19}$. Men zou kunnen zeggen dat de wetgever van art. 3:305a BW de representatie door zo'n organisatie van 'andere personen' fingeert door de invoering van een 'opt-out' systeem. 
Waar het gaat om de behartiging van 'een algemeen belang', kán een private organisatie als bedoeld in art. 3:305a in het geheel niet aan het (publiekrechtelijke) representativiteitsbeginsel voldoen. En het 'opt-out' systeem heeft hier uiteraard geen enkele reële betekenis: wanneer één of meer individuen al op de hoogte zouden zijn van het voornemen van een milieustichting om via een civiele actie op te komen voor het 'milieubelang' en kenbaar maken dat zij zich niet door die organisatie vertegenwoordigd wensen te zien, resteren er altijd nog meer dan vijftien miljoen van die actic onwetende Nederlanders tot bescherming van wier belang de actie - zogenaamd - strekt.

In de nota naar aanleiding van het eindverslag - het Kuunders-arrest is dan net gewezen ${ }^{20}$ - wordt gesteld dat óók de voorwaarde van feitelijke werkzaamheid als zelfstandige ontvankelijkheidseis naast het vereiste van voorafgaande overleg goeddeels overbodig zou zijn en een te grote breuk zou betekenen met de jurisprudentie van de Hoge Raad:
'In steeds meer uitspraken van de Hoge Raad wordt immers geoordeeld dat een uitzondering moet worden gemaakt op de regel dat de doelomschrijving van een rechtspersoon deze niet zonder meer bevoegd maakt een collectieve actie in te stellen. Het stellen van nadere eisen, zoals bijvoorbeeld ter zake van feitelijke werkzaamheid, wordt in deze uitspraken dan ook niet op zijn plaats geacht. (...) In dit licht bezien is het ook onverstandignaast het vereiste van voorafgaandoverleg nog nadere vereisten ter zake van feitelijke werkzaamheid te stellen' ${ }^{21}$.

De relativiteitseis is dan bij een 'collectieve actie' uit hoofde van onrechtmatige daad nauwelijks nog een probleem. Waar de (beweerde) onrechtmatigheid is gelegen in overtreding van een wettelijk voorschrift, is in beginsel slechts vereist dat de door een rechtspersoon blijkens zijn statutaire doelstelling nagestreefde belangen geheel of gedeeltelijk corresponderen met de belangen die het overtreden voorschrift beoogt te dienen. In het Kuunders-arrest geeft de Hoge Raad als zijn oordeel, dat de overtreding door Kuunders van de Natuurbeschermingswet ook een aantasting zou betekenen van de door de eisende milieuorganisaties blijkens hun statutaire doelstelling behartigde belangen en derhalve jegens deze organisaties onrechtmatig zou zijn:

'(I)ngeval deze belangen worden aangetast door schending van tot hun bescherming strekkende normen, (is) zulks jegens rechtspersonen tot wier statutaire taak het behartigen van die belangen behoort, onrechtmatig ..., zodat deze daaraan in elk geval de bevoegdheid ontlenen in rechte een verbod van verdere schending te vorderen'.

Frenk merkt op dat er met de inwerkingtreding van art. 3:305a BW een tweede belangrijke grondslag, náást art. $6: 162 \mathrm{BW}$, bestaat voor het collectief actierecht: zonder dat belangenorganisaties zèlf als aanspraakgerechtigden zijn aan te merken, kunnen zij - aldus Frenk - op basis van art. 3:305a BW voor personen die dat wèl zijn, hun aanspraken geldend maken ${ }^{22}$. Het zal echter duidelijk zijn geworden, dat 
er in deze visie tussen het 'eigen belang' van de organisatie, het 'algemeen belang' - dat immers geconstrueerd wordt tot 'eigen belang' - en de 'gelijksoortige belangen van andere personen' géén principiële verschillen meer aanwezig worden geacht.

En waar het gaat om overtreding van een wettelijk voorschrift is volgens Frenk, anders dan bij overtreding van een 'zorgvuldigheidsnorm', voor onrechtmatigheid jegens de organisatie niet vereist dat de overtreder reeds ten tijde van de overtreding had kunnen voorzien dat enige organisatie zich de gevolgen van die overtreding zou kunnen gaan aantrekken. Voldoende zou doorgaans zijn dat binnen de 'belangensfeer' waar de overtreding plaatsvindt, enige belangenorganisatie reeds actief is en de overtreder hiervan op de hoogte kon zijn.

De twee belangrijkste 'voordelen' die het collectief actierecht op basis van art. 3:305a BW biedt bóven de collectieve actie die gebaseerd is op onrechtmatigheid ex art. 6:162 BW tegenover de belangenorganisatie zelf, zijn volgens Frenk:

'Bij het kollektief aktierecht op basis van artikel 3:305a BW wordt ... voor ontvankelijkheidnog nauwelijks enige aktiviteit van de eisende organisatie vereist. Dit betekent dat op die terreinen waar het in de kringen van de overtreder niet algemeen bekend is dat daar belangenorganisatieswerkzaam zijn, het beste een beroep kan worden gedaan op artikel 3:305a BW. (...) Het wellicht grootste voordeel van artikel 3:305a BW boven de kollektieve aktie die gebaseerd is op onrechtmatigheid tegenover de organisatie zelf, is natuurlijk het feit dat op deze basis alle mogelijke vorderingen ingesteld kunnen worden. Men is hierbij niet beperkt tot vorderingen uit onrechtmatige daad. Nakoming, ontbinding, vernietiging, onverschuldigdebetaling etcetera zijn vorderingendie door een belangenorganisatiealleen op basis van artikel 3:305a BW ingesteld kunnen worden' $v$.

\section{Een 'opt-out' systeem past niet in het Nederlands burgerlijk (proces)recht}

Zo'n maatschappelijk verband overschrijdt de grenzen van zijn eigen rechtssfeer, wanneer het zich in een civiele actie opwerpt als de beschermer van de belangen van 'andere personen', zonder dat het daartoe van die 'andere personen' is gemachtigd. Dit is goed gezien door het kamerlid Schutte, die bij de behandeling in de Tweede Kamer van wetsvoorstel 22.486 betoogde:

'Ieder zal beseffen dat willekeurige derden zich niet zomaar kunnen opwerpen als behartiger van onze belangen. Het gaat immers om de uitoefening van onze burgerlijke rechten tegenover medeburgers, bedrijven, instellingen of ook de overheid. Daarmee hebben derden in beginsel niet te maken. De afweging of de veiligstelling van bepaalde belangen een rechtszaak waard is behoort in beginsel ook door de betrokken burgers zelf te worden gemaakt' ${ }^{24}$.

Waar op bepaalde terreinen de belangen van vele individuele burgers tegelijk in gevaar komen terwijl deze burgers vaak zwak staan tegenover een sterke tegenpartij, kan - aldus Schutte - de kwaliteit van de rechtsstaat worden gediend door aan maatschappelijke organisaties met specifieke doelstellingen (zoals consumentenorganisaties) de procesbevoegdheid te geven zich als collectief tot de rechter te wenden ter bescherming van de belangen van duidelijk herkenbare individuen die zich ook door de organisatie weten vertegenwoordigd ${ }^{25}$. Om die reden was door Schutte ook meegewerkt aan de opneming van een collectieve procesbevoegdheid 
in de regeling betreffende algemene voorwaarden in het BW. Maar een algemene regeling van de bevoegdheid tot collectieve actie ten behoeve van de belangen van 'andere personen' achtte Schutte te ver gaan:

'Krijgt de aantasting van een belang als zodanig hier niet een te grote nadruk los van de andere personen van wie de belangen zouden worden geschaad? Wordt op deze wijze niet de mogelijkheid geschapen dat het bij veel collectieve acties uiteindelijk niet meer zal gaan om het opkomen van belangenorganisaties voor de aangetaste belangen van andere personen, maar om datgene wat bepaalde groepen mensen van belang achten voor andere mensen? Nu gun ik iedereen de vrijheid om daarover opvattingen te hebben, maar ik vind niet dat dan ook maar de mogelijkheid moet worden geschapen, dit gelijk voor de rechter te gaan bevechten. De juridische mogelijkheid van collectieve actie verwordt dan tot een actiewapen in een ideologische strijd'.

Terecht merkte Schutte over het wetsvoorstel op:

'Dit leidt tot een vorm van verzelfstandigingvan belangenvan organisaties, welke dunkt mij strijdig is met het karakter van het burgerlijk recht' ${ }^{\prime 26}$.

Schutte lijkt vooral ook moeite te hebben met het in het vijfde lid van art. 3:305 BW neergelegde 'opt-out' systeem. Dit 'opt out' systeem is kenmerkend voor de 'class actions' in de Verenigde Staten. Een 'class action' is een figuur waarbij op initiatief van één of meer personen een vordering wordt ingesteld ten behoeve van een talrijke groep personen met een gemeenschappelijk belang bij het geschil ${ }^{27}$. Het verdraagt zich o.i. echter niet met de aard van ons burgerlijk recht - en evenmin met het burgerlijk recht in vergelijkbare rechtsstelsels, zoals het Duitse en het Franse - om daarin in algemene zin de collectieve actie met 'opt out' systeem in te planten. Recentelijk is Roger Mann ingegaan op de vraag, of een 'class action'-vonnis van een Amerikaanse rechter in Duitsland executeerbaar is ${ }^{28}$. Hij komt tot de conclusie dat de 'class action'-procedure op gespannen voet staat met de Duitse 'ordre public', zodat zo'n vonnis in de Duitse rechtsorde niet erkend kan worden. Dit vooral in verband met het 'opt-out' systeem:

'Diese Regelung verstösst gleich gegen zwei tragende Prinzipien des deutschen Zivilprozessrechts:

(1) Die Möglichkeit, dass einer der Geschädigtenohne Kenntnis und ohne seinen Willen als Mitglied der 'class' in den Prozess einbezogen wird, ist unvereinbar mit dem im deutschen Recht herrschenden Prinzip der Unzulässigkeit der Popularklage und stellt einen Verstoss gegen die Dispositionsmaxime dar. Durch die 'class action' wird in das Recht des Geschädigten eingegriffen, selbst zu entscheiden,ob er seinen Schaden gerichtlich geltend machen will oder nicht. Ein Eingriff in dieses Recht ist im Rahmen der Grundrechtswirkung auch ein Eingriff in die durch Art. 2 I Grundgesetz garantierte allgemeine Handlungsfreiheit, die eben auch ein Unterlassen freistellt.

(2) Zudem erwächst die "class action"-Entscheidung,mit Ausnahme derjenigen die aus der 'class' ausgetreten sind, gegenüber allen übrigen Mitgliedern der 'class' in Rechtskraft (Federal Rule of Civil Procedure 23 lit. c Nr. 2 und 3). Damit wird die Geltendmachung von individuellen Ansprüchen präkludiert, obwohl der Anspruchsinhaber mōglicherweise von der prozessualen Durchsetzung seines Anspruchs keinerlei Kenntnis hatte und deshalb auch auf den Prozessverlauf keinen Einfluss nehmen konnte. (...)

Die dargestellten Abweichungensind unvereinbarmit der im deutschenZivilprozessrechtherrschenden Dispositionsmaximeund dem Grundsatz der Unzulăssigkeitder Popularklageund führen letztlich 
dazu, dass eine Anerkennung einer "class action"-Entscheidungnach Par. 328 I Nr. 4 ZPO ausgeschlossen ist'.

Gelden vergelijkbare bezwaren niet óok in het Nederlandse burgerlijk recht en burgerlijk procesrecht?

Bezwaren gelden a fortiori voor zgn. 'algemeen belang-acties'; algemeen belang vereist democratische legitimatie

En de genoemde bezwaren gelden a fortiori, waar dergelijke organisaties zich beroepen op een 'algemeen belang', als legitimatie om via een civiele actie in te dringen in de private sfeer van anderen. In 1990 wees Van der Grinten, evenals eerder reeds de Commissie Burgerlijk Procesrecht, een algemene collectieve actiebevoegdheid voor belangenorganisaties af ${ }^{29}$. Het voorontwerp van wet verdiende volgens Van der Grinten een onvoldoende:

'Behartiging van het algemeen belang is de taak van de overheid, niet van particuliere organisaties. (...) Of het een gelukkige ontwikkeling is om organisaties die zich behartiging van algemene belangen ten doel stellen actiebevoegdheid bij de burgerlijk rechter te verlenen, acht ik hoogst twijfelachtig. De organisatie gaat zich daarmee opwerpen als een pseudo-overheid, een pseudoopenbaar ministeric:.

Reeds het Nieuwe Meer-arrest gaat volgens Van der Grinten 'heel ver': 'Representativiteit van de organisaties werd niet nodig geoordeeld', zij het in dat arrest nog als een uitzondering op de regel.

Brunner spreekt in zijn noot bij het Kuundersarrest treffend van 'schaduwoverheid', terwijl ook de door Damen in zijn naschrift in 'De Gemeentestem' gebruikte aanduiding 'verstatelijkt particulier initiatief' zeer toepasselijk is ${ }^{30}$. Brunner stemt in zijn noot in de NJ in met het oordeel van Scheltema:

'dat het algemeen belang - dat een resultante is van een groot aantal deelbelangen- exclusief wordt behartigd door de overheid, aan wie verstrekkende bevoegdhedenzijn verleend om dat te doen (...) Het algemeen belang dient niet als een door art. 6:162 $\mathrm{BW}$ beschermd belang te worden aangemerkt. Omdat de stichtingen geen privaatrechtelijk belang hadden, zijn zij naar mijn mening ten onrechte in hun vordering ontvangen' $"$.

Hiermee kan worden ingestemd: de term 'algemeen' duidt er op dat het gaat om een evenwichtige afweging van alle bijzondere belangen binnen de samenleving en een harmonisering van die bijzondere belangen in dat algemeen belang, zulks met inachtneming van de interne rechtssfeer van individuen en niet-statelijke gemeenschappen. Deze afweging en harmonisering kan slechts worden verricht door de daartoe aangewezen rechtsorganen van de publieke rechtsgemeenschap, zijnde de gemeenschap die een ieder binnen het staatsterritoir omvat en die als enige een publiekrechtelijke bestemmingsfunctie heeft. De zelfstandige behartiging van 'het algemeen belang' 
c.q. van publiekrechtelijke belangen kàn niet het maatschappelijke doel zijn van een niet-statelijk verband ${ }^{32}$.

In dit verband is ook de in de jaren zestig gevoerde discussie omtrent de vernieuwing van het ondernemingsrecht interessant, waarin o.a. de vraag aan de orde kwam of wettelijk zou moeten worden bepaald dat het ondernemingsbeleid moest zijn gericht op de behartiging van het 'algemeen belang'. Het in 1965 uitgebrachte rapport 'Herziening van het ondernemingsrecht' van de Commissie-Verdam ging wat minder ver: voorgesteld werd in de taakomschrijving van de commissaris van een naamloze vennootschap op te nemen, dat deze zijn taak zou dienen te vervullen 'binnen het raam van het algemeen belang ten behoeve van de belangen van de vennootschap en van de met haar verbonden ondernemingen' ${ }^{33}$.

De discussie is samengevat door C.A. Boukema, die o.i. gelijk heeft wanneer hij betoogt dat de maatschappelijke functie van een onderneming niet betrokken kan zijn op het algemeen belang, met andere woorden: dat de behartiging van het 'algemeen belang' niet beschouwd dient te worden als een (der) doelstelling(en) van de onderneming ${ }^{34}$. De behartiging van het algemeen belang behoort niet als eigen zelfstandige doelstelling binnen het gezichtspunt van de onderneming te worden geplaatst,

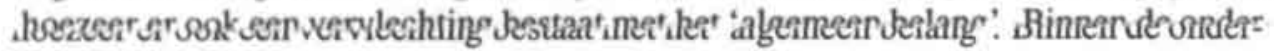
neming kan niet worden beoordeeld wat het algemeen belang eist. Reeds de autocratische structuur van de onderneming is daartoe niet geschikt. Behartiging van het algemeen belang impliceert een afweging, overeenkomstig publieke waarderingsmaatstaven, van alle betrokken belangen binnen de samenleving. En voor deze weging der verschillende belangen behoren - aldus Boukema - materiële regels te worden opgesteld, zodat de vaststelling van wat het algemeen belang eist op objectieve wijze geschiedt. Een van de belangrijkste condities daarbij acht hij dat de besluitvorming zoveel mogelijk in het openbaar geschiedt. Belangrijk daarbij is - zo voegen wij toe - de inachtneming van het publiekrechtelijke beginsel van de representatieve democratie.

'Het niveau en de structuur van de private onderneming biedt niet de minste waarborg dat de vaststelling van wat het algemeen belang eist overeenkomstig deze waarderingsmaatstaven zal geschieden',

aldus Boukema ${ }^{35}$. Het 'algemeen belang' behoort niet het doel maar de - door de overheid getrokken - grens van het ondernemingsbeleid te zijn. Ter bepaling van die grens dient de overheid over toereikende bevoegdheden te beschikken.

Hayek wijst er op dat de opvatting dat de onderneming ook het algemeen belang dient te behartigen, ertoe leidt dat de macht van ondernemingen zich zal gaan uitstrekken op politiek en cultureel gebied. Als we de machtsinvloed der ondernemingen met succes wensen terug te dringen tot waar deze een gunstige uitwerking 
heeft, dan zal die - aldus Hayek - moeten zijn beperkt tot een specifieke doelstelling, nl. tot een nuttig gebruik maken van kapitaal en arbeid ${ }^{36}$. Van een vrije maatschappij kan slechts sprake zijn, wanneer het dualisme Staat-'maatschappij' wordt aanvaard. Hayek kritiseert in 1960 dan ook de:

'in der kontinentalenTradition besondersstarke, aber mit der Ausbreitungvon sozialistischenIdeeen auch in der angelsächsichen Welt schnell wachsende Tendenz, 'Staat' und 'Gesellschaft' zu identifizieren' $n$.

Even gevaarlijk is overigens de sinds de jaren tachtig bestaande tegengestelde tendentie tot het vóóropstellen van economische beginselen ook buiten het bedrijfsleven, niet alleen in andere sectoren van de 'maatschappij' maar ó́k in de Staat. De publiekrechtelijke sector dreigt door deze ver-economisering steeds verder te verloederen ${ }^{38}$.

Ook Böckenförde maakt duidelijk, welke ernstige bezwaren zijn verbonden aan een aanvaarding dat bepaalde niet-statelijke organisaties zelfstandig publieke belangen behartigen. Gaat men ervan uit dat slechts 'de overheid' publieke - beter: publiekrechtelijke - belangen mag behartigen op basis van een wettelijke bevoegdheidstockenning, dan is daarmee ook de democratische legitimatie en de grondslag voor een beperking van de individuele vrijheid gegeven. De behartiging van publieke belangen door niet-statelijke organisaties ontbeert een democratische legitimatie, is in strijd met het rechtsstatelijke gelijkheidsbeginsel - want leidt tot een bevoorrechting van bepaalde private organisaties - en is een gevaar voor de vrijheid van andere particulieren. Zoals het Kuundersarrest duidelijk laat zien, kan dan immers op basis van een actie van zo'n private organisatie de vrijheid van een andere particulier worden beperkt, zulks teneinde aantasting van een publiek belang tegen te gaan.

Een dergelijke privilegiëring van bepaalde niet-statelijke organisaties - omdat ze bepaalde publieke belangen zouden behartigen - leidt tot:

'ein neues System der Herausnahmeaus der allgemeinen rechtlichen Gleichheit, d.h. von Vorrechten und Privilegien .... das dem demokratische Prinzip widerspricht. Die Konzequenz im Sinne des demokratischen Prinzips kann dann nur sein, alle Träger solcher bevorrechtigter öffentlicher Positionen und Aufgaben auch einer demokratischen Willensbildung und Kontrolle zu unterwerfen. Das führt freilich, bei der Reichweite solcher in der Gesellschaft wahrgenommenen öffentlichen Aufgaben und Positionen, zu einer weitgehenden Verstaatlichung oder ... 'Demokratisierung' gesellschaftlicher Bereiche .... ",

Met een zodanige democratisering wordt het probleem echter niet opgelost. Democratische representatie is immers betrokken op het staatsvolk als geheel; het is een typisch publiekrechtelijk beginsel dat geworteld is in het moderne staatsverband: 'volk' in democratische zin betekent het geheel van alle burgers, die zich als staats- 
burgers manifesteren in hun publiekrechtelijke status activus (actief en passief kiesrecht). Maatschappelijke verbanden kunnen zich echter niet op zo'n democratische legitimatie beroepen:

'Beliebig gruppierte einzelne Bürger aus dem Volk bleiben einzelne (singuli), auch wenn sie - durch

Zusammenschluss und Aktivităt - zu pouvoirs de fait werden; weder sind sie noch repräsentieren sie das Volk' (curs. dzz.; JT).

Een interne democratisering van dergelijke verbanden kan dit probleem niet wegnemen, want daardoor nog steeds niet een representatie van alle staatsburgers verkregen. Zo'n interne democratisering is volgens Böckenförde dan ook:

'demokratisch gesehen immer nur eine Schein-Legitimation. Sie bleibt gruppen- bzw. verbandsintern, funktions-und interessenbezogenvon den jeweiligen Mitgliedern bzw. Interessenträgernher, erreicht keinen Bezug zur Gesamtheit der Bûrger. Ihre Bedeutungliegt darin, die individualrechtliche Position der Mitglieder zu stärken und die interne Verbandsstruktur nicht oligarchisch werden zu lassen, Das ist eine durchaus positive Wirkung. Tritt sie aber mit dem Anspruch demokratischer Legitimation auf, die einen besonderen Anteil an der politischen Willensbildung geltend macht, bindet sie die betreffenden Organisationen nicht in die demokratische Verfassungsstruktur ein, sondern verschafft ihnen über ihre sektorale politischeEinflussmachthinaus eine Art allgemeinpolitisches Mandat. Das würde diese Organisationen ... in eine Nebenstellung und ein Konkurrenzverhältnis zu den demokratisch-repräsentativ legitimierten politischen Instanzen bringen, die dadurch geschwăcht würden, und erschwerte überdies ihre tatsăchliche und notwendige Mittlerfunktion auf die politische Willensbildung hin' * $*$

Maar zelfs van een 'interne democratie' behoeft bij de verband als bedoeld in art. 3:305a BW geen sprake te zijn - denk aan de milieustichtingen -, willen ze kunnen worden ontvangen in een civiele actie ter behartiging van 'algemene belangen'. En wanneer men al in interne democratisering van maatschappelijke verbanden een legitimatie zou zien voor behartiging van publieke belangen, dan zou men aanvaarden: 'dass alle Bereiche gesellschaftlicherFreiheit einer 'demokratischen' Bestimmungsgewalt partieller Kollektive unterstellt werden müssen ... (S)o ist sie eine Wegemarke zum Totalitarismus. Sie löst dann eben jene Konzentrierungder politischen Entscheidungsgewaltbei der staatlichen Organisation auf, die eine notwendige Bedingung zur Sicherung individueller Freiheit ist, gerade um sie gegenüber den Lenkungs- und Vereinheitlichungsansprücherpartieller gesellschaftlicher Kollektive zu gewăhrleisten' 4".

Nogmaals: een taak kan slechts een publiekrechtelijke taak zijn, wanneer deze door de democratische wetgever tot statelijke taak is verklaard:

'Ist sie zur staatlichen Aufgabe erklärt, so muss auch ihre Wahrnehmung in den staatlichen Organisations- und Verantwortlichkeitszusammenhang hineingenommen werden; sie darf dann nicht, unbeschadetder Möglichkeit staatlich beaufsichtigter Selbstverwaltung ${ }^{2}$, einzelnen Gliedern der Gesellschaft oder gesellschaftliche Gruppen, die ausserhalb des demokratischen, auf das Staatsvolk bezogenen Verantwortlichkeits- und Kontrollzusammenhanges stehen, als einer 'öffentliche' Aufgabe zur Erledigung überantworten werden. Das bedeutete die Errichtung parakonstitutioneller Gewalten" ${ }^{3}$. 
In dit verband zij er ook op gewezen dat de Duitse doctrine en rechtspraak in overwegende mate een afwijzend standpunt innemen tegenover de zgn. 'altruistische Verbandsklage', dat wil zeggen een actie ingesteld door organisaties die in rechte niet opkomen voor een eigen groepsbelang ${ }^{4}$ maar ter bescherming van publieke belangen, zoals het natuur- en milieubelang. En zulks niet alleen voor het civiele procesrecht, maar ó́k voor het bestuursprocesrecht. De Verwaltungsgerichtsordnung is nog altijd gebaseerd op de conceptie van de individuele rechtsbescherming. Het hiertegen door sommige auteurs aangevoerde argument dat deze conceptie is ontleend aan de idee van de liberale rechtsstaat en niet meer zou passen bij een sociale rechtsstaat, wordt van de hand gewezen, mede omdat een 'altruistiche Verbandsklage' 'individuumfeindlich' zou zijn ${ }^{45}$.

Met art. 3:305a BW is eigenlijk een nieuw soort algemeen contentieux objectif geïntroduceerd in het Burgerlijk Wetboek: een contentieux subjectif kan men een procedure waarin een private organisatie opkomt voor een zgn. 'algemeen belang' toch moeilijk noemen, zeker nu gekozen is voor het 'opt-out' systeem ${ }^{46}$. Dit is te meer opmerkelijk, omdat tezelfdertijd een nieuw bestuursprocesrecht is ingevoerd, dat - althans volgens de memorie van toelichting - uitdrukking zou geven aan een ontwikkeling waarbij 'het primaat van de functie van het handhaven van het objectieve publiekrecht (het contentieux objectif-model; JT) heeft plaatsgemaakt voor het primaat van de rechtsbeschermingsfunctie (het contentieux subjectif-model; JT) ${ }^{4}{ }^{4}$. $\mathrm{Nu}$ is er met name door Tak reeds op gewezen dat zeer betwijfeld moet worden, of het nieuwe bestuursprocesrecht wel plooit met de primaire hoofddoelstelling die het volgens de memorie van toelichting zou hebben: 'veeleer lijkt de afgezworen hoofddoelstelling van objectieve rechtmatigheidscontrole van overheidshandelen nog steeds maatgevend' ${ }^{48}$. Ons nieuwe bestuursprocesrecht gaat dus - zoals Tak terecht concludeert - mank aan dubbelhartigheid, hetgeen o.a. blijkt uit de uitdrukkelijke erkenning van een algemene actiemogelijkheid voor organisaties die opkomen voor 'collectieve en algemene belangen'. Maar het is bepaald simplistisch aan deze algemene mogelijkheid van een 'administratieve kollektieve aktie' de conclusie te verbinden, dat dergelijke belangenorganisaties 'dus' óók een algemene bevoegdheid tot een 'civiele kollektieve aktie' zouden moeten hebben. Want met de aard van het burgerlijk recht en van het burgerlijk procesrecht verdraagt zich in het geheel niet, dat een civiele actie het karakter zou hebben van een contentieux objectif. Bovendien blijft in het contentieuze administratieve proces de verantwoordelijkheid voor het besluit - en voor de daaraan ten grondslag liggende belangenafweging - rusten bij het bestuursorgaan. Daaraan doen niet af dat een belangenorganisatie als bedoeld in art. 1:2 lid 3 Awb tegen zo'n besluit beroep kan instellen bij de administratieve rechter en dat de rechter, ingeval van vernietiging, onder omstandigheden zelf in de zaak kan voorzien (art. 8:72 lid $4 \mathrm{Awb}$ ). De rechter blijft 
daarbij gebonden aan het object van geschil - het bestreden bestuursbesluit en, nader, de omvang van het beroep - en mag niet op 'de stoel van de administratie' gaan zitten. De rechterlijke bevoegdheid om zelf in de zaak te voorzien zal dus slechts aangewend mogen worden, als het relevante feitensubstraat bekend is en duidelijk is wat rechtens het juiste bestuursbesluit moet zijn ${ }^{49}$. Een algemene 'civiele kollektieve aktie' zoals erkend in art. 3:305a BW, impliceert echter een bevoegdheid van private belangenorganisaties om zelfstandig uit te maken, wat het door hen behartigde 'algemeen belang' in concreto vereist, en, via tussenkomst van de burgerlijke rechter, in te dringen in de rechtssfeer van individuen of groepen ${ }^{50}$.

Iets anders is dat een maatschappelijk verband als een milieuvereniging, zich kan inzetten voor 'het algemeen belang' door te participeren in het non-contentieuze proces dat voorafgaat aan de besluitvorming door de bevoegde bestuursorganen. Dat voor participatie van belangenorganisaties zoals milieuverbanden, ruimte dient te zijn in het non-contentieuze proces wordt ook in Duitsland - waar het contentieux subjectif reeds lang dominant is - onderkend door een auteur als Heinz, die we hierboven reeds citeerden. Aan 'Umweltverbänden' kan niet een 'Klagerecht' - dus een beroepsmogelijkheid bij de rechter - toekomen, maar voor de non-contentieuze procedure is de deelneming van dergelijke verbanden - aldus Heinz - mogelijk, ja zelfs wenselijk:

'(D)ie Beteiligung von Umweltverbānden in Planungsverfahren(ist) zu begrüssen, weil hierdurch nicht nur die vorhandenen Interessen des Umwelschutzes in die Entscheidung des Verfahrens eingebrachtwerden, sondern auch Anlass für positive Lösungsbeiträge in einem möglichen Konflikt zwischen staatlichem Auftrag und Umweltschutzrücksichten gegeben ist' ${ }^{31}$.

In meer algemene zin kan een maatschappelijk verband zoals een milieuorganisatie opkomen voor het 'algemeen belang' door bepaalde milieumaatregelen in zo breed mogelijke kring te propageren en aldus de publieke opinie te beïnvloeden.

Zo kan invloed worden uitgeoefend op de politieke besluitvorming. Voor een democratische rechtsstaat is het van groot belang is, dat er een 'openbare ruimte' bestaat op basis van vrije meningsuiting, informatieverschaffing, vrijheid van vereniging e.d., waarbinnen de verschillende vanuit de 'maatschappij' naar voren gebrachte belangen en opinies zich kunnen bewijzen, om vervolgens door de wetgever - en nader door de bevoegde overheidsorganen (gelede besluitvorming) - te worden afgewogen en geharmoniseerd in het algemeen belang ${ }^{52}$. Deze 'publieke' functie van maatschappelijke verbanden in het kader van de vorming van de publieke opinie in een democratische rechtsstaat is goed tot uitdrukking gebracht door het Bundesverfassungsgericht:

'Das Recht des Bürgers auf Teilhabe an der politischen Willensbildung äussert sich nicht nur in der Stimmabgabe bei Wahlen, sondern auch in der Einflussnahme auf den ständigen Prozess der politischen Meinungsbildung, der Bildung der 'öffentlichen Meinung'. Die öffentliche Meinung ... 
beeinflusst die Entschlüsse der Staatsorgane. Weiterhin versuchen Gruppen, Verbànde und gesellschaftliche Gebilde verschiedenerArt auf die Massnahmender Regierungund die Beschlüsse der gesetzgebenden Körperschafteneinzuwirken' 's?.

In de woorden van Böckenförde:

'Was (Gruppen und Organisationen von Bürgern) zusammenfuhrt und eint, sind bestimmte Eigenschaften (berufsmaIssiger Art), wirtschaftlicheund soziale Interessenoder geistig-kulturelle,gegenenfalls auch politische Bestrebungen. Sie bilden sich auf dem Boden der Gesellschaft, beziehen ihre Legitimation aus der (grundrechtlichen)Freiheit der einzelnen, sich zu betätigen, zu organisieren und gemeinsame Interessen oder Auffassungen zu vertreten und zur Geltung zu bringen. In dieser Weise wirken sie auch in den offenen Prozess politischer Meinungs- und Willensbildung hinein, an dem sie dadurch teilnehmen und - in einer Mittlerfunktion - teilhaben. Aber sie stehen dabei nicht in irgendeiner Weise schon für die Gesamtheit der Staatsbürger, selbst wenn sie zahlenmâssig uber ein 'demokratisches' Potential verfügen. Demokratisch gesehen bleiben sie pouvoir de fait, deren Ziele und Bestrebungennicht bereits demokratisch legitimiert sind, sondern allererst der demokratischen Legitimation von der Gesamtheit der Bürger her bedürfen' 'st.

In een rechtsstaat, gekenmerkt door het beginsel van de representatieve democratie, mogen overheidspersonen noch maatschappelijke verbanden zich identificeren met belangen die zij persoonlijk zien als 'algemene belang' om hun wil op te leggen aan anderen. Het algemeen belang eist immers juist een afweging, harmonisatie en integratie van alle belangen door de daartoe aangewezen - en democratisch gelegitimeerde - competente staatsorganen, primair door de (Grond)wetgever, die aan andere staatsorganen de bevoegdheden toedeelt ter behartiging van publiekrechtelijke belangen. Hierbij past niet een algemene bevoegdheid voor maatschappelijke verbanden - als erkend in art. 3:305a BW - om zelfstandig via civiele acties op te komen voor 'algemene belangen', zoals zij ze zelf zien. Waaraan ontlenen dergelijke verbanden eigenlijk de democratische legitimatie om civiele acties in te dringen in het private domein van andere verbanden of individuen, via civiele acties op de grond dat aldus zou worden opgekomen voor het 'algemene belang'?

Door art. 3:305a BW wordt dan ook, evenals door art. 3:305b BW, zowel het burgerlijk recht als het publiekrecht ontwricht.

Art. 3:305a BW verdraagt zich, evenmin als art. 3:305b BW, met de constitutieve rechtsbeginselen die ten grondslag liggen aan het publiekrecht (algemeen belang, representatieve democratie, non-identificatie, wetmatigheid) en aan het burgerlijk recht. Evenals art. 3:305b is art. $305 \mathrm{a}$ darom o.i. te beschouwen als non-recht. 


\section{Noten bij hoofdstuk 8}

1. HR 27 juni 1986, NJ 1987, 743, AB 1987, 173 (Nieuwe Meer).

2. Aldus bijv. R. van Acht, 'Milieubelangen en milieunormen in het privaatrecht', Nijmegen 1990, p. 6.

3. Noot in AB-klassiek (eerste druk), 18, p. 173.

4. Frenk, 'Kollektieve akties in het privaatrecht', a.w., p. 7.

5. C.J.J.C. van Nispen, 'De kinderjaren van de collectieve actie', in: 'Verdediging van collectieve belangen via de rechter', Zwolle 1988, p. 5.

6. Frenk, a.w., p. 7.

7. H. Dooyeweerd, 'De verhouding tussen individu en gemeenschap rechtswijsgeerig gezien', Ned Tijdschrift voor Wijsbegeerte en Psychologie', 1946, pp. 5-12 (p. 9).

8. HR 14 april 1989, AB 1989, 486, M\&R 1989, 6 (Benckiser-arrest), waarin ook de relevante overwegingen van het arrest van het Haagse Hof in de casus zijn weergeven.

9. HR 26 jan. 1990, Gst. 6914.10, AB 1990, 408 (Windmill).

10. Vgl. de noot van G.A. van der Veen onder HR 18 febr. 1994, AB 1994, 415 (Kabayelarrest), alwaat hij met verwijzing naar o.a. het Nieuwe Meerarrest en het Kuunderarrest stelt: 'Het is korton begrijpelijk dat de Hoge Raad het 6:162 BW-belangvereiste laat vallen'.

11. HR 18 dec. 1992, NJ 1994, 139, Gst. 6970.5, M\&R 1993/4, 24, TVVS 1993/3, p. 75, AA 1993/9. p. 664 (Kuundersarrest).

12. Voor de door publiekrechtelijke rechtspersonen in te stellen civiele acties is - zoals we zagen - in he: tweede lid van art. 3:305b BW bepaald: 'De leden 2 tot en met 5 van artikel 305a van dit Boek zijn var overeenkomstige toepassing:

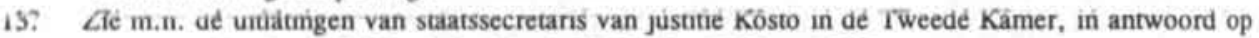
vragen van het kamerlid Korthals; Hand. TK 28 okt. 1993, p. 1295.

14. SER-publicatie $1990 \mathrm{nr}, 1,19$ jan, 1990, p. 12.

15. Frenk, a.w., p. 116.

16. TK 1991-1992, 22.486, nr. 3, p. 22.

17. TK 1991-1992, 22,486, nr. 3, p. 21.

18. Frenk, a.w., p. 132.

19. Vgl. Frenk, a.w., o.a. pp. 211, 279/280.

20. HR 18 dec. 1992, NJ 1994, 139, Gst. 6970.5, M\&R 1993/4, 24, TVVS 1993/3, p. 75, AAe 1993/9, p. 664 (Kuunders).

21. TK 1992-1993, 22.486, nr. 8, p. $3 / 4$.

22. Frenk, a.w., p, 64 .

23. Frenk, a.w., p. $65 / 66$.

24. Hand. TK 28 okt. 1993, pp. 1279-1280.

25. Zoals we zagen, was dit ook de opvatting van de SER.

26. Inconsequent is Schutte o.i. echter, waar hij betoogt dat in milieuzaken - waarin een relatie met het belang van andere personen moeilijk is te leggen - 'de collectieve actie bij uitstek geschikt (is) om een rechtsvordering in te stellen'.

27. C.A. Groenendijk, 'Bundeling van belangen bij de burgerlijke rechter', diss. Nijmegen 1991, Zwolle 1991 , p. 310.

28. Roger Mann, 'Die Anerkennungsfahigkeit von US-amerikanischen 'class-action'-Urteilen', NJW 1994. pp. 1187-1189.

29. W.C.L. van der Grinten, 'Vorderingsrecht belangenorganisaties; collectieve acties', De Naamloze Vennootschap 1990, pp. 172-174. Het advies van de Adviescommissie Burgerlijk Procesrecht is uitgebracht op 31 jan. 1990 en wordt besproken door Frenk, a.w., pp. 108/109.

30. HR 18 dec. 1992, NJ 1994, 139, M\&R 1993, p. 234, AA 1993, p. 664, Gst. 1993, nr. 6970.5 (Kuunders-arrest). 
31. HR 18 dec. 1992, NJ 1994, 139, Gst. 6970.5, M\&R 1993/4, 24, TVVS 1993/3, p. 75, AAe 1993/9. p. 664 (Kuunders). Niet ingestemd kan echter worden met het betoog van Brunner dat, "indien de overheid schade lijdt of dreigt te lijden door overtreding van de wet, zij ook uit onrechtmatige daad voor de gewone rechter kan vorderen, omdat zij dan tevens een privaatrechtelijke belang heeft'. Dit moet reeds volgen uit zijn opvatting, dat het algemeen belang niet een door art. 6:162 BW beschermd belang is. En over eigen, private subjectieve vermogensbelangen beschikt 'de overheid' niet. Juist omdat de principiele verschillen tussen publiek- en burgerlijk recht uit het oog zijn verloren en is aanvaard dat 'de overheid' publieke belangen zou kunnen behartigen via civiele acties terzake van maatschappelijke onzorgvuldigheid, is bevordend dat - omgekeerd - maatschappelijke organisaties eveneens dergelijke acties zouden moeten kunnen entameren.

32. Opmerkelijk is dat voorstanders van een actiebevoegdheid van belangenorganisaties ten behoeve van 'algemene belangen' strenge wetspositivisten zijn geworden, waar zij zich tegen kritiek verweren met een verwijzing naar de wettelijke vastlegging van die actiebevoegdheid in art. 3:305a BW. Een voorbeeld is P.C.E. van Wijmen, 'Bescherming van natuur-en milieuwaarden in rechte; de verdediging van collectieve goederen', M\&R 1994/9, pp. 234-243 (p. 243), waar over de door Scheltema en Brunner in hun noten bij het Kuundersarrest geuite opvarting (dat het algemeen belang exclusief wordt behartigd door de overheid) wordt gezegd dat deze 'niet juist kan zijn': 'Niet alleen heeft de wetgever er nu juist door middel van art. $305 \mathrm{a}$ blijk van gegeven ook ideelle en dus algemene belangen 'vatbaar' te achten voor behartiging via een op dit wetsartikel gebaseerde actie - en voorzover er nog onduidelijkheid kon blijven bestaan, heeft de regering daaraan in de ... MvT een definitief einde gemaakt -, maar ook moet worden beseft dat de behartiging juist van algemene belangen ... steevast door particulieren en idežle organisaties werd aangevat, soms al eeuwen geleden; de nachtwakerstaat ligt nog niet zo ver achter ons en de privatisering lijkt momenteel de slinger weer terug te doen slaan. Allerminst kan worden staande gebouden, dat de zorg veor twet algemeen belang uissluitend een taakopdracht aan de overtheid zou zijn. die dan privatief zou werken ten aanzien van burgers'. Enkele pagina's daarvóór merkte vW op (p. 238): 'Ook overheidslichamen kunnen zich trouwens bedienen van de collectieve actiebevoegdheid, zoals blijkt uit art. 305b. (I)k acht de overheid juist als behoedster-bij uitstek van algemene belangen terecht ook de toegang tot de burgerlijke rechter expliciet toegekend, al was het maar ter uitsluiting van twijfel die op dit punt veroorzaakt zou kunnen worden door de tweewegenleer', De logica en zuiverheid in dit soort betogen is vaak ver te zoeken. Alsof de wetgever alles wat hij maar wil, mag vastleggen in de wet. Alsof niet ook een wettelijke regeling non-recht kan inhouden! In het betoog van vW heeft de term 'algemeen belang' geen onderscheidend vermogen en zijn de grenzen tussen publiekrechtelijke belangen en maatschappelijke, collectieve belangen volledig vervloeid.

33. Rapport van de bij beschikking van de Minister van Justitie van 8 april 1960 ingestelde commissie (Commissie-Verdam), pp. 78, 82 en 115.

34. C.A. Boukema, 'Algemeen belang en ondernemingsbelang in het nieuwe ondernemingsrecht', in: Op de grenzen van komend recht, opstellen aangeboden aan J.H. Beekhuis, Deventer/Zwolle 1969, pp. 53 . 65. Zie ook: P.P. van Berkum, 'Plaats en inhoud van het begrip algemeen belang in de theorie der economische politiek', in: 'Rechtsvinding', opstellen aangeboden aan J.M. Pieters, Deventer 1970, pp. 21-34.

35. Boukema, a.w., p. 62.

36. F.A. von Hayek in de bundel Management and Corporations 1985, New York 1960, Nederlandse vertaling 1967, Marka-boeken nr. 75, pp. 97-115 en 211-218. In het private ondernemingsrecht horen dan ook geen bepalingen thuis van dezelfde strekking als Par, 70 van het in 1937 ingevoerde - overigens pas met de nieuwe wet van 1966 ingetrokken - Duitse Aktiengesetz van 1937, waarin de directie werd opgedragen de onderneming te leiden zoals $0 . \mathrm{m}$. 'die gemeinen Nutzen von Volk und Reich es fordern'. Een bepaling die duidelijk paste in de op 'Gleichschaltung' - c.q. opheffing van de grenzen tussen Staat en 'maatschappij' - gerichte politiek van het Derde Rijk.

37. F.A. von Hayek, 'Recht, Gesetzgebung und Freiheit', Bd. 3: Die Verfassung einer Gesellschaft freier Menschen, 1981, p. 191/192. 
38. Vgl. ook J.K. Galbraith, 'The new industrial State', London 1967, p. 406, die wijst op de noodzaak van scheiding van Staat en 'het industriêle systeem', omdat anders 'onvermijdelijk het industrièle systeem de Staat (zal) beheersen en ... de staatsmacht in dienst (zal) staan van dit systeem', Variěrend op de zoēven geciteerde kritiek van Hayek zou men nu kunnen wijzen op de 'in de angelsăchsischen Tradition besonders starke, aber mit der Ausbreitung von neo-liberalen Ideeen auch in der kontinentalen Welt schnell wachsender Tendenz 'Wirtschaft' und 'Staat' $z u$ identifizieren.

39. Bockenforde, 'Die Bedeutung der Unterscheidung von Staat und Gesellschaft', a.w., p. 201/202.

40. E.-W. Bockenforde, 'Demokratie als Verfassungsprinzip', in: J. Isensee/P. Kirchhof (Hrsg.), Handbuch des Staatsrechts der Bundesrepublik Deutschland, Band 1, Heidelberg 1987, pp. 887-950 (p. 904 en p. 906); ook opgenomen in: dez., 'Staat, Verfassung. Demokratie', Frankfurt aM. 1991, pp. 289-378.

41. Böckenforde, 'Die Bedeutung der Unterscheidung von Staat und Gesellschaft', a.w., p. 199.

42. Te denken is aan het verrichten van publiekrechtelijke taken door gemeenten op het terrein van de autonomie en het facultatief medebewind.

43. Bockenforde, a.w., p. 202.

44. Dan zou het een zgn. 'egoistische Verbandsklage' zijn.

45. Vgl. O. Tschira/W. Schmitt Glaeser, 'Verwaltungsprozessrecht', 8edruk, Stuttgart/München/Hannover 1988, p. 93, die invoering van de 'altruistische Verbandsklage' afwijst vanwege haar 'individuumsfeinliche Tendenz'. $\mathrm{VgI}$. ook K.E. Heinz, 'Staatsziel Umweltschutz in rechtstheoretischer und verfassungstheoretischer Sicht', Natur und Recht 1994, pp. 1-8 (p. 6/7): 'Es versteht sich ..., dass den Umweltverbalnden niemals ein Klagerecht zur Durchsetzung ... ihrer Interessen gebührt; denn diese Verbände können sich weder auf entsprechende materielle Rechtslagen ihrer Mitglieder noch auf eigene Rechte berufen, und für eine Wahmehmung des Gesamtinteresses der Bürger fehlt ihnen die notwendige

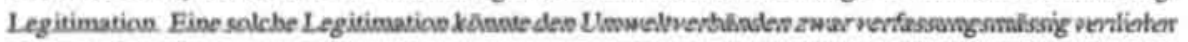
werden....; doch empfiehlt sich dies nicht weil ein Verband normalerweise dazu neigt, seine eigene Interessen als die Interessen der Allgemeinheit auszugeben'.

46. Zie over de opzet van administratieve rechtspraak als 'contentieux objectif resp. als 'contentieux subjectif: J.P. de Jong, 'Bestuursrecht van vreemde herkomst', diss. Tilburg 1988, Zwolle 1988, i.h.b. pp. 149-299.

47. TK 1991-1992, 22.495, nr. 3, pp. 33-35, MvT bij wetsvoorstel tweede tranche-Algemene wet bestuursrecht, betreffende (o.a.) het nieuwe geharmoniseerde bestuursprocesrecht.

48. A.Q.C. Tak, 'De Algemene wet bestuursrecht. Het nieuwe bestuursprocesrecht', 2e druk, Zwolle 1993. pp. 14-23 (p. 15); vgl. dez., 'De ongewenste discussie', in: J.B.J.M. ten Berge e.a. (red.), 'Nieuw bestuursprocesrecht', pp. 67-84, Deventer 1992, en de daar vermelde andere bijdragen.

49. Deze bevoegdheid zal in de praktijk dus slechts kunnen worden aangewend bij 'gebonden beschikkingen' en - daarbuiten - bij 'Ermessensreduzierung auf Null'.

50. Hierboven wezen we er reeds op dat zo'n algemene 'civiele kollectieve actie' ook verder gaat dan wat in het Nieuwe Meer-arrest werd aanvaard (HR 17 juni 1986, NJ 1987, 743, AB 1987, 173): een civiele procesmogelijkheid werd in dit arrest juist daarom geboden geacht om te voorkomen dat de bestuursrechtelijke - ingevolge de Wet Milieubeheer aan de betrokken milieuorganisaties toekomende inspraak- en beroepsmogelijkheden zouden worden gefrustreerd door de betrokken overheidsinstantic zelf.

51. Karl Eckhart Heinz. 'Staatsziel Umweltschutz in rechtstheoretischerund verfassungstheoretischer Sicht', Natur und Recht 1994, pp. 1-8 (p. 6). Aldus ook Erich Gassner, 'Umweltaspekte der Verkehrswegeplanungsbeschleunigungsgesetzes unter besonderer Berücksichtigung der Planungsgenehmigung'. Natur und Recht 1992, p. 449 e.v. (p. 452); Ulrich Hellmann, 'Die Öffentlichkeitsbeteiligung in vertikal gestuften Zulassungsverfahren für umweltrelevante Grossvorhaben nach deutschem und europāischem Recht', Mûnster 1992, pp. 24 en 29. Vgl. ook de kritiek van Tak, die er op wijst dat bij een consequente doorvoering van het contentieux subjectif-model scherp moet worden onderscheiden tussen het (non-contentieuze) bestuurlijke besluitvoermingsproces en het (contentieuze) rechterlijke rechtsbeschermingsproces, waarbij hij het scheidende moment typeert als het moment $\mathrm{X}$. Vóór dit 
moment moet de objectieve controle vorm krijgen en dienen alle relevante belangen, zoals naar voren gebracht door alle geinteresseerden, te worden afgewogen. Ná het moment $\mathbf{X}$ moet afscheid worden genomen van algemeen-abstracte en algemeen-ideele acties en dient alleen de belanghebbende burger zich terzake van (beweerde) schending van zijn eigen, individueel en rechtstreeks te beschermen belang te kunnen wenden tot de rechter.

52. Vgl. Van Erp, a.w., p. 43.

53. BVerfGE 20, p. 98.

54. Bóckenförde, 'Demokratie als Verfassungsprinzip', a.w. 



\section{Slot}

Het dualisme Staat-'maatschappij' - dat wil zeggen: de erkenning van alle eigengeaarde niet-statelijke ('maatschappelijke') rechtssferen - is constitutief voor een ware rechtsstaat (juridisch pluralisme). Dit betekent ook dat een principieel onderscheid moet worden gemaakt tussen publiek- en privaatrecht en tussen algemeen privaatrecht (burgerlijk recht) en bijzonder privaatrecht (het eigen recht van de nietstatelijke samenlevingskringen), hoezeer al die rechtskringen ook met elkaar vervlochten (niet: gemengd) zijn.

Het publiekrecht is typisch (publiekrechtelijk) gemeenschapsrecht, het recht van de publieke rechtsgemeenschap, dat gekwalificeerd wordt door het leidende beginsel van het algemeen belang (de iustitia distributiva) en gepositiveerd door de daartoe competente organen. De zgn. ambtentheorie, die een 'scherp onderscheid' meent te moeten maken tussen enerzijds overheidsorganen (ambten) en anderzijds openbare lichamen, en die een openbaar lichaam slechts ziet als een 'gemeenschappelijk dak' van ambten, moet als bloot wetspositivistische theorie worden verworpen. Hét principiële bezwaar tegen de ambtentheorie is dat zij in wezen slechts een formeel competentiebegrip kent en aldus miskent dat alle positief recht slechts kan ontstaan door de juridische vormgeving (= positivering) door daartoe competente rechtsorganen binnen materiële competentiesferen - zoals die worden bepaald en begrensd door de typische eigenaard van de desbetreffende samenlevingskringen - aan de daaraan inherente materiële rechtsbeginselen. Door haar miskenning van een materiële competentiesfeer van de Staat én daarmee ook van die van andere niet-statelijke samenlevingskringen, herleidt de ambtentheorie ten onrechte ook alle positief recht tot de overheid. Bij haar uitééndenken van ambten en openbare lichamen kan zij $66 \mathrm{k}$ niet verklaren, wat de zin is van de rechtspersoonlijkheid naar burgerlijk recht van openbare lichamen en wat de omvang is van de functies van die rechtspersoonlijkheid.

Elk optreden van de Staat dient - wil hij rechtsstaat zijn - te zijn gekwalificeerd door het typisch publiekrechtelijke beginsel van het algemeen belang; dit beginsel 
is het voor de materiële competentiesfeer van de Staat leidende beginsel. Dit beginsel houdt in positieve zin het beginsel in van de verdelende gerechtigheid (iustitia distributiva), dat eist dat alle bijzondere rechtsbelangen van individuen en groepen evenwicht worden geharmoniseerd en geïntegreerd in dat algemeen belang en impliceert dus ook een verbod van dienstbaarstelling van de Staat aan specifieke individuele en groepsbelangen (waaronder de eigen belangen van overheidspersonen; non-identificatiebeginsel). Publieke bevoegdheden mogen dan ook niet worden beschouwd als private vermogensbelangen (scheiding van 'imperium' en 'dominium'). In negatieve zin houdt het beginsel van het algemeen belang de erkenning in van de eigen, interne rechtssfeer van niet-statelijke samenlevingskringen. Een en ander vereist een representatieve democratie, omdat deze de beste waarborg is voor een integrale belangenafweging.

Publieke belangen zijn eerst publiekrechtelijke belangen, dat wil zeggen: door de overheid te behartigen belangen, wanneer deze belangen als zodanig zijn aangewezen en bevoegdheden tot behartiging ervan zijn toegedeeld door de tot deze rechtsvorming bevoegde hogere staatsorganen, primair door de (Grond)wetgever (legaliteitseis). Men dient dus het algemeen belang, zijnde het voor de materiële competentiesfeer van het staatsverband leidende rechtsbeginsel, te onderscheiden van de specifieke publieke rechtsbelangen die binnen die materiële competentiesfeer zijn aangewezen door de tot deze positivering bevoegde hogere staatsorganen. Hierbij geldt dus zowel een materieel criterium (het belang moet passen bij de publiekrechtelijke bestemming van de Staat als instituut van het algemeen belang; de eigen private sfeer van individuen en niet-statelijke gemeenschappen moet worden gerespecteerd) als een formeel criterium (de aanwijzing van dat belang door een tot positivering competent orgaan, primair door de (Grond)wetgever (legaliteits- en specialiteitsbeginsel). Met het legaliteitsbeginsel wordt mede uitdrukking gegeven aan het rechtszekerheidsbeginsel, representatiebeginsel, het gelijkheidsbeginsel en het non-identificatiebeginsel, alsmede het beginsel van de erkenning van de eigen rechtssfeer van niet-statelijke levenskringen (beperkingen daarvan moeten in ieder geval herleidbaar zijn tot de algemene wet). De wetmatigheidseis staat in verband met het dualisme Staat-'maatschappij'.

Het burgerlijk recht is een door de Staat gepositiveerd integrerend privaat ius commune voor de maatschappelijke verhoudingen, dat wil zeggen: de verhoudingen waarin mensen en/of gemeenschappen op juridisch gelijke voet met elkaar omgaan (maatschapsrecht). Het is gebaseerd op de leidende beginselen van de burgerlijke vrijheid en gelijkheid en de iustitia communitativa. Het burgerlijk recht is door de Staat gepositiveerd in de ontstaansvormen van wetgeving (en burgerlijke rechtspraak). Een wet is ontstaansvorm van positief (statelijk) recht, maar dit zegt nog niets over haar inhoud. In die ontstaansvormen is het burgerlijk recht enerzijds 
'extern' vervlochten met het staatsrecht, inzoverre dit laatste de wijze regelt waarop wetgeving tot stand komt en burgerlijke rechtspraak instelt en organiseert, en anderzijds met het interne recht van niet-statelijke levenskringen, met eerbiediging van de eigen rechtssfeer van die kringen. We kunnen dus een onderscheid maken tussen het burgerlijk recht als het algemene privaatrecht, en het bijzondere privaatrecht binnen die samenlevingskringen, dat door het burgerlijk recht wordt vóorondersteld. Zo is de competentie van contractspartijen binnen hun eigen maatschappelijke betrekking niet een door de wet (het BW) verleende, maar een oorspronkelijke rechtsmacht, die door de wet wordt erkend en gepositiveerd en daarmee extern - naar haar burgerrechtelijke kant - geïntegreerd in de algemene private rechtsorde van het burgerlijk recht. De bepalingen van het BW doen niets anders dan vaststellen aan welke burgerrechtelijke beginselen de inhoud van een contract moet voldoen, om burgerlijke rechtskracht te verkrijgen, waardoor ook aanspraken uit het contract zonodig geldend kunnen worden gemaakt voor de burgerlijke rechter en vervolgens eventueel door inschakeling van statelijke executieorganen (statelijk 'Zwangsmonopol'). Door zijn karakter als integrerend 'extern' maatschapsrecht - als 'vervlechtingsrecht', dat dus niet zelf bijv. de contractsbevoegdheid verleent - kàn het burgerlijk recht de omvang en inhoud van de rechts- en handelingsbekwaamheid van enkelingen en met rechtspersoonlijkheid beklede organisaties zelf niet concreet regelen, doch met het hun vermogen om (ook) naar burgerlijk recht drager te zijn van subjectieve rechten, rechtsbelangen en plichten resp. hun vermogen om (ook) naar burgerlijk recht actief rechtsvormend op te treden in algemene zin erkennen en formeel regelen. Reeds daarom mag de burgerrechtelijke rechtssubjectiviteit - en dus ook de burgerrechtelijke rechtspersoonlijkheid - niet absoluut worden opgevat. Zo zegt ook de toedeling aan openbare lichamen van burgerrechtelijke rechtspersoonlijkheid in art. 2:1 BW en de gelijkstelling 'wat het (burgerlijk) vermogensrecht betreft' in art. 2:5 BW van rechtspersonen - waaronder die als bedoeld in art. 2:1 - met 'natuurlijke personen' op zichzelf nog niets over de omvang van de functies van de aan deze rechtspersoonlijkheid verbonden (burgerrechtelijke) handelingsbekwaamheid.

Als de Hoge Raad als zijn opvatting geeft dat 'de overheid' publieke belangen, behalve via de publiekrechtelijke weg, 'ook mag behartigen door gebruik te maken van haar in beginsel krachtens het privaatrecht toekomende bevoegdheden, zoals aan het eigendomsrecht ontleende bevoegdheden, de bevoegdheid een overeenkomst naar burgerlijk recht te sluiten of de bevoegdheid een vordering op grond van een jegens haar gepleegde onrechtmatige daad bij de burgerlijke rechter in te stellen' ', en dat die onrechtmatigheid óók gelegen kan zijn in maatschappelijke onzorgvuldigheid jegens 'de overheid' die optreedt in het kader van de behartiging van publieke belangen ${ }^{2}$, geeft dit rechtscollege er o.i. blijk van de wezensverschillen tussen publiekrecht en privaatrecht en tussen algemeen privaatrecht (burgerlijk recht) en niet- 
algemeen privaatrecht (het interne recht van niet-statelijke samenlevingskringen) niet te erkennen en slechts oog te hebben voor de rechtsvormen die zijn neergelegd in het BW.

In wezen is de recente jurisprudentie van de Hoge Raad dan ook nogal rechtspositivistisch. Waar de Hoge Raad spreekt van de aan 'de overheid' 'in beginsel krachtens het privaatrecht toekomende bevoegdheden', lijkt hij aan te nemen dat er maar één 'privaatrecht' is - te weten het statelijk burgerlijk recht - en er bovendien van uit te gaan dat het bij de contracteerbevoegdheid en de aan het private eigendomsrecht ontleende beschikkings- en genotsbevoegdheid gaat om door de burgerlijke wetgeving verleende bevoegdheden. Daarmee zegt de Hoge Raad toch eigenlijk óók dat de in het burgerlijke rechtsverkeer opererende individuen en private organisaties hún burgerrechtelijke bevoegdheden ontlenen aan het burgerlijk recht, dus aan delegatie door de Staat. En dat is nogal een staatsabsolutistisch standpunt! Miskend wordt dat het door de Staat gepositiveerde burgerlijk recht de contractsbevoegdheid, de private eigendom en de daarmee verband houdende bevoegdheden etc., niet verleent maar deze erkent teneinde een vrij en geordend maatschappelijk verkeer te waarborgen, in het bijzonder door dit verkeer te binden aan het beginsel van de burgerlijke vrijheid en gelijkheid en door bij geschil een rechtsgang bij de burgerlijke rechter open te stelfen. A fortiori verleent het burgerlijk recht ook aan 'de overheid' geen 'privaatrechtelijke bevoegdheden' ter behartiging van publieke belangen. In de recente jurisprudentie van de Hoge Raad is de 'zorgvuldigheid in het maatschappelijk verkeer' echter gaan fungeren als een cliché-begrip, een containerbegrip, waardoor de eigen aard van de maatschappelijke zorgvuldigheidsnorm wordt miskend en geen principieel onderscheid wordt gemaakt tussen de publieke gemeenschapsverhoudingen en de burgerlijke maatschapsverhoudingen. Aldus wordt 'de maatschappij' kennelijk opgevat als een totaal-structuur.

De 'strijd met de zorgvuldigheid die in het maatschappelijk (!) verkeer betaamt ten aanzien van eens anders persoon of goed' is echter een typisch materieel burgerrechtelijk onrechtmatigheidscriterium, dat niet past op de publieke gemeenschapsverhouding tussen overheid en burgers. Slechts een leer die geen oog heeft voor de eigen aard van het burgerlijk recht resp. het publiekrecht en die het onderscheid Staat-'maatschappij' miskent, toont geen begrip voor de principiële onderscheiding tussen de onrechtmatige daad in het maatschappelijk verkeer en het door de overheid jegens haar burgers veroorzaakte publieke onrecht. Of van het laatste sprake is, zal moeten worden beoordeeld met inachtneming van eigen publiekrechtelijke beginselen, waarbij in het bijzonder het op de iustitia distributiva gebaseerde égalitébeginsel een rol speelt.

De recente jurisprudentie van de Hoge Raad, waarin hij de eis van de zorgvuldigheid in het maatschappelijk verkeer ó́k is gaan aanleggen op de verhouding tussen private (rechts)persoon en de overheid die optreedt ter behartiging van publieke belangen, 
betekent een vérgaande relativering van het beginsel van wetmatigheid van overheidsbestuur, en daarmee ook van de daarmee samenhangende beginselen (representatie, respectering eigen vrijheidssferen etc.) Had het toepasselijk achten van art. 1401 BW (oud) op de overheid 'als zodanig' aanvankelijk een rechtsbeschermingsfunctie, mét de recente jurisprudentie is art. 1401 resp. 6:162 BW geworden tot wapen van 'de overheid' tegen de burger. Wat hierbij uit het oog is verloren, is dat de toepasselijkverklaring van art. $1401 \mathrm{BW}$ op (ook) publiek onrecht, begaan door de overheid jegens de burger, een 'uitwijkmethode' was die uit rechtsbeschermingsoverwegingen (het achterwege blijven van algemene administratieve rechtspraak) nodig werd geacht. Het is echter een onaanvaardbare omdraaiing - een staatsrechtelijke ironie - wanneer art. 1401 resp. art. 6:162 BW wordt beschouwd als een algemene bevoegdheidsgrondslag voor 'de overheid' om ter behartiging van publieke belangen civiele schadevergoedings-, gebods- en verbodsacties in te stellen jegens private personen of organisaties, die zich 'maatschappelijk onzorgvuldig' jegens 'de overheid' zouden hebben gedragen.

Voorts neemt de Hoge Raad ten onrechte aan dat bij de naleving publiekrechtelijke bevoegdheidsverlenende - voorschriften, maar óók bij de behartiging door 'de overheid' van 'ongeschreven' publieke belangen, tevens eigen vermogensbelangen 'private' belangen - worden beschermd. Aldus vindt weer een vermenging van 'imperium' en 'dominium' plaats, die zo kenmerkend was voor het feodale bestel. De doorbraak van de rechtsstaatsidee impliceerde juist een definitieve loskoppeling van 'imperium' (overheidsbevoegdheden)en 'dominium' ('privaat' subjectief vermogensbelang): bij de behartiging door de overheid van publieke belangen mogen geen private vermogensbelangen in het geding zijn.

In het Kabayelarrest ${ }^{3}$ heeft de Hoge Raad weliswaar de eis van een 'vermogensbelang' laten vallen, maar deze vervangen door de eis van een 'voldoende belang' als bedoeld in art. 3:303 BW - welk 'voldoende belang óók gelegen kan zijn in het 'eigen vermogensbelang' van 'de overheid' - en daarmee in wezen alle sluizen open gezet voor wat nog steeds 'privaatrechtelijke handhaving' van publieke belangen wordt genoemd.

Ook de - in de literatuur verdedigde - opvatting dat 'de overheid' ter behartiging van publieke belangen onrechtmatige-daadsacties zou mogen entameren omdat zij via zo'ń actie zou opkomen voor de 'gebundelde belangen van burgers' (de vertegenwoordigings- c.q. zaakwaarnemingsconstructie) moet worden verworpen. Het leidende beginsel van het algemeen belang, het beginsel van de representatieve democratie en het non-identificatiebeginsel - welke beide laatste beginselen ook de uitdrukking zijn van het beginsel van de publiekrechtelijke vrijheid en gelijkheid impliceren dat de overheid niet voor de belangen van bepaalde burgers of groepen van burgers mag opkomen. 
Het doorkruisingscriterium moge dan enige waarborg bieden tegen 'onaanvaardbare doorkruising' van het publiekrecht, een voldoende waarborg is het zeker niet gebleken, getuige bijvoorbeeld het arrest-Kunst- en antiekstudio/Lelystad ${ }^{4}$ en het Magnus-arrest ${ }^{5}$.

We wezen op de 'logische contradictie' in de met de ambtentheorie vermengde gemene rechtsleer. Enerzijds wordt een 'wezenlijk onderscheid' gemaakt tussen overheidsorganen (ambten) - de dragers van door publiekrechtelijke regeling verleende specifieke publiekrechtelijke bevoegdheden ter behartiging van bepaalde publieke rechtsbelangen - en de openbare lichamen-rechtspersonen naar burgerlijk recht - de dragers van 'privaatrechtelijke bevoegdheden'. Anderzijds wordt aangenomen, dat gebruikmaking van die 'privaatrechtelijke bevoegdheden' niet mag leiden tot een doorkruising van publiekrechtelijke regeling. Als er echter sprake zou zijn van een 'wezenlijk onderscheid' tussen ambten en openbare lichamen-rechtspersonen naar burgerlijk recht, zou er óók geen sprake kunnen zijn van doorkruising! Want daartoe is vereist, dat één en dezelfde 'persoon' twee wegen kan bewandelen. En als men zoals de Hoge lijkt te doen in het Windmill-arrest, waar hij slechts spreekt van 'de overheid' - géén wezenlijk onderscheid maakt tussen beide soorten 'personen', dan is moeilijk te verklaren waarom de regelgever aan 'de overheid' welbewust slechts specifieke publiekrechtelijke bevoegdheden heeft toegekend ter behartiging van bepaalde belangen, terwijl diezelfde 'overheid' daarnáást nog zou beschikken over algemene, niet-gespecificeerde - van het etiket 'privaatrechtelijk' voorziene bevoegdheden ter behartiging van allerlei, ook 'ongeschreven' publieke belangen. Een en ander bewijst o.i. slechts, dat de aan deze jurisprudentie ten grondslag liggende 'leer' niet deugt.

Voorts wezen we op de grote gelijkenis die dit doorkruisingscriterium vertoont met het 'doorkruisingscriterium' dat de Hoge Raad hanteerde vóór het Meerenbergarrest van 1879 , toen dit rechtscollege immers aannam dat de Koning slechts dàn niet bevoegd werd geacht om op basis van zijn algemene politiebevoegdheid algemeen bindende regels uit te vaardigen voorzover de Grondwet uitdrukkelijk een wet in formele zin voorschreef, met andere woorden: voorzover er sprake zou zijn van een doorkruising van de Grondwet. Door de aanvaarding dat art. 6:162 BW voor 'de overheid' als algemene bevoegdheidsgrondslag kan dienen voor de behartiging van publieke belangen, is deze bepaling in wezen gaan fungeren als een para-wettelijke 'Generalklausel' die het nieuwe 'ius politiae' fundeert.

Het moge duidelijk zijn, dat naar ons oordeel de door de Hoge Raad ongemotiveerde stelling dat 'de overheid' in beginsel zou beschikken over 'privaatrechtelijke bevoegdheden' ter behartiging van publieke belangen, als een contradictio in terminis dient te worden aangemerkt. Ook de op de gemene rechtsleer gebaseerde opvatting, die het publiek domein in beginsel beschouwt als burgerrechtelijke eigendom, dient 
te worden afgewezen. Het is naar zijn aard geen private doch publiekrechtelijke eigendom: het is een publiekrechtelijke gebonden subjectief recht van een publieke rechtsgemeenschap, dat de subjectieve deel-rechten op 'Gemeingebrauch' (Otto Mayer) van iedere mens als zodanig ten aanzien van het object (binnen de door uit de publieke functie voortvloeide grenzen) impliceert. Het object van dit subjectieve recht kan dan ook niet worden gevat met het begrip 'zaak' als bedoeld in art. 3:2 BW en het eigendomsbegrip van art. 5:1 BW. Met dit subjectief recht correleert een publiekrechtelijke beheersbevoegdheid (tevens zijnde verplichting) van een daartoe aangewezen bestuursorgaan, dat ervoor moet te zorgen dat het domein aan zijn publieke functie blijft beantwoorden, waardoor het 'Gemeingebrauch' gewaarborgd blijft.

De verabsolutering van het positiveringselement in het recht, zoals deze tot uitdrukking komt in de twee-wegenjurisprudentie (aan 'de overheid ... in beginsel krachtens het privaatrecht' - c.q. het BW - 'toekomende bevoegdheden') verklaart óók, waarom de wetgever heeft gemeend 'privaatrechtelijke bevoegdheden' aan 'de overheid' te kunnen verlenen in art. 3:305b BW. Deze nieuwe bepaling, die aan publiekrechtelijke rechtspersonen de algemene bevoegdheid geeft om ten behoeve van 'andere personen' zgn. civiele gebods- en verbodsacties te entameren, is o.i. te beschouwen als non-recht, omdat door deze bepaling de nauw met elkaar samenhangende, constitutieve rechtsbeginselen van legaliteit, representativiteit en non-identificatie worden geschonden. Dezelfde conclusie trekken wij ten aanzien van het nieuwe art. 3:305a BW, dat uitgaat van de bevoegdheid van maatschappelijke organisaties om - $66 \mathrm{k}$ in het kader van de behartiging van zgn. 'algemene belangen' - op te komen voor de belangen van 'andere personen'. De behartiging van 'het algemeen belang', dat immers de afweging en harmonisering eist van alle bijzondere belangen van individuen en niet-statelijke gemeenschappen op het staatsterritoir - en daarom ook een representatieve democratie en non-identificatie -, is de exclusieve functie van het staatsverband. De zelfstandige behartiging van 'het algemeen belang' kan nimmer samenvallen met het eigen belang van een maatschappelijke organisatie en het maatschappelijk doel van die organisatie zijn. De democratische legitimatie om ter behartiging van 'algemene belangen' in te dringen in de interne rechtssfeer van individuen of van andere organisaties, ontberen zulke organisaties ten enenmale.

Wat is nu de omvang de van burgerrechtelijke rechtspersoonlijkheid van openbare lichamen en van de daaraan verbonden burgerrechtelijke handelingsbekwaamheid? Duidelijk is dat ook een openbaar lichaam in het (burgerlijk) maatschappelijk verkeer als zelfstandige juridische eenheid (rechtssubject) moet kunnen fungeren (al is het maar om potloden voor zijn ambtenaren te kunnen kopen) en dat het daartoe de rechtspersoonlijkheid naar burgerlijk recht niet kan ontberen. Dat het deze 
kwaliteit slechts 'min of meer toevallig' ${ }^{\prime}$ zou bezitten, kan door ons niet worden aanvaard. Bij de beantwoording van de gestelde vraag dient men in het oog te houden dat de door het BW gegeven regeling van de handelingsbekwaamheid noodzakelijkerwijs een 'externe', een formele is; het BW verleent niet zelf de contractsbevoegdheid etc. maar erkent deze. De burgerrechtelijke organisatievorm van de rechtspersoonlijkheid moet worden verstaan als een extern-juridische organisatievorm in een noodzakelijke correlatie van 'intern' (publiek) verbandsrecht en extern (burgerlijk) maatschapsrecht. Inherent aan het karakter van het staatsverband als institutaire publieke territoriale rechtsgemeenschap - en een verschil met de zgn. maatschappelijke verbanden (vrije corporaties) - is bovendien, dat de staatsdoeleinden (de publieke rechtsbelangen) zoals die zijn vastgesteld door zijn daartoe competente rechtsvormende organen binnen de grenzen van de door de aard van het staatsverband bepaalde materiële competentiesfeer, primair intern werken, dus binnen het publieke (verbands)recht. De burgerrechtelijke handelingsbekwaamheid van de in art. 2:1 BW bedoelde openbare lichamen heeft dus een annex, accessoir karakter - is een 'implied power', zo men wil -, die materieel (inhoudelijk) slechts kan worden bepaald door het publiekrecht.

Instructief is o.i. het onderscheid dat in de Duitse literatuur wordt gemaakt tussen twee wijzen van deelneming door de Staat aan het burgerrechtelijk verkeer:

- het 'Verwaltungsprivatrecht', dat wil zeggen 'die Erfüllung von Verwaltungszwecken mit privatrechtlichen Mitteln' ?, de gebruikmaking dus door 'de overheid' van het burgerlijk recht ter zelfstandige behartiging van publieke belangen;

- de 'privatrechtliche Hilfsgeschäfte' c.q. 'privatrechtliche Bedarfsverwaltung', waarbij het gaat om de aanschaffing van de voor de overheidsactiviteiten noodzakelijke hulpmiddelen. Het betreft dus de burgerrechtelijke contracten etc. die ertoe bij moeten dragen dat de overheidsorganisatie kan blijven draaien ${ }^{8}$. Daartoe moeten gebouwen gehuurd worden, bureaus en computers etc. gekocht worden etc. Schoolvoorbeeld in Nederland is de aankoop van potloden voor ambtenaren; in Duitsland is dat de 'Kohlenkauf des Finanzamts'. Faber zegt hierover:

'Zweck des Kaufvertrages ist der Erwerb des Eigentums an der gekauften Sach; offensichtlich ist das kein spezifischer Verwaltungszweck' (curs. dzz.; JT) ?.

Het gaat hier niet om het de gebruikmaking door 'de overheid' van het burgerlijk recht ter directe behartiging van publieke belangen - zoals in het 'Verwaltungsprivatrecht' -, doch meer om het optreden door 'de overheid' in het burgerrechtelijk verkeer waar dat nodig is in het kader van de uitoefening van publiekrechtelijke bevoegdheden, om burgerrechtelijke rechtsvorming dus ter ondersteuning van het overheidsbeleid. En tot deze 'Hilfsgeschäfte' is, bij voorbeeld, ook de uitgifte door de overheid van bouwgrond te rekenen. 
Problematisch is uiteraard vooral het 'Verwaltungsprivatrecht'. Als de Hoge Raad in het Windmill-arrest spreekt van de mogelijkheid van 'de overheid' om publieke belangen te behartigen 'door gebruik te maken van haar in beginsel krachtens het privaatrecht toekomende bevoegdheden, zoals aan het eigendomsrecht ontleende bevoegdheden, de bevoegdheid overeenkomsten naar burgerlijk recht te sluiten of de bevoegdheid een vordering op grond van een jegens haar gepleegde onrechtmatige daad in te stellen' ${ }^{10}$, dan gaat het om 'Verwaltungsprivatrecht'. We hebben duidelijk gemaakt, waarom de opvatting van de Hoge Raad niet kan worden aanvaard. Püttner wijst er terecht op, dat het burgerlijk recht niet een zelfstandige bevoegdheidsgrondslag ('Grundlage') kan bieden voor de 'Staatstätigkeit':

'(D)die Verwendung von Privatrecht (betrifft) nur die Form des Staatshandelns ...., walhrend die materiellen Bindungen und Pflichten davon unberuhrt bleiben. (...) Die Form des Privatrechts erweitert und beschränkt den verfassungsrechtlich vorgesehenen Umfang der Staatstătigkeit nicht: sie kann nur den faktischen Spielraum bei der Durchführungzulässiger Aufgabenvergrössern' (curs. dzz.: $/ T$ " .

En de staatsrechtgeleerde Krüger noemt het zelfs 'grotesk', als wordt aanvaard:

'dass der Staat als durch und durch verfasstes Gebilde sich, im übrigen ohne jede Ermächtigung und Form, in einen Fiskus mit voller Bewegungsfreiheitverwandelnkann. (...) Wie ist es môglich, dass der Staat als ein ausschliesslich durch das Gemeinwohl bestimmtes und auf hoheitliches Handeln verwiesenes Wesen sich selbst in ein kommerziell motivierendes und zivilrechtlich handelndes Gebilde verwandeln kann? Gerade solche strukturelle und materielle Selbstverwandlungdes Staates wirkt auf den ersten Blick geradezu grotesk: Nachdem man die Scheidung in offentliches und privates Recht vorgenommenhat, um den Staat durch die hierdurch ermöglichte Ausschliesslichkeit der Unterstellungunter das Öffentliche Recht jegliche private Motivation, insbesondereauch die von Gierke so genannte vermögensrechtliche Auffassung der öffentlichen Rechte ein für allemal unmöglich zu machen, verwandelt sich dieser Staat selbst in den Fiskus, um sich nun in einem von jedem offfentlichem Gesichtspunkt gelăuterten Privatrecht freier bewegen zu kōnnen als je zuvor. Damit verliert die Auseinanderlegungdes Rechts in offentliches und privates jeden Sinn. Es ist höchste Zeit, dass die Theorie des Fiskus einmal einer grūndlichen Nachprüfung unterzogen wird, wobei vor allem nach der Ermăchtigung zu forschen wăre, kraft deren der Staat sich selbst zum Fiskus erklärt, um sich ungehemmt kommerziellen Regungen hingeben zu können' ${ }^{12}$.

De kritiek van Krüger op het 'Verwaltungsprivatrecht' is overtuigend: de onderscheiding tussen publiekrecht en burgerlijk recht verliest inderdaad alle zin wanneer zou worden aanvaard dat 'de overheid', die binnen het publieke verbandsrecht slechts publieke rechtsbelangen mag behartigen voorzover die behartiging haar op basis van de wet is toevertrouwd, bij haar optreden in burgerrechtelijke hoedanigheid ineens zou beschikken over een 'absolute Vollhandlungsfähigkeit' die eveneens ter behartiging van publieke belangen kan worden aangewend. Het is niet mogelijk dat de binnen het publieke verbandsrecht aan overheidsorganen toebedeeld bevoegdheden ter behartiging van publieke rechtsbelangen, worden verruimd door het burgerlijk recht. Dit komt duidelijk naar voren in de juiste uitspraak van het Bundesverfassungsgericht van 8 juli 1982 : 


\begin{abstract}
'Nach den ... gesetzlichen Bestimmungen ist davon auszugehen, dass die Nutzung von Vermōgen und die erwerbswirtschaftlicheBetătigung öffentlich-rechtlicherKörperschaftenin der Regel nur im Zusammenhang mit der Wahmehmung öffentlicher Aufgaben zulässig ist. Die ... gesetzlichen Regelungen machen beispielhaft deutlich, dass jedenfalls Gemeinden, soweit sie nicht öffentliche Aufgaben wahrnehmen, sich regelmãssig ausserhalb ihres eigenen Aufgabenbereichsbewegen; ihre offentliche Zwecksetzung erfordert eine solche Betâtigung nicht zwingend' (cursivering dzz.; JT) ${ }^{1}$,
\end{abstract}

En in een uitspraak van 31 oktober 1984 luidt het:

'Die Erfullung öffentlicher Aufgaben durch juristische Personen des öffentlichen Rechts vollzieht sich in aller Regel nicht in WahmehmungunabgeleiteterursprünglicherFreiheiten, sondernaufgrund von Kompetenzen, die vom positiven Recht zugeordnet und inhaltlich bemessen sind' ${ }^{4}$.

'Nur im Zusammenhang mit': de burgerrechtelijke handelingsbekwaamheid staat in onverbrekelijke correlatie met de behartiging van publieke rechtsbelangen, welke laatste echter moet geschieden op basis van publiekrechtelijke bevoegdheden. De vermogensrechtelijke gelijkstelling met de 'natuurlijke' persoon in art. 2:5 BW kan slechts betekenen dat de in art. 2:1 bedoelde openbare lichamen als zelfstandige juridische eenheid (burgerrechtelijke rechtspersoon) kunnen fungeren in de door het vermogensrechtelijk deel van het BW gepositiveerde rechtsvormen, voor zover zulks inherent is aan de uitoefening van de binnen die organisaties bestaande publiekrechtelijke bevoegdheden. Waar in verband met 'Hilfsgeschäfte' wordt opgetreden in het burgerrechtelijke verkeer via de in het BW geregelde rechtsvormen wordt 'de overheid' geen 'privaat' c.q. 'bijzonder persoon'; zij verandert hier evenmin van karakter, als het bedrijf waarvan door 'de overheid' potloden of computers worden aangekocht. Het vorenstaande impliceert overigens ook dat de beslissing van het daartoe bevoegde orgaan van een openbaar lichaam tot, bij voorbeeld, het sluiten van een burgerrechtelijke koopovereenkomst, een 'interne' beslissing is, dus een beslissing genomen binnen het kader van de publiekrechtelijke verbandsorganisatie. Het is op zichzelf een publiekrechtelijke rechtshandeling, die is aan te merken als een besluit in de zin van art. 1:3 Awb ${ }^{15}$.

Bij dit alles dient overigens niet uit het oog te worden verloren dat het BW niet uitsluitend regels van burgerlijk recht bevat ${ }^{16}$, en dat het bovendien een aantal rechtsregels bevat die het burgerlijk recht als het ware overstijgen en zijn te beschouwen als een positivering van algemene, dus aan het publiek- en burgerlijk recht gemeenschappelijke rechtsbeginselen ${ }^{17}$. Van der Poel wijst er terecht op dat in het BW ook algemene rechtsbeginselen zijn gepositiveerd, bijvoorbeeld in de bepalingen over de overeenkomst, die óók voor de publiekrechtelijke pendant van betekenis kunnen zijn. Dan gaat het

'in werkelijkheid (om) algemeen recht, dat aldus wordt toegepast, niet omdat het burgerlijk recht, maar omdat het algemeen recht is, niet omdat het civielrecht het algemeene is, maar omdat in de code civil en het BW ook algemeen recht is overgebleven. Had men destijds het bestaan van de wenschelijkheid van het afscheiden van het administratief recht ingezien - het recht dat, in 
tegenstelling tot het huidige privaatrecht, niet gericht is op de behartiging van het belang van de burgers onderling, maar op algemeene belangen - dan zou men ook een begrip als publieke overeenkomst - gesteld, dat men daar toen al voor voelde - een eigen vorm en uitwerking hebben gegeven.

En hoe komt het nu, dat men in de negentiendeeeuw zoover en zooveel verder in de vereering van het BW is gegaan? De practijk ging ook hier, zooals m.i. veelal in het juridische, aan de theorie vooraf. Men vond in het BW beginsel (dat men kon gebruiken) en daarnaast uitwerking van de overeenkomst tusschen burgers onderling. De mensch is gemakkelijk: wat klaar ligt, behoeft geen eigen overdenking en uitwerking: men volgt het BW Eerst wanneer het niet meer past en in strijd komt met de beoogde doeleinden, houdt men halt en formeert men - ten deele - bijzondere of afwijkende bepalingen' $" \mathrm{H}$.

Men behoeft geen moeite te hebben met de opvatting dat bepaalde in het BW gecodificeerde regels kunnen gelden als regels van gemeen recht, mits men maar - anders dan in de Nederlandse gemene-rechtsleer - (a) 'gemeen recht' niet beschouwt als synoniem voor 'burgerlijk recht' doch als (aan het publiek en burgerlijk recht) gemeenschappelijk recht, en (b) onderkent dat zo'n in het BW opgenomen regel meestal verbijzondering behoeft, gelet op de typisch publiekrechtelijke verhoudingen, en (c) dat 'de overheid' voor haar optreden steeds een publiekrechtelijke bevoegdheidsgrondslag behoeft, hoe ruim die soms ook moge zijn omschreven. De bijzondere ('typische') publiekrechtelijke beginselen zullen nimmer mogen worden veronachtzaamd! Waar een bevoegdheidsgrondslag aanwezig is maar een (volledige) uitwerking ervan in het geschreven publiekrecht ontbreekt, zal dus onder omstandigheden teruggegrepen kunnen worden op in het BW neergelegde regels die te beschouwen zijn als gemeen recht in de evenbedoelde betekenis. Te denken valt aan de publiekrechtelijke overeenkomst ${ }^{19}$, de terugvordering van onverschuldigd door de overheid betaalde gelden ${ }^{20}$, en wellicht ook aan publiekrechtelijke zaakwaarneming (met name in noodsituaties) ${ }^{21}$. De in het BW neergelegde 'gemene regels' kunnen - aldus Tak - bruikbaar zijn:

'als (gemene) vormgeving bij de invulling van een overheidsbevoegdheidlie reeds aanwezig (dient) te zijn. (...) Er is dan ... geen sprake van privaatrecht, doch nog altijd van publiekrecht, bestaande uit gebruikmakingvan een aan privaat- en publiekrechtgemene rechtsregeluit het BW. Geen osmose derhalve, zoals de gemengde rechtsleer wil, maar absorptie. De regels van het BW worden als het ware geabsorbeerddoor het publiekrechtbij toepassing op overheidshandelen'z

De reden dat Tak kiest voor de aanduiding 'invullende rechtsleer', zal zijn dat de term 'gemene rechtsleer' in Nederland zo is besmet. Want om burgerlijk recht gaat het hier niet: 'de overheid' treedt hier op binnen het publieke verbandsrecht jegens een rechtssubject aan wie ten onrechte een publiekrechtelijke betaling is verricht, of met wie een publiekrechtelijke overeenkomst wordt gesloten, etc. Van gemengde rechtsverhoudingen c.q. van 'osmose' kan o.i. niet worden gesproken ${ }^{23}$. 


\section{Noten bij Slot}

1. HR 26 jan. 1990, AB 1990, 408, NJ 1991, 393, Gst. 6914.10 (Windmill).

2. HR 9 febr. 1990, NJ 1991, 462, AB 1990, 409 (Staat/Van Amersfoort).

3. HR 18 febr. 1994, AB 1994, 415 (Kabayel).

4. HR 8 juli 1991, AB 1991, 659, NJ 1991, 691 (Kunst- en antiekstudio/Lelystad).

5. HR 22 okt. 1993, AB 1994, 1 (Staat/Magnus).

6. Kortmann, 'Constitutioneel recht', a.w., p. 4.

7. Faber, a.w., p. 20.

8. Daarnaast wordt veelal nog een derde vorm onderscheiden, t.w. de 'erwerbswirtschaftliche Betãtigung', waarbij het gaat om de deelneming door de Staat of zijn sub-verbanden aan het economisch verkeer, via staatsbedrijven of door staatsdeelnemingen in bedrijven etc. Vgl. Maurer, a.w., pp. 32-34. Zie voor Nederland: H.J. de Ru, 'Staatsbedrijven en staatsdeelnemingen', Nijmegen 1981.

9. Faber, a.w., p. 20.

10. HR 26 jan. 1990, AB 1990, 408, NJ 1991, 393, Gst. 6914 (Windmill).

11. Püttner, a.w., p. 83-85.

12. H. Krüger, 'Das besondere Gewaltverhalltnis', in: Veröffentlichungen der Vereinigung der Deutschen Staatsrechtslehrer', Heft 15, Berlin 1957, p. 120. Deze 'vermőgensrechtliche Auffassung der offentlichen Rechte' is precies datgene, wat naar voren komt in de recente jurisprudentie van de Hoge Raad. Zoals we eerder zagen, neemt de Hoge Raad daarin aan dat door publiekrechtelijke - bevoegdheidsverlenende - voorschriften tevens eigen vermogensbelangen van 'de overheid' zelf worden beschermd, en dat 'de overheid' voor publieke belangen als eigen (vermogens)belangen kan opkomen via onrechtmatige-daadsacties tegen degenen die deze belangen zouden schenden.

13. BVerfG 8 juli 1982, E 61, nr. 10. I.c. ging het om een Verfassungsbeschwerde van een gemeente.

14. BVerfG 31 okt. 1984, E 68, nr. 6. 'Vom positiven Recht zugeordnet und inhaltlich bemessen', dit uiteraard binnen de grenzen van de materiële competentiesfeer van de Staat.

15. Stellinga heeft dan ook terecht kritiek geuit op de jurisprudentie van de Afdeling rechtspraak van de Raad van State, dat dergelijke beslissingen zich zouden 'oplossen' in rechtshandelingen naar burgerlijk recht en niet zouden zijn te beschouwen als beschikkingen in de zin van art. 2 lid 1 Wet-Arob. Zie bijv. de noot van Stellinga bij ARRS 11 aug. 1978, AB 1979, 111, waarbij een raadsbeslissing om een gemeentelijk badhuis te verhuren aan een jeugdvereniging werd aangemerkt als een rechtshandeling naar burgerlijk recht. St. betoogt dat een overeenkomst van huur en verhuur weliswaar een burgerrechtelijke rechtsvorm is, doch daaraan toch vooraf gaat een besluit van de raad in het kader van zijn publiekrechtelijke bevoegdheid genomen. En dit besluit werd genomen in het kader van het welzijnsbeleid van de gemeente. In zijn noot onder Vz.AR 21 oktober 1976, AB 1977, 284, betoogt Stellinga - onder verwijzing naar zijn 'Grondtrekken Ned. Staatsrecht', a.w., p. 216 - 'dat bijv. besluiten van de gemeenteraad tot het kopen ruilen of vervreemden etc. van gemeente-eigendommen ... niet louter te zien zijn als het deelnemen aan privaatrechtelijk verkeer. Aan deze besluiten kan men het publiekrechtelijk karakter niet ontzeggen. Er komen punten aan te pas als de bevoegdheid van de gemeenteraad, toezicht van hogerhand (vernietiging door de Kroon, goedkeuring door gedeputeerde staten). Dit zal men moeten onderscheiden van de privaatrechtelijke kant, die zal bestaan in de terzake te sluiten contracten: koopcontract, huurcontract etc. Deze kunnen eerst worden gesloten, als de publiekrechtelijke besluiten daartoe, t. $w$, tot de rechtshandelingen naar burgerlijk recht, de weg hebben ontsloten.' In gelijke zin: A.Q.C. Tak, 'Publiek domein, overheidscontract en rechterlijke wetshandhaving', NTB 1990, pp. 265 270. Dat die beslissing een publiekrechtelijk karakter heeft, is overigens ook erkend door J. van der Hoeven, de eerste Voorzitter van de Afdeling rechtspraak. Zie Interview met Van der Hoeven in: J. van Dunné (red.), 'Ex tunc, ex nunc', Zwolle 1990, pp. 261-298, p. 292: 'Het erfpachtscontract is een civiel contract natuurlijk, maar het besluit tot uitgifte in erfpacht is een beschikking'. Juister dan de 'oplostheorie' zoals die werd gehanteerd in de jurisprudentie van de Afdeling rechtspraak van de Raad 
van State, is dan ook de 'Zweistufentheorie' die bekend is uit de jurisprudentie van de Duitse administratieve rechter. $\mathrm{V}_{\mathrm{g} l}$. Faber, a.w., p. 146/147. Deze theorie houdt in, 'dass zwar echte privatrechtliche Vertràge ... gegeben seien, dass die aber die zweite Stufe (das 'Wie', die Abwicklung) betraffen, und dass die Entscheidung auf der ersten Stufe ('uber das 'Ob', die Begründung) durch Verwaltungsakt getroffen werde'. Overigens wordt deze theorie bij de zgn. Bedarfsverwaltung niet onverkort toegepast.

16. Zo bevat Boek 1 BW allerlei bepalingen van publiekrecht, zoals de artt. 1:16 e.v. (instructies aan de ambtenaar van de burgerlijke stand).

17. Zie in dit verband: A.Q.C. Tak, 'Overheid en burgerlijk recht, Naar een invullende rechtsleer', Recht en Kritiek 1993, pp. 174 e.v.

18. J. van der Poel, Interventie VAR-vergadering 1943, VAR-geschrift IX, Haarlem 1943, pp. $32-41$ (p. 36), inzake de preadviezen van L.J.M. Beel en G.J. Wiarda over 'Publiekrechtelijke overeenkomsten'.

19. $\mathrm{V}_{\mathrm{gl}}$. inzake de eigen aard van die overeenkomst bijv. KB 10 sept. 1955, nr. 29, AB 1955, p. 762; Hof 's-Hertogenbosch 9 jan. 1973, NJ 1974, 26: Pres.Rb. Den Haag 13 aug. 1985, KG 1985, 266. Zie ook de noot van E.M.M. Meijers bij HR 29 jan. 1926, p. 231, waar wordt gezegd dat met dit arrest niet is gezegd dat de ambtenaarsverhouding niet een publiekrechtelijk contract zou kunnen zijn, "beheerscht door vele overeenkomstige bepalingen als voor het privaatrechtelijk contract gelden'. Voor het fenomeen van de publiekrechtelijke overeenkomst zij vender verwezen naar de instructieve beschouwingen van H.J. Simon, 'De publiekrechtelijke overeenkomst', TAR 1994, p. 612 e.v., en van H.Ph.J.A.M. Hennekens, 'De bestuursovereenkomst op de juridische korrel', in: Bestuursrecht aan de horizon, Opstellen bij gelegenheid van de $80 \mathrm{e}$ verjaardag van prof. mr. S.F.L. baron van Wijnbergen, Zwolle 1994, pp. 53-78. Vgl. ook H. Lubach, 'Convenanten in de ruimtelijke ordening en volkshuisvesting', NJB 1993. p. 537, die concludeert dat bevoegdhedenovereenkomsten nimmer meer kunnen behelzen dan inspanningsverplichtingen.

20. Vgl. CRvB 30 dec. 1952, AB 1953, p. 477, waar wordt overwogen 'dat de Raad de bepaling, hetgeen zonder verschuldigd te zijn betaald is, kan worden teruggevorderd, in art. $1395 \mathrm{BW}$ vastgelegd voor het Burgerlijk recht erkent als een algemeen rechtsbeginsel, van toepassing ook in het administratieve recht, en wel als een algemeen rechtsbeginsel, in principe van gelijke waarde als dat van de rechtszekerheid .... Zie ook CRvB 7 juli 1953, AB 1953, p. 729; CRvB 26 juni 1959, AB 1960, p. 471. In HR 25 okt. 1991, NJ 1992, 299, AB 1992, 88, luidt het: 'Deze voorschriften (art. 1395 BW resp. art. 6:203 NBW: JT) geven uitdrukking aan een beginsel dat voor het gehele recht geldt. Dit brengt mee dat zij ook toegepast dienen te worden op betalingen van publiekrechtelijke aard, voor zover uit de wet niet het tegendeel voortvloeit'. Men zie reeds de door de HR gevolgde conclusie van proc.gen. Van Maanen vóór HR 24 maart 1865, Ned.Rechtspraak dl. 79, par. 49, waar de stelling dat de condictio indebiti als geregeld in art. 1395 BW alléén gegeven zou zijn aan degene die onverschuldigd een op het burgerlijk recht gebaseerde en niet t.a.v. een op het publiekrecht gebaseerde schuld, wordt verworpen omdat 'zoowel naar algemeene rechtsbeginselen als naar art. $1395 \mathrm{BW}$ kan worden teruggevorderd al wat zonder het verschuldigd te zijn is betaald, en aan dien algemeenen rechtsregel is niet gederogeerd t.a.v. de plaatselijke belastingen'.

Vgl. ook CBb 10 april 1964, SEW 1964, p. 559, waar wordt geoordeeld dat een besluit tot terugvordering van ten onrechte betaalde toeslagen als bedoeld in een algemeen bindende toeslagregeling geten rechtshandeling naar burgerlijk recht is, ook als is de bevoegdheid tot tenugvordering niet uitdrukkelijk in de toeslagregeling geregeld. Men kan o.i. zeggen dat, waar een bevoegdheid bestaat tot intrekking of herroeping van een besluit tot een betaling van publiekrechtelijke aard, de bevoegdheid tot terugvorderingsbevoegdheid daaraan inherent is. Vergelijk ook de jurisprudentie van de CRvB neergelegde opvatting, dat behoort te worden uitgegaan van het algemeen rechtsbeginsel, dat de gevolgen van een nietig verklaard besluit zoveel mogelijk ongedaan dienen te worden gemaakt.

Zie voor Duitsland: F. Ossenbühl, 'Der 'offentlichrechtliche Erstattungsanspruch', NVwZ 1991, pp. 513-522, met tal van jurisprudentie- en literatuurverwijzingen: 'Der offentlichrechtliche Erstattungsanspruch bildet die öffentlichrechtliche Parallele zum zivilrechtlichen Bereicherungsanspruch'. De hoofdregel van het Duitse civiele verrijkingsrecht is te vinden in Par. 812 Abs. 1 BGB. Deze bepaling 
behelst een combinatie van de vordering uit onverschuldige betaling (durch die Leistung ohn rechtlichen Grund') en de meer algemene verrijkingsactie ('in sonstiger Weise').

21. Vgl. Maurer, a.w., p. 710; Verburg, a.w.

22. Tak, t.a.p., pp. 185 en 189. Ook in de Duitse literatuur wordt hierop gewezen. Vgl. O. Bachof, 'Ũbe offentliches Recht in: Verwaltungsrecht zwischen Freiheit, Teilhabe und Bindung. Festgabe aus Anlas des 25jährigen Bestehens des Bundesverwaltungsgerichts, München 1978, p. 1 e.v.. 12, 15 en 17: M Bullinger, 'Öffentliches Recht und Privatrecht', Stuttgart/Berlin/Köln/Mainz 1968, pp. 13 en 75, di spreekt van 'Gemeinrecht'.

23. Wèl merken we nog op dat zich ook in de hierbedoelde publiekrechtelijke ontstaansvormen van rect allerlei externe vervlechtingen - wat iets anders is dan 'osmose' of 'vermenging' - kunnen voordoe: metprivaatrechtelijke verhoudingen. Indien bijv. t.b.v. bepaalde activiteiten(ontgrondingen, busvervoe etc.) aan een onderneming een monopolistische concessie wordt verleend, raakt de uit deze publiekrech telijke overeenkomst voortvloeiende rechtsverhouding óók de burgerrechtelijke verhoudingen waari de onderneming verkeert of gaat verkeren. De publiekrechtelijke rechtsverhouding waarin di onderneming als publiekrechtelijk (deel-)subject optreedt, is hier extern vervlochten met de burgerrech telijke rechtsverhoudingen waarin de onderneming optreedt als rechtssubject. Organisatorisch vervlechtingen zien we bij de in de burgerrechtelijke organisatievorm van de vennootschap opererend: monopolistische nutsbedrijven, waarvan het aandelenkapitaal geheel of overwegend in handen van d: overheid is, en bij de zgn. overheidsstichtingen. 


\section{Zusammenfassung}

Hat die öffentliche Verwaltung die Freiheit, sich neben oder statt der öffentlichrechtlichen auch bürgerlichrechtlicher Formen zu bedienen? Der niederländische Hohe Rat (Oberster Gerichtshof) hat diese Frage bejaht. In seiner Entscheidung vom 26.1.1990 (Windmill-Entscheidung) ging er davon aus, dass die öffentliche Verwaltung grundsätzlich auch dann von privatrechtlichen Befugnissen zur Wahrnehmung öffentlicher Interessen Gebrauch machen kann, wenn im Einzelfall der Verwaltung zur Wahrnehmung dieser Interessen bestimmte öffentlichrechtliche Kompetenzen gegeben worden sind. Nur wenn und sofern in diesem Falle die Anwendung privatrechtlicher Befugnisse das Verwaltungsrecht in nicht annehmbarer Weise durchkreuzen würde, muss von der 'Regel' der Formenwahlfreiheit eine Ausnahme gemacht werden. Dabei sollen, wenn die öffentlichrechtliche Regelung darüber nichts ausdrückliches sagt, u.a. der 'Inhalt und Anwendungsbereich dieser Regelung' und außerdem Art und Umfang des Schutzes von Bürgerinteressen im Rahmen dieser Regelung berücksichtigt werden.

Wenn auf öffentlichrechtlichem Weg ein 'vergleichbares Resultat' erzielt werden kann, ist dies ein Hinweis, dass im Einzelfall kein Spielraum für den Gebrauch einer privatrechtlichen Befugnis besteht. Danach handelt es sich also eher um einen Ausnahmefall, der die Grundregel der grundsätzlichen Verfügbarkeit sog. privatrechtlicher Befugnisse zur Wahrnehmung öffentlicher Interessen und der Wahlfreiheit ('Zwei-Wege-Lehre') eher bestätigt als in Frage stellt. Die grundsätzliche $\mathrm{Zu}$ lässigkeit der sogenannten privatrechtlichen Betätigung als solche wird dabei nicht in Frage gestellt.

Angesichts der nahezu vollkommenen Einmütigkeit, mit der in der Rechtswissenschaft und der Rechtsprechung das Dogma der grundsätzlichen Zulässigkeit dieser privatrechtlichen Betätigung der öffentlichen Verwaltung behauptet wird, muss es 
erstaunen dass eine tragfähige juristische Begründung zu seiner Rechtfertigung immer noch aussteht.

Das erstaunt auch deshalb, weil die Frage dieser privatrechtlichen Betätigung der öffentlichen Verwaltung und die Freiheit der Formenwahl grundsätzlicher Art sind Die seit längerer Zeit zu beobachtenden Bestrebungen in der Literatur, den Unterschied von Öffentlichem und Privatem, von Staat und Gesellschaft und in der Konsequenz von öffentlichem und privatem Recht für überholt zu erklären, verdeutlichen das. Die Unterscheidung zwischen öffentlichem Recht und Privatrecht entspricht de: Trennung von Staat und Gesellschaft. Die Frage der Wahlfreiheit stellte sich ga: nicht oder doch nur in einem ganz anderen Sinne, wenn diese Trennung - ode: besser: dieser Dualismus - und damit auch das Nebeneinander von öffentlichem und privatem Recht 'überholt' wäre.

Der Auffassung, dass die prinzipielle Unterscheidung zwischen Staat und Gesellschaft und zwischen öffentlichem und privatem Recht überholt ist, wird in diesen Buch eine deutliche Absage erteilt. Dies muss auch bedeuten, dass das Dogma det Wahlfreiheit auf schwachen Füssen steht. Bei genauer Analyse ist festzustellen, das! die genannte Auffassung und deshalb auch das Dogma der Wahlfreit, entwede: einem absolutistischen Staatsverständnis oder einem rein positivistischen Rechtsverständnis entstammen, nach dem alles Recht - also auch das Privatrecht - vom Staate kommt oder auf Delegation durch den staatlichen Gesetzgeber beruht. Dieses Rechtsverständnis beruht auf der Annahme, dass der Staat die Personifikation der Rechtsordnung sei und das Recht 'nur die Form ist für irgendwelche Zwecke' Wenn Staat und Recht identisch sind, gibt es nur eine Rechtsordnung und öffentliches und privates Recht können dann nicht artverschieden sein. Diese Unterscheidung hätte dann eigentlich überhaupt keinen Sinn mehr; sie hätte nur eine verwerfliche ideologische Funktion ${ }^{2}$.

Er ist aber verfehlt, als 'Recht' nur das staatliche Recht anzusehen. Der Staat ist keineswegs das einzige soziale Gebilde, innerhalb dessen es positives Recht gibt. Auf einem differenzierten Kulturniveau zeigt das positive Recht eine grosse Verschiedenheit typischer und ursprünglicher Rechtssphären, deren typische Art durch den inneren Charakter und die Struktur der pluralistischen 'soziale Kreise' bestimmt ist, denen sie zugehören. Es gibt staatliches, zwischen- bzw. überstaatliches, und nicht-staatliches Recht von verschiedener Ausprägung.

Der kulturhistorische Entwicklungsprozess kennzeichnet sich durch eine fortgehende Differenzierung, Individualisierung und Integrierung der menschlichen Verhältnisse. Auf einem differenzierten Kulturniveau gibt es verschiedenartige gemeinschaftliche und gesellschaftliche Sphären des menschlichen Zusammenlebens. Als 'gemein- 
schaftlich' können die sozialen Beziehungen bezeichnet werden, in denen die Menschen als Mitglieder eines mehr oder weniger dauerhaften sozialen Ganzen auftreten, abgesehen von der Frage ob die Bande zwischen den Mitgliedern einen 'naturwüchsigen' oder vielmehr 'organisierten' Charakter haben. Die Gemeinschaften können erstens eingeteilt werden in die natürlichen, keiner Organisation bedürfenden, weil in organischen Lebensbeziehungen fundierten Gemeinschaften (wie die kognatische Familie in ihrem engsten Sinne), und die sog. organisierten Gemeinschaften, die nach ihrer Art typisch kulturhistorisch in einer organisierten Machtstruktur fundiert sind. Letztere Gemeinschaften können nach der geläufigen deutschen Terminologie 'soziale Verbände' genannt werden. Die Gemeinschaften können zweitens eingeteilt werden in nicht-instititionelle Gemeinschaften, die auf dem Prinzip des freien Bei- und Austritts ihrer Mitglieder beruhen und institutionelle Gemeinschaften, die nach ihrer Art dazu bestimmt sind ihre Mitglieder oder Angehörigen ohne Wahlmöglichkeit entweder während ihres ganzen Lebens (so der Staat) oder wenigstens während eines Teiles desselben (so die kognatische Familie) zu umfassen.

'Gesellschaftlich' können die sozialen Verhältnisse genannt werden, in denen die Menschen nicht als Mitglieder eines sozialen Ganzen, sondern in Koordination auftreten, sei es in gelegentlichem, sei es in regelmässigem Zusammentreffen, und entweder kooperativ oder in einer Kamf- oder Konkurrenzlage. Hiermit sind nur die Haupteinteilungen bezeichnet. Es gibt z.B. eine Vielzahl differenzierter, nichtinstitutioneller Verbände, wie Religionsgemeinschaften, Unternehmungen, Vereine verschiedener Art usw.; die typische innere Struktur jeder Gemeinschaft ist begründet in ihrer inneren Wesensart. Ebenso gibt es eine Vielzahl von gesellschaftlichen Verhältnissen eigener Wesenart. Zwischen den gemeinschaftlichen und den gesellschaftlichen Beziehungen besteht nicht nur ein Gegensatz, sondern auch eine Korrelation. So ist das Entstehen nicht-institutioneller Verbände (freie Vereine, Unternehmungen usw.) erst möglich geworden auf der Grundlage der gesellschaftlichen Beziehungen eines differenzierten Kulturniveaus. (Darum können diese Verbände auch gesellschaftliche Verbände genannt werden). Und zwischen den inneren Gemeinschaftsverhältsnissen einer Gemeinschaft und ihren äusseren Gesellschaftsverhältnissen besteht ebenfalls eine Korrelation: die typische innere Art und Struktur einer Gemeinschaft bestimmt auch ihr Auftreten in ihren äusseren Verhältnissen. Zwischen den verschiedenartigen gemeinschaftlichen und gesellschaftlichen Kreisen des menschlichen Zusammenlebens gibt es keine Hierarchie, aber zahlreiche äussere, korrelative Strukturverflechtungen. 'Korrelation' bedeutet, dass gemeinschaftliche und gesellschaftliche Beziehungen einander gegenseitig voraussetzen, aber nicht ineinander aufgehen. Die Entstehens- und Bestehensformen der betreffenden sozialen Beziehungen sind vielfach Knotenpunkte zahlreicher äusserer Verflech- 
tungen zwischen sozialen Kreisen von prinzipiell verschiedener Art und Struktur. Infolge ihrer prinzipiellen inneren Art- und Strukturverschiedenheit stehen die Kreise niemals in der Beziehung eines Teils zum Ganzen; sie sind deshalb auch nicht ei Teil des Staatsverbandes. Das würde bedeuten, dass auch der Mensch in einen grösseren Ganzen aufgeht. Der Mensch kann aber in keinem dieser sozialen Kreise völlig aufgehen, auch nicht im Staatsverband. Die menschliche Persönlichkeit hat sehr viele Seiten. Der Mensch ist nach einer Seite seiner Persönlichkeit (nach der öfentlich-rechtlichen Seite) Mitglied des Staatsverbandes, aber daneben ist er auci Mitglied von vielen anderen Gemeinschaften eigener Art und tritt in verschiedenartige Gesellschaftsverhältnisse (letzteres gegebenfalls auch gegenüber Gemeinschaften, deren Mitglied er nach einer anderen Seite seiner Persönlichkeit ist).

Innerhalb der internen Sphäre der sozialen Kreise der verschiedenartigen Gemeinschaften und Gesellschaftsbeziehungen besteht eine 'Souveränität im eigenen Kreise'. Das heisst auch, dass ein solcher sozialer Kreis eine nach seiner eigenen Art und Wesensstruktur bestimmte interne typische Rechtssphäre hat, innerhalb dere auf Grund einer ursprünglichen materiellen Rechtsmacht (Kompetenz) eigenständiges positives Recht gebildet wird, indem durch juristische Formgebung (=Positivierung Gestaltung, Konkretisierung, Rechtsbildung) überwillkürliche, materielle Rechtsprinzipien gestaltet werden. Diese Rechtsprinzipien können unterschieden werden in allgemeine Rechtsprinzipien, die also für alle soziale Kreise von Bedeutung sind, und typische Rechtsprinzipien, die fundiert sind in den typischen Strukturen (Natur der Sache) der menschlichen Gemeinschafts- und Gesellschaftsbeziehungen unter ihrem Rechtsaspekt ${ }^{3}$.

Die Differenzierung des sozialen Lebens muss sich also auch innerhalb seines rechtlichen Aspekts äussern; die typische Verschiedenartigkeit der Rechtssphären ist bedingt durch die innere Strukturverschiedenheit der differenzierten sozialen Kreise gemeinschaftlicher und gesellschaftlicher Art (Rechtspluralismus). In der Literatur werden die nicht-staatlichen sozialen Kreise vielfach kurzweg als 'Gesellschaft' angedeutet, als das Pendant des Staates. (Der Terminus 'Gesellschaft' sieht dann also auch auf die nicht-staatlichen Gemeinschaften). Das innerhalb dieser Kreise erzeugte positive Recht darf nicht mit dem formalen staatlichen Recht identifiziert werden. Auf einem differenzierten Kulturniveau zeigt das positive Recht eine grosse Verschiedenheit typischer, ursprünglicher Rechtssphären, die bestimmt sind durch die eigene typische Art der sozialen Kreise, denen sie zugehören.

Die zunehmende Differenzierung dieser internen Rechtskreise hat aber ihre notwendige Kehrseite in einer zunehmenden Integration. Dabei kommt dem Staat eine ganz eigene, besondere Stellung zu. Eine Betrachtung des geschichtlichen Entwicklungsprozess, in dem sich der Rechtsstaat herausgebildet hat und seine nähere 
Ausgestaltung erfahren hat, lässt erkennen, dass dieser Prozess gekennzeichnet war durch die Erwerbung des Monopols der Schwertmacht (Zwangsmonopol) innerhalb eines Staatsgebiets und dass auf der Grundlage des Zwangsmonopols eine einheitliche, öffentlichrechtliche Rechtsmacht erworben wurde. Die im Mittelalter und noch in der frühen Neuzeit vielfach zerstreuten politischen Herrschaftsbefugnisse (imperium) wurden zunehmend bei einer Person (dem Fürsten) bzw, bei einer Instanz konzentriert und dort $\mathrm{zu}$ einer einheitlichen und umfassenden politischen Herrschaftsgewalt organisiert und ausgebaut. Dies führte gleichzeitig zur Auflösung der alten undifferenzierten sozialen Verbänden (wie die Sippen, die Gilden und die primitiven herrschaftlichen Grund-, Stadt-, Kirchenverbände u.s.w.), die die Menschen 'totalitär', d.h. nach allen ihren Lebensseiten, umfassten, und die dazu auch über politische Herrschaftsrechte (imperium) verfügten, die als private Vermögensbestandteile (dominium) betrachtet wurden. Dies bedeutete auch die Befreiung der Menschen aus diesen Verbänden (Individualisierung) und gleichzeitig die Aufnahme aller Menschen als gleiche Bürger in die Staatsgemeinschaft, die umschrieben werden kann als 'öffentlichrechtlicher, institutioneller Verband von Obrigkeit und Bürger innerhalb des Staatsgebiets, auf der Grundlage des Zwangsmonopols'.

Auf der Grundlage des mit der Freisetzung der Menschen aus der Einbindung in die alten Herrschafts- und Lebensordnungen ermöglichten freien gesellschaftlichen Verkehrs wurde, wie gesagt, die Errichtung freier, differenzierter Verbände möglich. Die 'Gesellschaft' (als Andeutung für alle nicht-staatlichen sozialen Kreise) ist eine Gesellschaft 'sine imperio'. Der Staat hat innerhalb seines Hoheitsgebietes das Monopol der typisch öffentlichrechtlichen Rechtsgewalt, und die Träger dieser Rechtsgewalt können sie nur als ein öffentlichrechtliches Amt, nicht als einen privatrechtlichen Vermögensbestandteil ('dominium') haben. Der Staat ist seiner Wesensart nach res publica. Dieser ganze Differenzierungs-, Individualisierungsund Integrierungsprozess kann auch charakterisiert werden als eine Trennung von imperium (öffentlichrechtliche Befugnisse) und dominium (private Interessen). Innerhalb seiner materiellen Rechtssphäre wird von den dazu kompetenten Rechtsorganen das eigene öffentliche Verbandsrecht positiviert, das als solches Organisations- und Handlungsnormen umfasst. Als überwillkürlichen Grundlagen dieser Rechtbildung begegnen wir, neben den allgemeinen Rechtsprinzipien, der iustitia distributiva, dem Prinzip der repräsentativen Demokratie, dem Neutralitäts- oder Nicht-Identifikationsprinzip, dem Prinzip der trias politica und den in den Grundrechten anerkannten Freiheitsprinzipien, die alle typisch öffentlichrechtlich sind. Aus diesen Prinzipien und dem Prinzip der Rechtssicherheit folgen die Prinzipien des Vorbehalts und des Vorrangs des Gesetzes (Legalitätspinzip). Innerhalb des materiellen Rechtsgebiets des Staates sehen wir eine stufenweise Rechtsbildung, 
wobei die Kompetenzen der niedrigeren Stufen formell durch die von höheren Stufer gebildeten Kompetenznormen begrenzt werden ${ }^{4}$. Eine Aufgabe ist erst dann eine von der öffentlichen Verwaltung zu erfüllene Aufgabe, wenn sie durch eine in Rahmen des materiellen Rechtsgebiets des Staates getroffene Entscheidung des demokratischen Gesetzgebers zu einer staatlichen, d.h. öffentlichrechtlichen Aufgab: erklärt ist und der Verwaltung Kompetenzen zur Erfüllung dieser Aufgaben verliehen sind. Innerhalb der 'Gesellschaft' (in dem oben bezeichneten Sinn) gibt es viele Interessen, die öffentlich-relevant sein können. Um welche Interessen di: Verwaltung sich kümmern darf oder muss, ist aber Sache des Gesetzgebers, der seine Entscheidungen in einem Prozess demokratischer Rechtswillensbildung unter Abwägung aller relevanten besonderen Interessen trifft. Böckenförde hat darun dafür plädiert, die staatlichen Aufgaben nicht als öffentliche Aufgaben zu charakterisieren, sondern als öffentlichrechtliche Aufgaben's . Der Entscheidungsspielraun des Gesetzgebers ist allerdings begrenzt durch die materielle Rechtssphäre des Staates. Und dies bedeutet auch, dass die eigenen, inneren Rechtssphären de: respektiven nicht-staatlichen sozialen Kreise respektiert werden müssen.

Neben dem eigenen öffentlichen (Verbands)recht gibt es noch ein anderes, von staat. lichen Organen positiviertes Recht, das bürgerliche Recht. Einerseits ist das moderne bürgerliche Recht aufs engste verflochten mit dem öffentlichen Recht des Staates. Es ist im letzteren fundiert, da seine juristischen Entstehensformen - Gesetzgebung und Rechtsprechung der Zivilgerichte - öffentlichrechtlicher Art sind. Es konnte erst zustandekommen auf der Grundlage einer gefestigten, einheitlichen, öffentlichrechtlichen Rechtsordnung im Zusammenhang mit dem Erwer des Zwangsmonopols innerhalb des staatlichen Territoriums. Aber obwohl das bürgerliche Recht nach seinen juristischen Entstehensformen zweifelsohne von staatlichen Verbandsorganen gebildet und angewandt wird, ist es seinem inneren Charakter gemäss kein Recht für gemeinschaftliche Beziehungen (also auch kein öffentliches Recht), sondern ein Recht für gesellschaftliche Beziehungen. Die juristischen Entstehens- und Bestehensformen des positiven Rechts sind als solche nämlich noch nicht entscheidend für die innere Art des in diesen Formen positivierten Rechts. So wie die Entstehens- und Bestehensformen der betreffenden sozialen Kreise Knotenpunkte zahlreicher äusserer Verflechtungen zwischen sozialen Kreisen von prinzipiell verschiedener Art und Natur sind, gilt dies auch für die Entstehens- und Bestehensformen des innerhalb dieser Kreise positivierten Rechts. Das durch Staatsorgane in den Entstehensformen der (bürgerlichrechtlichen) Gesetzgebung und bürgerlichrechtlichen Rechtsprechung positivierte bürgerliche Recht ist ein typisches 'Verflechtungsrecht'. In diesen juristischen Formen ist das bürgerliche Recht einerseits mit dem öffentlichen Recht (insoweit dieses Recht das Zustandekommen von Gesetzen regelt und es bürgerliche Rechtsprechung organisiert) und andererseits mit dem nicht-staatlichen Privatrecht verflochten. Es hat die Bestimmung, allen Menschen als solchen innerhalb des 
Staatsgebietes eine Rechtssphäre für ihre privaten gesellschaftlichen Rechtsbeziehungen zu sichern auf der Grundlage der zivilrechtlichen Prinzipien der bürgerlichen Freiheit und Gleichheit (als Menschenrechte), und ihnen im Falle des Rechtsstreites die ordentliche Gerichtsbarkeit und ggf. staatliche Exekutionsorgane (staatliches Zwangsmonopol) zur Verfügung zu stellen. Durch diese beiden Rechtsprinzipien, welche sich nur auf der Grundlage eines stark fortgeschrittenen Differenzierungs-, Invidualisierungs- und Integrierungsprozesses durchführen liessen, unterscheidet das moderne bürgerliche Recht des Rechtsstaates sich grundsätzlich von früheren Rechtsordnungen.

Das bürgerliche Recht setzt jedes besondere, nicht-staatliche Privatrecht voraus und ist als privates ius commune ein staatliches Integrationsrecht im Verhältnis zu jedem besonderen, nicht-staatlichen Privatrecht. So ist die Kompetenz kontrahierender Parteien zur Bildung von Vertragsrecht innerhalb ihrer eigenen gesellschaftlichen Beziehungen keine vom staatlichen Gesetzgeber delegierte, sondern eine ursprüngliche, materielle Rechtsmacht. Diese Vertragsfreiheit wird vom staatlichen Gesetzgeber im Bürgerlichen Gesetzbuch anerkannt und nach ihrer bürgerlichrechtlichen Seite positiviert. Die Bestimmungen des Bürgerlichen Gesetzbuchs legen 'nur' fest, welchen bürgerlichrechtlichen Anforderungen private Verträge entsprechen müssen, so dass ihnen auch bürgerlichrechtliche Verbindlichkeit beigelegt werden kann, wodurch Ansprüche aus dem Vertrag wenn nötig beim Zivilgericht und ggf. durch Zwangsvollstreckung durch dazu angewiesene staatliche Organe geltend gemacht werden können. Die integrierende Funktion des bürgerlichen Rechts kann also nicht gesehen werden in der Weise einer Absorbierung oder Nivellierung der verschiedenartigen nicht-staatlichen Rechtssphären. Men sollte deshalb nicht nur unterscheiden zwischen 'offentlichem Recht' (staatlichem Verbandsrecht) und 'Privatrecht', sondern auch eine Unterscheidung machen zwischen 'bürgerlichem Recht' und nichtstaatlichem Privatrecht. Kurz: das bürgerliche Recht ist ein integrierendes privates ius commune für gesellschaftliche Verhältnisse, das in den Entstehensformen von Gesetzgebung und bürgerlicher Rechtsprechung einerseits verflochten ist mit dem öfentlichen Recht und andererseits mit dem besonderen Privatrecht der verschiedenartigen, nicht-staatlichen sozialen Kreise, welches es zur bürgerlichrechtlichen Einheit bringen will. Hinsichtlich seiner unselbständigen, abhängigen Sinnstruktur kann das bürgerliche Recht selber die Rechts- und Handlungsfähigkeit der Rechtssubjekte nicht konkret bestimmen. Nach bürgerlichem Recht soll die Fähigkeit, Träger von privaten subjektiven Rechten und Pflichten zu sein, sowie die Fähigkeit zur Rechtsbildung (durch Vertragschluss, usw.) jedem Menschen als solchem, bzw. jedem mit bürgerlichrechtlicher Rechtspersönlichkeit bekleideten Verband, unterschiedslos zukommen. Das ist, wie Pawlowski zu Recht sagt, 'aber nur möglich, wenn man diese Fähigkeit rein formal - abstrakt - versteht und von jeder Beziehung auf konkrete Fähigkeiten absieht' ${ }^{6}$. Die Anerkennung der Vollrechtsfähigkeit und 
der vollen Handlungsfähigkeit von Individuen und Verbänden nach bürgerlichen Recht ist notwendigerweise eine generelle, 'åussere', 'formelle' Regelung, die sich jeder Bezugnahme auf einzelne Fähigkeiten enthalten muss. Inhaltlich-konkret werden diese Fähigkeiten bestimmt durch das besondere Privatrecht der nicht-staatlichen, sozialen Kreise.

Der formalistische Rechtspositivismus klammert sich aber fest an die Entstehens: (und Bestehens)formen des Rechtes, wobei es das staatliche Gesetz zur höchstea Rechtsquelle erklärt. Er beruht auf dem naiven Dogma, dass der Staatswille die einzige Geltungsquelle des Rechtes ist, m.a.W. dass der Staat die volle juristische Kompetenz-Kompetenz besitzt. Er identifiziert ein 'Wie' (d.h. den juristischen Aspekt der sozialen Beziehungen der Menschen) mit einem 'Was' (d.h. einem sozialen Kreis, nämlich dem Staat) und er sieht ganz und gar nicht, dass eben die Entstehensformen des positiven Rechts vielfach Knotenpunkte zahlreicher Verflechtungen zwischen Rechtskreisen von prinzipiell verschiedener innerer Art und Struktur sind.

Wenn der Hohe Rat in seiner Windmill-Entscheidung erklärt, dass die öffentliche Verwaltung öffentljche Interessen auch wahrnehmen darf 'durch Anwendung ihr in Prinzip auf der Grundlage (!) des Privatrechts zukommender Befugnisse', dann kann dies nur auf die Annahme gegründet sein, dass das Privatrecht diese Befugnisse verleiht. Dabei können mit 'Privatrecht' nur das Zivilgesetzbuch und die übrigen bürgerlichrechtlichen Gesetze gemeint sein. Das würde aber bedeuten, dass auch die Bürger und die privaten Verbände ihre privatrechtlichen Befugnisse dem 'Privatrecht', d.h. dem Zivilgesetzbuch verdanken. Diese Auffassung entspricht, wie gesagt, entweder einem absolutistischen Staatsverständnis oder einem rein positivistischen Rechtsverständnis.

Wenn der Hohe Rat sagt, dass 'das Privatrecht' der öffentlichen Verwaltung diese 'privatrechtlichen Befugnisse' auch verliehen hat zur Wahrnehmung öffentlicher Interessen, dann muss man die Frage stellen, was eigentlich das 'Privatrechtliche' ist an diesen Befugnissen. Diese Frage stellt sich u.E. aber nicht bei einem absolutistischen Staatsverständnis oder bei dem rein positivistischen Rechtsverständnis einer Rechtslehre, die Staat (im juristischen Sinne) und Recht identifiziert und die deshalb auch keine materiellen Unterschiede zwischen öffentlichem und privatem Recht anerkennen kann. Aber warum werden diese Befugnisse dann noch als 'privatrechtlich' bezeichnet? U.E. ist eine solche Bezeichnung ein Etikettenschwindel.

Zur Aussage des Hohen Rates, dass von der 'Regel' der Wahlfreiheit eine Ausnahme gemacht werden muss, wenn durch die Anwendung privatrechtlicher Befugnisse das Verwaltungsrecht 'in nicht annehmbarer Weise' durchkreuzt würde (sog. 'Durchkreuzungslehre'), lässt sich Folgendes sagen: 
Erstens: in der niederländischen Literatur wird vielfach ein prinzipieller Unterschied gemacht zwischen den öffentlichen Ämtern und den juristischen Personen des öffentlichen Rechts in der Gestalt des 'Fiskus', d.h. als Privatrechtssubjekt. Eine Analyse dieser 'Ämtertheorie' zeigt übrigens, dass auch diese Theorie auf einer merkwürdigen Kombination der rein positivistischen Rechtslehre und der Lehre des frühen 19. Jahrhundert beruht, die den obrigkeitlichen Staat und den Fiskus ('Zweipersönlichkeitslehre') unterschieden '. Während die öffentlichen Ämter Teile (Organe) des Staates sind, sind nach dieser Ämterheorie die öffentlichrechtlichen Körperschaften-Privatrechtssubjekte zu betrachten als durch die staatliche Rechtsordnung konstruierte und deshalb von den Ämtern zu unterscheidende Gebilde. Und während die Ämter über begrenzte öffentlichrechtliche Kompetenzen verfügen, würden die öffentlichrechtlichen Körperschaften 'wie jedermann' als Privatrechtssubjekte über (nicht begrenzte) privatrechtliche Befugnisse verfügen. Weil diese Theorie auf Grund ihres formalistischen Rechtsverständnisses aber keinen Unterschied zwischen öffentlichem und privatem Recht der Wesensart nach sehen kann, nimmt diese Theorie an, dass diese sogenannten privatrechtlichen Befugnisse auch zur Wahrnehmung von sog. öffentlichen Interessen angewandt werden können.

Auch diese Theorie ist abzulehnen. Wenn es wirklich so wäre, dass es einen prinzipiellen Unterschied zwischen den öffentlichen Ämtern und den juristischen Personen des öffentlichen Rechts in der Gestalt des Fiskus gäbe, dann könnte natürlich auch niemals die Rede von einer 'Durchkreuzung' sein. Zweitens: wenn man diesen 'prinzipiellen Unterschied' - u.E. zu Recht! - als untauglich verwirft, dann stellt sich die Frage, wie es sich erklären lässt, dass die öffentliche Verwaltung, die auf Grund der öffentlichrechtlichen Kompetenzordnung mit ihr ausdrücklich zugeordneten und inhaltlich bemessenen - also spezifischen - Kompetenzen zur Wahrnehmung bestimmter öffentlichrechtlicher Interessen (Vorbehalt des Gesetzes) ausgestattet ist, zugleich in der Gestalt des Fiskus allgemeine, nicht inhaltlich bemessene - sog. 'privatrechtliche' Befugnisse zur Erfüllung auch 'ungeschriebener', öffentlicher Interessen hat. Herbert Krüger hat dies zu Recht als 'grotesk' bezeichnet ${ }^{8}$.

Eine Begründung zu der vom Hohen Rat übernommenen 'Lehre', dass die öffentliche Verwaltung auf der Grundlage des Privatrechts über Befugnisse zur Erfüllung öffentlicher Interessen (Verwaltungsprivatrecht) verfügt und dass die Verwaltung im Prinzip eine Wahlfreiheit hat, lässt sich also u.E. nicht geben. Ganz im Gegenteil! Eine Erklärung - nicht: eine Rechtsfertigung - ist schon zu geben. Es zeigt sich, dass diese 'Lehre' eine Ironie der Geschichte ist. In unserer Untersuchung haben wir gezeigt, das die Anerkennung eines Verwaltungsprivatrechts und der Wahlfreiheit in geschichtlichen Verhältnissen begründet sind. Vor allem die alte Fiskustheorie i.V.m. dem anfänglichen Fehlen ausreichender unabhängiger Rechtsschutzinstanzen 
auf dem Gebiete des öffentlichen Rechts ist für die Entwicklung des öffentlich Rechtes in Deutschland aber auch in den Niederlanden von nicht zu übersehendr Bedeutung gewesen.

Im Zeitalter nach der Revolution hatte man in Frankreich aus der Anerkennung dr Eigenart des öffentlichen Rechts bzw. des bürgerlichen Rechts die Konsequez gezogen, das die Zivilgerichte nur zuständig waren zur Beurteilung von bürgerchrechtlichen Streitigkeiten und Strafsachen. Für die Beurteilung von öffentlichreck lichen Streitigkeiten wurden innerhalb der Verwaltung selbst Instanzen zur Rechtkontrolle geschaffen. Nachdem der Conseil d'Etat 1871 eine selbständige Positio bekommen hatte und damit eine allgemeine verwaltungsunabhängige Verwaltungsg. richtsbarkeit begründet war, entschied das Tribunal des Conflits am 8.2.1873 in Falle Blanco, dass die Grundlage für die Haftung wegen rechtswidriger Handlunge im Rahmen der 'service public' nicht in der deliktischen Generalklausel des A. 1382 ff. des Code Civil gefunden werden kann, und dass deshalb der Conseil d'Ett - und nicht die Zivilgerichte - zuständig zur Beurteilung solcher Handlungen sin In dieser Entscheidung heisst es, 'que la responsabilité, qui peut incomber à l'Ett pour des dommages causés aux particuliers par le fait des personnes qui'l emplé dans le service public, ne peut être régie par les principes qui sont établis danse

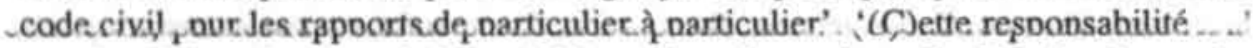
- so das Tribunal - 'ses règles spéciales qui varient suivant les besoins du service et la nécessité de concilier les droits de l'État avec les droits privés'. Wie Fritz Fleiner gesagt hat ${ }^{9}$, wurde in der französischen Praxis aus der Unzuständigkeit der Zivilgerichte - und der Zuständigkeit der Verwaltungsgerichte - in allen Angelegenheiten der öffentlichen Verwaltung der Schluss gezogen, dass in diesen Angelegenheiten das materielle bürgerliche Recht nicht anwendbar ist. Daraus lässt sich z.B. erklären, warum die Entwicklung des Eigentums an öffentlichen Sachen in Deutschland und in den Niederlanden anders verlaufen ist als in Frankreich. Während in Deutschland und in den Niederlanden die Lehre vom modifizerten Privateigentum vorherrschend ist, wird in Frankreich - u.E. zu Recht - mit der Lehre des 'domaine public' eine rein öffentlichrechtliche Beurteilung des Eigentums an öffentlichen Sachen vertreten ('öffentliches Eigentum').

Dass die Entwicklung in Deutschland und in den Niederlanden anders vor sich ging als in Frankreich, hängt u.E. also vornehmlich zusammen mit dem Umstand, dass es in Frankreich bereits im 19. Jahrhundert eine allgemeine Verwaltungsgerichtsbarkeit gab. In Deutschland und in den Niederlanden dagegen war der Bürger, der Schadensersatz wegen rechtswidriger Eingriffe der Obrigkeit fordern wollte, auf die ordentlichen Gerichten angewiesen. Solange es noch keine (allgemeine) Verwaltungsgerichtsbarkeit gab, konnten nur die ordentlichen Gerichte Rechtsschutz gegen hoheitliche Staatsgewalt bieten. In Deutschland war (und ist) ihre Kompetenz aber - auch nach Par. 13 des Gerichtsverfassungsgesetzes (GVG) - grundsätzlich be- 
schränkt auf bürgerliche Rechtsstreitigkeiten (und auf Strafsachen). Der Begriff 'bürgerliche Rechtsstreitigkeit' in Par. 13 GVG ist zwar ein prozessualer Begriff, der aber an die Art der vorprozessualen materiellen Beziehung der Parteien anknüpft. Um trotzdem Rechtsschutz gegen hoheitliche Staatsgewalt bieten zu können, bedienten die ordentlichen Gerichten sich der alten Fiskustheorie, indem sie öffentlichrechtliche Streitfalle mit geldwertem Gegenstand als bürgerliche Rechtsstreitigkeiten erachteten. Mit der Errichtung einer einheitlichen Staatsgewalt musste sich dabei eine Wandlung des Fiskusbegriffs vollziehen in dem Sinne, dass der Fiskus nicht mehr als eine vom Staate verschiedene Persőnlichkeit (der 'Prügelknabe des Staates') angesehen werden konnte, sondern als die vermögensrechtliche Seite des Staates. Und um dem gegen die Verwaltung rechtsuchenden Bürger Rechtsschutz gewähren zu können, musste diese vermőgensrechtliche Seite als die bürgerlichrechtliche Seite des Staates charakterisiert werden. Weil in Frankreich die Praxis aus der Unzuständigkeit der ordentlichen Gerichten in Angelegenheiten der öffentlichen Verwaltung auf die Unanwendbarkeit des materiellen bürgerlichen Rechts schloss, geschah in Deutschland das Umgekehrte. Die modifizierte Fiskustheorie lieferte die Rechtfertigung der Lehrmeinung, nach der der Staat nach zweierlei Recht lebt, nach öffentlichem Recht und nach bürgerlichem Recht: der Fiskus wäre der Staat als Privatrechtssubjekt. Damit war der Keim für das Verwaltungsprivatrecht gelegt und für die Formenwahlfreiheit. Beim Fehlen einer allgemeinen Verwaltungsgerichtsbarkeit bedeutete das sog. fiskale Handeln des Staates für den Bürger aber einen Vorteil, der insbesondere in der Unterwerfung unter die Rechtsprechung der ordentlichen Gerichte zum Ausdruck kam. Seit 1863 (Gründung des ersten Verwaltungsgerichtshofs in Baden) hat sich in Deutschland eine verwaltungsunabhängige Rechtspflege entwickelt. Die allgemeine Verwaltungsgerichtsbarkeit in ihrer heutigen Gestalt wurde 1961 durch die Verwaltungsgerichtsordnung (VwGO) begründet; Par. 40 VwGO eröffnet diesen Rechtsweg für alle öffentlichrechtlichen Streitigkeiten ${ }^{10}$. Seit die Staatsgewalt durch den Ausbau des Verwaltungsrechtsschutzes, die Bildung von allgemeinen Verwaltungsverfahrensgesetzen und anderen Normen des öffentlichen Rechts (Vorbehalt des Gesetzes), die Festlegung von Grundrechte usw. immer wirksameren rechtsstaatlichen Schranken unterworfen wurde, ist das sog. privatrechtliche Auftreten des erstarkten Staates aus einer Wohltat zur Plage geworden ('Flucht in das Privatrecht' "). Die 'Lehre' des Verwaltungsprivatrechts und der Wahlfreiheit hat sich leider als sehr zäh erwiesen und sich fest in Rechtspraxis und Rechtswissenschaft verankert. Auch in der Rechtsprechung des Bundesgerichtshofes wird angenommen, dass 'die öffentliche Hand im Regelfalle, soweit die Eigenart der betreffenden öffentlichen Aufgabe nicht entgegensteht, die Wahl hat, ob sie sich der Aufgabe mit Mitteln des Privatrechts' - in der Gestalt des Fiskus, d.h. als Privatrechtssubjekt - 'oder hoheitlich entledigen will' (BGHZ 60, 54 , NJW 1973, 460). Eine tragfähige juristische Begründung für dieses Dogma kann 
aber nicht gegeben werden. Der hin und wieder in der Literatur vorgetragene Hinweis auf die Rechtstradition, derzufolge die Wahlfreiheit 'schon immer' in fester Übung gestanden habe, ist genaugenommen nur dazu angetan, das Begründungsdefizit besonders eindringlich vor Augen zu führen. Schaut man zurück auf die Rechtsgeschichte, dann erkennt man, dass diese gerade gekennzeichet ist durch eine zunehmende Ausdifferenzierung der menschlichen sozialen Verhältnissen und deshalb auch des Rechts. Übersehen wird, das die Fiskustheorie nur eine Zweckkonstruktion im Interesse des Rechtsschutzes der Bürger gegen den verwaltenden Staat war, und dass deshalb die mit dieser Theorie gerechtfertigte Zuständigkeit der ordentlichen Gerichte in Rechtsstreitigkeiten mit der öffentlichen Verwaltung, nicht bedeuten konnte, dass diese Rechtsstreitigkeiten auch wirklich ihrer Art nach bürgerlichrechtlich waren. Man kann also mit einigem Recht von einer Ironie der Geschichte sprechen.

Anders als in Frankreich und in Deutschland war in den Niederlanden die Kompetenz der ordentlichen Gerichte nicht auf bürgerliche Rechtsstreitigkeiten und Strafsachen beschränkt. Auf Grund von Art. 2 des Gesetzes über die Richterliche Organisation waren die ordentlichen Gerichte auch kompetent in den Fällen, in denen der Bürger wegen rechtswidriger Eingriffe der Obrigkeit Schadensersatz forderte. Bereits Thorbecke (1798-1872), der die Trennung von öffentlichem Recht und Privatrecht als eine für den Rechtsstaat grundsätzliche auffasste, warnte aber vor dem 'bürgerlichen Rechtsauge' des ordentlichen Richters, und plädierte für den Ausbau des Verwaltungsrechtsschutzes. In der Tat hat u.E. das Fehlen einer umfassenden Verwaltungsgerichtsbarkeit in den Niederlanden verheerende Folgen für die Entwicklung des öffentlichen Rechts gehabt. Wenn der Bürger beim ordentlichen Gericht Rechtsschutz gegen das Handeln eines Obrigkeitsorgans suchte, dann prüfte das Gericht die Rechtmässigkeit oder Rechtswidrigkeit dieses Handeln im Rahmen der deliktischen Generalklausel des Art. 1401 des niederländischen Zivilgesetzbuchs. Dieses Zivilgesetzbuch (1838) war inhaltlich im wesentlichen an den französischen Code Civil von 1804 angelehnt, wozu Locré sagte: 'Voila donc ce qu'est le droit civil ou privé; son object est de régler les rapport individuels' ${ }^{12}$. Und Art. 1401 war orientiert an Art. 1382 des Code Civil, wozu, wie wir bereits gesehen haben, der Tribunal des Conflits 1873 entschied, dass darin nicht die Grundlage für die Haftung wegen rechtswidrigen Handelns im Rahmen des 'service public' gefunden werden kann.

Zwischen 1883 und 1901 wurde vom Hohen Rat bei der Prüfung von Handlungen der öffentlichen Hand ein Unterschied gemacht zwischen dem Handeln der Obrigkeit als solcher und dem Handeln der öffentlichen Hand als Privatrechtssubjekt. Nur letzteres Handeln könnte vom ordentlichen Richter geprüft werden. Wahrscheinlich war diese Rechtsprechung auch beeinflusst durch die (modifizierte) deutsche Fiskustheorie ${ }^{13}$. 
Diese Rechtsprechung hat mit dazu geführt, dass um die Jahrhundertwendende in der Literatur die sog. gemeine Rechtslehre entwickelt wurde. Nach dieser Lehre gibt es keinen Wesensunterschied zwischen privatem Recht und öffentlichem Recht. Das bürgerliche Recht wurde als das (all)gemeine Recht bezeichnet, dass grundsätzlich auch für die öffentliche Verwaltung gilt, während das Verwaltungsrecht als das besondere Recht (Sonderrecht) für die öffentliche Verwaltung bezeichnet wurde. Weil es nach dieser Lehre keinen Wesensunterschied gibt, kann der ordentliche Richter nicht nur das privatrechtliche Handeln der Verwaltung, sondern auch deren öffentlichrechtliches Handeln prüfen. Obwohl diese Lehre dem Bürger Rechtsschutz gegen die Verwaltung bieten konnte, lieferte sie auch eine Begründung für das Verwaltungsprivatrecht und die Wahlfreiheit. Nur wenn das besondere Recht (das Verwaltungsrecht) sich der Anwendung der Handlungsformen des gemeinen Rechts (d.h. des Privatrechts) widersetzt, wenn also eine 'Durchkreuzung' des Verwaltungsrechts möglich ist, gibt es diese Wahlfreiheit nicht.

Wir sprachen von einer Ironie der Geschichte. Um dem Bürger, beim Fehlen einer adäquaten Verwaltungsgerichtsbarkeit, Rechtsschutz gegen Obrigkeitshandeln zu gewähren, wurde Art. 1401 des BGB vom Hohen Rat auch auf dieses Handeln anwendbar geachtet. In der rezenten Rechtsprechung hat aber eine Wendung stattgefunden. In der Windmill-Entscheidung heisst es, das die öffentliche Verwaltung öffentliche Interessen auch durch Gebrauch ihr im Prinzip auf der Grundlage des Privatrechts zukommender Befugnisse erfüllen darf, und dass sie die Befugnis hat einen Anspruch wegen rechtswidrigen Handelns, das ihr gegenüber stattgefunden hat, beim Zivilrichter anhängig zu machen. Und eine solche 'Rechtswidrigkeit gegen die öffentliche Verwaltung' kann schon bei Verletzung ungeschriebener Sorgfaltsnormen vorliegen, wenn der Bürger bestimmte 'öffentliche' Interessen mißachtet. Dabei kann es sich auch um 'öffentliche Interessen' handeln, die der Verwaltung nicht gesetzlich anvertraut sind, die sie aber selbst an sich gezogen hat.

Als der Hohe Rat im Jahre 1919 in der berühmten Entscheidung Lindenbaum/Cohen (HR 31. Januar 1919, NJ 1919, S. 161) den Kampf um die Interpretation des Begriffes 'unerlaubte Handlung' ('onrechtmatige daad') in der deliktischen Generalklausel in Art. 1401 BW mit einer Interpretation entschied, nach der auch die 'Missachtung der im gesellschaftlichen (!) Verkehr erforderlichen Sorgfalt' als unerlaubtes Handeln im Sinne des Art. 1401 zu betrachten ist, hatte dieser Sorgfaltsmassstab einen rein privatrechtlichen Inhalt. Seit 1919 konnte anhand der typisch bürgerlichen Sorgfaltspflichten, die nur im privaten, gesellschaftlichen Verkehr zwischen privaten (individuellen oder kollektiven) Rechtssubjekten gelten, die Rechtmässigkeit oder Rechtswidrigkeit des Handelns der Rechtssubjekte in diesem gesellschaftlichen Verkehr geprüft werden. In der Legaldefinition des Art. 6:162 Abs. 2 des neuen Burgerlijk Wetboek, das am 1.1.1992 in Kraft getreten ist, sind die vom Hohen Rat ausgearbeiteten Tatbestandsmerkmale der unerlaubten Handlung 
im wesentlichen enthalten. Diese Definition lautet: 'Als unerlaubte Handlung weren der Eingriff in ein Recht und ein Tun oder Unterlassen, das gesetzlichen Pflichen oder ungeschriebenem Recht des gesellschaftlichen Verkehrs widerspricht, betrahtet, dies alles vorbehaltlich eines Rechtfertigungsgrundes'.

In der neuen Jurisprudenz zur Wahlfreiheit ist diese 'Sorgfalt im gesellschaftlickn Verkehr' zu einem Klischeebegriff entartet, der keine wirklich inhaltliche Bedeutug mehr hat, weil kein Unterschied mehr zwischen den privaten, gesellschaftlickn Verhaltnissen und den öffentlichen Gemeinschafts(Verbands-)verhältnissen gemaat wird. Die Grenzen zwischen Staat und 'Gesellschaft' werden damit völlig verwisct. In der genannten Rechtsprechung ist Art. 6:162 BW umgedeutet in eine parageseliche Generalklausel für die öffentliche Verwaltung. Wie gefährlich dies ist, zejt z.B. die Kabayel-Entscheidung vom 18.2.1994 (AB 1994, 415). Es erstaunt auh nicht, dass die vermögensrechtliche Betrachtung der öffentlichrechtlichen Kompetazen wiederaufgelebt ist. In einigen Entscheidungen hat der Hohe Rat angenomme, dass durch öffentlichrechtliche Kompetenznormen zugleich auch eigene Vermögerinteressen der öffentlichen Verwaltung selbst gesichert werden.

Der Hohe Rat verkennt in dieser Rechtsprechung die eigene Art sowohl des bürgelichen Rechts wie auch des öffentlichen Rechts, und damit auch das wichtige.öffetlichrechtliche Prinzip der repräsentativen Demokratie. Die Frage, welche Interessen durch die öffentliche Verwaltung wahrgenommen werden sollen, wird beantwortet in einem Prozess der politischen Willensbildung, wobei der Volksvertretung ein gewichtiger Einfluß zukommt. Innerhalb des Staatsverbands werden alle zu berücksichtigenden besonderen Interessen vom (Grund)gesetzgeber gewertet und harmonisiert und das Ergebnis wird in gesetzlichen Normen niedergelegt. Die Abwägung der Interessen verläuft also nach dem Demokratieprinzip. Auch der Gebrauch bürgerrechtlicher Handlungs- und Organisationsformen durch die öffentliche Hand muss immer auf eine öffentlichrechtliche Kompetenz zurückgeführt werden können. Das bürgerliche Recht kann niemals selbständige Grundlage der Verwaltungstätigkeit sein; die Anwendung des bürgerlichen Rechts betrifft nur die Form des Verwaltungshandelns. Das bürgerliche Recht erweitert also die Befugnisse der öffentlichen Verwaltung zur Wahrnehmung öffentlicher Aufgaben (besser: öffentlichrechtlicher Aufgaben; Böckenförde) nicht. Das Auftreten der öffentlichen Hand in bürgerrechtlichen Formen ist nur möglich im Zusammenhang mit der Erfüllung öffentlichrechtlicher Aufgaben (vgl. BVerfGE 61, nr. 10), welche sich in aller Regel nur aufgrund von Kompetenzen vollziehen kann, die ausdrücklich vom positiven öffentlichen Recht zugeordnet und inhaltlich bemessen sind (vgl. BVerfGE 68, nr. 6), und dies innerhalb der materiellen Rechtssphäre des Staates.

'Nur im Zusammenhang mit ...': dies bedeutet, dass der Staat und seine autonome Untergliederungen (Provinzen, Gemeinden, 'waterschappen' u.s.w.) im bürgerlich- 
rechtlichen Verkehr handlungsfähig sind, soweit sie den zur Erfüllung ihrer Aufgaben erforderlichen Sach- und Dienstleistungsbedarf nur in den Formen des bürgerlichen Rechts befriedigen können. Man könnte die bürgerrechtliche Handlungsfähigkeit öffentlichrechtlicher Körperschaften eine 'implied power' bzw. 'Handlungsfähigkeit kraft Sachzusammenhang' nennen, weil anzunehmen ist, dass die Kompetenz- und Zuständigkeitsnormen des öffentlichen Rechts (öffentlichrechtliche) Aufgaben und Zuständigkeiten nicht zuweisen, ohne auch deren Realisierung und Durchführung rechtlich zu ermöglichen ${ }^{14}$. Diese bürgerlichrechtliche 'Handlungsfähigkeit kraft Sachzusammenhang' reicht also nur so weit, wie es der AufgabenBedarf wirklich verlangt. Die privatrechtliche Betätigung der öffentlichrechtlichen Körperschaften ist m.a.W. notwendig auf die sogenannten privatrechtlichen Bedarfsund Hilfsgeschäfte beschränkt, die zur Ausfüllung der jeweiligen öffentlichrechtlichen Aufgaben unabdingbar sind.

Der Staat und seine Untergliederungen besitzen dagegen nicht eine unkodifizierte, allgemeine (oder auch 'nur' partielle) privatrechtliche Handlungsfähigkeit zur Erfüllung von öffentlichen Aufgaben. Die Lehre vom Verwaltungsprivatrecht bzw. die Lehre des gemischten Rechts ist daher insgesamt aufzugeben. Es handelt sich hier um eine u.E. gefährliche Fehlentwicklung in der Rechtswissenschaft und in der Rechtssprechung des Hohen Rates. (Zur Gefährlichkeit dieser Entwicklung sei noch einmal auf die Kabayel-Entscheidung des Hohen Rates hingewiesen). Das bürgerliche Recht, dessen modifizierte 'Anwendung' diese Lehre vorschlägt, kann ihrem Wesen nach keine selbständige Zuständigkeitsgrundlage bieten für die Erfüllung von öffentlichrechtlichen Aufgaben.

Daher gibt es auch keine staatliche Formenwahlfreiheit ('Zwei-Wege-Lehre'). Das Dogma von der Formenwahlfreiheit gründet nämlich auf der, wie wir gezeigt haben, unzutreffenden Annahme, dass die Körperschaften des öffentlichen Rechts sich als 'Privatrechtspersonen' sog. 'privatrechtlicher Befugnisse' zur Wahrnehmung von sog. 'öffentlichen Aufgaben' bedienen können. 


\section{Noten bij Zusammenfassung}

1. H. Kelsen, 'Allgemeine Staatslehre', 1925, p. 40. Und 'der Staat' - der also identisch ist mit dr Rechtsordnung; JT -ist 'nur das Mittel' - d.h. die Form; JT - 'zur Realisienung irgendwelcher sozialm Zwecke'. Bekanntlich beruht Kelsens reine Rechtslehre auf einer Synthese des Rechtsposititismus dis spāten 19. Jahrhunderts mit dem Neo-Kantianismus, mit seiner Trennung von Form und Inhalt, bzv. 'Sollen' und 'Sein'. Was 'Recht' ist, wird nach der reinen Rechtslehre nicht von seinem Inhalt bestimmt: 'Recht' wird identifiziert mit positivem Recht und die (positive) Rechtsordnung ist identisch mit dem Staat im juristischen Sinne (Im soziologischen Sinne ist der Staat ein rein faktiseher Kompla sozialer Machtverhăltnisse und gehört zum 'Sein').

Vgl. auch D. Schindler, 'Verfassungsrecht und soziale Struktur', Zürich 1944, p. 61/62, der meint, das es besser wäre, statt von 'Gesellschaft', 'vom Ausserstaatlichen, resp. wenn vom Recht ausgegangen wird, vom Ausserrechtlichen' zu sprechen. 'Recht' und 'Staat' sind also für Schindler identisch: de 'Gesellschaft' ist für ihn (das 'Ausserstaatliche', bzw.) das 'Ausserrechtliche'.

2. $\quad \mathrm{Vgl}$. H. Kelsen, 'Reine Rechtslehre', 2. Auflage, Wien 1960, S. 285.

3. Dabei ist zu beachten, dass die allgemeinen Rechtsprinzipien innerhalb der unterschiedlichen Rechtskreise eigener Art eine typische Verbesonderung enthalten. So fordert z.B, das allgemeire Rechtsprinzip der Rechtssicherheit, dass die Klagefristen im Verwaltungsprozess, im Vergleich mit den Klagefristen im Zivilprozess, relativ kurz zind (vgl. \$74 VwGO: Eine Anfechtungsklage muss innerhab eines Monats nach Zustellung des Widerspruchsbescheids erhoben werden). Dies hăngt zusammen nit der typischen Eigenart des offentlichen Rechts, im besonderen mit dem für dieses Recht typischen Rechtsprinzip der res publica.

4. Dies ist das Richtige an Merkls und Kelsens Stufenbaulehre. Falsch an dieser Lehre ist aber, dass sic nur eine einzige Rechtsordnung kennt, d.h. die staatliche.

5. E.-W. Bōckenfōrde, 'Die Bedeutung der Unterscheidung von Staat und Gesellschaft im demokratischen Sozialstaat der Gegenwart', in: 'Staat, Gesellschaft, Freiheit', Frankfurt a.M. 1976, S. 185-220; auch in: 'Recht, Staat, Freiheit', Frankfurt a.M. 1991, S. 209-243.

6. H.-M. Pawlowski, 'Allgemeiner Teil des BGB', 2. Aufl., Heidelberg 1983, S. 47/48.

7. Vgl. M.M. van Praag, 'Algemene Rechtsleer', Alphen a/d Rijn 1949. Van Praag war stark beinflusst durch Kelsen. Er besorgte auch die niederländischen Übersetzung der 'Reinen Rechtsiehre'.

8. H. Krüger, 'Das besondere Gewaltverhältnis', in: Veröffentlichungen der Deutschen Staatsrechtlehrer', Heft 15, Berlin 1957, p. 120.

9. F. Fleiner, 'Über die Umbildung zivilrechtlicher Institute durch das öffentliche Recht', Akademische Antrittsrede, Tübingen 1906.

10. Ausgenommen sind Streitigkeiten verfassungsrechtlicher Art. Daneben enthalten $\S 40 \mathrm{VwGO}$ und $\S 13$ GVG ausdrücklich den Vorbehalt der anderweitigen gesetzlichen Zuweisung eines anderen Rechtswegs.

11. F, Fleiner, 'Institutionen des deutschen Verwaltungsrechts', 8. Auflage, Tübingen 1928, S. 326.

12. J.G. Locré, 'Esprit du Code Napoléon, tiré de la discussion', Paris 1805.

13. Auch dies ist eine Ironie. Wăhrend in Deutschland diese Theorie entwickelt wurde um dem Bürger bei den ordentlichen Gerichten (die ja nur waren in bürgerlichen Streitigkeiten zustăndig waren) gegen die Verwaltung Rechtsschutz zu gewähren, führte diese Theorie in den Niederlanden dazu, dass der ordentliche Richter nur noch sog, fiskalische Streitigkeiten prûfen konnte. In Deutschland brachte diese Theorie also eine Erweiterung des Rechtsschutzes, in den Niederlanden dagegen eine Verringerung des Rechtschutzes.

14. Man kann hier eine Paralelle zichen mit der Gesetzgebungszuständigkeit (des Bundes) kraft Sachzusammenhang, die nur so weit reicht, wie es zur Regelung einer ausdrücklich zugewiesenen Bundesgesetzgebungskompetenz unbedingt erforderlich ist. Vgl. BVerfGE 3, S. 407 (423). 


\section{Literatuurlijst}

N. Achterberg, 'Allgemeines Verwaltungsrecht', 2. Auflage, Heidelberg 1986.

N. Achterberg, 'Rechtsverhältnisse als Strukturelemente der Rechtsordnung',

Rechtstheorie 1978, S. 385-410.

N. Achterberg, 'Die Rechtsordnung als Rechtsverhăltsnisordnung, Grundlegung der Rechtsverhältnistheorie', Berlin 1982.

M. Albert, 'Kapitalisme contra kapitalisme', Amsterdam 1992 (oorspr. titel 'Capitalisme contre capitalism', Paris 1991).

N.E. Algra, zie P. Gerbenzon

L.J. van Apeldoorn, 'Het Romeinsche recht in Friesland', Amsterdam 1940.

L.J. van Apeldoorn, 'Inleiding tot de studie van het Nederlandse recht', 17e druk, bewerkt door J.C.M. Leyten, Zwolle 1972.

'Van Apeldoorn's Inleiding tot de studie van het Nederlandse recht', 18e druk, bewerkt door P. van Dijk e.a., Zwolle 1984.

0 . Bachof, 'Reflexwirkungen und subjektive Rechte im öffentlichen Recht', in:

'Gedăchtnisschrift für Walter Jellinek', 1955, Neudruck 1962, S. $287 \mathrm{ff}$.

0 . Bachof, 'Teilrechtsfähige Verbände des öffentlichen Rechts', Archiv des öffentlichen Rechts 1958, S. 208-279.

0. Bachof, 'Über einige Entwicklungstendenzen im gegenwärtigen Deutschen

Verwaltungsrecht', in: 'Staatsbürger und Staatsgewalt', Bd. II, 1963.

O. Bachof, 'Die Dogmatik des Verwaltungsrechts vor der Gegenwartsaufgaben der

Verwaltung', Veröffentlichungen der Vereinigung der Deutschen Staatsrechtslehrer, Heft 30, 1972, S. 193-244.

O. Bachof, 'Über öffentliches Recht', in: 'Verwaltungsrecht zwischen Freiheit, Teilhabe und Bindung', Festgabe aus Anlass des 25jährigen Bestehens des

Bundesverwaltungsgerichts', München 1978, S. 1 ff.

R.E. Bakker, zie A.Q.C. Tak

P.H. Banda, 'Administratief procesrecht in vergelijkend perspectief', diss. Tilburg 1989. Zwolle 1989.

R. Bartlsperger, 'Strassenrecht', Deutsches Verwaltungsblatt 1979, S. 1 ff.

J.J. de la Bassecour Caan, 'Handleiding tot de kennis van het administratief regt

in Nederland', 2 delen, $2 \mathrm{e}$ nieuwe bewerkte uitgave 1865-1866.

C.J. Bastmeijer, 'De algemene zorgplicht in de Wet milieubeheer', Milieu en Recht 1993, pp. 466 e.v.

G. von Below, 'Der deutsche Staat des Mittelalters', Teil I, 'Die allgemeinen Fragen', Leipzig 1914.

P. van den Berg/M. Trappenburg, 'Lokale rechtvaardigheid', De politieke theorie van Michael Walzer, Zwolle 1984. 
G.C.J.J. van den Bergh, "Eigendom. Grepen uit de geschiedenis van een omstreden begrip', 2e druk, Deventer 1988.

G.C.J.J. van den Bergh, 'Geleerd recht. Een geschiedenis van de Europese rechtswetenschap in volgelvlucht', 2e druk, Deventer 1985.

G.C.J.J. van den Bergh, 'Iets over publiek- en privaatrecht', in: 'Ter Regognitie'. Opstellen aangeboden aan prof. mr. H. van der Linden bij zijn afscheid als hoogleraar in de Nederlandse rechtsgeschiedenis aan de Vrije Universiteit, Hilversum 1987, pp. 9-17.

P.A. van Berkum, 'Plaats en inhoud van het begrip algemeen belang in de theorie der economische politiek', in: 'Rechtsvinding', Opstellen aangeboden aan prof.mr. J.M. Pieters, Deventer 1970, pp. 21-34.

H. Bethge, 'Grundrechtsträgerschaft juristischer Personen'. Zur Rechtsprechung des Bundesverfassungsgerichts, Archiv des öffentlichen Rechts 1979, S. 54 ff., 265 ff. K.-A. Bettermann, 'Juristische Personen des offentlichen Rechts als Grundrechtsträger', Neue Juristische Wochenschrift 1969, S. 1321 ff.

P.G.E.H. de Bieberstein, 'Proeve over zaken buiten den handel', diss. Leiden 1849.

A.S. de Blécourt, 'Heerlijkheden en heerlijke rechten', Tijdschrift voor rechtsgeschiedenis 1918-1919, pp. 45-107; 175-190; 1920-1921, pp. 42-134; 163-219.

A.L. de Block, 'Toeneming van de macht der Kroon', oratie Tilburg 1938.

A.R. Bloembergen, 'Interne rechtsvergelijking, een comparatieve kijk op privaatrecht, administratief recht en bouwrecht', BR 1977, pp. 125 e.v.

A.R. Bloembergen/D.A. Lubach, 'Burgerlijk recht en administratief recht: twee gelijkwaardige rechtsgebieden, open verbonden in én rechtsorde', WPNR 5885 (1988).

A.R. Bloembergen, bespreking van Asser-Hartkamp 'Verbintenissenrecht', dl. III, 7e druk, Zwolle 1986, in NJB 1987, p. 631-633.

M. Bock, 'Zur Verbandstheorie Otto von Gierkes', Rechtstheorie 1994, S. 87-100.

E.-W. Böckenförde, 'Die verfassungstheoretische Unterscheidung von Staat und Gesellschaft als Bedingung der individuellen Freiheit', Opladen 1973.

E.-W. Böckenförde, 'Die Bedeutung der Unterscheidung von Staat und Gesellschaft im demokratischen Sozialstaat der Gegenwart', in: ders., 'Staat, Gesellschaft, Freiheit', Frankfurt aM 1976, S. 185-220; auch in: ders., 'Recht, Staat, Freiheit', Frankfurt aM 1991, S. 209-243.

E.-W. Böckenförde, 'Grundrechtstheorie und Grundrechtsinterpretation', in: ders., 'Staat, Gesellschaft, Freiheit', Frankfurt aM 1976, S. 221 ff.

E.-W. Böckenförde, 'Lorenz von Stein als Theoretiker der Bewegung von Staat und Gesellschaft zum Sozialstaat', in: ders., 'Staat, Gesellschaft, Freiheit', Franfurt aM 1976, S. 146-184

E.-W. Böckenförde, 'Demokratie als Verassungsprinzip', in: J. Isensee/P. Kirchhof (Hrsg.), 'Handbuch des Staatsrechts der Bundesrepublik Deutschland', Bd. I, Heidelberg 1987, S. 887-950, auch in: ders., 'Staat, Verfassung, Demokratie', Frankfurt aM 1991.

E.-W. Böckenförde, 'Das Grundrecht der Gewissensfreiheit', in: ders., 'Staat, Verfassung, Demokratie', Frankfurt aM 1991, S. 200-263.

J. Bodin, 'Les six livres de la république', 1576, herdruk Parijs 1984. 
Th. de Boer, 'De filosofie van Dooyeweerd', Algemeen Nederlands Tijdschrift voor Wijsbegeerte 1984, pp. 247-261.

C. Bornhak, 'Preussisches Staatsrecht', Bd. II, 2. Auflage, Breslau 1912.

B. Bouckaert, 'De exegetische school', Een kritische studie van de rechtsbronnen- en interpretatieleer bij de 19de eeuwse commentatoren van de Code Civil, diss. Gent 1981 . Antwerpen 1981.

C.A. Boukema, 'Algemeen belang en ondernemingsbelang in het nieuwe ondernemingsrecht', in: 'Op de grenzen van komend recht', Opstellen aangeboden aan prof. mr. J.H. Beekhuis, Deventer/Zwolle 1969, pp. 53-65.

M.H. Bregstein, 'De arresten van de hoge raad van 19 maart 1943 en 18 februari 1944 en het leerstuk van de onrechtmatige daad', RMTh 1951, pp. 273 e.v., ook opgenomen in: 'Verzameld werk van prof, mr. M.H. Bregstein', dl. 1, pp. 339-365.

A.F.M. Brenninkmeijer, 'Harmonisatie van procesrecht', NJV-preadvies 1991.

A.F.M. Brenninkmeijer, 'Burgerlijk procesrecht als publiekrecht', oratie Amsterdam 1993, Zwolle 1993.

H. van den Brink, 'Johann Heinrich Adolf Logemann (1892-1969)', in: T.J. Veen en P.C. Kop (red.), 'Zestig juristen in Nederland'. Bijdragen tot een beeld der Nederlandse rechtswetenschap', Zwoll 1987, pp. 324-327.

W. Brohm, 'Soziale Grundrechte und Staatszielbestimmungen in der Verfassung', JuristenZeitung 1994, S. 213-220.

P.W. Brouwer, 'Rechtsbeginselen en rechtspositivisme', bijzonder nummer Ars Aqui mei 1991 over 'Rechtsbeginselen', pp. 757-772.

M. Bullinger, 'Öffentliches Recht und Privatrecht', Stuttgart/Berlin/Köln/Mainz 1968.

F.H. van der Burg, 'Preventieve justitie en plaatselijke politie', diss. Leiden Utrecht 1961.

F.H. van der Burg, 'Mens en burger', in: 'De mens in het recht', Opstellen aangeboden aan prof. mr. W.F. Prins, Den Haag 1975, pp. 47-60.

F.H. van der Burg, 'Quod omes tangit ab omnibus approbetur', in: Opstellen aangeboden aan prof. mr. J.G. Steenbeek, Den Haag 1984, pp. 65-84.

F.H. van der Burg/G.J.M. Cartigny/G. Overkleeft-Verburg, 'Rechtsbescherming tegen de overheid', 5e druk, Nijmegen 1985.

F.H. van der Burg, 'Een nieuw materieel wetsbegrip', in 'Bestuur en norm', Opstellen opgedragen aan prof. mr. R. Crince le Roy, Deventer 1986, pp. 57-72.

F.H. van der Burg, 'Regelgeving en bestuur', Zwolle 1993.

M.C. Burkens, Bespreking van: P.P.T. Bovend'Eert en C.A.J.M. Kortmann, 'Inleiding constitutioneel recht', Deventer 1993, in RMTh 1995, pp. 21-23.

P.J.J. van Buuren, 'Twee-wegenleer is niet van de baan', NJB 1991, pp. 1501-1503.

P.J.J. van Buuren/F.C.M.A. Michiels, 'Bestuursdwang', Zwolle 1989.

J.Th Buys, 'De Grondwet. Toelichting en kritiek', dl. I, Arnhem 1883; dl. II, Arnhem 1887.

R.C. van Caenegem, 'Over Koningen en Bureaucraten', Oorsprong en ontwikkeling van de hedendaagse staatsinstellingen, 2e druk, Amsterdam/Brussel 1980. 
R.C. van Caenegem, 'Geschiedkundige Inleiding tot het Recht, II, Publiekrecht', Brussel 1988.

G.J.M. Cartigny, zie F.H. van der Burg

J.P. Chaplin, 'Pluralism, Society and the State: The Neo-Calvinist Political Theory of Herman Dooyeweerd (1894-1977)', PhD Dissertation, University of London 1993.

B.J. de Clercq, 'Macht en principe', Over rechtvaardiging van politieke macht, Tielt 1988.

P.B. Cliteur, 'Conservatisme en cultuurrecht', diss. Leiden 1989, Amsterdam 1989.

H. Coing, 'Grundzüge der Rechtsphilosophie', 3. Auflage, Berlin/New York 1976.

H. Coing, 'Epochen der Rechtsgeschichte in Deutschland', 4. Auflage, München 1981

H. Coing, 'Europäisches Privatrecht', Bd. II: '19. Jahrhundert. Überblick über die

Entwicklung des Privatrechts in den ehemals gemeinrechtlichen Ländern', München 1989

H. Conrad/G. Kleinheyer (Hrsg.), 'Vorträge über Recht und Staat", Köln/Opladen 1960.

S.W. Couwenberg, 'De strijd tussen progressiviteit en conservatisme', Sociologische en cultuurhistorische belichting van een veelomstreden tegenstelling, Den Haag 1959.

S.W. Couwenberg, 'De omstreden staat', Ontwikkeling en problematiek van de staatstheorie in de 20ste eeuw, Alphen a/d Rijn 1974.

S.W. Couwenberg, 'Westers staatsrecht als emancipatieproces', Ontwikkeling van de constitutionele emancipatiefunctie in de democratische rechtsstaat, Alphen a/d Rijn 1977.

S.W. Couwenberg, 'Modern constitutioneel recht en emancipatie van de mens', dl. 1, 'Van monarchale machtsstaat naar liberale democratie', Assen 1979

S.W. Couwenberg, 'Modern constitutioneel recht en emancipatie van de mens', dl. 2, 'Liberale democratie als eerste emancipatiemodel', Een inleiding in het westerse constitutionele recht', Assen 1981.

S.W. Couwenberg, 'Modern constitutioneel recht en emancipatie van de mens', dl. 3, 'Constitutionele onwikkelingsmodellen', Constitutionele variaties op het grondthema van de moderne cultuur, Assen 1984.

S.W. Couwenberg, 'Modern constitutioneel recht en emancipatie van de mens', dl. 4, 'Dialectiek van macht en emancipatie', Theorie en perspectief van het constitutionele ontwikkelingsproces, Assen 1984.

S.W. Couwenberg, 'Hoe wordt de samenleving het best ingericht?', Opstellen over constitutionele en ideologische strijdvragen, Assen/Maastricht 1987.

S.W. Couwenberg (red.), 'Opstand der burgers', De Franse Revolutie na 200 jaar, $2 \mathrm{e}$ druk, Kampen 1989.

S.W. Couwenberg, 'Gezag en vrijheid', Inleiding in de constitutionele rechts- en ontwikkelingstheorie, Zwolle 1991.

S.W. Couwenberg, 'Een nieuwe kijk op staatsrecht en staatsrechtbeoefening', uittreerede Rotterdam 1992, Kampen 1992. 
L.J.A. Damen, 'Bestaat de Awbmens?', in: J.L. van Boxum e.d. (red.), 'Aantrekkelijke gedachten', Beschouwingen over de Algemene wet bestuursrecht, Deventer 1993, pp. 109-129.

L.J.A. Damen, 'De assisten-kampeerbeheerder die graag ambtenaar had willen zijn', Nootbij Pr.Rb. Amsterdam 13 april 1994, Awb 94/947/V), AAe 1995, pp. 290-296.

P. Dekker (red.), 'Civil Society', Sociaal en Cultureel Planbureau, Rijkswijk

J.D. Dengerink, 'Critisch-historisch onderzoek naar de sociologische ontwikkeling van het beginsel der 'Souvereiniteit in eigen kring' in de $19 \mathrm{e}$ en $20 \mathrm{e}$ eeuw', diss. VU Amsterdam 1948, Kampen 1948.

J.D. Dengerink, 'De zin van de werkelijkheid', Amsterdam 1986.

E.J. Dijksterhuis, 'De mechanisering van het wereldbeeld', Arnhem 1953.

G. Dilcher, 'Die Auseinandersetzung von Staat und Gesellschaft im deutschen Vormärz (1815-1848)', in: 'Sozialwissenschaften im Studium des Rechts', Tl. 4:

Rechtsgeschichte, München 1978.

A.M. Donner, 'Over representatie', in: 'De mens in het recht', Opstellen aangeboden aan prof. mr. W.F. Prins, Den Haag 1975, pp. 105-114.

A.M. Donner, 'Nederlands bestuursrecht. Algemeen deel', 4e druk, Alphen a/d Rijn 1974.

J. Donner, 'De vrijheid van het wetenschappelijk onderwijs', diss. VU Amsterdam 1978, Zwolle 1978.

H. Dooyeweerd, 'De structuur der Rechtsbeginselen en de methode der Rechtswetenschap in het licht der Wetsidee', in: 'Wetenschappelijke bijdragen door hoogleeraren der VU t.g.v. het vijftigjarig bestaan der VU', Amsterdam 1930, pp. 223-266.

H. Dooyeweerd, 'De Crisis in de Humanistische Staatsleer', Amsterdam 1931.

H. Dooyeweerd, 'De theorie van de bronnen van het stellig recht in het licht der wetsidee', Handelingen Vereniging voor Wijsbegeerte des Rechts XIX $(1932,1)$, pp. 1-28; XIX $(1932,2)$, pp. 1-10, 24-31.

H. Dooyeweerd, 'De Wijsbegeerte der Wetsidee', 3 dln, Amsterdam 1935/1936.

H. Dooyeweerd, 'Grondproblemen in de leer der rechtspersoonlijkheid', Een critische beschouwing naar aanleiding van H.J. Wolf's standaardwerk 'Organschaft und juristische Person', Themis 1937, pp. 199-263, pp. 367-421.

$\mathrm{H}$. Dooyeweerd, 'De vier religieuze grondthema's in de ontwikkelingsgang van het wijsgerig denken van het avondland', Philosopha Reformata 1941 (jrg. 6), pp. 151-179, ook opgenomen in: M.E. Verburg, 'Herman Dooyeweerd. Grenzen van het theoretisch denken', Baarn 1986, pp. 123-140.

H. Dooyeweerd, 'De idee der individualiteitsstructuur en het Thomistisch substantiebegrip', Philosophia Reformata 1943, pp. 65-99, 1944, pp. 1-41, 1945, pp. 25-48, 1946, pp. 22-52.

H. Dooyeweerd, 'De verhouding van individu en gemeenschap rechtsphilosophisch gezien', Algemeen Nederlands Tijdschrift voor Wijsbegeerte en Psychologie 39 (1946), pp. 5-12.

H. Dooyeweerd, 'Het wijsgerig denken', in: 'Vijftig jaren', Officieel gedenkboek ter gelegenheid van het gouden regeringsjubileum van Hare Majesteit Koningin 
Wilhelmina', Amsterdam 1948, pp. 76-87, ook opgenomen in: M.E. Verburg, 'Herman Dooyeweerd. Grenzen van het theoretisch denken', Baarn 1986, pp. 141-157.

H. Dooyeweerd, 'De strijd om het souvereiniteitsbegrip in de moderne rechts- en staatsleer', rede ter gelegenheid van het zeventigjarig bestaan der VU op 20 oktober 1950, Amsterdam 1950.

H. Dooyeweerd, 'De modale structuur van het juridisch oorzakelijkheidsverband', in: Mededelingen der Koninklijke Academie van Wetenschappen afdeling Letterkunde, Nieuwe Reeks, dl. 13, no. 5, pp. 93-141.

H. Dooyeweerd, 'Het substantiebegrip in de moderne natuurphilosophie en de theorie van het enkaptisch structuurgeheel', Philosophia Reformata 1950 (jrg. 15), pp. 66-139.

H. Dooyeweerd, Bespreking van R. Kranenburg, De grondslagen der rechtswetenschap; juridische kennisleer en methodologie', 3e druk, in: RMTh 1951, pp. 548-551.

H. Dooyeweerd, 'A new Critique of Theoretical Thought', 4 dln, Amsterdam/Philadephia 1953-1958, reprint Philadelphia 1969.

H. Dooyeweerd, 'Maatstaven ter onderkenning van progressieve en reactionaire bewegingen in de historische ontwikkeling', in: Verslag plechtige viering 150-jarig bestaan der Koninklijke Nederlandse Academie van Wetenschappen, Amsterdam 1958, pp. 61-77 (Ned.0, pp. 139-154 (Frans), pp. 213-228 (Engels).

H. Dooyeweerd, 'Het typisch structuurprincipe van de staat en de leer der staatsdoeleinden', WPNR 4701 (1961), pp. 507-515.

$\mathrm{H}$. Dooyeweerd, 'Vernieuwing en bezinning', Om het reformatorisch grondmotief, bewerkt door J.A. Oosterhoff, Zutphen 1959.

H. Dooyeweerd, 'Verkenningen in de wijsbegeerte, de sociologie en de rechtsgeschiedenis', Amsterdam 1962.

H. Dooyeweerd, 'De verhouding tussen rechtsfilosofie en rechtssociologie', in: Opstellen aangeboden aan F. van Goethem, Leuven 1964.

H. Dooyeweerd, 'Die Philosophie der Gesetzesidee und ihre Bedeutung für die Rechtsund Sozialphilosophie', Archiv für Rechts- und Sozialphilosophie 1967, S. 1-30, S. $465-513$.

H. Dooyeweerd, 'Het juridisch wilsbegrip en de juridisch-normatieve uitlegging van rechtshandelingen', in; 'Speculum Langemeijer', Zwolle 1972, pp. 29-48.

H. Drion, 'Het rechterlijk verbod en de vrijheid van meningsuiting', in: 'Op de grenzen van komend recht', Opstellen aangeboden aan prof. mr. J.H. Beekhuis, Zwolle 1969, pp. 91-108, ook opgenomen in: 'Verspreide geschriften van H. Drion', Deventer 1982, pp. 259-278.

H. Drion, 'Het rechterlijk bevel of verbod als wapen voor de overheid', in: Van Opstallbundel, Deventer 1972, pp. 51-67.

J. Drion, 'Administratie contra rechter. Tot de intrekking van het Conflictenbesluit (1822-1844)', diss. Leiden 1950, Den Haag 1958 (handelsuitgave).

J. Drion, 'Een nieuwe koers in 's hogen raads jurisprudentie over de onrechtmatige daad', WPNR 3992-3996 (1947).

E. Drooglever Fortuijn, 'Dient de wetgever regelen te geven met betrekking tot overeenkomsten met de overheid?', preadvies NJV 1965. 
Th. G. Drupsteen, zie P. de Haan

P. Duez, 'La Responsabilité de la Puissance Public (en dehors du contrat)', Paris 1927.

L. Duguit, 'Le droit social, le droit individuel et les transformations de l'État', Paris 1911

L. Duguit, 'Les transformations générales du droit privé depuis le Code Napoléon', Paris 1912.

L. Duguit, 'Les transformations du droit public', Paris 1921.

L. Duguit, 'Traité du droit constitutionnel', 2e edition, Paris 1921-1925.

R. van Duijn, 'Voeten in de aarde', Amsterdam 1984.

R. Dworkin, 'Law's empire', Massachusetts/London 1986.H.J. (van Eikema) Hommes, 'Een nieuwe herleving van het natuurrecht', diss. VU Amsterdam 1961, Zwolle 1961.

H.J. (van Eikema) Hommes, 'De betekenis van de algemene rechtsbeginselen voor de rechtspraktijk', preadvies Calvinistische Juristen Vereniging 1967.

H.J. van Eikema Hommes, 'Relatieve constantie en dynamiek in de rechtsvorming', in: 'Recht als instrument van behoud en verandering', Opstellen aangeboden aan prof.mr. J.J.M. van der ven, Deventer 1972, pp. 27-34.

H.J. van Eikema Hommes, 'Hoofdlijnen van de geschiedenis der rechtsfilosofie', Deventer 1972.

H.J. van Eikema Hommes, 'De elementaire grondbegrippen der rechtswetenschap'. Een juridische methodologie, Deventer 1972.

H.J. van Eikema Hommes, 'Methode der encyclopedie en Hoofdlijnen van de geschiedenis der rechts- en staatsfilosofie', Zwolle 1975.

H.J. van Eikema Hommes, 'Hoofdlijnen der rechtssociologie en de materiële indelingen van publiek- en privaatrecht', Zwolle 1975.

H.J. van Eikema Hommes, 'De samengestelde grondbegrippen der rechtswetenschap', Een juridische methodologie, Zwolle 1976.

H.J. van Eikema Hommes, 'De verhouding van rechtsfilosofie en juridische vakwetenschappen. De transcendentaal-empirische methode', NJB 1979, pp. 941 e.v.

H.J. van Eikema Hommes, 'De transcendentaal-empirische methode. Haar betekenis voor de juridische vakwetenschappen', AAe 1979, pp. 719-730.

H.J. van Eikema Hommes, 'Rechtsbeginselen', in: G.J. Scholten/D.F. Scheltens/H.J. van Eikema Hommes, 'Rechtsbeginselen', 2e druk, Zwolle 1983, pp. 33-69.

H.J. van Eikema Hommes, 'Die Bedeutung der Staats- und Gesellschaftslehre des Johannes Althusius für unsere Zeit', in: 'Recht und Staat im sozialen Wandel', Festschrift für Hans Scupin zum 80. Geburtstag'. Berlin 1983, pp. 211-232.

H.J. van Eikema Hommes, 'Vrijheid in juridische zin', Tijdschrift voor Rechtsfilosofie en Rechtstheorie 1984, pp. 96-108.

H.J. van Eikema Hommes, 'De wijsgerige grondslagen van de rechtssociologie',

Deventer/Zwolle 1986.

N. Elias, 'Het civilisatieproces', Sociogenetische en psychogenetische onderzoekingen,

Utrecht 1987 (oorspr. titel: 'Über den Prozess der Zivilisation', 1939).

H.-U. Erichsen/W. Martens (Hrsg.), 'Allgemeines Verwaltungsrecht', 9. Auflage,

Berlin/New York 1992. 
H. van Erp, 'Het politiek belang', Over de politieke orde in een pluralistische samenleving, Amsterdam 1994.

H. Faber, 'Verwaltungsrecht', 2. Auflage, Tübingen 1989.

F. Fabricius, 'Relativităt der Rechtsfähigkeit', Müchen/Berlin 1963.

R. Feenstra, 'Philip of Leyden and his treatise De cura reipublicae et sorte principantis', Glasgow 1970.

R. Fernhout, zie P. de Haan

R. Fernhout, zie H.Ph.J.A.M. Hennekens

R. Foqué, 'De ruimte van het recht', oratie Rotterdam 1992, Arnhem 1992.

R. Foqué, 'Rechtsstatelijke vernieuwing. Een rechtsfilosofisch essay', in: P. Kuipers e.a. (red.), 'De lege plek van de mach, over bestuurlijke vermieuwing en de veranderende rol van de politiek', Amsterdam 1993, pp. 18 e.v.

F. Fleiner, 'Über die Umbildung zivilrechtlicher Institute durch das öffentliche Recht', Akademische Antrittsrede Tübingen 1906.

F. Fleiner, 'Institutionen des deutschen Verwaltungsrechts', 8. Auflage, Tübingen 1928.

S.J. Fockema Andreae, 'De Nederlandse Staat onder de Republiek', Amsterdam 1961.

N. Frenk, 'Kent Nederland een governmental action?', NTB 1993/4, pp. 144-155.

N. Frenk, 'Kollektieve akties in het privaatrecht', diss. Utrecht 1994, Deventer 1994.

R. Fruin, 'Geschiedenis der staatsinstellingen in Nederland tot den val der republiek', uitgegeven door H.T. Colenbrander, Den Haag 1901 (2e druk, Leiden 1922).

J.K. Galbraith, 'The new industrial State', London 1967.

J.K. Galbraith, 'The culture of contentment', Boston 1990.

H.J.A.M. van Geest, zie H.Ph.J.A.M. Hennekens

P. Gerbenzon/N.E. Algra, 'Vortgangh des rechtes', 4e druk, Groningen 1975.

P.S. Gerbrandy, 'Het Burgerlijk Wetboek en het administratief recht van 1838 tot heden', in: P. Scholten en E.M. Meijers (red.), 'Gedenkboek Burgerlijk Wetboek 1838-1938', Zwolle 1938, pp. 579-610.

Z. Giacometti, 'Allgemeine Lehren des rechtsstaatlichen Verwaltungsrechts. Allgemeines Verwaltungsrecht des Rechtsstaates', Zürich 1960.

L.J. Giebels, 'Ontwikkeling van het democratisch denken', Democratie; participatie en delegatie, Amsterdam 1987.

O. von Gierke, 'Das Deutsche Genossenschaftsrecht', Bd. II, Berlin 1877.

O. von Gierke, 'Die Genossenschaftstheorie und die deutsche Rechtsprechung', Berlin 1887, Nachdruck Aalen 1963.

J. Gijssels, 'Onherleidbare rechtskringen en rechtswetenschap', Tijdschrift voor Rechtsfilosofie en Rechtstheorie 1980, pp. 42-66.

J.F. Glastra van Loon, 'Dooyeweerd in gesprek met de filosofie', in: J. de Bruijn (red.), 'Dooyeweerd herdacht', pp. 95-114.

R. von Gneist, 'Der Rechtsstaat und die Verwaltungsgerichte in Deutschland', 2. Auflage, Berlin 1879.

B. de Goede, 'Het beheer in het waterstaatsrecht', diss. leiden 1951. 
B. de Goede/M. Troostwijk, 'Het gebruik maken van burgerrechtelijke vormen bij de behartiging van openbare belangen', VAR-preadvies 1956.

B. de Goede, 'De straat', Den Haag 1977.

F.H.M. Grapperhaus, 'Belasting, vrijheid en eigendom', Hoe belastingheffing leidde tot meer zeggenschap voor burgers en meer eenheid tussen staten, Zutphen 1989.

F.H.M. Grapperhaus, 'Alva en de Tiende Penning', Zutphen 1982.

J.L.M. Gribnau, 'De wederkerige rechtsbetrekking als nieuw paradigma', Rechtsfilosofie en rechtstheorie 1993, pp. 87-95.

S. Griffioen, 'Dooyeweerds programma voor de sociale wetenschap', in: H.G. Geerstema e.a. (red.), 'Herman Dooyeweerd 1894-1977. Breedte en actualiteit van zijn filosofie', Kampen 1994, pp. 143-171.

D. Grimm, 'Soziale, wirtschaftliche und politische Voraussetzungen der Vertragsfreiheit', in: 'La formazione storia del diritto moderno in Europa', dl. III, Firenze 1977. pp. 1221-1248.

J.H.P.M. van der Grinten, 'Het Plakkaat van Verlatinge', opgenomen in: dez., 'Verspreide opstellen', Nijmegen-Utrecht 1934, pp. 3-18.

W.C.L. van der Grinten, bewerking van 'Vertegenwoordiging en rechtspersoon", dl. II, 'De rechtspersoon', van C. Asser's Handleiding tot de beoefening van het Nederlandsch Burgerlijk recht', 5e druk, Zwolle 1980.

W.C.L. van der Grinten, 'Vorderingsrecht belangenorganisaties; collectieve acties', De Naamloze Vennootschap 1990, pp. 172-174.

C.A. Groenendijk, 'Bundeling van belangen bij de burgerlijke rechter', diss. Nijmegen 1991, Zwolle 1991.

V. Gsovski, 'Soviet Civil Law', 2 dln, Ann Arbor 1948/1949.

P. Guba, 'Die öffentlichrechtlichen Grundlagen des Wegerechts', Leipzig 1917.

P. de Haan, 'De grond als grensgebied van publiek- en privaatrecht', in: 'Op de grenzen van komend recht', bundel opstellen aangeboden aan prof. mr. J.H. Beekhuis, Deventer/Zwolle 1969 , p. 125 e.v.

P. de Haan/Th. G. Drupsteen/R. Fernhout, 'Bestuursrecht in de sociale rechtsstaat', 2 din, 3e druk, Deventer 1986.

P. de Haan, 'Over de vervlechting van publiek- en privaatrecht', in: H.J.A.M. van Geest, L.J.M. de Leede en A.B. Ringeling (red.), 'Regel en praktijk', Opstellen aangeboden aan prof. mr. S.F.L. baron van Wijnbergen, Zwolle 1979, pp. 39-62.

P. de Haan, 'Vrijheid en aansprakelijkheid van de overheid', BR 1992, pp. 893 e.v.

P. de Haan, Bespreking van H.Ph.J.A.M. Hennekens, 'Openbare zaken naar publiek- en privaatrecht', Zwolle 1993, in: RMTh 1994, pp. 129-135.

H.J. Hamaker, 'De burgerrechtelijke aansprakelijkheid voor overheidshandelingen naar de jongste jurisprudentie van den Hoogen Raad', WPNR 1501, ook opgenomen in: dz., 'Verpreide Geschriften', dl. IV, Haarleim 1912, pp. 173-188.

H.J. Hamaker, 'De tegenstelling van publiek- en privaatrecht', Mededelingen Koninklijke Akademie voor Wetenschappen 1894, ook opgenomen in: dez., 'Verspreide geschriften', dl. VII, Haarlem 1913, pp. 134-163. 
L. Hardenberg, 'De 'eigendom' van de Staat. Regalia en burgerlijk recht', in:

'Ter Regognitie'. Opstellen aangeboden aan prof. mr. H. van der Linden bij zijn afscheid als hoogleraar in de Nederlandse rechtsgeschiedenis aan de Vrije Universiteit, Hilversum 1987, pp. 354 e.v.

M. Hariou, 'Précis de Droit Administratif', 5. druk, Paris 1943.

A.S. Hartkamp, bewerking van 'Verbintenissenrecht', dl. III, 'De verbintenis uit de wet', van C. Asser's Handleiding tot de beoefening van het Nederlandsch Burgerlijk recht', 8e druk, Zwolle 1990.

R.H. Hartog, 'Onrechtmatige overheidsdaden in de Republiek der Verenigde Nederlanden', Deventer 1971.

F.A. Hayek, 'De weg naar slavernij', Amsterdam 1985 (oorspr. uitgave 'The road to serfdom, 1944).

F.A. Hayek, 'The constitution of liberty', 1960, reprint London 1990.

F.A. Hayek, 'Recht, Gesetzgebung und Freiheit', Bd. 3: 'Die Verfassung einer Gesellschaft freier Menschen', München 1991 (oorspr. titel 'Law, Legislation and

Liberty', A new statement of the liberal principles of justice and political economy, 3 Vol., 1982)

E.J.J. van der Heijden, 'Het Burgerlijk Wetboek en het vereenigingsrecht', in: P. Scholten/E.M. Meijers (red.), 'Gedenkboek Burgerlijk Wetboek 1838-1938)', Zwolle 1938, po. 529-557.

K.E. Heinz, 'Staatsziehl Umweltschutz in rechtstheoretischer und verfassungstheoretischer Sicht', Natur und Recht 1994, S. 1-8.

H. Heller, 'Staatslehre', Leiden 1934.

U. Hellmann, 'Die Öffentlichkeitsbeteiligung in vertikal gestuften Zulassungsverfahren für umweltrelevante Grossvorhaben nach deutschem und europãischem Recht', Münster 1992.

H. Henkel, 'Einführung in die Rechtsphilosophie', 2. Auflage, München 1977.

H.Ph.J.A.M. Hennekens, 'De openbare weg en het privaatrecht', diss. Nijmegen 1977, Zwolle 1977.

H.Ph.J.A.M. Hennekens/H.J.A.M. van Geest/R. Fernhout, 'Decentralisatie', 2e druk, Nijmegen 1993.

H.Ph.J.A.M. Hennekens, 'Openbare zaken naar publiek- en privaatrecht', Zwolle 1993.

H.Ph.J.A.M. Hennekens, 'De Kaderwet bestuur in verandering', Gst. 1994, nr. 6997.1

H.Ph.J.A.M. Hennekens, 'De bestuursovereenkomst op de juridische korrel', in:

H.J.A.M. van Geest e.a. (red.), 'Bestuursrecht aan de horizon', Opstellen bij gelegenheid van de $80 \mathrm{e}$ verjaardag van prof. mr. S.F.L. baron van Wijnbergen, Zwolle 1994, pp. 53-78.

B. Hermesdorf, 'Schets der uitwendige geschiedenis van het Romeinse recht', 7e druk, Utrecht 1971.

W. Hins, 'Uitingsvrijheid voor de Staat?!', Mediaforum 1993, p. 37 e.v.

E.M.H. Hirsch Ballin. 'Het grondrecht op vrijheid en de wet', Alphen a/d Rijn 1989.

E.M.H. Hirsch Ballin, 'Het grondrecht op behoorlijke rechtspraak in het Nederlandse administratieve recht', HNJV 1983-1, 2e stuk. 
Th. Hobbes, 'Leviathan or the Matter, Form and Power of a Commonwealth Ecclesiastical and Civil', Oxford 1965.

H.R. Hoetink, 'Over het verstaan van vreemd recht', oratie Batavia 1929, ook opgenomen in: dez., 'Rechtsgeleerde opstellen', Alphen a/d Rijn 1949, pp. 13-29.

J. van der Hoeven, 'De magische lijn. Verkenningen op de grens van publiek- en privaatrecht', in: 'Honderd jaar rechtsleven', feestbundel NJV 1970, 201-219, ook opgenomen in: 'Staatsrecht en bestuursrecht', Opstellen van mr. J. van der Hoeven, Zwolle 1984.

J. van der Hoeven, 'Publiek- en privaatrecht', in: 'Osmose tussen publiek- en privaatrecht', bijzonder nummer Ars Aequi, jrg. 1987 (jrg. 36), pp. 277-280.

J. van der Hoeven, 'De drie dimensies van het bestuursrecht', VAR-geschrift 100 , Alphen a/d Rijn 1989.

J. van der Hoeven, Interventie Vergadering Vereniging voor Administratief Recht 1989 over 'Overheidsaansprakelijkheid', VAR-geschrift 103, Alphen a/d Rijn 1990, pp. 12-16.

J. van der Hoeven, Interview met Van der Hoeven in: J. van Dunné e.a. (red.), 'Ex tunc, ex nunc', Zwolle 1990, pp. 261-298.

Ph.A.N. Houwing, 'Subjectief Recht, Rechtssubject, Rechtspersoon', Zwolle 1939.

F.J.A. Huart, 'Misbruik van burgerlijk recht door de administratie', in: 'Staatsrechtelijke opstellen, aangeboden aan prof. H. Krabbe', dl. II, Den Haag 1927, pp. 176 e.v., ook opgenomen in: dez., 'Verspreide Geschriften', Alphen a/d Rijn 1947, pp. 13-29.

P.W.A. Immink, "'Eigendom" en "heerlijkheid". Exponenten van tweeërlei maatschappelijke structuur', Tijschrift voor Rechtsgeschiedenis, dl. 27 (1959), pp. 36-74, ook opgenomen in: N. Algra (red.), 'Verspreide geschriften van prof.mr. P.W.A. Immink', Groningen 1967, pp. 55-84.

J. Isensee, 'Der Dualismus von Staat und Gesellschaft', in: E.-W. Böckenförde (Hrsg.), 'Staat und Gesellschaft', Darmstadt 1976, S. 317 ff.

R. Jacquelin, 'Le droit social et la réparation des dommages en régions envahies', Paris 1917.

E.H. 's Jacob, 'De Staat als zuivere vorm des menschen', Zwolle 1946.

E.H. 's Jacob, 'Het masker der rechtspersoonlijkheid', WPNR 4701 (1961), pp. 534-540.

H.H. Jakobs, 'Karl Larenz und der Nationalsozialismus'. JuristenZeitung 1993, S. 805-815.

B. Jeand'Heur, 'Von der Gefahrenabwehr als staatliche Angelegenheit zum Einsatz privater Sicherheitskräfte', Verwaltungsarchiv 1994, S. 107-136.

G. Jellinek, 'System der subjektieven öffentlichen Rechte', 2. Auflage, Tübingen 1919.

G. Jellinek, 'Allgemeine Staatslehre', 3. Auflage, 1914, 7. Neudruck, Bad Homburg 1960.

G. Jèze, 'Les principes généraux du droit administratif', dl. III, 3e druk, Paris 1925.

J.P. de Jong, 'Bestuursrecht van vreemde herkomst', Een onderzoek naar de bronnen en grondslagen van een drietal centrale elementen van de Nederlandse bestuursrechtstheorie', diss. Tilburg 1988, Zwolle 1988. 
L. Kalsbeek, 'De wijsbegeerte der wetsidee', 5e druk, Amsterdam 1983.

J. van Kan, 'Het Burgerlijk Wetboek en de Code Civil', in: P. Scholten/E.M. Meijers (red.), 'Gedenkboek Burgerlijk Wetboek 1838-1938)', Zwolle 1938, pp. 243-276.

A. Kaufman, 'Durch Naturrecht und Rechtspositivismus jur juristischen Hermeneutik', Juristenzeitung 1975, S. 337-341.

I. Kant, 'Grundlegung zur Metaphysik der Sitten', 1785, in: Werkausgabe Immanuel Kant in 12 Bănden, Frankfurt aM 1974.

1. Kant, 'Over de gemeenplaats: dat kan in theorie wel juist zijn, maar deugt niet voor de praktijk', Kampen 1989 (Ned. vertaling in bloemlezing, samengesteld en ingeleid door B. Delfgauw, van 'Über den Gemeinspruch: Das mag in der Theorie richtig sein, taugt aber nicht für die Praxis', 1793)

H. Kelsen, 'Allgemeine Staatslehre', Wien 1925.

H. Kelsen, 'Reine Rechtslehre', 2. Auflage, Wien 1960.

B. Kempen, 'Die Formenwahlfreiheit der Verwaltung', München 1989.

O.R. Kissel, 'Gerichtsverfassungsgesetz. Kommentar', München 1981.

G. Kleinheyer, zie H. Conrad

B. van Klink/P. van Seters/W. Witteveen (red.), 'Gedeelde normen. Gemeenschapsdenken in het recht', Zwolle 1993.

M. Kobussen, 'De vrijheid van de overheid', diss. Tilburg 1991, Zwolle 1991

M. Kobussen, zie J.A.F. Peters

K. Kodal/H. Krämer, 'Strassenrecht', 4. Auflage, München 1985.

A.K. Koekkoek, 'Bijdrage tot een christen-democratische staatsleer', oratie Tilburg 1982, Deventer 1982.

A.K. Koekkoek, 'Hoe ver kan de staat gaan met het sturen van de samenleving', Tijdschrift voor Rechtsfilosofie en Rechtstheorie 1983, pp. 7-33.

A.K. Koekkoek, 'De betekenis van grondrechten voor het privaatrecht', WPNR 5742 , 5743, 5744 (1985), pp. 385-389, 405-412, 425-434.

A.K. Koekkoek, 'De onderlinge verhouding van grondrechten', preadvies Calvinistische Juristenvereniging mei 1985.

A.K. Koekkoek, 'Overheidsorganisatie en overheidszorg: een rechtsvergelijkende verkenning', in: A.M.J. Kreukels/J.B.D. Simonis (red.), 'Publiek domein. De veranderende balans tussen staat en samenleving', Meppel/Amsterdam 1988, pp. 30-56.

W. Konijnenbelt, zie H.D. van Wijk

P.C. Kop, 'Legisme en privaatrechtswetenschap'. Legisme in de Nederlandse privaatrechtswetenschap in de negentiende eeuw, Deventer 1982.

E.J. Korthals Altes, 'De staatsaansprakelijkheid volgens de rechtspraak van den Conseil d'État in Frankrijk', diss. UvA 1923

C.A.J.M. Kortmann, 'Égalité en défense', diss. Nijmegen 1971, Alphen a/d Rijn 1971.

C.A.J.M. Kortmann, 'Constitutioneel recht', Deventer 1990.

E.H. Kossmann, 'Politieke theorie en geschiedenis', Verspreide opstellen en voordrachten, Amsterdam 1987.

H. Krabbe, 'Administratieve rechtspraak', Bijdrage, Groningen 1901.

H. Krabbe, 'Die Lehre der rechtssouveränität', Groningen 1906 
H. Krabbe, Interventie vergadering Nederlandse Juristenvereniging 1914, HNJV 1914-II, p. 132.

H. Krabbe, 'De moderne Staatsidee', Den Haag 1915.

H. Krabbe, 'Kritische Dahrstellung der Staatslehre', Den Haag 1930.

H. Krämer, zie K. Kodal

R. Kranenburg, 'Publiek- en privaatrecht', in: 'Staatsrechtelijke opstellen, aangeboden aan prof. H. Krabbe', dl. II, Den Haag 1927, pp. 60 e.v.

R. Kranenburg, 'De ontwikkeling der rechtspraak betreffende de staatsaansprakelijkheid', in: 'Studiên over Recht en Staat', 3e druk, Haarlem 1946, pp. 190-225.

R. Kranenburg, 'De grondslagen der rechtswetenschap', Juridische Kennisleer en Methodologie, 4e druk, Haarlem 1952.

R. Kranenburg, 'Het Nederlandsch Staatsrecht", 7e druk, Haarlem 1951.

W. Krawietz, 'Recht ohne Staat', Spielregeln des Rechts und Rechtssystem in Normenund Systemtheoretischer Perspektive', Rechtstheorie 1983, S. 81-133.

J.H. van Kreveld, 'In hoeverre mogen en moeten bij het verlenen van subsidie voorwaarden worden gesteld', preadvies NJV 1977, CVII, dl. 1, 2e stuk, Zwolle 1977, pp. 59-153.

J.H. van Kreveld, 'De wisselwerking tussen publiek- en privaatrecht. Een uitdaging yoor juristen van beide zijden', in: J.H.F. peters/M.H. Kobussen (red.), 'Bestuursrecht en nieuw BW', Zwolle 1988.

H. Krüger, 'Das besondere Gewaltverhältnis', Veröffentlichungen der Vereinigung Deutscher Staatsrechtlehrer 1959, S. 109 ff.

H. Krüger, 'Allgemeine Staatslehre', 2. Auflage, Stuttgart/Berlin/Köln/Mainz 1966.

A. Kruisinga, 'De vervuiler betaalt?', Recht en Kritiek 1994 (jrg. 20), pp. 27-45.

T.S. Kuhn, 'De structuur van wetenschappelijke revoluties', Meppel 1987 (oorspr, titel 'The structure of scientific revolutions', Chicago 1962).

A.J.M. Kunst, 'Historische ontwikkeling van het recht', dl. I, Zwolle 1967.

K. Larenz, 'Rechts- und Staatsphilosophie der Gegenwart', 2. Auflage, Berlin 1935.

C. Lefort, 'Essay sur le politique', Paris 1986.

C. Lefort, 'Het democratisch tekort: Over de noodzakelijke onbepaaldheid van de democratie', Amsterdam-Meppel 1992 (Ned. vertaling van een aantal opstellen van Lefort).

E.C.H.J. van der Linden/A.Q.C. Tak (red), 'Eenzijdig en wederkerig', Deventer 1995.

L. Lietaert Peerbolte, 'De Woningwet', 2e druk, Alphen a/d Rijn 1935.

G. Lock en M. Plon, 'Frederik de Grote en Machiavelli', Wijsgerig Perspectief 1982/3, pp. 82-90.

J. Locke, 'Two treaties of civil government', 1690, ed. London 1978.

J.H.A. Logemann, 'Over de theorie van een stellig staatsrecht', Leiden 1948.

J.H.A. Lokin/W.J. Zwalve, 'Hoofdstukken uit de Europese codificatiegeschiedenis', 2e druk, Groningen 1990. 
D. Loose, 'Van de ene democratie naar de andere. Over vrijheid en gelijkheid in de politieke filosofie van Alexis de Tocqueville en Claude Lefort', in: L. Heyde/H. Visser (red.), 'Filosofie en Democratie', Tilburg 1990.

F.J.W. Löwenstein, 'Het rechtspersonenrecht', dl. 1A van Pitlo's Het Nederlands Burgerlijk Wetboek, 2e druk, Arnhem 1986.

D.A. Lubach, 'Convenanten in de ruimtelijke ordening en volkshuisvesting', NJB 1993, p. 537 e.v.

D.A. Lubach, zie A.R. Bloembergen.

H.G. Lubberdink, 'De Awb: hoedster van de individuele vrijheid?', in: J.L. van Boxum e.a. (red.), 'Aantrekkelijke gedachten', Beschouwingen over de Algemene wet bestuursrecht, Deventer 1993, pp. 131-139.

G.E. van Maanen, Onrechtmatige daad'. Aspekten van de ontwikkeling en struktuur van een omstreden leerstuk, diss. Groningen 1986, Deventer 1986.

G.E. van Maanen, 'Publiek domein en twee-wegenleer'. Opmerkingen naar aanleiding van het arrest Staat/Windmill, Recht en Kritiek 1990 (jrg. 16), pp. 195-209.

G.E. van Maanen, 'Publiek domein en het belang van de overheid bij bodemsanering', oratie Maastricht 1990, Deventer 1990.

H.Th.J.F, van Maarseveen, 'Een opmerking over de onrechtmatige overheidsdaad', NJB 1954, pp. 914-920.

N. Machiavelli, 'De Heerser', Amsterdam 1876 (Nederlandse vertaling door F, van Dooren van 'Il Principe', 1532)

C.B. MacPherson, 'The political Theory of Possessive Individualism: Hobbes tot Locke', Oxford 1962.

C.B. Macpherson, 'Property. Mainstream and critical positions', Oxford 1978.

R. McCarthy, zie J.W. Skillen

R.M. van Male, 'Rechter en bestuurswetgeving', diss. Tilburg 1988, Zwolle 1988.

R.M. van Male, 'Onvoltooid recht', Over rechtsbetrekking, bestuursrecht en bestuursprocesrecht, oratie Rotterdam 1993, Zwolle 1993.

R.M. van Male, zie H.D. van Wijk.

J.B. Manger, 'Thorbecke en de historie'. Bijdragen tot de kennis van het Nederlandse Liberalisme, 2e druk, Utrecht 1986.

R. Mann, 'Die Anerkennungsfähigkeit von US-amerikanischen 'class-action'-Urteilen', Neue Juristische Wochenschrift 1994, S. 1187-1189.

W. Martens, zie H.-U. Erichsen

Maunz/Dürig/Herzog/Scholz, 'Grundgesetz-Kommentar', Losbelatt, München.

H. Maurer, 'Allgemeines Verwaltungsrecht', 9. Auflage, München 1994.

O. Mayer, 'Deutsches Verwaltungsrecht', 2 Bănde, Leipzig 1895/1896 (3. Auflage, Berlin 1924).

K. Mannheim, 'Man and society in an age of reconstruction', London 1940.

E.M. Meijers, 'De onrechtmatige overheidsdaad', dl. II, WPNR 2884 (1925), pp. 241-244. 
E.M. Meijers, 'Belastingen als rechtsbegrip', in: 'Tractatus Tributarii', Opstellen aangeboden aan prof. mr. P.J.A. Adriani, Haarlem 1949, pp. 1-28.

E.M. Meijers, 'De algemene begrippen van het burgerlijk recht', 2e druk, Leiden 1958.

F. Meinecke, 'Die Idee der Staatsräson in der neuen Geschichte', Leipzig 1924, Neudruck München 1963.

J.P.A. Mekkes, 'Proeve eener critische beschouwing van de ontwikkeling der humanistische rechtsstaatstheorieēn', diss. VU Amsterdam 1940, Utrecht/Rotterdam 1940.

D.H.M. Meuwissen, 'Recht en vrijheid', Inleiding in de rechtsfilosofie, Utrecht/ Antwerpen 1981.

F.C.M.A. Michiels, zie P.J.J. van Buuren

L. Michoud, 'La théorie de la personnalité morale', dl. II, Paris 19909.

R. von Mohl, 'Die Polizeiwissenschaft nach den Grundsatzen des Rechtsstaates', 2 Bde, Tübingen 1832-1833.

W.L.P.A. Molengraaff, 'De oneerlijke concurrentie voor het Forum van den Nederlandschen rechter, tevens een bijdrage tot de uitlegging van art. $1401 \mathrm{BW}$ en van de wet op de handels- en fabrieksmerken', RM 1887, pp. 373-435, ook opgenomen in: 'Molengraaf Bundel', Keuze uit de verpreide geschriften van Mr. W.L.P.A. Molengraaff, Zwolle 1978, pp.

E. Molitor, 'Über öffentliches Recht und Privatrecht', Karlsruhe 1949.

J.Ph. de Monté Ver Loren, 'Hoofdstukken uit de ontwikkeling der rechterlijke organisatie in de Noordelijke Nederlanden tot de Bataafse omwenteling', bewerkt door J.E. Spruit, 5e druk, Deventer 1972.

Nederlands Instituut voor Volkshuisvesting en Stedebouw, 'Rapport van de commissie, ingesteld door den stedebouwkundigen Raad van het Nederlands Instituut voor Volkshuisvesting en Stedebouw, tot onderzoek van de vraag, of en in hoeverre privaatrechtelijke regeling van bebouwing geoorloofd moet worden geacht', afgedrukt in Gemeente bestuur 1934, pp. 351-378.

P.L. Nève, 'Het Rijkskamergerecht en de Nederlanden', Competentie-territoir-archieven, diss. Nijmegen 1972, Assen 1972.

P. Nicolaï, 'De rechtspersoon in artikel 7 Wet Arob', NJB 1988, pp. 183-187.

B.W.M. Nieskens-Isphording, 'Het fait acoompli in het vermogensrecht', diss. Tilburg 1991, Deventer 1991.

J.H. Nieuwenhuis, 'Drie beginselen van contractenrecht', Deventer 1979.

J.H. Nieuwenhuis, 'Welke belangen worden beschermd door art. 1401 BW?', WPNR 5821 (1987), pp. 145 e.v.

C.J.J.C. van Nispen, 'De kinderjaren van de collectieve actie', in: 'Verdediging van collectieve belangen via de rechter', Zwolle 1988.

W.C.D. Olivier, 'Proeve over de beperkingen van den eigendom door het politie-regt', diss. Leiden 1847.

J. Oppenheim, 'Het Nederlandsche Gemeenterecht', 2 delen, 5e druk, Haarlem 1913. 
F. Ossenbühl, 'Der öffentlichrechtliche Erstattungsanspruch', Neue Zeitschrift für Verwaltungsrecht 1991, S. 513-522.

J.P. Oud, 'Het Constitutionele Recht van het Koninkrijk der Nederlanden', 2 dln, Zwolle 1956-1959.

J.K. Oudendijk, 'Het 'contract' in de wordingsgeschiedenis van de Republiek der Verenigde Nederlanden', Leiden 1961.

G. Overkleeft-Verburg, zie F.H. van der Burg

H.-J. Papier, 'Recht der öffentlichen Sachen', 2. Auflage, Berlin/New York 1984.

H.-J. Papier, 'Empfehlen sich ergănzende gesetzliche oder untergesetzliche Regelungen der Altlasten, und welchen Inhalt sollten sie haben', JuristenZeitung 1994, S. 810-822. H.-M. Pawlowski, 'Allgemeiner Teil des BGB', 2. Auflage, Heidelberg 1983.

J.A.F. Peters/M.H. Kobussen (red.), 'Bestuursrecht en Nieuw BW', Zwolle 1988. Philippus de Leyden, 'De cura reipulicae et sorte principantis', ed. R. Fruin en P.C. Molhuysen, Den Haag 1900.

M. Plon, zie G. Lock

J. van der Poel, 'Rondom compositie en compromis', diss. Utrecht 1942.

J. van der Poel, Interventie Vergadering Vereniging voor Administratief Recht 1943 over 'Publiekrechtelijke overeenkomsten', VAR-geschrift IX, Haarlem 1943, pp. 32-41.

J. van der Poel, 'Een nieuw kleed voor het fiscale strafrecht', Tijdschrift voor Strafrecht 1951 (jrg. LX), p. 181 e.v.

G.A. van Poelje, 'Osmose. Een aanteekening over het elkander doordringen van de beginselen van openbaar bestuur en particulier beheer', Alphen a/d Rijn 1931

(2e druk 1959).

J.M. Polak, 'Inleiding tot het Nederlands rechtspersonenrecht', Groningen 1960.

M.V. Polak, 'Pluralistische staatsleer', in: 'Staatswetenschappelijke opstellen aangeboden aan prof.mr. R. Kranenburg', Alphen a/d Rijn 1949, pp. 92-110.

R.J. Polak, 'Aanspraak en aansprakelijkheid uit onrechtmatige daad', diss. UvA 1949.

E. Poortinga, 'De scheiding tussen publiek- en privaatrecht bij Johan Rudolph Thorbecke (1798-1872), Theorie en toepassing, diss. Utrecht 1987, Nijmegen 1987.

E. Poortinga, 'De figuur van de onrechtmatige daad jegens de overheid en art. 21 Interimwet Bodemsanering', AAe 1987, pp. 319-327.

J.E.M. Portalis, 'Inleidingsrede', vertaald, toegelicht en besproken door B. van Roermund/F. Tanghe/H. Willekens, Zwolle 1994 (oorspr. titel: 'Discours préliminaire', $1800)$.

C.W. van der Pot, 'Handboek van het Nederlande staatsrecht', 6e druk, Zwolle 1957.

C.W. van der Pot, 'Handboek van het Nederlande staatsrecht', bewerkt door A.M. Donner, 9e druk, Zwolle 1972.

C.W. van der Pot, 'Handboek van het Nederlande staatsrecht', bewerkt door A.M. Donner, 1le druk, Zwolle 1983.

C.W. van der Pot, 'Wet en Algemeene maatregel van bestuur in het Nederlandsche Staatsrecht', Leiden 1916.

L. van Praag, 'Op de grenzen van publiek- en privaatrecht', Den Haag 1923. 
M.M. van Praag, 'Publiek recht contra privaatrecht', WBA 1932, pp. 317-327.

M.M. van Praag, 'Algemene rechtsleer', Alphen a/d Rijn 1949.

M.M. van Praag, 'Algemeen Nederlands Administratief Recht', Den Haag 1950.

M.M. van Praag, 'Het vraagstuk der souvereiniteit', RMTh 1951, pp. 115-125.

W.F. Prins, 'Verkenningen in het grensgebied van bestuursrecht en strafrecht',

RMTh 1958, pp. 133 e.v., p. 227 e.v.

W.F. Prins, 'Dient de wet regelen te bevatten inzake het toekennen van rechtspersoonlijkheid aan overheidsinstellingen, -diensten en -bedrijven, en, zo ja, welke?', preadvies NJV 1957, pp. 1-62.

J.B.V. Proudhon, 'Traité du domaine public ou de la distinction des biens', $2 \mathrm{e}$ druk, bewerkt door V. Dumay, Dijon 1843-1845.

A. van der Putte, 'Macht en maatschappij. Cl. Lefort over democratie en totalitarisme', Tijdschrift voor Filosofie 1987, pp. 396-433.

G. Püttner, 'Die öffentlichen Unternehmen', 2. Auflage, Stuttgart/München/Hannover 1985.

G. Radbruch, 'Vorschule der Rechtsphilosophie', 2. Auflage, göttingen 1959.

G. Radbruch, 'Rechtsphilosophie', 8. Auflage, herausgegeben von E. Wolf und H.-P. Schneider, Stuttgart 1973.

K. Raes, 'Rechtsbeginselen en de morele eenheid van het recht', bijzonder nummer Ars Aqui mei 1991 over 'Rechtsbeginselen', pp. 773-784.

C.G. von Reeken, 'Uitoefening van private regten op zaken met een publieke bestemming', Themis 1893, pp. 1-66.

N. Reich, 'Sozialismus und Zivilrecht', Frankfurt aM 1972.

J.V. Rijperda Wierdsma, 'Politie en Justitie'. Een studie over de Hollandse staatsbouw tijdens de Republiek, diss. Leiden 1937.

J.V. Rijperda Wierdsma, 'Over het begrip 'politie', in: 'Rechtshistorische opstellen aangeboden aan A.S. de Blécourt', Groningen/Batavia 1939, pp. 155-168.

H. Rittstieg, 'Eigendtum als Verfassungsproblem'. Zu Geschichte und gegenwart des bürgerlichen Verfassungsstaates, Darmstadt 1976.

N.H.M. Roos, 'Enige opmerkingen over de grondslagenproblematiek in de rechtsfilosofie van H.J. van Eikema Hommes', Tijschrift voor Rechtsfilosofie en Rechtstheorie 1980, pp. 26 e.v.

N.H.M. Roos, 'Herman Dooyeweerd', in: T.J. Veen en P.C. Kop (red.), 'Zestig juristen in Nederland'. Bijdragen tot een beeld der Nederlandse rechtswetenschap', Zwoll 1987, pp. 397-402.

J.-J. Rousseau, 'Het maatschappelijk verdrag', Amsterdam/Antwerpen 1947 (oorspr. titel 'Du contrat social, ou principes du droit politique', 1762).

H.J. de Ru, 'Staatsbedrijven en staatsdeelnemingen', diss. VU Amsterdam 1981, Nijmegen 1981.

H.H. Rupp, 'Die Unterscheidung von Staat und Gesellschaft', in: J. Isensee/P. Kirchhof (Hrsg.), 'Handbuch des Staatsrechts der Bundesrepublik Deutschland', Bd. I, Heidelberg 1987, S. 1187-1223. 
R. Samwalt, 'Die Reform des Grundgesetzes', Neue Juristische Wochenschrift 1994, S. 3313-3320.

F.C. von Savigny, 'System des heutigen Römischen Rechts", Bd. II, Berlin 1840.

A.F. de Savornin Lohman, 'Onze Constitutie', 4e uitgave, Utrecht 1926

S. Schama, 'Burgers', Een Kroniek van de Franse Revolutie, Amsterdam 1989 (oorspr. titel 'Citizens', New York 1989)

F.G. Scheltema, 'De zaken der openbare lichamen', in: C.W. van der Pot e.a. (red.), 'Nederlandsch Bestuursrecht', Alphen a/d Rijn 1932, pp. 115-134,

C.H.J. Schepel, 'Wegenrecht in Nederland', diss. Groningen 1895.

O. van Schilfgaarde, 'Rechtspersonen. Algemeen deel', 2e druk, Deventer 1979

D. Schindler, 'Verfassungsrecht und soziale Struktur', Zürich 1944.

H. Schlosser, 'Grundzüge der Neueren Privatrechtsgeschichte', 5. Auflage, Heidelberg 1983.

C. Schmitt, 'Der Hüter der Verfassung', Tübingen 1931.

C. Schmitt, 'Nationalsozialismus und Rechtsstaat', Juristische Wochenschrift 1934, S. $717 \mathrm{ff}$.

W. Schmitt Glaeser, zie O. Tschira

G.J. Scholten/D.F. Scheltens/H.J. van Eikema Hommes, 'Rechtsbeginselen', Zwolle 1980.

P. Scholten, 'Algemeen Deel', van: Mr. C. Asser's Handleiding tot de beoefening van het Nederlandsch Burgerlijk recht', 3e druk, Zwolle 1974.

J. Schwarze, 'Europäisches Verwaltungsrecht', Bd. II, Baden-Baden 1988.

H. Sendler, 'Friedrich der Grosse und der Müller Arnold', Juristische Schulung 1985, S. $756 \mathrm{ff}$.

J.B. Sens, 'Eigendom van zaken voor den openbaren dienst bestemd', diss. Nijmegen 1934.

J.B. Sens, 'Geld breekt wet', TvO 1968, pp. 146-149.

P. van Seters, zie B. van Klink

H. Simon, 'Publiekrecht of privaatrecht'. Een geschiktheidsonderzoek aan de hand van het nutsmaximalisatiebeginsel toegespitst op het gebruik van het privaatrecht door het bestuur, diss. VU Amsterdam 1993, Zwolle 1993.

H. Simon/A.Q.C. Tak, 'Het BW als zwart gat', Nederlands Tijdschrift voor Burgerlijk Recht 1994/8, pp. 173-180.

H. Simon, 'Publiekrecht en burgerlijk recht', WPNR 6156 (1994), pp. 753-764.

H. Simon, 'De publiekrechtelijke overeenkomst', Tijdschrift voor Ambtenarenrecht 1994, pp. 612 e.v.

H. Simon, 'Financiële voorwaarden en voorschriften', NTB 1994, pp. 149-164.

J.W. Skillen/R. McCarthy, 'Political Order and the Plural Structure of Society', Georgia 1991.

W.J. Slagter, 'De rechtsgrond van de schadevergoeding bij onrechtmatige daad', Den Haag 1952.

R. Smend, 'Staatsrechtliche Abhandlungen', 2. Auflage, Berlin 1968. 
A. Soeteman, 'Hercules aan het werk. Over de rol van rechtsbeginselen in het recht', bijzonder nummer Ars Aqui mei 1991 over 'Rechtsbeginselen', pp. 744-756.

F.W. ter Spill/A.Q.C. Tak, 'Onwetmatig bestuur', VAR-geschrift LXXXVI, Alphen a/d Rijn 1981.

J.E. Spruit, zie J. Ph. de Monté Ver Loren.

F.J. Stahl, 'Die Philospohie des Rechts', Bd. 2.2, 'Rechts- und Staatslehre auf der Grundlage chritslicher Weltanschauung', Heidelberg 1846.

L. von Stein, 'Geschichte der sozialen Bewegung in Frankreich von 1789 bis auf unsere Tage', Leipzig 1850, neudruck Darmstadt 1959.

L. von Stein, 'Zur preussischen Verfassungsfrage', 1852, Neudruck Berlin 1941.

L. von Stein, 'Die Verwaltungslehre', 2. Auflage, Stuttgart 1869.

L. von Stein, 'Gegenwart und Zukunft der Rechts- und Sozialwissenschaften Deutschlands', Stuttgart 1876.

J.R. Stellinga, Bespreking van M.M. van Praag, 'Algemene rechtsleer', Alphen a/d Rijn 1949, in TvO 1949, p. 549.

J.R. Stellinga, 'Bevoegdheden en verplichtingen, subjectieve rechten en schulden van de overheid en van de onderdanen', RMTh 1949, pp. 445-454.

J.R. Stellinga, 'Grondtrekken van het Nederlands staatsrecht', Zwolle 1953.

J.R. Stellinga, 'De overgang van rechten en verplichtingen uit administratieve rechtsbetrekkingen', TvO 1958, pp. 241-243.

J.R. Stellinga, 'Grondtrekken van het Nederlands Administratiefrecht', 2e druk, m.m.v. B.J. van der Net, Zwolle 1973.

J. Stoop, zie H.D. Stout.

F.A.M. Stroink, 'Het leerstuk der deconcentratie', diss. Utrecht 1978, Den Haag 1978.

F.A.M. Stroink/J.G. Steenbeek, 'Inleiding in het staats- en administratief recht', 3e druk, Alphen a/d Rijn 1989.

H.D. Stout/J. Stoop, 'Het falen van de wet. Een inleiding tot het autopoietische denken van Gunther Teubner' en 'Aotopoiese aan de Maas' (vraaggesprek met Teubner), RegelMaat 1991, pp. 3/4, 5-9.

H.D. Stout/J. Stoop, Bespreking van G. Teubner, 'Recht als autopoietisches System', RegelMaat 1991, pp. 28-31.

H.D. Stout, 'De betekenissen van de wet', diss. UvA 1994, Zwolle 1994.

A.H.H. Struycken, 'Het Staatsrecht van het Koninkrijk der Nederlanden', 2e druk, Arnhem 1928.

A.H.H. Struycken, 'Het wetsbegrip', in: 'Verzamelde staats- en administratiefrechtelijke opstellen', Arnhem 1918, pp. 61-69.

Z. Szirmai, 'Schtes van het Sovjet-Russische Eigendomsrecht', RMTh 1957, pp. 265-281.

A.Q.C. Tak, 'Overheidsbestuur en privaatrecht', Alphen a/d Rijn 1978.

A.Q.C. Tak, 'Drie magische lijnen?', in: Osmose tussen publiek- en privaatrecht, bijzonder nummer Ars Aequi 1987 (jrg. 36), pp. 281-290. 
A.Q.C. Tak/R.E. Bakker, 'De centrale rol van het willekeurverbod bij de toetsing van overheidshandelen', in A.W. Heringa/N. Verheij (red.), 'Publiekrechtelijke bewegingen', Deventer 1990, pp. 205-218.

A.Q.C. Tak, 'Publiek domein, overheidscontract en rechterlijke wetshandhaving', NTB 1990, pp. 198 e.v.

A.Q.C. Tak, 'Overheid en Burgerlijk Wetboek'. Naar een invullende rechtsleer, Recht en Kritiek 1993 (jrg. 19), pp, 174-190.

A.Q.C. Tak/J.M.H.F. Teunissen, 'Wie zorgt er voor de rechtsstaat? Een voortgezet debat', Recht en Kritiek 1994 (jrg. 20), pp. 340-354.

A.Q.C. Tak, 'De Algemene wet bestuursrecht. Het nieuwe bestuursprocesrecht', $2 \mathrm{e}$ druk, Zwolle 1993.

A.Q.C. Tak, zie E.C.H.J. van der Linden

A.Q.C. Tak, zie H.J. Simon

A.Q.C. Tak, zie F.W. ter Spill

A.Q.C. Tak, zie J.M.H.F. Teunissen

J.L. Talmon, 'The origins of totalitarian democracy', London 1952.

J.L. Talmon, 'The myth of the nation and the vosion of revolution', London 1981.

P. Tessier, 'De la Responsabilité de la Puissance Public', Paris 1909.

G. Teubner, 'Reflexief recht: de kracht van niet-statelijk recht', in: N.J.H. Huls/

H.D. Stout (red.), 'Reflexies op reflexief recht', Zwolle 1992, pp. 71-84.

J.M.H.F. Teunissen/A.Q.C. Tak, 'Recht ist, war der Umwelt nützt?'. Over zorgplichtbepalingen, civiele acties en tweewegenleer. Een overdenking n.a.v. de opneming van een zorgplichtbepaling in de Wet milieubeheer, NJB 1994, pp. 605-616.

J.M.H.F. Teunissen, zie A.Q.C. Tak

J.J.R. Thorbecke, 'Aantekening op de Grondwet', 2e herziene uitgave, 2 dln, Amsterdam $1841 / 1843$.

A. de Tocqueville, 'De democratie in Amerika', Kampen 1990 (Ned. vertaling in bloemlezing, samengesteld en ingeleid door J.J.M. de Valk, van 'De la démocratie en Amérique', 2 dln, 1835/1840).

A. de Tocqueville, 'Over de Franse Revolutie', Kampen 1988 (Ned. vertaling in bloemlezing, samengesteld en ingeleid door J.J.M. de Valk, van 'L'Ancien Régime et la Révolution', 1856).

F. Tönnies, 'Gemeinschaft und Gesellschaft: Grundbegriffe der reinen Soziologie', 1887, Neudruck Berlin 1973.

M. Trappenburg, zie P. van den Berg.

M. Troostwijk, zie B. de Goede.

O. Tschira/W. Schmitt Glaeser, 'Verwaltungsprozessrecht', 9. Auflage, Stuttgart/ München/Hannover 1988.

R.M. Unger, 'Law in Modern Society', Toward a Criticism of Social Theory, New York 1976. 
W.G. Vegting, 'Publiek domein en zaken buiten den handel', Alphen a/d Rijn 1946.

W.G. Vegting, 'Plaats en aard van het administratiefrecht', oratie UvA 1946, Alphen a/d Rijn 1946.

W.G. Vegting, 'Het Algemeen Nederlands Administratief Recht', 2 dln, 1954/1957.

G. Verburg, 'De vrijwillige zaakwaarneming', diss. VU Amsterdam 1949.

M.E. Verburg, 'Herman Dooyeweerd', Grenzen van het theoretisch denken, Baarn 1986.

M.J.P. Verburgh, 'Privaatrecht en kollektief belang', oratie Utrecht 1974, $2 \mathrm{e}$ druk, Zwolle 1975.

N. Verheij, 'Onder dexel van politie', Het Nederlandse bestuursrecht onder het EVRM, in: A.W. heringa e.a. (red.), '40 Jaar Europees Verdrag voor de Rechten van de Mens', Leiden 1990, pp. 225-248.

P. Ver Loren van Themaat, 'Economisch recht, sociaal recht en economische orde', Alphen a/d Rijn 1982.

J.M. Verschuuren, 'Wettelijke algemene zorgplichten in het milieurecht', in: C. Backx e.a., 'Recht doen door wetgeving', opstellen over wetgevingsvraagstukken aangeboden aan E.M.H. Hirsch Ballin, Zwolle 1990, pp. 419-430.

J.M. Verschuuren, 'Het grondrecht op bescherming van het leefmilieu', diss. Tilburg 1993. Zwolle 1993.

R. Victor, 'Rechtsstaat en welvaartsstaat bij Robert von Mohl', in: 'Album Professor

Fernand van Goethem', Antwerpen 1964, pp. 623-636.

M. de Villiers, 'Le principe d'égalité dans la jurisprudence du Conseil Constitutionnel', Revue Administrative 1984, p. 39 e.v.

H. Vos, 'Publiek domein', WGB 1931, pp. 61 e.v., ook opgenomen in: 'Uit de geschriften van mr. H. Vos', Alphen a/d Rijn 1933, pp. 128-134.

H. Vos, 'Overheidsrecht krachtens overeenkomst', WGB 1933, p. 97 e.v., ook opgenomen in: 'Uit de geschriften van mr. H. Vos', Alphen a/d Rijn 1933, pp. 84-87.

C.W. de Vries, 'Het arrest van den Hoogen Raad van 31 December 1915, W.v.h.R. no. 9974 , aangaande de bevoegdheid van de rechterlijke macht krachtens art. 2 der Wet op de Rechterlijke organisatie', Themis 1917, pp. 337 e.v.

E.C.M. Wagemakers, 'Artikel 47 van de Wet Bodembescherming', NJB 1994, pp. 1029-1034.

M. Walzer, 'Sphers of justice', A defence of pluralism and equality', New York 1983.

M. Walzer, 'The idea of civil society', Dissent 1991.

P.C. Westermann, 'John Locke', in: P.B. Cliterur e.a. (red.), 'Filosofen van het klassieke liberalisme', Kampen 1993, pp. 47-66.

G.J. Wiarda, 'Overeenkomsten met overheidslichamen', diss. UvA 1939.

G.J. Wiarda, 'De overheid als contractante', WPNR 5067 (1970).

H.D. van Wijk, 'Hoofdstukken van administratief recht', 2e druk, Den Haag 1972.

H.D. van Wijk/W. Konijnenbelt/R.M. van Male, 'Hoofdstukken van administratief recht', 9e druk, Utrecht 1994.

P.C.E. van Wijmen, 'Zorgplicht in natuur- en milieuwetten', Milieu en Recht 1991, p. 1. 
P.C.E. van Wijmen, 'Bescherming van natuur- en milieuwaarden in rechte: de verdediging van collectieve goederen', Milieu en Recht 1994, pp. 234-243.

P.C.E. van Wijmen, 'Samenloop van bestuursrecht en burgerlijk recht bij onrechtmatige daad', in: H.J.A.M. van Geest e.a. (red.), 'Bestuursrecht aan de horizon', Opstellen bij gelegenheid van de $80 \mathrm{e}$ verjaardag van prof. mr. S.F.L. baron van Wijnbergen, Zwolle 1994, pp. 135-148.

W. Wilhelm, 'Zur juristischen Methodenlehre im 19. Jahrhundert. Die Herkunft der Methode Paul Labands aus der Privatrechtswissenschaft', Frankfurt aM 1958.

D. Willoweit, 'Deutsche Verfassungsgeschichte', Vom Frankenreich bis zur Teilung Deutschlands, München 1990.

W. Witteveen, zie B. van Klink

A. van der Woud, 'Het lege land', De ruimtelijke orde van Nederland 1798-1848, diss. Groningen 1987, Amsterdam 1987.

A.C. Zijderveld, 'Schimmen en schaduwen van de revolutie der revoluties', in: S.W. Couwenberg (red.), 'Opstand der burgers', 2e druk, Kampen 1989, pp. 39-49.

P. Zonderland, 'Het kort geding tegen de overheid', 2e druk, Zwolle 1976.

J.W. van Zundert, 'Overheidsbestuur en grondeigendom', diss. Utrecht 1980, Alphen a/d Rijn 1980.

H.H. Zwager, 'De motivering van het algemeen kiesrecht in Europa', Groningen 1958, herdruk Utrecht 1981.

W.J. Zwalve, zie J.H.A. Lokin. 


\section{Jurisprudentieregister}

\section{Hoge Raad}

HR 18 juni 1844, W. 506 (broodzetting) 139

HR 24 febr. 1846, W. 696119

HR 24 mei 1853, W. 1491119,124

HR 16 mei 1854 , W. 1664119

HR 31 dec. 1857, W. 1833119

HR 22 okt. 1861, W. 2331139

HR 22 mei en 28 juni 1863, W. 2499 (Zuidplaspolder) 70

HR 1 nov. 1864, W. 2664139

HR 24 maart 1865, W. 2681, Ned. Regtspraak, dl. 7, par. 49 97, 199, 280

HR 24 dec. 1867, W. 2972119

HR 22 jan. 1868, W. 2978110

HR 9 juni 1871, Red. Regtspraak, dl. 98, pp. 115-129 ('Stad Vlissingen') 97

HR 21 juni 1872, Ned. Regtspraak, dl. 101, pp. 195-205 142, 280

HR 15 dec. 1873, W. 3679119

HR 23 maart 1874, W. 3718119,290

HR 16 okt. 1876 , W. 4045110

HR 19 maart 1877, W. 4113119,123

HR 13 jan. 1879, W. 4330 (Meerenberg) 182, 290

HR 30 juni 1879, W. 4404 (Noordzeekanaal) 140

HR 30 juni 1879, W. 4406 105, 119

HR 20 okt. 1879, W. 4435125,129

HR 26 jan. 1880, W. 4477123

HR 12 april 1880, W. 4498124

HR 6 okt. 1884, W. 5086140

HR 29 mei 1896, W. 6817, Gst. 2338, WBA 2460 (Vrouwe Elske) 164

HR 21 april 1898, W. 7116, Gst. 2436, WBA 2559 (Rhedense koe) 164

HR 10 mei 1901, W. 7606, gst. 2599, WBA 2714 (Pothuis) 165

HR 4 maart 1904, W. 8050 (Lantaarnpaal) 142

HR 29 april 1910, W. 9027 (Mark en Dintel) 185, 248, 254

HR 31 dec. 1915, W. 9947 (Guldemond/Noordwijkerhout) 132

HR 7 juni 1918, NJ 1918, p. 717, W. 10289 (Hofvijver) 142

HR 12 jan. 1923, W. 11060, NJ 1923, p. 307 (Schielands Hoge Zeedijk) 128, 131, 254

HR 20 nov. 1924, W. 11293, NJ 1925, p. 89, Gst. 3835 (Osterman I) 198

HR 29 jan. 1926, NJ 1926, p. 231 (Staat/Kok) 272, 327

HR 20 juni 1927, NJ 1927, p. 969 (Waddenzee) 142

HR 29 juni 1928, NJ 1928, p. 1138 (Strooppot) 200

HR 5 mei 1933, NJ 1933, p. 875 (Meerboei) 200

HR 20 dec. 1940, NJ 1941, 365 (stamboekvaarzen) 200 
HR 17 jan. 1941, NJ 1941, 644 (Parlevinker) 133, 242

HR 19 maart 1943, NJ 1943, 312 (Voorste Stroom VI) 200

HR 18 febr. 1944/45, 226 (duinwaterleiding, ook bekend als het Jochems- en als het wateronttekkingsarrest) 200

HR 19 dec. 1952, NJ 1953, 642170

HR 24 okt. 1961, NJ 1962, 86, AAe 1962, p. 118 (Zeijense nachtbraker) 118

HR 19 jan. 1962, NJ 1962, 151, AB 1962, p. 540 (Usselmeer I, ook bekend als

Huizen/Staat I) 110

HR 12 nov. 1963, NJ 1964, 205 (weerspannige kloosterling) 118

HR 19 jan. 1968, AB 1968, p. 585, NJ 1968, 166 (Eindhoven/Staals) 134, 190

HR 24 jan. 1969, NJ 1969, 316, AB 1969, p. 194, AAe 1969, p. 266 (pocketsbooks II) 201

HR 26 maart 1971, AB 1971, 135 (Verkiezingsafspraak Elsloo) 70

HR 22 juni 1973, AB 1973, 187, AAe 1973, p. 457 (fluoridering) 277

HR 9 nov. 1973, NJ 1974, 91 (Limmen/Houtkoop) I75, 288

HR 19 dec. 1975, NJ 1976, 280 (Rijksweg 12) 192, 249

HR 22 febr. 1977, NJ 1977, 288 (Rode vlag) 118

HR 26 mei 1978, NJ 1978, 615 ('Zuidpool', ook bekend als Staat/Gaasterdijk) 206

HR 6 april 1978, NJ 1980, 34, AB 1979, 356, AAe 1980, p. 250 (Knabbel en Babbel) 283 HR 28 juni 1985, NJ 1986, 356, BR 1986, p. 121 (Claas/Van Tongeren) 231, 287

HR 7 febr. 1986, NJ 1987, 477 ('Attican Unity') 233

HR 17 juni 1986, NJ 1987, 743, AB 1987, 173 (Nieuwe Meer) 295, 312

HR 10 april 1987, AB 1987, 336, NJ 1988, 148 (GCN/Nieuwegein I) 198

HR 1 mei 1987, tB/S, rubr. burg. r., nr. 3 (Van Dalen/Aerle/Rixtel) 283

HR 14 april 1989, NJ 1989, 469 (Harmonisatiewet) 197

HR 13 april 1989, AB 1989, NJ 1990, 712 M\&R 1989, 6 (Benckiser/Staat) 297

HR 23 april 1989, AB 1989, 551, NJ 1991, 673 (GCN/Nieuwegein II) 280

HR 26 jan. 1990, Gst. 6914.10, AB 1990, 408, NJ 1991, 393 (Staat/Windmill) 142, 156, $197,283,315$

HR 9 febr. 1990, NJ 1991, 462, AB 1990, 409 (Staat/Van Amersfoort) 153, 176, 185, 207, 240,317

HR 9 juli 1990, Gst. 6914.11 (De Pina/Helmond) 197, 320

HR 18 jan. 1991, AB 1991, 2441, NJ 1991, 638, tB/S rubr. burg. r., nr. 1 (Leffers, ook bekend als Varkensmesters- en als Swill-arrest) 197, 201

HR 8 juli 1991, AB 1991, 659, NJ 1991, 691 (Kunst- en antiekstudio/Lelystad) 178, 189, 320

HR 25 okt. 1991, NJ 1992, 299, AB 1992, 88325

HR 24 april 1992, NJ 1993, 643 (Staat/Van Wijngaarden) 157, 182, 184, 197, 240

HR 11 dec. 1992, AB 1993, 301 (brandweerkosten) 203

HR 18 dec. 1992, NJ 1994, 139, Gst. 6970.5, M\&R 1993, 24, AAe 1993, p. 664 , TVVS 1993, p. 75 (Kuunders) 157, 303

HR 22 jan. 1993, AB 1993, 198, NJCM-bulletin 1993, p. 410 e.v. 195

HR 18 juni 1993, NJCM-bulletin 1993, p. 786, Tijdschrift voor Gezondheidsrecht 1993, p. 368 (HIV) 206 
HR 22 okt. 1993, AB 1994, 1 (Staat/Magnus) 176, 178, 184, 186, 240, 320

HR 18 febr. 1994, AB 1994, 415 (Kabayel) 71, 206, 258, 288, 319

HR 30 sept. 1994, RvdW 1994, 188c (Staat/Van den Brink) 181

HR 30 sept. 1994, BR 1995, p. 42 (Staat/Shell) 179

HR 7 okt. 1994, AB 1995, 47 (Nieuwveen/Van Schaik, ook bekend als zomerhuisjesarrest) 204, 283

HR 14 okt. 1994, AB 1995, 48 (Wrakkenwet) 283

\section{Gerechtshof}

Gerechtshof Den Bosch 9 jan. 1973, NJ 1974, 26327

\section{Rechtbank}

Pres.Rb. Den Haag 13 aug. 1985, KG 1985, 266 (Moerdijk) 327

Pres.Rb. Den Haag 16 jan. 1990, KG 1990, 78 (Noordwijkerhout/Bonte) 292

Pres.Rb. Amsterdam 13 april 1994, AAe 1995, p. 290271

Afdeling rechtspraak Raad van State

ARRS 11 aug. 1978, AB 1979, 111324

ARRS 28 febr. 1980, Gst. 1980, nr. 6625.8 (weigering uitweg Laren) 255

ARRS 30 aug. 1985, AB 1986, 243 (Rabobank Zoeterwoude) 282

Voorzitter Afdeling rechtspraak Raad van State

Vz.ARRS 21 okt. 1976, AB 1977, 284326

Vz.ARRS 28 febr. 1980, Gst. 6625.8 (weigering uitweg Laren) 282

Vz.ARRS 26 maart 1981, tB/S, IV, p. 262270

Vz.ARRS 6 mei 1991, AB 1992, 414255

Vz.ARRS 12 mei 1992, Gst. 1992, nr. 6960.2255

Afdeling bestuursrechtspraak Raad van State

AbRS 10 april 1995, AB 1995, 498 ('Long Lin') 255, 256

\section{Centrale Raad van Beroep}

CRvB 30 dec. 1952, AB 1953, p. 477325

CRvB 7 juli 1953, AB 1953, p. 729325

CRvB 26 juni 1959, AB 1960, p. 471325 
College van Beroep voor het bedrijfsleven

CBb 10 april 1964, SEW 1964, p. 559325

Kroon

KB 10 sept. 1955, AB 1955, p. 762327

\section{Preussisches Oberverwaltungsgericht}

Preussisches Oberverwaltungsgericht (PrOVG) 16 juni 1882, E 9, S. 353 (Kreuzberg) 117

\section{Bundesverfassungsgericht}

BVerfG 19 dec. 1951, E 1, S. 97277

BVerfG 17 jan. 1978, E 47, Nr. 6118

BVerfG 1 maart 1979, E 50, Nr. 26 237, 244

BVerfG 12 juni 1979, E 52, Nr. 1244

BVerfG 28 febr. 1980, E 53, Nr. 17245

BVerfG 23 mei 1980, E 54, Nr. 14118

BVerfG 1 juli 1981, E 58, Nr. 4244

BVerfG 14 juli 1981, E 58, Nr. 5 101, 244, 279

BVerfG 8 juli 1984, E 61, Nr. 10244,323

BVerfG 31 okt. 1984, E 68, Nr. 6324

BVerfG 8 juni 1988, E 78, S. 250292

Europees Hof voor de rechten van de mens

EHRM 26 april 1979, NJ 1980, 146 (Sunday Times) 118 


\section{Curriculum vitae}

De auteur dezes werd als Joost Maria Hermanus Franciscus Teunissen op 24 april 1954 geboren te Gennep. In 1972 behaalde hij het diploma Gymnasium-B aan het Gabriëlcollege te Mook. Na twee jaar biologie en Duitse taal- en letterkunde te hebben gestudeerd en zijn militaire dienstplicht te hebben vervuld, trad hij in 1976 in dienst bij de gemeente Cuijk en Sint Agatha, als medewerker bij het bureau grondzaken. In 1978 behaalde hij de diploma's Gemeenteadministratie-I en -II. Van medio 1979 tot medio 1984 was hij als medewerker bij de Afdeling Algemene en Juridische Zaken verbonden aan de Vereniging van Nederlandse Gemeenten te Den Haag. In deze tijd studeerde hij als extraneus respectievelijk als avondstudent aan de juridische faculteit van de Rijksuniversiteit Leiden, waar hij in 1982 slaagde voor het doctoraalexamen Nederlands recht, staatsrechtelijke richting. Van medio 1984 tot medio 1987 was hij hoofd van de Afdeling Algemene Zaken en Ruimtelijke Ordening van de gemeente Boxmeer. Sinds 1987 is hij verbonden aan de Rijksuniversiteit Limburg als universitair hoofddocent bij de vakgroep publiekrecht. 



\section{Summary}

Is public administration at liberty to use, in addition to or even in lieu of the powers afforded under public law, powers that are governed by private law in order to further public interests (the two-track doctrine)? In its Windmill judgment of 26 January 1990 , the Netherlands Supreme Court answered this question in the affirmative. However, there is no such freedom if the use of private-law powers were to unacceptably frustrate public law. Especially where a comparable result can be achieved by using private law, this, according to the Supreme Court, is in itself an important indication that a private-law track may be followed. We are dealing with an exception, which confirms rather than questions the rule that, in principle, it is acceptable to use powers governed by private law.

The view underlying this case law, that the fundamental distinction between State and civil society and between public and private law is outdated, is not shared by the author. The Supreme Court's statement in the Windmill case that, 'in principle', the administration can also defend public interests 'by using powers that are founded on private law' can only be based on the premise that the Civil Code does grant these powers. This would entail, however, that private individuals and organizations also derive their powers under private law from the Civil Code, i.e. from the state legislature. This would be absolutism or at least a purely legal-positivist view!

Where the Supreme Court says that 'private law' grants the administration these 'privatelaw powers', also to further public interests, inevitably, the question arises as to what exactly is the private-law character of these powers. However, if one holds an absolutist or purely legal-positivist view and consequently does not wish to make a substantive distinction between public and private law, this prompts the question as to why these powers are characterized as powers under private law.

Another question is how to explain that the legislature has intentionally afforded a public authority only certain public powers to further specific public interests, where that same authority has at its disposal, on top of these public powers, also general, non-specified powers under private law to further all kinds of public interests, including unwritten ones.

In its case law, the Supreme Court fails to acknowledge the specific character of either private or public law, and in so doing, it ignores the important public-law principle of democracy through (proportional) representation. The question as to which interests may be defended by the administration must be answered in a political decision-making process, in which there is a major role to play for parliament. The administration's use of private acts and private forms of organization must be inferable from a power under public law. In no instance can private law be a separate and independent legal basis for administrative action. Consequently, private law is not capable of broadening administrative powers. The administration's legal capacity under private law could be characterized as an implied power, which means that the administration can only act in a private capacity in so far as this is necessary in exercising powers granted under public law. 
